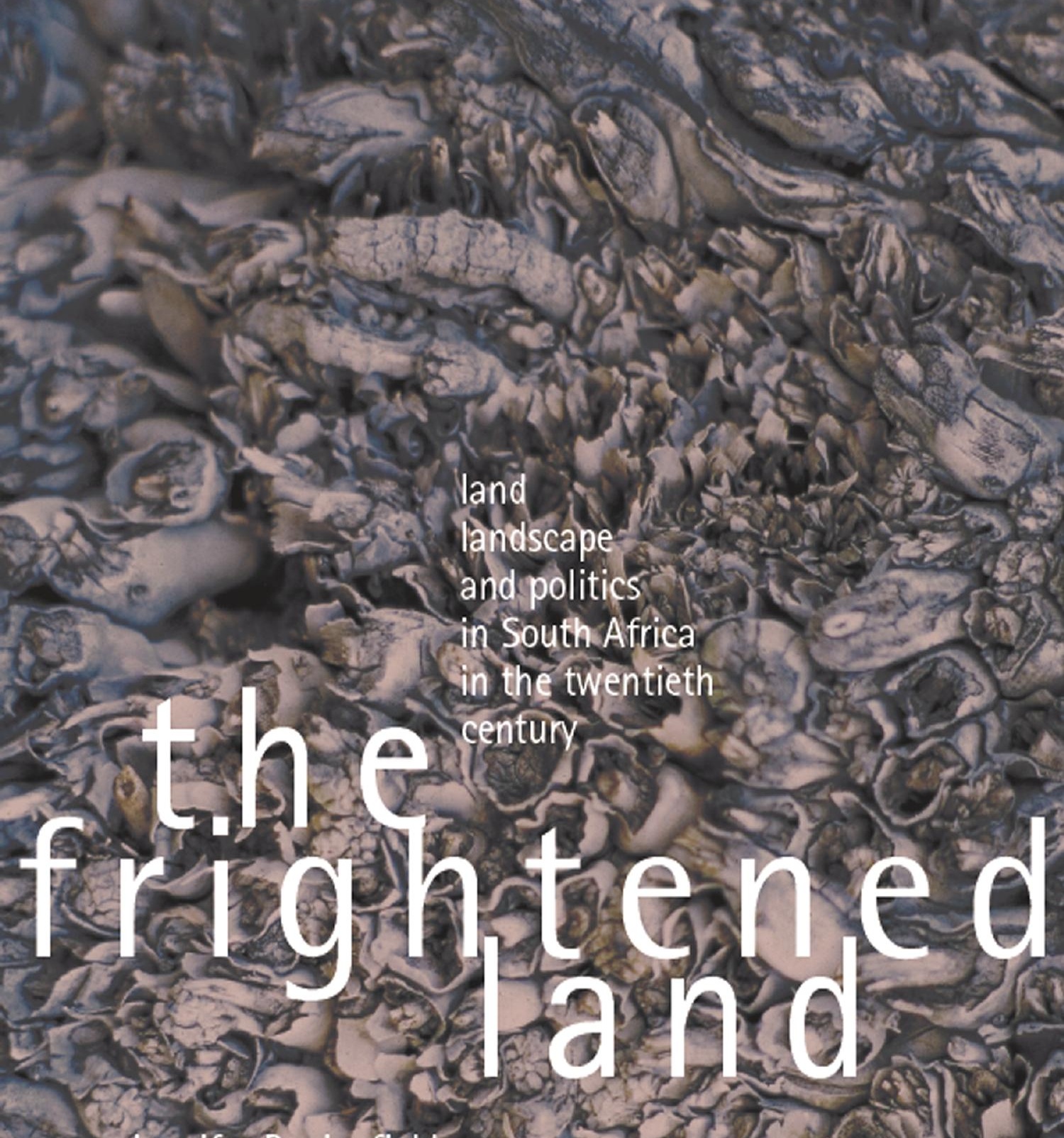

(3) Jennifer Beningfield

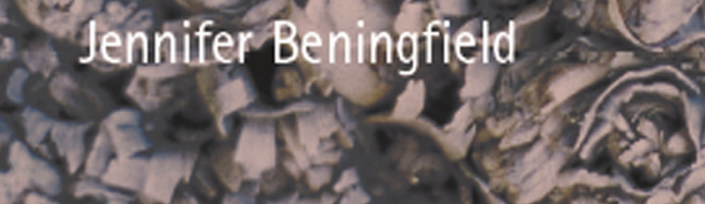
1052 (5)

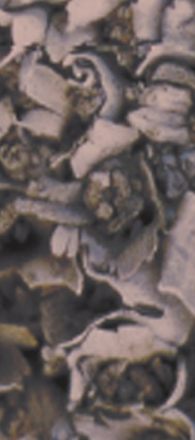




\section{The frightened land}

This book investigates the consequences for the imagination and meaning of the land of the spatial politics of separation and division in South Africa principally during the apartheid years. It probes the uncertainty and ambiguity of identities and cultures in contemporary post-apartheid society in order to gain a deep understanding of the history that individuals and society now confront. This critique examines the relationship between representation, landscape, politics and cultural identity in South Africa focusing on the twentieth century.

Jennifer Beningfield is founding principal of Openstudio Architects. She divides her time between London and Johannesburg. She holds a Masters in Architecture degree from Princeton University in the United States, and a PhD in architecture and landscape planning from the University of London. She has worked as an architect on private houses and museum and art gallery projects in South Africa, the United States and the United Kingdom. Her particular research focus is on the meaning and representation of landscapes. She has been involved in design studios and theory seminars at the University of the Witwatersrand, Princeton University, the Architectural Association, the Bartlett School of Architecture and the University of Virginia and is currently a regular critic at Liverpool University. 



\section{The frightened land \\ Land, landscape and politics in South Africa in the twentieth century}

Jennifer Beningfield 
First published 2006 by Routledge

Published 2017 by Routledge

2 Park Square, Milton Park, Abingdon, Oxon OX14 4RN

711 Third Avenue, New York, NY 10017, USA

Routledge is an imprint of the Taylor \& Francis Group, an informa business

Copyright @ 2006 Jennifer Beningfield

Typeset in Univers by Keystroke, 28 High Street, Tettenhall, Wolverhampton

The Open Access version of this book, available atwww. tandfebooks. com, has been made available under a Creative Commons Attribution-Non Commercial-No Derivatives 4.0 license.

British Library Cataloguing in Publication Data

A catalogue record for this book is available from the British Library

Library of Congress Cataloging in Publication Data

Beningfield, Jennifer.

The frightened land: land, landscape, and politics in South Africa in the twentieth century / Jennifer Beningfield.-1st ed.

p. $\mathrm{cm}$.

Includes bibliographical references and index.

ISBN 0-415-36593-7 (hb : alk. paper) - ISBN 0-415-36555-4 (pb : alk. paper)

1. Landscape-Political aspects-South Africa-History-20th century. 2. Landscape in literature. 3. Land use-Political aspects-South Africa-History.

4. Apartheid-South Africa. 5. South Africa-Politics and government-20th century.

I. Title.

DT1928.B46 2006

8209 '320968-dc22

2005033936

ISBN13: 9-78-0-415-36593-2 (hbk)

ISBN13: 9-78-0-415-36555-0 (pbk) 
For Peter and Hilary Beningfield 



\section{Contents}

Illustration credits

Foreword

Acknowledgements

Introduction

\section{Part 1 Veld}

1 Wilderness and veld

2 Memory and inscription

3 Map and monument

\section{Part 2 Farm}

4 A failed Eden $\quad 75$

5 'Natural' identity 89

6 The fertile desert 107

Part 3 'Native' lands

7 'Native' lands 121

8 Language, nation and landscape 142

9 Tribal landscapes 157

\section{Part 4 Invisible landscapes}

10 Desire and distance 173

11 Veld and city 191

12 Invisibility and silence 207

\section{Part 5 Erasures}

13 Landscapes and erasures 229

14 Landscapes of the imagination 256

15 Transforming landscape 272

Notes $\quad 284$

Appendix A: South African time line $\quad 307$

Appendix B: Main apartheid legislation in South Africa 311

Bibliography $\quad 315$

Archives and other sources $\quad 322$

Index 332 


\section{Illustration credits}

(C) Bailey's African History Archive Figures 7.1, 7.2, 9.3-9.5, 10.1-10.4, 13.1, 13.3, $13.15,13.16,14.1$

Jennifer Beningfield (photographs) Plates 3.1, 3.2, 11.1, 11.2, Figures 2.7, 3.2, 3.8, 3.9,

$15.1,15.3$

Brown, Davis and Platt Plate 2.5

Cape Town Archives Repository Plates 2.3, 13.3, Figures 2.1-2.3, 2.8, 2.12, 3.1, 3.3, 4.1, 4.2, 5.3-5.7, 9.1, 10.5, 13.3, 13.14

(C) Chief Directorate: Surveys and Mapping Plates 6.2, 6.3, 6.4, 13.1, 13.2, Figures 6.1, $12.1,13.4-13.10$

Bernard Clark (photographs) Plate 2.1, 6.1, 8.2, 11.2, 13.2, 13.11, 13.12, Figures 2.5, 2.6, 3.12

Department of Bantu Administration and Development Plate 7.2

(C) Die Transvaler newspaper Figures 2.2, 2.8, 4.2, 7.4

Heemkring/Paarl Archives Figures 8.1, 8.3

(c) Hendrik Oosthuysen Figure 3.7

Historical Papers, University of the Witwatersrand Figures 2.10, 2.11, 9.2

(C) Jan van Wijk Figure 8.3

Kunst Palast, Dusseldorf Figure 2.4

(C) Map Studio Plates 7.3, 7.4

National Library of South Africa Plate 4.1, Figures 3.4-3.6, 5.8, 11.1

Nasionale Pers Plates 2.2, 2.4, Figures 2.3, 3.11, 10.5

(C) Nienaber \& Le Roux Figure 2.9

Pretoria Archives Repository Plates 2.1, 6.1, 8.2, 11.2, 13.2, 13.11, 13.12, Figures 2.5, 2.6, 3.12

(C) Rand Daily Mail newspaper Figure 7.3

(C) Reproduced under South Africa Government Printer's Copyright Authority No. 11296 dated 1 November 2005 Plates 1.1, 5.1, 5.2, 5.3, 6.2, 6.3, 6.4, 7.1, $10.1,10.2,13.1,13.2$, Figures 5.6, 5.7, 6.1, 12.1, 13.4-13.10

Sally Gaule (photographs) Plates 1.1, 2.2, 2.4, 2.5, 5.1, 5.2, 5.3, 7.1-7.4, 10.1, 10.2, Figures 2.10, 2.11, 5.1, 5.2, 7.1-7.4, 9.2-9.6, 10.1-10.4, 10.6, 10.7, $12.2-12.5,13.1,13.3,13.15,14.1$

(C) F Steyler Plate 2.3

(C) The Sowetan newspaper Figure 12.2

(C) The Star newspaper Figure 9.6, 12.3

Transvaal and Orange Free State Chamber of Mines and the Transvaal Chamber of Mines Figures 5.1, 5.2

(C) Uitenboogardt, Barac, de Souza Santos, de Souza Santos, Mayle Plates 11.1, 11.2 
Uniewinkels Figure 2.12

Voortrekker Board of Control Figure 3.12

(C) Die Volksblad newspaper Figure 2.1

(C) The Weekly Mail newspaper Figures 12.4, 12.5 


\title{
Foreword
}

\author{
From fright to fraternity
}

When I take groups on a tour of the new Constitutional Court building which is located on the site of the Old Fort Prison in Johannesburg, I sometimes share a secret with them. Why, I ask, do I feel so special when I come to work here each day? It's not just that the building is particularly light and beautiful, I answer. Nor is it simply that the placing of the Court in the heart of the notorious prison in which both Gandhi and Mandela were locked up, represents a profoundly moving visual and emotional journey. Nor is it only that unrestricted day and night circulation on the site encourages people from three adjacent yet divided parts of the city comfortably to encounter each other, whether they come from the populous, vital and problematic flatland of Hillbrow, perhaps the most diversely African area on the continent; or from the spaciously tree-and-gardened homes of the Northern Suburbs, not a poor person in sight; or from the huge cluster of concrete civic buildings of bureaucratic Braamfontein. It is something much deeper, I respond to my own question, more intimate, more related to how I imagine myself as a human being and as a South African. The answer, I continue, is that when I walk up to my Chambers I feel at a deeply subliminal level different to the way I feel in almost any other part of the country. I don't feel I am a white man in a white area, or a white man in a black area. At last, I say, I am just a person going to work in a zone of South Africa that is both historically and imaginatively free.

This is what this book is about: how we can transcend the trauma that inheres in our landscape and at last begin to live in truly liberated surrounds. Certainly, all the old colonial and apartheid laws that once formally mapped out the whole surface area of the country in racial terms, are dead and buried. Our Constitution today declares unambiguously that South Africa belongs to all who live in it, united in our diversity. The racist statutes in terms of which African people were forbidden to own land in $87 \%$ of the country, and every inhabitant was physically consigned to specified areas according to their race, have been abolished. Yet even if the legal structures of apartheid are no longer there, actual ownership of the land still coincides largely with the avowedly racist legal appropriations of the past. And as this book forcefully shows, the divisions of the country linger on powerfully in the way we imagine the physical world in which we live. The central concern of the book, then, is not so much to recount the processes in terms of which grossly discriminatory legal title was established, as to outline mechanisms used over the centuries to promote hegemonic forms of imaginative entitlement. The objective is through science and intuition to link up the given, the made and the imagined. 
In the past the land was projected simply as an empty space awaiting the tread of civilised boots and the roll of four-wheeled carriages. The people who lived there were regarded as part of nature, not part of society. The land did not belong to them, they belonged to the land. The spaces were called 'open' and represented as terra nullius, land belonging to no one. Conquest was always presented as the invasion of emptiness, as filling a natural void, as though the African continent was a vacuum to be abhorred rather than an already populated and governed part the world.

Thus dispossession came to be nine tenths of the law. The expulsion from the land was not primarily physical, it was legal and psychological. Indigenous people remained on the land, but in a subaltern position as servants or migrant workers. Slaves were imported and deposited on South African soil, deprived of their names, their families, their languages and frequently, their faith. The Boers, who for a time were the expropriators, became the expropriated. Avid immigrants came from all over the world to hunt ruthlessly for diamonds and gold. Yet though the peopling of our land was conflictual and violent, it was never presented by the dominant groups as being driven by greed. It was always justified in terms of some higher ideal, some purpose derived from scripture or notions of history.

Perhaps the most profound fallacy of our history has been that of 'our beautiful country' providing a natural and innocent backdrop to the sordid and noble enactments of history. The implication is that all we need to do now is to journey back to a pristine paradise. Yet nature has never been natural, just as the 'landscape' has never been neutral. As the author points out, it has always been and continues to be both physical ground and theoretical territory. The meaning of any place has been traumatically ploughed into the soil. Far from the landscape providing an image of order and harmony in a 'natural' world, it represents damage and debris. Landscape is thus not only a sensory medium of soil, grass, stone and water, of hills and valleys, not only physical typography. It is an experienced world which is drenched with meaning through inhabitation, conflict and violence.

Never has knowledge of the meaning of place had such great current relevance. The implications for professionals working with the built environment are enormous. We must recognise that the landscape is not simply or even primarily a setting in which homes and cities are built. Our vision of the land is a central if unacknowledged protagonist in every design conceived, and every planning decision made. The unexpressed assumptions are all the more powerful for being hidden. This book calls for the inarticulate memory structures relating to the land to be discerned, spelt out and questioned. The vision of designers and planners in the past has been shaped not so much by the intrinsic physical qualities of the land as by the way successive generations have occupied, related to, imagined and mythologised them. We should not try to escape from our history, but rather seek to acknowledge and channel in open and democratic fashion its intense and continuing energy.

Today we are rightly memorialising past struggles and honouring sacrifices made. This book gives timely warning against temptations to give expression to shallow democratic triumphalism. The Voortrekker Monument now stands as 


\section{Foreword}

a strange and poignant reminder of how empty the earnest vanity of a once superconfident generation can be. The soft, open and ambiguous contours of nearby Freedom Park hill-top turn out to be far more powerful and optimistic than the once arrogant and now curiously deflated pile that is the Monument, looking today like an orphaned concrete straggler on the kopje seeking new forms of historical companionship.

It is apt that a book on landscape should be described as a path-breaker. Yet the scholarly path chosen, marked out by written sources, both archival and literary, necessarily confines the trajectory. It cannot take in the vast treasure-house of popular memory that by its very nature articulates itself in a multitude of diverse idioms. We do not yet have systematized accounts of how the various indigenous communities perceived the world they lived in. The voices of women in all classes are largely absent from the records. Subaltern claims only began to emerge strongly on the eve of the achievement of democracy; they need to be heard. One longs for a whole range of companion volumes with different tracks and emotions. Yet any new work emerging will have to acknowledge the intellectual beacons found in this extraordinarily intense, intelligent and layered book. In a dialogue across the disciplines, it evokes, provokes and ultimately pleases. This book represents not just an extraordinary journey of rediscovery. It opens the way to new forms of imagining South Africa, facilitating the emergence of a sense of shared rather than competitive ownership. There is too much blood in our soil, too many mangled bones lie there. In racist South Africa anatomy was destiny. Now in our new democracy it is physicality that is fate.

We have to find ways of sharing the land as equals, not only in terms of legal title and productive use, but in terms of our imaginative understanding. Under democracy our imaginations are slowly but progressively beginning to develop the lineaments and textures of a common vision and a shared sense of belonging. Bit by bit the fright gives way to a sense of tranquility and rootedness. The historical hurt is progressively assuaged as we shuffle off the inheritance of our existential fright. Our imaginations sometime surge ahead, sometimes lag behind. This book will help keep them moving along at a steady and even pace, as the frightened land rediscovers and reconfigures itself as the fraternal land.

Albie Sachs

Justice of the Constitutional Court of South Africa

Johannesburg

21 March 2006 


\section{Acknowledgements}

This book has been more than five years in the making, and would not have been possible without the involvement of a great many people. It has developed from initial conversations with friends and colleagues, to undertaking the research with the assistance of the people working at the archives, libraries and museums in South Africa, to writing and editing the text with the help of those who commented on it.

Alessandra Ponte offered insightful suggestions when this project was just beginning. Dr lain Borden has read and commented on drafts. I also appreciate the advice and input of Dr Adrian Forty at a critical moment. Professor Lindsay Bremner and $\mathrm{Dr}$ Catherine Nash independently gave me detailed comments on one of the early versions of this book and without their comments the text would be poorer. Lindsay Bremner, in particular, has challenged me to improve and deepen the references and scope of the work and offered some important suggestions as to additional material which I have subsequently included, and which I now cannot imagine the book omitting. David Jenkins took the time to read the text with an expert eye and helped to refine it. His desire to see the book constantly improve has helped me to regard it as an evolving project. My discussion with Dr Nhlanhla Thwala was crucial in positioning the work in this book alongside a history of speaking the land that existed before white settlement and I wish to thank him for his time and insights.

The staff members at the national and independent archives and libraries in South Africa were invaluable. The papers, maps and photographs are catalogued with an efficiency which allowed me to source and consult documents rapidly. The staff at all the archives consistently took great care to ensure that I had access to all the documents which I required, and often suggested valuable additional material. Thank you to the staff at the British Library in London, Jo Pretorius, Zane Nywayo and Simon Makhubele at the Pretoria State Archives, Jaco van der Merwe at the Cape Town Archives Repository, Michele Pickover at Historical Papers at the University of the Witwatersrand, Margaret Northey at the Africana Library at the University of the Witwatersrand, the staff at the University of Cape Town and UNISA library, Ivan Arendse at the Heemkring/Paarl Archives, Jack Louw at the Afrikaanse Taal Museum, Najwa Hendrickse, Melanie Geustyn and John Dwyer at the National Library of South Africa in Cape Town, lan Black at the Cape Town City Council Map Archive, Trevor Moses at the National Film, Video and Sound Archive, Alan Garlick, Godfrey Chauke and Ann Antrobus at the Johannesburg Public Library, Salim West and Debbie 


\section{Acknowledgements}

Sutherland at the Chief Directorate, Surveys and Mapping in Cape Town and Bongi Maswanganyi, Marie Human and Jacqui Masiza at Bailey's African History Archives.

For the use of illustrations, thank you to Bailey's African History Archives, the Pretoria State Archives, the Cape Town Archives Repository, Historical Papers at the University of the Witwatersrand Library, Map Studio, The Sowetan, The Weekly Mail, The Star, the South African government, the National Library of South Africa, the FAK, the Chamber of Mines and the Board of Control of the Voortrekker Monument. Mapping and aerial photography have been supplied by the Chief Directorate, Surveys and Mapping, W3sli.wcape.gov.za.

Sally Gaule is responsible for the photography of the majority of the illustrations in this book. Her expertise served to make a complex task appear simple, and it was a pleasure to work together. Achmat Smith at the Cape State Archives took all the photographs of the many documents in their collection which appear in this book, and thanks are also due to John Dwyer of the South African Library and Bernard Clark in Pretoria for their photographs.

I received financial support for travel and research from the University of London at a critical time in the research. I also greatly appreciate the support of the Oppenheimer Memorial Trust in Johannesburg as well as Clare Digby, who administers the Trust, for its generous funding of the final completion of the book, including the archival photography and colour printing.

Caroline Mallinder, Jules Mohm and Fiona Wade at Routledge, as well as Christine Firth, as copy editor, have carefully shepherded the book into its final form. Mark Vernon-Jones has created a striking cover that captures the ambiguities of the book.

Albie Sachs' foreword, as well as his generosity with the time and care he took to read and comment on the book, means a great deal to me. He has helped me to see the book in its wider context, and I cannot imagine anyone better qualified to introduce it.

Any errors or omissions in the book are mine. Every effort has been made to contact copyright holders. Please advise the publisher of any errors or omissions and these will be corrected in subsequent editions. 


\section{Introduction}

To my compatriots, I have no hesitation in saying that each one of us is as intimately attached to the soil of this beautiful country as are the famous jacaranda trees of Pretoria and the mimosa trees of the bushveld.

Each time one of us touches the soil of this land, we feel a sense of personal renewal. The national mood changes as the seasons change.

We are moved by a sense of joy and exhilaration when the grass turns green and the flowers bloom.

That spiritual and physical oneness we all share with this common homeland explains the depth of the pain we all carried in our hearts as we saw our country tear itself apart in a terrible conflict, and as we saw it spurned, outlawed and isolated by the peoples of the world, precisely because it has become the universal base of the pernicious ideology and practice of racism and racial oppression. ${ }^{1}$

Land, landscape, politics, race and violence are woven together in this extract from Nelson Mandela's Inauguration Address, given at the Union Buildings in Pretoria, South Africa, on 10 May 1994. In this critical speech, made at the moment in which the formal and ceremonial transition of political power was made from white minority rule to that of a democratic black majority, Mandela identified two recurring themes of the South African land, which contribute to the image and experience of the contemporary landscape. The first is the land, and the soil in particular, as the site of the sensory experience of nature, which is experienced through the touch, sight, and smell of individuals who have invested spiritual meaning, and personal and national identity, into their relationship with the land. The second theme is the land as the medium, the 'base', of the politics of racial division and of the conflict and violence that was a consequence of political policies. There is an implicit 
tension and ambiguity between these two images of the land, an oscillation and contamination between the comfort and 'renewal' of personal and national identity that the land can offer through close sensory experience and the distance from the landscape that is a precondition of its meaning as a site in which culture and politics are embedded.

Mandela's description of the South African land towards the end of the twentieth century bears the weight of the past, while seeking to offer its image of natural cyclical renewal as a means of reconciliation to those who contested its ownership. He both describes the violence that arose out of conflicting claims on the soil, and recognises the beauty and fear that characterises the contemporary landscape. This book is preoccupied with the contradictory and ambiguous landscape that Mandela describes and which persists in the negotiations, experiences, violence and uncertainties of the present. It takes as its starting point, and final date, the moment at which Mandela speaks about the land as he is inaugurated, looking back, through the lens of the contemporary southern African landscape, at the past that has formed it.

The book focuses on the relationship between politics, land and landscape in South Africa during the twentieth century. It emphasises the way in which politics imagines the land, represents it and actively transforms it. The title, The Frightened Land, is taken from an article printed in the South African magazine Drum in $1963,{ }^{2}$ on the eve of the 'independence' of the Transkei, the first of the apartheid government's black bantustans. The article describes the fear and mistrust in the land, which is a result of political change.

South Africans inhabit this landscape of beauty and violence, of nature and politics. It is a landscape both innocent and knowing; as we breathe pleasurably in the fresh air of the bushveld, we temporarily suspend our knowledge of the landscape's darker secrets, of the racial division of the land and the claiming of it by different people over time.

I argue, therefore, that landscape in South Africa has always been inseparable from uncertainty and contradictory meanings - comfort and unease, renewal and destruction - and that this understanding of landscape can contribute to the reimagination and remaking of the land in the post-apartheid period. I ask what landscape is and how it operates, in order both to lay bare the complicity of landscape and politics in the claiming of South Africa and to propose that an understanding of landscape as altered, contested and complex is critical in the post-apartheid years. Landscape remains fertile ground for the debates about ownership, identity, culture and politics in South Africa and can help us to retain memory, conflict and ambiguity. From the settlement at the Cape in the mid-seventeenth century, landscape was subject to tension, contradiction and contestation, not only through different claims on the land, but also in the types of representations through which the land was described and depicted. Landscape has therefore been forced to stretch and alter over time, from a representation of a harmonious natural world, dependent on pictorial illustrations and pastoral poetry, to a means to disrupt the stability of this image through 
political writing, performance poetry, and an emphasis on memory and personal histories. Its recent history offers a means to reimagine the South African landscape, not as a series of apparently stable, discrete, areas of land (both urban and rural), but rather as a connected site of complexity and ambiguity, where the construction of stability is rejected in favour of the uncovering of layered networks and meanings, which are embedded, one within (or over or beneath) the next.

The contemporary context is post-apartheid South Africa, where the image of the land and its inhabitants has been subject both to scrutiny and renewal, and where this process is still underway. While South Africa has had a democratically elected government since 1994, the decades of control by the National Party government, together with the centuries of white control before 1948, have meant that what is at stake in the transformation of South Africa is not only the physical form of the land and its inhabitation, but also the imagination of it and the way in which this will determine the choices that are made in South Africa's future.

Central to this reimagination and remaking is the issue of the land - how it should be inhabited, who should inhabit it, how cities should develop, how rural land is to be used and cultivated - concerns which exist alongside an awareness of the inequitable distribution of land in South Africa's past, and the need both to redress these imbalances and to re-present a different, more inclusive vision of what it may mean to be a South African. While the majority of studies of apartheid South Africa have emphasised political and social history, there is a developing interest in different forms of culture, representation, memory and identity in the post-apartheid years. ${ }^{3}$ These debates, as during the apartheid years, penetrate into political legislation, art works, literature, monuments, buildings and the spaces of everyday life. The construction of landscape is complex: spaces, buildings, land and boundaries are resistant to rapid transformations. The political and spatial practices that guided their making persist in the physical evidence that lingers, despite changes in political power. The landscapes of urban and rural areas are complicit in each other's making and imagination; they are connected by economics, politics and culture, and through the bodies of their inhabitants. In this sense there is no 'natural' landscape, untouched by physical alteration or a cultural 'way of seeing'. ${ }^{4}$

The term 'landscape' is used in order to identify physical places and representational forms in which social, cultural and political meanings are embedded and through which these meanings are communicated. It suggests a detachment and distance from the land into which cultural practices are inserted. The term 'land', by contrast, is understood in another way. It suggests a different kind of inhabitation, one which is not dependent on representation and in which direct and unmediated interaction with aspects of the natural world remains possible.

Landscape, as a word and a concept which puts land at a distance in order to look upon it, represent it and claim it, derives from European sources and does not therefore have an equivalent in traditional black society or language (although this is changing as people grow increasingly urbanised). 'Land' on the other hand can be described by a profusion of words, each one denoting a different type of land that 
is put to use in a different way. In a discussion that I had with a doctor of linguistics, Nhlanhla Thwala, ${ }^{5}$ he elaborated on the relationship between language, the body and the land, as well as how some of the ways of knowing and naming the land have been eroded as people move to the cities and relationships with the land have altered over time. For black South Africans, who still maintain (or remember) a close relationship with the land, the concept of landscape as land which is mediated by distance is an inversion of a different relationship of ownership - where rather than a person owning land, the land owns the person. In language the possessive term is inverted, which implies that a person is a custodian of the land and has a responsibility to care for it, while who they are is fundamentally connected with where they were born. In this sense death is a reclaiming of the body of the person back to where they ultimately belong, while having access to land is the equivalent of being alive. When a child is born its umbilical cord is buried adjacent to the family house, and when people die their bodies are traditionally returned to the same place, unifying birth and death through the earth. ${ }^{6}$

In Zulu, 'umhlaba' is the land and the earth, and different ways of naming the land through language refer to this root term. The naming of the land in different ways is related to its different functional values, which include not only productive use of the land for grazing or cultivation, but also sites of pleasure. While 'amathafa' is used to describe grasslands (a looser and less specific equivalent of the veld) and its meaning is tied to youth - to running free through open land - 'amathuba' describes vast areas of rolling hills and 'ukhahlamba' is used to describe both a sharp rise in land and the body of a huge person. The connection to the body in and within the land is therefore maintained through naming and language. While a series of words are used to describe different areas of land, put to use in different ways, the most important land traditionally is 'amasimu' - the land on which people subsist and which they cultivate. Land is described in terms of its fertility: 'umhlaba onothile' is fertile land, 'ugwadule' is barren land and 'inkangala' is treeless or featureless land. This vocabulary of the land was traditionally acquired by growing up within it, and Thwala makes a distinction between those who are born in the rural areas, who still actively use and understand this vocabulary, and those who are born in urban areas, who, while they may recognise the words, do not fully understand their meaning. He also points to an alteration in language, as the concept of looking at the land, and commenting on its appearance detached from use, is becoming increasingly widespread as people live remotely from the land and travel in order to look upon it as a landscape.

The concept of 'home' is also similarly mutating over time. While home, life and death would have previously occurred within the same land, now migration, urbanisation and the long-term consequences of apartheid policies have split and altered its stability. For rural-born people, Thwala maintains, 'home' remains where you were born (where your umbilical cord is buried), while other places are only where you live. For those born in urban areas, 'home' is where they live: it changes as people move. The forced removals, in particular, severed the traditional 
attachment with land and placed a new emphasis on housing, on finding a place to live in the land.

This overlap of urban lives and links to rural land means that personal identity may be described in different ways in different contexts and that a single person can feel themselves to be both urban and rural. Thwala tells of when he met Govan Mbeki (Thabo Mbeki's father and one of Nelson Mandela's colleagues and friends), who asked him who he was, at a party in Johannesburg. Thwala replied that he was head of the School of Literature and Language Studies at the University of the Witwatersrand, but Mbeki responded by saying, 'No, who are you? Where is your umbilical cord buried?' The sense that the connection to the land is something fundamental, and that the physical body is irrevocably tied to the land through birth, can therefore persist even with urbanisation and changes to the society over time.

In his inauguration speech, Mandela placed his emphasis on an uninterrupted (and natural) connection that exists simply between a human being and the land. In this understanding the land is available equally to all as a natural resource, a place of spiritual meaning. The tension between nature and convention that is implicit in landscape is also present in Mandela's account of the land. While he suggests a longing for land to be innocent, to offer unmediated natural pleasures, this longing is tempered by the awareness of its implication in political narratives. The violence that is acknowledged in his speech hints at the scale of the disruption of the natural inhabitation of a harmonious world and at the cultural and racial conflict which has marked South Africa's past.

Landscape is therefore an inevitable (if unspoken) presence in Mandela's speech and in the cultural and social history of South Africa. It is part of the narrative of colonial settlement, cultural displacement and political change. It is a primary concern here, however, to understand landscapes and their representations as both altering and being altered by their interaction with the South African land. Landscape is regarded as a means not only to attempt to bring the land within cultural and social convention and to within the dominant political vision of the twentieth century in South Africa, but also to record, disrupt and oppose this control.

Rather than focus on the certainties of landscape, this book offers an examination of uncertainty, false starts, contradictions and silences. It documents how the desire of twentieth century governments in South Africa, and particularly that of the National Party (who governed from 1948 to 1994), to present a seamless cohesion between modern political power and the natural world contributed to the violence, confusion and ambiguities of the contemporary landscape that Mandela describes. While representation is central to the presence of landscapes, representation and politics also fail to control the elusive meaning of the land. In these failures, through political and material changes to the land, and through the development of different forms of representation, an altered understanding of landscape can emerge. The conception of 'landscape' that emerges is therefore one which is subject to pressure and revision and which reflects changes in social and cultural meaning, as well as changes in political power, over time. 
There remains, however, in contemporary South Africa, a sense that the land (unmediated, untouched and natural) can still be a resource for a political reworking of the image of South Africa - a way to unify its different citizens, to connect body and nation, to enable a different conception of country and continent to emerge from the past that tainted it. In Thabo Mbeki's 1996 statement, 'I am an African', the bodies of its inhabitants are inseparable from the natural life of the African continent.

I owe my being to the hills and the valleys, the mountains and the glades, the rivers, the deserts, the trees, the flowers, the seas and the everchanging seasons that define the face of our native land...

The fragrances of nature have been as pleasant to us as the sight of the wild blooms of the citizens of the veld.

The dramatic shapes of the Drakensberg, the soil-coloured waters of the Lekoa, iGqili noThukela, and the sands of the Kgalagadi, have all been panels of the set on the natural stage on which we act out the foolish deeds of the theatre of our day.

At times, and in fear, I have wondered whether I should concede equal citizenship of our country to the leopard and the lion, the elephant and the springbok, the hyena, the black mamba and the pestilential mosquito.

A human presence among all these, a feature on the face of our native land thus defined, I know that none dare challenge me when I say - I am an African! ${ }^{7}$

Land and landscape therefore exist in apparently conflicting forms physical and imaginary, urban, rural and natural. However, these forms have been integrated and intertwined - images of an apparently natural world guiding decisions made about the inhabitations of cities, and desire for a particular (racially exclusive) urbanity directly affecting the inhabitation and imagination of remote lands. While partly dependent on physical places, landscape is also a product of representations, which are distant from the place that they present. The forced removals and dispossession of the land that occurred during apartheid have resulted in a splitting of the landscape, so that images of landscape and home are often dependent on memory, detached from the contemporary state of the physical place. Remaking the land can therefore become a kind of remembering, but a remembering which is increasingly forced to confront the physical traces of the past.

For William Kentridge, a contemporary South African artist whose work is often concerned with the representation and transformation of the land, it is the alterations to the landscape that structure its meaning and the sense that it is no longer innocent.

I had not seen a picture which corresponds to what the South African landscape feels like. I suppose my understanding of the countryside is an essentially urban one. It has to do with visions from the roadside, with 
landscape that is articulated or given a meaning by incidents across it, pieces of civil engineering, the lines of pipes, culverts, fences ... [l]t has become clear that the variety of ephemera of human intervention on the landscape is far greater than anything the land itself has to offer...

And a sense of space which has been acted upon, which is not as simple or bathed in grace as one would wish. ${ }^{8}$

Representations of the South African landscape are plagued by the notion of forgetting (Kentridge calls it disremembering, which emphasises forgetting as an active, rather than a passive process), of the understanding that the landscape seldom holds the impressions of, even very violent, events and inhabitations, and that the significance of these events is held within other forms of representation, and therefore remade, shifted, and even forgotten as they are represented. Because of the tendency of the land to forget the events of history, a space opens up between the land itself, and the reconstitution of its image over time that occurs in representations. Representation therefore offers not only the power to naturalise political change, but also to reremember, and to reconstitute in different forms, that which has been erased.

In contrast to the connectivity between land, the body and culture that existed before white settlement, the twentieth-century South African landscape has been represented by its inhabitants as becoming increasingly elusive, much in the way that the politics of apartheid appeared to outsiders. In one instance, an American visitor to South Africa described his search for political consistency as being frustrated by the lack of tangibility of the grand project of apartheid.

[My] quest across South Africa slowly turned into a search for a definition of 'big' apartheid, a coming to terms with it, and an attempt to judge its sincerity or falseness, its efficiency or applicability. But it seemed at every turn to become more elusive, more of a will-o'-the-wisp, vanishing just as I had thought I had seen its face. ${ }^{9}$

While the dominant political vision of the landscape offered a certain and secure destiny, this was undermined by the way in which both black and white people documented their relationship with the land. The decisions of those in power, seeking to control the image and the inhabitation of the landscape, had implications for the way in which it, in turn, was represented and understood. Representations and writings of the land produced by South Africans who were not classified as white under apartheid, including black, Indian and 'Coloured' South Africans, ${ }^{10}$ as well as white Afrikaans-speaking and English-speaking people, are placed together here. While the majority were produced during the twentieth century, a few examples from before this period are also discussed. The text examines how ideas about the landscape recur and transform through different representations and at different moments in time by examining physical sites and monuments, events and commemorations, newspapers, magazines, tourist brochures and ephemera alongside literature, oral histories, political writings and legislation. Illustrations are taken from contemporary photographs 
(including those published in magazines and newspapers), surveyed and popular maps, aerial photographs, magazine covers and advertisements, souvenirs, architects' drawings and models and photographs of physical constructions.

A distinction is made between representation - a visual, written or oral depiction or event which itself has political and cultural content - and image, a term which links to the imagination and therefore to ideas. While 'representation' is used to describe a particular object or event which exists in the material world, 'image' is used to articulate a composite of representations, experiences and beliefs which is held in the mind. Unlike representation, therefore, it is not used to refer to a single object but to a cultural perception, which may have visual and aural components, which is dependent on representation, but which also exists independently from it. The relationship between the image of the land and the imagination of it also hints at the possibility that the image of the land may be able to include conceptions and future possibilities which remain, as yet, unrepresented.

One of the issues in the research and writing has been the weight and proliferation of some types of representation and the lack of others. The dominance of white representations of the land is allied not only to the economic and political power that was wielded by both English and Afrikaans-speaking white South Africans, but also to the presence of landscape in cultures that had European cultural antecedents and to the perception that the representation of the land was central to claiming it. The existence or lack of representation is therefore in itself political, and is influenced both by cultural and social norms and by political restrictions and censorship. It is notable that, as black political resistance gained power and momentum during the twentieth century, the production of black representations of the land (primarily written or performed) increased. Through the different representational means that are used to describe and claim the landscape the way in which it is defined and understood alters.

The government crackdowns of the 1960s - on publications, individuals and organisations - that followed the violence of Sharpeville in March 1960, ${ }^{11}$ suppressed organised political dissent throughout this decade, and it was not until the early 1970s, with Steve Biko and the Black Consciousness Movement, that the silence was broken. Written representations of the 1970s and 1980s, particularly after the Soweto riots in 1976, registered that which was omitted and recorded the invisibility of people, places and texts that were repressed from popular representations. The power of government control of people and representations was extreme and pervasive. The control of the state acted not only to censor, but also to prevent production. It has also been argued that the National Party state destroyed enormous amounts of government material between 1990 and $1994 .{ }^{12}$

The twentieth century in South Africa was a period of intense political change: from the South African War between the British and Boer Colonies at the very beginning of the century; to the creation of the Union of South Africa in 1910; to the coming to power of the National Party in 1948; to the democratic elections in 1994 when the African National Congress (ANC) became the ruling party. Various conflicting 
narratives are therefore present, which entangle in the desire to claim and to 'know' the land. The control of the land was one of the primary means through which political power was gained and held, and its representation, as a landscape, is woven into the narratives which seek to claim it. The instability of political power, and the insecurity of the tenure of the land during this period, meant that the land was focused on not only as a physical place, but also as a means to naturalise political change and to bring the land within evolving cultural references.

The book is organised into five parts, each of which contain three chapters. Parts 1 and 2, 'Veld' and 'Farm', investigate the two 'dream topographies' that the South African novelist and critic, J.M. Coetzee, identified in his examination of landscape in white South African English-language literature, White Writing. ${ }^{13}$ The first 'dream topography' is that of an impenetrable and ancient landscape in which the bones of the dinosaurs were embedded; the second a patchwork of farms, 'koninkrykies' (little kingdoms) in which the pastoral and patriarchal life could be lived in solitary isolation. 'Veld' and 'Farm' are both a response to this highly influential reading of the landscape and an investigation, on southern African soil, of the traditional and recurring opposition between the wilderness and the garden.

The thematic landscapes of veld and farm were appropriated and included into the narrative of the volk and an identification with the land that remembered and reconstructed a particular vision of the past. They were used as the two primary concepts, which were perceived to establish a natural right to the land. They were perceived as 'natural' landscapes onto which the nature of the volk could be inscribed and which also became the landscapes upon which debates and resistance to the dominant political vision of the land were sited. The definition and representation of the veld was an attempt to bring the enigmatic wilderness under the control of the Afrikaner - its wildness both present and held at bay through the natural knowledge of the volk. The veld therefore was an interpreted wilderness, a means to argue that the plains of the interior were destined for the occupation of the Afrikaner and to familiarise the volk with the 'empty' landscape. In other representations, however, the veld emerges as an unstable image, one whose ownership is contested and whose boundaries are elusive.

The farm, as the equal and opposite image to that of the veld, is bound up with the identity of the Afrikaner as Boer, as farmer and therefore as 'natuurmens', living close to the earth and expressing his knowledge of it. It was this closeness to the land, the familiarity with both its wildness and domesticity, that was used to argue for the natural right to the landscape - the speaking of the land that resisted occupation. The knowledge of the land that was needed to farm, to turn the unyielding wilderness into productive farmland, was offered as proof of the intimate knowledge of the land gained by the farmer. The image of the fertile Boer farm was also used as part of a dual myth that split the landscape into a productive abundant nature, occupied by the white farmer, and the impoverished, overstocked land occupied by the black South Africans. The farm was, therefore, presented as an innocent form in which debates about race, use of the land, and society were embedded. This view of 
productive landscapes as the preserve of white farmers was entrenched in legislation and was also countered by black South Africans who were excluded from it.

Part 3, "'Native" lands', looks at the separation of the claim on the land into two 'natures' with two separate meanings for the word 'native'. While it was the Afrikaner claim to know the land from the inside, 'like a native', the nature that was claimed was one of an innate ease with the world that was quite different from the connotation of inferiority and primitivism that was called up by the use of the term 'native' to name a black South African. The bantustans were ethnically determined, fragmented and constricted areas of land which were allocated for the inhabitation and eventual 'political independence' of black South Africans, although this independence was a veil behind which a political and economic relationship with white South Africa continued. Part 3 is concerned with the direct association of land with identity, and the consequences of the freezing of its meaning and inhabitation in order to maintain a primitive landscape, outside of historical time in the bantustans and a modern, evolving landscape inhabited by white South Africans. It discusses the image that was developed of the bantustans, that of an untouched rural existence in a traditional landscape, and examines how it both masked a politically conservative system that supported the politics of the South African state and was challenged by other accounts of the landscape.

The segregated landscape was also a goal in the cities, and the final two parts - 'Invisible landscapes' and 'Erasures' - examine the implications of the myth of the segregated society in dense urban space. The National Party government operated as a modern state, which also sought to represent modernity as part of its mythology. Part 4, 'Invisible landscapes', discusses the consequences of the desire to separate bodies and the burgeoning fear that was concealed behind the innocence of nature. The city landscape is examined as a place of fear and uncertainty, where the strategic political use of the symbolic landscapes of the city in the separation of different races had implications for the form and meaning of the city and its inhabitation.

Part 5, 'Erasures', documents the repercussions of the forced removals of people and buildings for the way in which landscape is understood and how it is being reclaimed in contemporary South Africa. It examines the way in which the removals were directed and represented, the proposals for the transformation of both sites that were made by the government, and the significance of the way in which these sites are represented as part of an alternative political history of landscape. The appropriation and assimilation of 'landscape' and techniques of representation derived from the political and representational control of South Africa's recent past suggests that landscape continues to be interpreted and transformed through cultural and political change, and through representation. It traces the way in which significant sites of South Africa's recent past are represented, not only as part of the reclamation of the land by those who were dispossessed of it, but also in white writings of the land. The exploration of contradiction and damage that is inherent in the representation of the contemporary South African landscape confirms it as a 
transforming and contested site - both physical and theoretical - in which ambiguities and violence are present.

The theorist W.J.T. Mitchell has contended that landscapes are an implicit part of the imperialist project, marrying the narration of the 'natural' expansion of the 'civilised world' to the transformation and naturalisation of colonised territories. Although his view of landscapes as being inseparable from imperialism concludes that landscape in the European tradition is an 'exhausted medium', he concedes that this may result in its 'renewal' in 'other forms, other places'. ${ }^{14}$ This opening that Mitchell suggests in landscape, that it can become part of other narrations not conceived of by the imperialism with which he associates its meaning, hints at the possibility of its transformation and assimilation into the cultural history of those who have been exposed to its practices. An implicit part of this project is to examine how the understanding of landscape transforms in a context, which is inseparable from the narratives of colonialist power, but which also seeks to foster a cultural history that includes erased pasts.

Landscape in South Africa emerges as a way of seeing, understanding, claiming, narrating, representing and remaking land that is still evolving. It forms part of the contemporary struggle with the transformation and reconceptualisation of a place and a series of images which are simultaneously products of past practices and histories and the material which is being negotiated in the imagination and making of an altered landscape. 



\section{Part 1}

Veld 



\title{
Chapter 1
}

\section{Wilderness and veld}

\author{
The Child \\ [Extract] \\ The child is not dead \\ the child lifts his fists against his mother \\ who screams Africa shouts the scent \\ of freedom and the veld \\ in the locations of the cordoned heart. \\ The child lifts his fists against his father \\ in the march of the generations \\ who are shouting Africa shout the scent \\ of righteousness and blood \\ in the streets of his warrior pride \\ The child is not dead \\ not at Langa not at Nyanga \\ not at Orlando not at Sharpeville \\ not at the police station in Philippi \\ where he lies with a bullet through his brain. ${ }^{1}$
}

Nelson Mandela selected an extract from this poem by the Afrikaans poet Ingrid Jonker (1933-1965) for inclusion in his State of the Nation Address given to Parliament on 24 May 1994. ${ }^{2}$ The 'scream' of Africa and the 'shout' of the 'scent of freedom and the veld' were not used in Mandela's speech, perhaps because the 'veld', as an assertion of the power of Africa, is an uneasy presence in a narration of political reconciliation and celebration. Jonker is evidence of the complexity of Afrikaner identity: her opposition to mainstream politics, early suicide and the inclusion of her 
poem in Mandela's speech contradict the representation of unity, untroubled morality and racial segregation that marked the years of her life. Jonker's poem hints at a conflicted history, one in which the meaning and ownership of the land is ambiguous: the veld is resolutely African, a scream and a 'scent' from the massive, undivided continent. If the veld is the scent of Africa, it is indivisible from the land, it is a sensory perception of the land; a smell of the continent. The reclamation of the veld as part of Africa in Jonker's poem, in the aftermath of the massacres at Sharpeville in 1960, implies an awareness of an older literary history, within which the narrative of the Afrikaner's veld was constructed - one haunted by insecurity and silence - as well as much older occupations of the land.

The claiming of the veld as fatherland, which Jonker's poem defies, was dependent on prior representations of the South African landscape, which struggled to describe the immense and unfamiliar land and challenged by others, which maintained black knowledge and ownership. In some early colonial literature and maps the land remains enigmatic, imbued with the weight of erased creatures and histories. The landscape image of the veld, fostered in the early twentieth century, became a means through which the immense wilderness could be brought within white imagination, familiarised, and yet remain as part of Africa; fulfilling both the desire of the early white settlers to name the unbounded interior and to claim an intimacy with it that could displace its earlier inhabitants. The use of the term 'veld' therefore, in preference to 'wildernis' or 'woestyn' (wilderness or desert), signifies an alteration in its nature and meaning, which seeks to confirm both ownership and intimacy.

This chapter focuses on the development of the image and contradictions of the veld, its appropriation into the narrative of Afrikaner Nationalism and its elusiveness and ambiguity, principally through the examination of poems and novels. It argues that, while the naming of the land enacted a transformation of an unknown wilderness into a known landscape, the meaning of the veld, and its integration into the Nationalist narrative, retained elements of violence, disquiet and unease that resisted this transformation.

The landscape theorist K.R. Olwig has argued that the words 'landscape', 'nature' and 'nation' were implicated in each other's meaning and that a nation was initially constituted by the common identity of a people, rather than by the definition of a territory. Later landscape became identified with a particular people, who had participated in the cultivation (and therefore the transformation) of a particular place. Landscape was therefore defined as a place which had been 'put to use' by a nation. ${ }^{3}$ During the nineteenth century and particularly for the political and nationalist purposes of Germany, Olwig continues, landscape became defined as a 'natural' geographic territory. ${ }^{4}$ It was during the seventeenth century that landscape and nature were associated directly in the Dutch school of 'landskip' painting and from there that the term 'landscape' came to mean a pictorial view of nature. ${ }^{5}$

Olwig's analysis of the relationship between landscapes and national identity is one which has been picked up by others, identifying fear and a confined territory as the two fundamental requirements for the creation of a nation. Ernest 
Rehan emphasises that the remembered history on which the nation is founded is one which is incomplete because, '[f]orgetting, I would even go so far as to say historical error, is a crucial factor in the creation of a nation. ${ }^{6}$ While nations are dependent on the narration of a naturalised history for the consolidation of their identity, the history that they remember is only partial and is dependent for its success on this partial history. André Brink, a prominent South African author, has cautioned that the process of making history, as well as attempting to recover an erased past, is dependent on the recall of memories which are dependent on the imagination of the past and that this remembering is also inevitably an active forgetting, recalling: ' $[\mathrm{m}] \mathrm{y}$ memory is what I use to forget with. ${ }^{7}$

\section{The image of the veld}

Originally a Dutch word meaning field, country or countryside, in Afrikaans 'veld' describes a field, pasture, plain, territory or ground. It is therefore a term which was transposed from Europe to Africa and which incorporates the possibility of cultivation, ownership and national identity tied to the land. Although the veld is not usually regarded as a cultivated landscape in the European sense, it may be included within the boundaries of a farm. In South African botany the word is used to describe the different types of vegetation which occur in southern Africa. The map of 'Veld Types of South Africa (1951-1953)' (Plate 1.1) defines and maps a detailed taxonomy of the veld. It depicts the geographic area of the country as being covered by 71 different groups and sub-groups of veld, including: 'laeveld'/lowveld, 'bosveld'/bushveld (which incorporates 'suur bosveld'/sour bushveld, 'vallei bosveld'/valley bushveld, 'berg renosterbosveld'/mountain rhinobushveld), 'Westelike bergkaroo'/Western Mountain Karoo, 'Strandveld van Westelike kusstreek'/beachveld of Western coast, 'Suidelike langgrassveld'/Southern Long Grassveld and 'Namakwalandse gebroke veld'/Namaqualand Brokenveld. The mingling of different plants over different areas of the country (with varying physical features and climates) creates different areas with distinct characteristics and distinct and evocative names.

This density of botanical naming, the precision and layered suggestiveness of the terms on the map and the qualities that the repeated words invoke - sour, broken, thorn, rhino, sand - begin to build up an intricate image of the land, one characterised not only by dryness and harshness but also by profound differences and complexity, invoking a landscape unfamiliar to European eyes. The mapping of this surface of grasses, trees and shrubs is a demonstration of the control of and intimacy with the vegetation that cohered both with the goal of rational scientific modernity and a desire to claim the landscape through knowledge during the mid-twentieth century. The veld is named on the map in Afrikaans with English translations - with the exception of the 'Ngongoni veld of the Natal Mist-belt' no traditional names intrude onto the list. The pervasiveness of the veld is traceable in contemporary common naming of areas of the country in terms of broad botanical veld types such as: Karoo, fynbos, lowveld, highveld and bushveld. 
The botanical diversity of southern Africa that the map describes was, however, belied by the dominance of a single image of it emphasised during the 1930 s and 1940s. A proliferation of poems, songs, paintings and prose writing incorporated the veld into the narrative of Afrikaner history that was used to underpin political and economic claims on South Africa. In the majority of these representations, the veld is described as endless golden grasslands slowly waving under a cloudless blue sky. ${ }^{8}$

Despite the identification of the veld with the progress of Afrikaner Nationalism it continues to retain other conflicting meanings: a collective term for the diverse botany of southern Africa; a biblical homeland; a place of self-knowledge and fear; a place of danger and violence; an originary landscape inseparable from the rest of Africa and her people; and a place of ambiguous ownership and identity where the contradictions of the apartheid state found fertile ground.

\section{Dream topographies}

White English writing has been characterised by the struggle of writers to translate representational cultural codes derived from European conventions into a new, and often resistant, context. Writing about the landscape, rather than producing a pictorial representation of it, has been offered as a means to penetrate through pictorial conventions in order to uncover a more meaningful relationship with the land. J.M. Coetzee has argued that writers sought to overcome the convention of vegetation, ponds and lakes that were inherited from European models by focusing on the bareness of the South African landscape.

This geological turn to South African landscape poetry is particularly intriguing because of its claim that vegetation disguises the landscape, that traditional landscape art, the art of the prospect, is superficial by nature, cannot tell the true story of the land, the story that lies buried, or half buried, beneath the surface. The new landscape art, calling on old analogies between distance and superficiality, closeness and depth, thus becomes above all an art of deep reading; the painter skilled in the representation of superficies is set aside in favour of the poet with his penetrative divining art. $^{9}$

Coetzee has described South African colonial landscape literature of the nineteenth to the mid-twentieth century as, '[revolving] around the question of finding a language to fit Africa, a language that will be authentically African'. ${ }^{10}$ Language and traditional landscape imagery appear in English writing as an obstacle to the rendering of the unfamiliar territory. The two recurring 'dream topographies' of the southern African landscape that Coetzee identified - the impenetrable wilderness and the familial farm kingdom - are reconciled through the presence of the veld in the farm. Coetzee argues that 'white writing', when viewed collectively, is plagued by doubts and insecurities. $\mathrm{He}$ records the inability to reconcile a cultural dislocation from the land with the desire 
to know it and argues that the false starts, conflicts, ambiguities and silences that mark the texts demonstrate the struggle with the land, and its inhabitants.

Coetzee's 'dream topography' of the ancient land emphasises the stony fossilised landscape of the Karoo - the geological landscape of rock, stone and dinosaur fossils - as detailed in the work of Olive Schreiner (1855-1920). Schreiner was a celebrated South African writer and proponent of women's rights. In her writing the 'true' southern African landscape is bare, stony, ancient and impervious to human settlement - almost naked. It is not clothed with a civilising veneer of plants and flowers.

The hostile ground of the Karoo which figures strongly in writing of the nineteenth and early twentieth centuries was gradually supplanted during the twentieth century by an emphasis on the vast savannah grasslands of the interior Boer Republics of the Transvaal and the Free State. The politicising of landscapes of the highveld and lowveld in particular was instrumental in both simplifying and reducing the complexities and ambiguities of the dream topographies that Coetzee describes and also in shifting the focus onto a specific geographical area. ${ }^{11}$ While Coetzee's study emphasises the struggle of white writers to describe the landscape, and of the failure and doubt that plagued their efforts, the poets, writers and leaders of Afrikaner nationalism often relied rather on an assertion of intimacy with the land. In the process the veld became a landscape which was characterised by its ability to receive and be distorted by the narrative of the Afrikaner nation. The complexity of the land and the lives of its inhabitants were predominantly represented not as a struggle of many histories, but rather as a seamless and coherent narrative in which contradiction was suppressed and the presence of other claims on the land denied.

It is the question of 'closeness' to the land that is critical to both politics and literature. Writing, drawing and narrating the land are indicative of a relationship that inevitably implies distance and estrangement. The Afrikaner political narrative attempted to disguise and confuse these contradictions of land, representation and landscape: claiming the land through the representation of the landscape as a medium in which nation and land are unified.

\section{Self-knowledge and the veld}

The novel for which Schreiner is best known, The Story of an African Farm (1883), describes a farm in the Karoo and the lives of people who live upon it as fragile and dystopic, played out on an immense and unknowable landscape. The farm is sited on a 'wide lonely plain', with 'a coating of stunted karroo bushes, a few inches high'.12 Of the characters who live on the farm, none are represented as being closer to the land than Waldo, the son of the German overseer, who spends much of his time alone in the veld.

[I]t seems that the stones are really speaking - speaking of old things, of the time when the strange fishes and animals lived that are turned into 
stone now, and the lakes were here; and then of the time when the little Bushmen lived here, so small and ugly, and used to sleep in the wild dogs holes, and in the 'sloots' [a dry watercourse] and eat snakes and shot the bucks with their poisoned arrows...

Now the Boers have shot them all, so that we never see a yellow face peeping out amongst the stones...

And the wild bucks have gone, and those days and we are here. But we will be gone soon, and only the stones will lie on here, looking at everything like they look now. I know that it is I who am thinking, . . but it seems as though it were they who were talking. ${ }^{13}$

The stones, imprinted with ancient fossilised remains, recall other, older, inhabitants. The Story of an African Farm seems to suggest that the narration that occurs in the novel is only one version of an infinite number of inhabitations and erasures. The Karoo in Schreiner's novel is a place outside of time. It is silent, but the silence is full of other histories and other creatures. Schreiner also connects the 'emptiness' of the landscape to the eradication of the 'Bushmen' by the guns of the Boers. The inhabitants of the landscape are themselves therefore agents in the erasure of others.

The desert of the Karoo functions not as a tabula rasa but as a place of continuous erasure, where only the fossils and the rocks withstand time. The hostility of the desert veld to dense botanical growth is analogous to its hostility to human occupation. The vacant landscape is not neutral, just as emptiness and omissions in maps are not neutral. Waldo's empathy with nature allows him to give voice to the history of the landscape and allow the stones to speak through him. In Schreiner's Karoo, civilisation is an impediment to a deep understanding of the qualities of the land. Waldo's narrative, although containing elements of violence, has a kind of inevitability about it, as though the stones and the land remain unscarred by the actions of the humans that skirt across its plains. The veld is represented, in common with other wilderness landscapes, as a site where self-knowledge can be gained, and contemplation of the human condition is possible. The effects of this knowledge may be liberating or terrifying.

One day we sit there (beyond the kopje) and look up at the blue sky . . . and suddenly it strikes us, Who are we? This I, what is it? We try to look in upon ourself, and ourself beats back upon ourself. Then we get up in great fear and run home as fast as we can. We can't tell anyone what frightened us. We never quite lose that feeling of self again. ${ }^{14}$

In the novel the encounter through which an individual is brought to self-awareness in the desert landscape is not a reassuring one. The veld is revealed as a place of fear, not of peaceful contemplation. Schreiner's writing deals with the futility of the desire to know the land, and the overwhelming power of its past. She also wrote at a time where political tensions had not reached the height of the mid- 
twentieth century - when the narrative of the veld was used to attempt to sustain the perceived unity of the Afrikaner nation in a context of increasing white and black urbanisation and political discontent.

Herman Charles Bosman (1905-1951), in contrast, was active during the 1930s and 1940s, when Afrikaner Christian Nationalism was gaining political prominence. Bosman was a Cape Afrikaner, who is famous in South Africa for his eccentric and carefully observed tales of rural Afrikaner life, told as short stories and novels. He was also a poet and a prolific literary critic. ${ }^{15}$ In Willemsdorp, written at the end of the 1940s, Bosman explores, through the minutely recorded interactions of individual characters, the claims made for the land and the violence that is a result of the transgression of artificial political, social and racial boundaries. As it was for Schreiner, the veld surrounding Bosman's highveld town is a place of self-knowledge together with unease, uncertainty and fear. Here, however, the confusion and violence which emerges as the novel unfolds are complicated by the certainty with which his characters describe the veld as a landscape 'understood' by the Boer.

We Afrikaners have got everything ... We've got a feeling for the country that is part of our blood. I can pick up a clod of earth, red Transvaal earth, between my fingers and crumble it. Where's your intellect and economics then? What I feel about that handful of soil is the guts of a nationhood. What English-speaking South African has got that? It is only we Boers that have got it. ${ }^{16}$

Through the series of events that unfold in the novel Bosman poses a series of questions about the veld, its boundaries, race and ownership. In the extract, Bosman emphasises the deliberate omission of black South Africans from the claim on the land, which is reduced to a contest between the Boers and the English. In Willemsdorp the veld is a place of instability, where the potential for violence is present under the surface of the golden grasslands and in the conflicting lives of the people who inhabit the land. Bosman's white characters are constantly negotiating their own identity, both with the landscape and with the black and 'Coloured' inhabitants, who live beyond the boundary of the white town, within the physical space of the veld. The open, vacant and uncultivated strip of land between white and black is represented as an almost insurmountable boundary to the town's white citizens; functioning as a one-way filter - blacks crossing routinely into the white town of Willemsdorp to sell their labour, whites compelled only by extreme circumstance or desire to bridge the same divide. Crossing into the veld from the town to its township is a transgression of societal norms: it both reveals the echo of a much deeper fear; that the land belongs to the shadowy, almost silent black presences in the veld; and that the boundaries between bodies and races are not as impermeable as they may first appear.

Charlie Hendriks, the main protagonist in the tale, is an Afrikaner from Johannesburg, estranged from the 'deep' knowledge of the land that is his presumed heritage by his years in the city. Hendrik's desire to draw closer to the land, to reclaim 
his birthright, is paralleled by his sexual desire for a black woman who lives outside the limits of the town. By moving out of an urban environment (and its veneer of civility and cultivation) into the place of the veld, Hendriks exposes himself to the innate contradictions of the politics of racial division of the land.

And suddenly Charlie Hendriks grew frightened. In the air he breathed there seemed to be the smell of blood but what frightened him was not the veld's blood smell. It seemed like a very ancient fear, something he could not define. The leaves of the prickly pear seemed ancestral. The fragments of weathered cowdung were timeless. The anthill had always been there, and it had always been that shade of grey. The weathered cowdung was more primeval than the Triassic rock that had been exposed by the cutting. About the anthill there was a vast antiquity that went beyond all geological reckonings. The prickly pear seemed alive in an awful whilom sense, ${ }^{17}$ in that aeons ago it should have been extinct...

All the same, the feelings that Charlie Hendriks experienced during those few moments in which he had found himself in the opening in the bush were in fact of a very commonplace order. Indeed, you can't, anywhere in the bushveld, turn away off the road and go a few yards into the bush and not get those feelings...

The name the old wise Boer applies to it is 'Ouma-bangheid' - fear of your grandmother - implying thereby that it is a terror not rooted in modernity, but that it is something going back pretty far.

But if that same old Boer has taken to you, he will also try and put you right, winking as he delivers himself of his statement. Why you get frightened, he will tell you, is because in that narrow opening in the bush, cut off from all human companionship, you actually meet yourself. You encounter yourself face to face, the wise old Boer will say, and before God, is not that the most frightening and spine-chilling meeting that any man can have. ${ }^{18}$

Unlike Waldo, in The Story of an African Farm, Hendriks is vulnerable to the bushveld and its inhabitants and is led by both ignorance and desire. He has become detached from the land, and is therefore unacquainted with its power. Bosman's text assures us that the 'old wise Boer' could put him right, but the sinister aspect of the veld and its potential for violence is a theme which saturates the novel.

The violence is a consequence not only of a man brought into confrontation with his deepest nature, but also of the contradiction between claiming ownership of the veld through the denial of its inhabitants and the recurring desire for the body of a black woman, who represents an elusive and mesmerising Africa. The edge of the veld is the supposed boundary between white and black (and the people of mixed race who are the physical evidence of their forbidden unions). This thickened boundary, and the almost inevitable transgression of it by Charlie Hendriks, results in the eruption of violence in the veld that this extract promises. 
Mhudi, completed in 1920 by Sol Plaatje (1876-1932), the missioneducated, founder member and first Secretary General of the African National Congress, offers a portrait of the innate connection between Mhudi, a Barolong woman, and the land. Published ten years after its completion, in 1930, it is the first novel in English written by a black South African. The scope of Plaatje's literary interests is demonstrated by the fact that he translated several of Shakespeare's plays into Setswana, wrote the first Setswana phonetic reader and collaborated on a book of Tswana proverbs. Mhudi is a hybrid of oral tradition, an English literary form and imagery (including 'landscape' and 'view') and fragments of Afrikaans. It seeks to recreate an image of a complex and sophisticated tribal society at the moment in which its destruction becomes inevitable, and also uses English language conventions and meanings to describe the landscape and the motivations of its characters. The novel is set in the early nineteenth century, and documents both the violence of the wars between different tribes and the coming of the Boers, through the lives of its two principal characters - Mhudi (strong, beautiful and fearless) and Ra-Thaga (brave, proud and trusting). 'Veld' never appears in the book: Plaatje's word for the uncultivated and ungrazed land in which wild animals live is 'wilderness'. Wilderness in the novel is a state of the land that does not necessarily denote an unfamiliar place: it is both unbounded territory, which is used for hunting and gathering herbs and collecting water by overlapping tribal groups, and a name for unknown and remote lands.

The novel emphasises Mhudi's thoughts, actions and wisdom, creating a portrait of a sophisticated tribal woman who is both at ease with herself and the land and who senses the threat that the Boers represent. The land that Mhudi travels over and settles within is unbounded, although sections of it are more familiar than others. Ra-Thaga and Mhudi, initially unknown to each other, meet in the wilderness after the attacks on their cities by the war-like Matabele tribe. Mhudi tells her story to Ra-Thaga and her words integrate fragments from European vocabulary with her experience of the land.

One day I decided to walk along the stony slope to the summit of a kopje at the far end of it . . I couldn't tell what part of the world that was, but when I reached the summit, a wide stretch of country was exposed to view and the sight of the outer world fascinated me immensely. Emerging from my limited outlook of many days in the ravine, where only the music of the birds could reach my ears, the sight of the extensive landscape was like being born afresh. The succession of wood and clearings, depressions and rising ground, with now and then the gambols of a frisky troupe of gnu among the distant trees, where the woods were less dense, refreshed me for I had never seen the world to such perfection ...

I enjoyed the refreshing view for a time, although haunted by fear in my loneliness, then I retraced my steps and wandered back to the ravine where there was food and water... 
My only living friends were the turtle doves whose language I almost thought I could understand. I think if this solitary existence had been extended by another month, I should have been able to sing their songs and learn to converse with them. ${ }^{19}$

Mhudi's description of the land is complex in terms of its meaning and antecedents: she both lives comfortably within the wilderness and looks upon it as a landscape when viewed from a height. Mhudi does not experience the rush of selfknowledge, the fear of God or oneself, which is triggered by solitary encounters in the veld in colonial writings: her only fear in being alone is that she may be attacked by a wild animal or a Matabele warrior. The wilderness is rather a haven, a language that she could learn to speak fluently, like that of the turtle doves. Later in the novel, when in search of Ra-Thaga far from their home, Mhudi recalls the known and named wilderness.

Mhudi missed the forests and the cooing of the wood pigeons of Bechuanaland. She missed the compact Mokgalo and Mogonono trees, the leaves of which had provided her with excellent awning when it rained, by day or night; and longed for the leafy undergrowth which, during her early wanderings, had shielded her from the cold winds. ${ }^{20}$

In Mhudi the couple create a home in the unpopulated wilderness, which, when back in civilisation later in the novel, Ra-Thaga nostalgically recalls in rhyming verse and vocabulary reminiscent of the English poems learnt in mission schools.

Speak not to me of the comforts of home

Tell me of the valleys where the antelopes roam;

Give me my hunting sticks and my snares

In the gloaming of the wilderness;

Give me back the palmy days of our early felicity

Away from the hurly-burly of your city

And we'll be young again - Aye:

Sweet Mhudi and $1 .{ }^{21}$

\section{The veld and biblical landscapes}

The desire to understand the fear that comes from solitary encounters with the land, or at least to attribute the disturbing nature of the land to a familiar belief system, is present in analogies made in white southern African writing between the land and biblical landscapes. Thomas Pringle (1789-1834), a Scottish poet and journalist who arrived in South Africa with the 1820 settlers and stayed for six years, found in the biblical analogy relief from his search for familiar landscapes in the strange and naked land.

In writings and poems the vast emptiness of the wilderness is represented as a place where a single human can find a degree of self-awareness not possible 
in inhabited regions. This contemplation is possible only because the landscape itself is perceived to be naked and empty; therefore meditations on an individual existence do not have to find resonance with the markings and alterations of others. It is therefore precisely the fact that the landscape is resistant, to European conventions of inhabitation and alteration, that allows Pringle and other writers to imagine that the experience that they themselves have is a primary one - one that is raw, naked and authentic. The desert is represented as being not a place without time, but a place that resists the markings of time. In the imagined closeness of the landscape to its origins in prehistory, and the lack of a filter of cultivation, religious Europeans could imagine themselves closer to God.

\section{Afar in the Desert}

\section{[Extract]}

Afar in the desert I love to ride,

With the silent Bush-boy alone by my side:

Away - away in the wilderness vast,

Where the White Man's foot hath never passed,

And the quivered Coránna or Bechuán

Hath rarely crossed with his roving clan:

A region of emptiness, howling and drear,

Which man hath abandoned from famine and fear;

Which the snake and the lizard inhabit alone,

With the twilight bat from the yawning stone;

Where grass, nor herb, nor shrub takes root;

And the bitter melon, for food and drink

Is the pilgrim's fare by the salt lake's brink:

A region of drought, where no river glides,

Nor rippling brook with osiered sides;

Where sedgy pool, nor bubbling fount,

Nor tree, nor cloud, nor misty mount,

Appears, to refresh the aching eye:

But the barren earth, and the burning sky,

And the blank horizon, round and round,

Spread - void of living sight or sound.

And here, while the night-winds round me sigh,

And the stars burn bright in the midnight sky,

As I sit apart by the desert stone,

Like Elijah at Horeb's cave alone, ${ }^{22}$

'A still small voice' comes through the wild

(Like a father consoling his fretful Child),

Which banishes bitterness wrath and fear, -

Saying - MAN IS DISTANT, BUT GOD IS NEAR! ${ }^{23}$ 
There are a number of recognisable images of the land in this extract, and in the poem, that are also present - politicised and mutated - in the representations produced by Afrikaner writers and political activists in the twentieth century. The power of the myths of the land that were used to justify and drive the political claim on South Africa was, at least in part, due to the pervasiveness of images of the landscape that had recurred during the centuries of white settlement. In Pringle's epic poem the land is empty, both of white men, and of black inhabitants (with the exception of Pringle's 'Bush-boy'), it is dry and hostile, and it is 'not Europe'. Schreiner, resonating with Pringle decades later, describes the activity of reading the Bible outside the protective buildings of the homestead, beyond the 'kopje' (a small rocky hill). She, too, reads 'the story of Elijah in his cave at Horeb, and the still, small voice'. ${ }^{24}$ For Schreiner, though, a solitary person in the undifferentiated wilderness is forced to examine him or herself rather than God, and the seeking of comfort in an ecclesiastical presence may just be a symptom of confusion and a desperate desire for reassurance in the face of the unknown.

While a number of white South African writers have struggled with insecurity, unfamiliarity, hostility and the absence of a language to describe the veld, in the early to mid-twentieth century Afrikaans poems and prose claimed a more secure and stable relationship with the land. Benjamin Akzin has argued that the development of a national literature is implicated in the way in which other nations (typically defined by race) are regarded and treated.

A significant trend in the literature of the last [nineteenth] century is that which strongly affirms the superiority of the author's own... nationality over all others, or at least over some other. Awareness of one's belonging to a given nationality and a purposeful self-identification with it (the so-called national consciousness) are intensified in this trend to the point of transforming the alleged superiority, and the other nation's alleged inferiority, into a major belief which is used to justify the application of radically different standards to their respective needs or claims. ${ }^{25}$

He continues later that the birth of nationalism is linked to a perception of difference and to a 'tension', which is itself generated from 'a territory claimed with some reason as the historical habitat, or the homeland, by more than one nationality'. ${ }^{26}$ In these terms it is the presence and claiming of the land by black South Africans that sparks both Afrikaans nationalism and its national literature.

\section{Veld as fatherland}

\section{Dis Al}

Dis die blond, dis die blou: dis die veld, dis die lug;

\section{That's All}

Gold,

blue:

veld,

sky; 
en 'n voël draai bowe in eensame vlugdis al. ${ }^{27}$ and one bird wheeling lonely,

high-

that's all.

Jan Celliers (1865-1940) was one of the founding fathers of Afrikaans poetry and among the first to establish the language conventions with which the veld was described. His poetic invocations of the interior grasslands of southern Africa remain powerful for their simplicity of language and clear imagery. As has been noted, in much Afrikaans poetry the lens through which the complex botany of the veld is viewed is narrowed so that the emptiness, silence and vastness of the interior plains are emphasised - rippling gold grasses against a blue sky. Through the work of the early Afrikaans writers, the strange and unfamiliar wilderness, occupied by wild creatures, and resistant to inhabitation and cultivation by the settlers, yields and transforms into a clear image of the veld. The power of the veld in Afrikaner myth is the perception that its 'natural' wildness itself naturalises the Afrikaner claim on the land. In reality much of the veld has been so altered by human occupation that its naturalness, and through this naturalness a connection to a time before human inhabitation, represents a desire for untouched nature, rather than its presence.

The focus on the grasslands of the interior was dependent on the construction of an Afrikaner narrative in which the Great Trek became the central event around which national consciousness was rallied, mythologising the rather sporadic and disorganised departure of a number of Boer families from the Britishcontrolled Cape, in the 1830s and 1840s, into a great sweeping exodus into the 'vacant' interior which stood for freedom, and against the restrictive injustices of Imperial rule. This migration was at least partly motivated by the formal end of slavery, ${ }^{28}$ and the fact that, under Ordnance 50 of 1828 , every person, regardless of race or religion, was regarded as equal under the law. ${ }^{29}$ The centenary (Eeufees) of the Great Trek was celebrated in 1938, while, in 1949, the Voortrekker Monument, erected to commemorate the actions of the trekkers and the future of the volk, was inaugurated.

\section{Die Lied van Jong Suid-Afrika The Song of Young South} Africa

En hoor jy die magtige dreuning? And do you hear the mighty roar?

Oor die veld kom dit wyd gesweef Over the veld it comes widely sweeping,

Die lied van 'n volk se ontwaking The sound of a volk's awakening

Wat harte laat sidder en beef, Which makes hearts shudder and quake,

Van Kaapland tot bo in die noorde, From the Cape to far in the north, Ruis dawerend luid die akkoorde: Sound thunderously loud the chords: Dit is die LIED van jong Suid-Afrika. It is the SONG of young South 


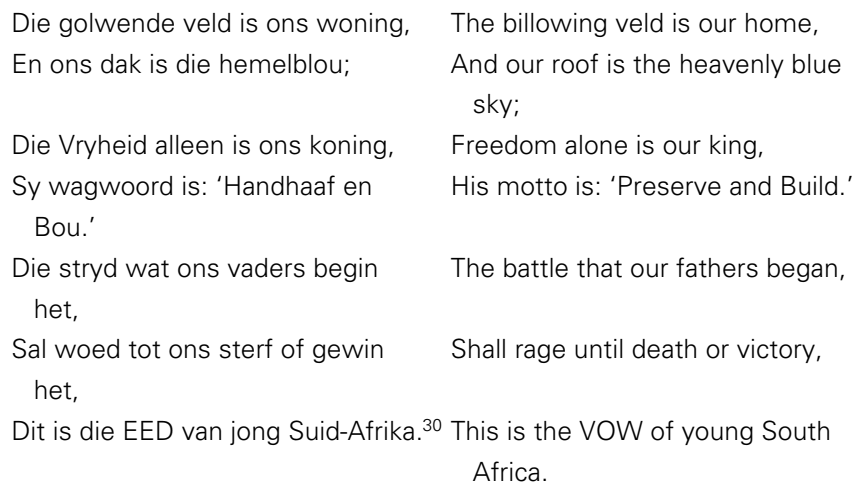

This song, sung as part of the festivities in 1949, celebrates the transformation of the once unknown interior into the veld: heartland of the Afrikaner volk, which resonates with the voices of the young awakening nation.

The significance for politics and national identity of the creation of an Afrikaans literature in the early twentieth century cannot be overestimated. Writing in Afrikaans, as opposed to Dutch or English, was seen as essential to the national consciousness of the volk and was itself a political act. The South African War (1899-1901) polarised English and Afrikaans-speaking South Africans and consolidated a history of oppression of which the Great Trek was seen to be a part. ${ }^{31}$ This war, named the Tweede Vryheidsoorlog (the Second Freedom War) by the Boers, accelerated the consolidation of Afrikaner (as opposed to Boer) identity. The First Freedom War (1880-1881) was symptomatic of the anti-English sentiment and rising Afrikaner Nationalism, and was roughly contemporary with the formation of the GRA (Genootschap van de Regte Afrikaners/Society of True Afrikaners) by a small group of Afrikaner intellectuals, in Paarl in the Cape in 1875. The group was instrumental in the creation of a unified Afrikaner culture that sought to unify language, literature, landscape and history. The writing generated in response to the philosophy of the GRA was called the Eerste Taalbeweging (The First Language Movement) while the proliferation of Afrikaans writing at the beginning of the twentieth century was named the Tweede Taalbeweging (The Second Language Movement), directly associating the development of the Afrikaans language with the two freedom wars. This fledgling culture, of freedom, land and language, was used to argue for the fulfilment of a national destiny on South African soil.

Afrikaans literature and the use of Afrikaans as a professional and cultural language is almost entirely a product of the twentieth century: Afrikaans was recognised as an official language only in 1925. The dominance of the Great Trek narrative during the same period meant that it provided many themes to the burgeoning body of work. In Die Voortrek, P.J. Nienaber asserts:

In our literature we shall recover the history of our volk, because the themes are influenced by the character of the volk. A poet or a writer 
depicts the spirit and will of their volk in their work. Literature belongs to the culture of a volk, it is an expression of it. ${ }^{32}$

The colours of gold grasses and blue skies provided a pure image that could readily provide a virgin land for occupation by the Voortrekkers. In the publications produced at the time of the 1938 Great Trek re-enactment the veld retained fragments of the enigmatic wilderness, its hostility and harshness, but was depicted as being known and understood by the Afrikaner who was its native son.

\section{Die Dieper Reg}

[Extract]

Hul is die mense wat ' $n$ land gekry het wyd en oop en mooi: vol donker glans van blad en druif en sagte reën; vol bitter brand oor dorre vlaktes; winters wit van gras en horison en lug; groot-skoon, maar hard en houtig soos

die skamele granaat se vrug.

En deur dié land het hul gegaan Steeds verder in die vreemde in, ... gesoek

of êrens nog kon ruimte wees

en vryheid in die wildernis.

O, wye en droewe land, alleen onder die groot suidersterre. [. . .] Jy ken die pyn en eensame lye

van onbewuste enkelinge, die verre sterwe op die veld, die klein begrafenis. ${ }^{33}$

\section{The Deeper Right}

They are the people who found a land wide and open and beautiful full of dark gleams of leaf and grape and soft rain: full of bitter fire over dry plains: winters white with grass and horizon and light; vast-beauty, but hard and woody like the meagre pomegranate's fruit.

And through this land they went Still further into the unknown, ... searched

if somewhere there could still be room

And freedom in the wilderness.

$\mathrm{O}$, wide and mournful land, alone under the big southern stars. [. . .]

You know the pain and solitary suffering of those who are solitary innocents, the far off death on the veld, the small burial.

In N.P. van Wyk Louw's (1947) play, Die Dieper Reg (The Deeper Right), the Voortrekkers are judged by God. Van Wyk Louw (1906-1970) was one of the most significant and influential poets and intellectuals of his generation, particularly because of his clear articulation of the connection between the Afrikaans language and the land. In the play of which this is an extract, the Voortrekkers beg to be remembered and plead with God that the veld does not return to silence on their passing. The suggestion is that the veld has found its voice through the lives of the trekkers, as much as they found their fatherland in it, and that the land acknowledges and is a witness to their suffering. 
The fear (common to colonial writing) that the actions of any human in the southern African wilderness will always be erased haunts the play, despite God's assurances that they do have a 'Deeper Right' to the landscape. By travelling over, and dying, on the distant grassy plains the Voortrekkers claim the right to name the land and to describe it. The narratives of the South African War in particular linked 'Blood and Soil' in an association familiar from the 'Blut und Bogen' of German Nationalism. The myth of the Voortrekkers is dependent on a mutation of the wilderness, from an impervious landscape to one that does not repel those who have earned the right to occupy it. By articulating its harshness and hostility to humans, yet arguing that it has a ripe and fruitful core, they demonstrate that they recognise the 'real' landscape and know how to cultivate it. The anxiety of erasure, however, is palpable and it is in this fear that the play connects to a history of landscape writing that fails to find resolution, and is less convinced of the certain right to inhabit the land.

While the physical similarity of the Karoo desert to the deserts of the Middle East allowed some southern African writers a welcome formal precedent in biblical landscapes, the story of a 'Chosen People' led through the desert into the land of milk and honey resonated with the political ambitions of the Afrikaner political leaders in the twentieth century. The highveld and lowveld took on the attributes of the 'Promised Land' because of the perceived similarities of the Voortrekker narrative with a biblical tale that told of an oppressed people led by God's hand into a land where they could flourish. The colonial belief (derived from the Bible) that black people were the sons of Ham, and therefore destined to be servants, similarly cohered with the claim on the land by white Afrikaners.

An extract from Celliers' poem, 'Die Brand' (The Fire), which describes the sweeping of the bitter winter wind, indicates that the deaths on the veld were not just the result of wars with black tribes but also the deaths of almost 27,000 Boer women and children in British concentration camps during the South African War. (The deaths of more than 20,000 black South Africans in British concentration camps have only recently been widely acknowledged.) The bodies of the women and children, so significant in the domestication and transformation of wilderness into veld, lie beneath the surface of the land. The scorched earth policy of the British - the destruction of Boer crops and livestock - threatened the ability of the veld to withstand the encroaching wilderness, but the suffering in the burnt landscape, and the presence of the women and children's blood and bodies within it, both confirms ownership of the land and provides a motivation to overcome the political and economic hegemony of the English.

\section{Die Brand}

Hy kom oor velde ver en wyd, oor grafte in hul eensaamheid, waar moeders van hul sorge rus, waar kindersnikkies is gesus dit is die lied van die eensaamheid hy kom oor velde ver en wyd. ${ }^{34}$

\section{The Fire}

He comes over fields far and wide, over graves in their loneliness, where mothers rest from their cares where children's sobs are soothed -

this is the song of loneliness he comes over fields far and wide. 
The South African landscape acquires, sheds and simultaneously maintains sometimes contradictory male and female genders, which are also associated with bodies of different nations and races, in different writings and representations. The claiming of the veld as fatherland associates South Africa with the bodies of the white male trekkers and Boer fighters and separates it from Africa - it is active, male, modern and directed towards a progressive scientific future, but the claim is also supported by the white female bodies (wives and mothers) who died and are buried in it. Alongside, and sometimes within, this characterisation of the land, Mother Africa, as a whole and undivided continent, fertile, nurturing and dark, like the skins of its women, persists. As is evident in Willemsdorp, in twentieth-century writing the desire of white men for the land is often associated with a desire for the bodies of its women.

The veld was a powerful image in the political narration because it both retained the appearance of nature - not presenting a formal rupture in the enduring myth of timeless, vast Africa - and also brought the wilderness under the control of the Afrikaner, who was presented as its natural heir. It was a landscape apparently not mediated and altered through cultivation. However the veld, particularly in political writing and poetry of the early twentieth century, undergoes a fundamental alteration in its value as a natural landscape. The political power of the veld resides in its representation as a virgin land, a physically and historically undifferentiated field, which receives the narratives of Afrikaner history, and is altered by them. Rather than remaining inscrutable and impenetrable to human narration, the veld is represented as being known 'from within' by the Boer and their descendants. This intimate knowledge of and closeness to the land becomes part of a political and historical narrative, which underpins future economic and political goals. The narration of the Afrikaner occupation of the land as national fatherland 'speaks' and gives form to the vast grassy plains of the interior landscape. The threat in the landscape remains, however, as an undertone in political narration - in the repeated denials of black history and the depiction of an empty, silent land.

\section{Fear and violence in the veld}

During the decades of National Party rule the veld became the site of politically sanctioned violence. The relative emptiness of the veld offered a vastness in which the secret activities of the state could be carried out, and the bodies of political dissidents could be concealed. During the writing of her report on the Truth and Reconciliation Commission, ${ }^{35}$ Country of my Skull, ${ }^{36}$ Antjie Krog (herself an Afrikaner poet attempting to come to terms with the violence of the political history of South Africa) periodically returns to the farm of her childhood, where her brothers and parents still live. Her image of the South African landscape is of the paradise garden of her youth, yielding fruits, meat and milk in response to care. In Country of my Skull Krog evokes the smells, textures and colours of the landscapes of veld and farm. Even the desert can bloom. When she writes of the land it is with passion and empathy and intimacy. It is part of her identity, one of the reasons she believes that she could 
never live anywhere else other than South Africa. For Krog the land is a nurturing presence, one to which she must retreat when the violence of the testimonies of the survivors of apartheid torture becomes too much to bear.

During the hearings of the Truth Commission, she hears testimony of one of the members of the elite South African Vlakplaas (literally 'flat' or 'level' farm) police unit that 'missing activists were tortured, killed and buried on farms all over the country. ${ }^{\prime 37}$ Her landscape refuge is complicated by the haunting spectre of death. The memory of nature as a nurturing environment concealed both the violence of its colonial past and the recent, more violent, past of National Party rule. The land which is the battleground of power also becomes a place of terror. Evidence presented to the Truth and Reconciliation Commission confirmed that activists who resisted the policies of the National Party were routinely taken into the veld, murdered, and their bodies interred there. In being forced to confront the evidence of death Krog is shaken with internal conflict. If the place which she identifies with, which is a source of strength for her, was also the place of death for those who resisted Afrikaner Nationalism, then is the land itself corrupted by the actions of those upon it? The veld of apartheid held up the innocence of nature behind which violence could be concealed, creating a place in which comfort is complicated by violence and blood.

The knowledge of the violence that occurred within the veld permeated through South Africa. This awareness contributed to the meaning of the landscape, which was bound up with the clandestine activities of the secret police units. In the following poem, the veld appears as a sinister incarnation of the apartheid government, a place inseparable from its identity and actions.

\section{In this World, my Sister}

\section{[Extract]}

Then I will start my march

Until I cross the River Congo

And if not dead with fatigue

I will reach Cameroon

To meet Mbella Sonne Dipoko ${ }^{38}$

I want to meet him and ask

If he knows what they do in the veld.

[...]

And I will ask them

If they know the veld

I want to tell them

That there

Baboons do eat mielies during the night 39

Then they will write

And the world shall know

What is happening in the veld

[. . .] 
No more turning back

I have seen enough of the veld

Where our lives are not our own. ${ }^{40}$

The veld is described in this poem by Nthambeleni Phalanndwa (written post-1976) as a place of concealed violence, a landscape of hidden knowledge and unspoken events. The veld here has been separated from the rest of the African continent, to which the poet desires to return. The cultural identification of the land with the Afrikaner nation and the violence that the land concealed renders it unfamiliar, distant, to the African identity of the poet. The representation of the veld as the homeland of the Afrikaner, as part of the political gain of power, thus constituted an active alteration of the land, a change and a shift in its meaning.

\section{Who wants to be mothered?}

\section{[Extract]}

On her breast she suckled me, as a baby;

On goat's milk she fed me, as a boy;

But as a lad I learned to feed on roots

Far away across the veld. ${ }^{41}$

Jonker's poem, with which this chapter began, also suggests that the political claiming of the veld as part of Afrikaner identity is a suspension of its meaning as part of the African continent. In 'The Child', the veld simmers behind political repression as an indivisible part of Africa, waiting to be reclaimed by those who were displaced from it. 'Who wants to be mothered?', by Basil Somhlahlo, is a narrative of childhood, weaving the veld into the story of the growth and development of a man. The interaction with the veld, the slow gaining of knowledge, of its ability to nurture life, suggests a resistance to representations which bind it to the identity of a single nation. A recent conversation with Albie Sachs, now a Justice of the Constitutional Court in Johannesburg and a former anti-apartheid activist who spent many years in exile, touched on this ambivalence held within the veld, on the power of the image of the grassland veld as part of the imagination of South Africa and of its lingering association with the Voortrekkers. ${ }^{42} \mathrm{He}$ said that during his years in exile, unable to return to South Africa, the image of his country that he held most strongly was not that of the cities, but of the vast grasslands of the veld - the land claimed by the trekkers. This imagination by Sachs, and by others, develops the pure image of the golden veld into one which is still being claimed and contested and reimagined by those excluded from its claiming as the land of the Great Trek. Similarly, the history of writing and describing the veld is one in which an awareness of the bodies of other races and of concealed desires reappears alongside the violence of denial. 


\section{Chapter 2}

\section{Memory and inscription}

The vanished spoor of Voortrekker commandos and the smothered ruts of Voortrekker wagons criss-cross the highways and railways of South Africa.

But even now, when the national monument to the founders of the Transvaal, the Orange Free State and Natal is about to be opened, few South Africans discover the stories of the Great Trek inscribed for seeing eyes on our kranses and valleys, our open plains and dwindling rivers.

Visit again in thought the beloved cradleland of the Trek, the drought stricken beautiful Eastern Province from which the explosion of Western civilisation into the virgin uplands of Southern Africa began.

Stand once more in memory above the Katberg Pass, if ever in the past you have hurried down it. But do not hurry now. For half the history of the Great Trek - the forgotten half - is written on the deep green forests, the rivers, the blue bush-filled valleys and far-away hills of Albany that lie at your feet. ${ }^{1}$

In this extract from a 1949 booklet, published as a supplement to The Star newspaper on the occasion of the inauguration of the Voortrekker Monument, the author, J.J. Bond, entreats us to read the land as a text upon which the history of the Great Trek is written; to focus our vision of the landscape so that it tells the story of the Afrikaner nation and their apparently natural relationship to the land. The description of the 'deep green forests' and 'blue bush-filled valleys' establishes an emotional connection to the land and associates these images with the events of the Trek. He identifies the Voortrekker Monument as a symbol of the conquest of a virgin land, but urges that its meaning spreads over the landscape in the journeys taken a century before. The equivalence given to the invisible traces of the Voortrekkers and the tracks of rail and highways is an intimation of the political argument that connected the 
journeys of the trekkers with the creation and future of a modern state. Bond advocates contemplation of the contemporary landscape in terms of a selected history, which is remembered and reconstructed in order to give depth to the political desires of the present. Representations such as these resisted the capacity of the land to erase traces of humanity and sought rather to entrench a perception of the landscape in which the narrative of white occupation was indivisible from the form of the land itself.

The re-enactment and reinscription of the land, which took place in 1938 for the centenary of the Trek, began as the wagons pulled by oxen lent by farmers and manned by Afrikaners in historical dress journeyed from Cape Town to Pretoria. The laying of the foundation stone of the Voortrekker Monument was the culmination of the 1938 festivities, while the inauguration of the monument in 1949 offered an opportunity to revisit and reinvigorate the legacy of the Great Trek in the light of the parliamentary victory of the National Party in 1948. The 1938 celebrations were largely organised by the Ossewabrandwag, which had been formed in the same year for this purpose. The similar celebrations of youth, vitality, history and hope for the future that took place in Nazi Germany during the 1930s, as well as the contact of the Brandwag with the government of the National Socialists, confirms the dependency of the centenary celebrations on those of Germany in the same period.

Both the 1938 and 1949 celebrations promoted the identification of many Afrikaners with the events that led to the mass migration in the early nineteenth century. This identification was fostered by a sense of continuing hardship and suffering of early-twentieth-century Afrikaners at the hands of the British. From the 1890s, white tenant farmers and small-scale farmers were forced into the cities by the consolidation of large areas of land into single farms. Their difficulties were exacerbated by the British scorched earth policy during the South African War and, in the 1930s, by the impact of the Depression. These desperately poor, white Afrikaners were often ill educated and were therefore forced to compete with blacks who were similarly seeking refuge from rural poverty (and the consequences of the 1913 and 1936 Land Acts) in the cities. The actions of the Great Trek leaders, in pursuing the idea of a white race in the interior (despite clear evidence that many black and mixedrace servants were taken along on the Trek) and in purging the 'empty' veld of 'savages' therefore resonated with contemporary concerns.

Central to the mythology of the Great Trek was the idea that a new nation had been able to discover itself in the isolated and empty interior. The 'platteland' (literally 'flatland') was depicted as being without history, ripe for inscription. The notion of an internal world, away from outside influences, was echoed by a trekker leader, who apparently shared with others the belief that the real home of the Voortrekkers was one where they could be totally secluded. 'Potgieter and his party always feared the Natal adventure, since access to the sea meant contact with the outside world. They preferred to segregate themselves on the highveld of the interior. ${ }^{2}$ Access to the sea also meant confrontation with the British, whose dominance of the world's oceans had enabled the expansion of their empire. The 
perception that the interior landscape was ripe for narration was shared by missionaries who were among the first Europeans to settle in the area. Jean and John Comaroff have argued in an analysis of early encounters between tribes people and missionaries that:

This undifferentiated landscape was disconcerting. It defied surveillance. The eye searched in vain for recognisable margins and limits. Indeed, it was the very act of narration that imposed an order of space and time, that made the metaphorical leap, linking the formless wastes to known cultural referents. ${ }^{3}$

The art historians Ann Bermingham and John Barrell have also argued for landscape to be understood as an aspect of political vision, which both orders and naturalises political change. In their accounts of English landscapes and politics, particularly over the period of the enclosures of the common land in the seventeenth and eighteenth centuries, politics emerges as central to the way in which landscapes operate as naturalising cultural representations, which order the way in which the land is seen and understood. ${ }^{4}$

The desire of generations of white South Africans to rewrite the history of land occupation to legitimise their ownership of appropriated land is consistent with Edward Said's characterisation of imperialism as a power which constructs a 'normalising narrative'. Said maintains that, 'at some very basic level, imperialism means thinking about, settling on, controlling land that you do not possess, that is abstract, that is lived on and owned by others. ${ }^{5}$ The claim of the Afrikaans people to South Africa as insiders, rather than as an external power, was one of the primary means through which a right to the land was established in the first half of the twentieth century but, like the imperialism Said describes, this claim was reliant on the fostering of a 'normalising narrative'. Said is essentially interested in a discussion of narrative as a cultural force, one which not only represents the legitimacy of power, but also influences the form that it takes in the minds of the colonisers and the colonised. By representing the imperial situation as culturally and politically normative, the narratives of the colonisers are critical in establishing a moral right to power.

This translation of change into order is consistent with Roland Barthes' proposal for a reading of myth which is inherently political, and unstable. In his 1957 text, Mythologies, Barthes focused on the language of mass culture in a series of essays which analysed aspects of everyday life and probed the transformation of popular culture into a 'universal nature'. He argued that:

Myth does not deny things, on the contrary, its function is to talk about them; simply, it purifies them, it makes them innocent, it gives them a natural and eternal justification, it gives them a clarity which is not that of an explanation but that of a statement of fact ... In passing from history to nature, myth acts economically; it abolishes the complexity of human 
acts, it gives them the simplicity of essences ... it organises a world which is without contradictions because it is without depth. ${ }^{6}$

Through Barthes' analysis, myth acquires a political dimension where it is a 'second order of meaning', a representative form which both naturalises meaning and impoverishes it. ${ }^{7}$ Barthes emphasises that the speech of myth is one which is actively depoliticised, where politics is concealed behind a form that appears innocent. The mythologies of the founding of the Afrikaner nation had as their concealed agenda the gaining of political and economic power. The inscription of the land, and its appearance as both innocent and natural, attempted to overlay a narration of natural ownership onto a land that was still lived on and owned by others.

\section{Public images - newspapers and poetry}

Newspapers and magazine supplements were central to the spreading of the myth of the Great Trek and to creating a collective image of the Great Trek and its reenactment. Newspapers were divided not only along racial lines, but also according to language. While English language newspapers were initiated as professional and commercial publications, like others in former British colonies, all five Afrikaans daily newspapers were allied to present and future leaders of the National Party. ${ }^{8}$ The English language Rand Daily Mail (founded 1902), The Sunday Times (1906) and The Star (1887) were all founded close to the turn of the twentieth century, while the Afrikaans press was linked more closely to the unfolding political progress of the Afrikaans people, proliferating from 1910 (when the two Boer republics of the Transvaal and the Orange Free State unified with the British-controlled Cape and Natal to form the Union of South Africa), when a separate Afrikaner identity was being fostered. Die Burger was established in 1915 under the editorship of D.F. Malan, who became Prime Minister at the victory of the National Party in 1948, while Die Transvaler was founded in Johannesburg in 1937 by future Prime Minister H.F. Verwoerd.

At the beginning of the twentieth century the new development of Afrikaans poetry was perceived as acting both to confirm the fitness of Afrikaans to serve as a full metaphorical and descriptive language for the nation and to 'give voice' to the 'silent' land through representation. The tradition of Afrikaans language literature is therefore relatively recent and is directly associated with the creation of a unified cultural and social identity. The 'writing' of the land, particularly through poetry, was conceived of as an act which had political content. It was seen to intertwine the land and the Afrikaans nation, and confirm their ownership of it.

\section{Re-enactment and reinscription}

In 1938, as the re-enactment was underway, a photograph appeared printed in a newspaper supplement as part of an article by Gustav Preller (1875-1943), 
the Afrikaner linguist who was one of the first to recognise and actively promote the powerful association between culture and politics in the fertile climate of earlytwentieth-century South Africa. ${ }^{9}$ Entitled 'Die Boer as Krygsman' ('The Boer as Strongman') (Figure 2.1), the photograph is a restaging of the journeys into the interior, forming part of the series of events ritually re-enacted and recorded to form surrogates for real or imagined events of which no trace remained. The photograph draws on pictorial conventions in its representation of the landscape; but rather than presenting a static image in which the landscape comes under the gaze of the outside viewer, here ownership of the view is transferred to those held within the frame. In common with other views of colonial landscapes, and particularly those popularised in nineteenth-century publications in the United States, ${ }^{10}$ the landscape is laid out before the viewer as a newly revealed territory, which is simultaneously unknown and recognised as the home of the nation that claims it.

As active and restless presences the figures are not the equivalent of static pastoral bodies, but are rather aggressors and conquerors. ${ }^{11}$ The elimination of the pictorial convention of the middle ground, and the gaze of the scene's occupants, shifts the emphasis to the far view. The elevation of the mountain ridge becomes a threshold to the future rather than a vantage point for contemplation. The trekkers appear restless to press on, gesturing into the unknown. Prospect and view are incorporated into a reconstruction that appears as a fragment of a larger narrative. The use of the representational medium of photography, together with public awareness of the re-enactment, promotes the perception that the photograph is a

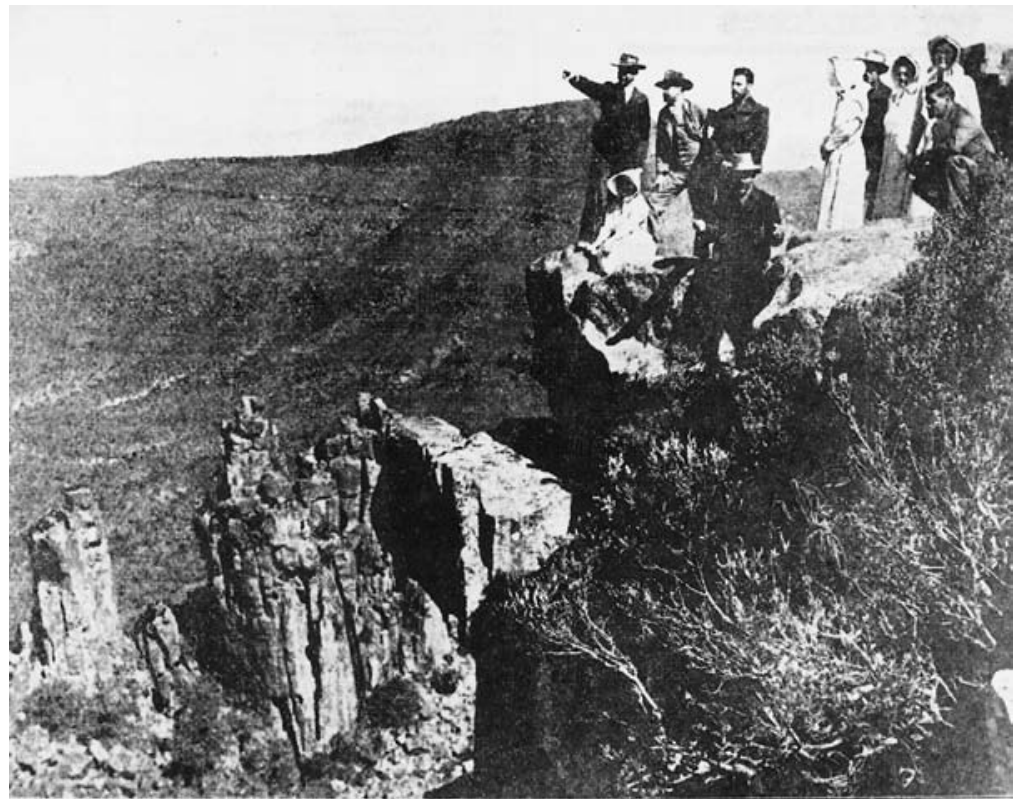

2.1

'Trekkers werp 'n vergesig oor die landskap' ('Trekkers gaze out over the landscape') from Gustav Preller (30 November 1938) 'Die Boer as Krygsman', article in a supplement to the newspaper Volksblad. 
fragment of a real, tangible and unfolding event. Similar mutations of landscape conventions are present in the covers of two newspaper supplements issued for the inauguration of the Voortrekker Monument in 1949 (Figures 2.2 and 2.3). They are popular images, by the same landscape artist, W.H. Coetzer (1900-1983), ${ }^{12}$ created specifically for the special editions in order to present a colourful, visually appealing and mystical representation of Voortrekker history. Both paintings employ the overgrown foregrounds, far-off mountains and light-filled cloudy skies of the European pictorial tradition, although the subject matter is tailored to the different audiences of the publications. Die Voortrek was produced as a supplement to Die Transvaler (a right-wing Afrikaans newspaper which was edited at the time by the so-called 'architect of apartheid', Hendrik Verwoerd) and depicts lines of single men on horseback, while the cover of Die Huisgenoot, a monthly women's magazine, includes the figures of a mother and child. The covers reflect the extent to which the tradition of the picturesque was embedded in representations of colonial landscape through the recurrence of the convention of a composed view with rough foreground, middle ground and high mountains which terminate the scene. The paintings resonate more strongly, however, with both the imagery and the philosophy of the German Romantics, who were active in the early nineteenth century. ${ }^{13}$

2.2

W.H. Coetzer

(illustrator), cover of Die Voortrek

(13 December 1949), special supplement to Die Transvaler.

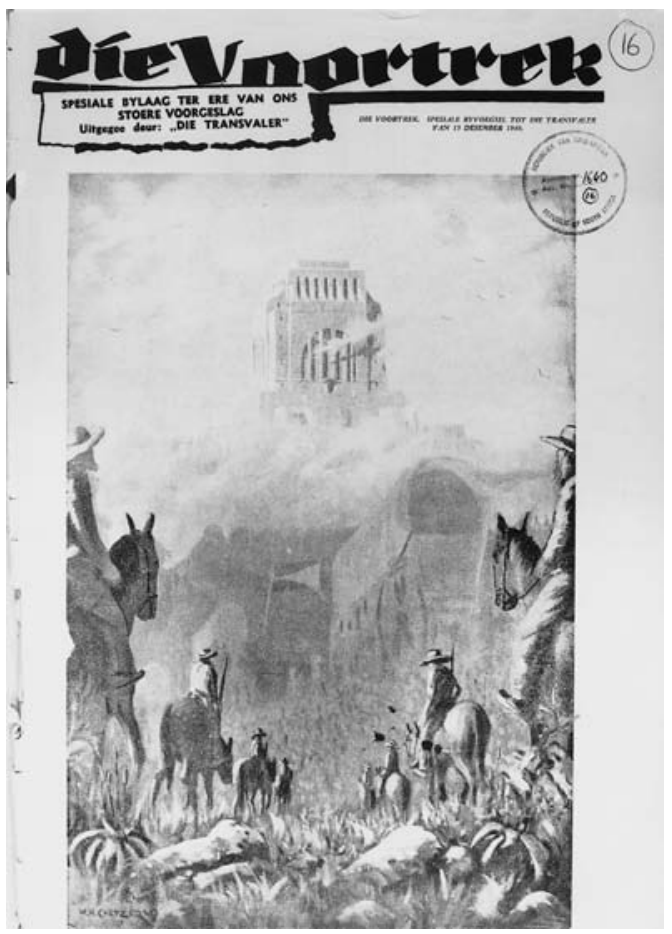




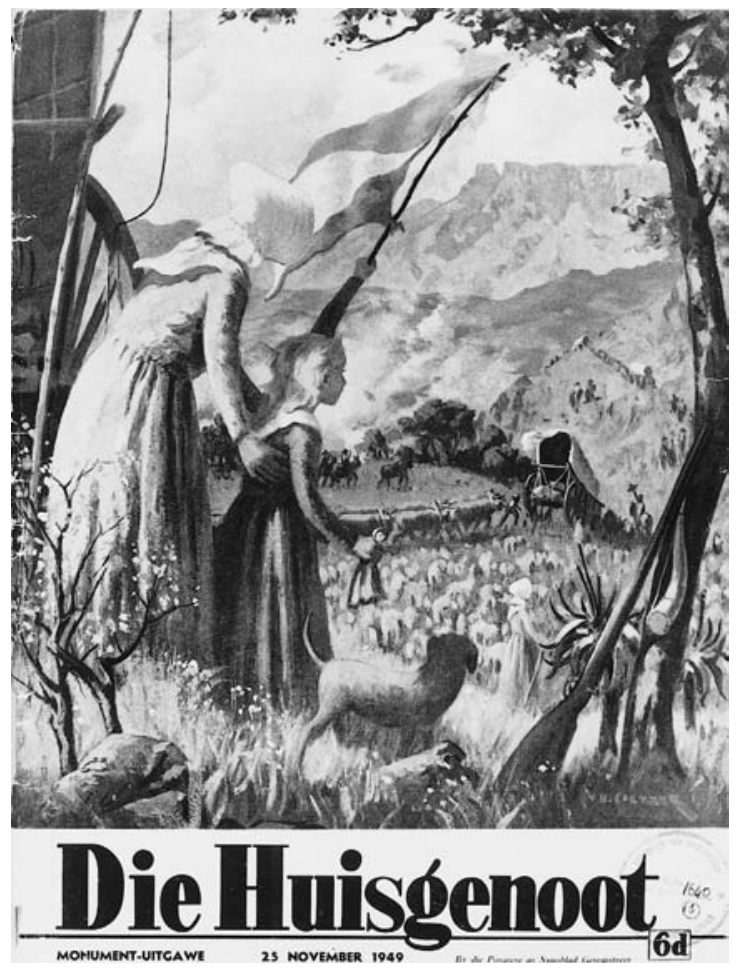

The work of the German Romantics is inseparable from the debate about national identity that was pervasive in Germany at the time and in the development of the idea of the union between the nation and the land through 'Blood and Soil'. In the work of nineteenth-century artists such as Caspar David Friedrich (1774-1840) and Philipp Otto Runge (1777-1810), nature is considered to be a repository of spiritual meaning. Landscape, as a representation of nature in which culture and history are embedded, becomes the medium in which nature, spirituality, history and national identity are bound together. The questions about national identity, and its expression through architecture and landscape, fuelled paintings which emphasised the 'Germanness' of landscapes and Gothic architecture. Landscape was seen as inseparable from nationhood and historical events, which were associated with the founding of the nation in a particular place. The nature that the artists embraced was filled with mysticism and either overt or covert Christian spirituality, while the architecture that appears in the paintings is depicted glowing in a halo of light, suspended above the mortal world. Friedrich's painting 'Das Kreuz im Gebirge' (c.1811) (Figure 2.4) depicts the attenuated form of a Gothic cathedral, hovering above the earth. Its elevation and the obscuring of the foundations of the church in the forest of trees emphasises the ambiguity of its location, between the mortal and heavenly realms.
2.3

W.H. Coetzer (illustrator), cover of Die Huisgenoot Monument Uitgawe (25 November 1949). 


\section{Caspar David \\ Friedrich - 'Das \\ Kreuz im Gebirge' (c.1811).}

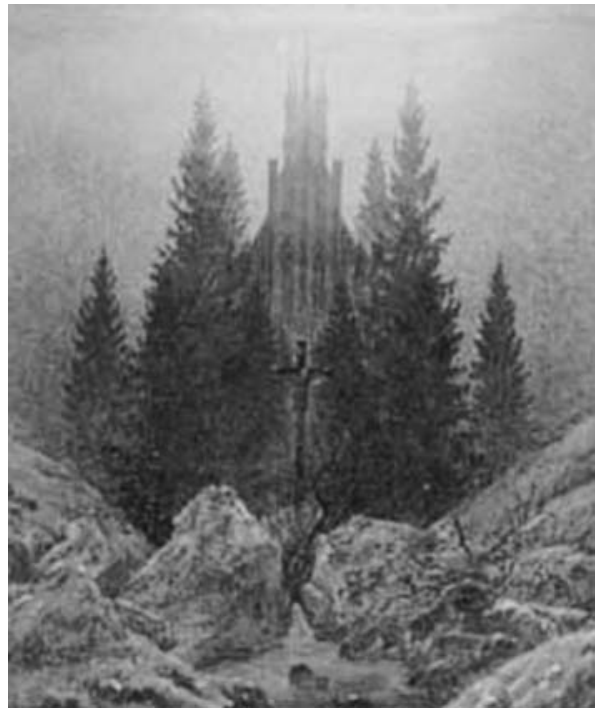

The German Romantic preoccupation with national identity and historical narrative in their depiction of landscape struck a chord with the agenda of the Afrikaner Christian Nationalists in the twentieth century, as did the religious mysticism of the paintings. The two magazine covers are not part of a larger body of similar work, nor were they popular versions of art works produced at the time: the significance of the images is in the narrative they support and in how the narrative and the presence of indigenous plants, such as aloes, attempts to render the landscape specific. The middle ground is occupied by wagons, rather than a 'natural' fragment of the landscape on which the eye can rest. Like the historical paintings of Philip Otto Runge, the paintings are frozen moments in time of a narrative which they assist in constructing.

On both covers, the travellers turn away from the viewer, into the page, following the tracks of the ox wagons before them. The landscape that they journey into is empty of other inhabitants - although a rifle that leans against a tree near the woman and child hints at a latent threat of violence. The flag held high in both illustrations is the triangulated red, white and blue of the short-lived Boer Natalia Republic (established in 1839 by Andries Pretorius and annexed by Britain in 1843) serving as a reminder of the injustices of the past and the unification of the Afrikaners against British imperialism and economic power. Here the mountain thresholds are still in the distance, yet to be surmounted. The glowing light that bathes the far landscapes heightens the power of the images, and the surge of nationalist emotion that they were meant to invoke. The hazy monument hovers above the clouds in the cover picture of Die Voortrek. Its elevation in the frame, as well as the intense lighting that floods over the building, recalls the image of the cathedral in Caspar David 
Friedrich's painting. Both covers represent the Great Trek as an event which opened up paths into the wilderness by the pulling of wagon wheels through the undergrowth. This notion of a route and a series of tracks which were laid down into the yielding earth featured as a recurring device in representations of the Trek.

While the covers recall the early-nineteenth-century paintings of the German Romantics, in the emphasis of historical subject matter, mysticism and the association of national feeling with particular 'identifiable' German landscapes, the southern African land eluded the complete incorporation into the representational conventions of European landscapes. One of the reasons for this was the unfamiliarity of the physical structure of the land, the perception that it lacked identifiable, distinguishable features, as well as its elusiveness and harshness. The interior of vast golden grasslands, while described in Afrikaans poetry of the early twentieth century, remained resistant to European pictorial conventions. When the illustrators searched for an appropriate pictorial landscape in which to site the history of the Voortrekkers, they settled on a mystical, mythical land, reminiscent of European sources. In these paintings the land itself is obscured and is shrouded in clouds. It confirms the presence of modified European political and philosophical models as well as conventions of landscape representation in the Afrikaner Nationalist movement. The image of the landscape that these illustrations support is one which acts as a distorting lens before the land, in which ambiguity is presented as clarity and a romanticised history is presented as inscription.

\section{The search for an 'authentic' South African landscape}

The specificity of the southern African landscape, and the belief in the immanence of God in nature, was explored by the Afrikaans landscape painter, Jacob Hendrik Pierneef (1886-1957). After a study trip to the Netherlands in 1926, where he studied the old Dutch Masters, he arrived back in South Africa to establish himself as the 'mees tipiese landskapskilder van Suid Afrika' ('the most typical landscape painter of South Africa'). ${ }^{14}$ The stark, architectonic and vacant landscapes that he became celebrated for cohered with the belief that the Afrikaner as 'natuurmens' (natural man) possessed an inherent empathy with his environment and offered a visual means through which this connection to the land could be both expressed and made. Pierneef studied the work of indigenous South African cultures, in particular the rock paintings and engravings of the Khoi and the San, and the influence of their simplified elongated forms, earth tones and spare elegant lines is evident in the development of his work. He developed a style of depicting the landscape in which stylised geometric forms were differentiated by sheets of even light and colour. He rarely depicted people; there is an intense stillness in his paintings, sometimes even a sense of disquiet that no breath of life or breeze disturbs the repose of the carefully composed forms.

A member of the Broederbond from 1918, ${ }^{15}$ Pierneef increasingly embraced the agenda of the Afrikaner Nationalists, referring to himself as a 
'Voortrekker' for the arts during the 1930s and 1940s. It has been argued by the art historian N.J. Coetzee that Pierneef's landscapes are inseparable from the contemporary political agenda in which they were produced. Coetzee maintains that Pierneef's work offers a visual means through which the veld, and in particular the landscape of the Transvaal province, could be imagined as the fatherland of the Afrikaner.

The landscape was the bare geological phenomenon regarded by the Afrikaner as the ware grootse Afrika [true, immense Africa], the Africa that God sent them to ... The empty land, denuded of human ecology and presence, as represented in Pierneef's landscapes, clearly and pictorially expresses this distinction. ${ }^{16}$

Pierneef's success in developing a distinctive style of landscape painting which resonated with contemporary Afrikaner cultural and political concerns meant that his paintings were collected as status symbols by those who considered themselves to be 'true Afrikaners'. ${ }^{17}$ The majority of Pierneef's wealthy patrons lived an urban existence and the paintings became almost displaced fragments of the land itself; magical totems invoking the land in its purity and stillness (Plate 2.1). Not only were the landscapes representations of remote 'natural' places, desired from within the confines of the city, but also they became integrated into the narration of the past, the political ambition for the future and the construction of Afrikaner identity. Pierneef's work was perceived to be extraordinary in the history of landscape painting in South Africa because, it was believed, he had been able to represent the Africanness of the land, without dependence on the norms of European tradition. Like the Cape Dutch farmhouses often depicted in his landscapes, Pierneef's paintings are a product of a complex genealogy which incorporated both African and European antecedents. The popularity and pervasiveness of his paintings, however, together with his active involvement in the production of book covers, Christmas cards and posters as a major exponent of 'kultuurpolitiek', ${ }^{18}$ meant that the still, geometric landscapes became iconic in Afrikaner culture. It was claimed in 1929 that:

The people understand his work because it speaks directly to them, because it is authentic, because it is made from and is of native ground, because it is typically 'volks' and typically Afrikaans ... During the turbid years he supplied to the young rising Afrikanervolk, and through them the jaded outside world, a picture of honest clarity, mature balance and rare artistic delight. ${ }^{19}$

Pierneef's images of the land were offered to the white urban public, who were increasingly distanced from it, both through exhibitions and, in 1929, the landscape panels for the new Johannesburg Station - designed by the architects Gordon Leith and Gerard Moerdijk (who was also the architect of the Voortrekker Monument). The panels, commissioned by South African Railways and Harbours (SAR \& H) were to have either 'historical' or 'natural' subject matter (Figure 2.5). As an organisation 


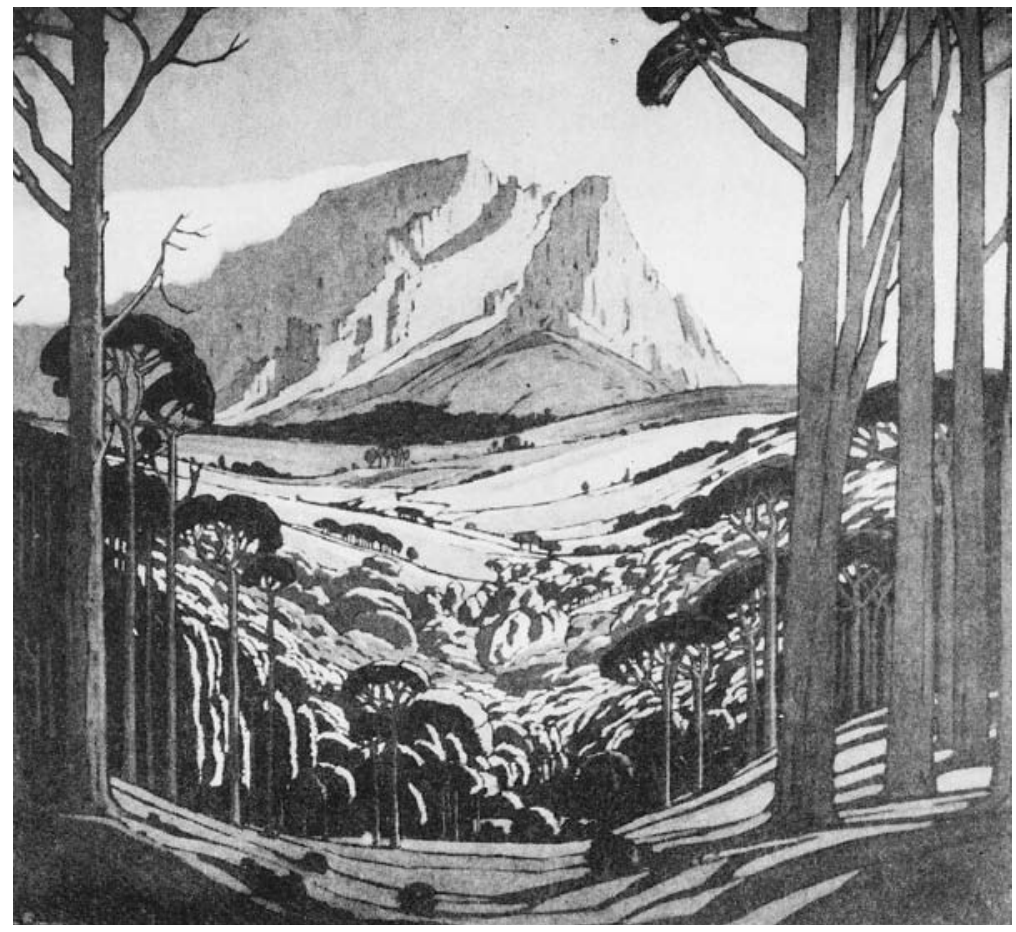

whose responsibilities also included tourism, SAR \& $H$ were involved in the presentation of the land to those separated from it. Given the commitment of SAR \& $\mathrm{H}$ to the elevation of the Afrikaner workforce, ${ }^{20}$ and Pierneef's ability to portray, 'die land wat in sy wreedste hardheid nog wonderskoon is' (the land that in its cruellest hardness is still exquisitely beautiful), ${ }^{21}$ he seemed an obvious choice. Furthermore, during the same decade, the SAR \& $\mathrm{H}$ actively promoted the idea of the bushveld safari as a kind of compensatory experience for those separated from the land. ${ }^{22}$

The veld was therefore presented as a place to which one could retreat to recall the timeless values of humans and nature, uncomplicated by the presence of other inhabitants. Pierneef's final set of paintings, like the image of the bushveld promoted by the SAR \& H, were silent, still and vacant. The emphasis given to the Transvaal (12 paintings out of 28 major panels) demonstrates the extent to which Pierneef's work, and his reputation, is dominated by his depiction of the spare landscapes of the interior veld. In the series of paintings the colours are subdued, applied flatly in almost monochromatic areas which are often delineated by dark lines and shadow. The landscape appears bare, hard and impenetrable, apart from the geometric, attenuated trees which provide a distant canopy of shade suspended high above the soil.
2.5

Hendrik Pierneef Paintings for the Johannesburg Railway Station (1929), from The Johannesburg Station Panels by J.H. Pierneef. 
The distinctive stylised trees became a signature of the artist. Their presence on the cover of Afrikaans literary magazines in 1929 attests to Pierneef's connection to literary and artistic circles in Pretoria, ${ }^{23}$ and to the centrality of his position in the debate about culture and politics that was to shape the century. The connection between Pierneef's work as an artist, and that of the literary pioneers of the written Afrikaans word, is represented on the cover of the Tydskrif vir Letterkunde (Journal of Literature) and Die Nuwe Brandwag: Tydskrif vir Kuns en Letterkunde (The New Fire-watch: Journal for Art and Literature) (Figure 2.6). ${ }^{24}$ The sketch shows books piled up in front of a window through which a simplified depiction of a Pierneef landscape is visible. His vision of the land is substituted for the land itself, forming a pervasive image which alters the way in which the land is seen and contemplated.

2.6

Cover of Tydskrif vir Letterkunde 1929 (Journal of Literature) including Die Nuwe Brandwag.

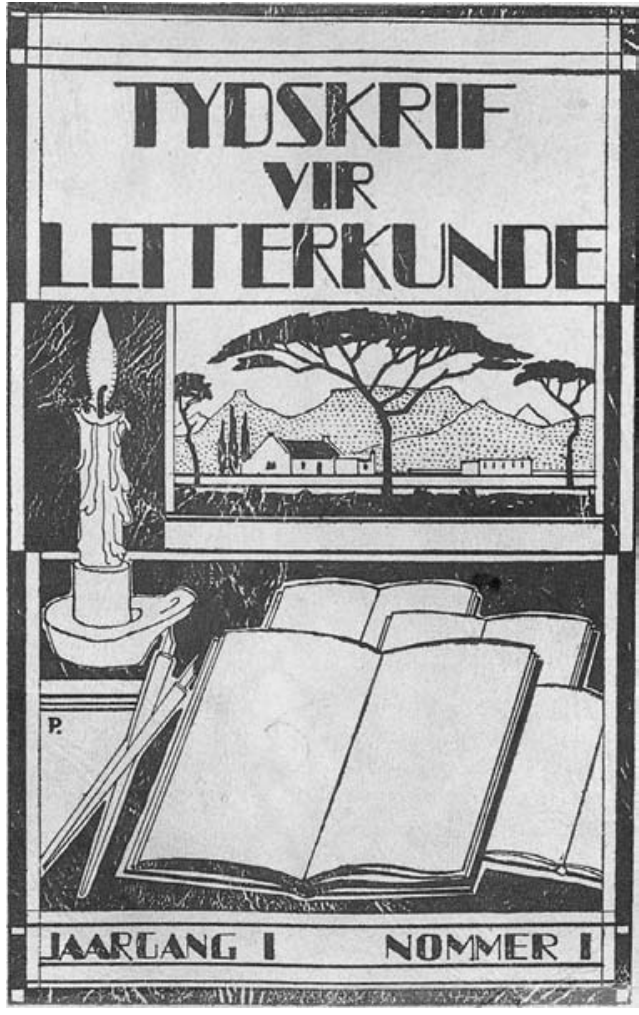

\section{Paths and maps}

The paths drawn by the wagon wheels into the apparently virgin wilderness represented the wheels of the ox wagons as drawing instruments which were 
fundamental to the inscription of the landscape. They also had a transformative role to play in the bringing of white civilisation to an interior represented as savage and primitive. The tracks are significant because, in terms of Afrikaner mythology, they both claimed the wilderness and effected its alteration into veld. The wheel of the ox wagon became a pervasive symbol in the boundary walls of homes and churches in small towns all over South Africa; embedded into walls, and welded into gates, it remains evidence of the enduring popularity of the Voortrekker narrative (Figure 2.7).

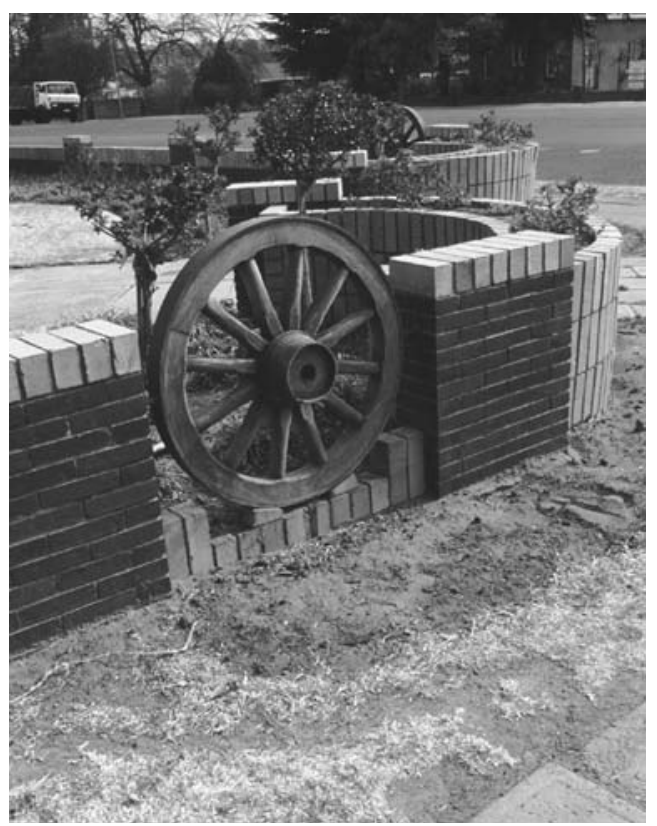

The path that the wheels inscribe is a sign of civilisation; the fact that no routes recognisable to European eyes existed prior to the journeys of the Voortrekkers was offered as confirmation of the lack of history of the interior and of its suspension outside the progressive march of modernity. In order to overcome the problem that the Voortrekkers had themselves left no enduring marks, and no written documentation of their routes, a series of maps were produced at the time of the centenary that offered clear, 'rational' and 'scientific' evidence of the invisible paths in the landscape. Together with the re-enactment, these maps were represented as bringing to the surface content that was already present in the landscape.

\section{Die Dieper Reg (Jongeling)}

ek is die jeug, nog in my dood

sal ek deur hierdie nasie trek

\section{The Deeper Right (Youth)}

I am youth, even in my death

will I journey through this nation
2.7

Wagon wheel in the brick wall of church in the town of Harrismith, South Africa. Particularly in small towns in South Africa, these symbols of the Great Trek are widely visible. 


$\begin{gathered}\text { a voortrek without end, in every } \\ \text { in elke eeu } \\ \text { as rus en rykdom te dierbaar vir } \\ \text { hul word, } \\ \text { sal hul die sweep hoor klap, }\end{gathered}$
$\begin{gathered}\text { if rest and riches become too } \\ \text { precious to them, } \\ \text { they will hear the crack of the } \\ \text { whip, }\end{gathered}$
al deur die land van son en wind
and through the land of sun and
wind
the wagons' tracks will lie
eternally.

This extract from Die Dieper Reg (The Deeper Right) reveals the extent to which, in literature as well as popular publications, the impressions made by the ox wagon wheels were portrayed as tracks lying forever latent in the land. By drawing speculations of the long vanished routes onto the surface of the pages of maps, and pressing them into the soil, they were represented as acquiring a validity and authenticity which erased and overwrote the uninscribed movements of black inhabitants before them. The representations were mnemonic devices, acting to both aid and reconstruct memories that could later be offered as evidence in the battle for the land. The proliferation of documents, maps, monuments and popular events was created as a body of evidence of occupation and ownership with an eye to the haunting fear of erasure, of the forgetting of time, that was part of the way in which the veld was understood.

The wagon wheels and tracks were a trigger for remembering the past, and for inculcating the responsibility of each individual to contribute to the modernity and progress of the future. It has been argued that the memory of the re-enactment, an ostensibly cultural event, 'would come to constitute a potent political force during the next decade. ${ }^{26}$ In one academic article, published in the academic journal Historia in 1958, the author writes of the land as 'die wye onbekende van 'n eie vaderlandsbodem' (the wide unknown of one's own native soil). ${ }^{27}$ The Afrikaners tied their own destiny to that of the land by arguing for it as a national homeland: that their fatherland began as an unknown wilderness does not lessen the determination and conviction with which it was claimed.

The desire of the National Party for the consolidation of Afrikaner power in the industrial economy was reflected in advertisements published in the inauguration supplements. Here the idea of a path, or road, replaces the rut of the wagon wheel with that of modern transportation networks. In one of these, by South African Railways, a train chases the ox wagon trail up to the Voortrekker monument (Figure 2.8). A poster of the Ossewatrek (Ox wagon Trek) of 1938 uses the outline of the South African coastline as the unifying formal device which embraces a series of scrolls on which the 'history' of South Africa is written (Plate 2.2). Released under the auspices of the FAK (the Association for Afrikaans Culture), it indicates the routes which the twentieth-century ox wagons followed, from Cape Town to Pretoria, and a 

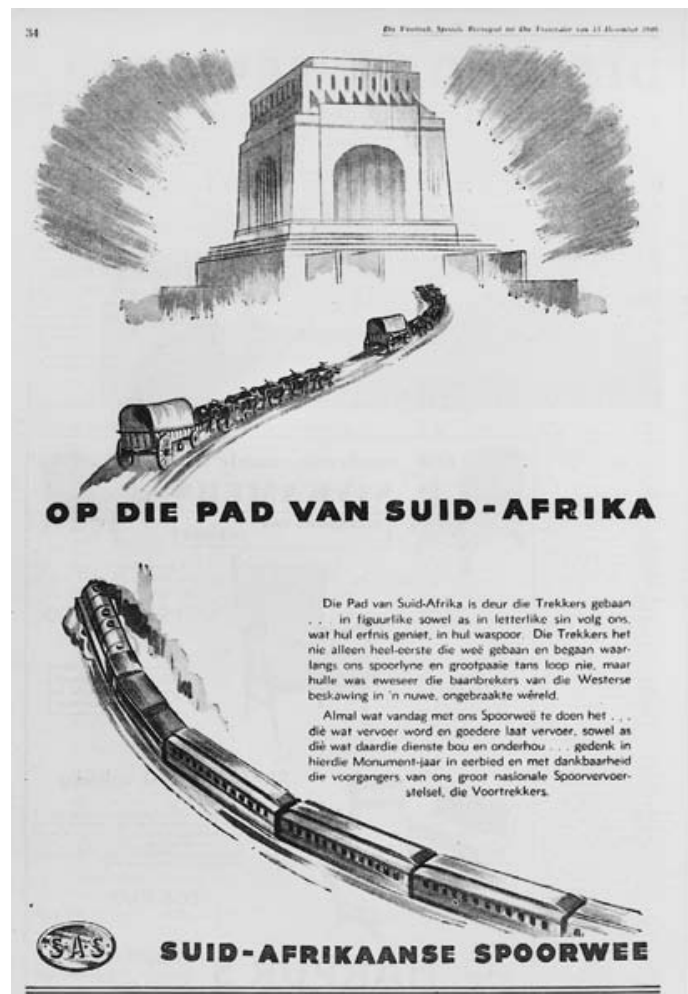

travel plan for the wagons. The title of the poster, 'Die Pad van Suid Afrika' (The Road of South Africa), extends the myth of the path to cover a political future, not only for the Afrikaners, but also for all South Africans. Apart from the considerable geographic extent of the re-enacted journeys, which make it clear that the most significant and extensive inscriptions during this period were made in the land itself, the poster uses several devices which contribute to the narrative of Voortrekker history.

In the centre of the map, a suspended oval encloses a drawing of the Voortrekker laager repelling the 'Zoeloe aanval' (Zulu attack), symbolising, to the initiate, one of the central events of the Trek. According to this history, Piet Retief, a trekker leader, along with a number of his followers and servants, was killed on the Zulu chief Dingaan's instructions, at Dingaan's kraal, while attempting to negotiate a land treaty. These killings, portrayed as 'betrayal' of the Boers by Dingaan, offered the necessary provocation for the Battle of Blood River, where an outnumbered band of Voortrekkers killed so many Zulu warriors from within a laager that the river ran red with blood. ${ }^{28}$ ' Kraal' is an Afrikaans word for a traditional settlement or homestead which, for a chief such as Dingaan, would have been a vast circular encampment of huts, arranged according to a strict tribal hierarchy, surrounding a
Advertisement for South African Railways, from Die Voortrek (13 December 1949), special supplement to Die Transvaler. 
circular space. A laager is a circular enclosure formed by the temporary linking of ox wagons end to end, enabling the Voortrekkers to repel attacks by shooting from within a shield formed by the wagons.

Another trekker leader, Louis Trichardt, was said to have made an oath on the day of battle, 16 December 1838, that his followers and their descendants would honour the day if God should grant them victory over the Zulus. ${ }^{29}$ The myth of the empty, 'silent' landscape is again threatened by the inclusion of an event which confirms the prior presence of settled black societies, but it is the deficiency (a lack of morality and dishonesty) of the tribe that confers the right to the land on the Afrikaners. Thus an event that was to play a significant role in the narrative of the Voortrekkers associates a conquest sanctioned by God with the betrayal of a tribe.

By associating the representational form of the map of 'The Road of South Africa' with selected events from Afrikaner history, the instability of the history is suppressed. The maps have their own mythological content, as symbols of objective and rational scientific activity, which was called upon to lend credibility to the potentially more unstable narratives of ox wagon and laager. The map seeks to represent three things: first, that it is only possible to have a map of South Africa in its present form because of the pioneering acts of the Voortrekkers; second, that these acts were civilising, bringing the light of quantifiable knowledge to the interior; and third, that the events can be located with accuracy on the land itself. By suppressing the ambiguities of events and associating them with the rational, mapped outline of South Africa the map conflates speculation and the appearance of rationality. It creates a factual base of knowledge upon which more tenuous narratives can be arranged.

The material counterpart to the surface of the printed map was the land of South Africa itself. Faced with the immense scale of the land, a system of markings was devised that would provide tangible evidence of the fleeting act of motion. Ephemeral lines drawn as routes on the maps were left as markings and monuments in concrete and stone during the re-enactment of the Trek in 1938. Rather than following the actual routes of the Voortrekkers, which were largely uncertain, a decision was made to shift the beginning of the journey to the city of Cape Town, the mother city. This stretching of the re-enactment was both geographical and historical. It both allowed the journey to take in many more towns, extending the influence of the narrative throughout the country, and expanded the events of the nineteenth century backwards in time, bringing the entire history of white settlements within the narrative of the Trek..$^{30}$

As the wagons travelled through the country their wheels were periodically rolled through areas of wet concrete (Figure 2.9). These sites represent a retroactive evidence of occupation, which, together with the 'authenticity' of the ox wagons and period clothing worn by the participants, ${ }^{31}$ created a kind of surrogacy in which the present stood in for and even supplanted an incomplete past. The sites selected for inscription were places where significant events had occurred: sometimes the horizontal concrete slabs were associated with towns, but more often they marked places in the open veld. 


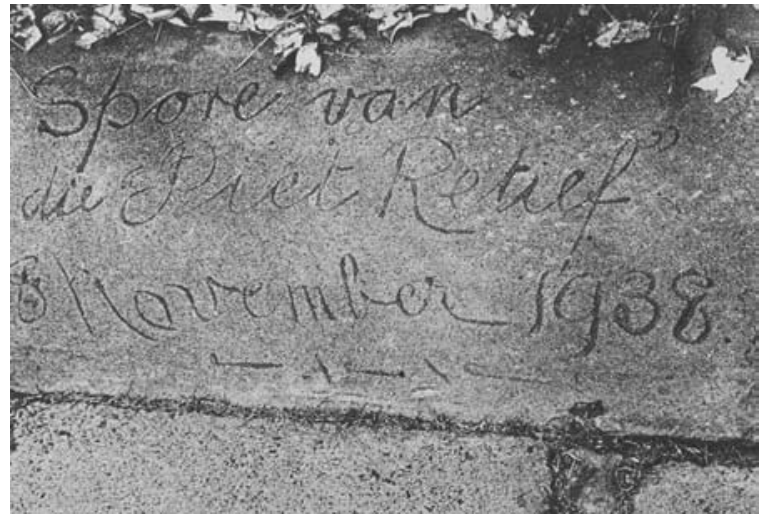

The wheels literally became the writing instruments of history. In some cases the concrete was also impressed with handprints, and signed on behalf of long-deceased heroes, who were associated with different wagons. Despite evidence that trekker women were instrumental both in the opposition to the British, the defence of the laagers and the creation of the Boer Republics, ${ }^{32}$ the handprints of women and children remain unidentified, while surrogate males inscribe the names of trekker leaders.

Concrete is an ambiguous material to use: it represents a desire to permanently mark the earth, to inscribe the movement of people over the land into a resistant substance which will preserve the ephemerality of the paths. It is a modern material, which was to figure prominently in the monuments and public buildings of National Party rule, in confirmation of technical skill and cultural and scientific progress. It is also of the earth, a mixture of aggregates and cement which come from the ground into which they are reintroduced. The edges of the panels were set flush with the earth so that the surfaces of ground and inscribed concrete are contiguous. This proximity gives the panels the status of primitive artefacts, or fossilised remains of modernity which are presented as natural objects. The panels are both part of and embedded into the land; grasses have blurred the edges over time and the veld is engaged in the process of incorporating the marked concrete. The almost incidental nature of the impressions and the fact that they are often sited in the open veld means that they are integrated into the land as the fragile fragments of a political dream for permanence that are themselves in danger of disintegration and assimilation. ${ }^{33}$

The desire for the hand of the past to touch and mark the present was pervasive. The intense documentation of the paraphernalia of everyday trekker life was pursued in books published at the time, offering intimate portraits with which present-day Afrikaners were invited to engage. Surviving photographs of the 1938 celebrations demonstrate the thousands of people involved in the event (Figure 2.10). This intensity of the occasion was matched only by that of the 1949 inauguration celebrations. In 1938, not only were the majority of the crowd dressed in Voortrekker
2.9

Great Trek

Re-enactment Wheel markings into concrete. 
2.10

Photograph of the crowds at the site of the foundations of the Voortrekker Monument, with ox wagons (December 1938).

2.11

Photograph of the 'Voortrekker' brides at the 1938 Centenary celebrations at the foundations of the Voortrekker Monument.
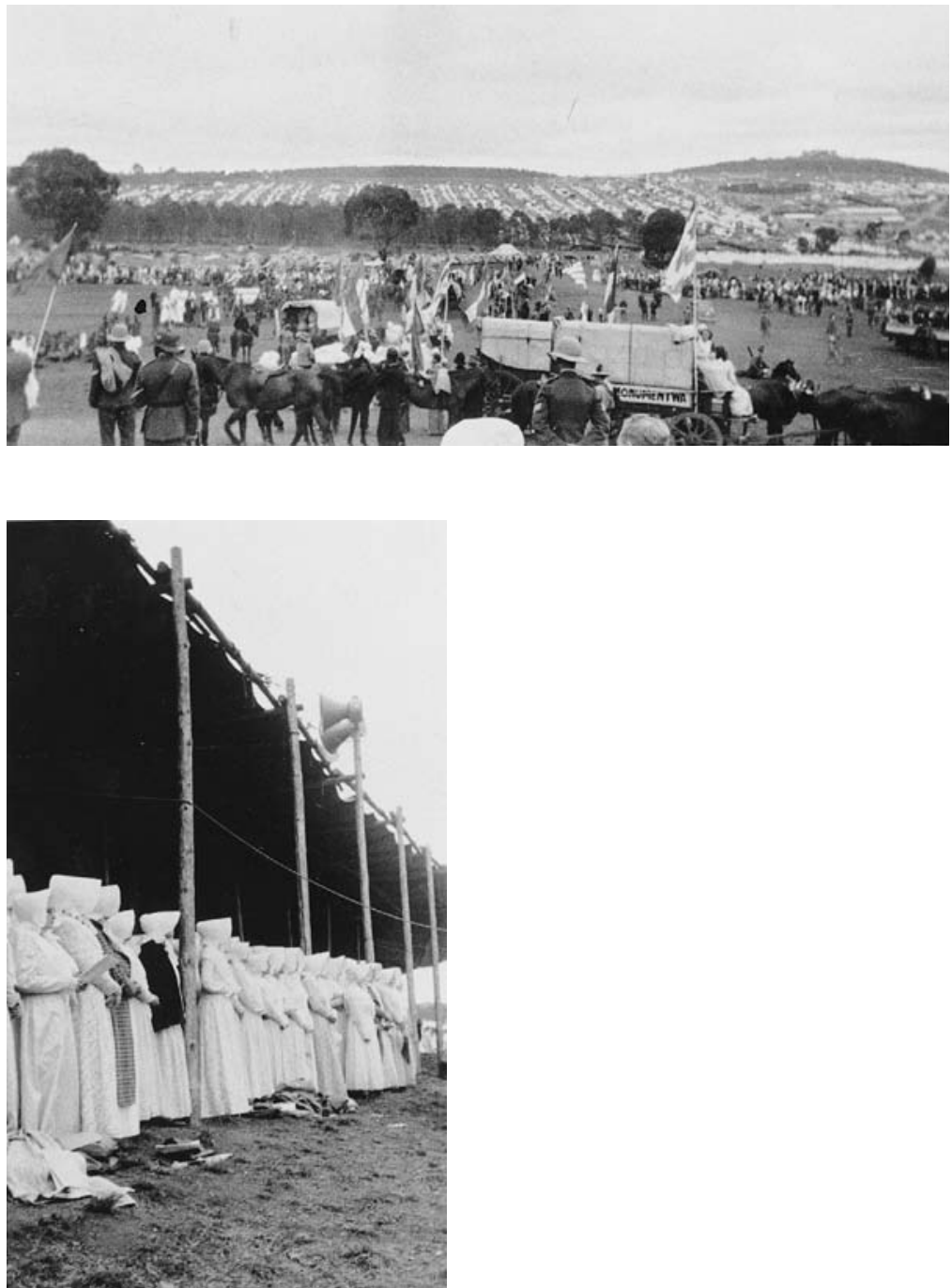

dress, but also 37 historically dressed couples were married in a tent on the site (Figure 2.11). The festivities and youth gymnastic displays were concentrated on the open veld, rather than in the nearby streets of Pretoria.

While a number of artefacts of the land - maps, posters and souvenirs were produced in support of contemporary political ambitions, it was to take much longer for maps to be produced which could show with any pretence at accuracy the routes of the Voortrekker journeys in the nineteenth century. This was not, however, an impediment to the many advertisements and documents of the late $1930 \mathrm{~s}$ 
and early 1940s which both represented the speculations about the journeys of the trekkers and their 'inscription' of the map of South Africa as a seamless map of the development of the Afrikaner volk and repeatedly depicted it as an autonomous geographic area, detached from the African continent. A souvenir pamphlet offers 'authentic' Voortrekker objects for sale alongside an ashtray which juxtaposes a floating map of the country and the edifice of the Voortrekker Monument, indicating the extent to which the image of an isolated map inscribed with trekker pathways had proliferated and gained a representational role which was tied to the meaning of the land (Figure 2.12).

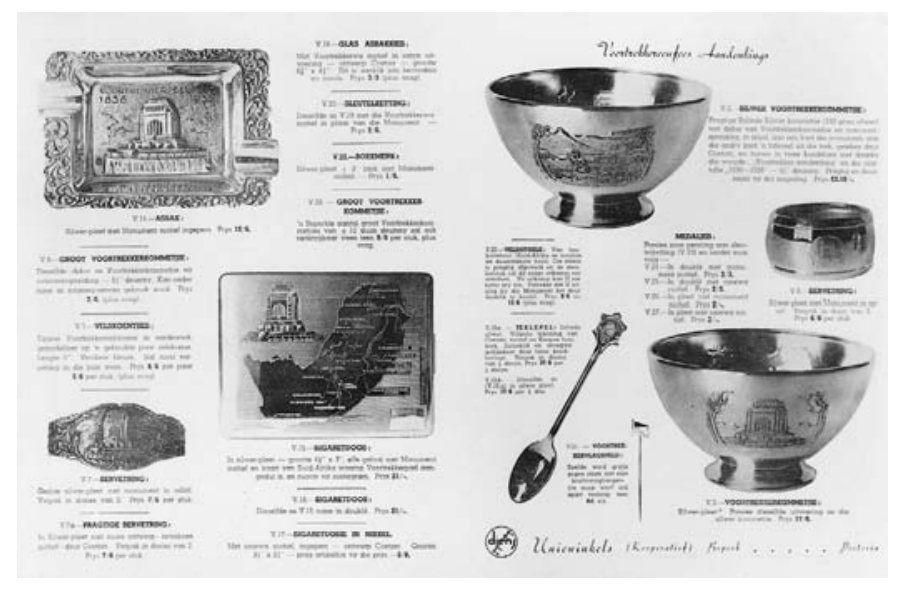

The longevity of the image of South Africa as a mapped landscape and its political power is suggested by the extent to which research into the Great Trek was pursued and popular maps published during the early decades of National Party rule. In the 1960s, maps were produced as supplements to magazines and as a means of advertising which were dependent on the work of academic researchers who, in the 1950s, collected the fragments of remaining evidence. At least one of these academic maps, F.A. Steyler's 'Routes of the Great Trek in the Cape Province', of 1950, was produced with the financial support of the Provincial government within a year and a half of the National Party government coming to power (Plate 2.3). ${ }^{34} \mathrm{He}$ notes the sources of his map: oral history passed down to the descendants of the trekkers, fragments of written historical evidence and his own intuition based on landscape features. In the accompanying report he cautions that, 'It is self evident that reliable information should not be expected'. ${ }^{35}$ However, the map could be, and was, later detached from its author's disclaimer in favour of a more certain history. The researcher's maps emphasised information, rather than image, and it is partly this attention to detail that makes them convincing. They also reveal the 'Great' Trek to be less cohesive and more tentative than the sweeping routes of popular maps
2.12

Uniewinkels,

Voortrekkereeufees

Aandenkings,

Pretoria

(Advertisement for

Voortrekker

Centenary

Memorabilia). 
suggest: routes begin and end unaccountably, joining and splitting in a pattern that discloses indecision and doubt in an unknown land.

The popular maps of the 1960s consolidate the mythology of the Trek by presenting the disparate journeys on a series of single drawn surfaces. Like maps of the 1930s and 1940s, they draw on the ability of 'scientific' drawings to command authority in the face of doubt. While it has been argued by J.M. Coetzee that South African 'white' writing about the land can be read as the struggle 'of the human imagination ... to conceive not a social order capable of domesticating the landscape, but any kind of relation at all that consciousness can have with it', ${ }^{6}$ Afrikaner politics sought to hold dual, and conflicting, images of the land. One aspect was the land as a magical landscape, an enigmatic and powerful place which eluded western conceptions of time and history; the other was the land known and understood, where mysteries were harnessed in pursuit of knowledge and modernity.

In terms of Afrikaner myth, the impenetrable and unknown interior was transformed by the tracery of wheel and wagon, not only pushing civilisation into the emptiness, but also redrawing and establishing boundaries on the map. The founding of the two Voortrekker republics, the Transvaal and the Free State, literally transformed European maps of the regions, inscribing political lines onto places and peoples to whom they were previously unknown. The maps which drew and redrew the events of the Great Trek were the descendants of a history of map-making and acquisition of the land that is itself bound up with colonialism. The maps act to transform the way in which the land is imagined by conflating the supposedly objective activity of surveying with the representation of the landscape into which political, historical and cultural meanings are embedded.

Historians have established that the appearance of rational and scientific objectivity associated with British map-making was a veneer behind which failures, slippages and conventions which carry their own internal contradictions and concealed values are hidden. ${ }^{37}$ These ambiguities are exaggerated when the information that is provided on a map is speculative and uncertain.

Maps depicting the Great Trek were sponsored by a series of commercial companies as well as being produced as inserts into popular magazines, demonstrating the continuing presence of political narrative in everyday South African life. ${ }^{38}$ The Personality map, ${ }^{39}$ printed in 1968 as 'The Story of South Africa', overlays thick coloured routes denoting Voortrekker routes onto a detailed map of the country while blue dots mark specific places in which significant historical events occurred (Plate 2.4). In this map, and others like it, the time of the landscape is measured only in terms of its relationship to white settlement, in a system of representation that is derived from European convention. This focus on the inscription of white history enacts a kind of erasure, in which the written and drawn representations of linear history supplant another experience of the land, recorded in the oral histories, poems and myths of tribal life. The surface of the country is represented as a densely inscribed surface, controlled by both temporal and spatial markers. The juxtaposition of the route and the single markers are significant not only because they associate the Great Trek 
with a wider narrative of white occupation, but also because they reveal the whole country of South Africa as the site for the inscription of a history which focused on the land, rather than on the city.

'Our Heritage: South Africa', produced by the Knorr Soups company in 1967, includes fragments of early historical maps of the age of the discoveries into a representation which collapses historical time onto a single printed surface (Plate 2.5). Strange and exotic sea creatures that were believed to roam ancient oceans join sail ships off the coast of contemporary South Africa, while the cartouche incorporates Voortrekker and Zulu weapons alongside the ubiquitous ox wagon wheel. The past becomes a picture book of visually appealing fragments which are selected and combined to form a responsive piece of advertising in the late 1960s. It was at this time that Verwoerd, as Prime Minister, had proposed the bantustans, and resistance to apartheid policies had been confronted with legislation designed to silence protest. The violence which had become an essential tool of the apartheid state is inadvertently recalled by the fragments in the cartouche: the ox wagon wheel leans behind a rifle, a cannon and its ammunition lie in front of a Zulu shield, spear and knobkerrie - the paraphernalia of war. The fear and violence that were inevitable partners in the acquisition of the land are temporarily neutralised by the veneer of history and by the mysticism and gaiety of the representation. The only markings which appear to attach to the land are the curving lines of the Voortrekker routes, while the majority of its surface remains curiously unpenetrated by the fragile figures upon it. The 'heritage' that the map, perhaps unconsciously, returns to is one in which all human activity is ultimately futile and fleeting against the immensity and age of Africa.

The narrative of the Voortrekkers, therefore, was a means to claim the surface of the country through a series of events, inscription, artefacts and mappings. The emphasis was on the construction of a physical history, one which sanctioned the contemporary political claims of Afrikaner leaders through the creation of a body of evidence which was both laid into and onto the land, and represented the land as a map drawn by the actions of the Voortrekkers. The physical extent of this claiming, and the proliferation of inscriptions, books, small and large-scale monuments and fragments, which exist in small towns all over South Africa, are testimony to the importance of a history of landscape which sought to bring a land which had been portrayed as resistant and opaque, within the political and cultural imagination of an emerging nation. 


\section{Chapter 3}

\section{Map and monument}

The Voortrekkers paid a terrific price for this country. To their descendants the monument is akin to a deed of transfer, proving their lawful ownership, acquired through blood and tears.

The Monument thus answers the question as to whom South Africa really belongs. The historical frieze will reveal to the uninitiated the great deeds of the Voortrekkers and the price that had to be paid in blood and tears. Filled with gratitude, and justifiable pride, the Afrikaner will add: 'This is my country. I am the heir, spiritually and physically, of the Voortrekkers who paid that price.' The Monument thus stands as the symbol of the Afrikaner's lawful ownership of this country. ${ }^{1}$

The architect of the Voortrekker Monument, Gerard Moerdijk (1890-1958), described its meaning and symbolism in 1949 as a legal text, built in stone, conferring the right to the ownership of the veld on the Afrikaners. The monument formed both the primary symbol and point of convergence of the mappings and re-enactments of the centenary trek in 1938 and the inauguration ceremony in 1949. It sought to consolidate the narrative into a single building, or document, of the Great Trek which had symbolic legal status spreading over the entire country.

This chapter discusses how the meaning of the monument was entwined with that of the landscape, and how its form, material and siting was represented as being the culmination of the mappings and re-enactments which both inscribed the surface of the ground with the wheels of the ox wagons and developed a way of seeing and claiming the landscape as fatherland.

The idea for the monument was conceived of in the early 1930s, while the elevated site was chosen because of its visibility from both within and outside of the city of Pretoria. While the foundations were laid in 1938, the Second World 
War interrupted the construction process; hence the delay of the inauguration until 1949. Nowadays, arrival is invariably by car or bus, through a veld grassland empty of other buildings. The massive rectilinear structure is accessed up a grand staircase, which opens onto a series of terraces. The first is a garden planted with indigenous vegetation, the surrounding wall of which is lined with granite ox wagons in low relief, while the gate to the garden is formed of black wrought iron spears. The first garden therefore refers directly to the Battle of Blood River; the spears are those of the Zulus, the reliefs reproduce the number of wagons used to form the defensive laager during the battle (Figure 3.1). The final terrace is a stone podium through which entry into the inner hall is gained. From here the visitor enters an internal world, the outside landscape is hidden from view, the light is filtered for solitary contemplation of the artefacts and the burning eternal flame.

The design of the Voortrekker Monument was intended to represent an architecture which was particular to the land; its scale, meaning, history, and to the Afrikaner nation. Moerdijk emphasised the use of African materials, with a formal language represented as being derived from African models, which responded to the image of the landscape as an immense, true and magical land, which had been penetrated by and had responded to white occupation (Figure 3.2). The site stood as a surrogate for the greater landscape of southern Africa, while the imposing granite
3.1

Photograph of an overall view of the Voortrekker Monument, just after the completion of the construction (1949?).

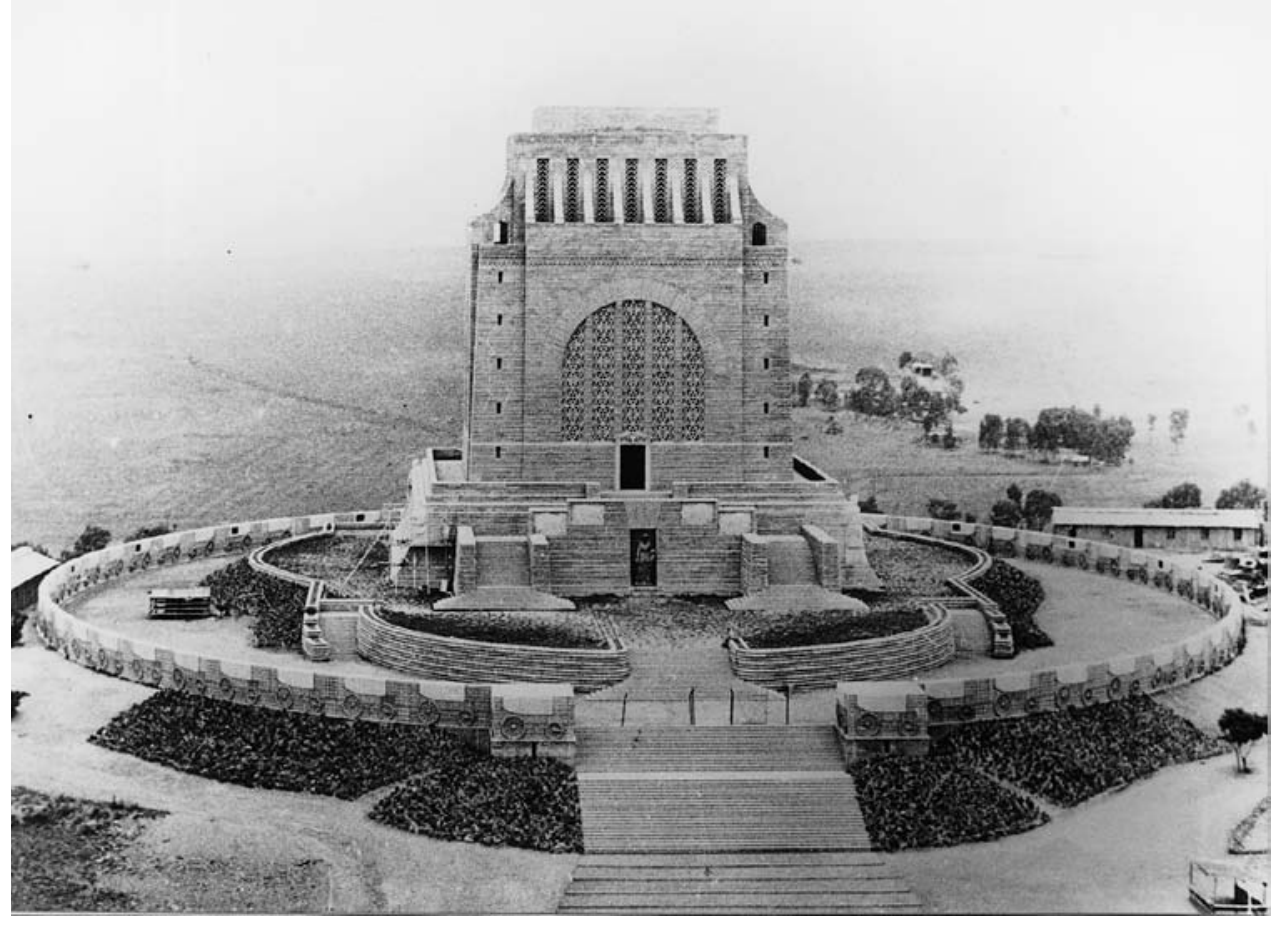


3.2

Indigenous garden with concrete ox wagons and black steel gates representing Zulu spear heads at the Voortrekker Monument.

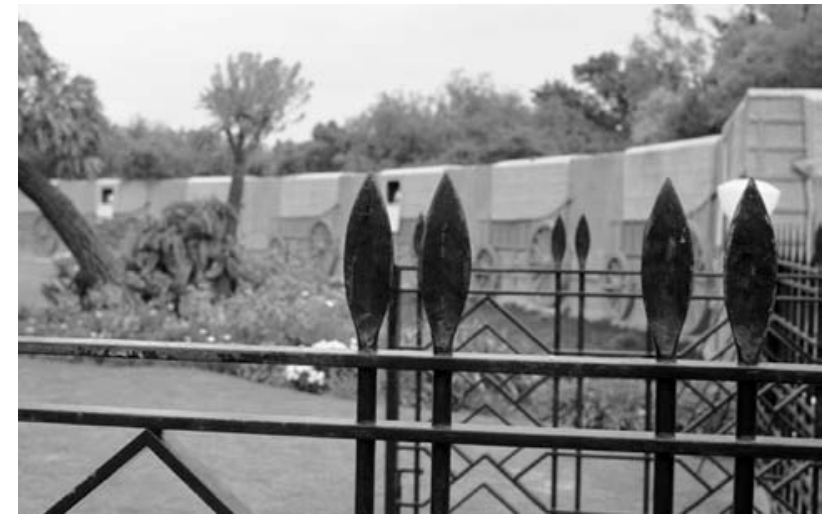

mass of the monument was placed on its highest point - dominating and overlooking the land in a defensive position. It is a symbol of strength, might and order; an ominous reminder of the violence which tainted the history of white occupation and a precursor of the violence which extended and maintained power over the land and its inhabitants. Publications at the time of the inauguration of the monument represented the achievement of the trekkers as being the establishment of a 'white' civilisation - not one in which there was complete separation between people of different races, but where the separation occurred through the subjugation of black to white.

As we see it today, the Great Trek was fundamentally a desperate protest against equality between black and white. It was a violent rejection of a policy which gave Natives rights alongside whites and aimed at equality before the law; a policy which to the frontier Boers seemed bound to lead to social equality as well ... In the two inland republics, founded after the abandonment of Natal, the trekkers finally established their Native policy ... The natives were by the will of God a subject race; so long as they realised this, there was no reason, and no excuse for other than friendly relations with them ... The trekker institutions, therefore, are based upon a clear and permanent principle - complete segregation between white rulers and black subjects. The trekkers had created something new. In their states a new civilisation emerged. ${ }^{2}$

\section{The vacant land}

The narrative of the Afrikaner Nationalists was not the one familiar from colonial travel documents and novels of the danger of corruption of the human nature of European settlers in the apparent absence of civilisation, but rather the purification and flourishing of the Boer nation through the withdrawal into the wilderness. The racial 
purity of the trekkers is associated with a virgin landscape. It is virginal, however, only if it has not been sullied by the occupation of others and it is here that one of the inherent contradictions of the narrative emerges. The descendants of the trekkers can legitimately claim the landscape only if there was no prior claim upon it, but the story of the Great Trek incorporates clashes and full-scale battles with black inhabitants. The unease with which the issue was addressed in the pamphlet publicly available at the Voortrekker Monument, during the years of National Party rule, is indicative of the incompleteness of the representation of the land as vacant.

Attention must be drawn to the fact that at the time the Trekkers left the Cape Colony, there were no Europeans living in the vast interior and that no power had laid claim to any portion of the hinterland. As a matter of fact it can be stated without contradiction that the whole area north of the recognised colonial boundary was a vast no-man's land. It is true that native communities had established themselves at various places but they were quarrelling amongst themselves and were waging destructive wars in which they were exterminating each other on a grand scale. The vast open stretches of no-man's land which the trekkers found wherever they went must in part be ascribed to these wars. ${ }^{3}$

In this extract the violence of the 'native communities' and the 'destruction' they were wreaking on each other, and on the land, rendered them unfit to inherit its riches. ${ }^{4}$ This sentiment echoes other colonial narratives, where the displacement of native peoples from their land was justified by the belief that the right to own the land was conferred on those who made best use of it. ${ }^{5}$ The land is rendered effectively empty of legitimate occupants because, in terms of the mythology, the tribes people demonstrated that they were unfit to own it. The extract also hints that the 'empty' land was at least in part the result of the 'mfecane', the sweeping tribal wars initiated by Shaka, the great warrior chief of the Zulus, that displaced thousands. The vacant land was therefore 'an emptiness crowded with ghosts'. ${ }^{6}$ The impossibility of resolving the necessary presence of black inhabitants within the dream of a white nation resulted in the mythologising of the landscape as empty, vacant and silent. Within this landscape the only acknowledged black presence flickered in the darkness as concealed danger.

The following extract, by a prominent Afrikaans writer, C.M. van den Heever (1902-1957), was published as the frontispiece to the official inauguration pamphlet for the newly completed Voortrekker Monument. It tells the contradictory narrative of an empty land in which (human) danger lurks. The poem linked the expressive power of the Afrikaans language with nationalist sentiments, through the retelling of history - sited on the landscape of the veld.

\section{Die Monument}

Die veld strek ver sy horisonne uit tot waar dit yl word in die blou,

\section{The Monument}

The veld stretches out its horizons to where it thins into the blue, 


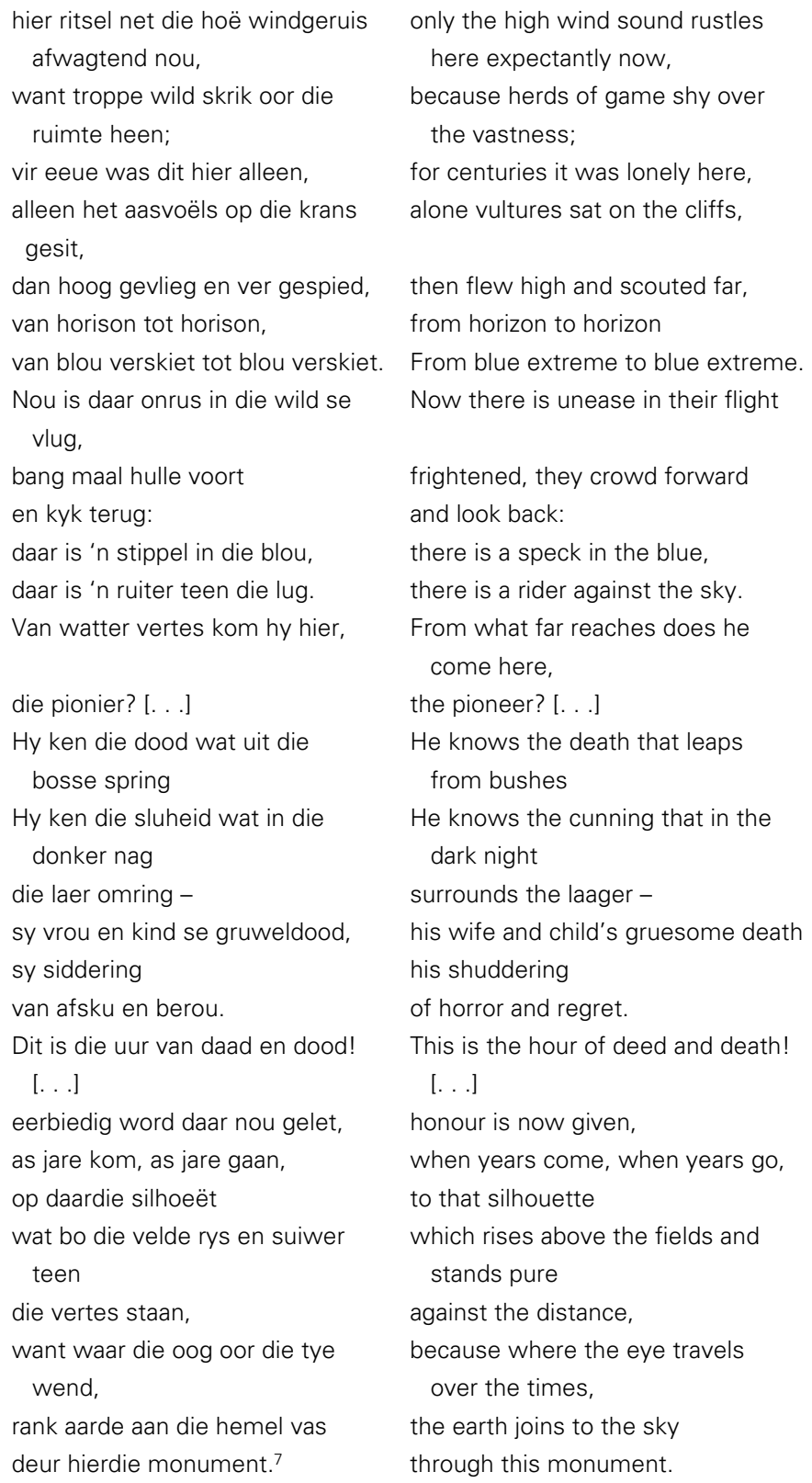

only the high wind sound rustles here expectantly now, because herds of game shy over the vastness;

for centuries it was lonely here, alone vultures sat on the cliffs,

then flew high and scouted far, from horizon to horizon

From blue extreme to blue extreme. Now there is unease in their flight

frightened, they crowd forward and look back:

there is a speck in the blue, there is a rider against the sky. From what far reaches does he come here,

the pioneer? [. . .]

He knows the death that leaps from bushes

He knows the cunning that in the dark night

surrounds the laager -

his wife and child's gruesome death his shuddering

of horror and regret.

This is the hour of deed and death!$$
\text { [...] }
$$

honour is now given,

when years come, when years go,

to that silhouette

which rises above the fields and stands pure

against the distance,

because where the eye travels over the times,

the earth joins to the sky through this monument.

The monument appears in the last two lines as the embodiment of the claim on the veld; as the body of the male rider stands proud against the light giving form to the emptiness, the monument connects veld and sky, earth and heaven. The form 
of the monument is therefore directly connected to the body of the volk, and through the body, to the land. The form of the monument centres on the symbolic sarcophagus of Piet Retief, the light that shines through the oculus at noon on 16 December each year therefore directly connects the body of the slain trekker leader with the highest Christian ideals of the nation.

\section{Bodies and the monument}

While the male bodies within the narrative and the monument are those of heroes, leaders and fighters, the makers of history, a different emphasis is placed on the representation of women. Elizabeth Delmont has stressed the role of female bodies, both living and dead, in the creation of the Voortrekker Monument, ${ }^{8}$ while Hermann Giliomee has traced the changing role of Afrikaner women from the time of the trek through National Party rule. He argues that Boer women were critical to the initiation and progress of the Trek, the prohibition on mixed-race unions and the fortitude and defiance of the Boer fighters in the wars against the British.

It was the vrouw who kept the war going on so long. It was in her heart that patriotism flamed into an all-consuming heat. She it is who returns, forgiving nothing and forgetting nothing. ${ }^{9}$

The women who had fought for autonomy and self-reliance mutate into the anonymous figures which appear in the concrete markings, sculptures and tapestries of the monument, in support of the overarching narrative of the fatherland. The historian Albert Grundlingh has identified this shift in a discussion of the changing meaning of the 1913 Women's Monument in Bloemfontein, over the period of National Party rule.

The different political context also brought a changed emphasis on the Women's Monument as a monument for women. Whereas the position of women was the focus of concern during the unveiling of the monument in 1913, subsequent brochures and other material interpreting the symbolism of the statues increasingly depicted the role of women as singularly in the service of male nationalism. It was often a case of no longer honouring women per se, but yoking them to another project in which they were represented as silent victims who sacrificed their lives on the altar of freedom and love of the fatherland. ${ }^{10}$

As Delmont has highlighted, women were involved in the production of representations for the monument; one of the four sculptors for the marble frieze depicting the story of the Trek was a woman - Laurike Postma - and, in 1952, the Vrou-en-Moeder (Wife and Mother) movement of the AKTV (a wing of the cultural movement of the South African Railways and Harbours) produced a 15-panel tapestry, now in the Voortrekker Museum. The most prominent representation of a woman appears at the entrance to the building: Anton van Wouw's (1862-1945) sculpture, 
3.3

Anton van Wouw's bronze sculpture at the Voortrekker Monument of an unknown

Voortrekker woman, staring resolutely ahead as her children clutch at her skirts. The photograph shows her flanked by two young female guards, 1949(?).
'Mother and Children'. In this bronze, a woman, her face shaded by a 'kappie' (sun hat), her lips set stern, stands upright, stilling her restless son and daughter who seek attention, pulling at her skirts, while she gazes levelly out over the landscape. Her identity is unknown; she stands, according to the official website of the Voortrekker Monument, as a 'triumphant . . carrier of Western civilisation'. ${ }^{11}$ The woman's body affirms the commitment of the Boers to their new homeland, domesticates the wilderness and nurtures the bodies of the children who are intended to become the heirs of the veld (Figure 3.3).

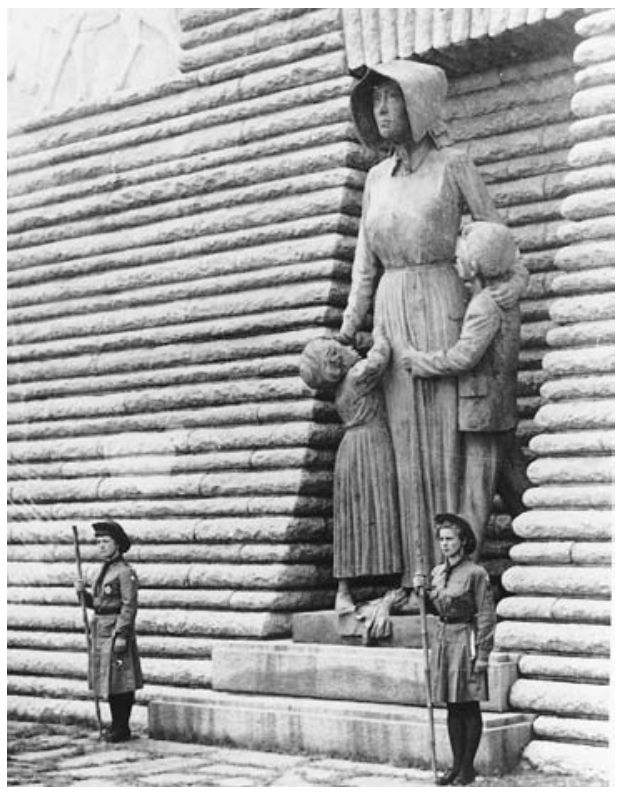

\section{Looking to the future}

The construction of the monument became a means to integrate the narratives of blood and sacrifice with the future of the Afrikaner nation. The chair of the Historical Monuments Commission described a policy in which the content of monuments were reconsidered; the desire for the future was to dominate the commemoration of blood shed on the land.

The form of our monuments is also a question to which we should give more attention. Our land is sown with gravestone monuments. This is partly because our history is marked by war. And now if a monument has to be erected on a battlefield or an historical grave, then it is self evident that the memorial takes the form of a gravestone. 
Our culture has long outgrown this stage! Monuments must speak to the heart of the volk. They must remind the volk of their rich past. They must depict not only difficulties and suffering. They must be an inspiration for nation building. ${ }^{12}$

The assertion that Afrikaner monuments are built to the future of the living, rather than in commemoration of the past, hints at the insecurity and tenuousness of the link to the land claimed by the volk as well as of the lack of temporal distance between the inscription of a version of the past and the call for that history to give legitimacy to the future. In contemporary publications, there is a constant invocation of the future, the work that still lies ahead, overlaid onto a past only recently inscribed.

The Afrikaner nation around their holy territory - Monument-hill. This photograph was taken in 1938, just after the foundation stone ceremony, taken from the air and it shows Monument-hill right in the middle with the enormous tented village which stood around the hill. The picture today is not that different - except that the building work which was just begun in that year, is now complete. The Afrikaner nation are again there, not only to honour the heroic events from the Trek period, but also to prepare for the task which still waits. ${ }^{13}$

This caption to a photograph which depicts the territory of the Voortrekker Monument covered with the tents of the faithful is still an encouragement for the nation to prepare for the journey ahead. The inauguration was marked by the production of pamphlets, stamps, and memorabilia, which carried the message of political triumph and ritual commemoration to those not directly involved in the inauguration. In 1949, a decision was also taken to attempt to replicate the success of the re-enactment of 1938 by organising a number of 'dispatch riders' - again dressed in historical clothing - who would spread over the land, carrying post marked with specially issued stamps and triggering small celebrations in rural towns. The dispatch riders were intended to represent the commando riders of the Voortrekkers, who were sent as scouts out into the land before the slow and cumbersome wagons entered it. The riders were therefore seen as the precursors of the civilisation (travelling in the bodies of the trekker women and children) that was to follow: they were the first to set eyes on the fatherland. As in 1938, the riders' journeys culminated on the monument site (Figure 3.4).

Their extensive routes, stretching from the Cape to Pretoria, brought the entire land once again under the overarching narrative of the Trek. Their mounted figures were incorporated into popular representations of the Trek; such as contemporary Christmas cards, as well as in the commemorative postage they carried, as the solitary ghosts of a past vacant interior. Through their journeys, the land was again subject to inscription which cast a dense net over the entire surface of the ground. Like representations of the journeys of the ox wagons before them, the artefacts and memorabilia made during the inauguration period sought to collapse historical time, weaving the appearance of the past into the present. 
3.4

Commemorative envelope and stamps from the 1949 Voortrekker Monument inauguration, from Voortrekkers: Album with Felt Flags etc. (1938-1949).
3.5

Commemorative

Christmas card from the 1949

Voortrekker

Monument inauguration - front picture showing a dispatch rider and a Voortrekker family.

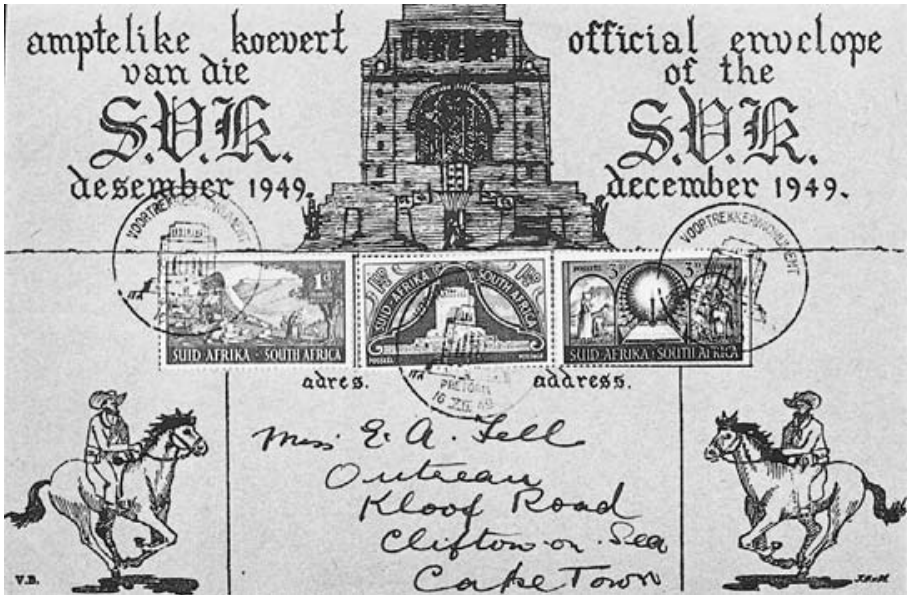

In a series of drawings printed on the front, interior and back of a 1949 Christmas card, a rider honours the elevated monument, a family group wave a rider off into a vacant landscape above which the ghostly form of the monument hovers and a map of South Africa documents the routes of the riders' journeys (Figures 3.5 and 3.6). The monument is not represented and conceived of as an isolated built fragment, a solitary moment, but rather as a symbolic structure which is present in every place in the land.

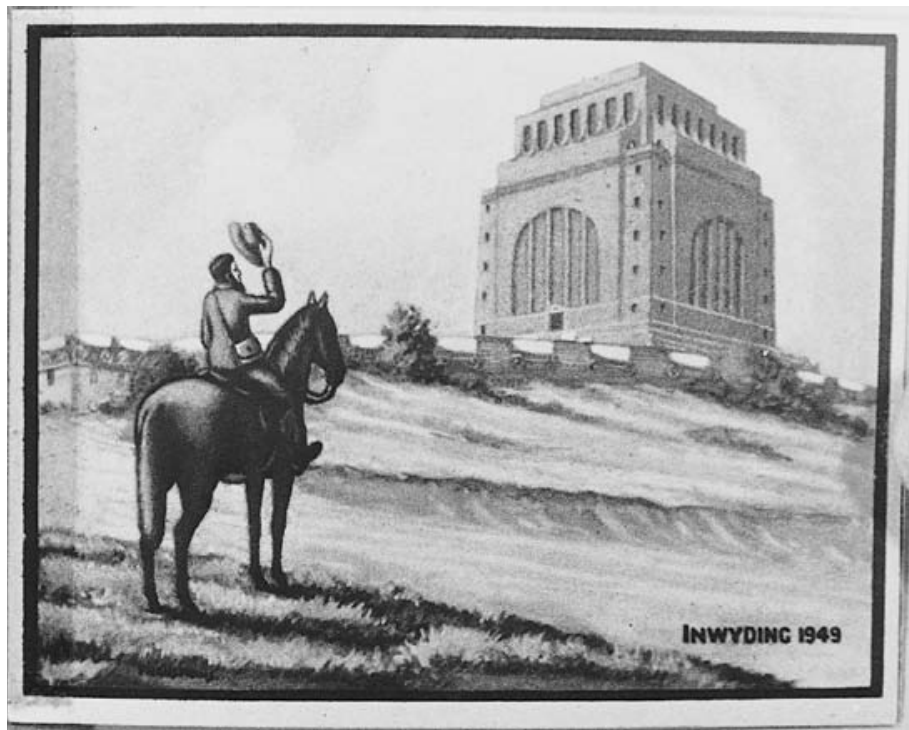




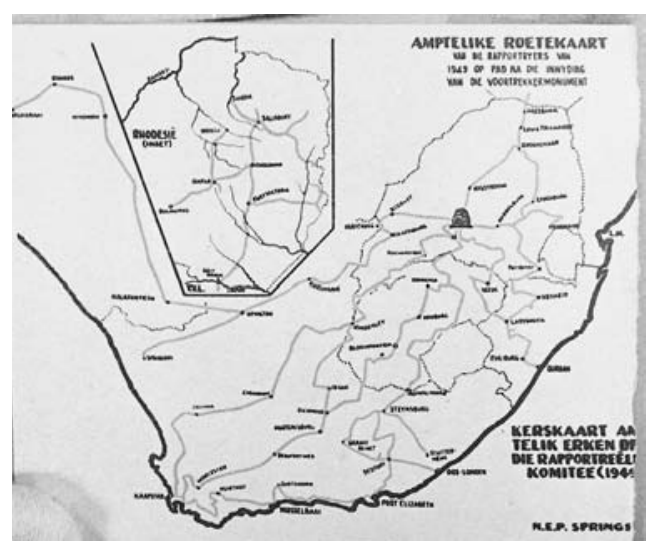

3.6

Commemorative

Christmas card

from the 1949

Voortrekker

Monument

inauguration - back picture showing the routes of the

dispatch riders in

South Africa for the inauguration of the Voortrekker

Monument.

\section{Map and monument}

Moerdijk's direct connection to this concept of the monument as map was confirmed in his executed design for the Karel Landman Monument, built between 1938 and 1939, in which a large tilted concrete globe is overlaid with a line of ox wagons and in the unexecuted map of South Africa which was planned for the dome of the Voortrekker Monument (Figure 3.7). Delmont has connected the relief map intended for the dome with the syndrome Harley identifies in which 'a people believe themselves to be divinely appointed to be the centre of the universe'. ${ }^{14}$ The mapping, however, not only imposed an order on the landscape, and the geometric form of the monument an order on the hill, but also the representation of the Great Trek reordered a past history which was itself fragmented, uncertain and fragile.

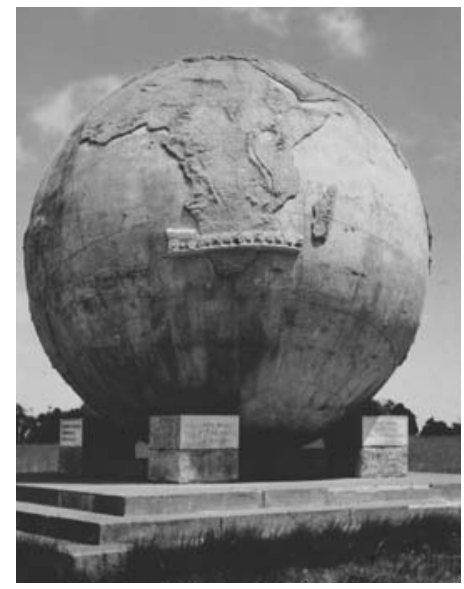

3.7

Karel Landman Monument (1939), a concrete globe with a span of oxen and a Voortrekker wagon appearing over southern Africa, by the architect of the Voortrekker Monument, Gerard Moerdijk. 
The interdependence between map, monument, narrative and landscape was reiterated on the slopes of the surrounding hill. In 1959, to the immediate south-east of the monument, a miniature landscape was constructed, with crude coloured-stone paths charting the four main routes of the various Trek leaders. These slate paths reproduce the winding trails drawn on maps of the same events (Figure 3.8). The new and permanent stone paths supplanted the ambiguity of the past with the certainty of the present. The landscape/map allowed visitors to the site to trace the path of various trekker leaders through the main events of the Trek in an environment planted entirely with indigenous plants. The laager of the Boers, at Blood River, was constructed in small scale a short distance from traditional Zulu beehive huts, representing Dingaan's kraal (Figure 3.9). The rounded grass forms of the latter not only provide a symbol of tribalism and betrayal, but are also a fragile architectural counterpoint to the rectilinear monumentality of the granite building that towers above them on the crest of the hill. The architectural fragments seek to pose primitivism and the danger that this still represents in contrast to the monumentality of white civilisation.

The execution of the landscape/map is in profound contrast to the immaculate construction of the monument itself. The paths are rough and simplistic, trekkers' names are impressed into raw cement, or cut into irregular slate pieces, and the Zulu 'hordes' that flood from Dingaan's Kraal are represented by small regiments of uneven black pebbles embedded into roughly made concrete trails. The presence of a hand-made, traversable map in close proximity to the monument entrenches the inseparability between the narrative that claimed the land and the presence of the monument itself.

3.8

Garden of 'Trekker Routes' at the Voortrekker

Monument (constructed 1959) converging slate paths.

3.9

Garden of 'Trekker Routes' at the Voortrekker Monument (constructed 1959) with grass beehive huts representing the Zulu chief Dingaan's kraal.
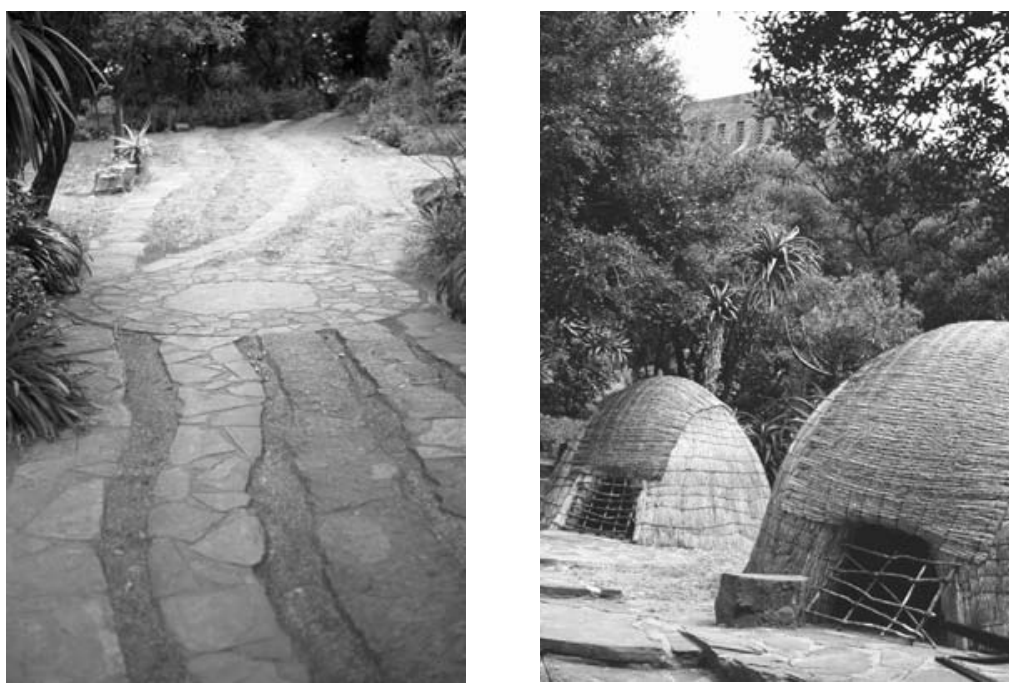
The tangled narrative of veld and Afrikaner ownership has been reinforced by the preservation of the emptiness and uncultivated 'naturalness' of the land around the monument. This stretch of open veld, in such close proximity to a metropolitan area, seems suddenly archaic, a frozen fragment of a land set apart from the concrete towers of Pretoria. When one drives into the city from Johannesburg, there is a moment of emptiness where all building has been prevented and the elevated cubic form of the monument still dominates the low, grassy hills. Leaving Pretoria, one enters the terrain of the veld before the monument becomes visible. Here, the physical relationship between veld and monument has been maintained, although the meaning of this relationship has altered in the surfacing of suppressed histories, violence and conflict.

\section{Precedent}

Just before one reaches the highway turn-off to the monument travelling from Johannesburg, another sign beckons - 'Valhalla'. The proximity of this site (a South African army base) and the cohesion between the northern European legend of Valhalla - a paradise for heroes and warriors slain in battle - and the goal of the monument to honour the nation's greatest heroes suggests a more complex set of antecedents for the monument than those claimed by the souvenir documents. The German Romantic obsession with the fallen warriors of their past culminated in the construction of Leo von Klenze's Walhalla of 1830-1842. The Walhalla, a neoclassical monumental temple to German heroes, was built near Regensburg, on the river Danube, where the Bavarian Forest meets the river and where it still stands today. The monument was created under the patronage of Ludwig, the Crown Prince, who announced: 'The Walhalla was erected that the German might depart from it more German and better than when he arrived.' 15 The siting of the monument at the confluence of two landscapes in which national consciousness was embedded confirms the perception that the form and meaning of the land was inseparable from the depiction of national identity and honour. Like the Walhalla before it, the Voortrekker Monument stands in the open landscape, here the veld, claimed as fatherland.

The dependence of Moerdijk's design for the Voortrekker Monument on German precedent is even more evident in the form, materials and motivation behind a more recent construction. In 1913, a century after the victory of the allied European armies against Napoleon in 1813, the Volkerschlacht Memorial by the architect Bruno Schmidt was opened in Leipzig (Figure 3.10). ${ }^{16}$ This massive stone monument, 91 metres high and crowned with figures of the dead heroes, was sited on the highpoint of the city, in an open green space. The elevation of the monument allows visitors views over the city, and ensures that it is as visible as possible from the surrounding areas. Like the later Voortrekker Monument, its interior is a vast hall, the main floor of which is pierced by a circular opening which looks down onto the tombs of the dead. Moerdijk's Voortrekker Monument borrows heavily from this precedent. 
3.10

Volkerschlacht

Memorial, architect:

Bruno Schmidt,

Leipzig (1900-1913).

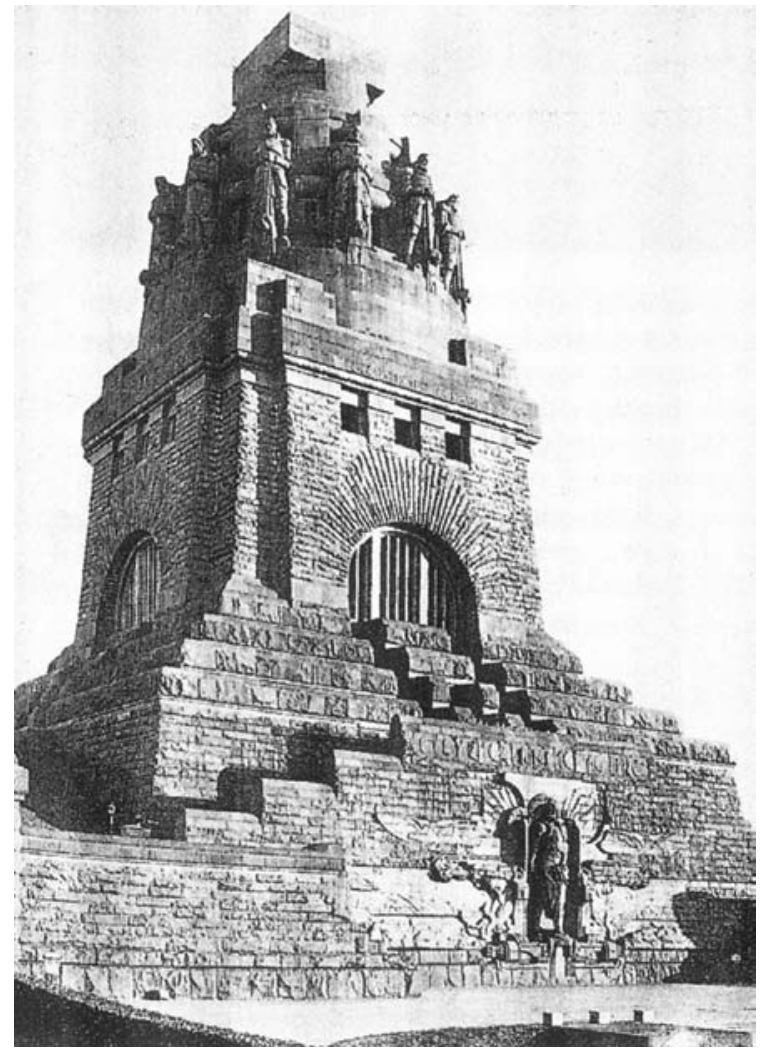

Apart from the obvious formal consistencies it is also sited, elevated, in a open landscape which relates to a city, it was constructed to mark the passage of one hundred years and commemorates the action of long dead heroes. The close similarity of the Voortrekker Monument to a German building, particularly in the light of Moerdijk's own stated claim that the design of the monument was derived from the particularities of Africa and Afrikaans culture, erodes the presented uniqueness of land, culture and nation. For if the architecture is a document both of the Afrikaner's right to the land and, together with its site, represents the specificity of the landscape of the veld and its history, then the promise of the monument is betrayed by its close association with European antecedent. The 'legal document' is a purloined text, a false history, clinging so unambiguously to European precedent and belief systems that its architect's claims for the building as a natural outgrowth of the southern African soil are contradicted by its very form and material.

Moerdijk's portrayal of his sources and motivation was, however, consistent with the political agenda of the Afrikaner Nationalists, who sought to intertwine the specific destiny of the volk with the land that they claimed. In the souvenir 
inauguration pamphlet of 1949, Moerdijk argues that his work is a response to the unique qualities of the continent.

Next to the greatest deed of the Voortrekkers (the establishment of white civilisation in the southern corner of Africa) the monument tries to symbolise the vastness of Africa. Africa is essentially the continent which makes the works of man appear dwarf-like and insignificant - it is indeed an overwhelming land. No wonder, then, that of all nations only one - the Egyptians - could give us in their art some conception of this vastness ... No wonder also, that the only structures in Southern Africa which succeed in capturing this spirit of vastness are the Zimbabwe ruins.

In this tribute to the Voortrekkers an attempt has been made to capture, in some small measure, some of this vastness. At Zimbabwe an impression of boundlessness is obtained by the use of small pieces of granite and the obliquity of these walls. This pattern has been followed at the Voortrekker Monument. ${ }^{17}$

Moerdijk articulated the wish that not only should the monument represent the narrative of the Great Trek but also it should resist the tendency of the 'vastness of Africa' to forget and to erase the particular history played out upon its plains. While it is the landscape itself that was the vehicle for claiming the land it is similarly the land that can remove all trace of human occupation. Moerdijk sought to counter the erasing tendencies of Africa by referring formally to the immense scale and power of the Mausoleum of Halicarnassus and to the ruins of Great Zimbabwe. ${ }^{18}$ Great Zimbabwe, dated between AD 1200 and 1450, has been a site of fascination to architects and historians because of the scale, age and sophistication of the immense structures and because of the continuing mystery of its purpose. It consists of two primary elements, a Hill Fortress and Elliptical Enclosure, built of dry-stack granite stonework, located between the Zambezi and Limpopo rivers in the southern part of what is now Zimbabwe. The enormous curved dry-stack stone walls are sometimes 11 metres high and over 5 metres thick (Plates 3.1 and 3.2). The inclusion of Great Zimbabwe as a model is complex not only because of the political debates surrounding the racial identity of its creators, ${ }^{19}$ but also because by invoking its forms Moerdijk wished to represent an engagement with 'African-ness' which was in sympathy with the 'vastness' of the continent.

The Mausoleum of Halicarnassus was one of the seven wonders of the ancient world. Completed around $350 \mathrm{BC}$ on a site near the Mediterranean in presentday Turkey, it was built to house the body of King Maussolus. The Voortrekker Monument has certain formal similarities to the tomb and its siting and it seems likely that the Mausoleum formed a model for the Volkerschlacht Memorial. The tomb was sited on a hill overlooking the city of Halicarnassus. It was a rectangular stone structure set on a podium, which was adorned with stone statues and decorated with relief sculpture depicting scenes from Greek mythology. A single burial chamber housed the white alabaster sarcophagus of the King. Moerdijk's reference to 
Classical Greek and African precedents sought to embed the monument in its Africa while imbuing the construction with the enduring achievements of antiquity.

The monument is built of granite, the most lasting stone for this purpose. The edges of the summit are encircled by a moulding of triangular depressions, similar to the material and design of those at Zimbabwe. This triangular design symbolises fertility. In ancient writings and on ancient monuments this zigzag design is used to indicate water, which is the symbol of fertility. This motif reminds one of the injunction given to Abraham: 'Be fruitful and multiply', from which came the idea of making and keeping South Africa a white man's country. ${ }^{20}$

In a strategy which characterised the methodology of the political narrative of South Africa, Moerdijk appropriated the form of an architectural fragment (in this case the triangular patterning of the walls at Great Zimbabwe) to create a new meaning (the fertility of the white Christian Voortrekkers in South Africa). The fragment was emptied of all meaning and context other than its 'African-ness' and 'fertility', which allowed Moerdijk to transfer the symbol from its site within an immense and enigmatic African settlement to a twentieth-century monument which was used to claim South Africa as a 'white man's country'. The longevity of the granite cladding was used to counter the tendency of the landscape to 'forget' the actions of its inhabitants, ${ }^{21}$ while the newness of the Voortrekker narrative gained weight through its association with ancient markings and African ruins.

The wall surrounding the Voortrekker Monument again illuminates one of the contradictions of the image of the vacant landscape by adopting a defensive position on the hillside. 'A laager of 64 wagons - the number used at Blood River serves at the monument as a symbolic wall defending the ideals and conceptions of the Voortrekkers against everything threatening them' (Figure 3.11). ${ }^{22}$ The 'everything' included the undeniable presence of the black South African in the landscape. The suppressed knowledge that the landscape is not vacant still haunts the narrative, and results in the defensive circular wall that forms an important part of the monument's composition and meaning.

The monument is built around the symbolic marble sarcophagus of Piet Retief and his followers, incised with the words 'Ons Vir Jou Suid-Afrika' (We for Thee South Africa), upon which a beam of sunlight is directed from an elliptical hole in the central dome on midday on 16 December each year - the date of the Battle of Blood River. Drawings by Moerdijk of the monument indicate this beam of light as integral to the composition of the architecture. It is drawn as an object in the interior which has physical presence (Figure 3.12). Even when not shining directly on the sarcophagus it signifies that potential, and the potential for the fulfilment of the destiny of the volk. It provides a visible connection between the earth-bound tomb and the intangible presence of God.

The 'lig van bo' (light from above) symbolically connects the natural and spiritual world with the architecture of the monument. The action of the light shaft 


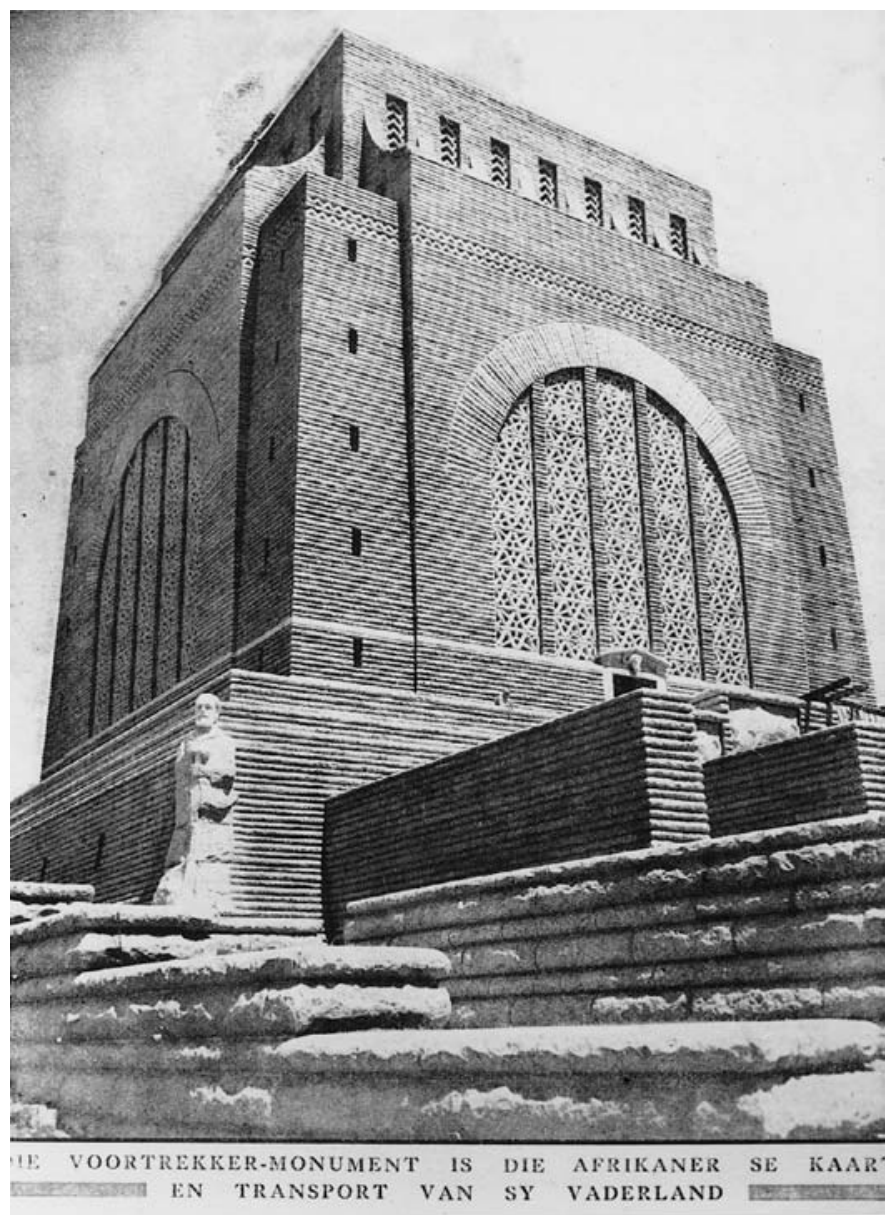

acts as a ritualistic moment which authenticates the myth of the vow of remembrance. God's status as creator meant that Moerdijk could invoke his presence through the architectural manipulation of light. It also reinforces the Afrikaner belief that the veld and nature itself responded to the presence of the Voortrekkers, recognised their presence and spoke to them, allowing the Afrikaner to claim knowledge of the veld, as a 'native son' might. The sarcophagus is made from South African marble. It is a fragment of the land that is the subject of the narrative and it reaches its full mythic and aesthetic power when it is struck by the rays of the South African sun.

The depiction of the veld, as natural landscape and fatherland to the Afrikaner nation, was based on a narrative which took its roots both from the European
3.11

View of the

Voortrekker

Monument from

Die Huisgenoot

(December 1949).

The text below the

photograph

translates as 'The

Voortrekker

Monument is the

Afrikaner's map and

legal title to his

fatherland'. 
3.12

Gerard Moerdijk, rendered cut-away axonometric of the interior of the Voortrekker Monument.

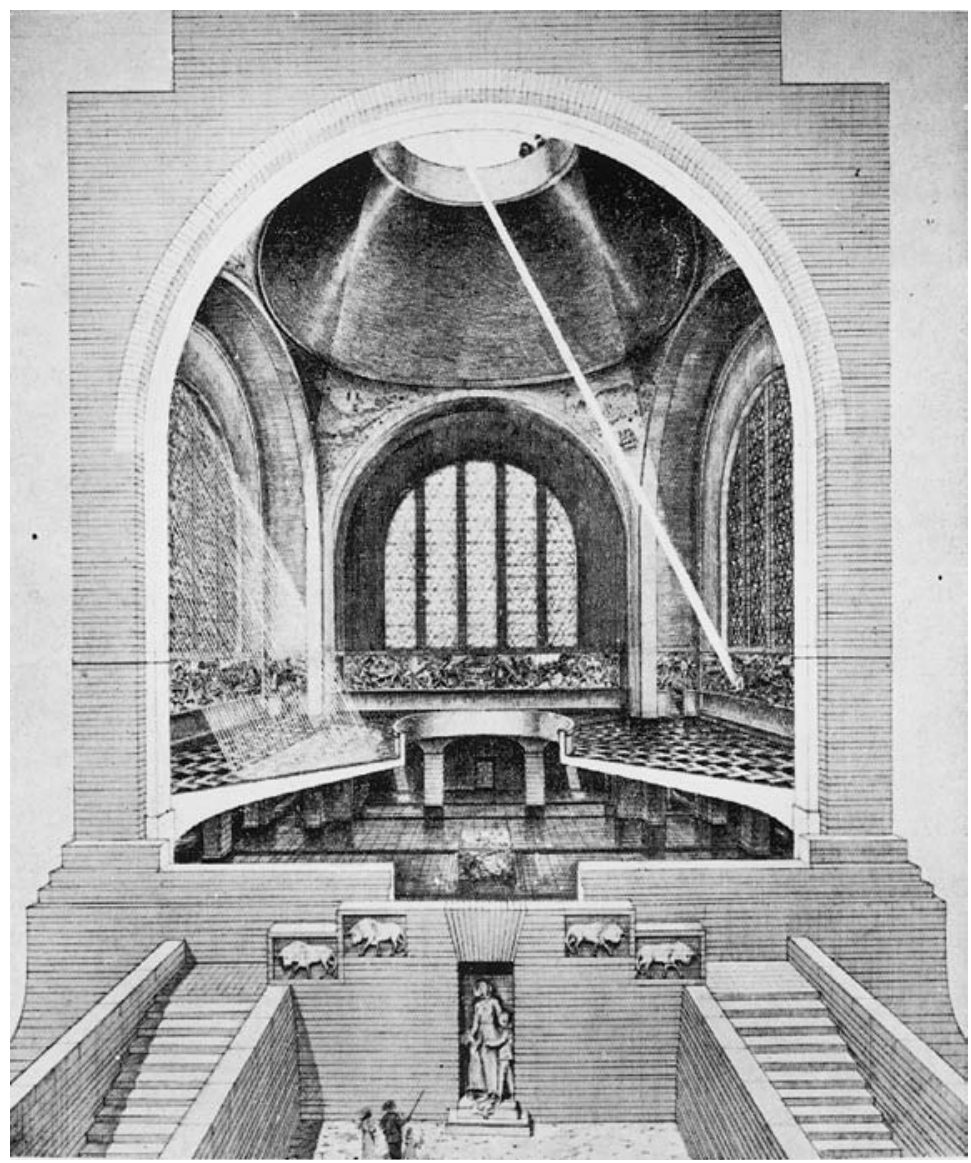

tradition and contemporary South African political debates. This representation required the suppression, not only of other conflicting histories of the land, but also of the extent to which European precedent influenced what was portrayed as a unique synthesis of a land and a nation. The veld that appears in these representations, therefore, can be read not so much as an 'authentic' African landscape, known from within by the Afrikaner, but rather as a complex construction which is dependent on the mythologising of fragments of a partially recovered history within a contemporary striving for political, social and economic dominance. Its representation is haunted by the fear that each myth contains its negative, and that the virgin wilderness is surging with the presence of other bodies and other histories that pose a real threat to the circular form of the laager and to the destiny of the Afrikaner nation. The rhetoric of enduring power and history remembered in monumental constructions 
Veld

and ritual commemorations sought to work against forgetting and erasure, and to deny the fragility of political power, even as this fragility, insecurity and tenuousness motivated both the construction of the Voortrekker Monument and the narrations that accompanied it. 


\section{Part 2}

Farm 



\section{Chapter 4}

\section{A failed Eden}

\section{Trekkerswee}

[Extract]

Verlore-klein lê op die Rand

hul huisie in die trekkersland

dit is ' $n$ stip net in die wei die rietedak en muurtjies van klei.

[...]

so dom-gerus; en bly-ontsteld

eers opspring as uit ruie veld

die koeie aandraf wat met hul geloei die awendstond vervul.

'n Bietjie verder van die huis, waar mielie blare helder ruis as windgeroer hul sanggeluid

hef bo die dowwe velddreun uit. [. . .]

'n Enkele perske, aan die lug

gewénd, dra daar sy goudgeel vrug,

\section{The woe of the trekker}

\section{[Extract]}

Lost-small upon the Rand 1

lies their little house in the trekker's land

it is only a speck in the openness the thatched roof and little walls of clay.

[. . .]

[the calves lie] so dumb-tranquil; and joyfully alarmed

leap up from the rough veld only when

the cattle come trotting

filling the eventide with their lowing.

A little further from the house

where leaves of corn clearly rustle

when the wind raises the sound of

their song

above the faint rumble of the veld.

[. . .]

A single peachtree, turned towards the sky

bears there its golden-yellow fruit 
en bied, gedroog, in wintertyd, and offers, dried, in wintertime,

'n skaars-verkrygbare soetigheid. a rarely obtainable sweetness.

Dit is die plasie wat daar leg, This is the little farm that nestles there,

Só rustig in die wydte weg -

'n koningkrykie op homself

waaroor ' $n$ helder hemel welf. ${ }^{2}$

\author{
so restful in the wide expanse - \\ a little kingdom in itself \\ over which stretches a clear heaven.
}

This extract from an epic poem from the early twentieth century by one of South Africa's best known early Afrikaans poets, J.D. du Toit (known as Totius, 1877-1953), establishes a romantic vision of the humble Afrikaner farm, and links its creation to the Voortrekkers, the powerful founding myth of the Afrikaner volk. Produced as a nostalgic reconstruction of a vanishing life, it constructs an image that is dependent on a tradition of writing of the pastoral that stems from the Roman poet Virgil. An Arcadia is created by the words of the poet, yearned for those displaced from it by urbanisation. In the poem the farm is modest, remote and silent in the veld of the trekkers, on whose legacy its presence is dependent. The farmer, ruler of the 'koninkrykie', coaxes the fruit from the unpromising landscape, tends the cattle and cultivates the fields. The landscape of the interior is no Eden; the fertility and lushness of the first garden is replaced by a harsh portrait of life in the dry landscape, whose emptiness drones with a low hum. The remoteness of the farm is significant. It exists as an area of hard-won fertility, carefully tended from the unpromising landscape of the veld. The idyllic farm has no discernible boundaries; the cattle come running from within the rough veld. It is solitary and isolated.

This chapter is concerned with the image of the farm within the context of an evolving Afrikaner nationalism. It examines how farming was imagined and represented as being the preserve of the white, predominantly Afrikaans farmerthe Boer (an Afrikaans word that literally means 'farmer'). The politicisation of veld and farm was critical to the normalisation of the 'natural' occupation of the ground by the Afrikaner, and to the consolidation of a common identity which supported the volk in their drive to gain greater political and economic power, particularly in the early part of the twentieth century. Control of the myth of the farm was important not only in the battle for the ownership of the land, which served to consolidate political control and guide legislation, but also in the creation and retention of a cherished vision of a vanished rural existence at the heart of Afrikaner identity. It therefore acted both in the rural areas as a mutating and well-rehearsed argument for white possession of the land, and as an invocation of a rural existence that offered even urban dwellers access to a past which 'naturalised' their presence in southern Africa. In a world in which the agricultural way of life was ever more under threat, the myth of its existence served as a reservoir of meaning of the natural world within an increasingly industrialised economy. The connection to the 'natural' world helped to justify the perception that the volk was a true 'organic creation' of God. As part of this process 
the complex identity of the southern African farm and the racial diversity of its owners, occupants and tenants were simplified in the narration of a political narrative that depicted the pastoral landscape as the exclusive preserve of the white man and his family.

There is a distinction between the genre of the pastoral, the representation of rural life and cultivation of the land which is often a product of a distancing from it, and the agricultural landscape, inhabited by farmers and labourers who actively tend and cultivate the soil. While the agricultural landscape is emphasised primarily as productive, the pastoral is reliant on the depiction of natural intimacy and pleasure in the natural world. Writing about North America, Leo Marx has argued that pastoralism as the 'image of a natural landscape, a terrain either unspoiled or, if cultivated, rural' functioned not only as a myth for those living within it, but also 'for those who had been forced to move away from it'. He continues that 'the movement towards such a symbolic landscape also may be understood as a movement away from an artificial world'. ${ }^{3}$ In South Africa, the pastoral was developed primarily through poetry, literature and paintings, such as Pierneef's series of paintings of remote Cape Dutch farmhouses in golden valleys. The pastoral therefore acted as a myth of stability and innocence which supported a transformation in the inhabitation and ownership of the agricultural landscape throughout the twentieth century.

The implicit danger in the pastoral is in its yearning for a purity that cannot exist. Marx's argument that, if remained unprobed, the desire for the pastoral can result in a 'simple minded wishfulness, a romantic perversion of thought and feeling', 4 has implications not only for the politics of rural areas, but also for the form and development of the cities. While in the early twentieth century, through poems such as 'Trekkerswee', the pastoral was used as a means to claim the transformation of the wilderness and therefore for Afrikaner ownership of the land, over the period of National Party rule farming was encouraged to become more modern and capitalist, in turn initiating a shift in the way in which the pastoral landscape was represented and imagined. ${ }^{5}$

The myth of the farm is embedded in political claims on the landscape as an equal and overlapping myth to that of the veld. While the veld was used as the location for the narrative of Afrikaner history, the farm as both pastoral and agricultural landscape became inseparable from a political and economic argument for the continuation and extension of white ownership of the land. The ambiguity of the physical landscape itself, and its ability to accommodate either construction, meant that threat of a reversion of the agricultural landscape to the wilderness was ever present. The association of race with physical characteristics of the landscape - of white with civilisation and cultivation and black with wildness and primitivism - ensured that the wilderness remained central to the definition of the territory of the farm.

A British visitor to South Africa, in 1902, commented that:

Today one of the most striking differences between the Dutch and other white people in South Africa is that the former belong to the soil. They have 
assimilated South Africa; they are the native growth of the veldt; their roots are deep in its soil. 6

The perception that existed among other settlers, visitors and the Boers themselves, that the Boer had established a 'rootedness' in the South African soil, became central to the mythology of the Afrikaner people. The connection between the Boer and productive nature enabled this connection to the land to be claimed as a particular and exclusive right.

\section{Bounding the garden}

The first settlers at the Cape in 1652 had a clear directive: they were sent by the Dutch East India Company to establish a supply garden, and to ensure that its produce, a permanent flow of fresh fruit, vegetables and meat, was available to those who were en route to a much greater prize than Africa - the Company's colonies in the Indies. The first group of people to establish a permanent settlement at the Cape had allegiance therefore not to an external government, but to a commercial enterprise. Unlike colonial settlements in North and South America, the settlement at the Cape was not conceived of as an incipient city. ${ }^{7}$ It was intended only to remain as two fragments of the European continent transplanted to Africa - the fort and the garden. The walled kitchen garden appears in early maps as a bounded figure, a world unto itself, its rectilinear sides sharply delineated against the white unknown of its surroundings. The garden was flanked by a fort, buttressed against attack from the sea and from the land. The presence of the fort betrays the potential for instability and violence. The undefined land harbours threat as well as being a container of potential fertility.

The first map that we have of the embryonic settlement is from 1654 (Figure 4.1). Produced for the information of the Company, it shows the extent of its landholding and cultivation at the Cape, as well as the means to protect it. The only visible dwelling, and therefore the only denoted human presence, is the house of the Company gardener, Hendrik Boom, his surname itself meaning 'tree'. The act of marking out and mapping the garden demarcated its area from the encircling unknown land, claimed it, and civilised it through cultivation. By defining the supply garden the officials of the Dutch East India Company created the first bounded European territory in southern Africa, marking us and them, inside and out, garden and wilderness. The settlement is a fragment that clings to the southern edge of the African continent; there is a sense in maps of the seventeenth and early eighteenth centuries that the stretch of the continent northwards is palpable, even if it remains largely unknown to Europeans.

Both the limited and tentative nature of the settlement at the Cape and the figure of the bounded garden indicate the reservations with which the officials of the Company regarded the southern African territory. The vigour and enthusiasm with which the New World of the Americas was approached was not paralleled 


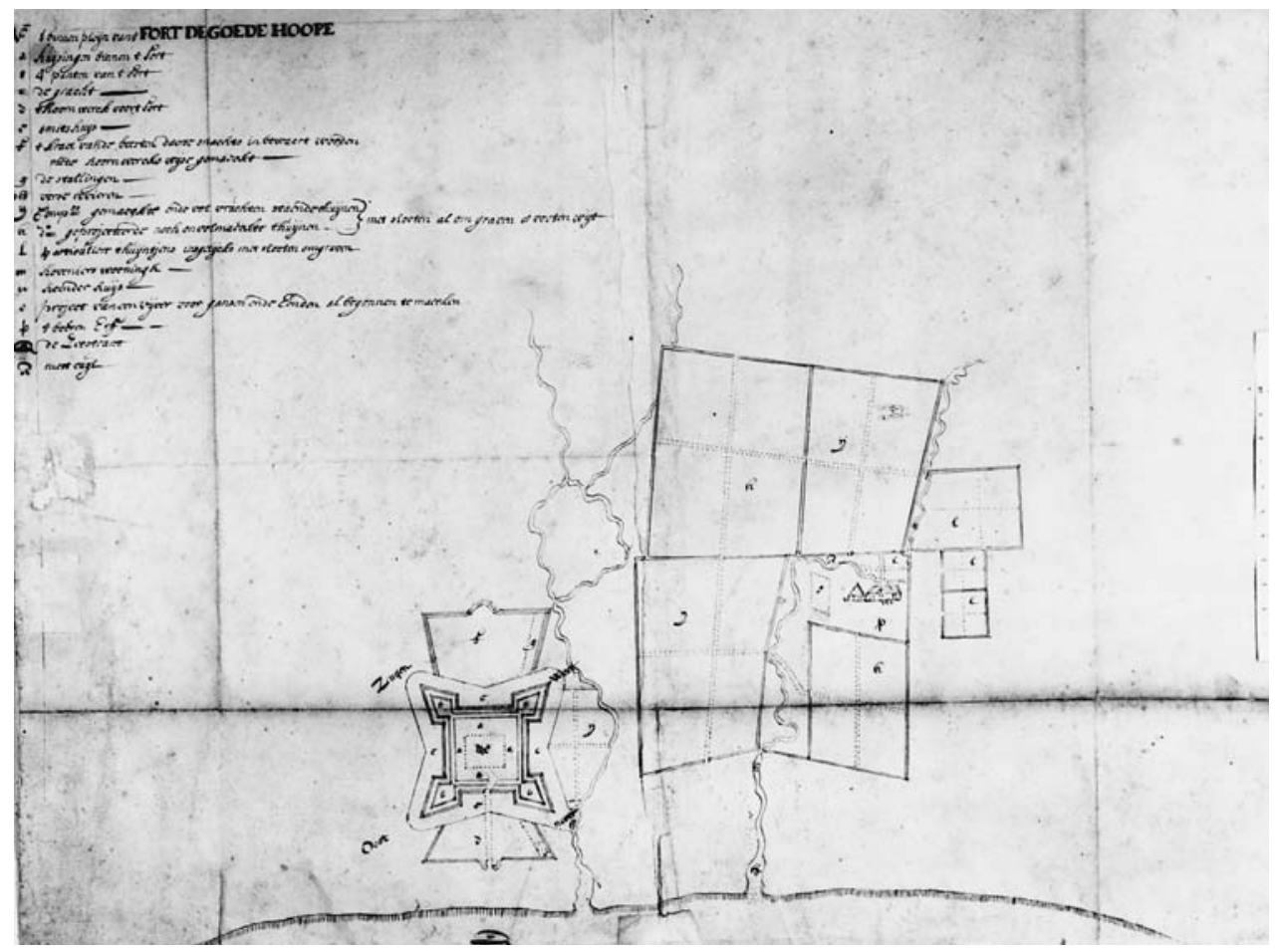

4.1

A Dutch East India Company map (1654), showing the Company's Garden, Fort and the house of gardener Hendrik Boom.

at the Cape. J.M. Coetzee has argued that the Edenic myth was not applied to the settlement at the Cape because Africa was understood, not as a New World, but as an Old one, drenched in a history at once present and unfathomable by its European settlers. ${ }^{8}$ If America was the New World where a new Arcadia could be constructed, then Africa was an Old World in its most primitive and savage form, alien and hostile to Europeans, peopled by savages, living not frequently in a state of grace. America was perceived to be a land without history, where new beginnings could be forged in a pastoral landscape away from the decay and industrialisation of Europe, while the weight of Africa's past was all too apparent - elusive, intangible but inescapable. Branded in the nineteenth century as the land of childhood, an ill-formed stage in the development of the human race, Africa was perceived as being at once ancient and undeveloped - layered with the crust of immeasurable centuries yet unable to register the passing of linear, historical time. ${ }^{9}$

Afrika

[Extract]

\section{Africa}

[Extract]

Ek dink aan Afrika, aan lang vervloë I think of Africa, of bygone times 


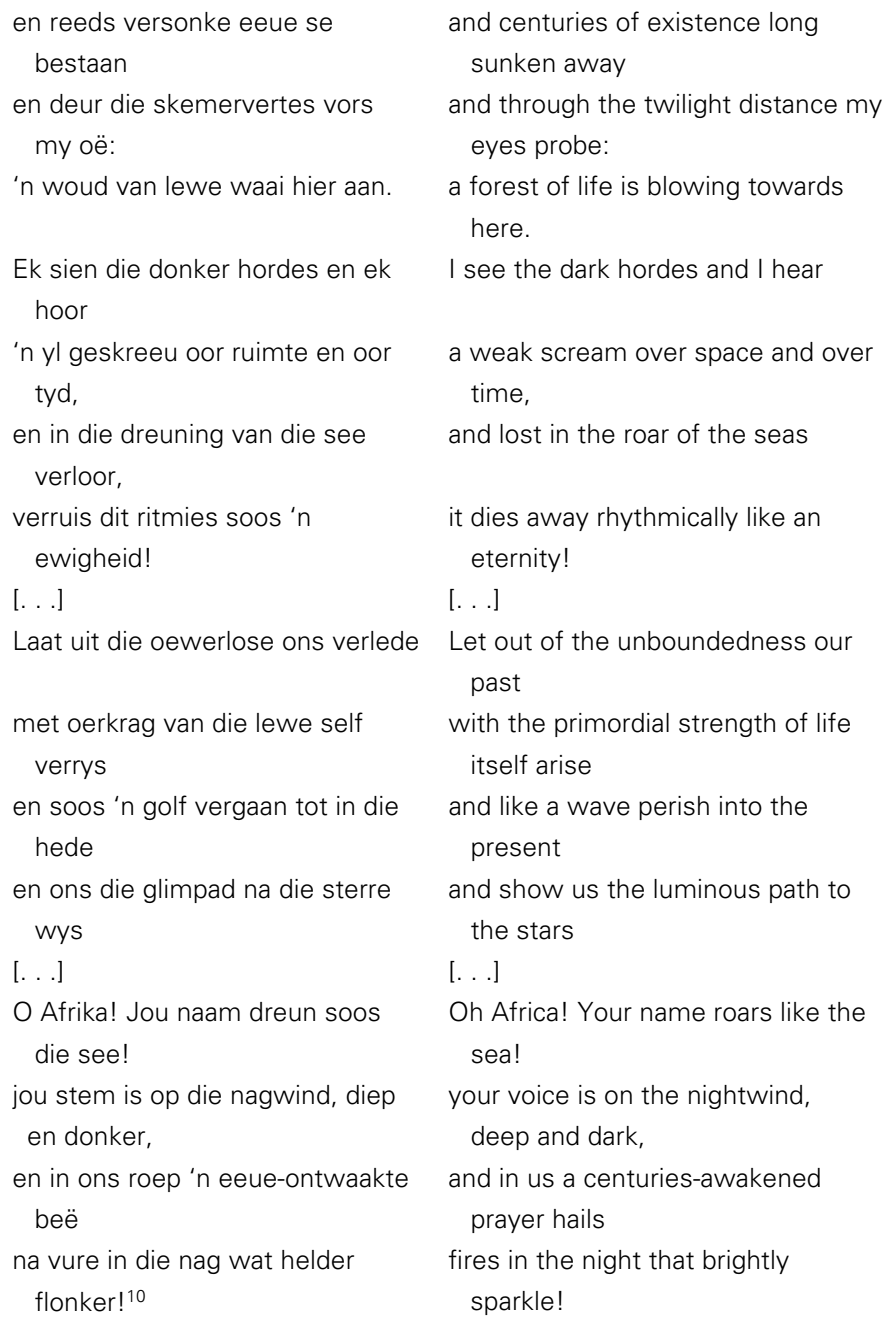

Here C.M. van den Heever (also a contributor to the 1949 Voortrekker Monument souvenir booklet) draws on the 'lost' ancient life of Africa as the impetus for a new, reinvigorated history. In the early to mid-twentieth century the ancient history of the African continent was addressed in writing that sought to inflame the volk with their ability to be remembered in a landscape, outside of linear time, populated with anonymous ghosts. The Afrikaner desire to imprint the land with the fulfilment of their nationhood, hinted that the 'dark' and unknown past of the continent could be overwritten by a narrative which both claimed a more specific and recent history and looked towards a modern future. In the poem, Africa herself was entreated to guide the volk to its destiny in the stars. The direct appeal marks the Afrikaner claim as one 
which was bound to the continent, although it is an appeal that is dependent, not only on the silencing of the 'dark hordes', but also on consigning their history to a period of night before the coming of the fires of white 'civilisation'.

Early colonists, however, unburdened by the destiny yet to come, extended the productive landscape up and beyond the mountain. The Khoikhoi tribes who inhabited the southwestern Cape, including the Table Mountain area, kept both cattle and sheep, but cultivated no crops apart from marijuana. The settlers established themselves on uncultivated land which the tribes used as pastures, enabling the settlers to interpret it as still being a wilderness. ${ }^{11}$ By 1693, when the map (Plate 4.1) of the settlement was drawn, further farms had been created. The Company Garden had been extended and formalised into a rectangle stretching from the sea up the slopes of Table Mountain. The boundaries of the farms, however, inflected towards the topography of the landscape and its rivers, replacing the formal geometry of the original garden with a loose irregularity. The Company Garden had the geometry of its edges enforced, and was already showing signs of transforming from a productive to a symbolic landscape, as its purpose altered from productive farm to formal garden.

One of the early images of the Cape settlement therefore splits the cultivated areas into those intended for pleasure, and those that were conceived of as being productive. The 'nature' held within the boundaries of the transformed Company Garden did not mimic the appearance of the outside landscape, but rather reproduced fragments of European pleasure gardens. The pleasure garden represents the possibility of clothing the nakedness of the African landscape in the familiar geometry of scenes of home, and therefore rendering it accessible and familiar. The farm, however, is distinct from the formal garden in both form and meaning. It did not seek to reproduce an image of nature recalled from a European homeland but rather represented a knowledge of nature in order to become productive. If the pleasure garden clothed the African landscape in the garments of foreign lands, farming sought to tend nature into clothing herself.

The early Cape farms were created in the embrace of mountain, rivers and sea - in the landscape of the 'Fairest Cape' - but as the farms expanded into the interior (an area both physically more hostile and increasingly densely populated by Khoi San people forced away from the Cape by white settlement) the depiction of southern Africa as a harsh landscape which repelled white settlement began to take hold. A persistent image of Africa as a dystopia developed, a land of futility and failure, which resisted the transformation into a fertile garden and had absorbed the specificities of black history.

\section{Die Verlate Tuin}

[Extract]

Staan daar nog 'n Eden êrens,

verwaarloos soos ' $n$ stad in puin, gedoem tot langsame verrotting

\section{The Abandoned Garden}

[Extract]

Stands there still an Eden somewhere, neglected like a city in ruins, doomed to gradual decay 
deur eeve die mislukte tuin ${ }^{12} \quad$ through centuries the failed garden?

Ina Rousseau (1926-2005), an Afrikaans poet of the twentieth century, followed in the footsteps of Olive Schreiner in her musing on southern Africa as a possible location for a 'failed garden', an Eden of decay rather than of fertility. The vision of the elusive garden was first published in 1953, during the first years of National Party rule, and the place that she describes seems to exist as a metaphor for other disenchantments in the southern African landscape. If there was an Eden in the expanse of southern Africa, it is one that had been neglected and abandoned. Rousseau's despair is born out of the failure of the garden itself as well as on the failure of recognition, and the failure of transformation. Her work represents a strain in twentieth-century Afrikaans writing that still saw the landscape as unresolved and opaque to the outsider, and resisted the resolution of the instability of the land in terms of Afrikaner political mythology.

In Rousseau's poem the garden is likened to a city in ruins, a place of fallen rock rather than fertile fronds, like the geological landscape of the Karoo described by Schreiner. In this place there is no possibility of cultivation, and no redemption of the land into territory more recognisable to those who desire European landscapes. It connects to a perception that a constant erosion of inhabitation was a permanent condition of the landscape of South Africa and that the characteristics of hostility and harshness were those in which the true meaning of the land resided. What differentiated the image of the wilderness in Afrikaner Christian National narratives from the enigmatic dystopia invoked by some nineteenth- and twentiethcentury writers was that the volk, as farmers, were depicted as offering the possibility of fertile transformation and progress to the resistant landscapes of southern Africa.

Schreiner, and in turn Rousseau, offer us the possibility that the landscape remains invisible because of the failure of those who turn their gaze upon it to cast aside their own preconceptions of pictorial landscape. By looking through a veil of representation the true land can never be known. Coetzee argues that the description of Africa by many English writers as 'not Europe' was based on the inability of the eyes and minds of the settlers to see Africa, because in searching for fragments of Europe they negated its value..$^{13}$ The significant and fundamental inversion to this way of thinking can be found in the flowering period of Afrikaans poetry in the early part of the twentieth century. The poets and writers chose rather to emphasise the hostile qualities of the landscape, sometimes rejecting fertility and greenery as 'not Africa'.

For the poet Peter Blum (1925-1990), the South African landscape could take on the identity of both the fertility and greenness of Surrey in the rain, or the special light of the Netherlands, but it was the relentless 'bergwind' (mountain wind) and the 'droogte en brand' (dryness and fire) and the 'skroeiende binnelandse lug' (blinding light of the interior) that revealed the true identity of the place he described as an African farm. ${ }^{14}$ Griesel has argued that, after 1920, in Afrikaans novels, 
the recurrent representation of the fertile Western Cape was abandoned in favour of the depiction of the barrenness of the grasslands of the interior, as landscapes which bore physical resemblances to Europe were overtaken by those which cohered with the political narrative. ${ }^{15}$ The descriptions of early settlers registered despair and dismay at the impenetrable characteristics of the land that confronted them, and which resisted their attempts to domesticate it, while later writers sought to embrace its 'true' meaning through a close examination of its surface and depth, even by registering their failure to understand it, and therefore to incorporate it into the newly forming cultural experiences and literary productions of the Afrikaner people.

\section{Intimacy with the land}

The development of a written Afrikaans literature that sought intimacy with the 'real' landscape of southern Africa created an image of the landscape that incorporated harshness, descriptions of dryness and the presence of geological structures. These images of the land were ripe for the incorporation into a political narrative that sought to justify both the separate identity of Afrikaners and the language of Afrikaans and a right to occupy the land. C.J. Langenhoven (1873-1932), poet and composer of the words to the old South African national anthem and one of the early twentieth-century protagonists of the 'language struggle', linked the birth of Afrikaans to the land, and to farming life.

In our wonderful Afrikaans, born from the lowly necessities and the rough soul of the countryman without privilege, the farmer and his tenants, the shepherd and the labourer ... you can express anything, from the lowest to the highest, from the most ugly to the most beautiful, from the foulest to the purest, better than in all the highly developed languages of the world. ${ }^{16}$

The writing of the landscape in the Afrikaans language, the emphasis on the specificities of desert, rock, light and grasslands at a time when identity, land and language were targets of political and economic ambitions enabled culture, language, landscape and nation to be represented as seamlessly integrated. The ambition and productivity of the Afrikaans farmer could be depicted as the civilising energy that rescued the land from centuries of erasure. The varied physical characteristics of the southern African landscape, the changes that it underwent during the different seasons, and its ability to be both fertile and harsh were often disregarded in favour of land against which the farmer had to continually battle. The image of the productive farm gained political power through the representation of the landscape of southern Africa as an originary wilderness. Under the political narrative of the twentieth century, and in common with other colonial narratives, the ambiguity of the landscape was suppressed and its simplified physical characteristics were used, not only to argue for a deep knowledge of the natural landscape, but also to claim continued ownership of the land. 
It is not uncommon for nature and landscapes to be the means through which political systems seek to resolve anxieties and contradictions. 'Nature' acts to normalise alterations to the environment that are frequently the product of political change. The presentation of the 'natural' world can act as a process both of recovery and of concealment by drawing a veil over the complexities of political relationships. Representations of landscapes can therefore be read as much as projections of other, perhaps lost, landscapes as reflections of real places. It has been argued by the art historian Ann Bermingham that: 'Naturalisation ... [i]s always involved in maintaining the status quo, in continuing to represent the given relationship of men to the means of production as "natural".'17

Bermingham has examined the role that the pastoral, and the representation of nature, played in the naturalisation of social, economic and political relationships during the period of landscape enclosures in England in the late eighteenth century. It is her contention that, as the enclosures absorbed what had been real natural landscapes and turned them into cultivated lands, so the estate gardens took on the appearance of the nature that was being removed from the outside landscape and therefore that the appearance of nature in the landscape gardens, 'depended on a completely non-functional, non-productive use of land. '18 Nature was desired as a picturesque fragment of what had been lost, restored only to those who had the financial means to reconstruct it.

Writing about the same period, Leo Marx has argued that the New World of North America was the site of projection for the dreams of the English who saw their countryside being destroyed by the enclosures and by industrialisation. ${ }^{19}$ In his narrative of the settlers' relationship to the North American continent, the newly discovered landscapes offered the chance to regain that which had been destroyed, and the opportunity to cultivate a new society. The virgin continent of America offered the promise of a vast fertile wilderness, which, with a little application, could be transformed into the new Arcadia. He argues that the North American wilderness was always seen as a potential farm, and that the aspect over the landscape was more a pause to survey the possibility for transformation than it was a chance to savour the (often non-existent) picturesque. Wilderness was important to the American farmer primarily in terms of its transformation into cultivated farmland and the possibility of expansion of the pastoral ideal so that the entire continent could become 'a collective representation' of the 'master symbol' of the garden. ${ }^{20}$ In common with the South African narrative, the cultivation of 'rude soil . . . into a pleasant farm' conferred rights on the farmer himself which displaced those of the local inhabitants. In order to argue for the right to occupy the landscape, the image of a bountiful Eden had to transform into one in which nature was not seen as sweet and benign, but as something to be improved by the actions of the settlers. ${ }^{21}$ The image of a virgin wilderness, open to cultivation and taming was similarly a strong metaphor to the settlers of the African continent. The wilderness and the farm were dual aspects of the natural world and the narrative of the farm was dependent on the existence and transformation of the originary wilderness. 


\title{
God in nature
}

\section{Om Boer te Wees} \\ [Extract] \\ O om 'n boer te wees wat werk \\ met sy hande in die son \\ die liewe, lange dag; om saans \\ moeg terug te kom \\ van die lande, en te slaap \\ tot die rooidag deur die vensters \\ breek, \\ en teen die tweede hanekraai, \\ oor die ryp, \\ die ploegstert vas te hou... \\ $\mathrm{O}$ om boer te wees en te werk \\ in God se sonskyn en reën; \\ om nooit te twyfel dat Hy weet \\ wat die beste is; om nog te glo, \\ as sy hart wil breek, \\ en voel dat hy, boer alleen, \\ met God kan praat, en dank \\ as laag-druipend daal die reën. ${ }^{22}$

\section{To Be a Farmer} \\ [Extract] \\ Oh to be a farmer who works \\ with his hands in the sun \\ the loved, long day; at dusk \\ to come back tired \\ from the land, and sleep \\ until the red dawn breaks through \\ the windows \\ and at the second cock's crow, over \\ the frost, \\ to hold the plough handle fast... \\ Oh to be a farmer and to work \\ in God's sunshine and rain; \\ and never to doubt that $\mathrm{He}$ knows \\ what is best; and still to believe \\ when his heart would break, \\ and to feel that he, farmer alone, \\ can speak with God, and give \\ thanks \\ as the rain pours down.
}

In W.E.G. Louw's (1913-1980) poem, farming life connects not only to the natural rhythms of the land, but also through nature back to God, the creator. The author yearns for farming life not only as a nostalgic affirmation of the simplicity and perfection of rural existence, but also as the natural habitat and vocation of God's children, the Afrikaners. The pastoral world offered a physical environment for the connection to God that formed a fundamental part of the Afrikaner Christian National belief system. The farmer as 'natuurmens' was subject to rain and sunshine in the same way as were his fields, and the call to rise was given, not by a clock, but by the living crow. He acted as part of the natural world, as an organic creation, and through his actions served to personify the natural relationship of the Afrikaners to the environment. In opposition to English-speaking people, who were often dismissed in the political narrative of the Christian Nationalists as being intellectual, city-bound and therefore displaced from the lifeblood of the country - its soil - the Afrikaner farmer was represented as living as part of the natural world, or at least being able to draw on this closeness as part of a mythologised past.

Afrikaner nationalism was depicted by Afrikaner politicians and intellectuals as anti-colonial and anti-imperialist; created in opposition to the imposed order of a detached and far-off power. The presence of God, as both the creator of the landscape and the protector of the volk, was important to the legitimising of the occupation of the 
land. The reference to God in the poem below, by Elisabeth Eybers (a contemporary of Louw and van den Heever of the so-called 'Generation of 1934'), recalls the association of the southern African landscape with the land of Israel, and of the peace and oneness with God that the bare desert landscape offered.
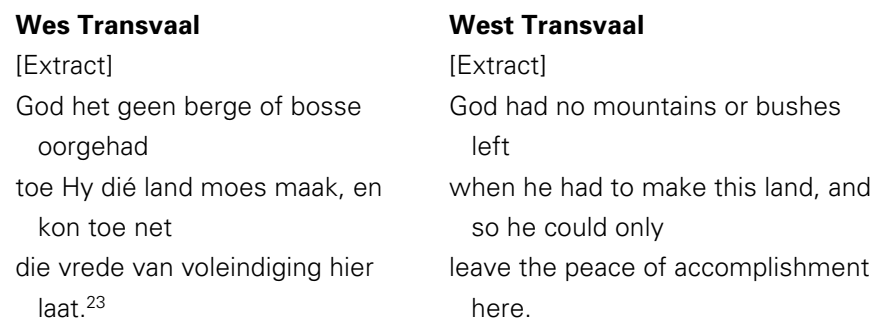

However, the narrative which sought to argue for the independence and particularities of the Afrikaner people, and their 'natural' occupation of the land, had strong connections to another which had its roots, not in Africa, but in northern Europe. At precisely the same time at which the Afrikaner narrative was being propagated another, strikingly similar, landscape mythology was being extended, entrenched and overtly politicised. The similarities between the German National Socialist narrative, which had at its core the desire for political power and the upliftment of a volk, and the imagery of the 'white tribe of Africa' exposes the Afrikaner narrative as one which was at least partially dependent on northern European sources, and points to the direct association of a number of influential Afrikaners with the National Socialist state. ${ }^{24}$ Hendrik Verwoerd (Prime Minister of South Africa 1958-1960) did postdoctoral studies in Germany. During this time he came into contact both with National Socialist ideas and with the theories of psychiatric eugenics, which were to influence his ideas on racial purity. ${ }^{25}$ As editor of the Transvaler newspaper from 1937, he had tremendous influence on public opinion during the critical years of Afrikaner Nationalism and would have had responsibility for the imagery of the land that appeared in the paper. ${ }^{26}$

The connections between Europe and Africa were both political and cultural. ${ }^{27}$ There was an awareness of the significance of landscape myths and imagery for Europeans in Afrikaans intellectual circles. Pierneef was born and spent considerable amounts of time in northern Europe, studying in the Netherlands. As has been mentioned, there were also direct connections between political groups in South Africa and Germany - specifically the right-wing Ossewabrandwag and the National Socialist government. The argument for a natural right to the land based on 'blood and soil' as well as the claim for a characteristic national landscape and the nostalgic reaffirmation of the farmer as the locus not only of individual toil, but also of the rebirth and renewal of a volk, connected to a history of nationalism and religious identification with the land that was characteristically northern European.

When there is so much sensibility related to the earth in which we are rooted, it is only natural for us to see our occupation with landscape as 
the purest of artistic endeavours ... For us today the landscape represents the territory of the Reich which demands our dutiful dedication . . . German painting attempts to emphasize healthy physical roots, the biological worth of the individual and the renewal of nation and spirit. 28

The Afrikaner farmer claimed the land both as an individual with present and future generations to provide for and as a representative of the volk. An advertisement for animal feed from Die Voortrek shows the connection between the actions of the Voortrekkers and the farmer through an image of the farmer, his wife and the cultivation of the 'trekkerland' (Figure 4.2). In a land where nothing could be relied upon to endure, the patriarchal farm offered a symbol of enduring occupation and ownership. 'Voortrekker' and 'Voorboere' are connected to the images of trekkers in the veld that were printed as covers for the inaugural editions both by the linking of the names, and by the presence of the female figure, which helps to diffuse suggestions of violence and consolidates the natural occupation of the land through the implication of fertility and growth. ${ }^{29}$

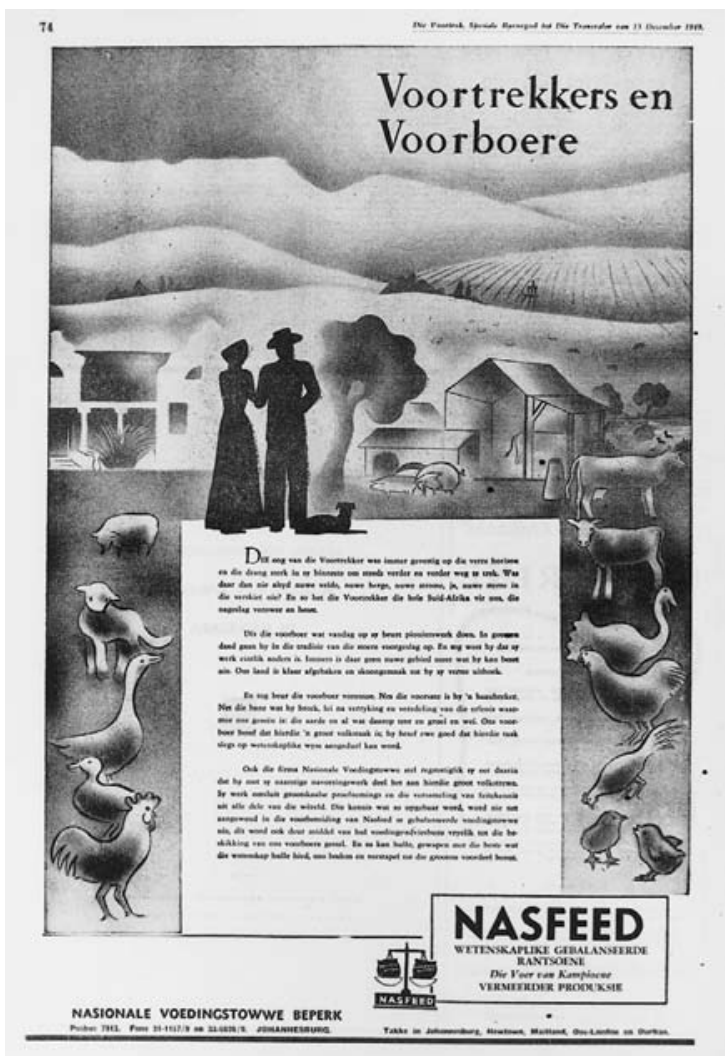


The power of the symbol of cultivation was such that the image of a plough was used as the first corporate symbol for the first co-operative Afrikaans bank, Volkskas (literally 'Nation's treasury'), which was created as a national bank for the Afrikaner in 1934 by members of the Broederbond, and became a commercial bank in 1940. The power of a shared rural past was used to appeal to the remaining farmers of the volk, and also to provide a reminder of eternal national values to urbanised Afrikaners. An advertisement for the institution, in the pages of Die Voortrek, associates a bank building in Johannesburg with the Voortrekker Monument.

Another monument has risen in the dawn of a nation's economic awakening. A monument erected by the nation itself, which shall be recognised in the annals of its history as the first pure national commercial bank, founded on the native soil that still invigorates it. ${ }^{30}$

The bank building shared with the Voortrekker Monument the architect Gerard Moerdijk. The representation of the volk as a natural entity, flourishing on its own native soil which it cultivates with energy and skill, was woven into the modernisation of the volk during the mid-twentieth century. The control and cultivation of the rural landscape became a symbolic stepping stone to economic control and an increasing investment in the belief of the power of the modern state.

The Afrikaner narrative of the twentieth century therefore made a virtue from the wilderness, and from the representation of the African farm as a place of struggle for fertility. The recurring belief in, and representation of, southern Africa as a harsh and impenetrable landscape was used to reinforce the Afrikaner claim that their actions were responsible for the transformation of the country into a series of productive farms. The continued right to the land was justified both by the ability of the wilderness to accommodate the potential for the farm and the possibility that the cultivated landscape could revert to wilderness. The insecurity of the farm and the transitory fertility of nature were employed as a strong argument for the extension of white control of the land. This argument was inevitably dependent on a belief that white hands were responsible for the perceived changes wrought to the landscape and a concealment of black labour. At stake was not only the naturalisation of the Afrikaner presence in Africa, but also the redefinition of the natural identity of the black pastoralists that they displaced. Coaxing fertility from the land was portrayed as being an unremitting task, handed down from one generation to the next. 


\section{Chapter 5}

\section{‘Natural' identity}

The image of the white pastoral was dependent on a forgetting of a past in which Boer and black lived in similar ways on the same land. The land itself had been the site of much of the political conflict, precisely because farming life figured so strongly in both Afrikaner and black identity. From the beginning of colonial history in southern Africa, the Dutch colonisers were in direct competition with its inhabitants (initially for pastures and cattle with the Khoikhoi and then for pastures, cultivated fields and cattle with the Xhosa). Both the land and the lives of people of different racial groups were therefore intermingled. The emphasis on the identity of the farmer grew in significance as the changing economic situation of the late nineteenth century saw many subsistence farmers forced off the land and into the cities. ${ }^{1}$ Therefore the myth of the idyllic rural existence resonated for displaced people across racial lines. ${ }^{2}$

This chapter examines 'nature' and 'natural' identity as racially and politically mutating terms that were fundamental to the division of land and people. The definition of the white pastoral required the representation of different landscapes as natural environments for different bodies. Reserve territory was defined as the natural landscape of the black South African, with its connotations of the picturesque and benign primitivism, while the veld and the farm were retained as symbolic landscapes by the white South African.

Labour, and the race of the labourer, were inseparable both from the image of the pastoral, and from the succession of land-based legislation that has punctuated politics in South Africa. This chapter emphasises the legislation, representations and debates that took place during the first half of the twentieth century, as the foundations for the later proliferation of laws and representations that were produced under National Party rule. The Union of South Africa was formed in 1910 and only a few years later the 1913 Natives Land Act, no. 27, was passed. This Act, and its subsequent amendment in 1936, the Native Trust and Land Act, no. 18, effectively 
removed the identity of black farmers from the landscape of South Africa, and replaced them with silent and invisible labour. By making it illegal to continue the established system of black tenant farming, and legal only to employ black labour, independent black farmers were either displaced to the overcrowded reserve territories, or reduced to labouring on land that they had once farmed for their own profit. The Acts can therefore be seen as attempts not only to remove legitimacy and autonomy from the black farmers, but also to force them to accept a revised role as a dependent producer within a landscape that concealed their presence. The Land Acts therefore sought to overcome the conceptual difficulty of reconciling contradictory histories and desires: the necessity for black labour in the cultivation and transformation of the land; the fact that tribes people had been independently cultivating their own fields and pastures for centuries; and the claiming of the productive landscape as an exclusively white preserve. The history of black fertility and productivity was problematic for the emerging politics of the twentieth century, which preferred to nurture an image of the landscape as a wilderness before the coming of the white settlers.

\section{Natural identities}

In contrast to the 'natural' identity of the white farmer, blacks were allowed two 'natural' identities in representations: one as tribes people, and the other as providers of labour, either for farming or industry. In the first part of the twentieth century the primary goal of legislation was 'as far as possible to force the natives, of course peacefully, into agriculture. The great object should be to get him to work for the white man on the farms at a wage. ${ }^{3}$ However, politics and the representation of black South Africans within the productive landscape had an uneasy relationship. Depiction of black South Africans as farm labourers would have confirmed their participation in the productive landscape, and therefore threatened the myths which required that the farmers themselves be the primary provider of labour.

The fact that the economy of South Africa was reliant on the labour of the black South African was indisputable, but the quest to maintain a moral and political authority meant that landscape remained subject to myth. The representation of blacks as tribes people or labourers therefore tended to emphasise simple and uncontested identities, and ones that did not overlap with the territory claimed by the white person. Both the dependence of the economy on 'natural' black labour and the interconnection between the dispossession that occurred on the land and the greed for labour in the mining and agricultural industries were concealed behind images that sought to extend the attributes of a simplified natural tribalism into a modern economy. ${ }^{4}$

The emphasis in representations was therefore either on the tribal person, or on the mine worker. ${ }^{5}$ The double identity is clearly shown in a map entitled 'Sources of Native Mine Labour' produced by the Transvaal Chamber of Mines in 1946 (Figure 5.1). While the map was not overtly a political product, it both drew from and

5.1 (opposite)

Sources of Native Mine Labour: Map of Southern Africa, showing the recruiting systems of the Native Recruiting Corporation and the Witwatersrand Native Labour Association (1946), drawn by A.D. Stead. 


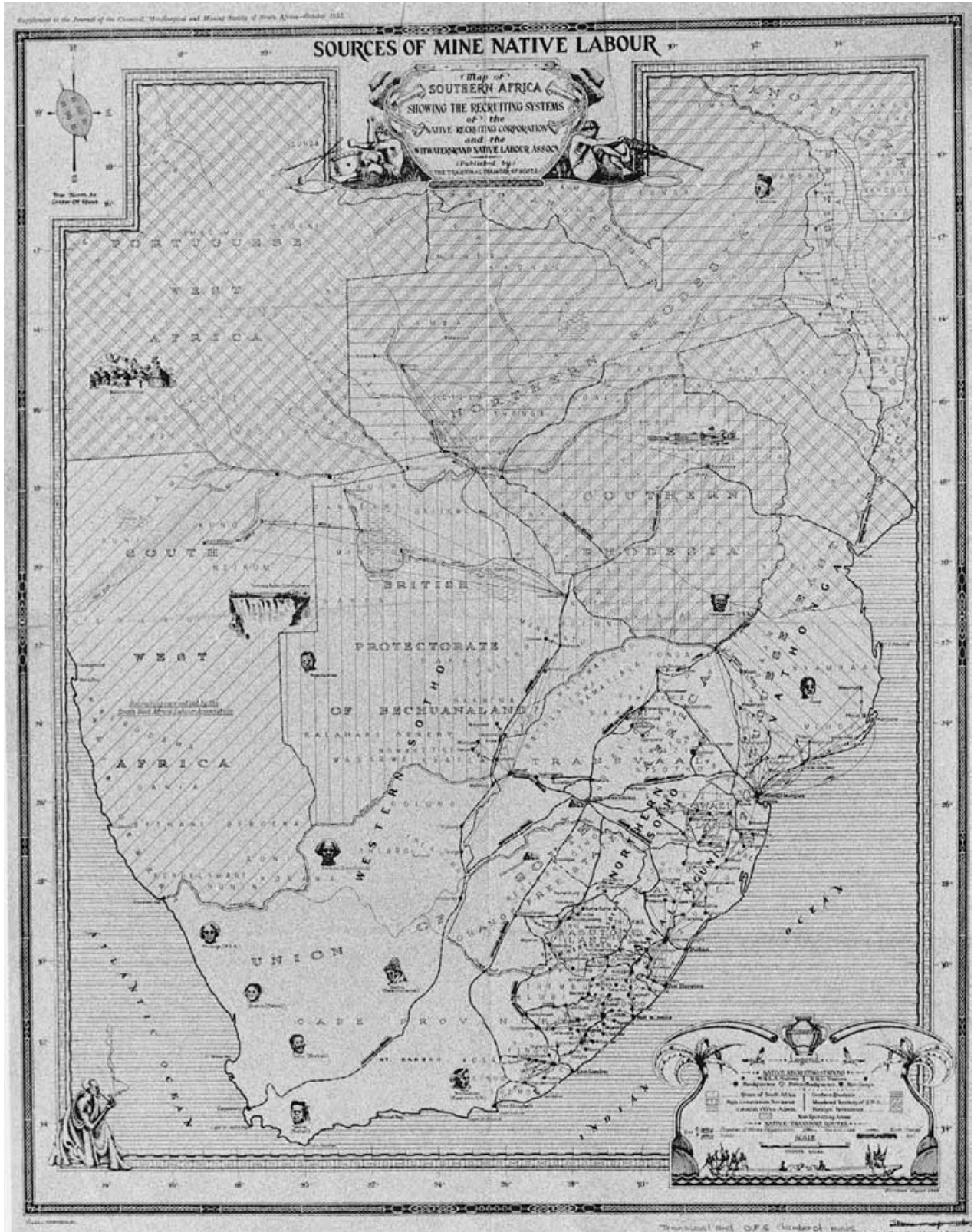




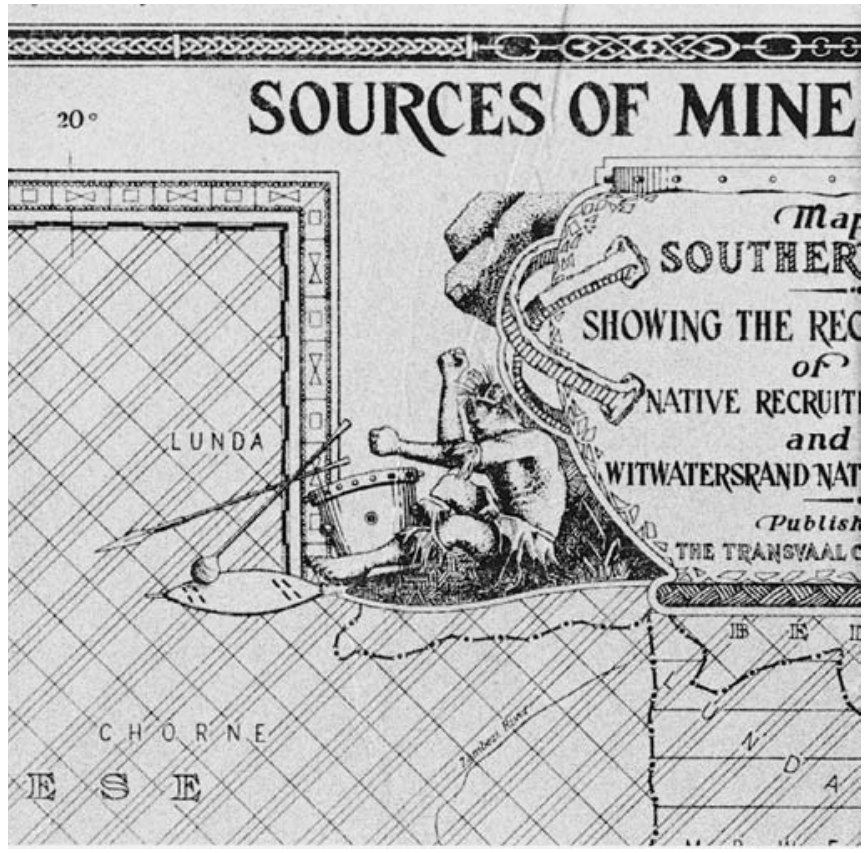

reinforced political ideas about the body of the black man in the landscape, and the sanctioned roles that he was able to perform there. It also reveals the political and economic interest in depicting a mythologised tribal identity and the dependent relationship between capital and government. ${ }^{6}$ The cartouche is flanked by two equal and opposite symbols: a kneeling man in tribal dress, and a miner wielding a hammer drill (Figure 5.2). The same individual assumes a similar pose on either side of the lettering, and the sticks used to beat the drum by the man in tribal dress metamorphosise into a blast drill when the man is clad in miner's clothing.

The direct relationship between the man as tribal, beating out the rhythms of his race on the skin-clad drum, and the blasting carried out under the ground, sought to normalise the migration of tribal workers between the mines and 'native' areas, and treated the different roles as analogous to clothing, which the miner/tribes man could take on or discard without disrupting his prescribed identity as a provider of labour. In exercising his strength in the mines, the 'native' was seen to behave in a way that was both consistent with tribal identity, and also that was non-threatening both to urban life and to the productive farm. ${ }^{7}$ While the natural identity of Afrikaner as farmer is dependent on a scientific skill and intimate knowledge, the black South African was shown as assuming an identity which involved the physical strength of his body. The representation of tribal identity relied upon the creation of an image of traditional life as a primitive and natural condition, separate from both the agricultural and 


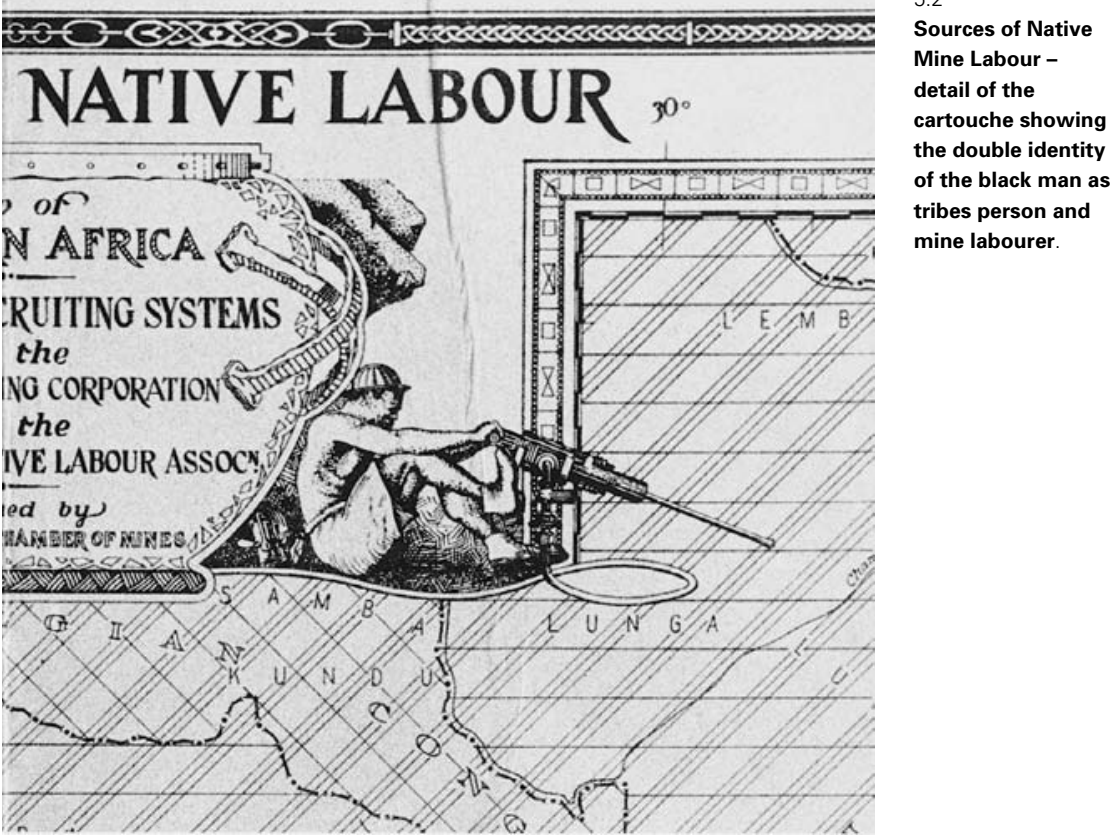

urbanised landscapes. The presence of the tribal man in the map's cartouche invokes traditional tribal life - life in its natural state - which could then be called up in order to legitimise his role as provider of mining labour. By using history as a reservoir of meaning the complexity of traditional life and the possibility of its transformation, or continued existence under pressure from changes in society, is held at bay, while the body of the man in tribal dress signifies strength, power, nature, labour, primitivism. The fact that the man was depicted beating a drum rather than wielding a weapon - which would perhaps have suggested itself as a more obvious counterpart to the drill - neutralised the threat of violence from the strong body. The mirroring of the flanking bodies ensured that the dual identity was read as belonging to the same man. It both confirmed and naturalised a new history, the history of black labour underground in the mines, and the cyclical return to the tribal landscape.

In maps of the seventeenth and eighteenth centuries, the cartouche offered a pictorial fragment of the country that was mapped. Its intent was partly to represent that which could not be included within the geographic parameters of the map. Invariably the inhabitants of the place, often drawn as exotic fragments, were surrounded by flora and fauna unfamiliar to European eyes. The people and vegetation, however, assumed a role which mirrored one present in imperial society (such as king or noble), therefore including the exotic in the language of the familiar. Like these antecedents, the cartouche in the twentieth-century map not only refers to 
historical convention, but also depicts the tribal person or mining labourer as an exotic body, one that is brought under the control of the map's sponsors and presented to the viewer as a benign, sanctioned image.

\section{Native Land Act of 1913}

The Land Act of 1913 confirmed the intent of the new Union of South Africa government to legislate for the restriction of black identity and ownership and occupation of the land. The image of the black South African immured in a tribal existence helped to ease the passage of the legislation because it supported the perception that their primitive state could not adequately respond to the demands of the farm. ${ }^{8}$ The Act targeted not the occupation of the land, but the ownership of it and the control of black labour upon it. ${ }^{9}$ What was at stake was not only the recurrence and repetition of myths over time, but also alterations to the physical landscape which were the result of land-based legislation, and then the integration of these alterations as renewed foundations to older images of people and the land. These changes to the productivity, appearance, fertility and population of the land became integrated into a renewed image of the landscape, which could be then presented as self-created evidence for the existence of separate identities for people of different races in the land. Ironically, the Act had the effect of forcing more people not only on to tribal lands, but also into the cities and the mines. ${ }^{10}$ The urban and rural, rather than being seen as separate and opposing entities, were conceived of as interrelated through their economies and through the bodies of the people who moved between them.

In his 1916 book, Native Life in South Africa, written to appeal to the British government to oppose the Native Land Act, Sol Plaatje documented the struggles of the people most affected by it. In it he argued that the legislation was a product of the north. The book emphasised the racial split between Afrikaners and Englishspeaking people in Parliament, arguing that the harsh law was passed only by the Afrikaner vote, and that it was resisted by the English. This was not only to argue that the Act had been imposed by the old Boer Republics, but also to appeal to the goodwill of the British by not accusing them directly of culpability in the passing of the Act. ${ }^{11}$

The 1913 Land Act designated particular areas of land as 'Scheduled Native Areas' in which anyone but a black would be unable to purchase land, while the 1936 Act tabled additional 'Released Areas' which were added to the total area for 'native' occupation. In addition, more critically, the Act disallowed blacks from purchasing any land outside the Scheduled Areas. Thus, in terms of the Act, 4.5 million blacks were allowed legal ownership of 8 per cent of the land, increasing to 13 per cent in 1936. The scale of the dispossession was staggering, as Plaatje noted:

They talk of having 'doubled the native areas'. They found us in occupation of 143 million morgen and propose to squeeze us into 18 million. ${ }^{12}$ 
The Act was seen by many as being the extension of Voortrekker ideals, particularly of the political desire that South Africa should be a 'white man's country', over the entire surface of the Union. The 1936 amendment, releasing more land for black occupation, was greeted with adulation in some publications, and was linked explicitly to the preparations for the Great Trek centenary in 1938. The legislation of a modernising state linked wilderness and farm with the political ambitions of the Afrikaner nation. As a contemporary journalist, in The Star, noted:

They withdrew into the wilderness to work out their own salvation ... [a]nd the trekkers' works live after them. Their grandchildren today have completed the edifice, for which the Trekkers laid the foundation. The Native Land Act of 1936 embodies and crystallizes the trekker policy. A century after the withdrawal into the wilderness, has come the triumphant return. ${ }^{13}$

While the Land Acts were represented as being consistent with the Voortrekker legacy, Plaatje's opening statement in Native Life in South Africa revealed his desire to counteract the myth of the black South African present, he believed, in British minds.

This appeal is not on behalf of the naked hordes of cannibals who are represented in fantastic pictures displayed in the shop-windows in Europe, most of them imaginary; but it is on behalf of five million loyal British subjects who shoulder 'the black man's burden' every day, doing so without looking forward to any decoration or thanks. ${ }^{14}$

The first assumption that Plaatje tackled in his text was the persistent myth of the tribe, and its uncivilised and savage state. He recognised the power that identity myths had, and demonstrated the extent to which he felt that he had to counteract the pervasive belief in the tribal identity of black people. The primacy of identity, in a political document about land legislation, also confirmed its fundamental relevance to the perception of the landscape. The alternative identity that Plaatje offered was that of the labourer, but a labourer who morally should not be distinguished by his race from other 'loyal British subjects'. The myth of the primitive tribal person held at bay both the history of black cultivation and the increasing urbanity of the populace.

One of the flawed arguments that smoothed the passage of the Act was the premise that black land ownership was increasing and therefore that the black pastoralists constituted a threat to the stability of the white-controlled Union, not only through sheer force of numbers, but also because they could succeed on what had been historically claimed as the white man's territory - the farm. Much of the rhetoric that was produced was contradictory. The threat posed to the white landscape was that of a productive black farmer, rapidly gobbling up the country, but it was also argued that the farming methods which the black farmers adopted were uneconomic and that the country would be better served by the return 


\section{Farm}

of black-owned land to whites, who knew how best to cultivate it. A contradiction that was to become a condition of apartheid was apparent in the early decades of the century - the economic dependence of white South Africa on black labour meant that the political arguments for the social and cultural separation of people of different races became a veil behind which countless (albeit unequal) everyday interactions across racial lines occurred. As a Member of Parliament (MP) noted in 1913, during the debate for the Land Act:

Under the Bill it would be possible for farmers to accumulate as many Natives as they could get, so long as they could use them as servants. So far as he could see, even if it were carried out to the extent that it was proposed to go, it would not very much reduce the social contact which at present existed between Natives and Whites. ${ }^{15}$

The people most affected were black tenants on white-owned farms who hired land, or grazing or ploughing rights in return for payment at the end of the harvest. This apparent partnership between black and white was also given as a reason for the enactment of the law, while a subtext was to provide for the upliftment of 'poor whites', mostly of Afrikaans origin, who were more likely to be accommodated as tenant farmers once their competition had been removed. The stock, traditionally seen as the most important possessions of an individual, were no longer to be accommodated on the farm, and often had to be sold if the tenant farmer refused to become a servant. ${ }^{16}$ In this way the labour of the black person was concealed within a map that sought to colour the country white. By stripping the black South Africans of their right to cultivate the land under their own names, their bodies became absorbed into the multitude and the multitude was branded as a ready supply of labour to serve white needs. The seemingly undifferentiated masses that were later to become increasingly threatening to white minority rule were therefore at least partially the creation of political will that removed the presence of black tenant farmers from the landscape.

One of the more illuminating moments for the interdependence of labour and the pastoral comes, not from the Land Commission, but from an interview that General Louis Botha (South African War Boer General and Prime Minister of the Union of South Africa during the passing of the Land Act of 1913) gave to the Labour Commission. Botha (responses in italics) argued that all reserve lands should be taken away from tribal authorities and given to white farmers:

11345 They at present occupy the land, we have it in evidence before us to the effect that every inch of land in Basutoland is occupied and worked by the Kaffirs themselves as their own property - That is just my argument ... because there is an opening for the Kaffirs there they go and live there without doing anything.

11347 But they do something. They work the whole country, they have a lot of grain. - Yes, for themselves. ${ }^{17}$ 
Botha discounts any labour that the Basutos perform for their own advantage. As he perceives it, the laziness of the tribes person is not a laziness in the sense of a lack of productive labour, but rather an unwillingness to labour for the profit of whites. For Botha it was only when the black person was displaced from tribal lands that his work could be recognised as productive.

The myth of the pastoral in South Africa therefore turns on the issue of labour. As the author Bessie Head has noted:

There were two reasons for the introduction of the Native Land Act: black farming was proving to be too competitively successful as against white farming and there was a demand for a flow of cheap labour to the gold mines. As long as black men were engaged in farming and were independent owners of livestock, their labour was hard to acquire ... Thus some parts of the Native Land Act were shaped by the desperate need for labour on the mines. ${ }^{18}$

The irony of the image of the tribal lands as a series of idyllic picturesque landscapes was exposed, as early as the second decade of the twentieth century, by Plaatje's analysis of the population density of the reserve lands.

As things are at present, the black population of these areas is as much as 70 to 90 persons to the square mile. In density of population, some of these 'rural' native districts are second only to Cape Town, Durban and Johannesburg - South Africa's most populous centres. Not one of the South African cities can show a population of more than 20 to 30 persons to the square mile. So that every individual inhabitant of a city occupies a larger space than some of these native farmers can have for themselves, their livestock and agricultural pursuits. ${ }^{19}$

The black labour sought in the farms and mines was primarily the labour of black men. Women were seen as superfluous to the economic equation and much effort was expended in ensuring that women stayed on the reserve lands, both to ensure the return of migrant labour, and to stabilise black urbanisation. (This changed in the 1960s when women became part of the migrant labour system to a much greater extent, entering the work force in large numbers as domestic and industrial workers.) The image of the single man was less potentially threatening to the white land claim than was the image of the black family, particularly because the Afrikaner claim on the pastoral landscape was made explicitly through the image of the white Voortrekker woman, bringing a benign civilisation to the wilderness. Single black men - present in the city without the roots of family - could be represented as temporary residents of the urban world. The lack of women and children was the sign of another, remote, home, linked to a more traditional, tribal way of life.

In order for the Act to be enforced land needed to be defined, and the vehicle for this definition was the map. General Botha raised an objection when the Land Act was first mooted because he foresaw the failure of the representation 


\section{Farm}

to accommodate the messiness of the real world. His concern, unsurprisingly, was for the white farmers, who were, as he saw it, in danger of being dispossessed of their farms in favour of the 'Native' areas.

The House would have to demarcate exactly and immediately those parts where the natives would have to live, and he asked them: was this House able to do so? It was all very nice to talk and take a map and draw lines on it. On the map they might be able to beacon off parts, and say, 'This is for the natives,' but then, when they put their scheme into effect, they might find that the ground of many individuals had been taken away without any inquiries or any investigations having been made. ${ }^{20}$

Botha's comments identify the complexity of the application of the Land Act in a country in which lives and land ownership were intertwined on the physical ground of the country. Maps play a definitive role in the definition of racial territories. The certainty which they are intended to provide is offered as a bulwark against the intricacies of the existing landscape, while the text of the Land Act required that a map be provided of each contested area. ${ }^{21}$

The definition of boundaries not only drew lines between different pieces of land under different ownership, but also created politically motivated territories that were based fundamentally on race. The boundaries were inevitably influenced by the boundaries of existing farms and reserves and represented the division of rural land into two opposing mythic landscapes; one fertile and accommodating the (primarily) Afrikaner farmer; the other representing tribal land which offered an idyllic and primitive traditional existence for its black inhabitants. The images served to entrench a political goal, and also enabled the true meaning of the division of the land to be camouflaged, concealing black labour within the white pastoral landscape.

Despite the confidence with which the white landscape of South Africa was argued, drawn and legislated for, the cohesion of this image was constantly threatened by the presence and numbers of both urban and rural black South Africans, as well as by the covert political knowledge that the assigned 'natural' identities were themselves inherently contradictory and unstable. The suppression of black tenant farmers did not mean that black people had been forced off the farms - as two maps of population distribution in 1946 and 1951 demonstrate (Plates 5.1 and 5.2). The maps are significant because they are government publications, productions of the census of 1946, and demonstrate the extent to which the myth of the segregated landscape, and a racially segregated society, was undermined by information held by the government of the day. The maps categorise the population according to race, the coloured dots are associated with different racial categories. These dots mix in swirls on the paper, overlapping and intermingling - sparsely over some areas, more densely over others. They are both a representation of the extent to which the lives of South Africans of different races occurred in close proximities and of how the population of the country was related to the fertility of the land and the economic power of the cities. 
The National Party's victory in 1948 was contemporary with the research for, and publication of, the population maps. D.F. Malan as Prime Minister faced a contemporary situation at odds with the political ambition of 'separate development' for different races and the belief in the right of each group to develop its own culture and destiny. As both maps show, the population groups were knitted in with one another, but the later map also offered a representational distortion of the real proportion of people of different races in the population. In the map of 1951 each major racial group ('European', 'Coloureds', 'Asians', and 'Natives') was assigned their own racially coloured bubble. The association of bright red with the 'European' population allowed the white race to dominate the maps in a way which contradicted their position as a minority, while the dark grey assigned to the 'Native' population forced their numbers to recede, concealed behind the shiny bubbles of the other groups. The superimposition of smaller circles upon larger ones emphasised the smaller, more brightly coloured numbers.

The Scheduled and Released Areas to the east and north of the country appear as darkened areas on the maps, their meandering outlines created not by the drawing of linear boundaries, but rather by the representation of dispersed bodies as a series of tiny circles. The optimistic pale green of the country is darkened by the superimposition of the corralled population. The consistent density of these areas is a witness to the effects of the Land Acts, and demonstrates the extent to which the reserves were under immense and consistent pressure from the people attempting to live an agricultural existence on reduced parcels of land. The shadow that the population casts over the green of the page, and the fact that the edge of the shadow can be used to generate a series of boundary lines, reveals the extent to which the land, as well as the map, was marked by the bodies that inhabited it. The zealous gathering of data, and the use of this data to generate a map, creates a representation of South Africa in the mid-twentieth century in which the contradictions of politics are present. Despite the manipulation of the image of the numerical data on the map of 1951, the maps serve to illustrate the extent to which the political narrative of racial separation in rural areas was undermined by the government's own publications. Multiple representations, read in conjunction with one another, can begin to reveal the failures and paradoxes of political will.

\section{Contradiction in representation and alterations to the land}

The density of the population in the reserve territories, as well as the integration of the population in urban and rural areas, challenges the picturesque image of the tribal lands present in political narrative and in the ephemera of everyday life. Concurrent with political debate about the wilderness, soil erosion and overpopulation of reserve areas (and later the bantustans), tourist brochures and Christmas cards (disseminated in white, urban populations in the mid-twentieth century) offered an image of rural life untroubled and unaltered by modernity. These images of stability and innocence 
were addressed to those who were not active participants in the struggle over rural land, and they helped to quiet the qualms that arose as to the true nature of black rural existence. In these representations the black pastoral landscape is one which remains untouched by modernity; clothing is traditional, implements are the hoe and the pestle, any cultivation depicted is at a subsistence level, just enough to sustain an idyllic existence, but not enough to alter or mark the landscape or enact a transformation of its surface.

Many of the Christmas cards indulge in caricature, exaggerating lips, breasts, athleticism, lengthening limbs and darkening skin tone into an even black, through which the sinuous form of the semi-clad body is expressed. A number of the cards depict women at, often solitary, work - hoeing the land, pounding grain or gathering water (Figures 5.3 and 5.4). The figures are benign and domesticated, transposed from the white homes of urbanites who employed black women as domestic workers, to a landscape represented as their natural home. The nostalgia for peace, simplicity and stability (the familiar territory of Christmas cards) is expressed through the representation of an idealised existence in an untouched rural land. A few of the cards use the image of the single-roomed thatched hut, surrounded by open ground, as the locus of this existence (Figure 5.5). The cards are intended to represent an ideal world, a place untouched by modernity but rather woven into the magical logic of Christmas. The image that they support is one which was increasingly at odds with the physical reality of contemporary South Africa. The difference between those who were represented in the cards and those who purchased and sent them was marked through physical features, attire, implements and building types. The world that appears in the pictures is both distant and exotic.

South African Railways and Harbours actively promoted the countryside as the means through which a relationship to the land could be recovered. As part of

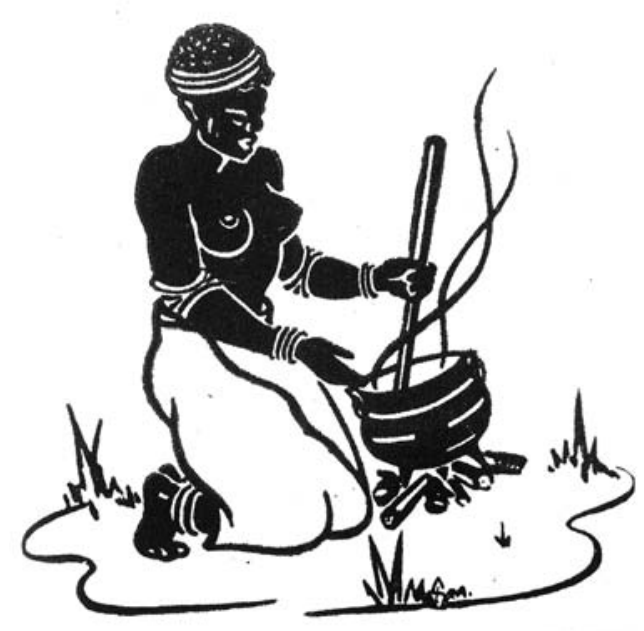

5.3

Christmas card black outline of woman with pestle. 
5.4

Christmas card outline drawing of a woman hoeing the fields, with grass huts in the background

5.5

Christmas card view of huts with scroll and 'Christmas Wishes'
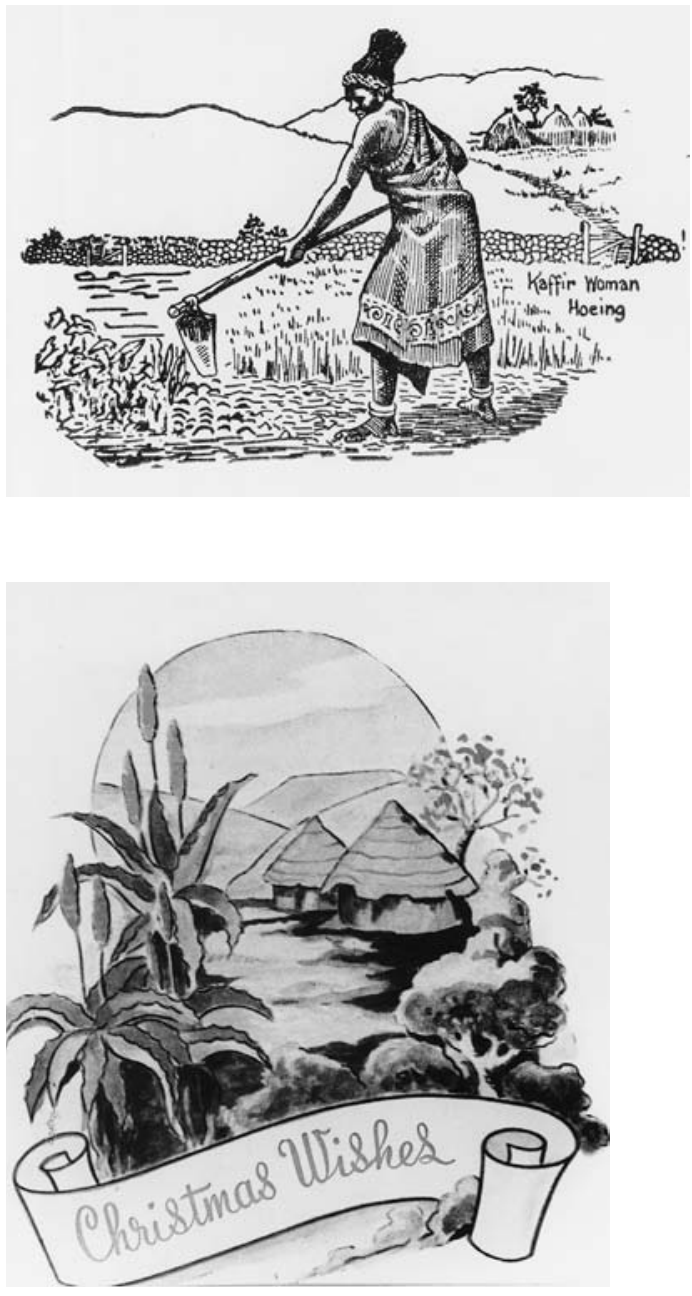

its campaign to encourage the urban population to enjoy the delights of travel within South Africa a series of pamphlets were issued, in the 1920s and 1930s, which documented a country in which an intact traditional tribal life was juxtaposed with the beaches, buildings and golf courses of white South African life. In the text of the pamphlets the appearance of people and landscapes was represented as part of evolutionary development, the primitivism of the tribes people was shown as being a temporary state along the evolutionary path to civilisation (Figures 5.6 and 5.7).

Here, in a single country, almost the whole story of life's evolution is unfolded - from the earliest fossilised forms, prehistoric animals and 

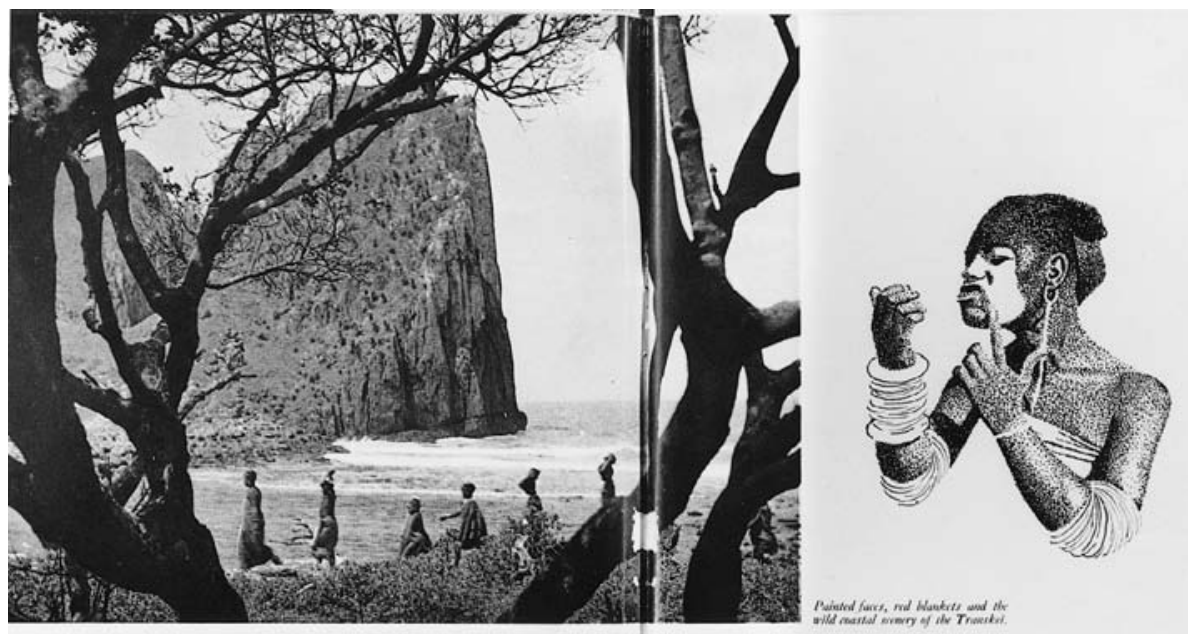

FL.OWING down to the Indian Ocean, which washes the east coast of the Cape Province, is a river called the Great Kei River that enters the sea some 60 miles north of East London. The country north of this river is known as the Transkei, while south of it lies the area called the Ciskei In the rolling hills and dales stretching north, south and west of East London lise two million Bantu in their varief tribal fashions. Wherever you po you will see the "ret

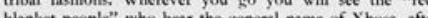
blanket people who bear the gencral name of Xhosa, after divided into the tribes known as Fingo, Baca, Hlubi, Themba

and Bomvana; furthest north to the Natal border are the Mpondo who live in Pondoland.

Let us start looking at these picturesque natives of the cast coast by travelling south from Natal into Pondoland. The home of the Pondos is divided into two by the Uimzimvulu River which enters the sea at Port St. Johns. The Paramount Chicf of Western Pondoland rules from Libode, near Limtata, and the Paramount Chief of Fasterm Pondoland has his seat at Lusikisiki, which losely nane Ponche the reeds. ape-man - through primitive native tribes and fascinating big game - to civilised man himself, secure in his modern cities. ${ }^{22}$

The South African Tourist Board, which took over from the SAR \& H in the early 1950s, continued to entrench the separation between the races in tourist material (Plate 5.3). The stability of the images of black primitivism and white civilisation were, however, rather more insecure in reality than the depictions of separate lives would suggest. The density of people of different races in so-called white areas, particularly in white-owned land adjacent to reserve areas, provided the basis for one of the persistent myths of the white landscape - that the individual farmer stood alone against the multitude, the 'duisternis' (dark masses) of primitive people, who could sweep down and overwhelm the 'koningkrykie'. This threat would metamorphosise into the 'Swart Gevaar' (literally 'Black Danger') that was perceived to threaten both rural and urban areas during the apartheid years.

The Afrikaner nation was therefore bound together not only by the definition of the volk but also by apparent threats offered to it. The myths of stable landscapes of farm and veld, with which the nation could identify, can therefore be read as much as products of the insecurity of the volk, as of its cohesiveness. Like the remote farm in the 'trekkersland', vulnerable to the danger of the silent landscape, the
5.6

South Africa's

Eastern Cape: Land of the Red Blanket People (no date -

late 1940s to early

1950s) - page

showing Xhosa

people in traditional

dress, tourist

brochure published

by the South

African Tourist

Corporation.

Reproduced under

South Africa

Government

Printer's Copyright

Authority no.

11296, 1 November 2005. 


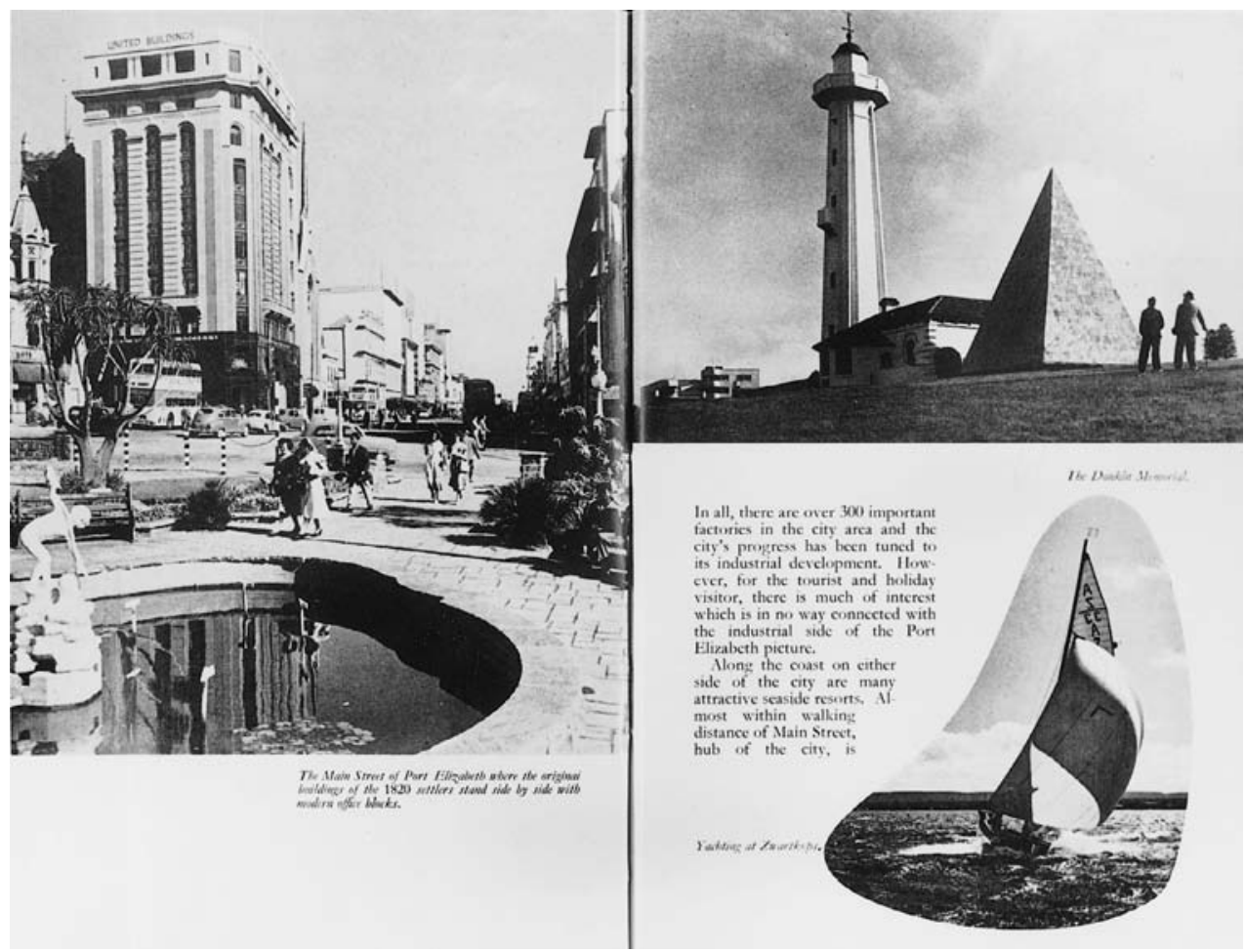

5.7

South Africa's

Eastern Cape: Land of the Red Blanket

People (no date late 1940 s to early 1950s) - page showing the modern cities,

Donkin Memorial and yachting.

Reproduced under

South Africa

Government

Printer's Copyright

Authority no. 11296 ,

1 November 2005. myth of the stalwart nation besieged by the outside world served to represent both internal and external threats to the Afrikaner nation. The laager became not only a symbol of strength for the volk, but also a reminder of its fragility, and of the fragility of its tenure of the South African landscape. The image of the tribes person or labourer is similarly an attempt to control the meaning of the insecure and unstable image of the black person within a land that is claimed by others. It concealed the fear that the pastoral ideal was always potentially vulnerable to the violence that enabled its creation.

\section{Bounding the farm}

By the mid-twentieth century, the surface of the country had been surveyed, mapped and physically bounded, primarily by barbed-wire fencing. The fencing served to both stake a claim on the ground and to prevent others from penetrating the land, or attempting its appropriation. The trekker farm - a cultivated place within the wider landscape of the veld - was overtaken by a much greater density of settlement and cultivation, where the veld was incorporated into the vast areas of fenced farmland. 
The bounded farm was a consequence of the penetration of techniques of survey and representation into even remote areas. The definition of the boundary of the South African farm is inconceivable in the absence of the survey, mapping and barbed-wire fencing. The presence of the British Empire in South Africa had provided both. Isabel Hofmeyr, a South African historian, has studied the impact of the introduction of survey and fencing on the perception of the landscape. In one of the interviews, conducted as part of her research, Hosea Bowale, an elderly resident of the rural district of the Zebediela district, commented:

The issue of fences was brought about by literacy . . . it was found out that when the Boers claimed land for themselves they did not know how to measure it. The English brought theodolites with them. The Boers never had fences. Even today no one can say he saw them putting up a fence. They had no skills in putting up a fence. They did not know how to do the corners. [The Boers] did not measure the land. They just used their heads, now they just said, 'This area, from here to that tree ... . it is my land. ${ }^{23}$

The import of the wire itself was a product of war and Empire. During the South African War the British built a series of blockhouses, defensive one-roomed towers, which set up a spider's web of points and wire fences intended to thwart the unpredictable Boer Commandos. ${ }^{24}$ Barbed-wire provided an instant solution to the problem of quickly erecting long and effective boundaries across the vast land,
5.8

Black and white photograph of the wire entanglements for British

Blockhouses, South

African War

(1899-1902)

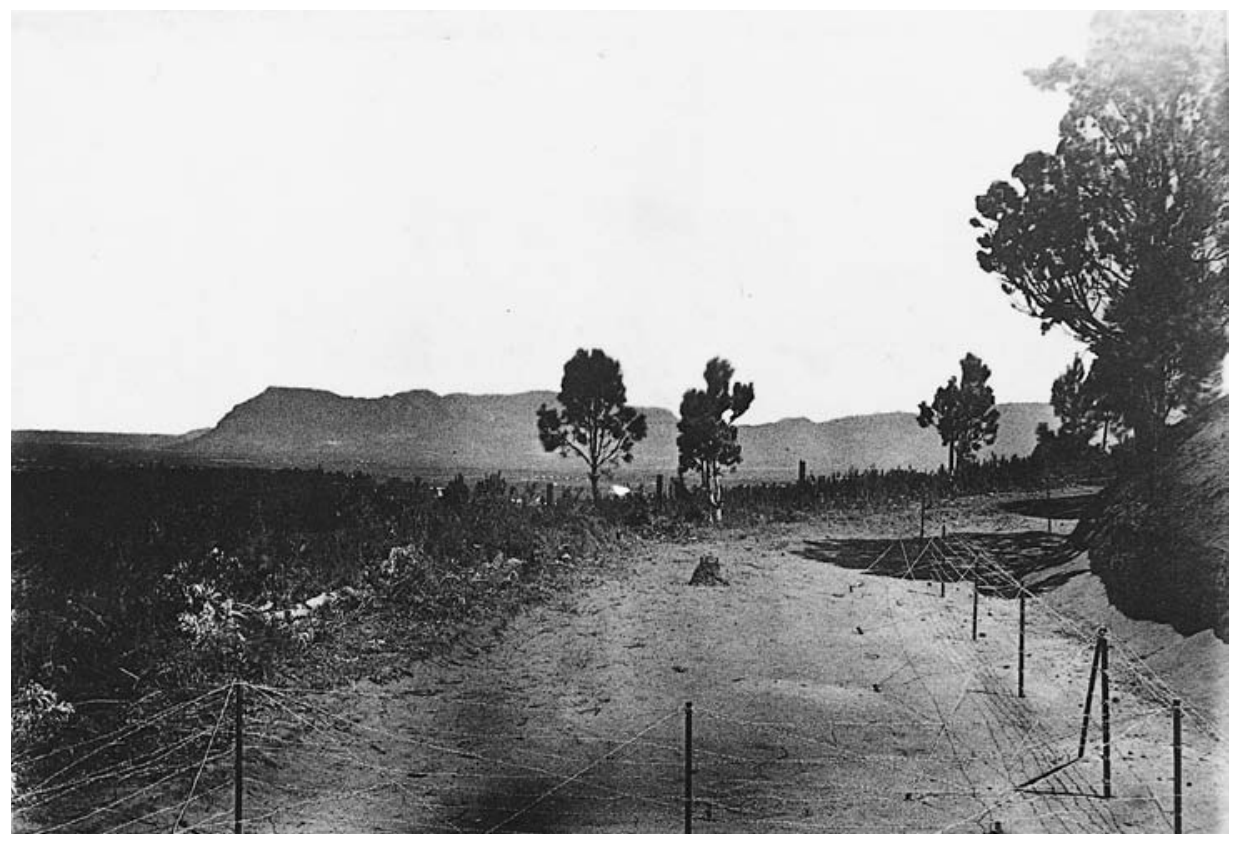


and was imported in unprecedented amounts as part of the defensive system of war. Contemporary photographs show the wire entanglement around the blockhouses, and the landscape beyond (Figure 5.8). The unidentified photographer, probably a British army officer, provided poignant images of the fragile tracery of the wires against the vast landscape. They seemed doomed to failure, too insubstantial to counter the overwhelming power of the land that stretched out beyond the incomplete boundaries which they tentatively staked. These delicate, deadly threads became the means by which extensive networks of defensive lines were created, but the lack of comprehensive maps of the surface of the land hampered the British in their attempts to control it.

Before the war each colony had its own mapping system, at different scales and levels of detail, which did not cover the entire land area, was not coordinated in scale or at boundaries and (particularly in the case of the Boer colonies) did not cohere with nineteenth-century advances in geodetic triangulation, which was still taking place in southern Africa. It therefore gave information only of (mainly developed) fragments of the land, but not of a uniformly mapped and traversable surface. ${ }^{25}$ In March 1904, a group of men sat down at a congress in the city of Cape Town, in order to discuss instituting a Topographic Survey of the British Colonies in Africa, south of the Zambezi. ${ }^{26}$ The meeting, as the chairman noted in his opening remarks, 'had its origin in a circular dispatch from Viscount Milner to the Governors of the South African colonies, dated 18th of May, 1903, in which he intimated that the War Office was desirous of instituting a Topographic Survey. ${ }^{27}$ The meeting of army officers and surveyor generals serves to confirm an ongoing relationship between surveying and war, not unfamiliar bedfellows in the age of colonial expansion. The War Office offered to supply topographers and surveyors in order to both carry out and direct the survey. ${ }^{28}$

One of the most urgent aims was to co-ordinate the topographic information gained from the comprehensive trigonometric survey with farm surveys, in order to create an accurate representation of ownership of the land. The largescale use of barbed-wire in the war was followed by the widespread use of wire fencing to enclose farms. ${ }^{29}$ This enabled large areas of land to be bounded quickly and economically, and transformed the farms from areas of land identifiable by characteristic land features to ones identifiable by enclosure, which could be associated with individual or familial ownership.

Edms. Bpk.

Ek het ' $n$ stukkie grond gekoop met melkhout op; dit afgekamp en teen die hek 'n naam geverf sodat verbygangers besef:

Dis Dirk se erf. ${ }^{30}$

\section{Pty. Ltd.}

I bought a piece of ground with milktrees on it; fenced it off and on the gate painted a name so that passersby realise:

This is Dirk's ground.

The production of maps with defined linear boundaries focused attention on the boundary as an edge and as a pencil-thin division between areas of land under 


\section{Farm}

different ownership. Hofmeyr sees the inscription of lines onto the surface of the page as being analogous to the erection of wire fences over and into the landscape.

Boundaries on survey diagrams were closely linked to the written word in that they came to represent a supposedly fixed and permanent reality. Transferred onto the actual territory, the pencil line becomes a wire fence which both fixed the line and represented it spatially as a thin sheer wall. ${ }^{31}$

In both cases, the surface for inscription is a neutral one, a tabula rasa, onto which the divisions of the land can be written. The emptiness of the map and the supremacy of the surveyed line supported the perception that the land was vacant, ripe both for inhabitation and inscription. The lack of representational information about the black inhabitants of the landscape both furthered the perception that their history was without weight in the great sweep of white civilisation and helped to anaesthetise possible qualms about their displacement.

The connection of the people to the land was, therefore, not a new construction but one which drew on a history of occupation, colonial expansion and dispute over the ownership and cultivation of land. The increasing emphasis on the racial division of land in the early part of the twentieth century, and throughout National Party rule, meant that disputes about occupation and ownership were focused around the ability of different racial groups to farm the land effectively. The political significance of separating land and bodies meant that the physical means of division - the boundary and its form and path - became an object of negotiation, and the supposedly fixed line of the surveyor's drawing was often subject to dispute.

Legislation targeted not only the occupation of the land according to race, but also the activities carried out upon it and the degree of ownership that was possible by people of different races. This layering of the land in terms of race, labour, ownership, productivity and identity was to underpin years of conflict, triggered by the inherent contradictions in the representation, imagination, occupation and use of the land. 


\section{Chapter 6}

\section{The fertile desert}

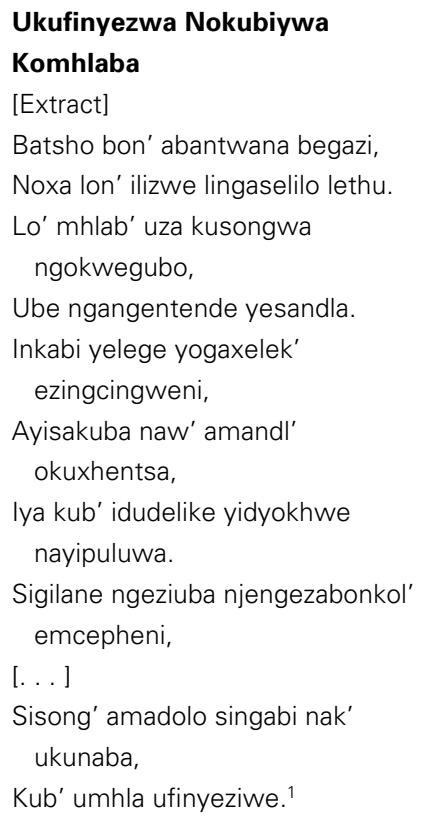

\author{
The Contraction and Enclosure \\ of the Land \\ [Extract] \\ Thus spake the heirs of the land, \\ Although it is no longer ours. \\ This land will be folded like a blanket \\ Till it is like the palm of a hand. \\ The racing ox will be entangled in \\ the wire, \\ Too weak to dance free, it will be \\ worn, \\ Out by the dance of the yoke and \\ the plough. \\ They will crowd us together like \\ tadpoles in a calabash ladle, \\ [. . .] \\ Yes, we fold up our knees, it's \\ impossible to stretch out. \\ Because the land has been \\ hedged in. ${ }^{2}$
}

Originally published in Xhosa, this poem by St. J. Page Yako (1901-1977), a Xhosa poet and teacher, employs imagery familiar to traditional oral poetry to elaborate the physical and cultural restrictions of the contemporary political situation in the late 1950s. St. J. Page Yako's poem not only elaborates the physical constrictions that 
were a consequence of the land legislation, but also mourns the loss of a traditional way of life and the loss of the land which was the physical and spiritual homeland of the tribe. The forced removal of (mainly black) people from the rural areas, continued a process of dispossession that began in the early days of settlement at the Cape. The loss of the land was a loss not only of a physical environment, but also of cultural and spiritual connections to a place. Tribal land was significant in the spiritual life of the tribe because it was the burial ground of the ancestors - the intermediaries between the living and God. Displacement from the graves of the ancestors was both an emotional and spiritual bereavement. ${ }^{3}$

This chapter focuses on the discussion of two examples, the Districts of Matatiele and Ladysmith, under the implementation of the Native Land Acts. It examines how the constituents of the pastoral - fertile nature, the productive landscape and the transformation of the wilderness - become increasingly based on race and the segregation of the ownership, rather than the occupation, of the land. The maps and aerial photographs of the area indicate how politics was inherent not only to the segregation of the landscape, but also to the material alteration of the land - so that it entrenched the narrative of a productive 'white' landscape in contrast to an eroded and unproductive 'black' landscape.

The perceived neutrality of the mapped surface both belied the complexity of the disputes which ensued, and concealed the extent to which myths of fertility and barrenness were invoked in the debates over land ownership. Maps produced in order to attempt to resolve areas of land ownership do, however, simultaneously provide a record of the struggle to implement a clean division of the landscape; emphasising the fragments of land that were under dispute. The surveyed drawings produced for internal government use were not representations of resolved practice, but acted rather as strategic surfaces which registered the struggle to force the land to conform to an altered political vision. They exhibit stresses and conflicts. Read in conjunction with government minutes, a history emerges which records not only the failure to complete the inscription of the segregated landscape, but also how race and labour were understood by the farmers locked in debate. The land became marked by fragmented and intertwined land parcels, coloured by race, belying the desire for distinct histories and identities.

\section{Boundaries and fertility}

The boundary not only acted as a thin line, dividing territory, but also ultimately affected the physical characteristics of the land that it demarcated - dividing white from black, fertile from infertile, as the increasing density of the reserve territories resulted in severe pressure on the land. The struggle of the administration to segregate ownership in terms of the Land Acts led to the definition of black spots (land owned by blacks in white areas) and white spots (land owned by whites in black areas). The terms themselves arose out of the practice of mapping and colouring territory in terms of race. They were therefore representational terms before they 
were spatial, and hint at the dependence of the racial division of land on the practice of representing the country as a two-dimensional map. In practice, the embedding of one category of ownership within another as black areas intertwined with white, exposes the paradox of the political desire for a segregated landscape, and the battle of government officials to assign race to the land and to overcome the complexity of the existing inhabitation. The neat political arguments for the segregation of land ownership were exposed to severe tests as the officials attempted to separate and define the race of the land.

With reference to the above I must communicate to you that the Municipal Area of Cofimbaba is a white spot in a black area, but it is both a Scheduled and a Released area. Within the white spots there are properties which are owned by natives. Must these be designated as black spots in a white area? ${ }^{4}$

Debates about the elimination of black spots and the consolidation of both black and white land were made in terms of conflicting racial identities and a 'deep' knowledge of the land. White farmers persisted in claiming the right to the most fertile pieces of land - the catchment areas and productive valleys - even if these were included in a Scheduled or Released Area. Black ignorance of modern farming methods was invoked in order to argue for the displacement of black landowners - both by government officials and white farmers. In 1951, S.J. Potgieter, Natal Provincial Secretary of the National Party, wrote to Dr Verwoerd, then Minister of Bantu Affairs.

At Waschbank the natives own the most important part of the valley's catchment area and you can guess how the ground there is devastated. They do not sell their cattle and let them just die of starvation, as is now the case. $^{5}$

Claims on the most fertile land were often justified by the 'evidence' of the destruction wrought to the landscape in areas reserved for black occupation. The argument was repeated not only in farmers' testimonies to the Department of Native Affairs, but also in the commemorative documents published in 1949, at the inauguration of the Voortrekker Monument. The quest for Afrikaner destiny, and the reliance on foundational myths in order to argue for political self-determination, included the justification for white land ownership based on the image of the idyllic pastoral landscape:

As you look east from the Katberg pass you see the fertile hills and plains of Kafirland - the Province of Queen Adelaide once - but now the parching, overpeopled wilderness called the Ciskei. How different are the green wheat fields and ripening oranges of the Kat River and its tributary valleys which beckon almost at your feet. ${ }^{6}$

The author, J.J. Bond, argues that the potential fertility of the land had been destroyed by the actions of its black inhabitants, who had reduced the land to a wilderness. He 


\section{Farm}

also insinuates that the appearance of the landscape was a reversion which occurred because its white inhabitants, those who had occupied the 'Province of Queen Adelaide', had been dispossessed of 'their' land. This extract associates white identity with fertile pastoralism, and black identity with a parched wilderness, consistent with the white narrative of race and land that was consolidated during the first half of the twentieth century.

We feel that the Natives have not yet proved themselves as capable husbandmen, and until such time as they have been taught to work the land why should we give them more and more land to turn into a wilderness. We have been told by the government that it is our duty as farmers to produce for the benefit of the community of South Africa we are doing it. Put Natives in that area and you get a load of liability from the first day they go there. ${ }^{7}$

The presence of the simplified narrative of land, cultivation and race weaves through political legislation, populist publications and oral records of contemporary disputes over the ownership of farmland. The power of the image of white farmland and black wilderness was dependent on a pre-existing meaning of the land, which in turn had been reinforced by the effects of the Land Acts, and by written and pictorial representation. By 1947, when the farmer, Mr van Straten, made his plea above for the retention of the land within a black area, he did so with the weight of history behind him - but it was a history which was cautious in its selection of moments in time, and which laid the blame for the eroded ground of the reserve lands at the feet of those who were also forced to bear the representational burden of existing in a timeless traditional idyll.

The myth of the ignorant black nation - unable to adequately farm the land allocated to them - persisted throughout the period of National Party rule. The immense pressure put on the land by the numbers forced into the reserves was interpreted for political purposes not as the result of land legislation, but of the underdeveloped and child-like qualities of the black person. The entire history of black cultivation of the land was concealed behind an argument that treated black people as new to agriculture. The areas of land, progressively less able to sustain their burgeoning populations, were targeted by the Betterment policy of the National Party government in the 1950 s and 1960 s. $^{8}$ 'Betterment' sought to institute alternative spatial forms of settlement and farming in order to repair the land after the devastation of soil erosion caused by overpopulation and overgrazing. As a government report on the Betterment project stated in 1963:

At one stage the whole of this vast area was heading for ruin, due to the wasteful and harmful manner in which the Bantu - in his ignorance - had utilised the arable land and grazing grounds, and in which he had settled there. The Department of Bantu Administration and Development realised that, unless the people were given expert advice and guidance in regard 
to matters agricultural, nothing could save the land from becoming a desert. $^{9}$

The report also emphasised that a failure would represent a failure of the citizens, rather than just a failure of the policy.

Only with the full and loyal support of every man woman and child in these Territories can this fair land - the Transkei - be transformed into the paradise it used to be before the malpractices of man started the deterioration which has become so evident. ${ }^{10}$

Citizens of the bantustans were therefore required to act cohesively to alter the land so that it could draw closer to the image of western methods of cultivation and occupation. The customary pattern of settlement - a central kraal ringed by dwellings, surrounded by communally held cultivated lands - was replaced by a dispersed pattern in which the land was divided into rectangular plots, for both inhabitation and cultivation by a single family. The implementation of the policies therefore influenced both what remained of the traditional occupation of the land, and the stability of the social order which had been inscribed in the hierarchical arrangement of the kraal.

The remoteness and anonymity of the politicians that sanctioned, and the officials that executed, land policies - particularly the Land Acts, the Bantu Authorities Act in 1951, and the Betterment policies - made the changes to the land elusive to those who lived in the areas there: difficult to rationalise, and difficult to resist. The closeness to the land that had characterised traditional tribal life was interrupted by distant scratchings of drawing implements held by faceless individuals, struggling to overlay political will onto the surface of the ground.

\section{Dividing the land}

\section{Dispossessed}

Someone is trying to erase the stain

By tip of nib

By piecemeal concessions

And elsewhere someone

By redivision of land

Into black and white blocks. ${ }^{11}$

The inscribing pen, both erasing and colouring the land by race, was recognised by the poet Modikwe Dikobe (b. 1913) as a process which occurred at a place which was remote both from the physical place of the land and from its meaning. Dikobe wrote during the years of apartheid; his collection of poems, Dispossessed, was published in 1983. The poem responds to the construction of the ethnically determined and fragmented bantustans through the passing of the Promotion of Bantu 


\section{Farm}

Self Government Act (No. 46 of 1959) and the continuing attempts by the South African government to consolidate dispersed land areas into geographically cohesive masses. The distance from the land, enabled by surveying and by the representation of the country on a series of sheets of paper, made it possible to filter its meaning, to shrink its presence to a series of ephemeral lines, and blocks of colour. Dikobe sensed that the colouring of land by race was part of a progressive strategy of erasure - of black identity from the 'white' land of South Africa - and that the drawing of lines and the redivision of the land were constituent processes of this erasure. Race was seen to stain the land with the colour of dark skins, so that the land itself was perceived as personifying the characteristics of the race of people that inhabited it. The land inhabited by white farmers was clothed in green fertility, while that of black inhabitants was represented either as a wilderness made dry and dusty by incompetence or as an uncultivated 'primitive' landscape in which tribal life continued to exist. In one of the debates conducted by the Native Affairs Commission, a farmer went further, claiming that the actions of the black farmers encouraged the spread of the desert vegetation into productive farmland.

We ask that these black spots be removed as they are detrimental to the European farmers around them. They have ruined the ground through overstocking and the grass that was there is finished and bitterbosch has come in its place and is now spreading to my farm. We know it as the Bitter Karroo bush. ${ }^{12}$

By qualifying the name of the vegetation (literally 'bitter bush') with the name of the Karoo the farmer nurtured an implicit connection between the wilderness and the confined areas which numerous black agriculturalists were attempting to farm.

The detachment of the processes of map-making meant that the surface of the paper served as an inaccessible interface - one which particularly the black farmers had great difficulty in reading and changing. It was a method of representation both unfamiliar and remote to many who were affected by its consequences. The process of drawing the land on the surface of the paper, and tracking its boundaries, superseded the way in which traditional rights to the land were determined. The closeness to the physical form of the land - to its rivers, hills and trees - which had traditionally guided settlement and cultivation, was replaced by a distant, stripped vision - of race as a material attribute of the landscape. Maps were a way to imagine, and to plan, a different future, to supersede social, spiritual and cultural connections with the land with a detached political vision, which sought an identification with the land through the displacement of others. Maps acted to disempower those without political power. This was quickly recognised by many black South Africans - one Chief remarking: 'How do you fight the drawings of a pen?'13 The rational appearance of maps concealed within the certainty of the drawn or printed lines the struggle of their making, and drew power from this deceit. 


\section{Ladysmith and Matatiele}

Maps recorded race overlaid onto the land for each area in which black and white ownership entangled. The areas of dispute and intersection were targeted by the Department of Native Affairs in a series of hand-drawn maps which were produced to document and determine the occupation of the land. There are two areas which are considered here - Ladysmith, in the Natal province in the eastern part of South Africa and Matatiele, adjacent to the Transkei (which was to become the first 'independent homeland' under National Party rule). In the Ladysmith area, one of the exploratory government maps shows the extent of white and black ownership and also demonstrates not only that the Scheduled Areas (red outline) floated as fragments within a sea of white ownership, but also that a 'Scheduled Native Area' could sometimes be a single farm (Plate 6.1). The fragmentation and intricacies of the land parcels contradicted the myth of 'Native reserve territories' as vast reservoirs of a traditional, tribal way of life and confirmed that, at least initially, the land parcels which were designated as part of reserve lands were made up of farms identical in appearance on the map to those owned by white farmers.

The hidden struggle to produce a landscape rationalised by race is revealed in two maps of Matatieleland - one produced by the Land Survey Office in order to record the areas described in the 1913 and 1936 Land Acts (Plates 6.2 and detail 6.3). Unlike the adjacent 'white' farms which are rigorously described in terms of dimension, location and orientation, the Scheduled and Released Areas on the maps are shown as undifferentiated areas. Black-owned farms were indicated as individual parcels of land only when they constituted part of a black spot, and were therefore under revision. As soon as the farms were integrated into a larger Scheduled or Reserved Area their individual boundaries ceased to exist on the maps.

The lack of internal divisions in the reserve lands (and later the bantustans) is therefore indicative of government policy which sought to control political and legal issues - including land use and distribution - through a system which involved the co-operation of 'traditional leaders'. Under the Bantu Authorities Act of 1951, Tribal Authorities were created - which were represented as being consistent with customary tribal law, even though in reality the leaders were often notorious for ruthlessness, corruption and brutality - and for their co-operation with the National Party government. Consistent with the principles of 'indirect rule' that Mahmood Mamdani has shown to be one of the primary methods through which colonial power was disseminated, tribal systems were retained as a veil to the new political systems that they concealed. ${ }^{14}$ In terms of traditional tribal custom, land was believed to be a communal resource and territories of different tribes could overlap in a fluid system of use and ownership. In the bantustans communal land was administered and controlled through the central government, while tribal leaders assumed a secondary and supportive role.

Allocation of land was dependent on the Tribal Authorities, which incorporated chiefs and headmen, appointed councillors and a tribal secretary. The lack 
of political legitimacy of many Tribal Authorities contributed to the instability and contradiction both of everyday life and of the represented, narrated and experienced meanings of the land within the bantustans. The maps reinforce the perception that, while the white-owned farms were associated with individuals and conformed to the modern norms of surveyed and bounded property, the land held within reserves was undifferentiated and unsurveyed, subject to different laws, customs and history, and that the bodies within it were anonymous.

Aerial photographs are both similar to and different from the maps that they sometimes help to produce because they record, in minute detail, alterations to the surface of the ground that indicate the use and transformation of the land under human occupation. Like maps, they are two-dimensional representations that reproduce scaled versions of the measurements and physical characteristics of the land. They are therefore dimensionally 'true' to the land they represent. Unlike maps, they record the collective movement and markings of people - paths inscribed into the surface of the ground by the passage of many feet and land that is damaged, eroded or fertile. There is a density of information held within aerial photographs that confounds the rationality of maps, because they also record that which is discarded, neglected or uncharted. Photographs of the Matatiele district, taken between 1952 and 1953, indicate not only the diminishing size of individual plots in the reserve lands under the influx of displaced people, but also the inscription of drawn boundaries onto the surface of the ground (Figure 6.1). While the boundaries on the ground were primarily fine vertical wire fences demarcating territory, and appeared as such on the maps that charted their paths, their political influence expanded and affected an alteration in the material characteristics of the entire area that they defined. On the aerial photographs, boundaries between areas owned by different racial groups appear not as inscribed lines, but as edges to a landscape that has been transformed by different densities of inhabitation - denoting white/black, fertile/infertile, lush/eroded. The boundary line was a deep cut, defining an area of race which soaked into the surface of the land. The map shown adjacent to the aerial photograph confirms that the 'international boundary' between South Africa and the Transkei (indicated by a dotted pink line) demarcates the difference visible on the aerial photograph between fertile ground and the overpopulated territory (Plate 6.4).

The focus on race in twentieth-century legislation shifted the emphasis from line to area, from bounding the landscape to an alteration in its nature. The bounded garden within the unknown wilderness that was the first act of colonial settlement was gradually transformed into an inverted garden, where the corralled 'wilderness' was surrounded by a series of white-owned farms. Like the tiny dots marking race on the Population Map of 1951 (Plate 5.2), the land had a shadow cast on it by the density of bodies that it was forced to accommodate, and boundaries became materially tangible through the density of this shadow. The staining of the land that Dikobe referred to in the poem 'Dispossessed' was in effect a stripping which, in turn, offered renewed justification for white farmers' claim on the land. ${ }^{15}$ 
6.1

Aerial photograph
of Matatiele
(1952-53) showing
the difference in
erosion and
division of the land
on either side of
the boundary
between white
and black-owned
land. Reproduced
under South
Africa Government
Printer's Copyright
Authority no. 11296,
1 November 2005.

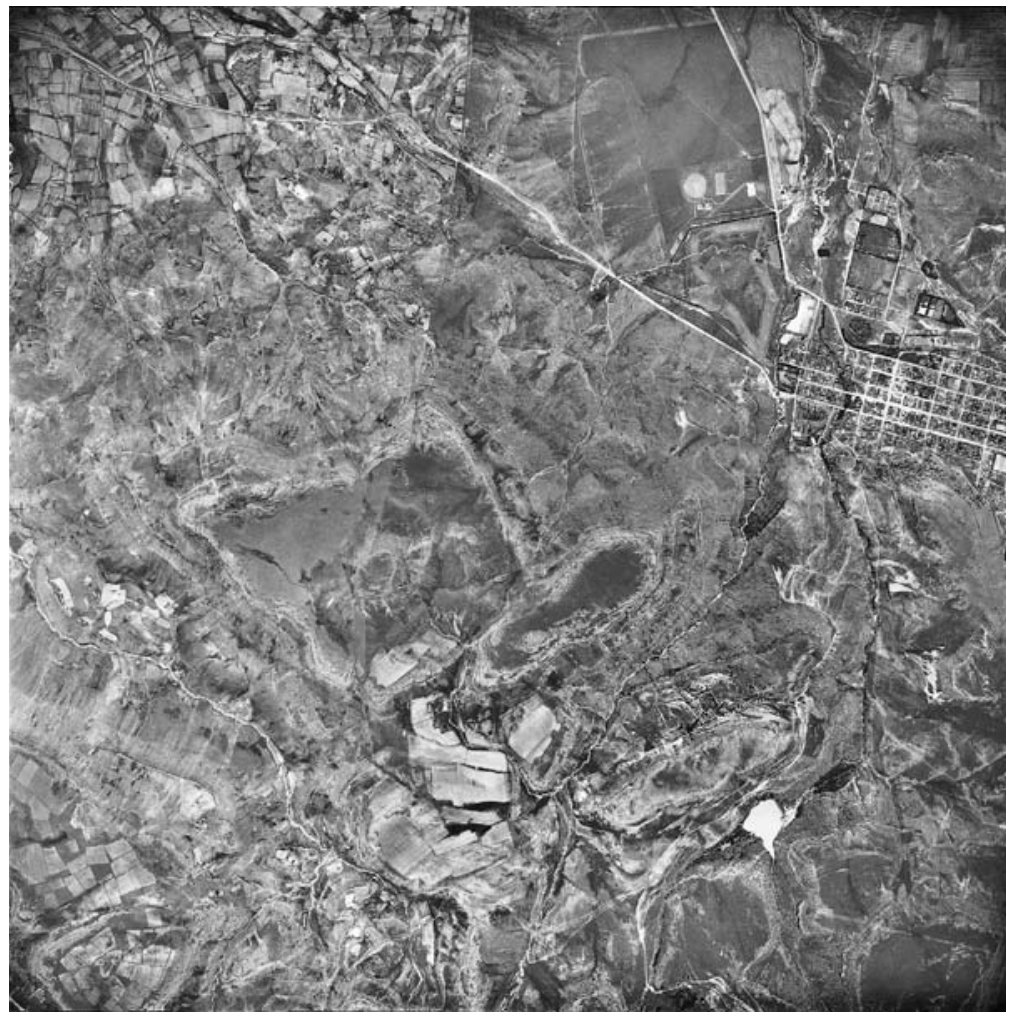

The documentation retained by the government in state-sponsored archives situates the debates over black and white ownership of the land firmly within the ideal of the productive landscape, and records black and white farmers repeating well-rehearsed mythologies of fertility and land ownership. In Matatieleland, the debates were concentrated on a strip of extremely fertile land, allocated to whites, called Ongeluksnek (Accidents Neck). The emphasis placed on race exacerbated tensions between the communities, and meant that race was invariably used as a bargaining tool by both black and white farmers. Under the terms of the Land Act of 1936, black land owners could technically be forced to move only if land, equal in both area and fertility, was offered to them as a direct compensation. (Under National Party rule this requirement was abandoned.) Race was employed by both groups as the means to acquire more land, although legislation, and political will, were firmly on the side of the white farmer. Many black farmers seemed willing to go along with the segregationist policies if they resulted in the allocation of additional land, and were often frustrated in their attempts to argue for a rationalised and equal approach to land distribution. In the government records of the period in which the disputes took place (1947-1949) black farmers displayed an awareness both of the arguments used 


\section{Farm}

against them, and of the inconsistencies of the policies that resulted in the upheaval of many more blacks from their homes than it did whites. As Chief Moshesh argued:

There have been many Commissions trying to get land for Native occupation. We asked for land because we are congested. The government then decided to segregate Natives from Europeans and we listened to them because we have been wanting land... You are the people who say the Europeans should leave Native areas, but this seems to be a one sided affair. Makoba's location has been moved, ${ }^{16}$ but these Europeans are in a black area. You should be fair to both sides. The Ongeluksnek area is a white spot in a black area. The same machinery that was used to move Makoba's people should be used to take away the white people. We are under you and have confidence in you if you treat us in the proper way. ${ }^{17}$

The emphasis on segregation as a motivation for the transfer of land masked the desire to place much of the productive landscape in white hands, something which was quickly recognised by the black farmers. As Daniel Moshesh asked: 'It [Ongeluksnek] is a small strip in a native area. How can the Europeans be entitled to it if segregation is run on proper lines?' 18 The mythology of destiny and entitlement was challenged by black land owners who recognised both the mechanism of their dispossession, and its roots in a political process.

I am sorry to hear that the same Parliament that recommended segregation, that black spots should be done away with in white areas, should turn around and say that these people cannot be moved. Ongeluksnek has been made a white area by an Act. ${ }^{19}$

In turn the Native Land Commission, battling for authority in the insecure and conflicted area, invoked parliamentary authority and, in so doing, exposed the complexity and irony of the way in which land ownership was decided.

You have said that it is a white spot in a black area, but that is not quite correct according to the law. If a European farm were in the midst of a Released or Scheduled Native area that would be a white spot, but if the farm falls in an area which Parliament declared to be a white area you cannot say it is a white spot even though there are locations either side. ${ }^{20}$

Black farmers identified both the contradictions in the removal of black and white spots and the myths of fertility and productivity employed by the white farmers and politicians.

Now we must remember what was said to the Makoba people. They had to remove from their area because it was said to be a black spot in a white area, and those people of Makoba were born there and their grandfather's graves were also in that area ... What is causing these people to resist, to make them refuse to move? Must not justice be done? And yet you 
will find that the reason that is given by them is that the ground is so fertile it is not fit for Natives. ${ }^{21}$

White farmers recognised the overcrowding of the land, but preferred to understand it as a consequence of the irresponsibility of the black farmer or tribes person, and not as the result of land-based legislation. ${ }^{22}$ While black farmers argued for more land on the basis that they were restricted, the white farmers argued in terms of fertility and of the threat posed to them and to their lands by the presence of the black people.

We want our area white and we want these Native farms excised in order to enable us to increase our production ... Last year we supplied Durban and Martizburg with fresh milk from this area. The Government also told us last year to produce potatoes, mielies, everything, which we have done on a large scale. Will you get anything of that nature from the Natives? ${ }^{23}$

Black identity was fluid and complex, dependent both on place and activity, so that the same activity, productive labour, carried out within the reserves, was seen to produce a wilderness peopled with 'squatters', while in white areas it disappeared as a 'natural' activity.

[W]e look forward to the time when the remainder of our European area would, as promised, in fact be a European area, and not a mixture of the races as we find here in the Mount Currie and Matatiele districts ... They swarm across our fences after cutting them, in order to get to the Nativeowned farms where the beer drinks are held. It was thought at one time that they would be sources of labour, but there is no such thing today ... These farms are overstocked with squatters. ${ }^{24}$

Despite the disproportionate allocation of land to white farmers they still felt the presence of black South Africans as a rising tide which could overwhelm them at any moment, particularly in 'white spots' that were close to or surrounded by black areas. The insecurity of white land tenure was exposed by the constant refrain of fear. The imagery of the maps and their colouring by race offered visual symbols for the physical threat that was perceived in the landscape. The powerful image of a land marked by race nurtured the perception that land occupied by people of a different race was almost a different substance - one unstable and volatile in contrast to the solidity and dependability of white land. Black South Africans were referred to as a 'sea', which surrounded the 'land' of the white farmers, one farmer stating: 'We feel our sorrows are greater than other people. We are a little white island. 25

The island of whiteness was occupied not only by white farmers, but also with black labour, but it was labour that was silent and all but invisible. While the white farmers looked around in fear at the black population around them, black people, dispossessed of their traditional lands, felt compressed and helpless at the changes to 


\section{Farm}

the land. The flood of black people onto the reserve lands, as well as into the cities, as an ongoing consequence of the Land Acts, belied the neat formula that sought to enact a comfortable transformation of black tenant farmer into labourer. The failure of the myth of dual black identity as tribes person and labourer was hastened by the ever-increasing subdivision of land plots in the reserves, rapid black urbanisation and in the struggle to keep cattle despite the pressure on the land. With the enactment of the Land Acts and the resultant subdivision of the land into white and black areas, an attempt was made to sustain the myth of the white pastoral landscape. Within this world, however, a fear of the land and its inhabitants remained.

The efforts to sustain and extend the segregation of land occupation and the separation of identities were increased under the National Party. New laws - governing relationships between people of different races, racial classification, areas of inhabitation, job reservation, different educational standards and the compulsory carrying of formal identification - were passed in the first five years of National Party rule. The image of the rural landscape - farms, game reserves, and bantustans - was integral to this political vision. Identities, the image of urban and rural landscapes and the economies of the city and the farm became increasingly entangled. The political will to segregate the land not only sought to superficially divide people according to race, but also controlled the image and use of the land that they were allowed to inhabit. Ultimately, the physical restrictions of the tribal areas, and the consequent pressure on the land resulted not only in an alteration of its surface, but also in the way in which it was seen and imagined. 


\section{Part 3}

'Native' lands 



\title{
Chapter 7
}

\section{‘Native' lands}

\author{
Death \\ [Extract] \\ And so to kill a bug \\ they set a house on fire \\ they flood a country \\ to save a country \\ drench a land in blood \\ to peg the frontiers of their colour madness \\ they'll herd us into ghettos \\ jail us \\ kill us slowly \\ because we are the Attribute \\ that haunts their dreams ${ }^{1}$
}

In 'Death' Es'kia Mphahlele (b. 1919) describes the fear of the continued presence of black South Africans in the imagination of white identity and in the disproportionate attempts to control of the landscape that is a result of this fear. Mphahlele is a prominent black writer, critic, poet, theorist and academic, who spent 20 years in exile in Africa, Europe and the United States, before returning to South Africa in 1977.

This chapter turns on two different applications of the word 'native', and two different assigned identities to 'native land'. It discusses the association of different landscapes with people of different races through legislation and representation, as well as how certain, particularly urban, places were seen to exclude citizens who were not white. As Raymond Williams has stated: "Native" is one of those interesting words which, while retaining a substantial unity of meaning, are applied in particular contexts in ways which produce radically different and even 
opposite senses and tones. ${ }^{2}$ Williams emphasises the split between the positive sense of 'native' - a sense of naturalness, innateness and belonging to the place in which one was born ('native' land, 'native' country), and the negativity and connotation of inferiority when applied to the inhabitants of a colonised territory. The split between the positive and negative senses of the same word is dependent on whether one's own community is referred to, or whether it is used to distinguish between a superior (invariably European) group and an inferior (invariably non-European) group. While the association with 'naturalness' is sustained in the first usage, in the second the 'nature' of the root word (nativus) appears as something which binds the people rather too closely to a rough and uncivilised world. The splitting of 'nature' into modern and ancient, progressive and static, was likewise associated with different peoples.

'Nature' therefore appears here in two different guises. In the first case it is used in an evolving and developing sense, from which strength, a strong sense of place and a national identification with the landscape can emerge. In the second case it is restrictive and binding, frozen in time, basic and primitive. What was at stake in the distinction between 'native land' as a claim and 'native land' as a designation was therefore a division between us and them, the former a representation of closeness to the land and the latter a concept of landscape which was put at a distance. 'Native', however, was also a term used by black South Africans to reclaim the land - to reassert their natural closeness and belonging - and to reimagine the unification of the natural world with traditional culture that was characteristic of tribal life.

The chapter looks at representations of 'native land' and 'native' identity within the particular political construct of the bantustans as well as how 'native' was a term which was claimed by both Afrikaners and black South Africans. It discusses how the image of a pristine African landscape was used in an attempt to conceal contradiction and inconsistencies.

Poetry has acquired a central role in the representation of the South African landscape in Afrikaans, English and black culture, and became significant in the writing and claiming of the land over the twentieth century. The tradition of using words to describe the land and its peoples connects not only to established European traditions, but also to the use of oral histories to record and narrate tribal cultural history. Like the other representations that form part of the research material, the production of prose and poetry are inseparable from the politics of representation in South Africa. In 1973, Nadine Gordimer, the Nobel Prize-winning novelist, connected the shift from black prose writing to poetry with the political restrictions introduced by the government in the $1960 \mathrm{~s}^{3}$ Gordimer emphasised that the exile of many black prose writers, and the fact that the government had not yet focused on poetry as a medium which needed to be censored, meant that poetry became one of the few means available to record resistance to apartheid laws. Poetry formed a kind of code, which could sometimes evade the attention of the government. While some earlier black poets such as St.J. Page Yako and Benedict Vilakazi wrote in their mother tongue - Xhosa and Zulu respectively - the majority of poems written by black writers during the apartheid period are written in English. This allowed them to reach a wider 
audience and to escape the potential divisions between people that could arise because of tribalism and ethnicity.

\section{Claiming as 'native'}

In Sol Plaatje's registration of his protest against the 1913 Land Act in Native Life in South Africa, he wrote in English, directly appealing to the British government to use its political powers in the Union of South Africa.

In the rest of the country they ask Parliament to confiscate our birthright to the soil of our ancestry in favour of 600000 Boers and aliens whose languages can show no synonym for home - the English equivalent of our ikaya and legae! The Britisher's vocabulary includes that sacred word: and that, perhaps, is the reason why their colonizing schemes have always allowed some tracts of the country for native life, with reasonable opportunities for future existence and progress, in the vast South African expanses which God in his providence had created for His Children of the Sun ... In 1910, much against our will, the British Government surrendered its immediate sovereignty over our land to Colonials and cosmopolitan aliens who know little about a Home, because their dictionaries contain no such loving term; and the recommendations of this Commission would seem to express their limited conception of the Word and its beautiful significance. ${ }^{4}$

Plaatje had spent three years in the United Kingdom, before the publication of the book in 1916, attempting to induce the British to act and trying to find a publisher for his book. His impassioned plea attempted to reassert a claim on his 'native land' by invoking within its pages: 'home' and the 'soil of our ancestry', which Plaatje believed was chosen by God for his 'Children of the Sun'.

When Plaatje wrote there was little doubt in his mind that the 'Boers and aliens' were the usurpers of the native land of his people. By the late 1950s, when the decision of the South African government was announced to consolidate the areas that were declared in terms of the Land Acts and rename them 'homelands', much of the language that Plaatje used to describe South Africa as his native land had reappeared in the language of Afrikaner Nationalism. The ancestral soil was the soil of the Voortrekkers, paid for in blood. The chosen people were the Afrikaners, and the native land theirs - given by the same God. Plaatje's invocation of the word 'home' as a word which described an innate sense of belonging was appropriated as the preferred term by which to designate the proposed ethnic territories.

Other black writers have emphasised both their right to use the term 'native' in its sense of natural belonging and of the inseparability of Africans and the land. This seeks to counter the representation of the land of South Africa as the landscape of the Afrikaner, which resulted in a distancing of the land, both from the bodies and imagination of black South Africans, as well as its suspension from the African 
continent. Black protest poetry became one of the primary means through which the reclaiming of the landscape could occur.

\section{black trial}

[Extract]

i resigned from paradise

and went back home to africa

in search of my image

to dig up the roots

and burn incense

to strengthen my stand

speaking to my ancestors

[...]

turn a new leaf

date this creation

scribble on the soil

[. . .]

i talk about me

i am africa

i am the blazing desert yonder

a tall proud grain amongst the sand

egypt my head the nile my oasis

flow on nile flow on my life blood

i talk about me

i am africa

i am man

ogun's image ${ }^{5}$

made from the soil

[... ]

land of my sons

sons of my soil

bed of my roots

roots of man

man son of africa

i want you

back

back home in africa

when I lost you

you were a virgin rich with love

until they split your loins

eagle spread and raped you all

within three centuries

when they boasted their manhood and 
you abandoned their first child

in the remote trans

$\mathrm{kei}^{6}$

oh child land of my sons

come back home to africa ${ }^{7}$

Ingoapele Madingoane performed this text as an oral poem after the riots in Soweto, ${ }^{8}$ on 16 June 1976, - the day on which a still undetermined number of Soweto schoolchildren were killed during a protest against the government's decision to implement compulsory Afrikaans-language education in black schools. ${ }^{9} \mathrm{O}^{\prime}$ Meara has described the Soweto riots as an event that

entered South African political culture not as a massacre, but as a proud and glorious rebellion. Those who died were not seen as victims of apartheid but as heroes in the battle to overthrow it. Soweto showed that significant numbers of urban black South Africans no longer perceived themselves as the passive victims of white power, but rather as the active makers of their own history. ${ }^{10}$

Soweto became a formative moment - a point of commemoration - around which a rallying cry could be raised by the writers of the generation. The continuity between oral history and poetry offered black writers a means to connect to their cultural history, while embracing and exploring a modern form of expression that is both cultural and political. Because the poems are intended to be performed, they relate to the presence of the body in the land, on a particular piece of the earth, to which the community is connected. The body, land, performance poetry and the spiritual life of the community are intertwined. In a study of Zulu poems, Masizi Kunene argued that traditional poetry is a form of history, a record of the life of a community made and performed on their behalf, while in the late 1980s Jeremy Cronin connected oral traditions to the use of performance poetry at political rallies. ${ }^{11}$ Poetry performed at large rallies not only circumvents the difficulties of publishing for a relatively small audience, but also confirms poetry as part of political life during a period of intense violence and upheaval.

In 'black trial', protest poetry, already an important part of black political resistance, was used as a means of speaking, representing and recording a response to the riots. Madingoane's insistence on the voice of a poet as a record against the silence is almost an incantation, and it is the land that was the surface of inscription: 'turn a new leaf, date this creation, scribble on the soil'. The rhythms of the spoken word are palpable in the written text. The speaking to the land and its opacity and elusiveness recalls the dislocation of white writing from the land - the battle to recognise it as a landscape - although here the poet invokes a past wholeness - an Africa of power and unity that can be recovered. The roots of Africa, in contrast to the ethnically divided and physically fragmented landscape of the bantustans, were described as running deep, from desert to Nile to savannah. The poet's distance from 
the land is revealed in the desire for writing the landscape, for dating events and recording a history that can be impressed into its surface. The silent land was represented as being a consequence of the division between people and the land that had been violently opened by white settlement. Representation in turn became a means to recover the land - through the speaking of the land in order to reclaim it.

The experience of black South Africans, that centuries of white rule had removed the land from them and from the body of Africa, was belied by the representation of the bantustans in government documents and reported speech of officials, where land policy was represented as a means through which cohesive societies could be restored. The policy directly linked ethnicity with land and the mythology of uncontaminated tribal existence in a picturesque landscape. Its implementation was coupled with the erosion of urban residential rights and the implicit government policy that there were to be, 'No more black South Africans'. ${ }^{12}$ In Citizen and Subject, Mamdani has argued that traditional African society was not as stable as it has been presented and that the representation of a politically and territorially stable cultural history was a necessary part of the establishment of direct rule, and control of the citizens that was concealed behind a 'natural' system. ${ }^{13} \mathrm{He}$ also argued that the emphasis on ethnicity rather than race during the later part of the twentieth century in South Africa was consistent with many other colonial situations which gave prominence to 'tribe' rather than 'race' as the constituent element of a people: ethnicity therefore becomes a form of modernity, rather than its precursor. The emphasis on ethnicity was used as a way to administer a modern state behind the visible mechanism of tribal authority. ${ }^{14}$ This ethnicity was highly politicised and was a strategy which was at least partly devised to damage increasing (and unified) black opposition to apartheid. Posel has argued that the 'practical' approach to black labour in the cities which was taken in the early 1950s was taken over by a fear in the 1960 s that was a response to increasing urban African resistance. This perceived threat resulted in a revision of policy and draconian crackdowns on protest. ${ }^{15}$ Thus the bantustan policy and its ethnic divisions should not be seen outside the context of modernity, a rationalised administration and the control of black labour and increased political opposition to government policy. Ethnicity, as Leroy Vail has recognised, 'is not a natural cultural residue, but a consciously crafted ideological creation. ${ }^{16}$

The mythology of the bantustans was, however, dependent on sustaining a perception of morality in the bantustan's systems of government, and of their correspondence with a traditional way of life. Dr Eiselen, secretary of the Department of Bantu Administration and Development, argued in a 1959 speech quoted in the Rand Daily Mail that:

Representative bodies should not be forced upon the Bantu from above, but should come into existence as a result of natural evolution from below. That is why the Bantu Authorities Act of 1951 starts from the principle of tribal authorities corresponding in great measure to the old Bantu tribal councils, whose opinion had always to be taken into account by the chiefs, 
and which will function in accordance with Bantu customs as far as can be reconciled with civilised standards. ${ }^{17}$

The reconciliation that Eiselen referred to maintained the control of the white government over the natural systems of government that the bantustans were supposed to foster. Likewise the supposedly immutable traditions of black South Africans were used to justify political policies which ensured the control of urban space by the Nationalist government. At the South African Bureau of Racial Affairs conference in $1972 \mathrm{Mr}$ van Onselen, then Secretary of Bantu Administration and Development, argued in the opening address that:

There are people who keep on pleading that the right to own land should be granted to Bantu living in white urban areas ... Individual ownership of land is not characteristic of the national identity of Bantu peoples. Communal land ownership is the accepted tradition. ${ }^{18}$

One incident serves to illuminate the political desire to read all Africans as tribal, despite the urbanisation of more than 30 per cent of the black population by 1959. In an article published by the Rand Daily Mail, a journalist told of his encounter with another journalist from a Nationalist newspaper. As the article reported, the Nationalist journalist, while in Meadowlands, a section of the dormitory city of Soweto to the south of Johannesburg, asserted that:

'Even these Natives living here have not forgotten their tribal ties.' He [went] on to ask three Africans who were standing on a street corner who their chief was. They stared at him blankly for a moment and then one of them replied, 'Mr Reid.' Nationalist political correspondent: 'No, no. I want to know who your tribal chief is. Your chief at home.' The face of one of the Africans brightened. 'You know who I mean?' asked the political correspondent. 'Yes, baas.' 'Well, who is he?' 'The Superintendent, baas. ${ }^{19}$

Without the stability of territory and ethnicity the policy was built on quicksand. Hence the reiteration of identity and the notion of 'homeland' throughout the period of National Party rule:

[E]very Bantu is a member of a recognised Bantu people. Bantu have strong family, tribal, sib and national ties. ${ }^{20}$ Although the attachment on the first three may be weak, this is not the case with attachment to the people or nation. National attachment remains the predominant relationship. This relationship is recognised and confirmed by the Citizenship of Bantu Homelands Act (1970) which stipulates that the Bantu, also those outside their homelands, are members of a specific people or nation. ${ }^{21}$

The belief in a stable tribal history froze the image of tribal existence and detached it both from historical narrative and the contemporary political narrative of apartheid; simultaneously emphasising modernity and progress and denying the contributions 
of black South Africans to the success of the state. In contrast to this separation of black South Africans from the cities, new portrayals of the complexity of ethnicity and urbanity were emerging in the work of black journalists and photographers. The two significant papers aimed at the black market, Zonk and Drum, were both owned and edited by whites, although the majority of the contributors were black. Of these Drum managed to both capture greater circulation figures $(75,000$ in South Africa and 12,000 in West Africa in 1954) and has continued to maintain a high profile throughout and beyond the apartheid years, particularly as a document of 1950s Johannesburg. ${ }^{22}$ It remains the most famous of papers published for black readership anywhere on the African continent. The black journalist Nat Nakasa (1937-1965), ${ }^{23}$ who was one of the important contributors to Drum and an independent writer, protested against this racial separation by articulating a claim on all aspects of the past and the cohesion of black and white history:

'My people' are South Africans. Mine is the history of the Great Trek, Gandhi's passive resistance in Johannesburg, the wars of Cetewayo and the dawn raids which gave us the treason trials in 1956. All these are South African things. They are part of me. ${ }^{24}$

By retaining the apparent innocence of tribal life, and depicting the inhabitants as childlike, the Nationalist government attempted to suppress the complexity of black identity; its urbanity and sophistication and the intertwining of the lives of all South Africans. It also sought to conceal the real population of the ostensibly 'white' areas which were revealed as little more than an elaborate fiction by papers presented at the South African Bureau of Racial Affairs Congress in $1972 .{ }^{25}$ As the chairman of the conference, Mr Boshoff, revealed:

The favourable population trends of the sixties should not blind us to the realities with which we are now confronted. In White areas only 26 percent of the population are White. ${ }^{26}$

\section{Fluid identities}

Drum was the most important black magazine of the 1950s and 1960s. The issues published in the early 1950s in particular are regarded as a golden period of black journalism, giving voice to black (primarily male) urbanity. Drum catered for black urban dwellers - increasingly politically savvy and hungry for intelligent and engaging reports of issues that affected everyday life. Initially the magazine did not include political content but this was revised because of demand from readers. As Anthony Sampson (editor of Drum) has commented:

[T]he Drum experience had a political significance which was lasting and which few (whites) realised. It was the urban world of black Johannesburg, so alienated from tribal rites and traditions, which had been the basis of the Drum expansion and experience. ${ }^{27}$ 
Drum not only published the politically aware popular commentary that urbanised blacks were hungry for, but also offered a vehicle for black reportage and photography that challenged the prevailing mythology. The photographs and texts that were published in Drum take black urbanity for granted, and focus rather on incidents, negotiations, difficulties and celebrations that made up everyday urban existence. The magazine sought to portray a particular vision of urban life, an often light-hearted, tongue-in-cheek, embrace of modernity and its ills and celebrations. It also looked outside South Africa's boundaries, particularly to the United States, and New York City, which was presented in the pages of Drum, mostly through advertisements, as a place of equal opportunity and sophisticated urbanity. ${ }^{28}$ The notorious gangs of Sophiatown in Johannesburg modelled themselves on American gangsters, calling themselves 'The Cowboys', 'The Berlins', 'The Americans' (with a member called 'The Durango Kid'), while the police were called the ' $\mathrm{FBI}$ '. ${ }^{29}$

A pair of photographs from the archive of the magazine repeat the same basic formal structure: a woman stretches up to the microphone, left knee bent as if dancing as she sings, while behind her a line of men, one row crouching, one row standing, participate in the performance. In one photograph the performers are dressed in modern clothes, in the other in tribal costumes (Figures 7.1 and 7.2). The pairing is mine: these photographs were not taken to be used in the same article and the intent was not to present two hybrid identities, the presence of which was taken for granted by the photographers and writers working for Drum. The singers, Thoko Thomo and her group the Lo-Six, appear in both photographs, confirming the coexistence, ease and comfort with what appear to be the trappings of conflicting identities. The photographs offer snapshots of the fusion between urban life and traditional urban life in the 1950s, freeze frames of performances with microphones on city stages, produced for a popular magazine. In this context all clothing was theatrical, rather than 'natural'; a consciously worn veneer which could be expediently taken up and discarded. Boundaries between different cultures were eroded by the immersion into city life that was experienced by the readers of Drum, and its pages provided a window into a heightened urban world in which inconsistencies and ambiguities were part of everyday existence.

The clothing that was most normalised, in terms of regularity of use, was that of the city dweller; the tribal clothing was worn as a reference, a partially recovered memory of an altered life that may have been sporadically revisited from the city. It represents an incomplete fragment transferred to an urban context where the traditional meaning of performance had been irrevocably altered. The flexible attire of the singers, and the appearance of the photographs in a magazine aimed at city dwellers, hints at the development of a complex identity in which aspects of modernity and traditional life were enmeshed in a way that was impossible to admit in the circular mythology of labour and tribalism. The photographs also hint at the future development of a hybrid identity, in which black South Africans become increasingly comfortable with what appear initially to be conflicting societies and cultures. 


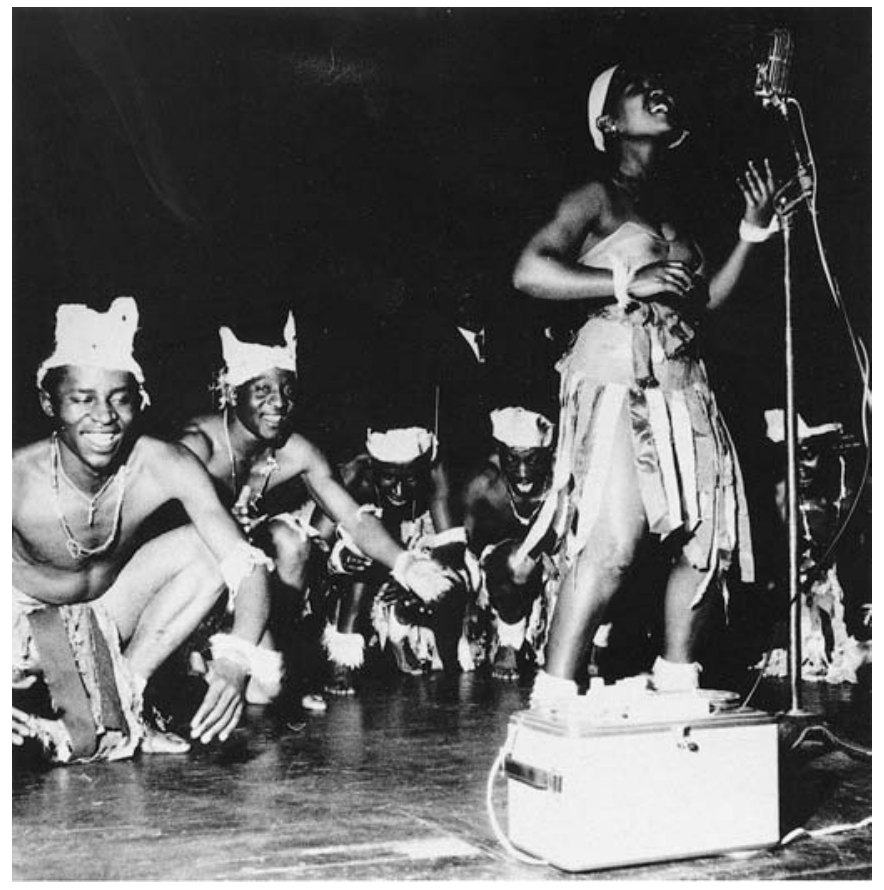

7.1

Thoko Thomo and her group the LoSix, from Drum, in tribal dress.

(c) Bailey's African History Archive.

7.2

Thoko Thomo and her group the Lo-Six, from Drum, in urban clothes. (c) Bailey's African History Archive. 
In contrast with the complex individuality of the black urban dweller, unified ethnic identity was regarded by the National Party government as an essential component of each nation, which determined each aspect of life. The focus on the precise determination of racial and ethnic identity was at odds with a world in which many people could trace diverse origins. Nat Nakasa recorded his thoughts on his own origins and their relationship to the bantustan which the government regarded as his only legitimate home:

I am supposed to be a Pondo, but I don't even know the language of that tribe. I was brought up in a Zulu speaking house, my mother being a Zulu. Yet I can no longer think in Zulu because that language cannot cope with the demands of the day ... I have never owned an assegaai or any of those magnificent shields. Neither do I propose to be in a tribal war when I go to the United States this year for my scholarship. I am just not a tribesman, whether I like it or not. I am, inescapably, a part of the city slums, the factory machines and our beloved shebeens. ${ }^{30}$

The complexity of racial and ethnic origins, and the fundamental effects that the assigned racial identity had on the lives of individuals, meant that - far from being perceived as integral to the self - identity became an aspect of life to be negotiated. The myth of complete and distinct identities was challenged at its borders, by those people whose immediate ancestors had been from racially diverse groups, and by those whose appearance could not be classified as belonging to a specific group with complete certainty. The Population Registration Act of 1950, which set out the parameters by which all citizens would be classified according to racial groups, was an inherent part of the process of segregation and division of urban and rural land. The officials who were given the task of enforcing the system of racial classification, unwittingly recognised the complexity and fluidity of the identities upon which the politics of apartheid was dependent. A 1951 internal memorandum from the Department of Coloured Affairs wrestles with the potential for ambiguity and confusion.

It is essential that it is clearly and simply set out what is involved with the definition of each recognised group ... Unless this is done, it is conceivable that it could happen, for example, that a person could live in a Coloured area, appear on the White voter's list, but pay tax as a Native!

White: - A person who comes from pure European ancestry, or who is accepted as such by the White group.

Native: - A person who comes from any of the indigenous tribes of southern Africa - i.e. including Bantus, Hottentots and Bushmen or who is primarily of that ancestry.

Asian: - A person who comes from any of the Asiatic nations or races - (excluding from the Malay group) - or who is primarily of that ancestry. 
Coloured: - A person who is not White, Native or Asian or who is not accepted as such, and is from mixed ancestry - but including Asiatic ancestry. This group includes primarily the Cape Coloureds, as well as recognised mixed groups such as the Griquas, the Dunns and Nunns etc.

Malays: - A Muslim Coloured.

[T]he identity card can be used for all practical purposes as prima facie proof of the race group to which any person belongs ... If the person, or another person, is unsatisfied, there should be machinery in place by which the description of a person's race can be changed. ${ }^{31}$

The definition of racial identity was flexible at its margins and therefore it was at the margins that the myth of separate development reveals its weakness. Even those living under the burden of racial classification were able to recognise the humour and absurdity in the process of appeal. Drum engaged with everyday stories of racial reclassification and appeal through the 1950s:

But some of this reclassification business can be real funny. There's a girl (don't ask me what race) around this Johannesburg who went to chance it. She got off with flying colours and was classified Coloured. Three months later she did even better. She went again and was reclassified European. ${ }^{32}$

The consequences of a change in racial classification could, as the journalist acknowledges, be devastating. The implications were not only political but also spatial; the right to occupy racially defined areas and to move freely in the country was dependent on racial categories. Had a man described by the journalist, William Modisane, in Drum failed in his appeal against his classification as 'African' and been unable to return to his status to 'Coloured',

he would have had his children removed from the Coloured School, have his application for a house in Noordgesig, Coloured residential area, cancelled. He would have had to carry a Reference book, pay Poll tax from the year he was $18 \ldots$ He would probably have lost his job. ${ }^{33}$

\section{The uncertainty of boundaries}

The intangible boundary lines that were drawn between different people by the system of racial classification were mirrored in the physical boundary lines that were drawn on maps and marked into the landscape. In both cases, however, the perfection of the boundary, its certainty and conviction, was broken by the imperfections of everyday life, and the negotiations and compromises that occurred in the implementation of political policy. While the long-term effects of the unstable and 
fluctuating margins were to subvert government power, the uncertainty of the periphery had repercussions for the experience of landscape and the meaning of identity. Rather than confirming the 'naturalness' of ethnicity and the authentic occupation of the primitive landscape, the inflections and stress at the margins meant that land and identity were experienced as fundamentally unstable forms. Although the myth of a stable past in a static landscape remained the dominant form which concealed the complete meaning of both landscape and politics, people were forced to live out the substance of their lives on the unstable ground that was both denied by and was a consequence of the desire to remake the land in the image of the prevailing mythology. This may begin to explain why apartheid appears to be so elusive, slipping away just as its form begins to become distinct.

The bantustan policy was based on the assertion that the proposals were not a fundamental revision of the occupation of the land, or the identity of its citizens, but rather arose out of a pre-existing natural inhabitation. However, the stability and tangibility of the rationalised authority of maps could not be matched in the physical environment, where any quest to discover the physical form and mental image of the bantustans uncovered little more than a mirage. As a journalist reported in the Rand Daily Mail in 1959:

The contention that the Union's Africans are not basically one people is open to challenge. Aware of this, the government has established elaborate machinery to preserve and encourage the linguistic and tribal differences that exist among the African people. Everywhere I went on my In-search-of-Bantustan tour, I came across maps depicting ethnic groupings or the locality of different African tribes. ${ }^{34}$

The overlap of science and myth onto the surface of the map was a technique which sought to present and modify real space in order to force it to conform to an imagined political space.

Like the black and white spots of the pre-1948 period, race was a layer that was both laid over the land and altered it, although racial categorisation of the land was fractured into ethnic groupings. As one Rand Daily Mail reporter testified, this had the effect of matching ethnicity to place and the production of maps that: 'contain[ed] more bright colours than a van Gogh landscape, show[ing] all the different tribes and sub-tribes into which ... Africans ... can be divided. ${ }^{35}$ The dependence of national identity on particular parcels of tribal land raises questions about these lands themselves; what their physical characteristics were and what the nature of the boundaries were that encircled them. Maps offered a way to imagine the divided landscape. The seduction of the mapped country was its resolution and precision, the crispness of the printed page, the certainty of its inscribed lines. As a reporter for Drum elaborated, the maps became a way of supplanting reality, a means of producing evidence of certainty and overwriting contradiction:

[T]he African has now reached the position where the basis of an independent existence for him has been undermined to such an extent that 
he finds himself with no alternative but to follow the way of interdependence. For him to be told in 1956 that he must return to the Reserves and endeavour to re-create there a social structure in keeping with a culture that the white man has done so much to destroy sounds strange in the extreme... One comes away from the Tomlinson Report with a feeling that one has been living for a time in a completely unrealistic world ${ }^{36}-$ a world of blueprints and plans and beautifully coloured maps. ${ }^{37}$

However, even this 'unrealistic world' of rationalised coloured maps of the bantustans does not sustain the image of stability upon inspection. First, the early proposals for the bantustans were not accompanied by publicly accessible maps - the indeterminate boundaries and fractured nature of the existing Scheduled and Released Areas was deemed too politically inflammatory for public exposure. Second, in the 1970s and 1980s, popular maps did not represent the land areas consistently. Through the apartheid period the powerful image of the divided land had an autonomy outside the imaginations of those in power and evaded their control. The rhetoric of the bantustan policy emphasised 'wholeness', 'stability', 'tradition' and 'political selfdetermination' but, seen as a series, the representations presented a fractured and indeterminate world.

When the bantustans were first proposed in the 1950s, parliamentary debates were recorded by the Rand Daily Mail in 1959 where the Minister of Bantu Administration and Development, De Wet Nel, is quoted as saying it was ridiculous to 'expect the government to draw a line and say that certain areas were for certain groups. ${ }^{38}$ The government preferred to use, at least initially, the more imprecise method of descriptive texts, incorporated into the Acts themselves. Maps would have offered an unambiguous method through which the spatial implications of government policy would have been scrutinised and challenged by both black and white interests. They would have not only precisely represented those farms under threat of appropriation, but also exploded the myth that the disparate parcels of land that the people were being offered could even hope to constitute independent territories that would allow them meaningful self-government.

In the late 1950s, when the bantustan policy had been formally announced, newspapers produced their own mapped speculations of the land areas, colouring in black the exploded shrapnel of the territories. Two similar maps, produced between March and May 1959, have very different agendas. The first, from the Rand Daily Mail, showed the existing 'Bantu areas' as a land problem which Verwoerd would have to solve (Figure 7.3). The map indicated all the 'black spots' of a reproducible scale, reflecting the fractured shapes that arose out of farm boundaries, as well as the major cities. The myth of independent, unified tribal lands seems unsustainable in the light of the disparate, floating fragments. The second map, published in Die Transvaler, was more supportive of the proposals, locating all the white towns in which industry would be developed in order to sustain black families in the bantustans (Figure 7.4). Its function was to confirm the normality and morality of the scheme. 

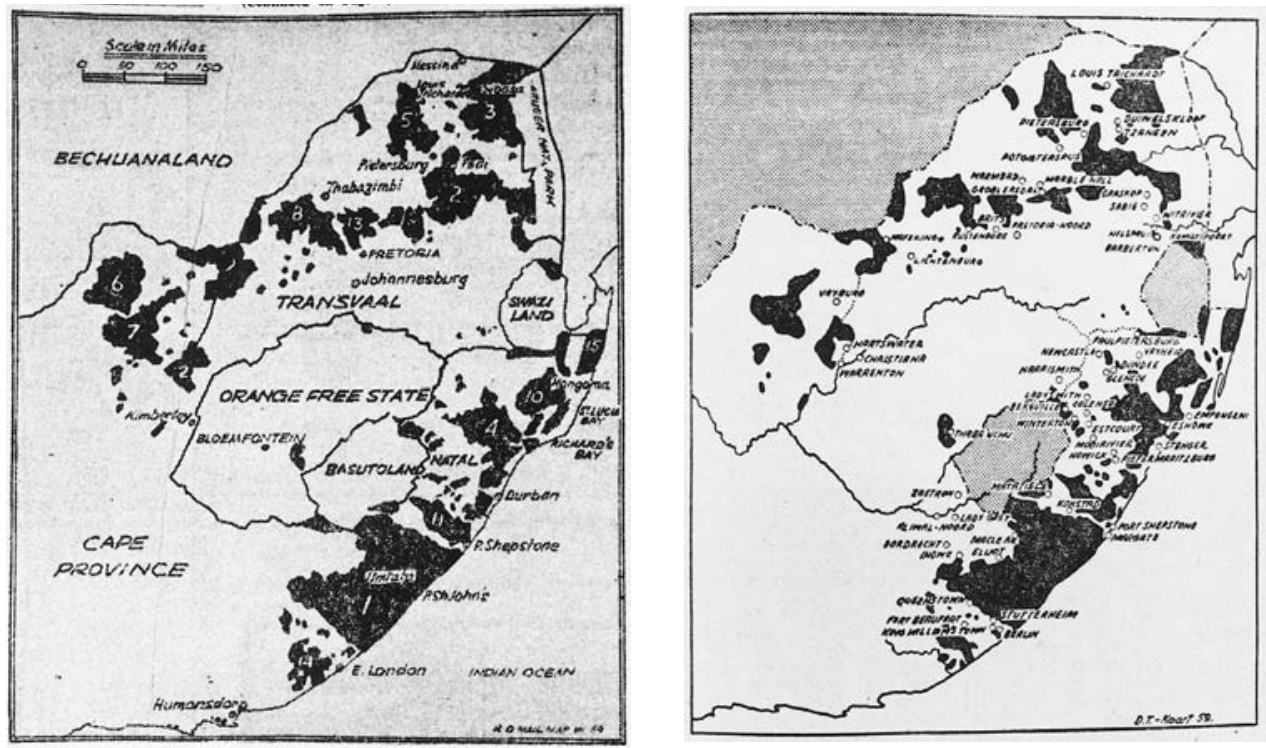

7.3

Rand Daily Mail,

13 March 1959 ,

Map of Bantustan policy.

7.4

Die Transvaler,

8 May 1959, Map

of industrial areas

related to the

Bantustans.
Here the primary motivation behind the map was not to question the logic of the bantustan policy, but rather to enforce it.

The ambiguous boundaries in different newspaper publications were not only a reflection of the scale and means of representation, but also the failure of the government to set fixed legal limits to the lands under consideration. The complex issues of land ownership and the risk of alienating their primary electoral group meant that the government was reluctant to confirm precise areas. The production of a map was frequently seen as an impediment to political change. In order to forestall (usually white) objections to the appropriation of land, the Ciskei, a Xhosa bantustan on the east coast of South Africa, to the south of the Transkei, was declared a separate administrative territory without its boundaries being determined. ${ }^{39}$ In the early 1970 s the problem had still not been resolved, leading to the Rand Daily Mail branding the then Prime Minister's attitude as one which belonged in 'cloud-cuckoo land'. It continued: 'Mr. Vorster['s] announcement that the bantustans were free to become fully independent before land consolidation and before their boundaries were finalised . . . added even more unreality to an already unreal situation. ${ }^{\prime 40}$ The bantustans remained, politically, spatially and economically, indistinct floating islands, that existed in an intangible world. Newspaper publications helped to make white South Africans aware of the presence of the bantustans, with their physical ambiguity, hazy borders and racial division of the land.

The representations that served to present and implement political policy likewise mutate, land areas appear and disappear, surfacing and receding from the pages. Four government-sanctioned maps of South Africa, produced for different 
purposes during the 1970s and 1980s, confirm this flickering between presence and absence, visibility and invisibility. The first map is a school map: 'Republic of South Africa: Political and Communications' produced under the authority of the Government Printers (Plate 7.1). It depicts the familiar outline of southern Africa, and divides the country into provinces, which are indicated by areas of different colours. As an educational map, its intention was to teach the political boundaries of South Africa, to imprint a geographical image of the land on its youth. In 1975, a year before the educational map was produced, a map was issued which is revealing both in form and title. The 'Black Homelands Consolidation Proposals' shows a pale yellow South Africa, pock-marked by coloured fragments, which are keyed as ethnically identified areas clustering to the north and east of the country (Plate 7.2). The fragmentation of areas of land that, in both speeches and photographs, were represented as whole and complete territories for the fulfilment of ethnic destiny is belied by the 'consolidation' offered by the title. Tribal lands float apart: the Zulu nation (represented by the brown fragments) was assigned 29 separate pieces of land. ${ }^{41}$ Crossing between the 'traditional lands' of the Zulu involved a process of gaining and shedding the right to freedom of movement. The density of the boundaries meant that movement was an act of continual border crossing, where even the location of the borders remained unstable and the political implications of crossing them varied from area to area.

The ephemeral quality of borders and the transient status of citizenship became representationally even more convoluted with the next map. Produced by the South African Tourist Board in the late 1980s, it shows political boundaries of territories recognised by the South Africa government (Plate 7.3).

Juxtaposed with the previous map, it is evident that the only bantustan areas that appear are those that had achieved 'independence' from South Africa, ${ }^{42}$ while the other bantustans are not marked onto the page. Another map, also produced in the late 1980s, documents the political status of the bantustans by the strength of their visual presence on the printed surface (Plate 7.4). While the 'independent' bantustans were given colour and clearly delineated boundaries, other territories appear as pale grey shadows, ghostly presences of uncertain status and clarity. The four maps therefore picture political and spatial territory in very different ways. The myth of permanence and immutability of ethnic territories was belied not only by the shifting of boundaries and the fragmentation of the territory but also by their changing representation on the printed surface of the map.

The fluctuating presence of the bantustans - sometimes invisible, sometimes partially present as shadowy figures and at other times drawn as more tangible coloured fragments - contributed to the perception that the spatial image of the territories was difficult to hold on to. Like a mirage, it offered a glimpse of certainty, only to dissolve as one drew closer. Even though maps were the vehicles for imagining and implementing the division of land, they also documented its failure. For those educated in the white school system, a conception of the bantustans developed from verbal, photographic and mapped representations. Because they were rendered invisible in maps, the bantustans entered the imagination as placeless 
fragments - descriptions or pictures of an imaginary world - without spatial limits, physical form or tangible locations. In contrast to the image of South Africa as a space with territorial limits, the bantustans were mutating figures detached from the mapped surface of the country, mirroring the status of the people who inhabited them.

The fragmentation of the areas also worked against the myth of political legitimacy. Steve Biko (1946-1977) was the leading proponent of the Black Consciousness movement in South Africa, first president of the Black People's Convention (BPC) and a victim of the brutal regime, dying in police custody in a Pretoria cell. He was an outspoken critic of the bantustan policy and recognised the division in the land between fertile and infertile areas that had as its consequence the fracturing of 'ethnic areas':

Geographically, i.e. in terms of land distribution, bantustans present a gigantic fraud that can find no moral support from any quarters. We find that 20 percent of the population are in control of 87 percent of the land while 80 percent 'control' only 13 percent. To make this situation even more ridiculous, not one of the so-called 'bantustan nations' have an intact piece of land. All of them are scattered little bits of the most unyielding soil. In each area the more productive bits are white controlled islands on which white farms or other types of industry are situated... [I]n all situations mineral rights are strictly reserved for the South African government. In other words bantustans only have rights extending six feet below the surface of the land. ${ }^{43}$

The fractured parcels of land that sometimes appeared on the maps failed to fulfil the political promise of coherent nation-states. Biko also identifies this partial control as one which had a limited physical thickness. 'Six feet of the country' (also the title of a Nadine Gordimer short story that identifies that thickness as the depth for the burial of a body) was enough to bury someone, but not enough to give 'deep' ownership of the land, and of its potential riches, which were still retained by white South Africa.

The failure to finally divide the land was recognised by the government as a failure to define the separate identities of all South Africa's people. At the South African Bureau of Racial Affairs conference in 1972, Mr Riekert, the Acting Chief Director of the Bantu Administration Board in the Western Transvaal, commented that:

The determination of homeland boundaries, homeland consolidation and the elimination of scattered pieces of Bantu land will contribute greatly towards the crystallisation of the concept of a White South Africa, distinct from the different Bantu countries. The process of establishing new international boundaries also serves to underline the loose or foreign status of the Bantu outside their own homelands. ${ }^{44}$

The definition of boundaries was significant, therefore, not only to the control of black South Africans, but also to the consolidation of the image of a white country. The 
persistent image of the map of South Africa as the primary and formative image of the white land, and as the means to claim that land, is here recalled in the language of politicians more than twenty years after the representations produced around the inauguration ceremony of the Voortrekker Monument incorporated the map as the primary signifier of an historical claim on the land.

However, the fragmentation of the people into ethnically determined groups, and the minute attention paid by the modern state to the movements, activities and whereabouts of every black South African meant that the 'nowhere-land' of the bantustans, outside the everyday lives of white citizens, was an unavoidable presence in black lives. Likewise the intangible web of political, racial and administrative boundaries necessitated an acute awareness of their limits, and the possibility of transgression. The ambiguity of racial classification and spatial inhabitation that was explored at the margins was itself an exploration of the limits of the rationalised modern state. White fear was mirrored by black South Africans. As Steve Biko wrote:

No average black man can at any moment be absolutely sure that he is not breaking a law. There are so many laws governing the lives and behaviour of black people that sometimes one feels that the police only need to page at random through their statute book to be able to get a law to charge a victim. ${ }^{45}$

The space in which black South Africans were able to operate was limited both physically and politically to such an extent that recovery of a more complete world seemed increasingly difficult to achieve. The fragmentation of the land, the focus on ethnic rather than racial identity, and the circumscription of movement between areas of land defined as separate political entities was a factor in the fragmentation of black opposition to apartheid and the contraction of the land into the areas defined as bantustans. As Biko argued:

What in fact is happening is that the black world is beginning to be completely fragmented and that people are beginning to talk sectional politics. I would rather like to believe that this was foreseen long ago by the National Party and that it is in fact a part of the programme. After the kind of noises made by Buthelezi, ${ }^{46}$ the Labour Party and of late Matanzima, ${ }^{47}$ who can argue that black opinion is being stifled in South Africa? Moreover any visitor is made to see that these people are fighting for more concessions in their own area (13 percent of the land). They accept that the rest of South Africa is for whites. Also none of them sees himself fighting the battle for all black people. Xhosas want their Transkei, the Zulus their Zululand, etc. Coloured people harbour secret hopes of being classified 'brown Afrikaners' and therefore meriting admittance into the white laager, while Indian people might be given a vote to swell the buffer zone between whites and Africans. ${ }^{48}$ 
The fragmented and confined land parcels with which individuals were so strongly associated both mirrored the fragmentation of black South African identity and were instrumental in their division into ethnic groups. Boundaries were inextricably associated with the political control of racial and ethnic bodies. They were not only drawn and erected between people of different racial groups, but also served to divide people along ethnic lines, dissipating their focus on communal issues.

\author{
Demarcation Line \\ [Extract] \\ A demarcation line \\ Runs on my doorstep \\ Leaving no space to stretch \\ And a little across \\ Is my neighbour \\ [....] \\ Now an artificial line \\ Demands a passport \\ Each time I stretch \\ Across the line \\ When visiting my neighbour \\ My neighbour \\ Tells me \\ He does not mind \\ Sliced into me. ${ }^{49}$
}

Modikwe Dikobe here describes a representational line as an active instrument, almost a physical object. The artificial line could be both a line drawn on a map or a racial border. The poet experiences this line both as false and real. It has no physical presence - it is not a fence nor a wall - but it still cuts his body. The penetration of black bodies into white South Africa was permitted by the government because it was deemed to be temporary - their rights and status impermanent. But the very presence of the bodies themselves was a reminder of the perceived threat of the masses. The association of ethnicity with bounded land politicised the spatial location of individuals and labelled their bodies themselves as displaced boundaries; fragments which ultimately belonged in a tribal landscape.

\author{
the border \\ the border \\ is as far \\ as the black man \\ who walks alongside you \\ as secure \\ as your door \\ against the unwanted knock $^{50}$
}


The poet, Shabbir Banoobhai (b. 1949), describes not only the association of political, mapped boundaries with the bodies they were intended to corral, but also the fear that was present in everyday life. The policy of segregation was in many ways a policy of fear, and the division and bounding of the landscape was based on a perceived threat to political control. The physical silencing and invisibility of the bantustans was inseparable from a policy which sought the silencing of political speech through physical confinement and censorship of individuals. The interpenetration of politics, power and spatial restrictions was argued for by Biko, who recognised the dependency of the 'noise' of political resistance on its ability to operate outside the borders of the bantustans:

As soon as the dissident factors outside the apartheid institutions are completely silenced, they will come for those who make noise outside the system. Once that happens the boundaries of our world will forever be the circumference of the 13 percent 'black spots'..$^{51}$

The spatial confinement of the bantustans can therefore be read as a strategic response to the threat against the fatherland of the Afrikaner by those with a prior claim upon it. Albert Luthuli, then president of the African National Congress, opposed the bantustans when they were first proposed and identified the fear that haunted their creation. He is quoted in The Star as saying:

Whites will not find any safety in the creation of bantustans. If anything separation will result in greater suspicion between Whites and nonWhites. ${ }^{52}$

The fear that contributed to the conception of the bantustans coloured the interactions both between people of different races and between people of the same race. Frank Barton, reporting for Drum in 1963, described the fear that permeated the Transkei, South Africa's first bantustan, ${ }^{53}$ and the 'homeland' of the Xhosa, on the eve of its political 'independence':

You can feel the bitterness and the bewilderment everywhere you go. You can sense it, you can see it in the eyes of the people and you can listen to it in all languages the different people speak. And you can almost smell the fright of the future deep in every soul. ${ }^{54}$

The body of the black South African was itself defined as a border, which legally could not penetrate, or be penetrated by, the body of an individual of another racial group, under the terms of the Immorality Act 1950 and the Mixed Marriages Act 1949. J.M. Coetzee has argued that the origins of these Acts 'lie in fear and denial: denial of an unacknowledgable desire to embrace Africa; and fear of being embraced in return by Africa'. ${ }^{55}$ Bosman offered a representation of this desire in his novel Willemsdorp, and it came in a familiar guise: 'The African woman's behind . . . was like the shape of the African continent on the map. ${ }^{56}$ Like the blank interiors within African maps so pondered over by Conrad's narrator Marlowe in The Heart of Darkness, ${ }^{57}$ 
the relentless documentation of the surface of the ground had, even in the twentieth century, not rendered the image of Africa less mysterious and less opaque, or the bodies (particularly of African women) less desirable. As Bosman read the body of the black woman as analogous to the map of Africa through the eyes of his main protagonist, it was the whole continent of Africa that he saw, and this complete place is something that is both desired by and distant from his gaze. Likewise the severing of South Africa from the body of the continent of Africa by naming it as a white man's land was an attempt to detach it and 'know' it. In doing so it became a place apart, a separate landscape, within which fragments of timeless Africa were ambiguously suspended. 


\title{
Chapter 8
}

\section{Language, nation and landscape}

\begin{abstract}
Afrikaans can remain vital only as long as it continues to be the medium for communicating all our fortunes and our fate; as long as it expresses the concrete as well as the abstract; as long as Europe and Africa live in it; Africa surely, but also always Europe. ${ }^{1}$
\end{abstract}

The political, economic and cultural claim made by the Afrikaner National Party on the land and landscape of South Africa was made as 'natives', as insiders - natural sons of the soil who had gained the right to the land through toil, the shedding of blood, and the development of the Afrikaans language (the Taal) in response to and in dialogue with the hitherto silent land. The Taal Monument was inaugurated in 1975, more than 25 years after the coming to power of the National Party in 1948 and after decades of apartheid legislation, segregated town planning, forced removals and political censorship. Raised on a hill overlooking the town of Paarl, in the Cape, the parabolic concrete curves of the monument sought not only to celebrate the decades of perceived success of the 'kultuurpolitiek' of the Nationalist project, through the construction of a piece of architecture through which the commitment to the Taal could be ritually renewed, but also to inscribe a natural right to South Africa - through the mingling of land, nation and language - on to the landscape.

The fear that haunted the creation of the series of Nationalist monuments in South Africa is not an uncommon presence in the formation and consolidation of nationhood. The fear of erasure that was a response to the qualities of the southern African landscape itself, and the perceived double threat of English Imperialism and the 'native' inhabitants, resulted in a desire for inscription in the land claimed as fatherland. Regis Debray has argued that fear is at the foundation of the formation of a nation, not only a contributor to its development. For him, the 'twin threats of disorder and death' are the elements which are the first 'founding gestures' of a nation 
- its structure being dependent on the ritual consecration of a point of origin. 'This zero point or starting point is what allows ritual repetition, the ritualization of memory, celebration, commemoration - in short, all those forms of magical behaviour signifying defeat of the irreversibility of time. ${ }^{2}$ Debray continues that the second condition for the definition of a nation is its delineation within a particular space, with tangible limits.

The landscape of southern Africa occupied a strange and contradictory role in the twin conditions of threat and enclosed space that Debray defines as critical for the creation of a nation. It was both the place that threatened to overwhelm the nation through its scale and hostility and also the site which was claimed as fatherland - the enclosed space upon which the nation could be founded. The sanctification of points of origin are therefore not only reiterations of the founding gestures of the nation, but also bulwarks against the continuing fear of 'death and disorder' that was part of the way in which the landscape was imagined.

This chapter examines the presence and meaning of 'native lands' within the design and the representation of the Taal Monument. It discusses the doubling and contamination of the concept of the meaning of 'native' in the monument and how this was debated and negotiated during the design and construction of the monument through the representation of nature, time, modernity and progress. It argues that there was an inherent instability and uncertainty in the claim on the land made through this monument, together with other forms of representation, during the period of National Party rule and that the desire to invoke the naturalising touch of Africa, and to hold the consequences of this touch at bay, has contributed to the ambiguities of the meaning of the landscape that are still present in contemporary South Africa.

Representations of the flowering of the Taal were, however, dependent on an interweaving between the supposed timelessness, stability and natural cycles of the southern African landscape and the ability to speak out its meaning made possible by the development of the Taal. The success of the Taal was therefore represented as being dependent both on a deep understanding of the land and its transformation - a simultaneous conjuring up of the inaudible whispers of 'primitive' Africa and the developing voice of white South Africa. Therefore two contradictory connotations of 'native land' were presented simultaneously in the monument. Language was dependent on a prior silence, one which suggested the existence of an unspoken history of the land, which had evaded the narrations of linear history. By seeking to draw closer to the land, to claim it as a place of natural belonging of the Afrikaans people (the volk), the representation of the Taal was forced to confront other, much older occupations of the land, those which had prior claims upon it.

These native occupations were distinguished from the 'natural' belonging of the Afrikaner settlers by exploiting different conceptions of historical time, nature and identity. In common with the Voortrekker Monument, the Taal Monument was built to commemorate the centenary of a central moment in the development of Afrikaner identity - the founding, in Paarl in 1875, of the GRA (Society for True Afrikaners), the primary goal of which was to transform the conception of Afrikaans as an inferior language, a 'kombuistaal' (kitchen language) into one fit for professional 
conversation, publication and a means of full cultural and political expression. As the name of the society, and its publication, Die Afrikaanse Patriot, ${ }^{3}$ suggests, this goal was tied to a desire for a cohesive national identity, dependent on land and language. ${ }^{4}$ The monument was therefore a score on the land made against forgetting, in order to counteract the persistent and relentless erasure of histories that was seen to characterise the African continent.

The distinction between two conceptions of time, one the linear historical time of progress and modernity (associated with western culture) and the other a cyclical time of nature and natural renewal (associated with 'primitive' societies), allowed a differentiation to be made between different occupations of the land which were associated with race. By the time of the construction of the Taal Monument the ethnically determined bantustans had long been established. The representation of 'timelessness' both of tribal life and the political system of 'tribal rule' (which was indirectly controlled by white South Africa) ${ }^{5}$ and the landscapes of the bantustans acted to disassociate the fragmented areas of land and their residents from the white narrative of linear historical time, which increasingly emphasised an embrace of modernity and technology. The re-creation of a nostalgic image of a destroyed rural existence in representations of the bantustans sought to separate the narratives of black and white and to associate black South Africans with a changeless cyclical vision of African time that was without monument, marking, inscription or development.

\section{Landscape and language}

The 1965 competition for the Taal Monument was won by the University of Pretoria trained architect, Jan van Wijk. The perceived success of his proposal was in the derivation of the final architectural form from fragments of key Afrikaans texts and the integration of this form with the natural site (Figure 8.1). C.J. Langenhoven and N.P. van Wyk Louw were both well-known Afrikaans poets who had described Afrikaans as a living, developing, natural growth. The use of their words to generate the design offered a precise link between the history of the Afrikaans language and the form of the monument. Langenhoven's 1914 description of Afrikaans as a hyperbolic curve, reaching into the blue South African sky, was translated by the architect into a 'sail' of curved concrete which was partnered by a shorter, but physically similar, 'sail' representing the South African Republic, which had been formed in 1960. The tourist brochure for the site refers to the inspiration to the architectural form given by the 1959 words of Van Wyk Louw, linking the formation of Afrikaans to the melding of 'Magical Africa' and the 'Enlightened West' on the South African landscape.

Afrikaans is the language that binds West Europe and Africa; it draws its strength from these two sources; it forms a bridge between the enlightened West and magical Africa - the sometimes still so unclear Africa; they are both great powers, and whatever greatness can spring from their union - that is perhaps what lies ahead for Afrikaans to discover 
8.1

\section{Photograph of the}

Taal Monument from a distance (no date).
... But what we must never forget, is that this change of land and landscape has shifted, kneaded and knitted the new language; new words, new concepts, new images have been created, old words and concepts have disappeared, every ripple and fold of the new world has been reflected. And so Afrikaans has become able to describe [literally to 'speak out'] this country as no other European language has done. ${ }^{6}$

Here Van Wyk Louw echoed the belief not only in the natural connection between taal and landscape, but also in the ability of the Taal to give voice to the still enigmatic land. In terms of this narrative not only had the Taal adapted itself to the land, but also the land had been offered a new articulate voice, and a new future, both because the language had evolved on its curves and fissures and by its connection to western Europe. The mystery of the landscape and the failure of the early settlers to find a language and an imagery to speak to the landscape were not banished, however. The 'onhelder' (literally 'unclear', 'cloudy') Africa that Van Wyk Louw refers to was still present, and the future still ambiguous.

The poet's emphasis on the Afrikaans language as a melding of West Europe and Africa was translated directly into architectural form. Hence, the pillars to the left of the entrance represent the 'Clear West' and the horizontal plane of the monument, into which three rounded forms are partially submerged, represents

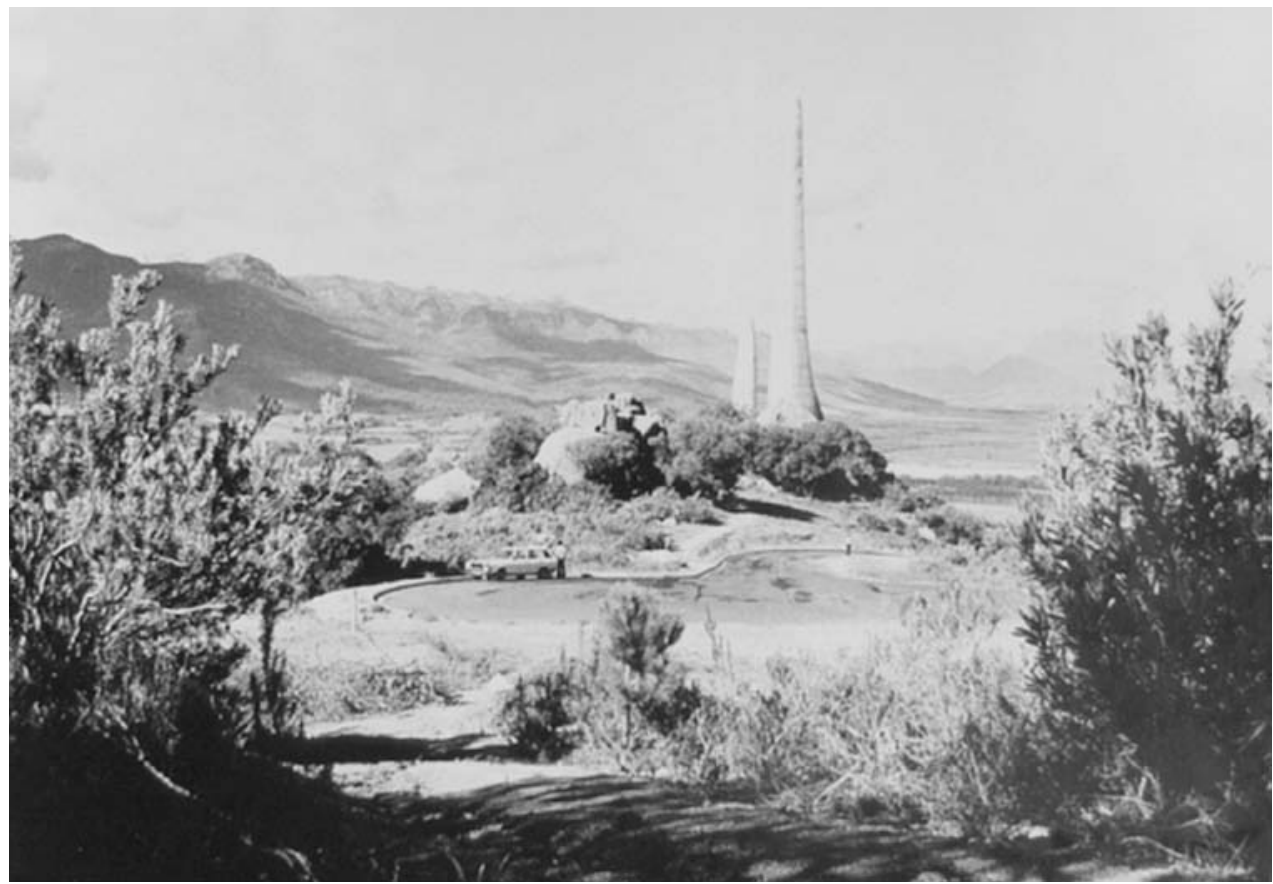


'Magical Africa'. The lone pillar in the centre of the steps symbolises 'Malay language and culture', which was also seen to contribute to the development of Afrikaans. The verticality of the pillars was associated with the activity of building - characteristic of the West - while the horizontal area of Africa was a rather more static surface, animated only by the bodies that travelled across it in order to observe the valley below.

In both Van Wyk Louw's description of Afrikaans, and the translation into architectural form of the Taal Monument, the relationship between the 'Clear West' and 'Magical Africa' remains ambiguous; polarised yet unified, with science and magic both contributing to the language of Afrikaans and the landscape of South Africa. The fact that this relationship was explored in a Nationalist monument complicated the matter further. The Taal was not only the means through which the volk could narrate its history, but also the vehicle for its creation and differentiation.

The connection between volk and language, that was referred to both by Van Wyk Louw and Langenhoven, and became an integral part of the design of the monument, was reiterated by government officials in a pamphlet published in order to raise funds for the completion of the structure and the inauguration celebrations. The political stake in the construction of the monument was evident in the composition of the Volkskomitee (Volk Committee) responsible for the Taal Monument. It showed a strong government presence, as well as the presence of those organisations which had been influential in the creation of a national past. ${ }^{7}$ B.J. Vorster, then Prime Minister of South Africa, picked up the significance of the cohesiveness of nation and language in his introductory comments to the publicity publication linking the 'suffering' of the past to the 'victory' of the future:

The language is the volk! ... It will be a monument which speaks of remembrance and suffering. It will also be a monument that speaks of victory and expectation for the future. ${ }^{8}$

In the face of such political certainty, repeated in the majority of comments in the publication, only W.C. du Plessis, the Administrator of South-West Africa, was to acknowledge, when proposing Afrikaans as a world language, that South Africa was too much of a political outcast for this to occur. He continued:

If the world cannot see through to accepting him, come let us do it in South Africa - all of the language groups together. Come let us build a monument for the youngest language, a phonetic language, a lyrical language, an easy language, a language which draws its life from one of the most beautiful countries in the world - a land of promise, served by a language which bursts through the earth's crust like the clear water of a fountain to give life and joy to everyone that has thirst and desires something that gives new power and new inspiration. ${ }^{9}$ 


\section{Politics and language}

Du Plessis seemed implicitly to acknowledge the political consequences of the link between nation, land and language, but glossed over the potential of this political history of language to divide and preferred to propose it as a language of unity. The occasion of the inauguration was used as an opportunity to involve a series of towns in a festival programme which allowed the influence of the monument to penetrate even into remote locations. The ambiguous rhetoric around the construction of the monument extended to the motivations of those who were to organise the Taalfees (Language Festival), and points to the divergence in opinion within the National Party. All racial groups that used Afrikaans as their language were invited to join in the festival. Although the group identified as 'Cape Coloureds' had their own committee, the organisers wanted them, as far as possible, also to be involved in local festivals. ${ }^{10}$

This tension between inclusivity and exclusivity developed over the period of the development of the monument. The open political involvement of the National Party government in the execution of the monument and the celebration of the Afrikaans language began in the early days of their rule, with the screening of a film entitled Die Pêrel van Paarl (The Pearl from Paarl) on 30 May 1954. ${ }^{11}$ In 1966, with the State President as the honorary president of the Taal Monument Committee, the unity of the volk was paramount and it was as an expression of the natural organic unity of the nation that the building was understood. As W.A. de Klerk (1966), the chair of the Monument Committee, recorded in the minutes of a meeting to decide the type of inauguration celebration, 'the Taal Monument is a volk's monument wherein the whole volk should participate as an organised unity'.

The iconography of twentieth-century South African monuments themselves reflected not only a preoccupation with a mythologised history, but also a naturalisation and rationalisation of the concerns of the present, and the political context which gave rise to these concerns. Both the Voortrekker Monument and the Taal Monument were designed as buildings which would be penetrated and experienced, with darkened interior spaces lit with symbolic light from above, which recalls God's blessing on the volk. ${ }^{12}$ In contrast to monuments built by the British colonisers, which tended to fix a static, spectacular point in the landscape about which the viewer moved, both the Voortrekker and Taal Monuments created enfolding internal worlds, which were tactile and evocative. The monuments were designed to be seen from a distance and to be experienced from close proximity, with careful attention being paid to material, scale and light that would envelop the body of the viewer.

Built commemorations offered both the experience of magical remembrance of the past guided by a built marker to the history of the volk and a ritualised return to the landscape that was represented as being the birthplace of the nation. The journey to the monuments traced a path through the landscape that inscribed knowledge and ownership, while the vistas gained provided an opportunity to survey the fatherland. The monuments provided a series of significant nodes which overlaid 
a narrative of myth and ritual observance to the land which was represented as being untouched and undifferentiated. They were the vehicles for a cyclical rebirth and reorientation of the volk, that served to remind the nation of the achievements of the past and the goals of the future.

The Voortrekker Monument is a bilaterally symmetrical construction that sits at the centre of a series of concentric layers (wall, garden, platform) which gradually elevate the visitor to the point of entry. The circular platform allows far views over the surrounding landscape, and over the city of Pretoria, before one penetrates the dimness of the large interior volume, a centralised space which is the culmination of the journey. Within this space, placed within yet ultimately defended from the threat of the surrounding landscape, race and violence can be contemplated through the specificity of an historical event.

In the Taal Monument a visitor travels up the staircase, beneath the curve of the concrete roof and past a 'life-giving pool' of bubbling water, which is lit by a series of holes punctured into the rapidly elevating curve of the parabola. The diffused light hints at a representation of the presence of God in nature which pervades the design of the monument. The most significant space, and the final one in the route, is the large elevated platform from which the landscape is contemplated (Figure 8.2). The monument becomes a fragment of a journey up and into the landscape which allows for a literal re-presentation of the land as a place of familiarity and majesty beauty - both natural (the mountains) and cultivated (the vineyards of the valley).
8.2

'Die Taalmonument met die Paarlvallei in die agtergrond' (The Taal

Monument with the Paarl Valley in the background) (1980).

A single figure contemplates the landscape, the foreground of which is framed by the platform and submerged rounded forms of the Taal Monument.

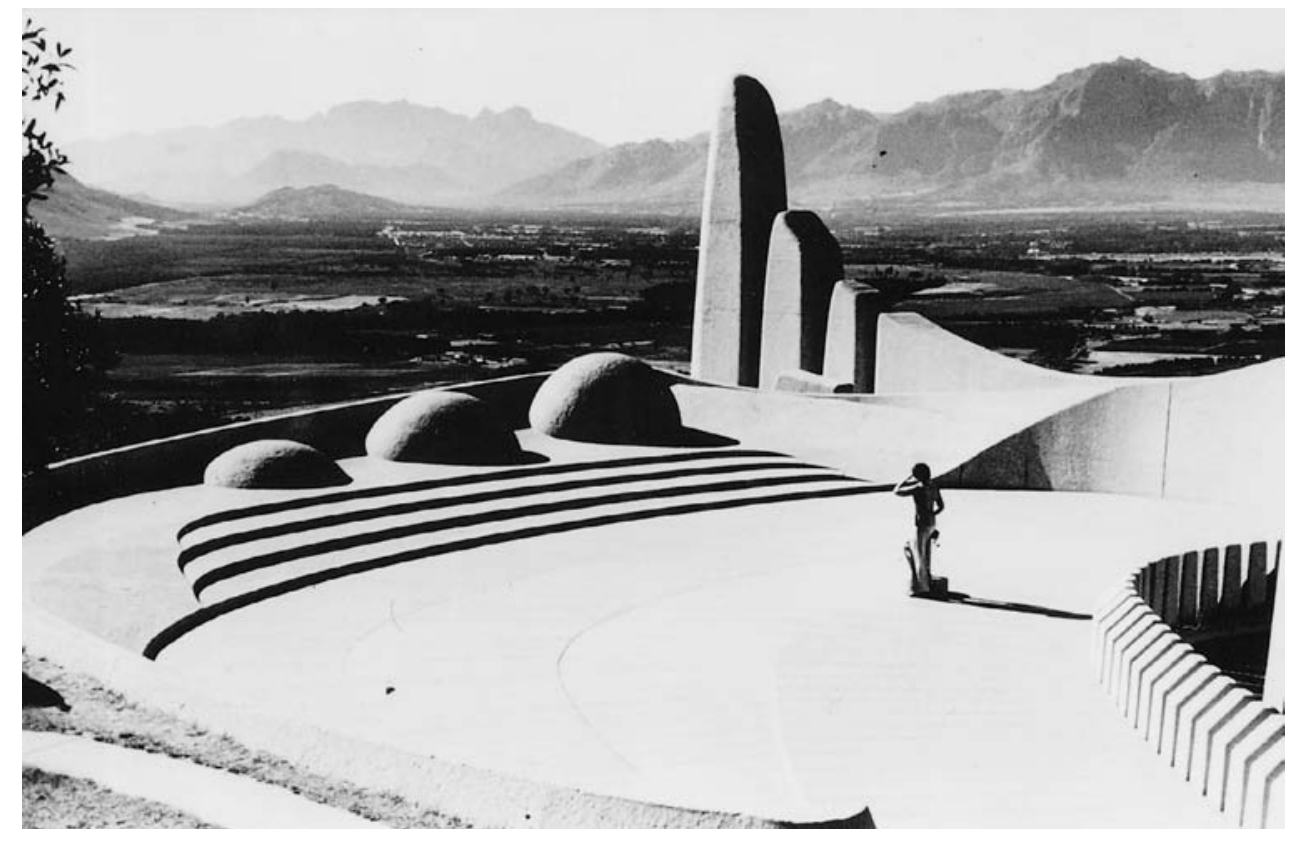


This benign landscape is presented through the narrative of the Taal, intertwining politics, landscape and language.

\section{Nature and modernity}

The Taal Monument, therefore, had an iconography which was characteristic of the shift in emphasis that occurred during the first two decades of National Party rule, incorporating 'native' forms, technology, landscape and nature into the architecture of a building that was represented, like Afrikaans, as a natural outgrowth of the soil. It also became a forum through which debates of inclusiveness were conducted. The Voortrekker Monument was dependent on the myth of separation and seclusion of the early Afrikaners within the landscape of the interior. Its vast internal space emphasised the sanctity of the volk's covenant with God. In the 1960s and 1970s, the unity of the volk was substantially established (along with the right to political and economic self-determination) and the nature of the narrative changed.

The design for the Taal Monument signalled the wish to associate the development of the Afrikaans language with technology, a forward-looking scientific modernity and rationalised government, rather than with a rural past. In descriptions of the monument the transformation of the Afrikaner nation is reflected in the emphasis on the precision which engineering can allow in the imitation of the natural world. The difficulty of producing three-dimensional curves in marine plywood shuttering involved the production of special wooden moulds at certain points in the structure. ${ }^{13}$ Other technical aspects of the monument's construction were emphasised in engineering publications: for example, the difficulty of setting out the curves and the wind pressures that the forms had to withstand were tested by the government's scientific research unit in a wind tunnel. ${ }^{14}$

The architect and other writers, however, took great care to emphasise that the monument was not a product of machine technology, but was rather made with human ingenuity and care, recording the touch of nature and the hands that formed it. It was desired not only that the monument would take on the appearance of the mountain, but also that it should be constituted of the same material. Paarl granite was therefore used as the exposed aggregate in the bush-hammered concrete work, the better to approximate the eroded granite boulders on the site. The recording of human touch, and the description of the monument as 'hand-made granite', ${ }^{15}$ give an account of a process in which technology was used in order to create a human-made form that sought to re-create a modified representation of nature. The granite boulders were transformed into a fragment of the landscape that was not only nature, but also narration, because their forms were woven into those of the monument, and its surface was contrived so as to reproduce that of its natural antecedents as closely as possible. The emphasis on the tactile qualities of the bush-hammered concrete also reveals the extent to which it was anticipated that the monument would be seen and experienced from 'close-up', its surface touched and the similarity to natural surfaces celebrated. ${ }^{16}$ 
Truly, the Taal Monument should over the years form such a complete unity with the mountains that it will look as though it has been carved out of them. This aspect is surely one of the most successful, because there is an expectation that the monument should represent the character of the mountains.

The innate belonging of language to landscape to form was therefore argued for through the drawing of a continuous thread of 'nature' and growth and language, through the words of two of South Africa's famous poet sons. As it is argued in the tourist brochure: 'Out of the environment of the site with its round granite rocks, and out of the two writer's descriptions of our language, this monument grew from the earth in which it is rooted. ${ }^{17}$

Science was called in to lend a helping hand to natural processes, so that neither the monument nor the celebration of modern technology were represented as breaking with the natural connection between volk and native land. Similarly, the models and drawings which were produced by the architect's office were careful to integrate the monument within its natural surroundings. In both drawings and models, the natural terrain and the construction are drawn closer together through the mimicking of the form of the boulders in the forms of the monument, particularly in the naturally occurring triple boulders which are repeated at the entrance (Figure 8.3).

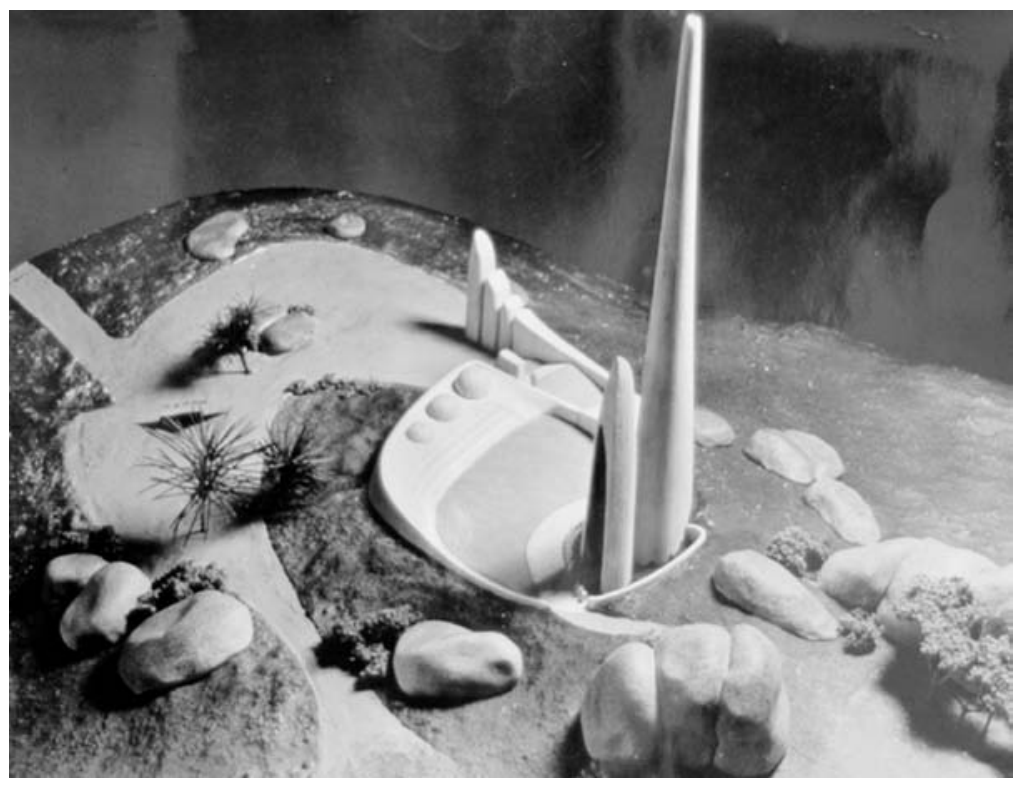

8.3

Jan Van Wijk, photograph of a balsa wood model of the Taal Monument from behind. 


\section{Nature and language}

The construction of the Taal monument marked a selected beginning of the narration of Afrikaner nationhood, that linked the creation of a national language with the landscape which was claimed as the 'native land'. In 1975, the Minister of Education, J. de Klerk, linked the beginnings of the 'new' language a century earlier, and its exclusive association with the birth of the Afrikaner nation, with a part of the physical landscape the Paarl mountain. He wrote, 'At the foot of the Paarl Mountain the first foundation stones were laid upon which a new language and a new nation would be built.'18

The Afrikaans language was represented as essential to the creation of the nation and the fulfilment of its economic destiny, by another politician, T.J.A. Gerdener, Administrator of Natal.

In the turn of events Afrikaans was the medium through which a new nation was born, through which it was encouraged to his own development, through which the greatest cultural prestige was brought into existence; the medium also through which the Afrikaner sought an economic identity, achieved national independence and adulthood and developed a spiritual awareness which determined the foundations of his deepest national character. ${ }^{19}$

The changes that Afrikaans nurtured in the volk were, in terms of the narrative, mirrored in changes to the landscape. The fertility and growth of the new nation was naturalised through the analogy with a newly fertile earth, a spring flowing from the dry soil, which was represented quite literally in the monument by the bubbling fountain beneath the attenuated parabola that represents the graph of the growth of Afrikaans. The moving water was seen as the symbol of '[The] young growth of Afrikaans which gets its strength from what has already been achieved, which gets its light from Above and from the native soil of Africa'. ${ }^{20}$ In addition the fertility and future of the nation was reinforced in the brochure printed at the time of the completion of the monument by a photograph of an eager child, pulling his mother through the garden to the monument beyond (Figure 8.4). Part of what was at stake in the description of Afrikaans as both western and African was a reconciliation between the Afrikaner's dual role as coloniser and native occupant of the fatherland. The tension between the sanctified beginnings of formalised Afrikaans use in 1875, which directly associated the language with the destiny of a nation, and the recognition that Afrikaans use was not racially exclusive, pointed both to intertwined histories and the repercussions of the myth that sought to separate people and histories. An internal memorandum by G.A. Greyling in 1975 to the members of the Taalfeeskomitee (Language Festival Committee) entreated:

Let us have such a festival that Afrikaans will be known as an adult language of Africa which offers to everyone who uses it the full opportunity to express all aspects of life: from the science and technology of the West to the natural rhythms of Africa and the deep emotions of the East. ${ }^{21}$ 


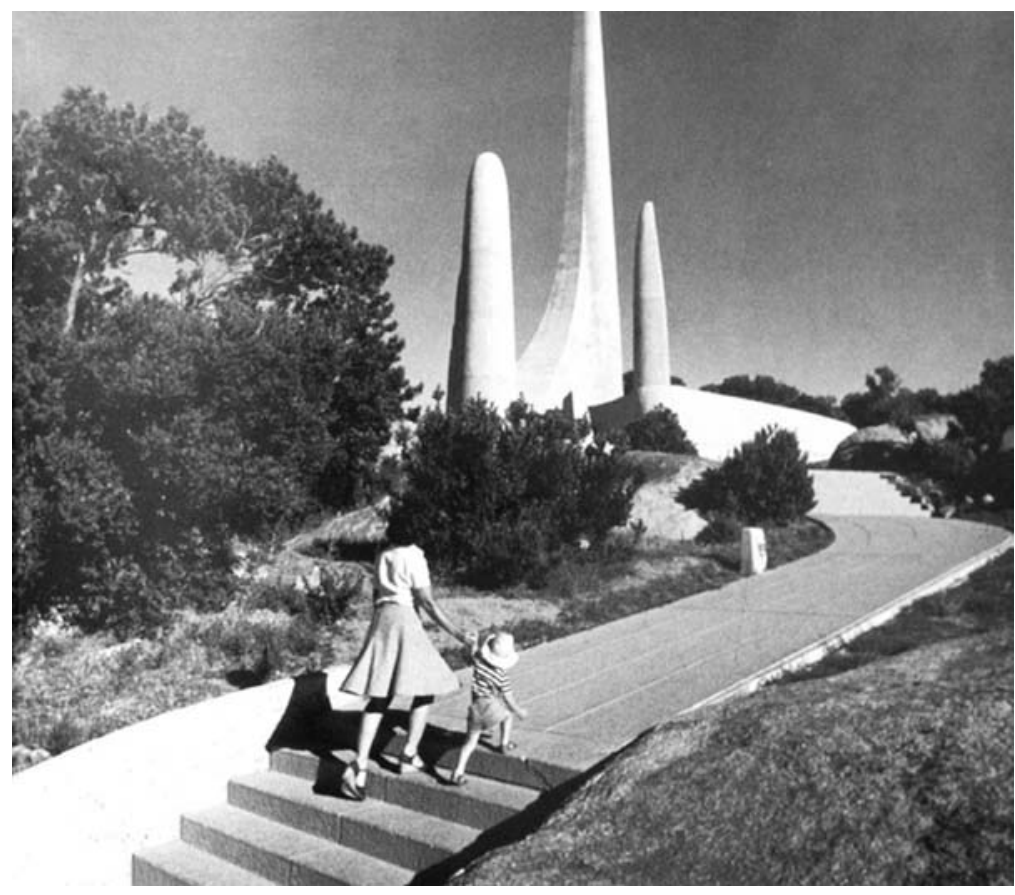

8.4

Photograph of a mother and child, walking towards the Taal

Monument, printed in the Taal

Monument souvenir brochure, 1975.

\section{Imagining the future in the land}

The construction of the monument, and the ritualised commemoration of the past that it allowed, also offered the opportunity for contemplation of the past and future of the volk. Contemporary debates are discussed below through reference to a number of uncatalogued documents in the Taal Museum, which include minutes of the meetings of the Taal Committee and other correspondence, in particular letters from Jan van Wijk and P.J. Loots, ex-chair of the committee. ${ }^{22}$ Van Wijk described the process of making the monument as a process of discovery. Likewise the landscape is presented to visitors so that they may familiarise themselves with the contours of the native land and imagine a future existence on its surface. As Van Wijk elaborated:

The English say - you build a monument for your language - is the thing dead? We say we build a monument because we still want to discover it. Is that not wonderful? If we speak about a monument it is something that still lies ahead.

To the architect the monument inscribed the destiny of the volk onto and in response to a landscape of nature and national identity. The monument was depicted 
as being in sympathy both with the natural world, and with the role that it was called upon to play in the naturalisation of an historical narrative. Van Wijk described the form of the monument as one which anticipated the future of the Afrikaans language through its sympathy to the natural world. He wrote: 'You can see that the monument turns towards the east. It turns towards the morning sun - to the rising sun - to the day of tomorrow - to the growing day - the following day.'

The 'naturalness' of the Afrikaans language was argued for through the representation of multiple cultural origins - an assertion that remained inherently problematic in the political climate of the 1970s, where Afrikaner identity was generally viewed as being racially exclusive. The cohesiveness of 'volk and taal' was asserted while the expansion of Afrikaans usage was encouraged through its increasing use in the inferior Bantu Education system, under which black South Africans were educated. Language and nation were held in an ambiguous relationship in the monument: first, because the intermingling of a language with a landscape was impossible to imagine without the intermingling of its inhabitants, and second, because contemporary politics included different strands of thought, some of which believed Afrikaans to be the exclusive language of the volk and others who believed that its use should be promoted across all language groups and across Africa. Miscegenation hovered over the Nationalist monument, ever present but usually steadfastly ignored. As late as 1987, there were challenges both to the location of the monument, and to its significance as a Nationalist monument. According to researchers, the earliest published documents in Afrikaans were 1830 prayers written in Arabic script, held in the Muslim school in the Bo-Kaap, which was the area of the city of Cape Town occupied by the Muslim descendants of slaves brought to the Cape. ${ }^{23}$ The inauguration, and the design of the monument itself, were subject to debate and tensions, precisely because it was at the point of language that the evidence for an intertwined history existed.

The deliberations on the inclusion of Afrikaans-speaking people of other races in the inauguration celebrations marked a shift in political stance, where Afrikaans was proposed as the 'adult language of Africa', and promoted as a language which would enable the schism between 'scientific' and 'natural' worlds to be overcome. However, this expansion of the Afrikaans language, that O'Meara has called the 'Afrikanerization' of South Africa, was brutally revealed to be an impossible dream by the violent reaction of the South African government to the student protests, in Soweto in 1976, only a year after the monument was inaugurated. ${ }^{24}$

\section{Contradictory identities}

The inauguration of the Taal Monument in 1975 can be read as the moment before the collapse of myth, where the innocence of nation and language could still be pretended to or even, perhaps, believed in. The contemporary debates, however, and the formal polarisation between the clarity of the West and the indistinct form of Africa are themselves difficult to navigate as the monument fulfilled in different descriptions, 
by different politicians, contradictory and ambiguous roles. The argument over the incorporation of 'African forms' was symptomatic of this uncertainty. The three domed shapes partially submerged into the platform of 'Magical Africa' are consistent with the innocent 'natural' forms of 'timeless' Africa familiar from countless tourist brochures and from descriptions of traditional life in the bantustans.

However, the presence of this myth within the Nationalist monument was unsettling to some of those involved. An undated letter from P.J. Loots, ex-chair of the working committee for the Taal Monument, reveals the unease with which he regarded the African references of the design. The whole tenor of the letter expresses dismay at the presence of 'Bantu', 'Hottentot' and Malay influences on the form of the architecture:

Renowned language experts estimate that there are about three Native and Malay words in our Taal for every ten thousand pure Afrikaans words ... Will the volk be content with this part of the monument if the truth of these matters were known?

For Loots the references to Africa were inappropriate and were a stain against the purity of the Taal and the actions of the heroes of the Taal. He wrote:

As long as the monument divests itself of its 'Africa motifs' it should be able to become very appropriate and correct, so that the proposed Afrikaans Taal Monument can depict everything like an ornament in our land to honour our Taal and the heroes of our Taal.

The architect's response was to label the forms as ambiguous. According to van Wijk, "The forms of the three "roundings" were inspired firstly by the rocks on the site, and secondly by building forms from "Magical Africa", in their final relationship to fit in with the whole.' As late as March 1974, as the monument was under construction, Loots was still complaining that the huts of Africa were embedded in the monument to the language of the volk. He resisted the idea of African influence on the Taal, and dismisses the reference to the boulders on the site as a way to excuse the infiltration of African forms, calling them 'strooise' (strawthings), 'pondokke' (shacks), and 'hutte' (huts). Thus the rounded forms concealed very different meanings even to those who participated in the design of the monument.

The debate about the presence of rounded forms was itself a debate of mythologies, which both exposed the tenuousness of the overarching myth that claimed an adaptation of land and landscape through the creation of a new language and that revealed the operation of myth at the level of architectural form and its signification. The argument for eradication of the rounded forms put forward by Loots was that their very presence depicted a false history. The solution that he proposed to this intrusion was erasure, which would then ensure an architectural form appropriate to the hermetic evolution of the Taal. The innocence of the myth proposed by Loots is a familiar one; that of the emptiness of the continent and the resultant purity of volk and language. In the debates with Van Wijk it coexists with a contradictory 
myth; that of the adaptation of volk and language to a specificity of place, which renders landscape into fatherland. The myth that the architect invoked was one of the transformation of place through the 'speaking' of landscape in a new language. Here the innocence of the myth was established through the retention and representation of the landscape of primitive Africa as unchanging and static. This 'natural' landscape was invoked as a signifier of the naturalness and specificity of the Afrikaans language because, in the monument, direct connections were made between the 'magical' mysterious landscape, a 'natural', evolving language and the hillside site, where natural boulder and 'native' dwelling share the same physical form.

To represent 'Africa' as a formal part of the narrative was to admit its influence, and therefore to deny the foundational myth of Afrikaner Christian mythology, which conceived of the volk in the Kuyperian model as an organic unity, a separate racially 'pure' nation which was created by God. Any intrusion into this volk threatened the basis of its existence, and questioned the existence of its boundaries. At the same time, the right to claim the landscape as 'natives' was dependent on a connection with the natural world, and the adaptation both of the volk, and language, to the specific landscape of southern Africa.

The claims of the English had been dismissed at least in part, particularly during the mid-twentieth century, because of the struggle they encountered in the description of the land, and their attachment and reference to a remote homeland. In terms of the Afrikaner Nationalist language of the 1930s and 1940s, it was the British Imperialists who were the outsiders, the intruders, and who constituted a severe threat to the destiny of the volk. The 'speaking out' of the land through the Taal conferred, according to the narrative, the right to self-discovery on a particular section of earth and gave the language itself the role of expressing the soul, not only of the volk, but also of Africa herself. Thus it is stated in the minutes of the Taal Committee (1967): 'The First Afrikaans Language Movement which began here, was more than a Language Movement. It was a movement for the liberation of the Afrikaner in cultural, national and religious domains.'

The Taal was therefore, for Loots and others, inseparable from the definition of Afrikaner identity, the exclusive identity which had directed the course of politics since 1948. The penetration of African forms within a monument to the Taal therefore not only threatened the foundations of Afrikaner mythology, but also exposed the contradiction of its right to the land being based both on naturalness and exclusivity.

Van Wijk, however, took a different viewpoint, one which emphasised the hierarchy of forms and the expression of the 'true natures' of the West and Africa. His preoccupations were less with the exposure of contradictions within established political narrative and more with the forms of the architecture. The stability of the myth of the natural right to the landscape through the development of a particular mingling of European, African and Eastern sources relies on the stability of its sources. Africa must be 'magical' - enigmatic, unfathomable, another world of primitivism and mystery - the place which entrances the 'scientific' Westerners with its expressive 
charm. For Van Wijk the forms represented a romantic connection both to the earth and rock of Africa, and to the architectural forms of the inhabitants that in themselves are an expression of an undisturbed, natural way of life, a closeness to the landscape which is reflected in the forms of the buildings.

The inclusion of the forms of 'Magical Africa' within the Nationalist monument controlled their meaning by representing them as part of a seamless, naturalised history. Taking his clues from poets Langenhoven and Van Wyk Louw, the architect's priority was to give form to the sentiments of the writers where the forms of the architecture were cohesive with the surrounding landscape. He responded to the challenge given by Loots by arguing that the monument reflected a 'deep knowledge' of the nature of the West and of Africa. His comments (1974) on the wider meaning of the verticality of the forms that represented the West, and the horizontal curving plane that represented Africa, reflected the polarised landscape, and its mythical division into places of primitivism and civilisation, that was a recurring theme of white occupations of southern Africa:

On the contrary, something much deeper. A timeless natural form on site, a concrete form on the environment where the Taal developed, an essential part of the Magical Africa podium. Whereas the enlightened West is represented by building structures which recall high towers and cultural heights, and where they must speak of where they come from, so must Magical Africa get its forms that speak of local languages and cultures. And if building forms must be chosen for this, then the most logical form was, for me as architect, the roundings, which in the final account, are inspired by the building form of the hut, whether it is that of the Bushman, the Hottentot or the Bantu.

The construction of the Taal Monument occurs at a moment in the political, social and cultural history of South Africa in which the contradictions of the segregated landscape were increasingly apparent. The monument is a spatial and material construction in which the uncertainties and tensions of politics become evident through the debates about the formal iconography of the architecture, the attempts to integrate nature and modernity and the desire to simultaneously draw on the 'native lands' of black South Africa and the intimate knowledge of the Afrikaner and the Afrikaans language. By playing on myths of natural cyclical time, linked to an undifferentiated past, the monument presented an understanding of political destiny which was tied to the development of white narrative on this same landscape of continuous erasure and silences. The uncertainty within the monument, however, and the ambiguity of its meaning, rests on how the silence of the land is interpreted, and how the 'native' forms speak within the spaces of the monument. As visitors contemplate the mountainous landscape and vineyards from the dished platform of 'Magical Africa', the vertical forms of the 'Scientific West' lie behind them and, in the foreground, the three domes emerge. 


\section{Chapter 9}

\section{Tribal landscapes}

The traditional forms of the emerging concrete domes that were used on the plane of 'Magical Africa', in the Taal Monument (discussed in Chapter 8), symbolised a tribal past and the myth of its continuing validity. The three rounded forms were symptomatic not only of the concerns and political context of the 1960s and 1970s, in which they were conceived and built, but also of a history of writing and representing the southern African landscape - throughout the period of white settlement - in which traditional dwellings appeared both as 'natural' native building forms that were close to the land, and as signifiers of the primitivism of its native occupants. J.M. Coetzee has argued that the Dutch settlers of the seventeenth and early eighteenth centuries predominantly depicted the local inhabitants, the 'Hottentots' (now known as the Khoikhoi), as idle and filthy. He makes the point that they are seldom referred to in the way that the Native Americans were depicted - as 'noble savages' in a state of nature before the Fall. ${ }^{1}$ The rounded form of the huts, therefore, signified primitivism from the beginning of Dutch settlement at the Cape. Over the centuries they became repeated forms into which various, and multiple, meanings were emptied: idyllic natural existence, savagery and betrayal, and an absence of civilisation.

This chapter examines both the primary myth of the tribal landscape and the representations that sought to counter the apparent completeness of this myth, through the study of representations that use the iconography of the traditional landscape and the building form of the hut to repoliticise the 'native land' of the bantustans. These representations cumulatively reveal the bantustan landscape as a site of political narrative inseparable from that of white South Africa and deny the immutable association of 'native' bodies with 'native' land. 


\section{Tribal identity in Nationalist narrative}

The reservoir of forms, which made up the image of the traditional landscape during the apartheid period, was part of a history of representation of the land, and part of a system of overlapping mythologies, that appropriated the meaning of the tribal landscape. During the period of National Party rule, not only were these forms used in order to represent a mythology, but also political motivations, which actively sought the retroactive return to the tribal landscape of all black South Africans, were concealed behind the repetition of the forms. Representations of traditional landscapes were able to draw on a history of writing and representing the land that emphasised nostalgia and primitivism, naturalness and an inferior nativism forever tied to a timeless landscape. These static images of tribal land, however, did not remain unscathed and unchallenged by representations that sought to expose the operation of myth. A photograph from the Cape National Archive repeats the base image of the 'roundings' that appeared in the design of the Taal Monument - clusters of huts set on a plane of ground in a fertile landscape (Figure 9.1). What is significant about this photograph, and the countless others with which it shares a concept, is their status as evidence of the existence of the picturesque landscape. ${ }^{2}$ The natural and harmonious primitivism of 'Magical Africa' that aroused such strong objections in the Taal Monument stands as the primary myth behind which other meanings are concealed: the violence of the state against a traditional way of life, the impoverishment and destruction of rural life, the stripping of opportunity from those participating in modern society and political isolation and banishment.

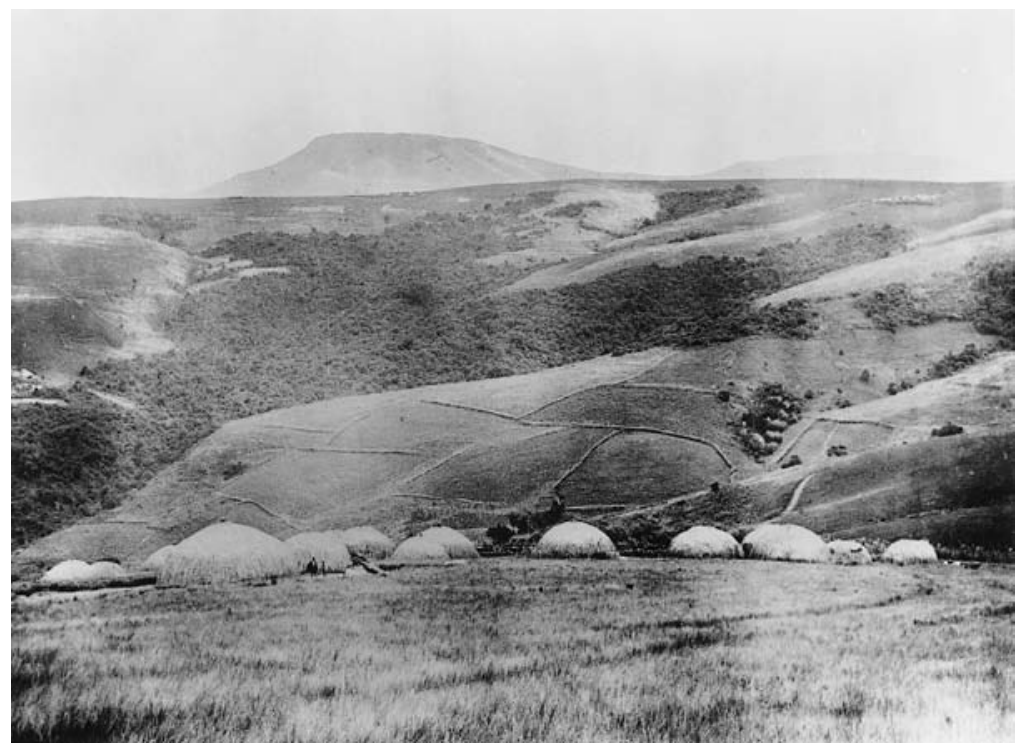

9.1

Photograph of huts in the landscape (no date). This idyllic scene is typical of the proliferation of illustrations of an undisturbed and continuing tribal existence. 
The debate around the inclusion of the rounded forms in the Taal Monument occurred because the very presence of, or reference to, the forms of Africa within a Nationalist monument was questionable. Political statements of the volk, however, had included references to the culture of unspoilt Africa from the early decades of Afrikaner nationalism. In 1949, at the inauguration of the Voortrekker Monument, an article in Die Huisgenoot celebrated 'Die Kultuur van die Bantoe'. ${ }^{3}$ In the article, A.L. Meiring argued that the preservation of the 'Mapogga' (Ndebele) culture was the responsibility of white South Africa. His initial comments are revealing:

The first impression of such a Mapogga environment is that one has suddenly been transported to a strange land, because here is something that almost reminds us of Egypt or Syria. ${ }^{4}$

The categorisation of the buildings as reminiscent of foreign (northern) architecture was itself complex. As has been discussed in Chapter 3, the timelessness and vastness of the ancient civilisation of Egypt was invoked by Moerdijk in his description of the design of the Voortrekker Monument in the same year. His references to Africa were drawn from outside South Africa's borders, from Egypt and Great Zimbabwe while the formal source of the design in a German monument was not mentioned. Although Meiring acknowledged that the Ndebele had been in occupation of the specific area of land only since the late nineteenth century, the association with the forms and colours of Egypt mythologised their occupation as an expression of the timelessness and tradition that was the 'truth' of Africa. The traditional architecture was both presented as 'native' of the soil and as 'strange'. 'Mapogga' architecture emerged in the article as an ambiguous presence in the landscape; a relatively new architectural development that must be preserved, but which was also outside of white understanding. In arguing for the preservation of a 'tradition' that was itself developed as a response to a transforming political environment, ${ }^{5}$ Meiring revealed the inherent sentimentalism that was often associated with the portrayal of 'native' identity and the distancing of cultural products of southern Africa from the land in which they were created. That this desire for the preservation of timeless Africa appeared in the Monument Uitgawe (Monument Edition) in 1949 reveals both the presence of Kuyperian thought in its portrayal of national destiny and organic unity applied to both volk and tribe and signals a continuing association between politics, land and identity that was to characterise the latter part of the twentieth century in South Africa.

The tribes of southern Africa were almost universally depicted through the symbol of the domed and woven grass hut, particularly during the Great Trek re-enactment and the inauguration of the Voortrekker Monument, although this was by no means the only building form employed by different peoples before the penetration of white settlement. ${ }^{6}$ In 1938, as the wagons arrived in Church Square in Pretoria, they were greeted by a large banner draped across one of the buildings that announced 'Segregasie' (Segregation). Beneath the lettering two pictures appeared, one a Cape Dutch farmhouse, the other a woven grass beehive hut (Figure 9.2). The 


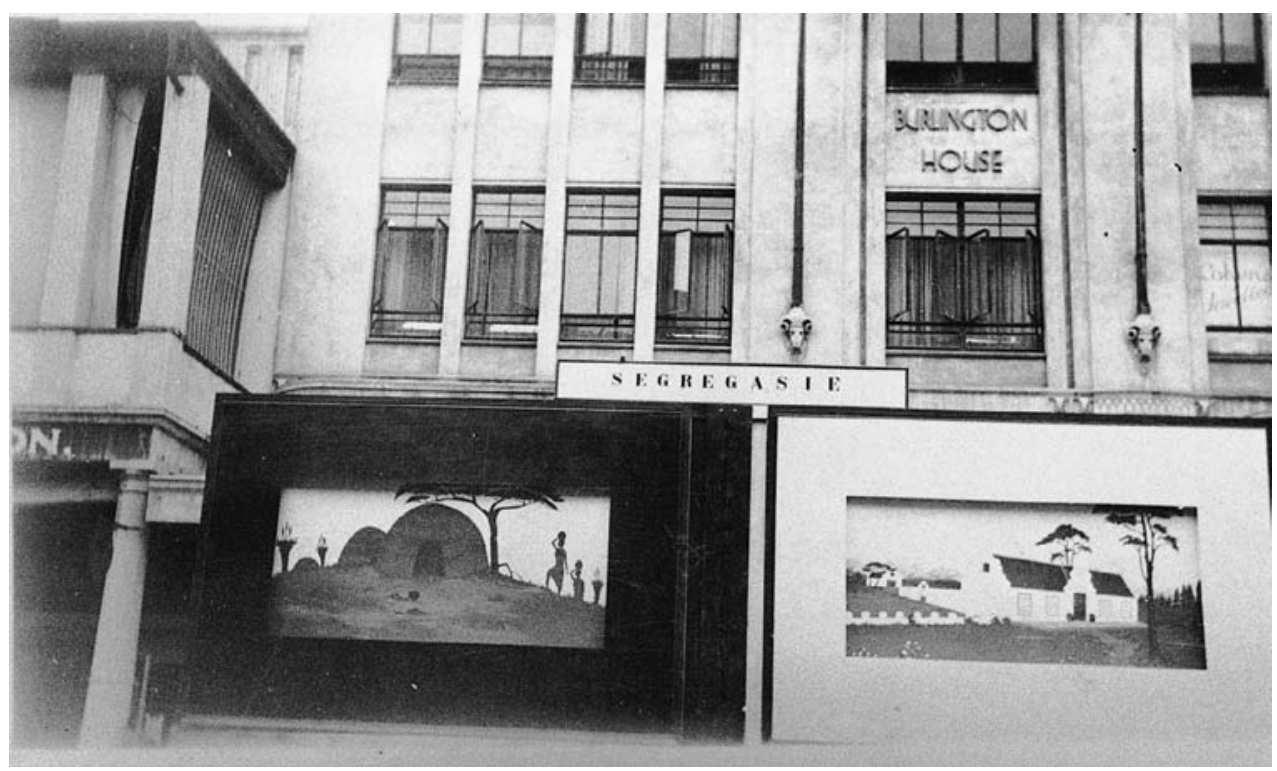

two architectural forms represented the argument for the separation of the races. The white gabled Cape Dutch farmhouse, with its forms adapted from European models by the first settlers, signified 'whiteness' and 'civilisation' while the rounded form of the traditional dwelling signified 'blackness' and 'primitivism'. Although the Boer farm was typically a humble collection of buildings, the imposing and impressive homesteads of the early Dutch settlers in the Cape were used as an idealised surrogate.

The derivation of the hut as an icon of primitivism was made explicit in its later appearance in the grounds of the Voortrekker Monument. The only architectural constructions in the 1959 trekker map, discussed previously in Chapter 3, are a series of grass huts depicting Dingaan's Kraal, 'waar Piet Retief en sy manne vermoor is' (where Piet Retief and his men were murdered). ${ }^{7}$ That the miniature map on the landscape, incorporating both the routes of the trekkers and the Zulu huts, was constructed on the site ten years after the inauguration, in the same year that the 9.2 'Segregasie' (segregation) (1938). As the wagons of the

Great Trek re-enactment reached Church Square in Pretoria, two pictures, framed in black and white, used architectural symbols as a means to argue for the continued segregation of the races. bantustan proposals were presented, confirms the status of the monument as a Nationalist centrepiece, and a belief in the tale of betrayal and primitivism of tribal peoples. It also reinforces the image of the hut as a mythical form, a fragment in which complex meanings were embedded and allowed to surface in the guise of a naturalised history. 


\section{Tribalism and the land}

The representation of the hut as mythical form, as 'native' form, was resisted by other representations, which sought to make it a less innocent symbol of black inhabitation, and integrate it into the forms of political resistance. Unlike the apparent stability of the image of apartheid representations, however, the image of these huts never pretended to completeness. In 1958, the decade before the design competition for the Taal Monument, a series of powerful images were published in Drum as a forced

9.3

Burning huts at Weenen (place of weeping), Naidoo, G.R. (June 1958)

'Weenen again', Drum, June, pp. 24-29. () Bailey's African History Archive. removal under the Group Areas Act resulted in the burning of a settlement of rounded grass huts by security forces (Figure 9.3). Families who had lived in the Weenen area for one hundred years were evicted from a soil-conservation area, ${ }^{8}$ which was government owned. They had been told that they were not allowed to till soil or to let their cattle graze. ${ }^{9}$ The black and white photographs of the huts ablaze were a deliberate attack on the image of stable and idyllic tribal life that had been cultivated by the government. They remain violent, shocking photographs, perhaps even more powerful because of the apparent innocence of the form that burns in the flames.

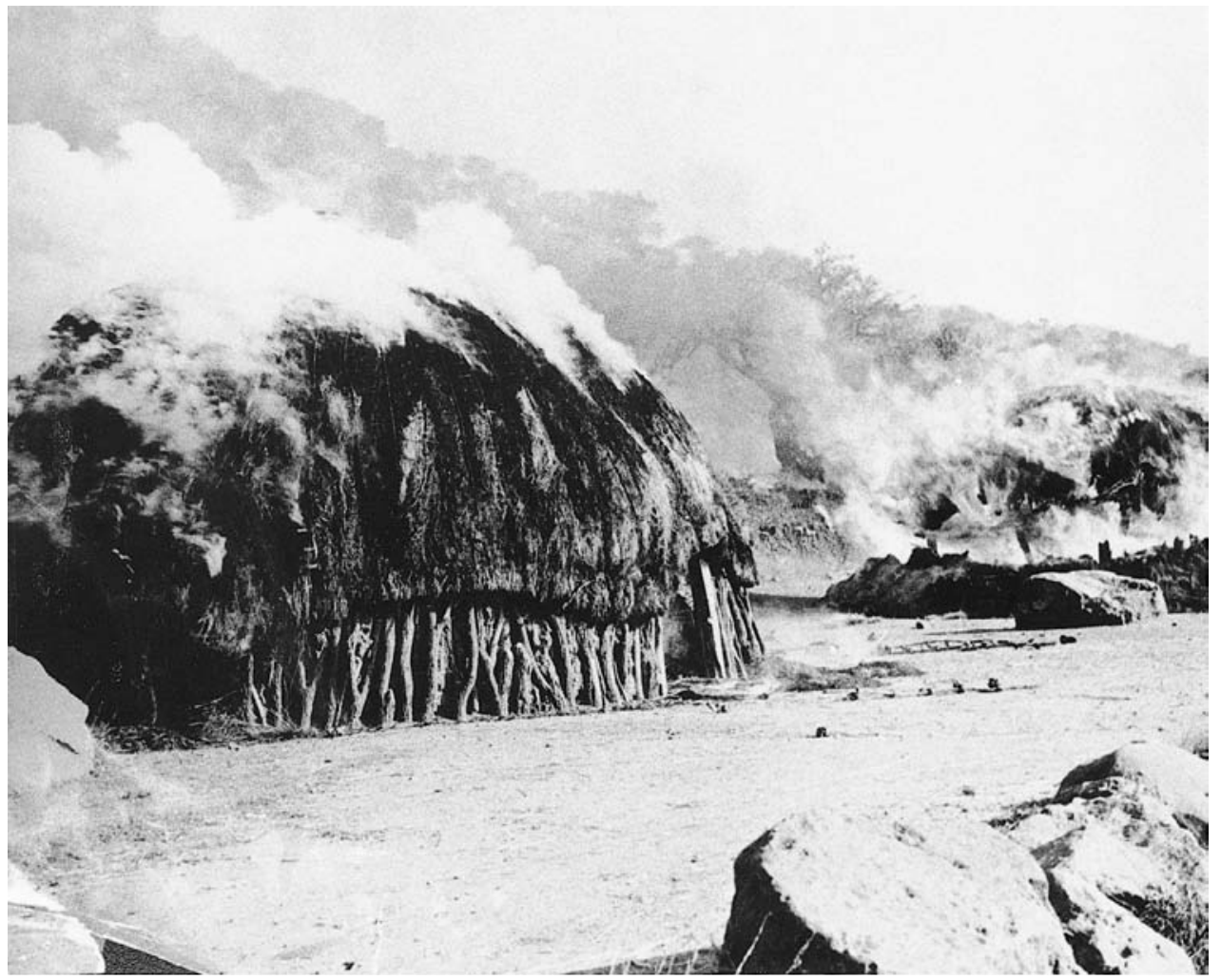


For the black South Africans who considered themselves primarily as urban citizens, the strict ethnic identity to which they were suddenly tied as part of the implementation of the bantustan policy was both fictitious and political. However, to some, the stripping of political representation for black South Africans - within the ambiguous borders of white South Africa - together with the constriction of movement and identity, meant that the bantustans offered some hope of recovery of a social and cultural past. The fact that the bantustans were intended to become the only places in South Africa where black land ownership was possible also meant that their meaning was conflicted for many black South Africans - some of whom (particularly those who were migrant labourers, travelling between urban and rural areas) saw these areas, restricted and barren though they were, as their only chance of a stable home.

Therefore the image of the tribal landscape was not static and complete, but uncertain, conflicted and yielding. It was also subject to different points of view from black South Africans, some of who lived close to the land, and others distant from it. The descriptions of the landscape, and the representation of the huts built upon it, varied depending on the audience to which they were directed.

In the evolving representation of the bantustan landscapes in Drum, the image of the hut was less a nostalgic icon than a symbol of repression. The erosion and infertility of the bantustans was indicated by photographs that called up the dryness and harshness of the real environment. In Drum, in 1956, an aerial view of a cluster of huts lying within a dry and eroded landscape headed an article about the policy of segregation (Figure 9.4). The image and the headline, 'Back to the desert!', ${ }^{10}$ offered an alternative representation to the image of a stable inhabitation of an unchanged natural landscape that was the political myth of the bantustans. In addition, remote rural areas were also the preferred place for political exiles to be sent. The establishment of rural camps, complete with single-roomed dwellings, removed political dissidents from the hotbeds of the cities in a kind of enforced 'ruralisation' of city dwellers. ${ }^{11}$ The reversion and removal of people to the 'tribal landscape' was resisted by urbanised black South Africans who regarded the bantustans as places in which indigenous law had been replaced by a political chimaera directed by

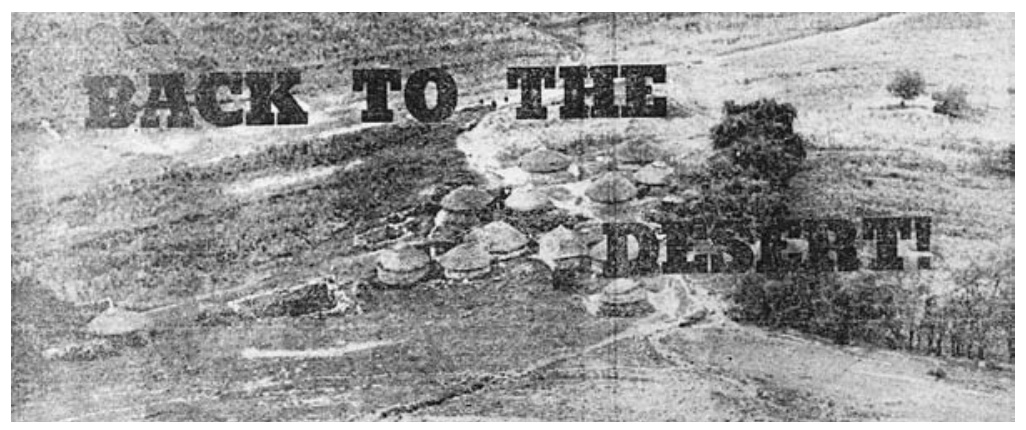

9.4

'Back to the desert!', aerial photograph of a group of huts to which political dissidents were sent, Matthews, Z.K. and Tomlinson, F.R. (1956) Drum, September, pp. 31-33. (c) Bailey's African History Archive. 
the government of white South Africa. Far from accepting tribalism as their 'natural' condition, many urbanised people saw it as a reversion to a vanishing way of life, which had become increasingly threatened over the period of white settlement.

For those people who had maintained a close relationship to the land, however, the forced removals that were an integral part of bantustan policy, enacted the separation from the land that others had experienced in the moves to the cities. The removal from the land that had been collectively owned by the tribe, opened up a distance between people and the land that has been documented in the recording of oral descriptions of the new landscapes.

The pervasiveness of this myth of an idyllic traditional existence is demonstrated by an article written by a black journalist, Benson Dyanti, published by Drum, after a visit to the Transkei in 1960. In Dyanti's article the initial desire to believe in the stability and viability of a tribal landscape offered a small chance of a recovery of a more innocent, independent existence and held out hope that tribal life had not been entirely destroyed by white inhabitation. However his encounter with the remote bantustan eroded his nostalgia for a long vanished past.

I have just returned from the Transkei, an area known by the whole world as a beautiful Bantustan. I went there with my heart beating fast, expecting to see maidens romping in green pastures. I went there to recapture the glory that once lingered in my imagination through the beautiful descriptions of the people... I went there expecting villagers to invite me to feasts that are usually held after the reaping season. ${ }^{12}$

Rather than a fulfilment of the image of a natural, fertile landscape, the author was shocked by the physical reality, his uncle's descriptions of the bantustans as the 'sword of the wilderness', and his likening of the trials that the residents were undergoing to the trials of the Jews under oppressive Egyptian rule. Rather than the 'glowing picture of happy, unworried life', ${ }^{13}$ represented by the government, the landscape was condemned as a 'wilderness', a 'desert', in language which recalled the landscape imagery of farm and veld that was discussed earlier.

An 1962 article in Drum on the forced removals juxtaposed a photograph of a school with one of a series of rounded huts. Here the architecture of the rectilinear school building stood for a familiar society, while the architecture of the hut was a form representative of a past that had been left behind (Figure 9.5). ${ }^{14}$ The forced removals that were a consequence of the bantustan policy and the Group Areas Act compelled many black South Africans towards an unfamiliar mirage of an abandoned past, which had itself been irrevocably altered. In relationship to these events the rounded huts that were referred to formally in the Taal Monument were symbols of a tribal past, which implied a shedding of hard-won education and literacy that were the escape routes from poverty.

The 'tribal lands' that were central to the myth of apartheid were portrayed as the traditional landscapes in which self-fulfilment of the ethnic groups could be achieved, but the lands themselves were often unfamiliar to the people that were 


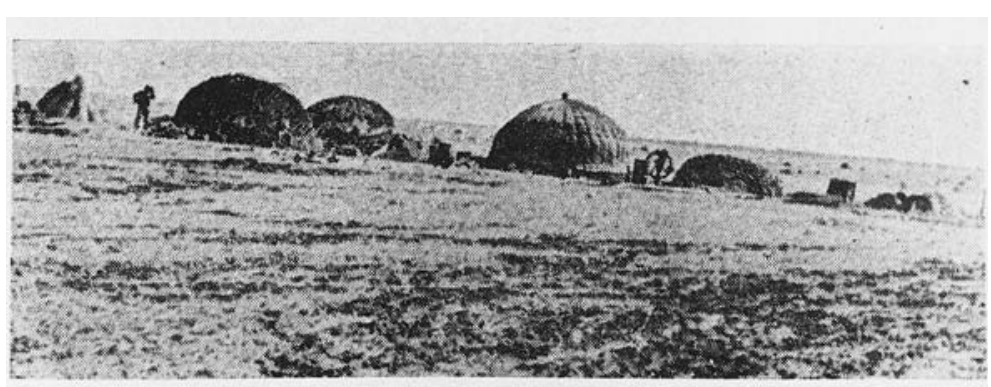

\section{MUST THEY GO BACK TO THIS? TRADITIONAL HUTS BEING BUILT AT BUFFALO FLATS, 50 MILES BY ROAD FROM CHARLESTOWN . . .}

portrayed as their natural inhabitants. The political will to divide land and to assign ethnicity to parcels of land meant that over a million people were moved off the land that they regarded as theirs. ${ }^{15}$ Repeatedly, black South Africans described the bantustans as 'nowhere', 'no place', a 'desert'. ${ }^{16}$ The removals were a process that disrupted a natural relationship with the land, replacing this rather with encounters in alien landscapes, for which the people subjected to the removals had no words. The bantustan land was perceived as a desert not only because it was largely infertile, but also because it was unfamiliar and 'un-natural' to those remaining inhabitants who had maintained an interrelationship of culture, society, spiritual belief and the land. The placelessness of the bantustans that was evident in descriptions recorded both in Drum, and in publications that documented the effects of the forced removals, echoed the ambiguity of their representation in maps and the artificiality of their moving boundaries.

The majority of the people affected by the forced removals were rural, ${ }^{17}$ and for many of these people a close relationship with the land was of fundamental importance. Mphahlele and others have described this interdependence as a tissue of experience, ${ }^{18}$ which was part of traditional systems of belief.

The mountains, the rivers, the soil and everything that grew on it, animal life, the stars and planets - all these, including man himself, combined to make the universe. And God was everywhere in them. They were interrelated. ${ }^{19}$

Rural people had retained, to a greater or lesser extent, some of the traditional interdependence between themselves and all aspects of the natural world, so that the separation from the true homeland was something that affected every aspect of their lives and was experienced as a profound loss. In oral descriptions that have been recorded by academics such as Patrick Harries, and by others - in the two major studies of the forced removals of the apartheid period: The Surplus People Project and No Place to Rest: Forced Removals and the Law in South Africa bantustan lands took on a surreal quality, which was deepened because of the
9.5

These traditional huts, constructed in order to house those forcibly removed from Charleston, were described as a regression from the modern, rectilinear, brick and tiled roof buildings which the residents occupied before the removal, from (Anonymous) (1962) 'Black spots', Drum, November, pp. 63-65.

(c) Bailey's African History Archive. 
centrality of the land in society and culture, which was emphasised by Petros Nkosi at a meeting held in July 1989:

Our purpose is the land, that is what we must achieve. The land is our whole lives, we plough it for food, we build our houses from the soil, we live in it and we are buried in it. ${ }^{20}$

In another case of a forced removal, members of the Bakwena ba Mogopa tribe described the place to which they were moved as 'covered in ash', 'dead and dry', while they felt that they had been transferred into the 'middle of winter, not the middle of summer'. ${ }^{21}$ The physical impoverishment of the land increased the dislocation that was experienced. The bantustans emerge as a series of nightmare landscapes in which attributes of home had been stripped and even the seasons were inverted. The wilderness that was so unfathomable to the first white settlers returned in the guise of 'native land' of ethnicised tribes people, who were no longer native to the land on which they were settled. The study of Harries, like the other research done in the 1980s and early 1990s, focused on the response to the displacement from the land, recorded in this oral poem (the words in parentheses are his own explanations).

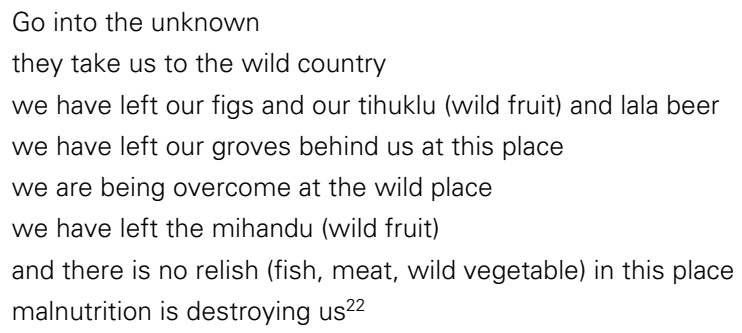

The policy of destroying all buildings inhabited by people who had been removed from the land meant that they were unable to return to their homes, schools and fields. The destruction of 'home' meant that some people began to see themselves as wanderers, 'homeless' in a fundamental sense. As one participant in The Surplus People Project stressed, the link between animal characteristics and humans was still explored in oral descriptions, while it was the land which was rendered unfamiliar and wild: 'We will never get used to one place. We lead the life of a bird'. ${ }^{23}$ This continual shifting of bodies in relationship to place was directly tied to the shifting boundaries of the bantustans. Another description, recorded in 1975, in response to the removal at the Tsitsikama reserve, also made the connection between the person interviewed, and their relationship to the natural world that had been disrupted by the removal: 'If only they can return me to Humansdorp to stay there, I will be like a fish in the river. ${ }^{24}$ The bantustans therefore become analogous to camps, where all settlement was temporary, the landscape silent and alien, and life bare of a cultural and spiritual world. ${ }^{25}$ 
The physical and cultural impoverishment of the bantustans was also present in the works of politicised black South African poets, who increasingly saw writing, primarily in English, as one of the ways in which protests at the government policies could be registered. Poetic writing became a way to elude the censors and became part of a narration of the land that was itself politically implicated. In contrast to the unity of ethnicity and land that was promoted by the National Party government, they explored the alienation from the land, and its emergence as an opaque and silent surface. The physical reality of the 'traditional homelands' became a subject of increasingly strident works that sought to shock the reader into an awareness of the brutal repercussions of the bantustans.

The poems 'Journey through a Naked Land', by Achmat Dangor, and 'Valley of Plenty', by James Matthews, both document the fissure that had opened up between people and the land. The two poets, along with others of their generation, were regarded with suspicion by the National Party government, and in the 1970 s were both subjected to restrictions: Dangor was banned between 1973 and 1978, ${ }^{26}$ and Matthews spent four months in political detention from 1976 to 1977. This was during a period of heightened political tension, particularly after the events in Soweto in June 1976, where opposition to the government, even if voiced through the medium of poetry, was subject to scrutiny.

\author{
Journey through a Naked Land \\ [Extract] \\ I do not know the valleys \\ I do not know the vineyard \\ mine is the naked land \\ where cold fingers \\ thumb the rigid leaf \\ word upon writhing word \\ silence sinks \\ heavily to the ground ${ }^{27}$
}

The nakedness of the landscape is depicted both as a physical nakedness, that called up the image of the erosion of the land that was the result of overpopulation, and a nakedness of meaning of the land - the unfamiliarity of an unknown place. In Dangor's poem it is both the land, and the experience of the land, that is impoverished. The land is still cultivated, with vineyards, but distant, foreign. The ambiguity of these landscapes, naked in their lack of meaning or through the paucity of vegetation, rests in the knowledge that the land was once familiar - that it could once be spoken without anxiety. The silence of the land, the anxiety of speech and the inability to form words that hold their shape in relationship to the land, was the result not only of the removals, but also a consciousness of the voicelessness of the black population that was only partially a result of their displacement. This idea of a physical nakedness relates to the belief of early colonial writers, notably Olive Schreiner, that the true landscape of southern Africa was naked - rather than clothed - and of bare rocks and 
soil - rather than vegetation. In the struggle to describe the land in its own terms, rather than those of Europe, it was this physical difference that enabled early colonial writers to mark the landscape as African. When a black South African described the altered landscape, almost a century later, the consequence of this struggle for meaning is an uneasy silence.

The myth of the fertile traditional land also came under attack from voices that documented the breakdown in social relationships; where the vacancy of meaning in the landscape and the futility of its cultivation infected the lives of its inhabitants. Images of fertility and plenty in the idyllic natural world enclosed within the borders of the bantustans were so pervasive that reference to the myth invoked a concept of landscape that could then be challenged.

\author{
Valley of Plenty \\ [Extract] \\ Valley of Plenty is what it is called; \\ where little children display their nakedness \\ and stumble around on listless limbs \\ [. . .] where mothers plough their dead fruit into the soil \\ their crone breasts dry of milk \\ [. . .] where menfolk castrated by degradation \\ seek their manhood in a jug \\ of wine as brackish as their bile. ${ }^{28}$
}

Matthews employed the myth of the bantustan landscape - its fertility and traditional social cohesiveness - in order to document the damaged world; the eroded land and the inversion of social relationships. His harsh poem describes a hopeless land, where nothing is left intact and both earth and people are broken. The devastation that is the subject of the poem is constructed deliberately and carefully in order to stand in resistance to the image of the 'Valley of Plenty'.

The representations of the bantustans produced by the government can be seen as an attempt to sustain the substitution of a stable image for a complex and uncertain landscape, and to conceal the consequences of this instability. The target audience for the image of traditional life is a complex one, and included tourists as well as white and black South Africans. While white South Africans were offered a mask of completeness of idyllic tribal life and government, which was calculated to anaesthetise perceptions of the inequalities of the bantustan policy, it was also important to the government that the bantustans were a means to both distance dissent and control it within a conservative political system. The emphasis that was placed on 'homeland' in government terminology, as well as the articulated desire to convince black South Africans that the bantustans offered them a traditional land, where land ownership and political representation could be achieved, was an attempt to stabilise a politically explosive issue. Internal government memos, such as the one here from the Bantu Affairs Commissioner, described the need to convince black South Africans of the viability of their 'traditional land': 
It is important that the Bantu also knows the positive side of the situation. He must know, namely, that there is a home for him in his own traditional area which offers him the possibility of rights of possession. ${ }^{29}$

Their physical distance from the bantustans, as well as the cultural and social distance between people of different races, allowed the majority of white South Africans to dissociate themselves from the remote and fractured lands, and from the effects that both the spaces and policies had on the lives of many black South Africans. Representations of landscape which depicted a pictorial view of the tribal life of the 'homelands' and their inhabitants were often addressed to those outside of the boundaries of the bantustans for whom the images and descriptions provided either moral validation of the government's political policy of separate development or nostalgic reaffirmation of an unspoilt tribal existence. The idea of 'landscape' in terms of prospect and view and 'scenery' in the contemporary language of the tourist brochure was directed to an external audience. A fragment which appeared in The Star, during the early 1960s, offers an insight into the territory of landscape claimed by some white South Africans. Entitled 'View that Few are Ever Able to See: Attraction of a Bantustan', 30 the article argues that a particular view, 'World's View', 'should be '[taken] from its Bantustan confine and [made] available to the nation' (Figure 9.6). In terms of this argument the 'craggy krantzes', 'meander[ing] river' and 'compelling hush' are components of a landscape view locked within restricted political boundaries. The author, given only as 'The Man on the Reef', proposed that the view, consistent with a pervasive (if diluted) understanding of the picturesque, could be separated from issues of land ownership, its value residing in the ability to see it as 'a picture'. Access to a vantage point could make it 'available to the nation'.

The appeal to allow access to the view held within the enclosed world of the bantustan and to offer it to 'the nation' confirms the distinction between the claim on native land and its designation with which this chapter began. 'Native land' was physically bounded and politically excised from the body of white South Africa, represented as the locus for a natural and coherent iteration of traditional African life. It was also the claim for the discovered fatherland of the Afrikaner nation and of
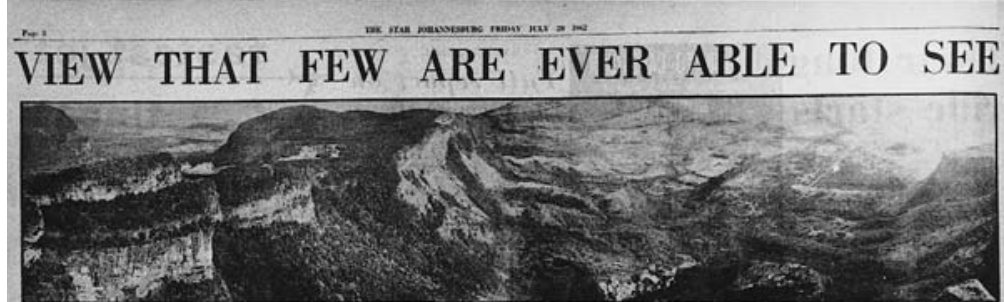

1962 MOBIL ECONOMY RUN nffinigl tact nmaune
9.6

'View that Few are Ever Able to See: Attraction of a Bantustan', a photograph of a sweeping view of mountains and valleys, located within the borders of a bantustan and therefore technically accessible only to the black South Africans resident there. 
white South Africa, which systematically imprinted its own nature through monument and inscription onto the landscape. Nature in the bantustans was represented as a static system of which the 'native' peoples were a part, while the nature that white South Africa promoted included the evolution of new building forms, new social and economic systems and the embrace of science and modernity. The desire to maintain the representation of a South African nation from which black South Africans were excluded engendered a set of complex myths which drew on a body of confused knowledge. The myths helped to mask the consequences to the imagined and physical landscape of the political policies of apartheid by creating separate 'natural' orders for lives that were intertwined.

However, the split meaning of 'native' was also subject to tension and contradiction during the apartheid period, through the assertion of an innate and close relationship with the land - by claiming it as 'native' - by black South Africans in both prose and poetry. The registration of the violence in the landscape, the nakedness of meaning of the land and the descriptions of the erosion of earth and social orders became a significant means of rewriting the traditional landscape, and of reconnecting to the body of the African continent. 



\section{Part 4}

Invisible landscapes 



\title{
Chapter 10
}

\section{Desire and distance}

\author{
City Johannesburg \\ [Extract] \\ Jo'burg City \\ I travel on your black and white robotted roads, \\ Through your thick iron breath that you inhale, \\ At six in the morning and exhale from five noon. \\ Jo'burg City \\ That is the time when I come to you, \\ When your neon flowers flaunt from your electrical wind, \\ That is the time when I leave you, \\ When your neon flowers flaunt their way through the falling darkness \\ On your cement trees. \\ And as I go back, to my love \\ My dongas, my dust, my people, my death, \\ Where death lurks in the dark like a blade in the flesh, \\ I can feel your roots, anchoring your might, my feebleness \\ In my flesh, in my mind, in my blood, \\ And everything about you says it, \\ That, that is all you need of me. ${ }^{1}$
}

Mongane Wally Serote's (b. 1944) Johannesburg breathes people, drawing them in and expelling them as night falls. His voice is one of the most significant and lyrical in black South African poetry from the 1970s and 1980s, registering the violent underbelly of the city, its ruthlessness and the antagonism between its citizens. As an urban dweller, and as a chronicler of the modern dystopia of city life, his poems also recognise the city as a mother, even if she is a dysfunctional, careless one. In 'City 
Johannesburg' he explores the experience of the city for those confined to its outskirts, who move constantly into and out of the 'white' city.

By the time Serote wrote, the physical effects of the Group Areas Act of 1951 had had a profound effect on the form and experience of the city. In terms of the Act, people of different racial and ethnic 'Groups' were separated into distinct areas. While the 'White' group occupied primarily the central areas of both cities and towns, other races were, for the most part, restricted to land in outlying townships, like Soweto in Johannesburg and the Cape Flats in Cape Town. These townships were consolidated and extended under the forced removals of people who were not classified as white from the central areas and by growth in the urban population.

Serote describes the city through the experience of the people, living on the margins, who are visitors to the city, daily suppliers of labour (of flesh and blood). Serote here offers us, not only the violence of the transaction of labour in the modern economy and a description of the spell that the city casts, but also a division between two worlds: the one of 'his' people with its dust, dongas and a spectre of death, ${ }^{2}$ the other an anthropomorphised city, a brutalised vision of cement trees and neon flowers blown by an 'electric wind'. Johannesburg is the city in which he spends his day, but it is described here only through the moments that begin and end each day moments recorded in the time taken to travel through the half-light of dusk and dawn.

Serote's exclusion of daytime Johannesburg mirrors his own exclusion from it and describes the process through which he travels through the city and is altered by it, but is unable to participate in its full life. Johannesburg has tarred roads, marked with white paint on crisp black; the place that he returns to has physical characteristics closer to the savannah grassland on which the city was founded. It is dusty and dry, an eroded landscape with an uneven surface. The violence that haunts the poem is not only that of the knife blade, but also of the shutting down of the city to the black poet, the ruthless face that it shows to him and the power of the city to draw its strength from the bodies that labour there. The Johannesburg that emerges from Serote's description is not a complete portrait of the city; it is a partial one dependent on fractions of time, on moments snatched out the window of a moving vehicle. While Serote sees only part of the city, its control over him is present even when he is 'back' with his people in the separated landscape, weaving the two places together through the movement of his body and the products of his labour.

The city of Johannesburg recurs in representations as the focus of economic and political desire, and its landscapes - particularly those of the street and the mining land - became the sites through which the contradictions of politics were experienced and represented. This chapter focuses on Johannesburg as a site of political and spatial negotiation. It examines the way in which the city has been represented by different groups and how politics has influenced the structure and meaning of its landscape.

The strategy in this and the following two chapters has been to retain and entangle two primary and interactive states of the city. The first is the presence of the land before the settlement was founded. The land has been read as many 
landscapes - a long, vacant horizon, a hidden landscape of gold-bearing rock, the veld (both the homeland of the Afrikaner and the ancient landscape of black South Africans), the trekker farm and a place inseparable from the rest of the African continent. The second state is that of the segregated city, in which visibility and partial visibility are intertwined with race and where those on the margins had only restricted access to the 'white' centre.

The partial presence articulated by black poets and writers from the 1960s to the end of National Party rule emerged under the Group Areas Act, and the series of forced removals enacted under the Act. The passing of the Act was significant because it redefined existing black urban rights as reversible and allowed every building, street, farm and suburb to be designated - for both ownership and occupation for any purpose - according to race. Those living or working in the area who did not conform to the designated group were forced, in many cases physically, to move. However, in contrast to what was to follow, the early 1950s has been represented as a golden period of black urbanity: ironic, dangerous, modern and urbane, which was celebrated in the pages of Drum and in the work of the writers it published - Can Themba, Nat Nakasa, Es'kia Mhlaphele and others. The perceived incompleteness - of both place and humanity - of the later decades must therefore be placed alongside this urban intensity, the defiant celebration of places such as Sophiatown and District Six, where a hybrid life was imagined and lived. The invisibility of people and place that was present in the twentieth-century South African landscape is therefore the product of a series of erasures, and its silences are the consequence of violence.

\section{Proximities}

The economic and political drive for the control of South Africa that was the goal of the Afrikaner elite was also a struggle for the control of the spaces of the cities, while, simultaneously, the burgeoning urban black population faced a battle to retain the places that they lived in. Both groups occupied the margins of the city, their position insecure and their identities in flux. As the city grew, black and white areas shared space in an inevitable consequence of the expansion of the city. The occupants of this shared space tended to be those whose employment options were restricted, and those people were primarily Afrikaans, black, Indian or 'Coloured'.

In representations of the 1950s the idea of proximity in the city is significant. As people rubbed shoulders in urban space, so did their dwellings. A photograph from Drum, published in March 1952, ${ }^{3}$ shows the extent of this proximity. The photograph seems innocuous - it is the title that reveals its significance: 'Where Black meets White: A street corner in the Western Areas, where a White Spot (right) adjoins a Black Spot (left)' (Figure 10.1). The photograph was published in the context of the proposed removals of citizens of Sophiatown, Martindale, and Newclare to Meadowlands, a suburb of Soweto, sited to the south of the mining land. Given later events - the separation of different races, the differentiation between the green 


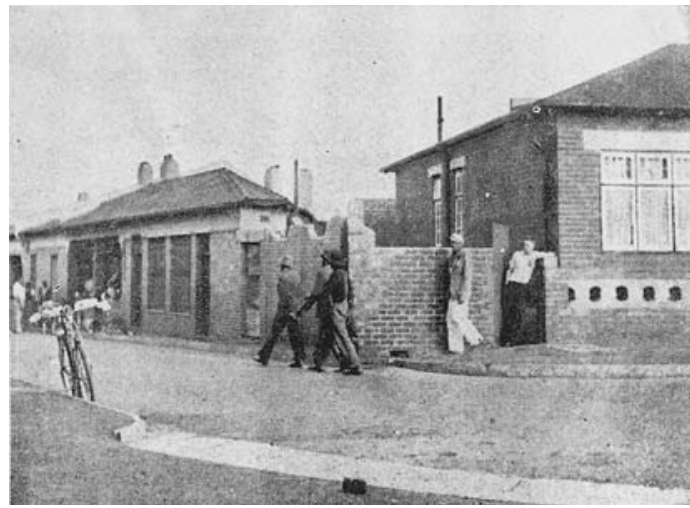

10.1

'Where black meets white', photograph of a street corner in the western areas of Johannesburg, where houses occupied by people of different races sit side by side, from Xuma, A.B. (1952) 'Black spots or white spots?', Drum, March, pp. 25-28.

() Bailey's African History Archive.

suburbs of Johannesburg and the repetitive small-scale houses of Soweto - this fragment is remarkable because it evokes a time when the boundaries, although present, were compressed into the thickness of a wall, the width of a street or the thinness of a property line. It was this closeness, intimacy and the invisibility of the boundaries between people of different racial groups that the Group Areas legislation sought to alter.

\section{Representations of the city in Afrikaner and black popular publications}

The relative newness and modernity of Johannesburg - which was settled with the discovery of gold in 1886 - its location on the highveld of the interior, the enormous wealth that was generated from the mines, and its power to draw labour to its industries, meant that it became the principal focus of representations that dealt with the rapid urbanisation of rural Afrikaners during the 1930s and 1940s. Rather than being separated from the narrative of veld and farm, the city was integrated into the historical narrative of white occupation of the land. With competition between white and black, urban space became a battleground for the stability of the belief in racial segregation and black identity tied to tribal landscapes. Representations regard it from afar - as a slightly terrifying prospect that must be engaged with if economic success was to be gained.

Unlike the representations of Johannesburg that appeared in the popular Afrikaans publications around 1950, Drum, and its writers and photographers, developed a language that was dependent on nuances of the streets - a sophisticated merging of southern African culture and a distant reading of American savviness and sophistication that grew out of the density, intensity and danger of life in Johannesburg. Drum's writers and photographers were resolutely urban, and with the confidence of city dwellers their imagery draws both from their immediate environment and other more distant places. 
The celebration of the irony and complexity of life in the black freehold townships was deliberately posed against the perceived numbness and stability of white (primarily English) suburban Johannesburg. On the occasion of the Drum journalist and writer Can Themba's death in exile in Swaziland in 1968, his friend and colleague Lewis Nkosi described Themba's attitude to the city: '[T]he swarming, cacophonous, strutting, brawling, vibrating life of . . Sophiatown', ${ }^{4}$ was the real medium of the urban environment, while 'incursion[s] into' 'white Johannesburg' were 'a kind of temporary surfacing' 5 from the life in which he was immersed. Despite the difficulties of life in the urban townships, the violence, decay and poverty, places such as Sophiatown and District Six have been represented, in the pages of Drum and elsewhere, as a 'complete' world, a saturated world, where 'the moments of splendour were very splendid indeed, surpassing anything that white Johannesburg could offer'. 6

Themba's 'Requiem for Sophiatown' detailed a world of experiences, rituals of everyday life in the secret places in the city - the shebeens (illegal drinking clubs), which were tucked away into the structure of the area. The physical layout of Sophiatown, its density and complexity, supported lives which were continually forced to negotiate the maze of legislation intended to control occupation of the city, and the activities that occurred there. Sophiatown was located approximately two kilometres to the west of the Central Business District (CBD) of Johannesburg, north of the mining land. The difficulty in policing and controlling it allowed room for negotiations and explorations of urban life.

Somewhere here, and among a thousand more individualistic things, is the magic of Sophiatown. It is different and itself. You don't just find your place here, you make it and you find yourself. There's a tang about it. You might now and then have to give way to others making their ways of life by methods that aren't in the book, but you can't be bored. You have the right to listen to the latest jazz records at Ah Sing's over the road. You can walk a Coloured girl of an evening down to the Odin Cinema, and no questions asked. You can try out Rhugubar's curry with your bare fingers without embarrassment. All this with no sense of heresy. Indeed, I've shown quite a few white people 'the little Paris of the Transvaal' - but only a few were Afrikaners.

What people have thought to be the brazen-ness of Sophiatown has really been its clean-faced frankness. And, of course, its swart ${ }^{7}$ jowl against the rosy cheek ${ }^{8}$ of Westdene. ${ }^{9}$

In a 1956 photo-story, 'Baby Come Duze', published in Drum and set on the streets of Sophiatown, Themba wrote in a composite new street lingo, 'made of Afrikaans, Zulu, Sotho, English and brand new words'10 - published with translations in English. The photographs taken to accompany the text mirrored this eclecticism (Figures 10.2, 10.3 and 10.4). The story is a modern love story, in which the hero vanquishes a villain to get the girl. The photographs draw on fragments of American 


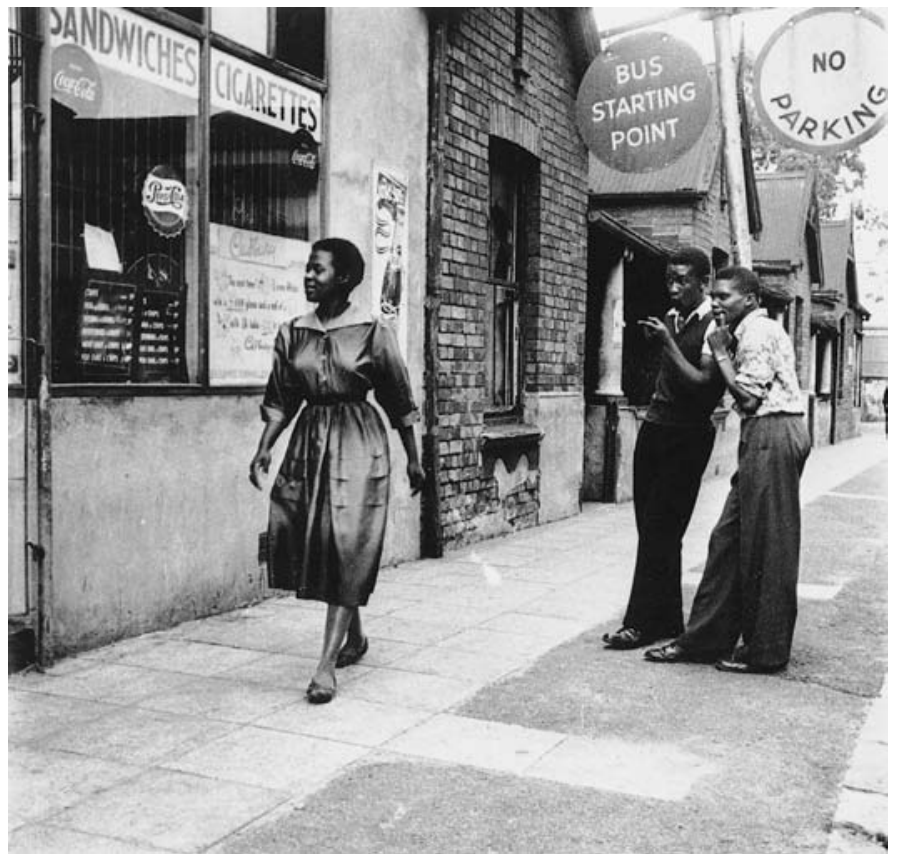

10.2

Street scene from 'Baby Come Duze': the male protagonist spots the object of his affections in a photo-story by Can Themba, pictures by Gopal S. Naransamy (1956) Drum, April, pp. 61-64.

() Bailey's African History Archive.

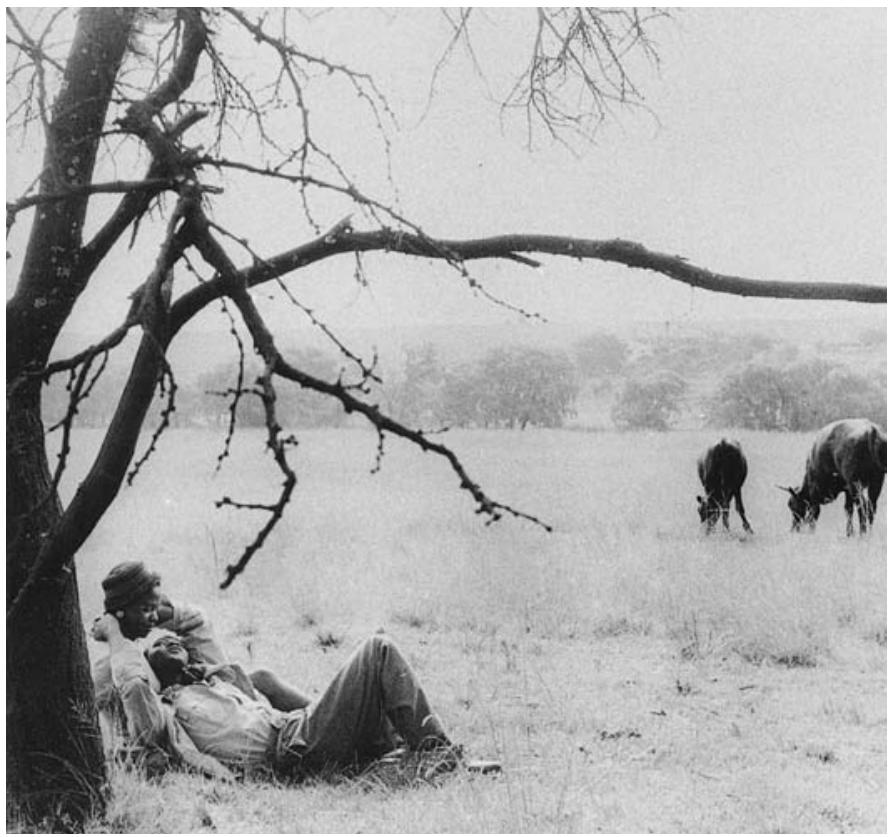

10.3

Scene in a field, from 'Baby Come Duze': the couple recline under a tree, while cows graze. (c) Bailey's African History Archive. 
10.4

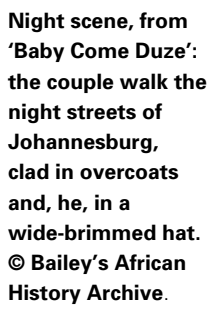

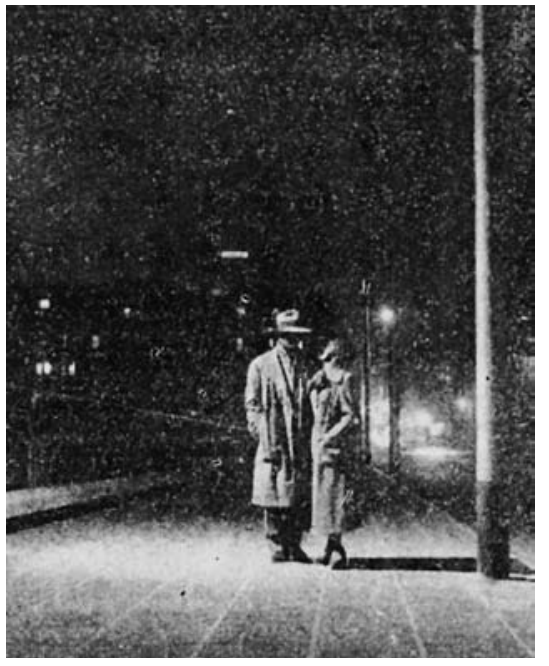

gangster movies - fight scenes (the gangster bad guy floored with judo moves), night streets and a romantic embrace in a pastoral landscape complete with grazing cows. Like Themba's description of the hybrid city culture that existed in Sophiatown prior to the removals, the photo-story offered up a narrative that was embedded in the immediate environment of Johannesburg and appropriated fragments of a world beyond South Africa's borders. While the story begins on the recognisable streets of Sophiatown, with its single-storey brick houses and shops built along the edge of the pavement along which the girl strolls, it ends with two photographs which refer to other, more remote landscapes. In one the two lovers retreat from the city and the gangsters that are shadowing them and recline under a tree which forms the foreground to distant hills upon which dark trees grow. The basic compositional structure borrows heavily from the English picturesque tradition, which had in turn become woven into the way in which the landscape of southern Africa was represented. On their return, Prettyboy and his lover stroll along a brightly lit, open and silent street and he records:

En daai aand mova ons titch-toe, cruel geklip. Die toun was mca, hinty man. Die baby ga my, is shandies kalykit crackets sgoer-goer in my koukie. Ek was weg, man, weg, man ...

And that night we went home, in close embrace. The town was beautiful. Silent. My girl pressed me, things exploded as if crackers burst in my head. I was gone, man, gone, man ... .11

While photo-stories such as 'Baby Come Duze' appropriated city landscapes and language from American cinema and recalled idyllic pastoral scenes which drew on English landscapes, the journalists and photographers of Drum also probed the impact 
of new government legislation on the places in which this urbanity had flourished. Can Themba's 'Requiem' was precisely that - a song of mourning for a place which no longer existed. The death of Sophiatown was not only a result of the removal of people, but also the removal of the buildings in which their lives were lived. With the demolitions, and the reconstruction of a new suburb upon the debris that was left, along with the reconfiguration of the street plan, Sophiatown itself became invisible. The razing of Sophiatown closed the city to its inhabitants and confirmed that the government would not fail to act, with calculated ruthlessness, in order to fulfil the dream of the segregated city.

In the mass move to the cities that occurred in the first half of the twentieth century the politics of the fatherland were forced to confront an urban context which itself was unfamiliar ground. As a result, the myth of the merging of nation and landscape was exposed to stress and contradiction in the proximities and complexities of the city. The urban environment offered new challenges, both to a Afrikaner workforce that was forced to compete with black workers, and to the myth of the segregated landscape and the 'natural' identities that were part of it.

\section{Imagining Johannesburg as a site of economic and cultural goals}

The reimagining of the city both as a segregated landscape and as a site in which the economic ambitions of the volk can be fulfilled connects directly to the narration of the history of the Great Trek and the celebration and ritual commemorations that accompanied the centenary of 1938 and the inauguration of the Voortrekker Monument in 1949. Dan O'Meara has argued that the development of 1940s Christian Nationalism, although reliant on the myths and symbols of Afrikaner identity, was fundamentally a break with the practices of the past because it emphasised the economic fulfilment of the volk through the alliance of all Afrikaners across class boundaries. ${ }^{12}$ His argument reframes the use of the symbols of the past, and the reproduction of dress and wagons of the trekkers during the ritual commemoration of the Trek and the inauguration of the Voortrekker Monument, and contends that these historical fragments were used as a way to transform the present. O'Meara is fundamentally concerned with a reading of Afrikaner nationalism as an economic movement, one in which the ambition of economic equality and even supremacy over English-speaking South Africans was the concealed motivation beneath the unification of the volk.

The city emerges as the concealed subject of the Voortrekker celebrations, and the future ground to which the nation aspires. Analogies were drawn between the new wilderness of the cities and the savagery of the undifferentiated interior before the coming of the Trekkers. The city, and Johannesburg in particular, was represented as a place which offered both the possibility of redemption to the volk and a threat to its existence. Fears for the unity of the Afrikaner nation, its social organisation and cultural cohesion, were expressed in reaction to what was seen as the power of 
the city to corrupt and spread miscegenation. The occupation of various areas of the city by people who were not white was itself seen as a stain on urban space - like the marking of the land into black and white spots in maps of the Land Acts that was discussed in earlier chapters. The trespassing into the realm of modernity was seen as a serious incursion because it was the dominance of the ground and economic structure of the city that was the covert economic agenda of Afrikaner Nationalism at this time. Because of the concern for the maintenance of the fragile national unity that the commemorations had fostered, the proximities of the cities were seen as being particularly threatening to the Afrikaner people as a whole and fostered a desire to purify the city through the separation of people of different races.

Slum clearance became a way of defining urban areas that were seen as impure contaminations of urban space and to argue that their eradication was essential to the physical health and hygiene of the modern city. A growing belief in the power of rationality and modernity as a force for social change was tied to a belief in racial exclusivity. The challenge posed to the government was to balance the need for cheap black labour with the political belief that the modern city was exclusively for the permanent occupation of white people. The often contradictory politics of apartheid therefore had repercussions for the spaces of the cities and for the stability of the meaning of landscape areas held within them. Slum areas were a representation not only of the contamination of race, but also of an incursion into an environment in which Afrikaner economic footholds were still uncertain: financial power was still held largely by the English, and the peripheral spaces Afrikaners occupied were in close proximity to many urbanised blacks.

Johannesburg appears in Afrikaner representations of the 1930s and 1940s as a shining vision of wealth and modern industrial power rising from the still vacant plains of the highveld. The narrative of its creation was bound up with the myth of the emptiness of the veld, the wilderness that was its original state, a hidden ancient landscape and the power of modernity to generate form and wealth. The presence of the mining land in representations at this time points both to the economic ambitions of the volk in a new urban environment and recalls a geological landscape which was already present, although concealed, beneath the wheels of the Voortrekker wagons. The mining land represented both the wealth that was the birthright of the Voortrekker descendants and a fragment of the originary landscape, unoccupied and enigmatic, that formed the artery of the city that it spawned.

In one drawing from a commemorative edition of Die Huisgenoot in 1949, Johannesburg is regarded from afar by the ghost of a commando rider (Figure 10.5). Rising as though just created, pure and shining, from the low hills of the highveld, the city is illuminated by the radiant sun breaking through low-lying cloud. This particular form of illumination recalled biblical images of the presence of God in the heavens, drawn from popular photographs and postcards, as well as the streaming rays of William Blake's religious drawings. The sun that beamed down upon the Golden City can therefore be seen as a reprise of the divine presence (and blessing) that was central to the mythologising of the Voortrekker past. They also reminded 


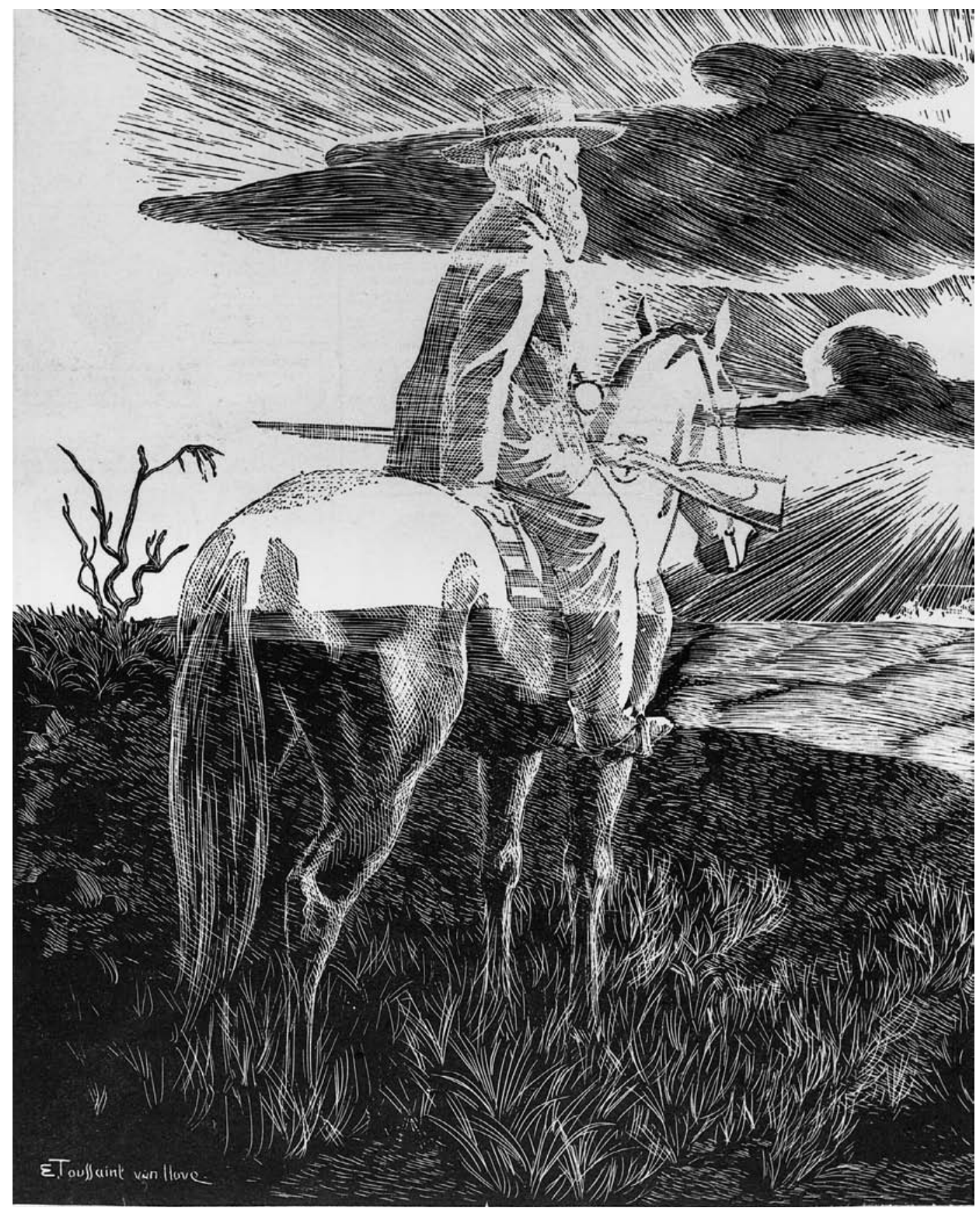

10.5

Drawing of Johannesburg by E. Toussaint van Hove with mounted outrider (25 November 1949). 


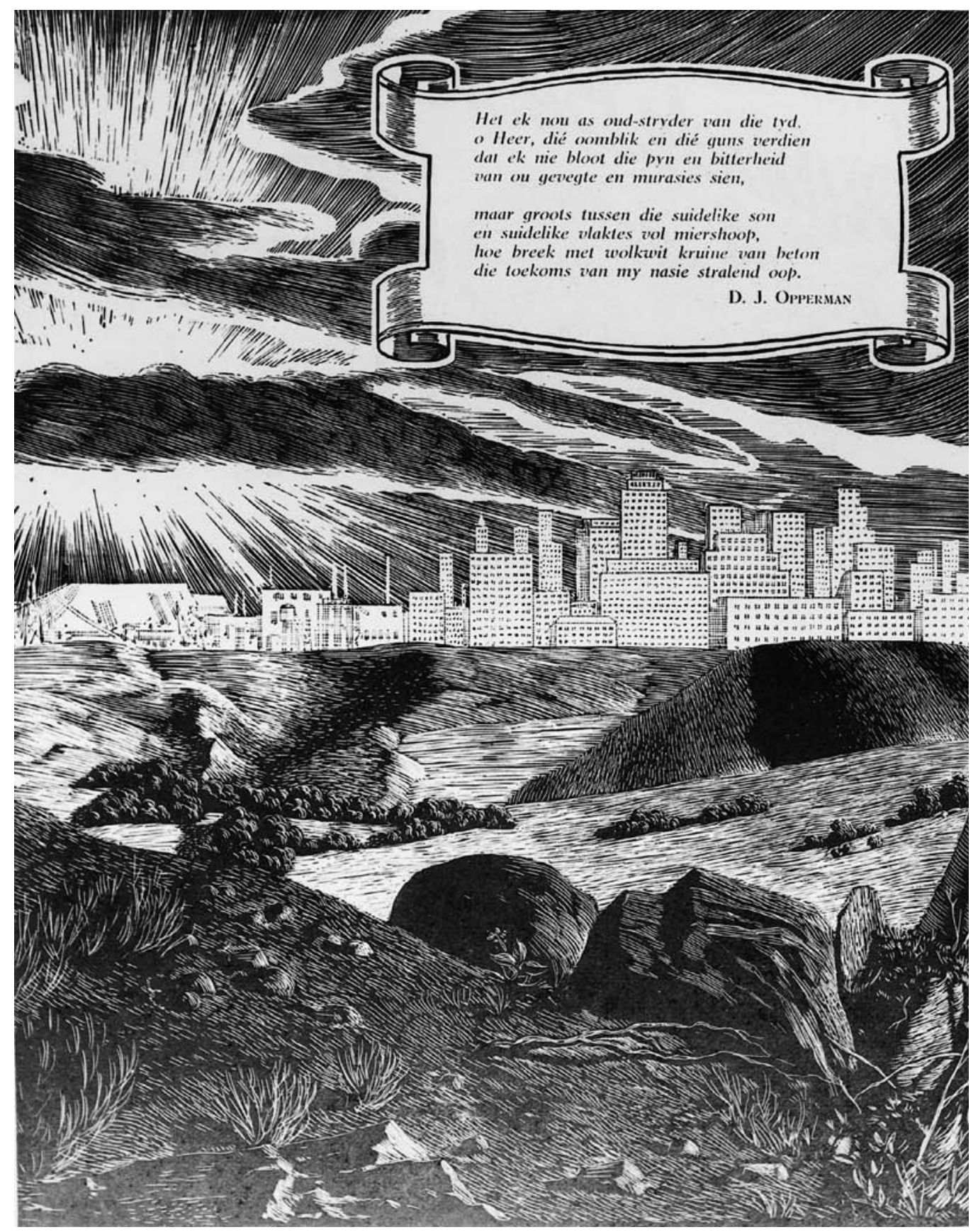


the reader of the analogy between the rising of the sun and the new dawn that awaited the Afrikaners in the cities.

The move to the cities from rural areas was christened 'Die Tweede Trek' (The Second Trek), which made a direct connection between the narrative of the Voortrekkers and that of the twentieth century. The ghost that contemplates the city is that of an outrider, an armed scout, sent to assess the unknown territory ahead. The city, like the wilderness before it, offered the possibility of both threat and fulfilment. It was represented as the next proving ground for the Afrikaner nation.

In the line drawing the city does not seem to belong to the plains; no roads lead to it and no alterations of the empty veld accommodate its presence. It is raised slightly on a plateau; a citadel of skyscrapers of concrete and glass that retains a glow of otherworldliness. The modern appearance of the city has been accelerated by the imaginings of the illustrator - the process of intense development that was to result in the proliferation of tall buildings that is characteristic of Johannesburg occurred only later, in the economic boom after the Second World War. The city was therefore represented as a vision of modernity and technology that did not yet exist. It does not gradually emerge from its site, but bursts through it. The stark juxtaposition between the grassy, uncultivated plains and the towering forms of the city seems to confirm its freshness, wealth and newness, and its fundamental separation from the landscape that preceded its creation. The city is an archetype of modernity. The main clue to its identity is found not in the city skyline but in the unmistakable mass of a large mine dump at the edge of the industrialised area to the back of the city. ${ }^{13}$

In the poem that accompanied the drawing, the Afrikaans poet D.J. Opperman (1914-1985) repeats the physical form of the city and the peaks of its buildings with the future of the nation. The plains are 'full of anthills', the landscape is still untouched, and the solitary presence of the rider confirms the mythology of the vacant and isolated landscape.

\begin{tabular}{|c|c|}
\hline $\begin{array}{l}\text { Het ek nou as oud-stryder van } \\
\text { die tyd, }\end{array}$ & $\begin{array}{l}\text { Have I now as old-fighter of the } \\
\text { time, }\end{array}$ \\
\hline $\begin{array}{l}\text { o Heer, die oomblik en die guns } \\
\text { verdien }\end{array}$ & $\begin{array}{l}\text { O Lord, the moment and the grace } \\
\text { deserved }\end{array}$ \\
\hline $\begin{array}{l}\text { dat ek nie bloot die pyn en } \\
\text { bitterheid }\end{array}$ & $\begin{array}{l}\text { that I don't see only the pain and } \\
\text { bitterness }\end{array}$ \\
\hline van ou gevegte en murasies sien, & of old battles and ruined houses, \\
\hline $\begin{array}{l}\text { maar groots tussen die suidelike } \\
\text { son }\end{array}$ & but large between the southern sun \\
\hline $\begin{array}{l}\text { en suidelike vlaktes vol miershoop, } \\
\text { hoe breek met wolkwit kruine van } \\
\text { beton }\end{array}$ & $\begin{array}{l}\text { and southern plains full of anthills, } \\
\text { how with snow-white summits } \\
\text { of concrete }\end{array}$ \\
\hline $\begin{array}{l}\text { die toekoms vir my nasie stralend } \\
\text { oop. }{ }^{14}\end{array}$ & $\begin{array}{l}\text { the future for my nation breaks } \\
\text { open, gleaming. }\end{array}$ \\
\hline
\end{tabular}


The references to 'pain and bitterness' and the 'old battles and ruined houses' also served to remind the reader of the actions of the British during the South African War. The juxtaposition of the suffering of the past and the goal for the future was linked through an awareness of the English-speaking presence in the cities and the wealth that was held in their hands. ${ }^{15}$

In the final pages of Die Voortrek, an article by an unnamed author entitled: 'Goud het onder hulle wawiele gelê: Voortrekkers het weg gebaan vir S.A. se grootste bedryf' (Gold lay under their wagon wheels: Voortrekkers paved the way for S.A.'s largest industry), ${ }^{16}$ argues that:

The gold mining industry has much to thank the Trekkers for. They opened up the land, achieved exceptional pioneering work, subjugated the hostile native tribes and went to farm in the interior... Before gold was discovered on the Rand, this area was sparsely populated. The Trekkers and their families, who established themselves on the Witwatersrand, farmed as they had done in earlier years on the Cape frontier. Their lives were primarily pastoral, and the rock outcrops that were destined shortly afterwards to become the richest rand in the world, were deserted. On the plains to the south of the rand, upon which a series of huge mine dumps would speedily grow, small groups of cattle grazed and only a couple of families lived in isolation and solitude - an image that is difficult to form in the tumult and bustle of present-day Witwatersrand. ${ }^{17}$

The author here repeats the essential elements of the mythology, inserting 'the enemy' - the hostile tribes - into the seamless narrative of wilderness and the isolated pastoral life, opposing Trekker and savage, civilisation and primitivism. It is significant that the article was illustrated, not by a conglomeration of city buildings, but rather by the enormous arc of the mining land. It was the landscape that came before the buildings, the artery that fed the heart. The mine dumps are processed rock, therefore offering resonances of a natural land transformed through industrial processes. They are objects which are both archaic and modern; archaic because it was ancient deposits that were mined and then deposited in massive monolithic mounds, and modern because their form and material were the result of modern industrial practice.

The modernism that was embraced by the National Party government was one which embraced change and also sought to embody it, but at the same time sought to frame this change as a natural and inevitable destiny of the land. A fragment from Die Voortrek in 1949 stated:

New life develops where it is still and isolated. So also the Afrikaner nation developed in the silence and isolation of the platteland . . . but the culture of a nation cannot reach its full unfolding in silence and isolation. As the Afrikaner wants to develop fully cultural, intellectual and spiritual life, he must also fulfil his role in the city. Therefore we say, 'The Trek Goes Forward!'18 
The abundant information available through books and films about the Great Trek, its participants and their values, can be seen not only as a call for volk's unity (volksgebondenheid), but also as a way in which the participation of the Afrikaner in city life was guided. The dangers of the city included miscegenation, and the loss of a cohesive Afrikaner identity together with the strict moral and social codes that were seen to be part of this identity.

There is much that is unhealthy in the city life and the Afrikaner with his land-based background can offer an important contribution to get rid of the unhealthy characteristics of the city life ... If he is going to gain control over the city, over management organisations and professions in the city, he must not only use these in order to raise his own power and honour, but also to make a contribution to the whole, and also to the other city dwellers...

We Afrikaners must find each other in the city. We must search each other out and we must be tied together in small strong groups ... The city with its bad social organisation is a danger for the family. ${ }^{19}$

The perceived corruption and danger of the city was seen to offer a threat to the social and cultural organisation of the Afrikaner, who were called to bond together and to maintain their separation from the other city dwellers, who did not share their values and belief systems.

By linking the city to the veld through the narrative of the Voortrekkers, the originary landscape of the interior - opaque, silent and elusive - was woven into the meaning of the city through the movement of bodies through the landscape and the rights that this movement conferred on their descendants. This veld, however, was not a place in which nationhood was resolved, but rather where the insecurities about white presence in southern Africa surfaced. The connection between the veld and the city was therefore one in which the uncertainties that were present in white landscapes were transferred to the fabric of the city.

\section{Tracing the hidden geography of the mining land through maps and aerial photographs}

South African landscapes were not only physical structures but also mythical concepts, which had been integrated into the narrative that was fundamental to the Afrikaner claim on the land. Therefore the right for an economic future was made by the overlaying of two landscapes: one the series of Boer farms, and the other the mineral-bearing rock beneath the once quiet plains.

The mining city exists on two symbiotic levels; one above and one below the surface of the land, creating a doubling of the influences on the form of the city. Not only is the city a product of social, economic and political forces, but also it is influenced and guided by a geological structure which itself cannot be seen, except through representations. The development of the city implied its own conventions of 
mapping and ownership, and the overlapping of the physical form of the gold vein with the boundaries which had already been laid down on the surface of the ground. It is through the maps produced at the beginning of the twentieth century, in order to document economic relationships between the land divisions on the surface and the geological structure beneath, that we are able to trace the impact of the hidden structure on the development of the form of the city.

Two early maps from the 1920s show the overlaying of the two systems of order that were to influence the future development of the city, and were to become appropriated as part of Afrikaner mythology: the gold vein and the boundaries of Boer farms. In terms of Afrikaner mythology the form that was presented as the mythical image was that of the Boer farm that 'discovered' the city. This mythology of city origins was intended as a means to recover that which had been usurped and ensure the national cohesion that was essential to the maintenance of political power. Early mapped representations of the city confirm both the existence of the Boer farms and the presence of the polygonal divided surface of the farmland above the reef series. The narrative power that was claimed for the farmland, however, was undermined by the distortion of the surface of the land in response to the concealed structure.

The map of the Witwatersrand and Balfour basins (1921) shows the main reef series underlying the surveyed outlines of the farms that lay above it (Figure 10.6). It represents the physical structure of the reef series and the effects of this geological order on the surface of the ground. The two systems of order were formally independent, but were brought together through an economic relationship that necessarily differentiated between those farms that were above the reef and those that were distant from it. The vast areas of farmland were dwarfed by the curves of the reef series, which was drawn as a snaking monumental sequence of arcs which rendered boundaries of the farming kingdoms impermanent, although the names of some of the farms, along with sections of their boundaries, were transferred to areas in the cities as partial fragments of a superseded past. The newly founded cities themselves - Johannesburg, Germiston, Heidelberg, Boksburg - formed a string of dense settlements along the arcs of the reef series. They connected the surface of the earth with the hidden wealth below, through the shafts and tunnels of the mining gear and through the capital that made the construction of the cities possible. The map, in common with another, slightly later and more detailed map, was concerned with the representation of a strategic economic and spatial relationship, which traced proximity and the effects of this proximity.

The later map, of the Witwatersrand Goldfields, published by the SA Mining Journal Syndicate for the South African Mining and Engineering Yearbook in 1927 , documented the changes in the surface of the land that were the result of the redrawing of boundaries and the repartition of the landscape in response to the physical form of the mining land around Johannesburg (Figure 10.7). While the earlier map had superimposed the geological structure of the reef series with the boundaries of the farmland above it, the later map shows only the divisions of the surface of the land. It was, however, a partitioned surface that had been penetrated and distorted 


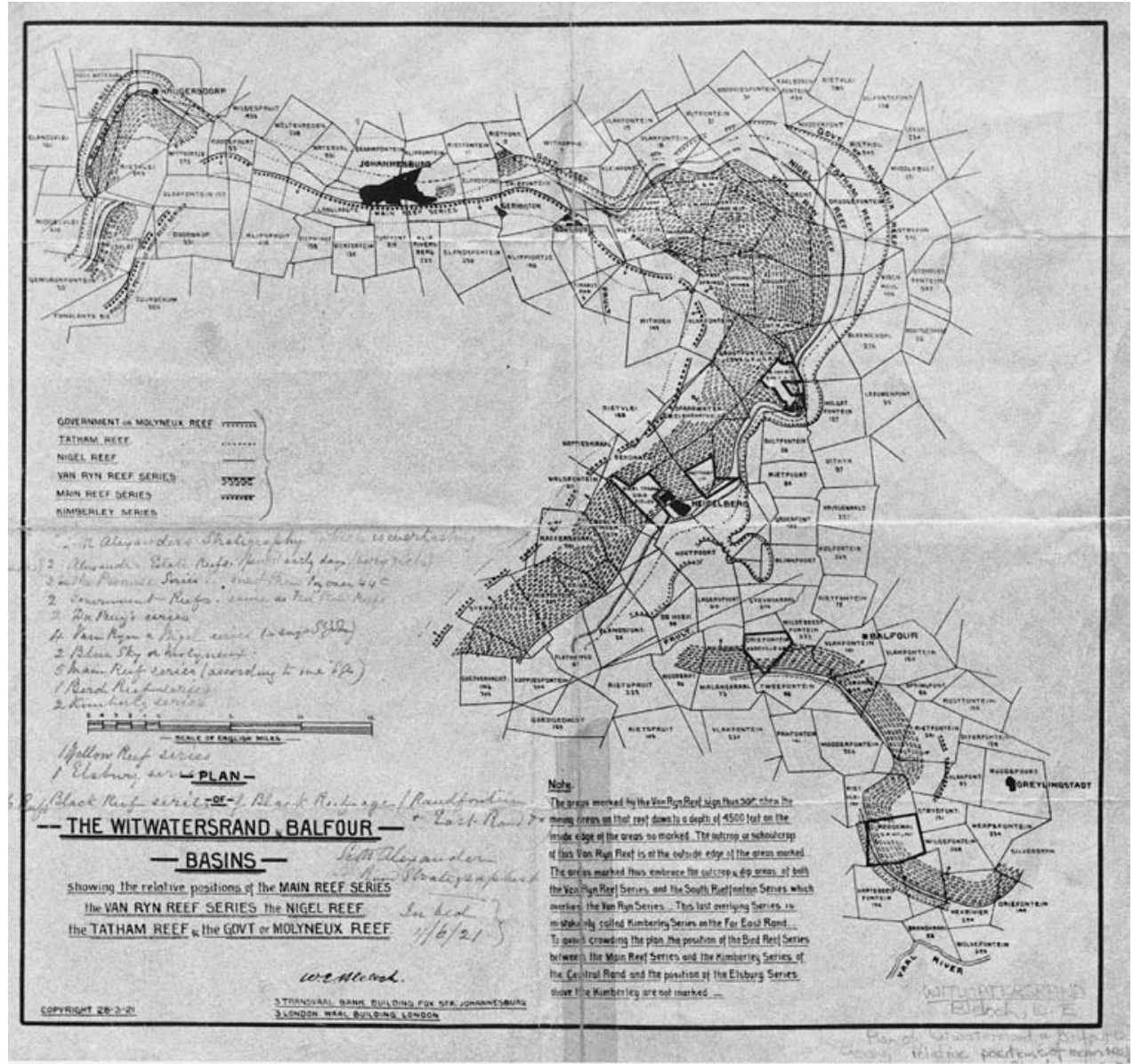

by the form of the reef beneath, so that we are able to read the geological form of the reef within the lines that delineate property divisions and the tracks of the rail lines that serve the industry. Like the earlier map, this printed document was produced for the people who were involved in the management of mining companies and, as such, it represents the surface of the ground as a strategic surface, one on which concessions could be negotiated and properties were mapped. The priorities of the mining industry are reflected in the sponsorship of the map by a manufacturer of mining equipment, which promoted their involvement through the depiction of equipment and a photograph of a black miner underground. This is the only fragment of the map in which the physical space of the concealed landscape becomes visible and it becomes visible through the constricted body of the black miner. The maps indicate that the process of building the city and mining the land was also a means
10.6

Map of the

Witwatersrand and Balfour Basins

- showing the relative positions of the Main reef series, the Van Ryn reef series, the

Nigel reef, the Tatham reef and the Government or Molyneux reef (1921). 


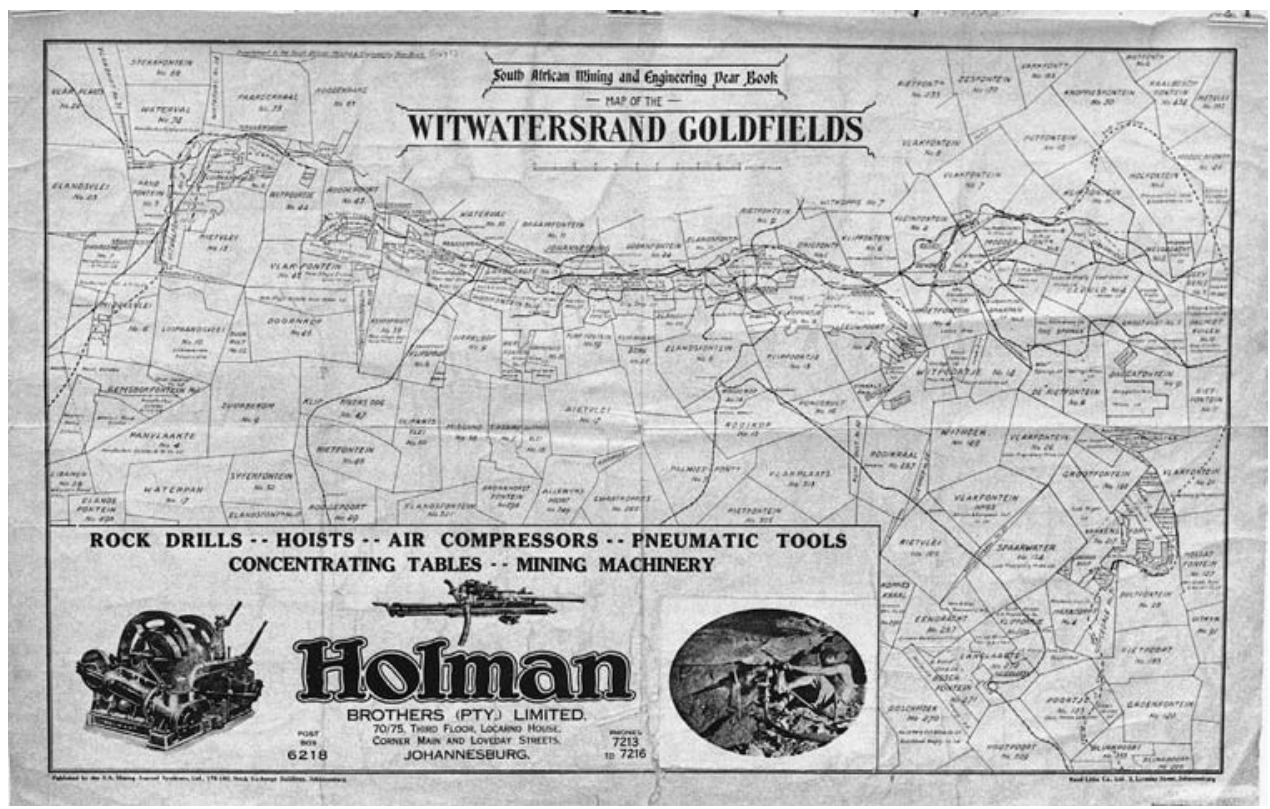

10.7

\section{Map of the}

Witwatersrand

Goldfields (c.1927)

Holmen Brothers.

Published by the SA

Mining Journal

Syndicate for the

South African

Mining and

Engineering

Yearbook through which the geological structure of the reef was made manifest on the surface of the ground. The influence of this concealed geological structure becomes more explicit in the juxtaposition of geological and photographic images of the land.

A 1984 geological map, in a series of sheets, covers the entire country, as well as the 'politically independent' bantustans. As all mineral rights were retained by South Africa, their new status did not exclude them from geological scrutiny (Plate 10.1). The map traces the formations below the surface of the ground, revealing the hidden structure in a representational form that assisted in the extraction of minerals. Held within the bulge of the northern area of South Africa is a small fan of pink, emerging from a gold and orange arc, all set within a flowing area of blue. The particular geological structure that defines Johannesburg is even more visible in a geological map from the early twentieth century (Plate 10.2). The gold reef retains its magical colour, the glow of an intense yellow. These maps may seem peripheral to discussions of politics and landscape, incidental reminders of a reality with which we have no direct contact. However, set alongside a map of the municipal area of the city, it is clear that a close physical relationship exists between that which is below the ground, and that which is above it (Figure 10.8). The placement of Soweto to the south and west of the CBD of Johannesburg confirmed its remote and peripheral status and its geographical and geological displacement from the development pattern of the rest of the city, and the primary geological structure of the area.

The landscape used to separate black and white was therefore present both above the surface and below it. The meaning of the mining land is further 


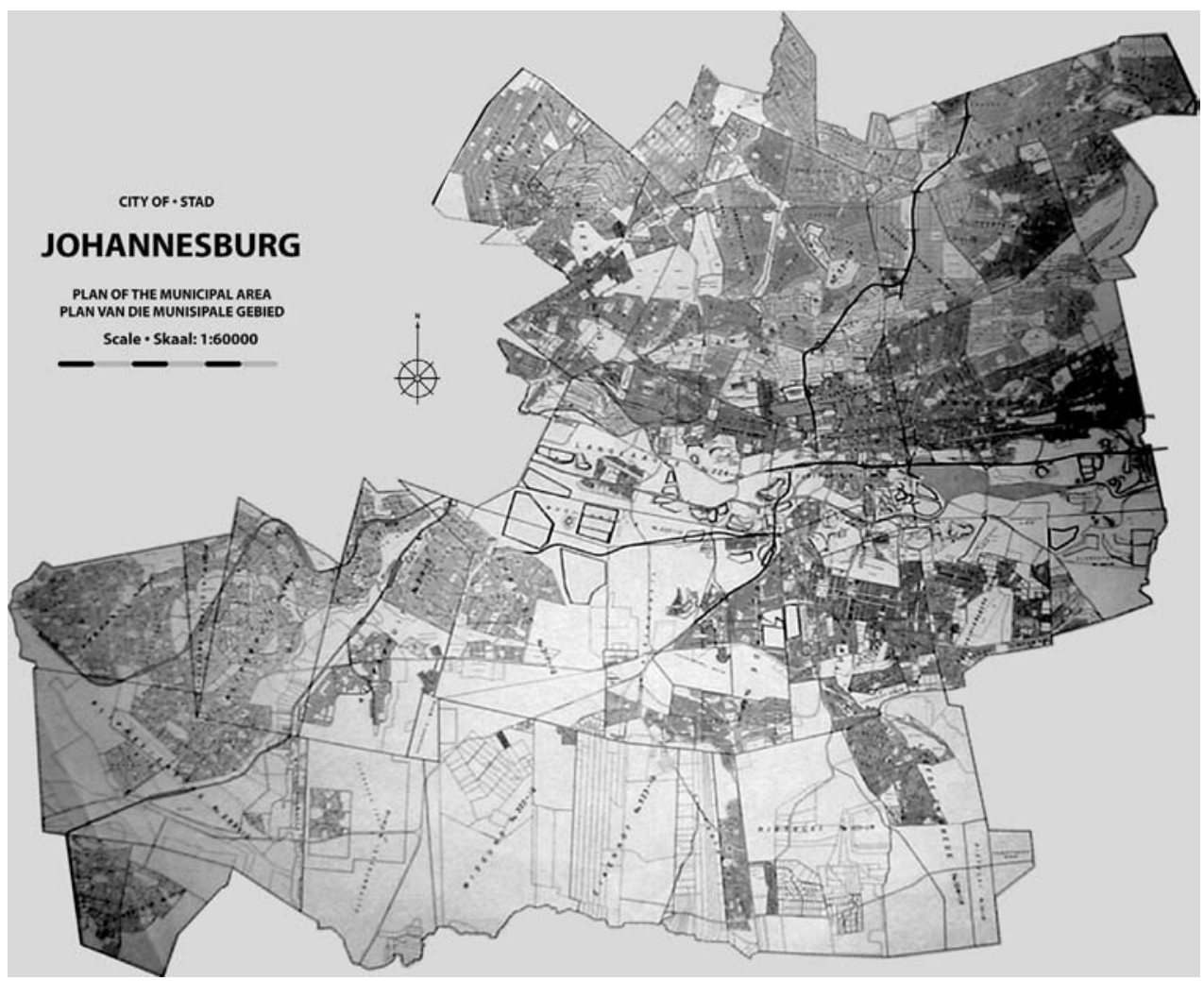

complicated by its physical depth, and by the effect of its presence on the structure of the city. Its invisibility as a landscape is at odds with its physical presence, the depth of its structure and the influence that the geology of the ground has on the form of the city. The early twentieth-century representation of the mining land as the icon that renders Johannesburg recognisable has been supplanted by a discomfort, a silence, and a lack of popular representations that engage with the earlier symbolic image. The ambivalence and anxiety which surfaces in the mining land is connected not only to the abandoning of the land by the gold-mining industry, but also to an awareness of its use to locate and conceal Soweto. The density of meaning of the mining land has left us unable to journey across it or along it without recognition of what it is that we are leaving behind, or what we are travelling towards. The use of this area of land as a strategic tool in the separation of the races has confirmed the use of landscape in the development of the politics of division and, like the rural landscapes of farm, veld and the mythical idyll of the traditional landscape of the bantustans, an unsettled and ambiguous landscape has emerged.

10.8

City of

Johannesburg: Plan of the Municipal Area. Compiled and drawn by the Town Planning Branch. In this map, the break between north and south along the curved arc of the mining land is clearly visible. 


\section{Chapter 11}

\section{Veld and city}

Maybe there was no veld that you could take long walks across, in the city. But the veld was still there, of course. At least the earth that the veld was made of was. Was and is and will be, evermore, meaning, existence. Only, in a city, the topsoil and subsoil and rock formation part of the veld were present in a more stylised form - in the tall, straight up and down of buildings. The soil of the veld was compressed into bricks and tiles. A whole stretch of what had been virgin highveld was telescoped into concrete... Repton House was, by reason of its origins, a concentrated piece of African hill. And on the four perpendicular sides of this piece of African hill that had been transported into the centre of Eloff Street, Johannesburg, there sprouted windows, the thorny panes catching at the garments of the passing sun; tearing off bits as the sun went by; holding fragments of yellow rag spiked for brief moments. ${ }^{1}$

In this fragment from Willemsdorp, Bosman's novel of veld and city, and the violence that is the result of the drawing, and the transgression, of boundaries of race and landscape, one of the principal characters moves to the city in order to escape the censure of the small community in the veld. In the extract above she describes Johannesburg as an analogous landscape to that of the veld. Here materials, from the land, come to constitute the city. The material transformation is an alteration of the veld, not a supplanting of it. Bosman refers to the history of landscape writing in this novel, and to the recurring representation in white writings of the South African landscape as timeless and impenetrable, not only by exploring the inscrutability of the veld, but also by associating its elusive and enigmatic qualities with that of the city landscape and buildings. The stone, concrete and glass are rendered not only as constituents of the rectilinear elongated forms of the skyscrapers, but also as simultaneously ancient and modern. 
In Bosman's narrative, the city is a vertical interpretation of the veld that retains some of its enigmatic and elusive qualities. It is no more intelligible than the landscape from which it had been constructed; the conflicts of the occupation of the land and the doubt that is present in the veld remain. The character of the veld, its harshness, spikiness, and uncertainty, has not been overcome by modern construction. The buildings represent a civilised veneer, an attempt to control and know the landscape, yet the potential hostility of the ancient landscape, and of the confusion of race and the occupation of the land, is hinted at through the tearing of the sun's yellowness on the sharp, shiny windows of the buildings. The novel emphasises that any inhabitation of the southern African landscape, even one built in the form of modern cities, is plagued by uncertainty and the possibility of an entropic reversion.

This chapter is concerned with the way in which the images of the vacant land continually resurface within the built structure of the city. In many representations of Johannesburg the modernity of the city seems never quite able to overcome the primary meanings assigned to its site and the failures of politics are associated with the failure to overcome the meaning of the land before white settlement. The changes in structure and meaning that were the consequences of political legislation that sought to force political and racial clarity onto the city have contributed to its ambiguity and to the complexity of histories overlaid onto the land.

The mining land remains the place in the city which is most strongly associated with some of the qualities of the veld. It is largely unmapped, dangerous, enigmatic and remains conceptually outside the city, even as it is present within it. It is also a place in which the dark underbelly of the city, modernity and racial politics intermingle. This chapter therefore probes how the mining land has been represented and imagined over the period of the city's development. It argues that the mining land should be read as a place which is able to hold seemingly contradictory images - city and veld, surface and depth, modernity and decay - and that in this multiplying of meaning it offers a means to conceptualise a hybrid South African landscape which is unstable, changing and within which traces of the past are inevitably held.

The landscape of the mining land has been an invisible one; both through the persistent failure to identify the land area as part of the cultural, social and political life of the city and because the geological landscape was itself invisible, concealed beneath the surface of the land. It is a made landscape and a revealed one, as the arc of the gold-bearing rock - once hidden beneath the vast grasslands - was brought to the surface and deposited there in huge yellow mounds strewn with the abandoned paraphernalia of mining engineering work, contaminated by the processes of gold extraction and polluting the southern land with dust. It is the mining land that is both the source of Johannesburg's secondary names in both English and Xhosa - the Golden City and Egoli (place of gold).

The mining land emerges as a section of land that remained outside of recognisable categories of landscape but also which has continued to be the single most identifiable symbol of the city. It has become a site of moral ambiguity - as a boundary and a buffer between separated groups of people. The meaning of the land 
remains elusive not only because of its physical characteristics, but also because the flickering between visibility and invisibility and the use of the landscape to control the presence of bodies in the city imply a confusion that has characterised white occupation of the land. While Willemsdorp traces the politics and violence of the veld, the ambiguity of its presence in the city also appears in a later novel, Burger's Daughter (1979), by Nadine Gordimer. She is a novelist, critic and short story writer - winner of the Nobel Prize for literature. Gordimer's work concentrates on the schisms (created by apartheid policies) between vastly different worlds inhabited by people of different races. She explores through personal narratives the contradictions and complexities of politics in South Africa during the second part of the twentieth century. Published in 1979, after the increased restrictions imposed after the Soweto riots of 1976, Burger's Daughter is a novel in which the narrator, Rosa Burger, is caught between the imperatives of the lives of her dead parents, white anti-apartheid activists in South Africa, and her own desire to uncover a life in which politics no longer dominates all other concerns. In the extract that follows, Rosa ends up in the old mining land, along the southern edge of Johannesburg, after giving a lift to a black woman who, like her, had attended a political gathering. The area of land is a forgotten place, invisible, littered with the debris of modernity, and supporting lives eked out on the remains of the city.

Small industries have taken over the property of worked-out gold mines, the hollows are mass graves for wrecked cars and machine parts, the old pepper trees are shade for shebeens, and prostitutes lie down for customers in the sand of the dumps. There were still hawker's mules tethered in grazed circumferences of tin-littered veld; a tiny corrugated iron church with broken windows, and a peach tree half hacked away for firewood; in abandoned cottages that had once belonged to white miners, and in the yards built up with shelters made of materials gathered from the bull-dozed mine compounds and the brick shells of concession stores, people were living in what had been condemned and abandoned by the white city ... I took wheel tracks deep enough to be well used that seemed to lead over the veld to a road away on the rise in the right direction. The hump of the dead grass down the middle swished against the belly of the car and now and then the oil-sump scraped hard earth. The track went on and on. I was caught in the counter system of communications that doesn't appear on road maps and provides access to 'places' that don't appear on any plan of city environs. ${ }^{2}$

Here Rosa comes across and watches a man violently beat his donkey. He is black - a woman and child lie cowering in the cart. In Gordimer's novel Rosa drives on, powerless, as she sees it, to act. Her agony at the pain of the animal cannot overcome the sense, perhaps also a conceit, that his actions are the consequence of racial politics - a pain which she cannot comprehend. The ambiguity of violence, race and authority render her unable to imagine how to intervene in a way which would not 
render her complicit in a system she abhors. The spatial intangibility of the landscape coheres with a moral intangibility in which all norms are suspended. In the novel this incident occurs within the space that was used to separate black and white, the mining land - the buffer zone, the thickened boundary - and Gordimer describes the area as the veld. It is unclassifiable, outside of mapped places, and therefore outside of the known city. The ambiguity of the originary landscape, the emptiness of the veld, and the intangibility and confusion of meaning and ownership is reasserted in the mining land. The land itself was the creation of modernity, economics and political will but it has become, rather than a zone which is tightly controlled, a wasteland without physical or social boundaries where nothing is stable. The violence that is present in Willemsdorp as a consequence of the conflicting claims on and occupations of the veld, is in Burger's Daughter a numbing, silent act, which occurs in the ground above the geological feature that is the reason for the establishment and development of the city, and the site of its discarded waste. In both novels, the veld is a landscape that is an inescapable part of the meaning of South Africa, an inevitable presence. The alterations to the mining land and the modern debris that litters it does not erase the veld. It emerges as an image of the land that holds within it both the timelessness of southern Africa, and the uncertainties and conflicts of modernity and racial politics.

\section{Early photographs of the mining settlement}

An initial, and persistent, image of the interior in colonial writing has been that of an immense, silent and empty landscape upon which all inhabitation will ultimately be erased. A nineteenth-century (c.1890) panoramic view of Johannesburg scans the gentle line of the horizon; the scattering of single-storey corrugated iron buildings and canvas tents does not interrupt the vastness of the land (Figure 11.1). In this photograph the surface of the ground is laid bare, and its physical form is exposed to the eye. The photograph was taken from the mining land and its fledgling mounds of gravel and soil offer a formal contrast to the treeless, even grey of the grassland beyond. The mining land is separated from the human settlements, which seem improbably fragile in the vastness of the stretched horizon beyond. The landscape is empty of all that would have been familiar to European prospectors; there are no trees, no mountains, no rivers, and no reflective pools of water. The panoramic format

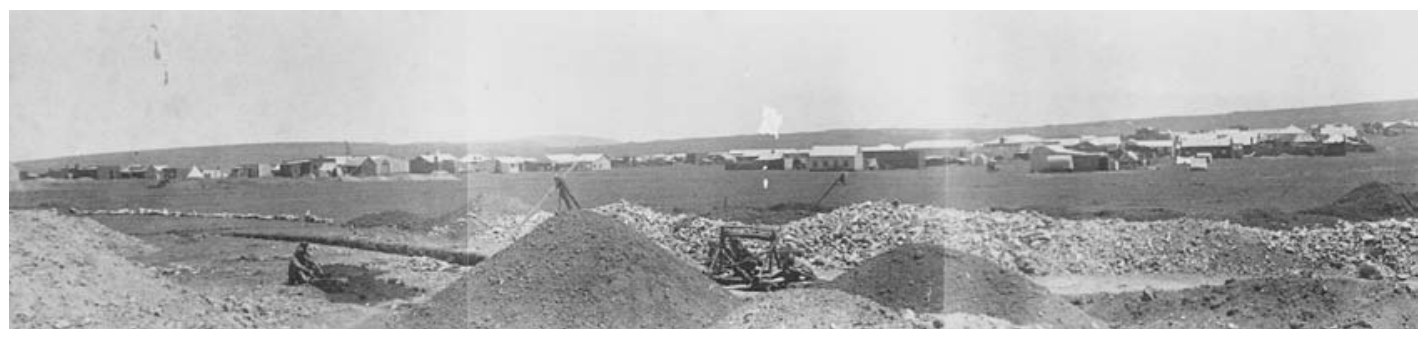


of the nineteenth-century photograph confirms this impression. It is made up out of six individual photographs, in postcard format, overlapped and glued together to form a long strip that emphasises the slow undulation of the horizon.

The format of the photograph was also a response to the form of the settlement - the long, linear strip of small-scale buildings - that had already begun to repeat the formal structure of the ribbon of reef that arced to the south. It is a photograph surprisingly empty of people; the strip of buildings only yields a few miners leaning in the workings of the foreground, while the intermediate area of empty land, between settlement and mines, appears abandoned. The landscape of the photograph seems silent; the settlement and its small-scale mining activity tenuous in the vastness of the plain, while the small heaps of excavated soil begin to provide a differentiation of the surface that is absent in the landscape encompassed by the panorama. This early photograph was one of the first that began to document the development of the area of land after the discovery of gold. Its emptiness, silence and isolation appear to confirm the myths of the interior that maintain the image of the highveld as vacant, impenetrable and frozen in time before the arrival of white settlement. What is notable, however, is that this early photographic record retains some of the uncertainty that was present in other narratives; the settlement is tiny, its materials are temporary, their appearance fragile: the vague unease of the veld permeates the sparsely populated photograph.

A later photograph, taken around the turn of the century, to the northeast of the settlement and the arc of the mining land looks back towards the southwest (Figure 11.2). On the ridge are two men, one sitting, one standing. The standing man turns towards the photographer - the invisible presence through whose lens we view the land - while our eyes follow the gaze of the sitting man back across the vacant area of land to the proliferation of single-storey buildings on the flat plain of ground before them. The man confronting the viewer appears to be white, the sitting

11.1

Johannesburg from south with

Wemmer's Mine in the foreground (c.1890), an early panoramic view of the gold-mining settlement. man, whose contemplation of the land is reproduced in the photograph, is black. Again the settlement, although growing, appears ephemeral; the scale of the land and the long, low line of hills in the distance immense and endless. The buildings are not anchored to the surface of the earth through the presence of infrastructure and this failure to embed the corrugated iron constructions to the land means that they still have the appearance of being a temporary settlement. The lack of established growth adds to the impermanence and to the sense of incompleteness.

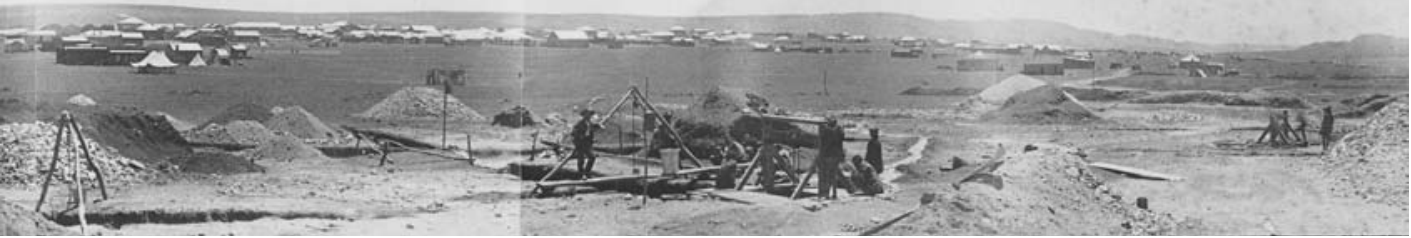




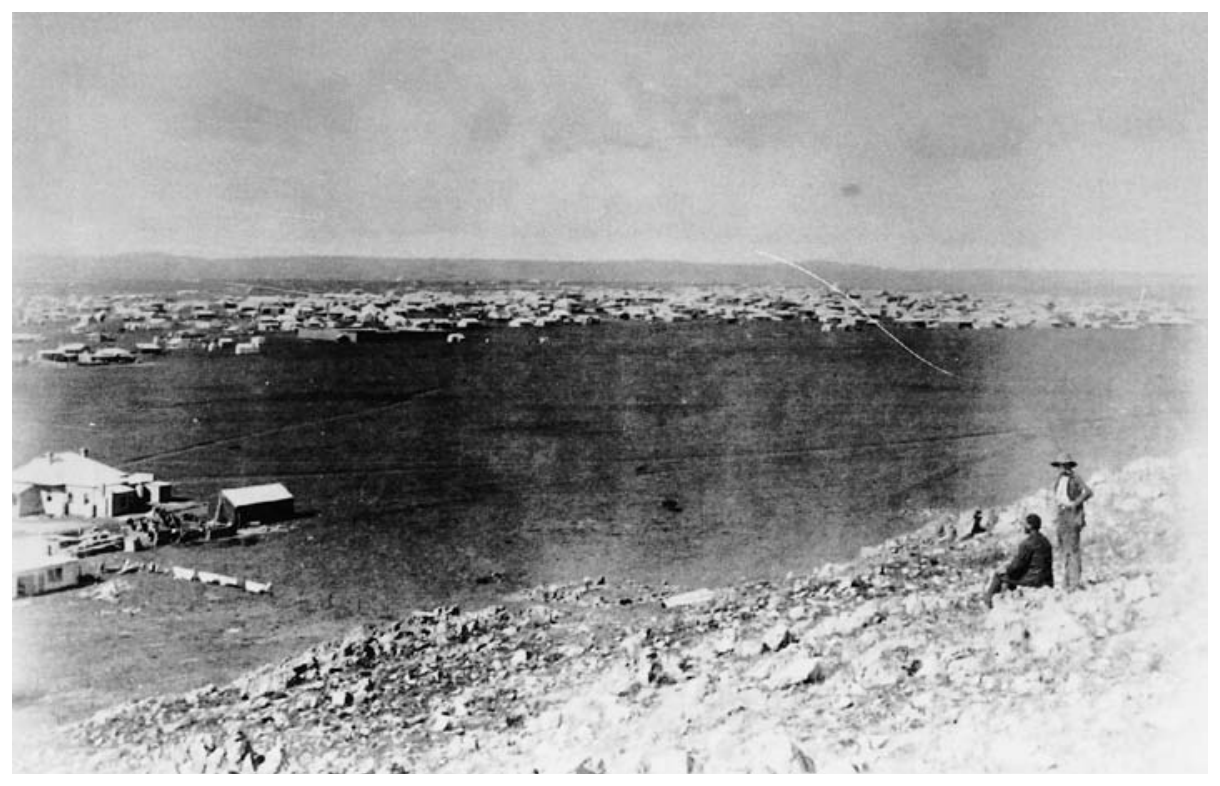

By the 1920s the impermanent settlement was transformed into a city. 11.2 The memory of the openness of the landscape of veld and farm was present only in the huge arc of the mining land that formed the southern edge of the CBD. The composition of a tourist photographic postcard of Johannesburg, from 1927, is split horizontally into two sections; the lower one occupied by the now dense and solid Photograph of early Johannesburg taken from Doornfontein Hill (c.1900) buildings, while the upper portion of the postcard is dominated by the massive rectangular mounds of the mine dumps (Figure 11.3). The transition is abrupt, an invisible wall, a cut edge. The line that defined the two areas occurs as the reef comes closest to the surface of the ground and was therefore the place at which the hidden geological landscape surfaces. This edge not only is the meeting place of two systems of order, one the rectilinear grid of city buildings and the other the irregular mounds and vacant land that were the products of the concealed reef, but also was, and is, a place of physical instability and danger, where the shafts and tunnels of the early miners are abandoned, unsignposted. As the reef descends below the surface, the ground gradually regains its stability but not without affecting the area of land above, and ensuring that it is often uneconomic to develop it commercially, despite its location. The shafts and routes cut into its depths, hollowing out the once solid ground and producing a thickened strip of land in which building activities are restricted. The danger of construction, and the contamination of the land, which has been rendered physically insecure, has maintained its emptiness and retained the scattered debris that the mining activity spawned: disused headgear, sheds, pylons, mine dumps and slimes dams. 


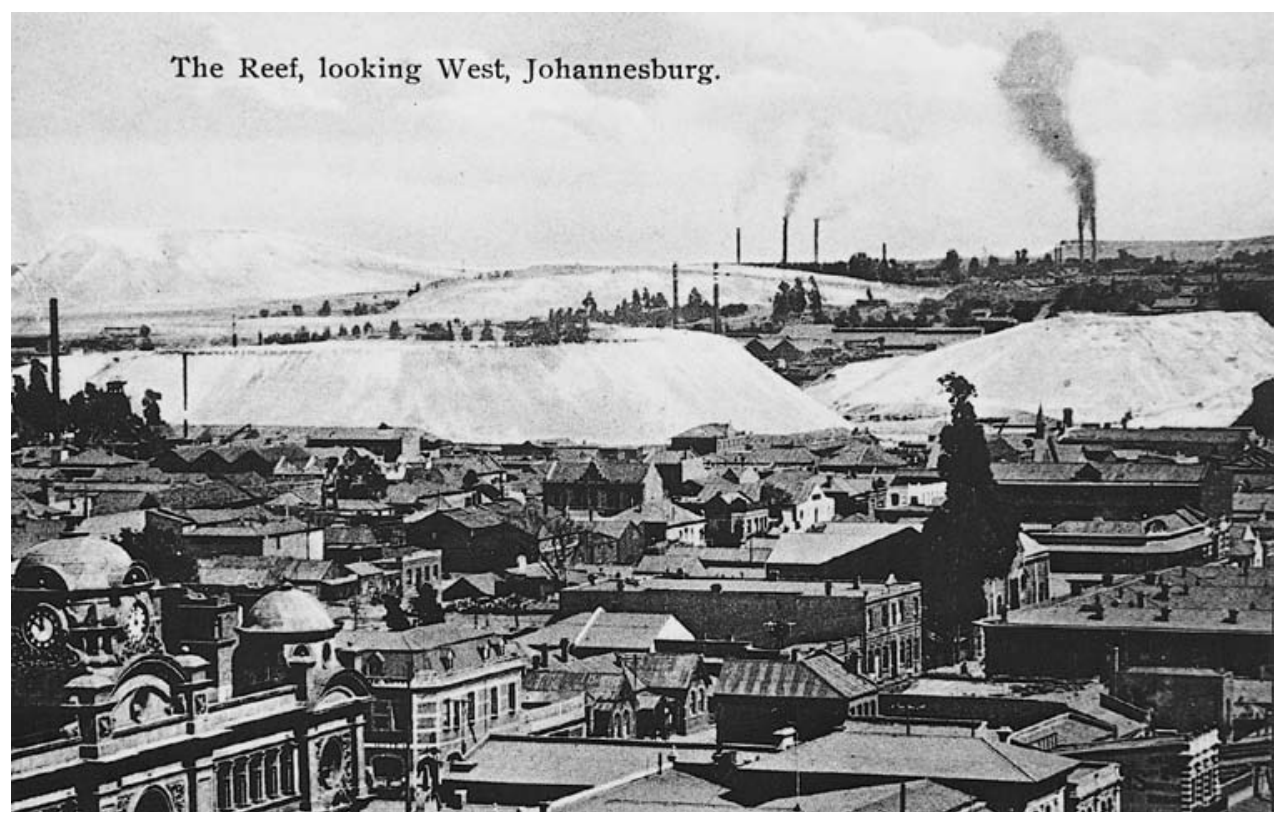

11.3

Reef looking west, Johannesburg, panoramic view with mine dumps (1927). Taken from the Southern African Tour Album of A.E. Wallis,

England, five month tour through South Africa.

\section{Politics, contamination and crime}

The mining land acts to physically divide two distinct geographic areas, which have represented racial division and physical difference: Soweto to the south and the wealthier (historically white) land to the north. Alexandra township, to the northeast of the $\mathrm{CBD}$, was the only black township to remain north of the divide during the apartheid years. The division between the two places, and the use of the mining land to ensure that division, has meant that it has become inseparable from the politics of racial separation in the city.

The area that became known as Soweto (an acronym for south western townships) in the 1960s was developed from the spreading settlement for black labour founded at Klipspruit in 1904, 20 kilometres from the city of Johannesburg. Swelled by forced removals, which took place from the dates of Klipspruit's founding and increased during the 1950s and 1960s, its population at the 2001 census stood at almost 900,000 people (although the real figure could be more than double that sum). The dolomitic soil of Soweto is physically more unstable than the ground of northern Johannesburg. The land south of the gold reef also lies in the path of the prevailing wind direction in Greater Johannesburg, which is north-northwest. It is windier, colder and more polluted than the land to the north and was therefore regarded as being less suitable for white settlement. It is fundamentally affected by the dust and contamination from the mining land, particularly in the suburbs of 
Diepkloof, Diepmeadow and Meadowlands (the area to which Sophiatown residents were removed in the 1950s). ${ }^{3}$ It is subject to twisters and violent hailstorms; its proximity to the mining land means that some areas are heavily undermined and subject to earth tremors which may cause cracking in buildings.

It is estimated that there are around 200 dumps from Boksburg to Krugersdorp, some of which reach over 50 metres in height, with a total volume of 438 million tons. The heaps are sometimes covered with vegetation, sometimes remaining glowing eroded slopes of sand stained by gold residue. There are two types of dumps that make up the mining land: sand dumps and slimes dams, with the slimes dams having finer particles of sand. The dust pollution from these structures has been mitigated by the alteration of the surface of the majority of the dumps; first by the irrigation of the sand to leach out the salts and then by composting and the planting of wheat, which forms a layer of fertile mulch when decayed. Grasses have been grown over this layer and often thirsty eucalyptus trees soak up water at the base.

However, pollution continues to occur through airborne particles, contamination of the sites and polluted water. The gold-bearing rock is associated with radioactive materials such as Uraninite and radon gas in particular, the level of which has to be monitored if any work is done to the land, causing researchers to state that mine dumps are 'internationally qualified as low-level waste disposal sites'. ${ }^{4}$ While some officials claim that polluted water from the dumps seeps into the normal water course only during high levels of rainfall, ${ }^{5} 2001$ research suggests that the presence of the mine dumps has 'resulted in large-scale pollution of the sub-surface, affecting an area of approximately $180 \mathrm{~km}^{2}$, [which] poses a potential threat to the scarce water resources (surface and ground) of South Africa'. ${ }^{6}$ The researchers' concern is that acid mine drainage leaves a 'contaminated footprint on the sub-surface, including sulphate, arsenic, cobalt, chromium, copper, iron, nickel, manganese, lead, zinc and cyanide'. ${ }^{7}$

While the presence of the gold-bearing land has had a fundamental effect both on the growth and development of the city and its image, the viability of gold extraction from the dumps, due to modern techniques and high gold prices, has meant that, from the beginning of the 1980s, Crown Mine Properties has been removing the dumps, extracting gold residue and moving the depleted sand away from the southern edge of the city. According to a 2004 article, 'dumps are [being] flattened, and the original landscape revealed' ${ }^{8}$ Because rehabilitation of the contaminated subsoil is expensive, the majority of the land is likely to remain contaminated by toxic residues for decades, preventing large-scale reuse and settlement of the land, as well as the growth of any vegetation upon it. The landscape that remains, therefore, is less likely to revert to gentle grassland, than to remain stripped and scarred swathe through the city.

The scale of the mining land and the specificity of its appearance have resulted in descriptions of it that emphasise its physical rather than symbolic presence. A tourist website, posted by the Johannesburg City Council in 2001, describes this area of land as geography rather than landscape - its author, like others, still struggling to come to terms with its physical character, and enigmatic qualities: 
'The mine dumps, artificial hills of golden sand left over from the mining process, also make for an unusual geographic feature on the southern flanks of the city. ${ }^{\prime 9}$ That this description appears as part of contemporary tourist information about the city confirms the ambivalence and uncertainty with which the mining land is regarded. The ambiguity of the landscape is also compounded by an awareness that its immense pale gold mounds sit as silent representatives of the labour that created the hollowness below. The instability and wealth of the ground itself, and its inability to support substantial constructions on its surface, gave rise to representations that use the image of the artificial landscape as a place of volatility and insecurity.

According to research carried out by Lindsay Bremner, this instability in the landscape is reflected in the intensity of crimes against the body which occur in the mining land. In 1997 she mapped the position and frequency of criminal acts in Johannesburg, including murder, rape, motor vehicle theft and car hijacking. She argues that:

The geography of crime is a geography of vulnerability. In Greater Johannesburg it is drawing to the surface new dimensions of apartheid's mapping of the city and adding further dimensions to its social and spatial divisions...

[T] he areas most disadvantaged or least protected under apartheid are now most vulnerable to murder, armed robbery, rape and violent assault Soweto, Alexandra and Orange Farm. These areas were characterized by the most extreme forms of political disempowerment and economic hardship. They are fragmented, disjointed, demeaning places ... [and] exhibit high levels of violence against women, rape and murder. The mining land, disembowelled and abandoned, that separates Soweto from the inner city, is particularly susceptible to these violent crimes against the body. Rapes, murders and serial killings frequently occur on this polluted and infertile waste land. ${ }^{10}$

The mine dumps remain difficult to categorise; their relationship to the natural world is shadowy and vague. As the contaminated simulacra of natural forms that constitute the only monumental site that the city can offer, they remain outside of familiar categories of landscape. The pictorial view of landscape implies a stable reference point, a stasis in which the completeness of a view can be contemplated. The mining land resists this stasis: even in the tourist images of Johannesburg in which the mining land appears it is only as a fragment, a fraction of the immense stretch of land that recalls the openness of the vast grasslands of the highveld.

\section{The mining land in black poetry}

The choice of the mining land as a physical barrier between white and black has implicated it in the strategies of containment that controlled the movement, occupation, sexual relationships, inhabitation and education of the citizens of South 
Africa. Its use as a strategic landscape has made its meaning more elusive and uncertain. As with other landscapes, and natural physical features that were used to divide people according to race, the mining land is now inseparable from the politics of separation, and the fear that this separation has fostered.

The mining land is further embedded in the instability and ambiguity of the South African landscape because it is partly the product of a process which itself is associated with a dislocation from the land. In a 1998 collection of writings, Negotiating the Past, Nuttall and Coetzee make the connection between the hollowing out of the land that happens during the process of mining and the severing of a link with the landscape.

South African literature is obsessively concerned with land and the emotional and proprietal relations one can have with it ... In the poetry of urbanisation by black South African writers, mining is sometimes described as a process that empties the land of meaning and disturbs men's proper relationship with the ancestors. Once one is forced to leave the land where men's ancestors are buried, the link is severed. Even if land restitution can be made, there is a sense in which particular relationships with land cannot be remembered and reconstituted. ${ }^{11}$

The narration of silence, dispossession, and the division of the city complicates the meaning of the mining land still further. An awareness that the mine dumps were created by black labour working beneath the surface of the earth was noted in an epic Zulu poem by the poet, linguist and lecturer Benedict Vilakazi $(1906-1947) .^{12}$

Ezinkomponi
[Extract]
Ngizwile kuthiwa emgodini,
Ngiyaguquka ngibheke
Ngicabanga ngithi niyozalana,
Khathismbe nande; kodwa qha.
[. . .]
Ngizongena phansi komhlaba
Ngiyoshay' ijombolo phezu
kwetshe
Naw' ongaphandle ongangizwayo.
Uyobona nakho ukuthi
sengiyalishaya
ljombolo lomLungu laph'ubona

\section{The Gold Mines}

[Extract]

Around the noisy compounds of the mines,

We hear that black men born of many tribes

Had come to raise these great white dumps,

Astounding to their ancestors.

[. . .]

See I am going underground

To shatter the rock-face with my pick.

And you above, though hearing nothing,

Will know I wield the white man's drill 


\begin{tabular}{|c|c|}
\hline ..] & {$[\ldots]$} \\
\hline Nmahl' anginandawo & Today I have no place to rest \\
\hline hansi kwethunzi lemicebo. & Beneath dark clouds of alien pov \\
\hline nhlaba wawobab' ulele ze, & Our fathers' fields lie barren now, \\
\hline $\begin{array}{l}\text { Uding' abokuwulima ngihlezi } \\
\text { ngibuka. }\end{array}$ & Untilled by men all cowed like $m$ \\
\hline ..] & [...] \\
\hline nans' ezweni lawobabamkhulu, & Down in our fathers' resting place \\
\hline zwe lamathingo ngamathongo, & $\begin{array}{l}\text { Where you, our ancestral spirits } \\
\text { dwell, }\end{array}$ \\
\hline Kuthiwa ninamandl' angedlulwa & $\begin{array}{l}\text { They say your powers are } \\
\text { unsurpassed. }\end{array}$ \\
\hline Ma nikkhuluma noNkulunkulu & When you commune with God \\
\hline wesikhumba. & $\begin{array}{l}\text { Who sees the man - but not his } \\
\text { colour! }\end{array}$ \\
\hline Elam' igazi lophela phansi, & $\begin{array}{l}\text { Here earth is reddened with my } \\
\text { blood }\end{array}$ \\
\hline _ishe yilanga lijiy' ihlule. & $\begin{array}{l}\text { That clots and dries in savage } \\
\text { heat. }\end{array}$ \\
\hline 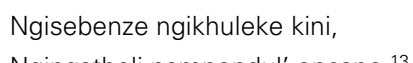 & While I, exhausted, pray to you - \\
\hline
\end{tabular}

'Ezinkomponi' links the form of the mine dumps to the devastation of tribal life, the silence of the ancestors, and the dispossession and 'plundering' of the land. In Vilakazi's nightmare, the silence of the land is linked to the lack of response by the ancestors, while the bodies of the miners work in 'our father's resting place'. The separation from the land that occurred under the system of migrant labour indicates not only a dislocation with the land, but also an uneasiness in spiritual life which is traditionally intimately connected to the earth, through the bodies of the ancestors.

The connection between the physical form of the mine dumps and the bodies that laboured under the soil is further explored in the work of Sipho Sepamla (b. 1932), a poet, writer and novelist. In 'Double-Talk' the mine dumps are not silent, enigmatic mounds of earth, but whisper through the streets of the city.

\section{Double-Talk}

\section{[Extract]}

I was here when the windswept dust dunes

rose in the streets

each footfall of sweatstained man standing up dust

and minedump clouds were rising into the air

galloping like an army of ghosts

tickling the air with whispering sands

teeth grinding grit on dry tongues ${ }^{15}$ 
Because the physical material that constitutes the land - its rock and soil - houses the bodies of the ancestors, who are the spiritual intermediaries between God and humanity, a disturbance of the land can be seen to constitute an interference with the relationship between land, the living and the dead. Any process which contributes to this severance - political removals, mining or migrant labour, for example - is a factor in the separation that occurs between people and the land. A relationship that is later reconstructed, if this is possible, is therefore not one of recovery, but one which incorporates both the disruption to traditional belief systems and the addition of aspects of modernity, with which the person has had contact. The characterisation of mining as an active process which inserts distance between people and the land is made more intricate because it was primarily black men who provided the labour for the mines in South Africa while women remained in the bantustans in order to tend the land and raise families. ${ }^{16}$ In black poetry that describes mines and labour, mining is a process which unsettles the land and cultural and spiritual life.

\section{The Miners}

[Extract]

Against the grating rock

Of these hills dug for gold,

And life is bitter here.

Crawling through the day

In a sleepwalker's dream,

Frightening the night away with my snores,

I dream of the diminished breath

Of miners planted in the stones -

The world is not at ease ${ }^{17}$

Mafika Mbuli describes the process through which gold is extracted from the soil, and lives are buried in the ground. The natural cycle of life lived on the surface, and dead bodies confined to the earth is reversed, as living men are held within the structure of the ground, creating a disturbance in the world, in an uneasy reversal of life and death.

In both 'City Johannesburg' (quoted in Chapter 10) and 'The Miners' the narrators of the poems are concealed; one within the buildings of the city as he labours, the other beneath the ground. Their inability to participate fully in the life of the city means that they are confined to places where they are less visible, less corporeal, and that their experience of the city does not take place in the full light of day. Therefore the invisibility affects both their perception of their lives in the urban economy, as well as how they are seen in the urban area. The physical changes to the city which their bodies create or enable are frequently disassociated from their labour - almost as though the city itself has created its physical form. 


\section{Proposals for development}

Projects which contemplated an alternative future for the mining land, after the decline of mining from 1965, were forced to confront not only the physical form of the landscape, but also its instability and contamination and the presence of bodies of different races to the north and the south. Despite the emphasis on the mines in black poetry, and the significance of mining for migrant labour in southern Africa, proposals for the reuse of the mining land have tended to represent it as a place which has historically excluded black bodies.

The most extensive and detailed proposal for the mining land was the Crown Mines Property Development Project for the Ormonde site, completed in April 1969 by Roeloef Uitenbogaardt, Anthony Barac, Adele de Souza Santos, Antonio de Souza Santos and John Mayle. The intention was to create a relatively high density, primarily residential, area to house upper-middle income whites. There are a number of key issues in the design proposal: the use of a 'natural' landscape as both boundary and circulation system; race as determinate of location, space and amenity, and the effect of Soweto on the design of a white residential area. The spatial fracturing of the city through the separation of races and ethnicities was continued in this proposal. The design proposes an intensification of the separating landscape to form a series of barriers, almost barricades, between different races. These become increasingly more 'natural' the closer that they get to white-occupied space, while Soweto's boundaries are to be reinforced with an industrial area. Landscape is therefore regarded as primarily a white amenity, inserted onto and into an industrial area, becoming simultaneously a buffer and an activator of inhabitation (Plate 11.1). As the report states:

The proximity of the site to Soweto cannot be overlooked. The existence of Soweto poses a number of environmental problems, these need not be detailed, but provisions to counter them should be outlined. Basically, all such provisions can be made in combination by the provision of a suitable hierarchy of buffer zones between the site and Soweto. A logical pattern of buffer zones would consist of an industrial zone bordering Soweto with due precautions to protect the residents from the disamenities of the industry, a band of open space, the Western bypass and finally, on the site, a judiciously designed screen of trees, shrubs, and other landscape features such as mounds and areas of open space. ${ }^{18}$

Along with the proposed trees, shrubs and mounds, the new area offered dense local and surrounding amenities: day care, playgrounds, open space, schools, religious education, sports and social clubs, vocational education, cultural activities, clinics, riding stables, hospitals, spectator sports, botanical gardens, picnic areas, show grounds and aquatic sports. The normative data used to inform the space standards and amenities came from the United States, the United Kingdom, Germany and Scandinavia. This application of western standards to white housing in Johannesburg 
should be seen in the context that (as has been noted by Japha) the space standards for 'native' housing were radically reduced after 1949 to reflect the race of their occupants. ${ }^{19}$ The landscape was activated in the design as an integrated environment which was essential to the success of the project. The project report stated that:

[O]pen space is not simply land not built on for the usual reasons ... that there be 'public open space' in any development; but that it is, in itself, a fully operative sub-system assuming a variety of important functions . . It has continuity - the entire site can be traversed without leaving the system; it has nodality ... and it has its own internal hierarchy of use. ${ }^{20}$

The emphasis on the aesthetics and amenity of landscape are evident in the section of the report headed 'Environmental Improvement'. Here the designers suggest that it should be determined, 'whether it is technically and economically feasible to tap the large quantities of water currently flooding the workings . . . and lead it, in a pleasant stream, to the small lake in the confluence of the east-west and north-south valleys'. ${ }^{21}$ Although the statement that 'Most of the land appears to be highly suitable for residential development' was qualified by noting this was based on 'observation only' and that no testing of ground conditions had been carried out, ${ }^{22}$ the schism between the designers' imagination of the land's future and its contamination of air, water and soil is profound. A verdant, modulated landscape, of mounds, trees, lakes and streams takes centre stage in a scheme which offers the transformative potential of white occupation: buffered by landscape features from adjacent black bodies (Plate 11.2). The conception of 'landscape as amenity', which structures the design proposals, 'appl[ies] to the site as if it were a piece of virgin land', and only its boundaries, with the presence of Soweto and nearby industrial areas, qualifies it as 'not such an area of virgin territory'. ${ }^{23}$ The site is to be transformed through the use of water, through streams, watercourses and ponds, it is intended to glisten with life, to be encouraged to clothe itself in 'grass, flowers, shrubs and trees' ${ }^{24}$

The economic feasibility of the proposal is itself dependent on race, and the report carefully maps out the projected population of South Africa, stating that by 2000 , because of the policy of Separate Development, 75 per cent of the 'natural increase' of the 'Bantu' would 'have moved or have been moved to the Bantu homelands'. ${ }^{25}$

An academic proposal, of October the same year, regards the mining land, and its present and potential landscape, differently. Its author, D.W.M. Moodie, is concerned with the viability of the land for multiracial development - to which he sees two main obstacles: inadequate maps and the proliferation of unlocated servitudes beneath its surface. Moodie is concerned that 'an area of such vital importance to the country has not yet been mapped to a suitable scale for planning purposes', and that the ' 100,000 . . compressed air pipe lines, water mains, roads, powerlines, railway lines and a host of other rights', which are uncharted and sometimes invisible, will present obstacles to development. ${ }^{26}$ Similarly the poor documentation of the undermined land and the fact that, below 800 feet, it was not 
mapped at all, led to the Government Mining Engineer's circular, relating to building restrictions on the undermined land.

(i) as this erf (stand, land etc) forms part of land which is, or may be, undermined and liable to subsidence, settlement, shock or cracking due to mining operations, past, present, or future, the owner (applicant, grantee etc) therefore accepts all liability for any damage thereto and any structure thereon, which may result from such subsidence, settlement, shock or cracking. ${ }^{27}$

For Moodie, the mining land represents a means to reintegrate the city and he therefore argues for a mix of 'white' and 'non-white' residential areas. Moodie imagines the reclaimed mining land as a great sweeping east to west park where 'the slimes dams and sand dumps will in time be covered with vegetation and if not used for residential and industrial purposes will remain as interesting topographical features on an otherwise flat and uninteresting landscape'. ${ }^{28}$ For Moodie, therefore despite growing concern over the polluting dust that blew from the land - the decline in gold mining offers a means to connect disparate areas and races; the landscape becomes a visually differentiated topographic area, which counteracts the surrounding flatness of the Witwatersrand. The land is to be encouraged to clothe itself in vegetation over time, and it is possible to imagine a series of buildings sitting in between the golden mounds. While Moodie's proposal is strategic rather than detailed, and he does not offer, as for the Ormonde site, design proposals including details of housing types and plans for the design of the landscape, the imagination of the landscape is very different. Moodie's attitude is much more passive - to let nature take over the site again over time - while the proactive design of the Crown Mines Property Development Project overlays the image of a verdant green and watery landscape onto the site as a means to claim and transform it.

The feasibility of both proposals is dependent on an ignorance of the scale of the contamination of the mining land, but in the Crown Mines Proposal economic and political pressures contribute to the imagination of a landscape which separates, buffers and segregates, creating an internal world in which a fertile nature, trickling with streams, is reclaimed as a resource for the cohesion of the white community. The Crown Mines proposal conceives of a made landscape which overtakes that of the veld. It is the antithesis of the vast undifferentiated grasslands that confronted the white settlers and is akin to the fertile green landscapes of home that proved so elusive to the early settlers. It is therefore notable that in the mining land - where the contradictions of race, landscape, modernity and politics are intense - an important design proposal should propose a fertile landscape as something that ameliorates both the form of the land and the proximity of bodies of different races.

The 1993 Interim Strategic Framework for the Central Witwatersrand, by GAPPS Architects and Urban Designers, sees the mining land as inseparably part of the city, an underdeveloped section of an 'urban system'. The land is not regarded as landscape (or even topography) at all, but rather as a 'discontinuity', which is to be 
viewed as offering a potential site for 'urban infill initiatives' ${ }^{29}$ The fragmentation of the apartheid city is to be overcome by adding infrastructure and housing to the 'vacant land' that is now occupied by the detritus of the mines. This is a proposal of transport networks and nodes - by analysing the city as a strategic surface it demonstrates little interest in experiences other than movement and connectivity or meanings that may incorporate the history and experience of the mining land.

This proposal offers to solve the 'problem' of the mining land by another kind of erasure - open space is to be filled with buildings, the space between Soweto and the city is to be breached, with land that is discontinuous regarded as being the 'highest priority'. The proposal represents a desire to overcome, to invert, the politicisation of landscape as buffer zone through an intensification of the city on the surface of the land that divided people according to race and modernity. It is a proposal that seeks a kind of equality - equal development, equal access to services, equal proximities to networks, which themselves (the proposal asserts) should be evenly distributed through the city. It relies on population growth and technology to overcome the vast scale and the contamination of the land, and also the limitations of its geological structure. The GAPPS proposal raises a series of questions about the meaning and change in meaning of the mining land, and the potential it may have to contribute to the image of the city in the post-apartheid period. Is the mining land to be seen only as a strategic surface, one which can overcome the past by becoming more like the city? Can a different understanding of landscape offer a means to negotiate and retain the complexity of the land, even as it is developed and altered?

The mining land is a site in which the concept of landscape stretches and is transformed. It is a place that connects rural areas into the city through the movement and memories of migrant labourers, weaves the geological structure of the city into its buildings and spaces, continues to separate bodies of different races, and offers a vision of modernity which incorporates decay and contamination. It has been represented as being both within and outside known categories of landscape and is both visible and invisible - accessible and inaccessible - to the imagination of the city. The mining land bears the consequences of its past - in the instability of its structure, its polluting sand, wind and water and the meanings that it holds. It is intricately tied to the history of the city and its development and to the physical and emotional experiences of the city that the next chapter discusses. 


\title{
Chapter 12
}

\section{Invisibility and silence}

\author{
Location Fires ${ }^{1}$ \\ Beneath my eyelids \\ the landscape is heavy \\ the people are buried in ground- \\ clinging shapes of houses \\ From Langa to Nyanga ${ }^{2}$ \\ the fires are hidden \\ the landscape is flattened \\ frightened and silenced \\ Where are the fires \\ for me to believe in \\ where are the tongues of flame \\ to lick and conquer the dark \\ In answer the black body \\ of the sky rears up \\ loud with roaring \\ voices of the stars \\ The stars tonight \\ are blue backyard fires \\ studding the black \\ location of the sky ${ }^{3}$
}

The invisibility of the landscape can imply not only an absence of meaning, and a removal from the visual field, but also an active silencing of the occupants of the land 
that has removed their ability to 'speak' its meaning. This silencing of the land, its quality of being 'flattened' and 'frightened', is articulated in the poem, 'Location Fires', by Jennifer Davids, a poet who was born in Cape Town in 1945, and who grew up with the changes to the city under apartheid legislation. The poem was published in 1974 in a collection called Searching for Words. The struggle for speech that was present in white representations of the land is here echoed in a black writer's battle to record the landscape, the alterations that have been made to it, and to occupy it again through this process of writing the transformed land. The title suggests that landscape requires its own language, one which is responsive to transformation and distance. The landscape that she describes is that of the Cape Flats, which houses the townships, beyond the city of Cape Town and Table Mountain. The 'flattening' of the land refers not only to a deadening of its meaning, but also to a description of its physical characteristics - flatness and dryness. The lack of electricity in many areas - particularly in the informal settlements - has resulted in a reliance on coal fires, which light the darkness of the townships. Davids uses an analogy with the overpowering presence of the sky, lit by tiny stars, to intimate that, as the sky's presence is pervasive and overarching, so is that of the many people who light the coal fires that burn like stars in the blackness.

At the time that this collection was published, District Six - the multiracial area in the heart of Cape Town - had largely been demolished, and many of its citizens had been moved to the Flats, and away from the landscape of mountain and sea. The process of removal from the city, along with the monotony of the townships of the Cape Flats, was instrumental in the rupture which opened up between people and the land that they were able to occupy.

This chapter is concerned with visibility and invisibility and with the relationship of seeing or not seeing the land and its inhabitants with the perception of completeness and incompleteness. It focuses on urban areas during the period of National Party rule. The use of the landscape to render people less able to participate in the social, cultural and political life of the city meant that the land itself was represented as being silent and unresponsive. Because the land was viewed as a strategic tool in the separation of people according to race, elements of the landscape that were present in the developed areas - rivers and mountains together with industrial land and roads - were viewed by those in control of the operation of the Group Areas Act as being significant primarily in terms of their ability to render people invisible.

While many white representations of the land can be seen as a struggle to understand the landscape of southern Africa, often with reference to pre-existing European cultural images, these representations are haunted by failure and by the same distance from the land that they seek to overcome. The recurrent failure by many white South Africans to 'see' the land and their inability to contain it within a system of cultural reference meant that the land - and representations of it - remained, at least partially, silent and 'invisible' and its meaning uncertain and elusive. The image of the city was also subject to the same uncertainty. The alterations to the land and the 
control of inhabitation and movement of black South Africans, under the increasingly restrictive legislation of the later part of the twentieth century, meant that unfamiliarity, uncertainty and violence were also present in black experiences of the city.

Urban and rural areas were locked together by labour and the image of the landscape. The apparent completeness that rural landscapes offered was dependent on the reciprocal removal of black urban rights. The presence of black South Africans in the city was regarded as impermanent - an incomplete and partial urbanity. The temporary status was dependent on the ability of the government to separate, to define and categorise. The separation of people according to race resulted in the use of areas of the city as thickened boundaries, which inserted distance into the proximities of the city and the proximities of the bodies that inhabited them. The inherited contemporary city landscape, therefore, is one which is dominated by the debris of modernity and complicated by the strategies of spatial planning that employed (often symbolic) landscapes in the separation of different racial groups.

The control over minutiae that was thought necessary to maintain political power resulted in the profusion in government files of information, an intensity of visibility over people, their labour, movement and occupation of land. It was this exhaustive detail that was used to suppress the visibility of those bodies who were not considered to be a legitimate part of the city, but whose labour was necessary to create and sustain it. While, for white South Africans, it was impossible not to see the black South Africans who walked down the street, worked in the factories, mines and in their homes, their presence in urban life was partial. The action of slipping in and out of the city at dawn and dusk rendered them not wholly invisible, but as incomplete participants in urban life. In black poetry people are often described as 'shadows', as 'ghosts', only partially present. This incompleteness was supported by the incompleteness of the urban environments constructed to house black South Africans, in the missing fragments of urbanity that were present in white suburbs to the north, and in the legal restrictions that governed their actions.

\section{The Group Areas Act and the apartheid city}

From 1923, under the Native Urban Areas Act, black South Africans were permitted to reside in the township areas only if they could prove employment in the city. ${ }^{4}$ The later Group Areas Act restricted where people of all races and ethnicities could reside and conduct business, so people who were not classified as white were unable to participate in the life of the central city, except as transitory labour. It was from the outlying townships, which were usually separated from the city by natural and humanmade barriers, that people would be expected to travel daily in order to supply labour. The exception to this was the presence of black domestic workers, usually female, who often had quarters adjacent to, and in the grounds of, white-owned houses. ${ }^{5}$ Physical segregation between the races was here suspended in order for black domestic workers to share the home environment of whites, and often to nurture their children. 
The political policies of twentieth-century South Africa created a city of multiples, where the dormitory cities of the townships formed the invisible ailing twins to their more robust siblings and where, within white properties, black domestic living quarters were not subject to the minimum room sizes and ventilation requirements of the National Building Regulations. Apartheid therefore created different physical environments for people of different races, even when these were embedded within one another. Black urbanity was never eradicated, just temporarily contained behind (or concealed within) natural and human-made symbolic landscapes. The artificiality of the multiple city, and the dependence of its establishment and growth on legislation was something of which black South Africans, in particular, were acutely aware. In the poem that follows, Modikwe Dikobe documents the absurdity of this spatial repetition, in the creation of Soweto, and of the wider political relationship that fostered its existence.

\author{
A City within a City \\ [Extract] \\ South of a city is a city \\ Ten miles south of a city \\ Founded fifty years ago \\ By the by-laws of a city \\ Under Ordnance 10 of a province \\ Up north. ${ }^{6}$
}

The Act provided evidence of the political zeal with which segregation was approached by the new government and of the extent to which maps were relied on as a source of information, in which people of different races were represented by a system of coloured symbols. The insistence on the rural and ethnic identities of black South Africans and a belief in social and physical segregation between all races underpinned this legislation. Race was fractured into smaller ethnic units: the definition of 'European', 'Bantu', 'Indian', 'Malay', 'Chinese' and 'Coloured' areas had physical and social consequences for the city and its citizens in the removal of people and the development of new racially specific areas. The focus on the ownership and occupation of every building that was possible with the government-sanctioned forms of representation resulted in an extreme visibility of bodies and places that facilitated their control. The ability to monitor individual lives, through (for example) the migrant labour pass laws, was used to control the presence of people in the city, in order to ensure that their bodies became less visible. The reliance on legislation did not remove people who were not classified as white from those who occupied the white city, but rather prevented equal contact, socially and economically, as well as the creation of equally developed environments.

This process was designed to ensure that black people were conscious both of the temporary status of their long-term occupation of city space and also that daily incursions into the white city always involved a return to the space outside its formal limits. It is worth noting that the idea of the segregated city was not a new 
political policy, but one which was already present before National Party rule. The Social and Economic Planning Council (SEPC) set up by Jan Smuts (then Prime Minister of the Union of South Africa and the leader of the United Party) to advise the Cabinet in 1944 recommended that the 'British model of planning', using green belts to separate residential areas be followed. In South Africa, this involved the use of green belts to divide people of different races. ${ }^{7}$ The use of vacant areas of land, which often cohered with existing landscape features, was not without precedent in international thinking about city and suburban planning, although its use in South Africa was dependent on policies of segregation.

A memo written in 1956 by the Commissioner for City Areas reveals the dependence of the implementation of the Group Areas Act on maps and plans of the area, as well as documentation of race and the natural and human-made features of the land as means through which the position of 'Native Locations' could be planned.

\section{THE CONTROL OFFICIAL (CITY AREAS) \\ THE LAW OF GROUP AREAS, 1950 \\ AS AMENDED: FOUNDING OF NATIVE LOCATIONS ...}

2. The method that I actually follow is to attach a clear plan of the town, environment and the location, upon which roads, mountains, rivers etc., are indicated to serve as my reference.

Further the surroundings are clearly set forth and the neighbourhoods of the different races are shown, and the possibility of the development of the town, location and/or other race groups neighbourhoods is also properly dealt with, as well as any available ground for future expansion. ${ }^{8}$

Deborah Posel has argued that the confidence of the National Party in the power of the centralised state to solve social problems through the implementation of a modern programme was held in common with others in the western world after the economic Depression of $1929-1932 .{ }^{9}$ She asserts that during the period of National Party rule this belief was directed at racial policy. Modernity, the state and race became inseparable during the second part of the twentieth century.

By re-imagining the capacities, scopes and entitlements of the state along more 'modern' lines, it became possible in turn to imagine a society in which constructs of race became the all-embracing, ubiquitous basis of the social order fashioned by that state. ${ }^{10}$

The reliance on forms of representation of the land that were seen to conform to the requirements of modernity, rationality and objectivity, therefore provided a means through which the landscape was represented purely as a means through which the social and political goals of the state could be achieved. The signs, maps and diagrams through which race was mapped were a product of the belief in 'true' and rational forms of representation to achieve social goals. But this veneer of 
completeness and control was troubled both by the scale of the ambition of the government and by the lack of properly trained personnel in the civil service. Posel has pointed out not only that the huge increase in size of the state bureaucracy during the apartheid years allowed the gathering of knowledge about South African citizens, but also that this intense scrutiny was less the efficient modern machine that the government desired and more a generator of 'incomplete and unreliable' information. ${ }^{11}$

The city and the bodies within it were so circumscribed by laws which overlapped and sometimes contradicted one another that the veneer of a rationalised modern state became undermined in the act of governing. The bodies of people who were not classified as white were caught in a profound contradiction. Not only did the legislation require the registration of their race, location and employment, engendering a state in which the person was controlled and 'known' through a wealth of documentation, but also the city closed its face to their presence, rendering them invisible, unable to penetrate the city, as they had themselves been penetrated by documentation and surveillance.

Early applications under the Group Areas Act, and replies to them from government, reveal the contradictions beneath the apparent surface of order, and the shifting boundaries which people had to negotiate to occupy property and carry out business in an area which was not assigned to their racial group. Because the legislation was dependent on previous ownership, as well as racial grouping, overlapping legislation sometimes created an area which could not legally be occupied, as is shown by the extract below, from a letter from the Land Tenure Advisory Board to a firm of lawyers, Shenker, Shenker and Solomon, in 1953, in response to their query about the occupation of a property by an Indian client.

The position is that nobody may at present lawfully occupy the premises vacated by Ganesh Ooka. A member of the Indian group will contravene the provisions of Section 131 of Act No. 35 of 1908 unless he can obtain an exemption in terms of Section 131 A of that Act and a member of a white group will contravene Section 12 of Act No. 41 of 1950 unless he can obtain a permit in terms of Section 14 of this Act. Members of the other coloured groups will require both an exemption in terms of Section $131 \mathrm{~A}$ of Act No. 35 of 1908 and a permit in terms of Section 14 of Act No. 41 of $1950 .{ }^{12}$

A letter from the same period precisely documents the intricacies of racial classification, and the repercussions that this classification could have for the right to occupy the city. Mr Coovadia, the applicant who wishes to buy a property, traces both the legislation that could affect the sale, as well as the processes of racial reclassification which establishes his right to purchase the property.

I am trading on this property under the style of the Bombay House, and I am also residing on this property. The property is situated in an area 
populated almost exclusively by Indians, and the area is known locally as the Indian area . . .

The aforementioned Erf is presently registered in the name of Mahomed Sadick Makda, who holds it by virtue of Deed of Transfer No. 9048/1934, dated 17th August 1934. At the time transfer was passed to him, he filed the Marriage Certificate of his parents with the Registrar of Deeds, as also an Affidavit to the effect that, as he was the offspring of a union between an Indian and a Cape Malay, he was a Cape Malay, and accordingly not affected by the provisions of Act No. 3 of 1885. The Registrar apparently accepted this as the correct position and he was accordingly given transfer of the property.

During 1934 Makda was officially recognised as a Malay and enjoyed the rights of Malays in South Africa. By virtue of the Group Areas Act of 1950, Makda was deemed to be an Asiatic, because he had the same daily habits as and associated with Asiatics. As he is now deemed an Asiatic, he is entitled to transfer the property to myself, because I am a member of the same Group. ${ }^{13}$

These letters, and others like them held in the government archives, provide us with an image of the city in the years immediately after the Group Areas Act was introduced. The city that emerges is one in which negotiations about race are familiar, which is overlaid with a tracery of legislation that creates intangible, continually shifting boundaries.

The presence of countless diagrams, maps, letters and instructions about how race should be appropriately represented in the city are signs of an attempt to control minute aspects of people's lives. The detailed information required for each application under the Group Areas Act was such that the applicant was required to map themselves, and the occupation and use of the land around them. The applicants were required to submit, with the Application Form, 'a certified or photostatic copy of the surveyor's diagram of the property' and '[a] locality sketch showing the group character of ownership and occupation of a sufficiently large area surrounding the property(ies) to which the application relates prepared in accordance with the Board's colour scheme.' ${ }^{14}$ This locality sketch was carefully prescribed, requiring street names, subdivisions and

if the application relates to one or two or more buildings on the same site or of a portion(s) of a building, a sketch plan (or building plan, if available) reflecting the racial occupation of each separate apartment of the building, must accompany the locality sketch. ${ }^{15}$

Race, ownership and occupation was indicated through the use of a set of colour and symbols set by the Department of Bantu Administration, which were as follows: 


\begin{tabular}{|c|c|c|c|}
\hline Colour & $\begin{array}{l}\text { Group or } \\
\text { sub-group }\end{array}$ & Colour & $\begin{array}{l}\text { Group or } \\
\text { sub-group }\end{array}$ \\
\hline Blue & White & Black & Native \\
\hline Brown & Cape Coloured & Red & Indian \\
\hline Mauve & Cape Malay & Yellow & Chinese \\
\hline Orange & Government & Green & Local Authority \\
\hline Symbol & \multicolumn{3}{|l|}{ Meaning } \\
\hline Circle & \multicolumn{3}{|l|}{ Ownership } \\
\hline Dot & \multicolumn{3}{|c|}{$\begin{array}{l}\text { Residential occupation or occupation } \\
\text { of an unspecified nature if the nature } \\
\text { of the occupation cannot be indicated } \\
\text { by a more appropriate symbol }\end{array}$} \\
\hline V & \multicolumn{3}{|l|}{ Unoccupied } \\
\hline $\mathrm{T}$ & \multicolumn{3}{|c|}{ Occupied for trading purposes } \\
\hline A & \multicolumn{3}{|c|}{ Occupied for agricultural purposes } \\
\hline S & \multicolumn{3}{|l|}{ School } \\
\hline Cross & \multicolumn{3}{|l|}{ Church } \\
\hline C & \multicolumn{3}{|l|}{ Cemetery } \\
\hline $\mathrm{R}$ & \multicolumn{3}{|c|}{$\begin{array}{l}\text { Recreation grounds, parks, open } \\
\text { spaces in towns }\end{array}$} \\
\hline$P$ & \multicolumn{3}{|c|}{ Government and Municipal buildings. } \\
\hline
\end{tabular}

The complexity of the inhabitation of the cities and the proliferation of the proximities that the Group Areas Act was intended to prevent can be traced in the examples given, by the same circular, which were offered as a guide to those preparing the documentation. So, for example, a 'Red dot in blue circle' indicated 'Owned by whites and residentially occupied by Indians', while a 'Yellow T in blue circle' indicated 'whiteowned and occupied by Chinese for trading purposes' and 'Red dot and red $T$ in red circle' indicated 'Indian-owned and Indian occupied for residential and trading purposes' (Plate 12.1). ${ }^{16}$ The elaborate system of signs and symbols was intended to act as a means through which the proximities of different races in the city could be rationalised and modernised, but it also created an image of the city in which the intertwining of lives became evident.

\section{Modernity, completeness and the occupation of the city}

The commitment to modernity in the production of a modern state was mirrored in the embrace of the forms of the modern city. Technology, efficiency and industrialisation were an implicit part of the political system of the National Party. The modern monuments of the cities were represented as being indicative of progressive policies and economic success, as was the growth of the settlement and the establishment of a landscape of trees and gardens in the white suburbs to the north of the city. The 'progress' that the landscape has made, in coming closer to the dense, 
differentiated tree-covered landscapes of Europe, is still celebrated in contemporary tourist information:

[V]isitors are often surprised by how attractive parts of Johannesburg can be. The older suburbs, for example, are sited in rolling hills and have treelined streets, nature reserves, hiking trails and parks. Indeed, there are said to be more trees in Johannesburg than in any other city in the world, making it the world's largest 'artificial jungle'. Maybe the obsession with trees relates to the subconscious yearnings of the earliest settlers, who trekked across the country to find nothing but a treeless savannah here. For the record, there are 1.2-million trees on Johannesburg's street verges alone; add to this all the tree-lined parks and lakes and the likelihood is that the city has more council-owned trees than residents... Johannesburg has 80 hectares of botanical gardens. ${ }^{17}$

The anonymous author, whose goal it is to present Johannesburg as an attractive place to visit, emphasises the transformation of the landscape, from a 'treeless savannah' to the 'world's largest "artificial jungle"'. The 'obsession with trees' is explained as a response to an area of land that lacked them, that was perceived to be an incomplete landscape because of this absence. The density of the established trees in the northern suburbs is even more noticeable on a journey which crosses the mining land, south, to Soweto. The micro-climate that Johannesburg's trees have created is absent in the townships. It has been noted by observers, such as Owen Crankshaw and Susan Parnell, ${ }^{18}$ that the township landscape was incomplete. The streets were often either non-existent or dirt tracks, there were no street lights, trees, street names, road signs or kerbstones. Steve Biko, writing in the early 1970s, remarked on the effect of these physical distinctions, and how they cohered with a perception that, as the landscapes of the townships were incomplete, so were the bodies that inhabited them.

The homes are different, the streets are different, the lighting is different, so you begin to feel that there is something incomplete in your humanity, and that completeness goes with whiteness. ${ }^{19}$

Biko's observation is that the physical differences between segregated environments are directly associated with differences in how people perceive themselves in relationship to others. A question that he does not raise is what the 'completeness' of the white environment is based on, what aspirations and hopes it represents, and how the image of a 'complete' environment may conceal another kind of absence, one which was hinted at by Can Themba in his celebration of Sophiatown. While Sophiatown was physically indistinguishable from its adjacent white neighbours, in the decades after the passing of the Group Areas Act physical distance and differences between areas which accommodated people of different racial groups became increasingly marked. It has been suggested by the Drum photographer Jürgen Schadeberg that it was the 'completeness' of Sophiatown, the trams, cinema and 


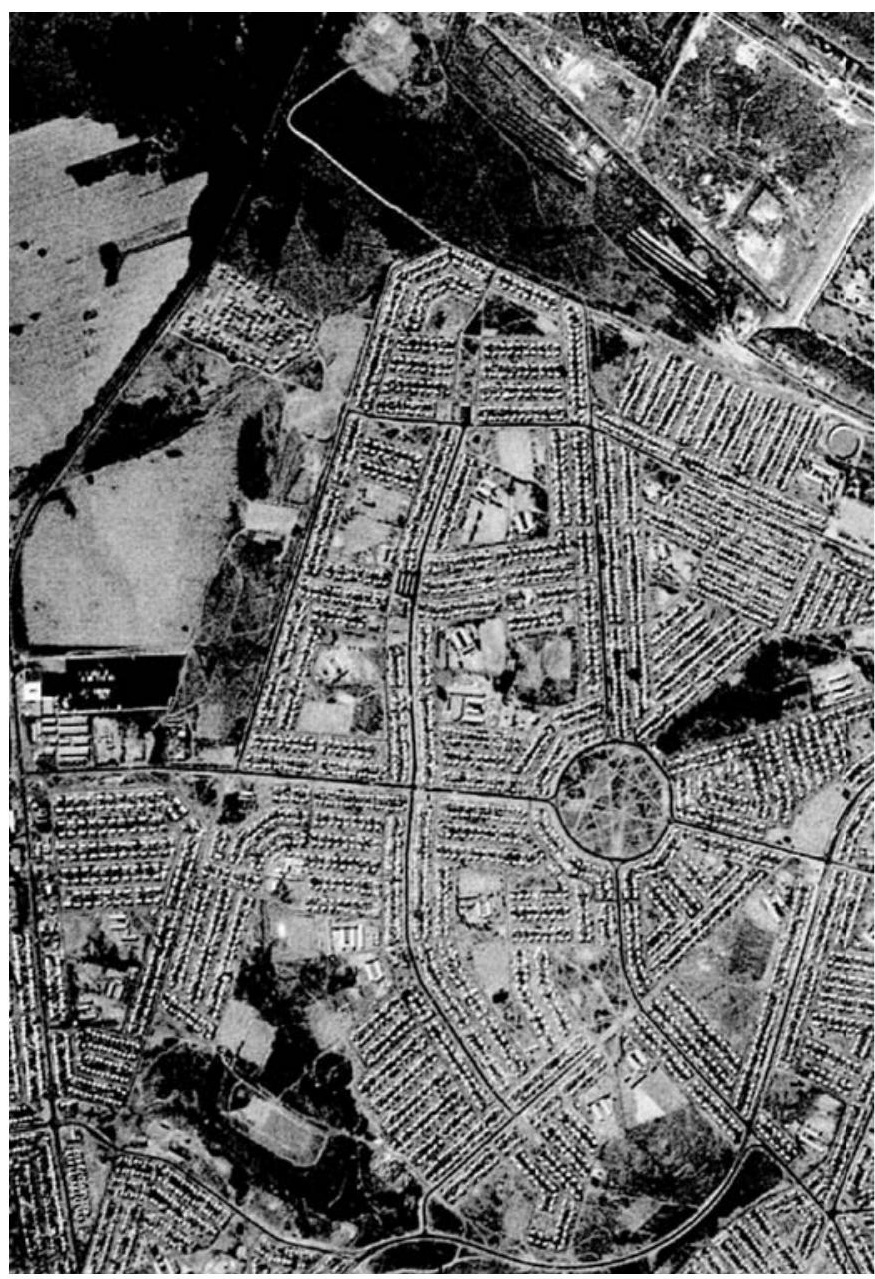

electricity, marking it out as a fully fledged suburb and not a township, that contributed to its removal. ${ }^{20}$ The ad hoc nature of the townships was also commented on by writers such as Nat Nakasa, who had witnessed the removals of Sophiatown and the transfer to the new suburb of Soweto - Meadowlands. His description here also recovers the argument made by Themba in the days of Sophiatown's existence, that the inhumanity of the surroundings did not mean that urban life, in the full sense of exhilaration and happiness, could not occur.

At a glance Soweto looks dull and lifeless. Almost all the houses are built to the same pattern - thousands upon thousands of small match box cottages separated from each other by wire fencing. In some parts the

12.1 (above) Aerial photograph of the suburb of Meadowlands in Soweto (1984).

Reproduced under South Africa

Government Printer's Copyright Authority no. 11296, 1 November 2005 


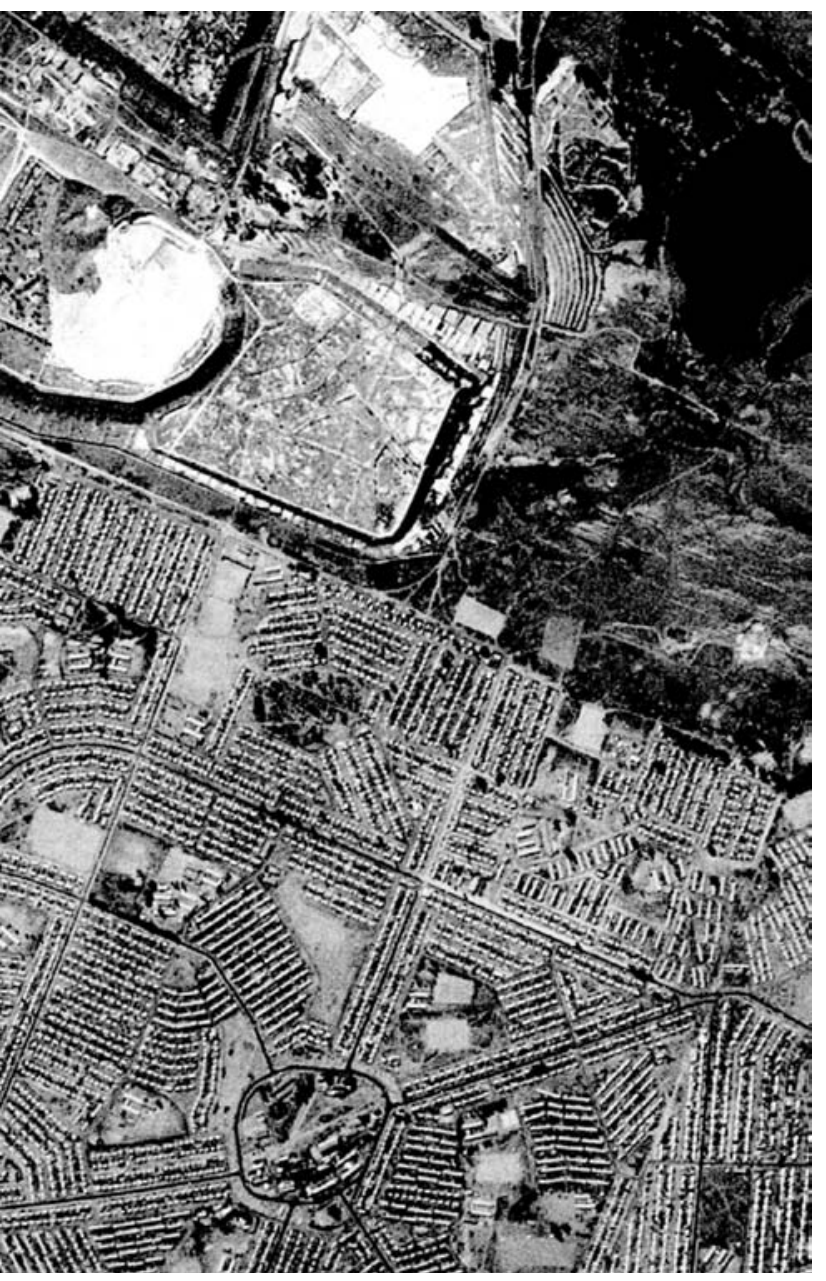

fence looks like an emergency camp ... Yet, in spite of all this, Soweto lives. It lives precariously, sometimes dangerously, but with a relentless will to survive and make the best of what I think is an impossible job. Soweto lives fitfully, mainly at the weekend, but it also survives for a few hours during the week. ${ }^{21}$

As well as being a spatial strategy whereby black presence was removed from white inhabitation, the creation of the townships contained the threat of violence within a policable area. The townships themselves were laid out with wide streets in a radiating pattern in order to assist in the control and surveillance of the population. The houses were detached and laid out in precise rows, which enabled the movement 
of bodies between properties to be seen from the street (Figure 12.1). The separation from the white city, the control of transportation systems and the internal planning of the townships also allowed the areas to be periodically sealed off during periods of intense resistance to National Party rule and allowed the violence to be held at a distance, seen by many white South Africans only through the governmentcontrolled news broadcasts on television, and heavily censored newspaper reports. The interdependence of the lives of all South Africans meant, however, that an awareness of the violence, if not direct contact with it, filtered through to the white cities. The distant violence of the townships was brought into the city by the bodies of those who were subject to it.

The policies of the National Party government were not unopposed, by the black population, some white organisations, and some local City Councils - who were increasingly being asked to shoulder the large financial burden of the removals and were forced to comply with the provisions of the Group Areas Act. An article in the Rand Daily Mail in 1951 documented opposition to the implementation of the Act, both from ratepayers and from the Johannesburg City Council. This article highlighted the financial cost to the white ratepayer in order to implement a policy which many felt was both political and ideological. ${ }^{22}$

\section{Silence, violence and invisibility in the experience of the city}

The perception that the bodies of people of different races were differentiated by their ability both to be seen and to affect the physical form of the city was developed in a number of works produced during the 1970s and 1980s, which evoke the invisibility of places and people. Dikobe's poem, 'Klip River', seems to suggest that the invisibility of people within the city is an extension of their status as suspended subjects of a place that cannot be seen or imagined.

\section{Klip River ${ }^{23}$ \\ [Extract] \\ Calm your current \\ We're strangers in this country \\ Beyond those towers, we come from \\ Beyond sight of eye. ${ }^{24}$}

The title of the collection in which this poem was published, Dispossessed, hints at the wider subject which connects the poems: an exploration of belonging to the land, and the disruption of this relationship. The place from which the people came to the city is no longer visible; perhaps because it no longer exists, perhaps because it is so far from the imaginings of the citizens of the city that it cannot constitute part of its reality. Dikobe also seems to suggest that the structure of the city - 'those towers' - contribute to the way in which the land is made strange, by dispossession and then transformation. 
The dystopia of the urban agglomeration of Johannesburg and its major townships of Soweto and Alexandra gives rise to the extreme violence of Serote's vision of race and the city that neither sees, hears nor acknowledges his presence.

\author{
A Poem on Black and White \\ if I pour petrol on a white child's face \\ and give flames the taste of his flesh \\ it won't be a new thing \\ i wonder how i will feel when his eyes pop \\ and when my nostrils sip the smell of his flesh \\ and his scream touches my heart \\ i wonder if $\mathrm{i}$ will be able to sleep; \\ $i$ understand alas i do understand \\ the rage of a whiteman pouring petrol on a black child's face \\ setting it alight and shooting him on a pretoria street, \\ pretoria has never been my home \\ i have crawled its streets with pain \\ i have ripped my scrotal sack at every door i intended entering \\ in that city \\ and jo'burg city has never seen me, has never heard me \\ the pain of my heart has been the issue of my heart \\ sung by me \\ freezing in the air \\ but who has not been witness to my smile? \\ yet, alexandra's night shadow is soaked and drips with my tears ${ }^{25}$
}

The violence that Serote describes is inseparable from the spatial divisions between the apparently white cities of Johannesburg and Pretoria and the place that does record his presence, the black township of Alexandra to the northwest of Johannesburg. Serote imagines brutal and intimate confrontations: closeness of flesh, smell, sight and sound which stands in opposition to the detachment of closing doors and turned away faces. The dispassionate face of the city and its impenetrability is set alongside the extreme violence of government agents, which have as a product these imaginings of aggression and frustrated rage. The image of the city that emerges is one in which the language of violence becomes the only means to communicate through the sightlessness and soundlessness of the city.

Serote's poem describes one reaction to the physical and social constraints of the structure and boundaries of the segregated city. The legislation which sought to control black interaction with urban places, closing the city to many of its citizens, also produced a culture of fear, which was represented in writing through the period of National Party rule. Under questioning in the Black People's Convention/ South African Student's Organisation (BPC/SASO) Trial, ${ }^{26}$ in May 1976, when Black Consciousness leaders were held and later convicted under the Terrorism Act, Biko responded to a question from the defence counsel, David Soggot, about the strength 
of the Black Consciousness movement by describing the fear with which many South Africans lived.

But part of what you are trying to kill has not quite died, the whole concept of fear, and black people are steeped in fear... They are afraid of existing structures and reactions you know, from the system (the South African security network), so that they may not come forth. ${ }^{27}$

The fear which Biko described in the 1970s was also articulated by earlier writers. After the events in Sharpeville in 1960, the violence of the government reaction and the increased scrutiny of all activity, which could be seen to oppose National Party rule, exacerbated the climate of fear which acted as a deterrent to many writers and artists. Nat Nakasa described the pervasiveness of this emotion, and the possibility of silence in response to it.

I may shut up for some time because of fear. Yet even this will not make me feel ashamed. For I know that as long as the ideas remain unchanged within me, there will always be the possibility that, one day, I shall burst out and say everything that I wish to say in a loud and thunderous voice. ${ }^{28}$

The silence that was present in the landscape was a product not only of an alienation from the land, but also of an active removal of speech that could oppose National Party rule through the legislation which could censor publications and 'ban' people by restricting their movements, speech, writings, political activity and personal associations. The poet Achmat Dangor's despair at the silencing of speech and writing through the banning of political activists, poets and writings is associated with a silence in the landscape.

\section{The Voices that are Dead}

[Extract]

There is silence

upon the river tonight.

No great floods of song

flow out into the darkness,

our voices are dead. ${ }^{29}$

\section{Silences in the texts - newspaper censorship and protest}

The silences in the land were represented in poetry, in prose writing, and were also recorded as omissions in the printed page of newspapers during a brief period in June 1986, the tenth anniversary of the Soweto riots. At this time a group of newspapers, inspired by the previous actions of colleagues in white-ruled Rhodesia, ${ }^{30}$ before it became Zimbabwe in 1980, decided that one way in which the extent of government censorship could be represented was to record it on the surface of the printed page. This period was significant because that which was not visible, and 
12.2

\section{Cartoon of silent speech. The Sowetan, 19 June 1986.}

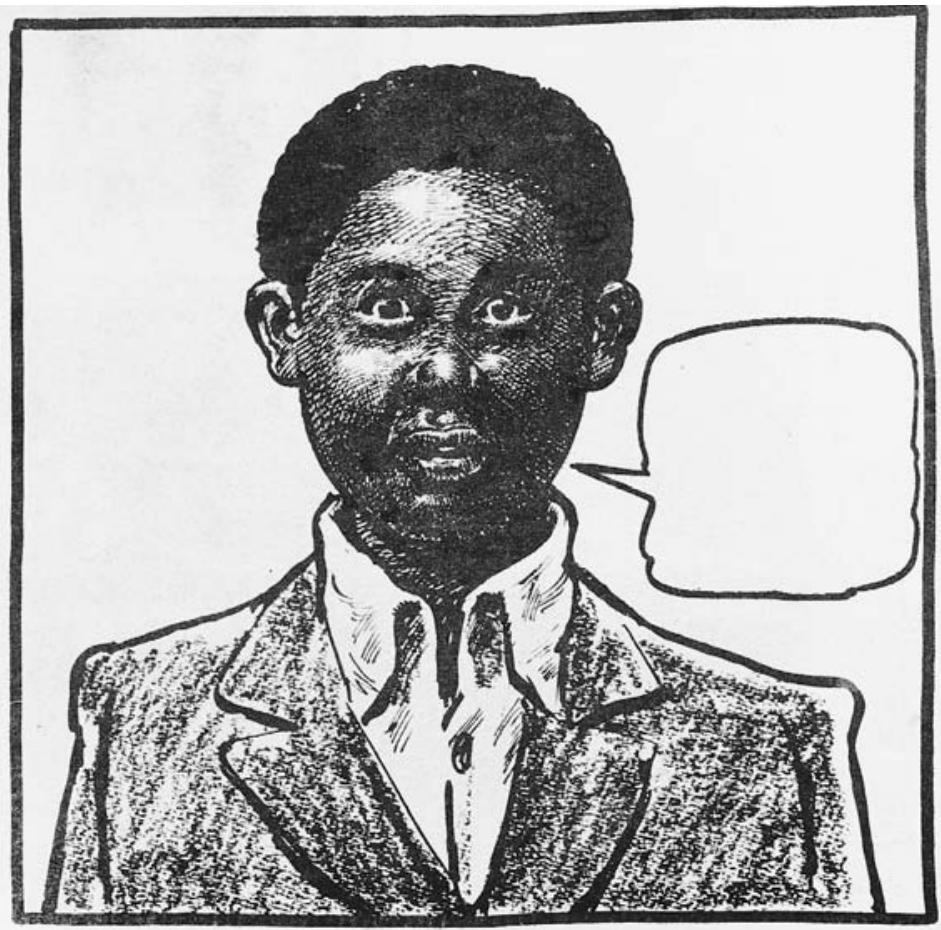

could not be printed or read, was given visual form, a shape, dimensions and physical presence through its proximity to photographs and texts.

From the page of the newspaper a man stares out, mouth slightly open as if speaking (Figure 12.2). He wears a jacket and shirt, open at the neck. His clothing is well-mannered, conventional. He doesn't appear in the guise of a warrior or a tribesman. He is clearly a city dweller. The speech bubble beside his head, however, is empty; his open mouth silenced by the emptiness of the space beside him. The drawing takes a familiar mode of communication common to newspapers - that of the cartoon - and substitutes the capitalised one-liners of comic and political cartoons with blankness. This blankness, as the authorities soon recognised, did not represent the absence of speech, but the removal of it. It indicated a silencing, a censorship, of the words that were emerging from between the ready lips of the man. It is clear that the meaning of the drawing is also dependent on its appearance in a newspaper, which exists to give information, to print words. In this dense document the appearance of blank spaces is evidence that the flow of text has been interrupted, impeded and altered; that the remaining text is incomplete.

The newspapers that engaged in the campaign to depict the censorship of information were The Weekly Mail (20-26 June 1986), The Star (Wednesday, 


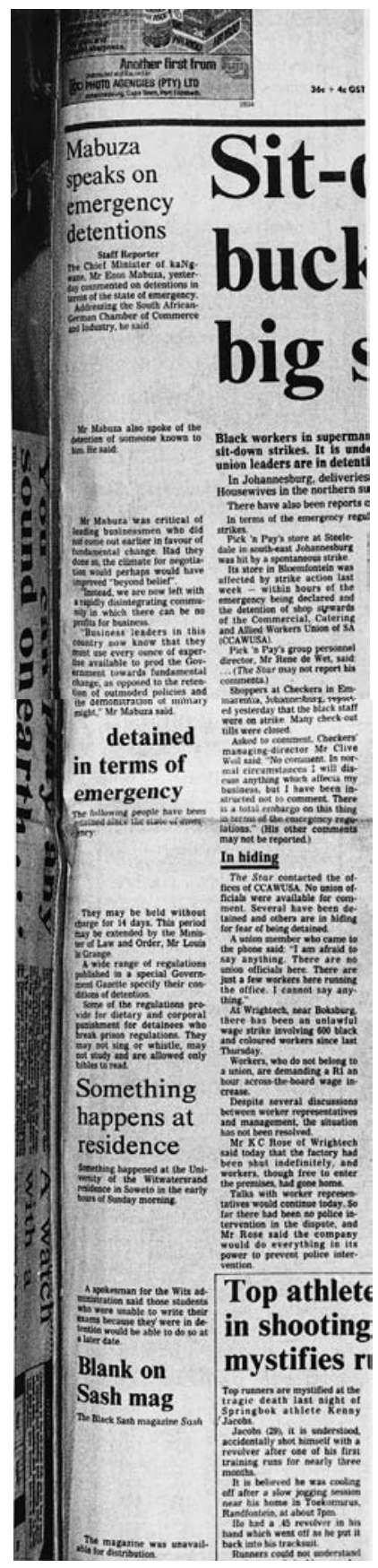

18 June 1986) and The Sowetan (17, 18 and 19 June 1986). The restrictions on the press were part of a national State of Emergency declared by the Prime Minister. The crackdown on reporting was part of a larger attempt to control the flow of information to the public, in anticipation of escalating political resistance. The newspapers recorded the erasure of information in two ways. The first method, used by The Star and The Sowetan, retained the empty space where the words, or photographs, should have been (Figure 12.3). Censorship was indicated by the absence of printed words and photographs, by emptiness. This action spatialised the censorship because it recorded not only the fact of censorship, but also its size and shape, relative to the text that was retained. It represented the extent of censorship in such a way that the lost information gained a visual form, a bulk, usually absent. The shape of the words remains nebulous, giving only a spatialised sense of their collective absence and emphasising our inability to recover their meaning. The empty spaces receded from the page. Because they did not adopt the alternative technique (used by the Weekly Mail of overprinting censored text with black lines, the blank spaces are not immediately obvious to the casual eye. One only becomes gradually aware of the presence of lines of omitted type, and then is drawn into guessing their content through the shape of the space left behind and the clues of the remaining text.

The Weekly Mail chose to represent the extent of the restriction of information by overprinting black rectangles on lines of text (Figures 12.4 and 12.5). Their presence became the subject of the newspaper. The information which remained uncensored is

12.3

Blank spaces in the text. The Star, 18 June 1986, front page. 
12.4

Censored page in the Weekly Mail, 20-26 June 1986, p. 12 , showing the combination of black lines overprinted onto the text, and the 'restricted' banner printed across the empty space where a photograph would have been located.

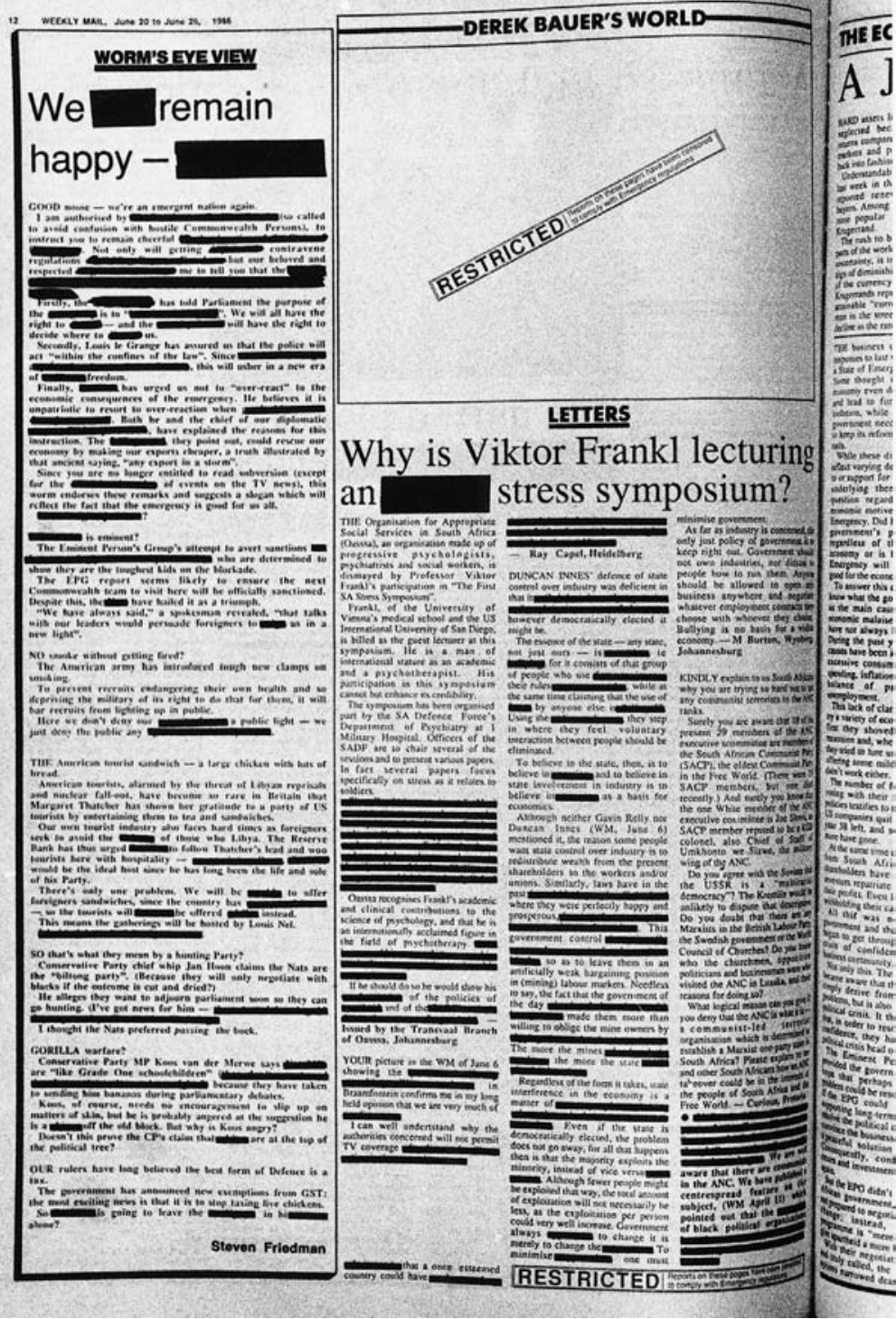

devalued, not only because it often becomes unintelligible, but also because it is rendered insignificant, and less informative, by the power and brutality of the black lines. By making the shape of the individual words palpable, and by embedding them in the text, the editorial board almost asked the readers to infer the content that has been erased, word by word. The list of persons in detention since 12 June asserted 


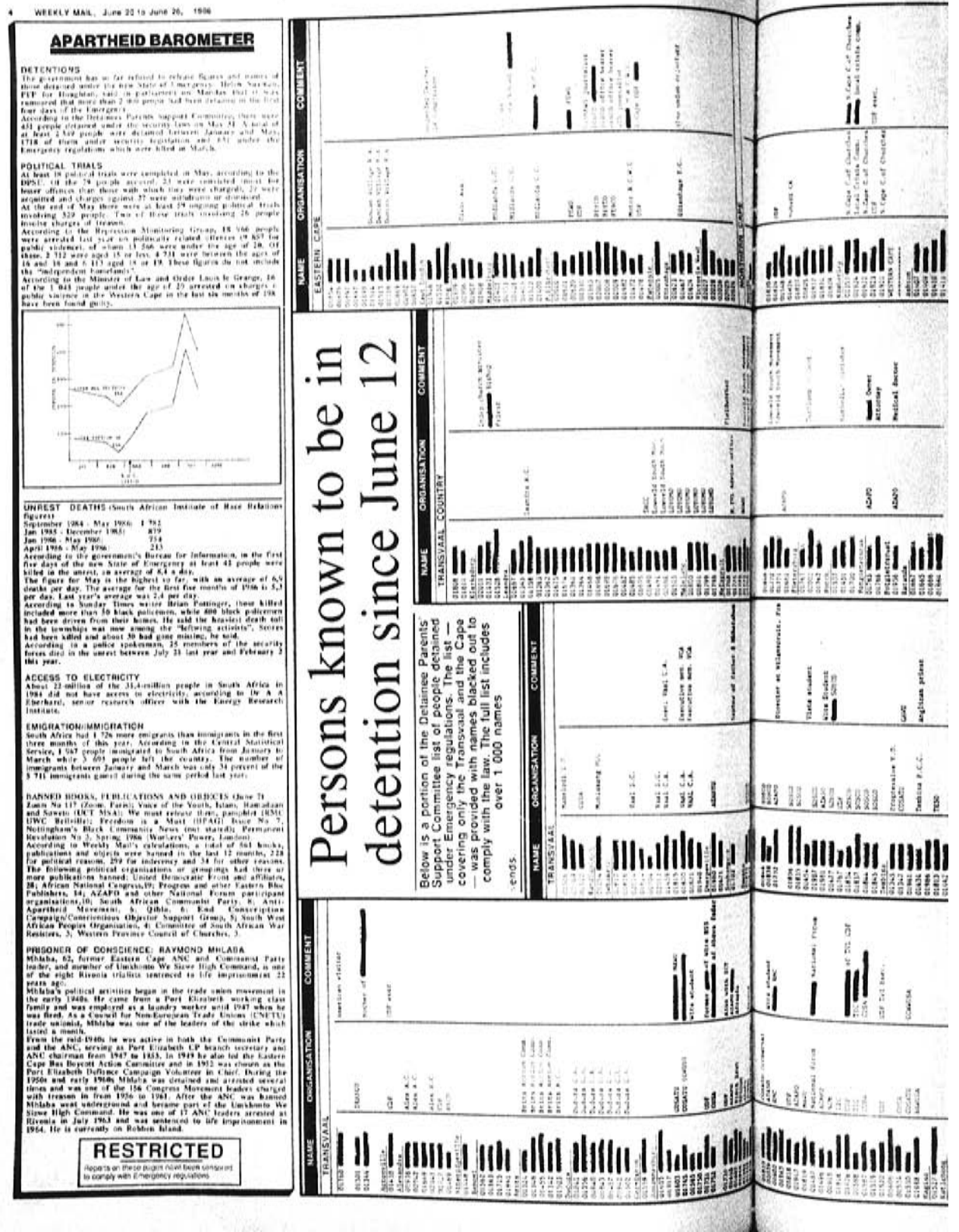


12.5 (opposite)

'Persons known to be in detention since June 12th', Weekly Mail,

20-26 June 1986 p. 4 , showing the list of detainees censored to comply with government powers under the State of Emergency. the scale of the recent detentions. The repetition of each number and (blacked out) name associated each black line with a unknown person (colleague, friend?). The person's identity was concealed, but present - the relentless and empty list giving no information other than numbers and the length of the names. The black stripes are ominous not only because they conceal identity but also because they point to a much greater government control, one that focused on the deletion of words and the detention of people. The black stripes made palpable the fear that governed the crackdown and, in turn, documented the fear that was offered in response.

The invisibility of certain places was extended through the control over publications, particularly photographs printed in newspapers - literally seeking to make some buildings and places in South Africa invisible to the eye, even though they were present in the city. For example, the prohibition on photographing or printing photographs of restricted buildings technically prevented the representation of buildings that were prisons, such as John Vorster Square or the Old Fort in Johannesburg, which were driven past, seen and recognised within the activities of everyday life.

The government was quick to control the spatial representation of censorship, forcing the papers to stop recording the space and place of the missing information and allowing them only to label articles as restricted. A columnist in the Sunday Star described the actions of the government, as well as the explanation that they applied to the removal of the empty spaces in the newspapers:

The black Press learned some of the harsher facts of State of Emergency life this week. They discovered, for example, along with all the other newspapers, that leaving blank spaces to indicate restrictions on the free flow of information is a subversive activity. The reason is that a blank space is considered 'a type of writing', which the authorities regard as any line, letter, number or symbol used to convey meaning. ${ }^{31}$

The government recognised that empty space could be politicised, and that the absence of objects (photographs, texts) could be made tangible if the space that they would occupy was made visible. The invisibility of the text was one reminder of the invisibility of parts of the city and its citizens. Another goal of the editors must have been to impress on their readers the scale of the political activity and the violence that accompanied it. It brought the places in which the protests were occurring, the invisible spaces of the townships, into the everyday life of those who were not directly involved and reminded those in the townships of the scale of political unrest.

The recognition of blank space as a 'type of writing' gives it presence and meaning. It recalls the representation of unknown lands by empty white areas on the maps that settlers and colonists produced and dreamed over. Here, however, information does not appear not because it was unknown, but because it was excised, creating a pressure of silence, erasures and voicelessness. The blank 
spaces soon contracted, pages became thick with text once again, but the flicker of incompleteness reminded white readers that the apparent completeness of their world concealed one dense with meaning, where things one could not see still had the potential to penetrate and disrupt the deceptively calm surface of the page. 


\section{Part 5}

Erasures 



\section{Chapter 13}

\section{Landscapes and erasures}

Imperialism after all is an act of geographic violence through which virtually every space in the world is explored, charted and finally brought under control. For the native, the history of colonial servitude is inaugurated by the loss of locality to the outsider; its geographical identity must thereafter be searched for and somehow restored. Because of the presence of the colonising outsider, the land is recoverable at first only through the imagination. ${ }^{1}$

Part 5, comprising the next three chapters, is concerned with landscape both as part of the political agenda which claimed urban land during the apartheid years as well as the 'landscape of the imagination' which enabled the recovery of the land both during and after apartheid had ended. Edward Said's invocation of the imagination as an alternative site for inhabitation and reclaiming 'geographic identity' is one which links violence done to a physical space with a stable space created in the mind. He writes that the land can be recovered only through the imagination, but frequently the land that is restored in this way has simultaneously been overlaid with the dreams, visions, memories and physical constructions of others. Through this interplay between the altered physical landscape and the landscape held in the mind, the instabilities and conflicts of meaning, identity and transformation inherent in landscape emerge. This part of the book therefore attempts to understand the physical processes of removal, and both the ambitions for the transformation and the construction of alternative imaginings of the sites of forced removal.

The interaction of political goals and economic agendas in the twentieth century meant that two contradictory states of the city were held concurrently. The first was urban terrain as a centre of modernity and progress, which was the 'natural' location of the 'white man'; the second was the city as an economic centre, which 


\section{Erasures}

required black labour in order to develop. The townships on the outskirts of the city can be seen as a solution to these contradictory goals. The processes through which the townships were expanded are, however, integral to their meaning and to the cumulative uncertainties of the contemporary city. The consolidation of the townships was dependent on the reversal of black urban rights and this meant that the growth in the population of the townships was dependent at least partially on a reciprocal emptying of the city.

Although forced removals occurred in the decades prior to National Party rule the passing of the Group Areas Act in 1950, together with other legislation, signalled an increase in their number and ferocity, with approximately 3.5 million people moved between 1960 and 1983 - approximately 860,000 of those mostly urban removals under the Group Areas Act or the Urban Areas Act. ${ }^{2}$ The fact that in 1960 South Africa's population was 16 million people, while by 1980 it had grown to 25 million, gives some idea of the proportion of people affected by the massive scale of the removals. While the Scheduled and Released Areas and later the bantustans were created in order to create tribal lands for black South Africans, the Group Areas Act focused mainly on urban occupation and therefore targeted a population defined as being increasingly racially differentiated into groups defined under the Group Areas legislation - White, Bantu, Coloured, Indian, Chinese and Malay.

The Group Areas therefore signalled the intent of the National Party government to expand racial segregation to those who were not regarded as belonging to tribal landscapes. It has been estimated that, 'by the end of 1968 only $7 \frac{1}{2}$ percent of all Indian and Coloureds in the Transvaal Province had not been affected by the Group Areas Act'. ${ }^{3}$ Ironically, while the Act pulled apart groups of people defined as being from different racial groups, partly in order to dissipate resistance to segregation, the targeting of urban Indians and 'Coloureds' had the initial effect of increased and unified political resistance to the removals across different racial groups. The removals under the Act therefore had profound implications for the form and meaning of the spaces of cities and the townships.

This chapter and the next examine primarily the two most notorious sites of urban forced removals - Sophiatown (removals 1955-1960) in Johannesburg and District Six (removals 1966-1980s) in Cape Town - first (in this chapter) through an examination of the erased ground and proposals for its transformation and second (in Chapter 14) the creation of alternative 'landscapes of the mind' which challenged the erasures. Chapter 15, which concludes this book, asks how landscape can be understood and used in the process of reclamation and rebuilding in the post-apartheid period. The focus of this part is not on tracing social histories of areas or communities (which have been extensively covered elsewhere), but rather probes how ideas of land and landscape appear and transform both within the sites and outside them, through representations which have a presence in the imagination of South Africans of different races.

This chapter discusses the alterations, and proposed changes to the physical landscape, first by tracing through aerial photographs how the spaces in 
the cities were transformed and second by examining the government proposals for rebuilding the land. It examines how the future of South African cities was imagined and how the transformations were connected to a particular understanding of modernity. Both Sophiatown and District Six were once multiracial parts of cities that were declared to be 'white' areas under the Group Areas Act. Apartheid planners used landscapes which were an intrinsic part of the identity of the cities and their citizens as barriers between people of different racial groups. Part 5, therefore, examines not only the areas that were subject to the removals, but also how the primary landscapes of the city - in Cape Town of Table Mountain and in Johannesburg of the mining land appear in the imagery both of the removals and of the reimagination of the land, and therefore what the consequences are for landscape of these changing images and meaning.

There are a number of critical questions which arise in this context. Can we use the word 'landscape' to describe these two urban sites, and, if so, what is the landscape that has resulted from the particular intersection of memory, culture, politics, loss and physical change that has characterised the two sites? How have the forced removals and the representations that challenged their finality contributed to the meaning of landscape in South Africa? How can an altered understanding of landscape offer a means to reconcile and reinhabit the altered places of our cities?

\section{Background}

Sophiatown was laid out as a township to the west of the Central Business District of Johannesburg in 1905, and was initially intended to become a white area. However, the close proximity of a sewage farm deterred many potential white purchasers and it rapidly became a multiracial area, with Chinese, Indian, 'Coloured', some white and a majority of black residents. Together with the later townships of Martindale and Newclare it became known as the Western Areas. As the South African Institute of Race Relations (SAIRR) identified at the time, the defined 'slum area' coincided with the only freehold territory available to blacks in Johannesburg, which was to be substituted with 30 years of leasehold in Meadowlands in Soweto after the removals. ${ }^{4}$ Because of the existence of freehold title, the social and economic structure of Sophiatown, Martindale and Newclare was a complex one, which encompassed both professional people and unskilled labour. The houses therefore ranged from detached middle-class homes to corrugated iron sheds erected in the back yards of row housing.

After the passing of the Group Areas Act the National Party was keen to pursue the removal of the Western Areas. Sophiatown, Martindale and Newclare were demolished partly because they had been enveloped by the expansion of white Johannesburg. A once remote area 'out of sight and out of mind' had been absorbed into the centre of things. ${ }^{5}$ The Johannesburg City Council opposed the proposed removals in 1953 and their jurisdiction was subsequently taken over by the Western 


\section{Erasures}

Areas Settlement Board. The Native Resettlement Act was passed in 1954 to legalise the removal of the inhabitants of Sophiatown, Martindale and Newclare and their resettlement in Meadowlands in Soweto. This paved the way for the removals, with many people being moved within the first year. The removals reached a total of around 60,000 by 1960 , when the area was declared a white area under the Group Areas Act. Shortly after this a new suburb of modest single-storey suburban homes - to house working-class Afrikaans families, mainly those of railway workers - was erected and named 'Triomf', only officially reverting to Sophiatown on the 21 April 2005, although individual land claims have been granted monetary compensation from June 2000.

District Six, in the city of Cape Town, was initially settled as part of the expansion of the city in the seventeenth century. Its proximity to the docks meant that it housed working-class people of all races and the area expanded rapidly in the 1830s with the settlement of former slaves. In the twentieth century District Six became a dense urban area, which housed a multiracial community in close proximity to the city centre. The inhabitants were predominantly 'Coloured' and Indian, with small numbers of whites and blacks. Many black South African residents were removed from District Six to Ndabeni in 1901, in Cape Town's first forced removal. District Six was proclaimed a white area in 1966 under the Group Areas Act, when the population of the area was approximately 50,000 people, despite the opposition of the Cape Town City Council. Demolitions and removals began within two years and continued into the early 1980s. After the demolitions of the residential buildings, the majority of the District Six area has continued to be vacant - due primarily to effective political protest and the lack of an economically feasible plan for the area. In the early 1980s a building programme for the Cape Technikon (a tertiary educational institution concerned mainly with technical disciplines) was begun, which was opposed by former residents and the Cape Town City Council. The Cape Technikon now occupies about 25 per cent of the land area of District Six, while another 25 per cent is used for motorways and roads. The remaining land has been left uncultivated and unoccupied. In November 2000, under the Restitution of Land Rights Act 22 of 1994, District Six was granted back to the residents.

The two sites are therefore now materially different but are linked through their common histories and their prominence in the narrative of reclamation of land and identity that has developed over the period of National Party rule, and beyond it. They are significant both as urban sites of removal and as places through which contemporary South Africa is reimagined as a place of multiple histories. The area that was once 1950s Sophiatown is traceable through contemporary photographs, newspaper articles, music, musicals, ${ }^{6}$ films and documentaries, while the forced removals of District Six have a visual presence in the city through the persistently empty land, scattered with a few remaining religious buildings, the nearby Museum of District Six, books, poetry, photographs as well as music and a musical. Walking the streets of Sophiatown, it is almost impossible to trace exactly where it was. The rubble below the topsoil that is the only physical evidence of the buildings of Sophiatown is 
discernible only in the sparseness of vegetation, or if one digs into the surface of the ground.

\section{Density and visibility}

The freedoms that the intricate forms of the buildings and irregular planning of the streets allowed were seen by the government to transgress the modern principles of health and visibility. The evasion of the authorities that was possible because of the density and complexity became much more difficult in the new townships, because of the separation of individual houses and radial street plans. Photographs of the main streets from Sophiatown show the typical dwellings as linear row houses with roofed verandas lining the streets (Figure 13.1). The proximity to the street and the creation of a stretch of shaded semi-protected space that was partially of the street and partially of the house allowed selected moments of domestic life to be lived adjacent to the thoroughfares where chance encounters were possible. The shops were often located on street corners and were either surrounded by the columns typical of the period or pushed forward onto the pavement.

In District Six a similar pattern of houses was typical, although here the raised semi-private space of the 'stoep' was sometimes not roofed (Figure 13.2). ${ }^{7}$ The photograph shows not only the layering of private space back from the street, but also

13.1

Photograph of a shopping street in Sophiatown before the demolition of the area. () Bailey's African History Archive.

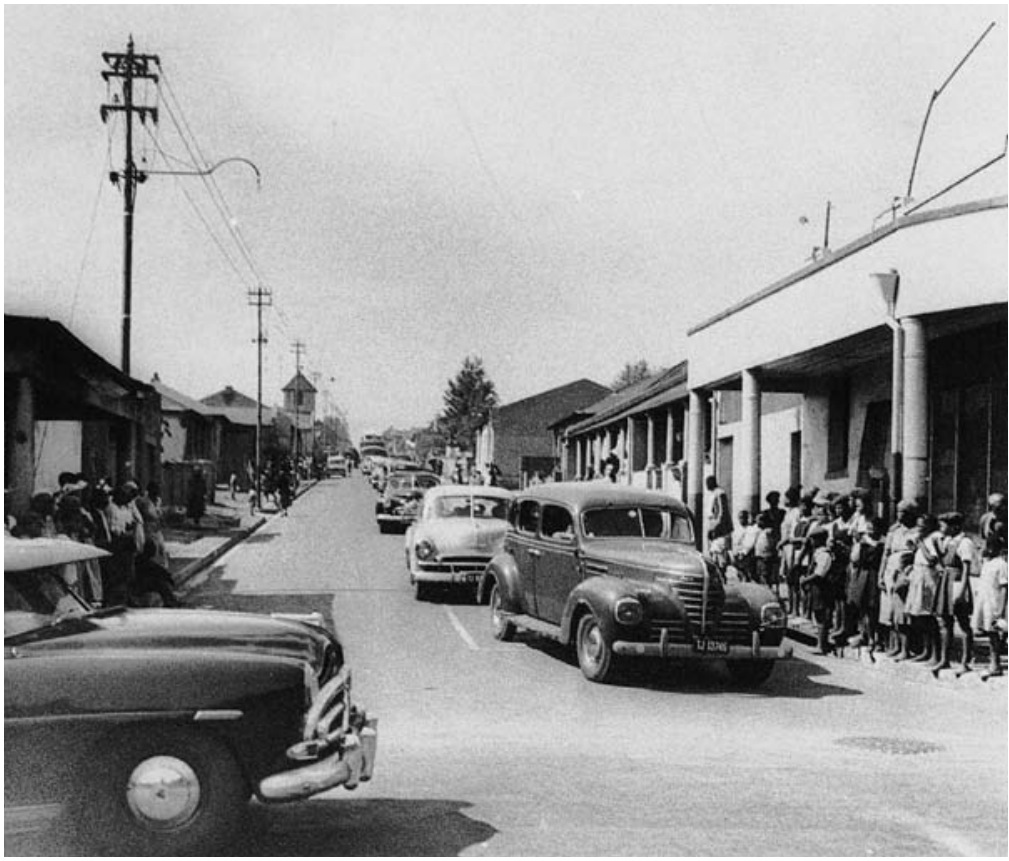




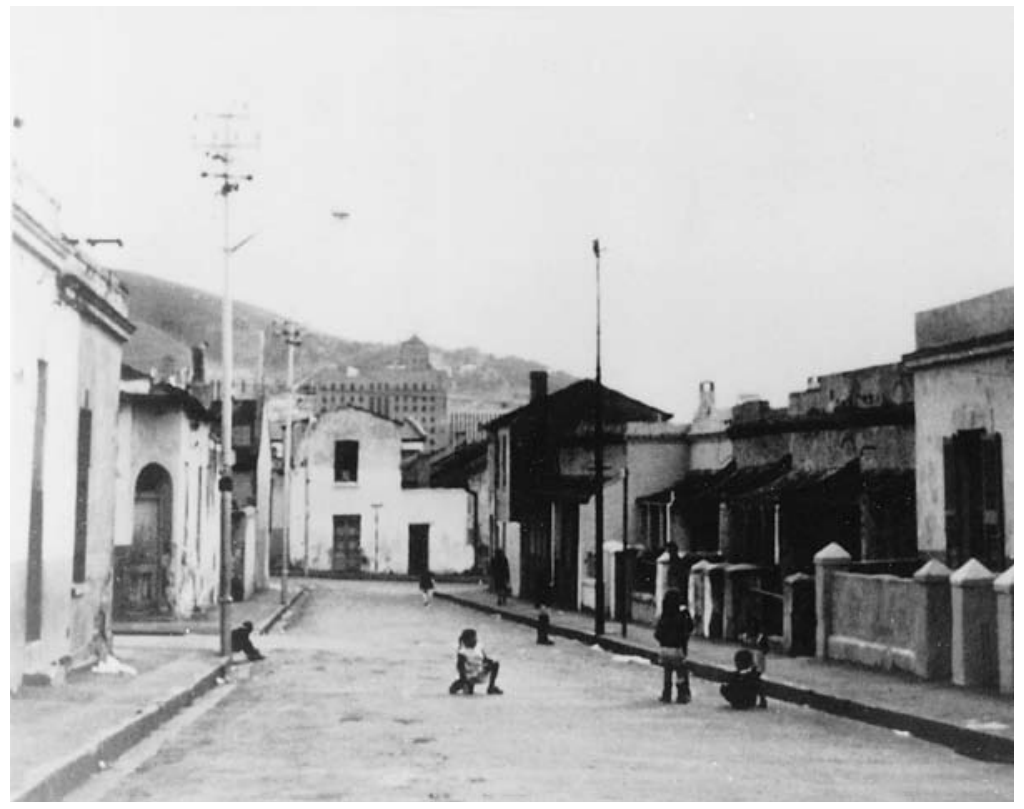

13.2

Photograph of Roger Street in District Six (late 1950s), before demolition.

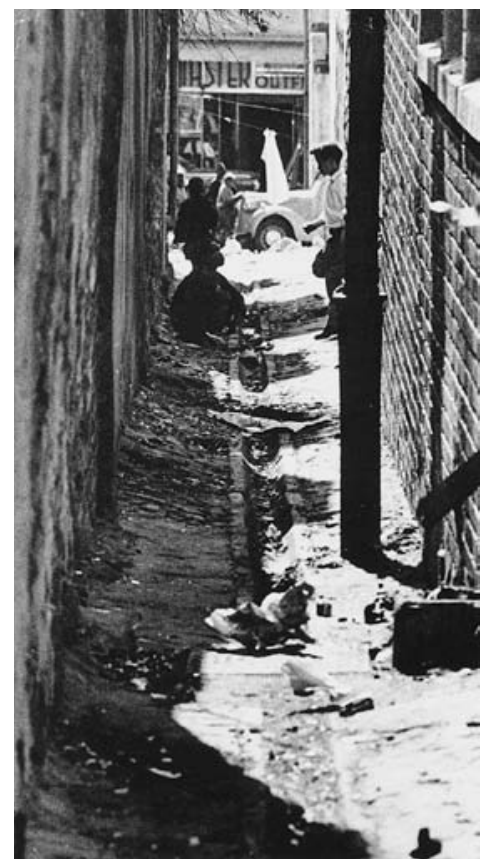

13.3

Photograph of alleys in District Six, from 'District Six - the razzledazzle good-bad land' (June 1963), Drum, p. 14

() Bailey's African History Archive. 
the outline of the lower slopes of Table Mountain beyond. As in Sophiatown, a network of back routes and alleys offered an alternative and less visible way, to initiates, of navigating the areas. There were therefore two overlaid pedestrian networks, one formal - the streets - and the other informal, which allowed the movements of the residents to be at least partially concealed in the physical complexity of the areas. The alleys allowed not only more private traversals to be made, but also transactions and activities to be concealed (Figure 13.3). The high density of buildings and people meant that shops, residential areas, businesses, schools and churches were all within walking distance, even if one chose not to leave the area. The close proximity of Cape Town to District Six meant that access to the city was part of normal life. Sophiatown and District Six therefore offered both internal proximities which fostered community interaction and identification and external proximities to the city centres.

\section{Health, hygiene and race}

The period during and after the Second World War in South Africa saw massive industrial growth and urban expansion. Like other western governments during the same period, the new National Party rulers were convinced by the ability of modernity to ensure economic growth and to modify social orders. The image of the modern city - a dream of technology and hygiene - was posited as a solution to the pre-war city - a place of confusion and fear - in which people of different races competed for urban space and employment. The Group Areas Act was conceived of being consistent with this vision of modernity, a rational, objective piece of legislation, which would enable the government to exercise its powers to modify the occupation of urban space.

The processes through which urban areas were removed were seen as operations on the body of the city that were essential to its social and physical health. By the late 1960s many town planners were working with a design vocabulary that was heavily dependent on the social and formal agenda of the early modernists and the post-war planning that was a development of these ideas. Like other architects and planners elsewhere at the time, some South African professionals regarded the street - the space of public life in densely built-up areas - as an outdated, slow-moving and inefficient conduit, which was to be replaced with a combination of high-speed traffic routes and open ground which became a surface upon which (often vertical) buildings were arranged. The complexity of the traditional city was to be replaced with the clarity and visibility of the new modern city of light and air, which was inseparable from the vision of a modern social utopia. The economic expansion of the mid-twentieth century in South Africa meant that it became possible to imagine and build modern buildings as an embrace of the outward signs both of technology and progress and social change. This agenda was allied to the work of the international modernists and to Le Corbusier in particular, while the Group Areas Act enabled the clearing of ground that could create the conditions for the building of new spaces and a new society. 


\section{Erasures}

We must concentrate our first activities at the city's centre, so that freedom of movement, accessibility and breathing space can be restored where they are vital. It is possible to achieve this radical organisation by radical methods only by a fresh start on cleared ground . . . This ruthless eradication directed towards a revitalising process we have, following Le Corbusier's lead, named the Surgical Method ... through surgery one must create order. ${ }^{8}$

The modernising agenda in South Africa was accelerated by racial anxieties and became largely cohesive with them. The complexity of the buildings and the existence of freehold title was a representation of the danger of the occupation - their dense populations and uneven growth over time became signifiers of social disorder. In addition, the wealth and prosperity of some residents meant that their homes were indistinguishable from those lived in by white South Africans. International modernism offered a means to justify political action on multiracial areas, both by supporting the removal of 'diseased' areas of the city, and confirming the potential of a rationalised approach to city planning to ameliorate social problems. Racial agendas therefore could acquire a cloak of rationality, stability, objectivity and progress.

The arguments against the 'slums' of the inner cities as dirty, contaminated areas of vice and decay should be framed against the larger anxieties - present in the early days of National Party rule - about the corrupting potential of cities themselves. Urban life was seen to pose a danger to stable rural existence and therefore to South African society as a whole. ${ }^{9}$

\section{Eradication and debris}

The forced removals in both urban and rural areas were invariably accompanied by the destruction of all (or the vast majority of) the residential buildings on the site typically only those buildings that had an independent legal status, such as churches and mosques, were spared. While the space above the land was cleared of buildings, the rubble that was produced by the demolitions has become part of the physical structure of both cities. Building fragments from District Six were dumped into the sea, and became the landfill below Duncan Dock in Cape Town Harbour, while the rubble from Sophiatown has been integrated into the ground on which the suburb of Triomf was constructed. ${ }^{10}$ Even as these fragments became part of the city however, the government believed that the transformation of an area of a forced removal into an entirely new environment (with a new name and buildings) would prevent the return of the residents, even in the imagination. ${ }^{11}$

The desire of the National Party government to appear to act according to rational principles resulted not only in the proliferation of apartheid laws, but also in the devising of legal procedures with which the removals were carried out. In Sophiatown, every household was formally notified of its removal in writing, family members were 
individually named and recorded in removal notices, houses were valued by the state, compensation paid to owners, and transportation to new areas was supplied, ${ }^{12}$ although this was not the case with all the removals under the Act. This state bureaucracy gave a veneer of legitimacy to the processes, but existed alongside the determination to perform the removals, the willingness to use violence and the decisive acts of sending in the bulldozers. It has also been argued that the Group Areas Act was both politically and economically motivated. By removing people from areas in which they had lived and worked for many years, and by paying vastly inadequate sums of money for both homes and businesses in compensation, the Act effectively cleared the field of competition for white business owners. ${ }^{13}$

\section{Altering urban landscapes}

The absent bodies that were removed from the cities under the Group Areas Act can regain a presence in the history of the city through the study of representations that have (sometimes inadvertently) recorded the history of their erasure. Aerial photographs, regularly produced by the government's Land Survey and Mapping Office as documents of development and change, attest to the erasures of the forced removals. The aerial photographs of Johannesburg and Cape Town form part of a wider mapping project to document comprehensively, and then to update periodically, the state of the entire surface of South Africa. The photographs enable the exploitation of the country's mineral wealth through a close examination of its surface as well as tracking development, targeting with greater frequency places which are subject to rapid alteration, growth and expansion, and paying less heed to remote rural areas. The intensity with which a city or town is photographed can therefore be seen as an index of its success in achieving the physical progress which was one of the goals of the modern state. The photographs reveal the desire of the state to 'know' the surface of the land through the production of representations, a belief in technology and the faith in a scientific and rationalised government.

The archive of aerial photographic studies held in the Land Survey and Mapping Office in Cape Town is therefore both cumulatively a record of change over time and an indicator of the extent of the centralised control over land that was exercised by the National Party Government. Aerial photographs are typically taken around midday when shadows are minimised. The dispassionate lens of the camera chooses scale over intimacy, sweeping changes over detail, and a visual image over the spoken word. The image of the landscape held in the enormous archive of photographs appears to suspend individual lives in the wider narrative of communal inhabitation.

The meaning and use of these representations, however, does not remain static. While generated by the state in order to control and 'know' the land they can also be used in order to study the physical consequences of politics. They are significant also as legal evidence for land claims. In one recent example (in connection with a claim for land restitution) the Department of Land Affairs requested aerial photographs of the Richtersveld around 1954 and 1989 in order to track mining activity 
and settlements over those years. ${ }^{14}$ Unlike maps, historical photographs were less vulnerable to alteration and editing. They therefore carry evidence of human interaction and inhabitation of the land - footpaths are worn into grassy slopes, buildings appear and disappear. The archive of photographs provides a framework around which narratives that oppose the state control over the land can be rebuilt. In the light of the erasures of the apartheid period, the surfaces of the aerial photographs can provide a means to reconstruct and to reclaim destroyed places and shifted boundaries. They also enable us to weigh erasure within the cities to growth outside its limits, to trace the texture and density of inner city areas against the crispness and regularity of new housing, the suspension of the townships within geological and geographical boundaries and to perceive how the close proximities of inner city inhabitation were supplanted by distance and visual barriers. The density and intensity of the photographs recorded not only a narration of progress and development, but also one of damage and debris. If these photographs offer us an image of modernity it is one that incorporates destruction and disorder, the demolition of large areas of the cities under the Group Areas Act and the burgeoning townships.

The photographs facilitated the production of maps which were used by state planners to set out infrastructure and housing and to plan modifications to the occupation of urban space in order to implement racial separation. Like the aerial photographs, however, the information embedded within them does allow these documents to be used to reconstruct erasures under the removals. A Cape Town City Council map - produced in the 1950s as a means to document rates payable on properties in District Six - has similarly become an important document in the attempt to achieve restitution of the land to the former residents as it gives details about each property, the extent of development and records the names of those who lived there. ${ }^{15}$

\section{Beyond the mining land - aerial photographs of Johannesburg from 1937 to 1985}

The political goals of the National Party resulted in changes to the city which were to have significant consequences for its physical structure, occupation and meaning. Through tracing the alterations to the city over time, the materiality of the city can be differently understood. The ground, rather than being a neutral surface for building, becomes a deep structure, layered with the debris of the demolitions.

Photographs from 1937 show Sophiatown before the demolitions: Westdene is encroaching on its southeastern boundary as the city develops outwards, gradually overtaking Sophiatown. In 1931 a competition had been organised for a township called Orlando of 80,000 people, which (together with Klipspruit) was to eventually expand to become Soweto. Many people had resisted moving to these remote areas, preferring the location and relative freedom of Sophiatown, Martindale and Newclare. In a detail of the aerial photographs the density of the area is evident - small buildings crowd the plots and there is very little open space other than the 
streets (Figure 13.4). The streets, as has been noted, were a place of social and cultural interaction - the primary public realm of densely populated areas, which were at least partially a consequence of the increasing restrictions on black occupation of urban space.

The regularity and order of Soweto were, however, generated from disorder and violence in the city. The aerial photographs of 1961 show a counterpoint to the development of the township - the partially demolished area of Sophiatown (Figure 13.5). While Soweto spreads to the south and west of the city, Sophiatown is slowly removed from it. Many of the streets have been completely stripped of buildings, while others retain some houses surrounded by vacant land. In a pattern that was repeated at other sites of forced removals, only the street layout remains imprinted on the ground. Its regularity is beginning to be criss-crossed by diagonal paths, worn by feet into the ground. The demolition of the area appears to be spreading north and west, out from the white area of Westdene, while some houses at the more distant corner of Sophiatown temporarily resist the bulldozers.

13.4

Detail of

Sophiatown (1937) from an aerial photograph of Johannesburg.

Reproduced under South Africa

Government

Printer's Copyright

Authority no. 11296,

1 November 2005.

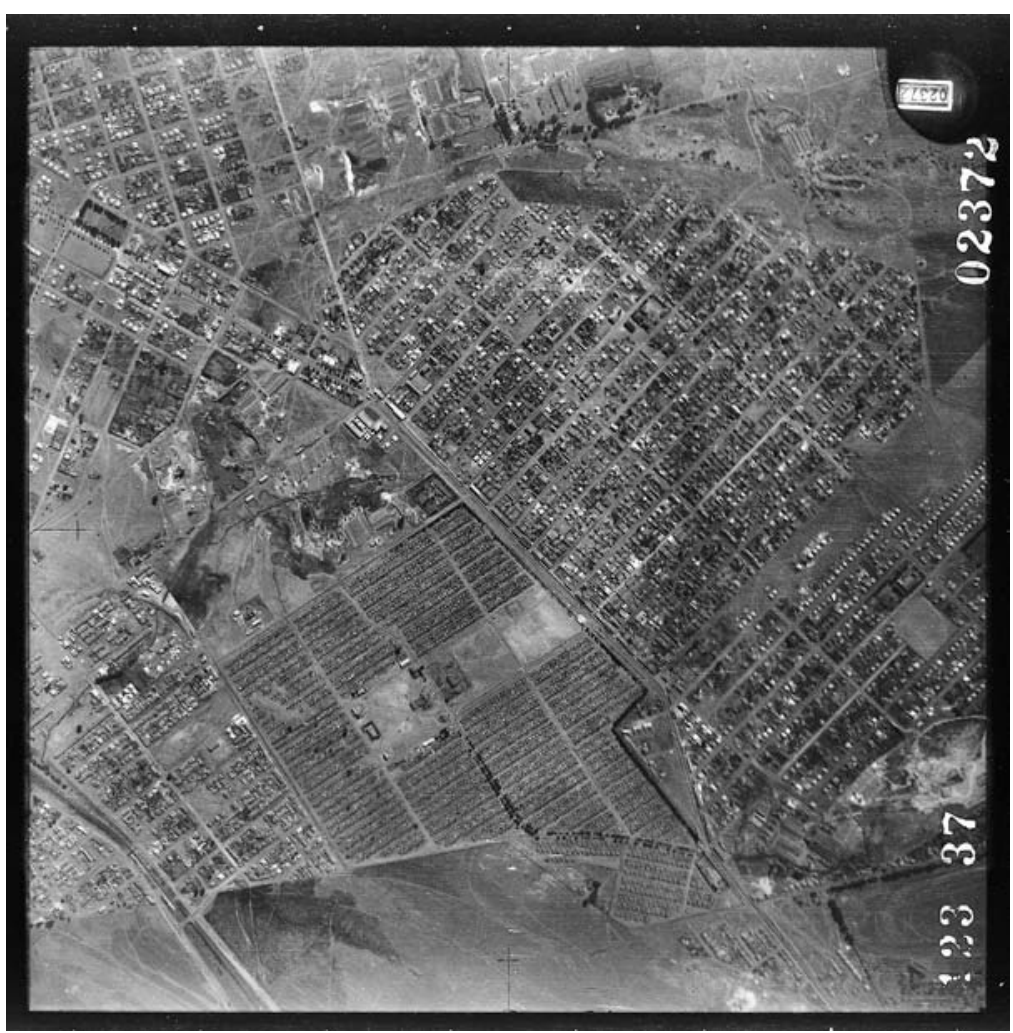




\section{Erasures}

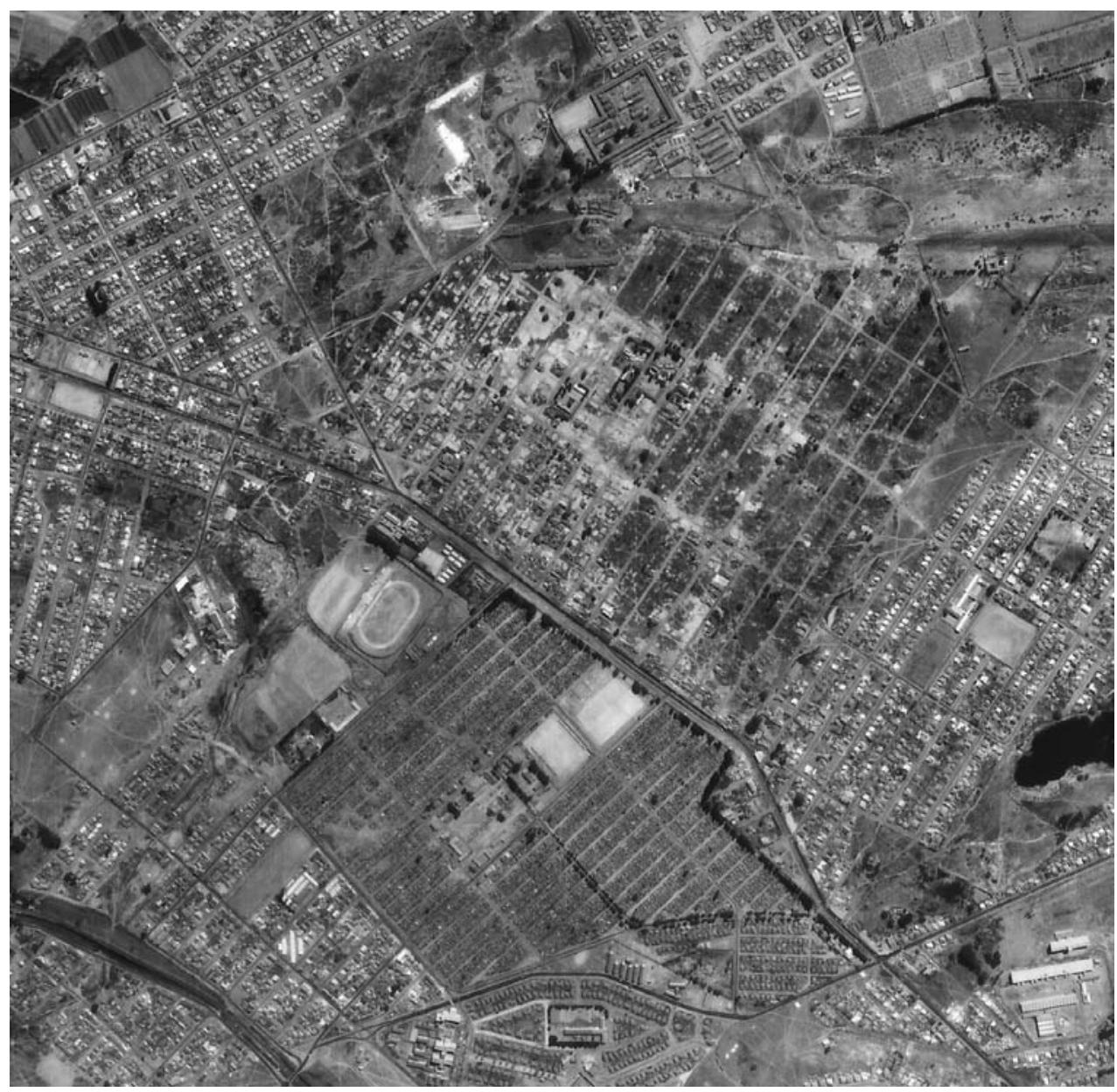

In 1969, the lens of the camera looked down on a city which had covered up the scars of its recent past. To the west of the Central Business District a series of pale-roofed houses line the streets of Triomf in an orderly and regular progression (Figure 13.6). Soweto spreads south in a homogenous profusion of intersecting radial street patterns, and tiny uniform units. It has none of the accidents of the greater city to the north, none of the shifts in density and heights of the city, few of the dark pauses for vegetation. The internal road pattern of Soweto does not distort in response to topography. It remains a faithful transfer of the planner's pen. The main road brushes past its northeastern tip and then arcs away. The rest of Soweto is surrounded by open ground. Travelling on the road past the vast area a citizen of Johannesburg's northern suburbs could easily be deceived, imagining the visible
13.5

Detail of

Sophiatown (1961)

from an aerial

photograph of

Johannesburg.

Reproduced under

South Africa

Government

Printer's Copyright

Authority

no. 11296,

1 November 2005 


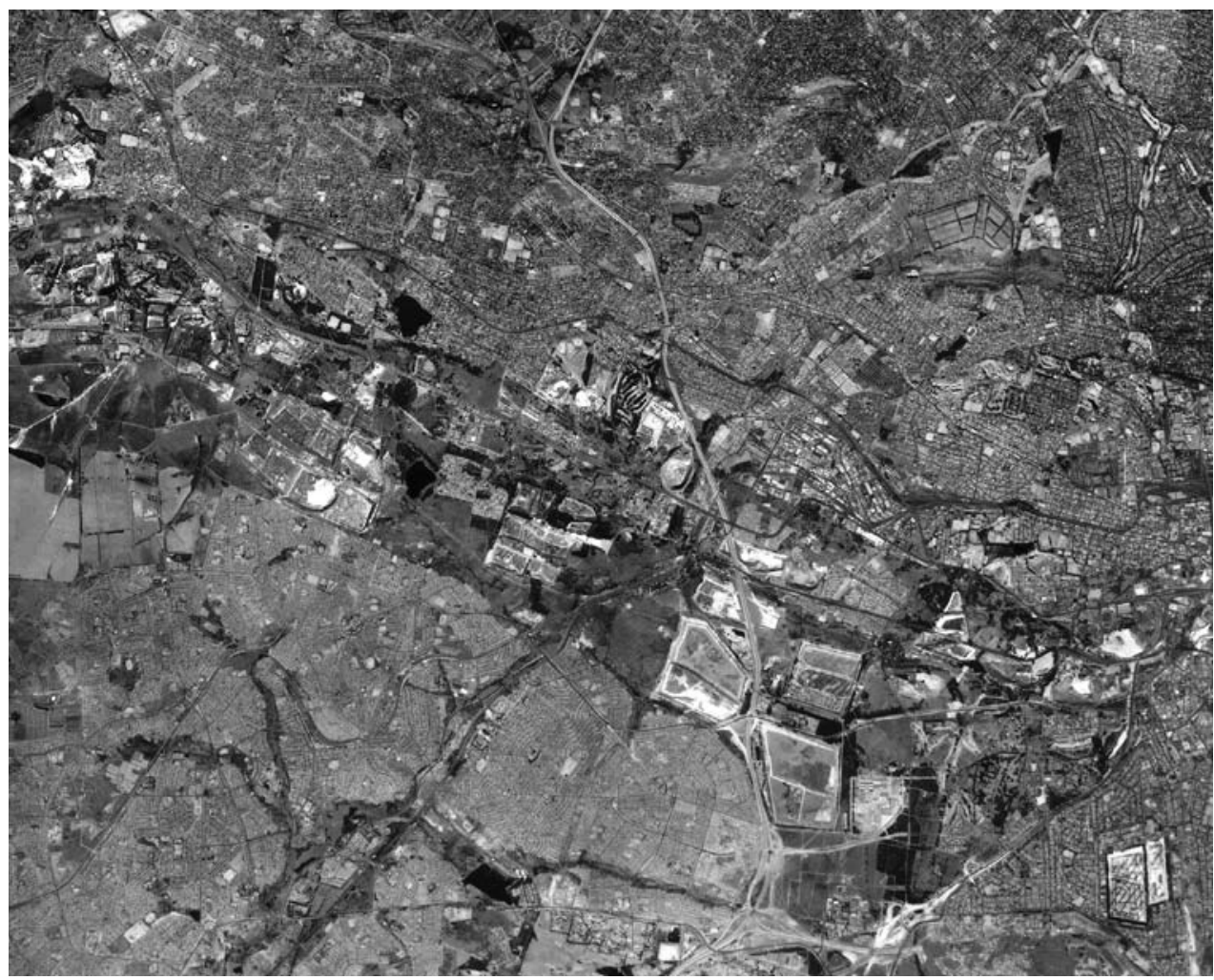

13.6

Detail of Triomf

(1969) from an

aerial photograph

of Johannesburg.

Reproduced under

South Africa

Government

Printer's Copyright

Authority no. 11296,

1 November 2005. fragment of Soweto to be its entire bulk, or that one did not actually see anything at all.

On either side of the mining land there is a distinct, wavering line that bounds it. Within these lines, dumps, slimes dams and industrial structures lie. They pay little heed to the adjacent geometries and density of the city to the north and of Soweto to the south. The aerial photograph flattens the land, belying the huge physical mass of the mounds of sand, but the immensity and proximity of the goldbearing land is still palpable. The mining land's effectiveness as a barrier between white Johannesburg (mainly to the north) and Soweto to the south is a result not only of its physical shape - a slightly arched ribbon - but also of its use. The position of industrial equipment and the form and location of the mine dumps made its traversal difficult for those unfamiliar with the area. The map detail in Plate 13.1 is that of a 1:50,000 map series produced by the Department of Land Survey and Mapping. The area marked in light orange is Triomf (once Sophiatown); the area in dark orange is Meadowlands - the newly built suburb to which the majority of the black residents of Sophiatown were moved. It clearly shows the cut made between 


\section{Erasures}

Johannesburg and Soweto by the mining land, the change in the street geometry to Meadowlands and the semi-vacant industrial land of the mining area.

\section{Behind the mountain - aerial photographs of District Six 1945-1992}

In these series of photographs the relationship of Table Mountain to the forced removal of people from the city centre becomes evident. A large-scale photo of the municipal area of Cape Town from 1989 confirms that the primary landscapes with which the city is identified - that of the harbour and the vertical mass of the mountain - are not equally available to all residents (Figure 13.7). The CBD occupies the city bowl formed by the lower slopes of the mountain and the boundary of the sea. Immediately to the east of the CBD a vacant area of land is visible - the area of the city that was once a densely occupied District Six. Behind the mountain, a seemingly endless carpet of small-scale buildings stretches to the eastern coast. The radial patterns, repetitive houses and homogeneity that are typical of Soweto and many other South African townships are repeated here. This is the Cape Flats to which many of the residents of District Six were moved; Mitchells Plain, Hanover Park (an ill-judged reference to demolished Hanover Street - the main street of District Six) and Bonteheuwel.

In 1958 District Six was an integral and intact part of the central city (Figure 13.8). Its location supported its dense population and increased pressure on the internal uses of the plots. The major roads ran to the north and south of the district, allowing the internal streets to become part of the social and cultural space of the area.

The photograph and detail of 1968 pinpoints the year in which the demolitions began and identifies the modernising agenda which was complementary to the doctrine of racial segregation (Figure 13.9). A new four-lane highway arcs along the western boundary of the area, confirming the intersection of modernist planning and political goals. Like other examples of its type in the western world at the time, 'slum areas' were regarded as necessary casualties in the facilitation of the speed of the modern city. The form of the road does not deflect to accommodate the existing street pattern - it carves a certain path through the site on the diagonal and creates a ragged edge to the area. While the majority of the buildings remain untouched, it is notable that the first incursion into the area, after its declaration as a 'white' area in 1966, was that of a major highway.

The photograph from 1977 shows the painful slowness of the demolitions, which were begun in 1968 and continued into the early 1980s (Figure 13.10). The aerial photographs represent the passage of time on the land. The drawn-out process and visibility of the District Six removals increased the level of political awareness of all of the citizens of the city. Almost contemporary with the Soweto riots of 1976 , the photograph represents a moment of political uncertainty and unease, which, through the forced removals of District Six, acquired a physical presence in the city of Cape Town. 


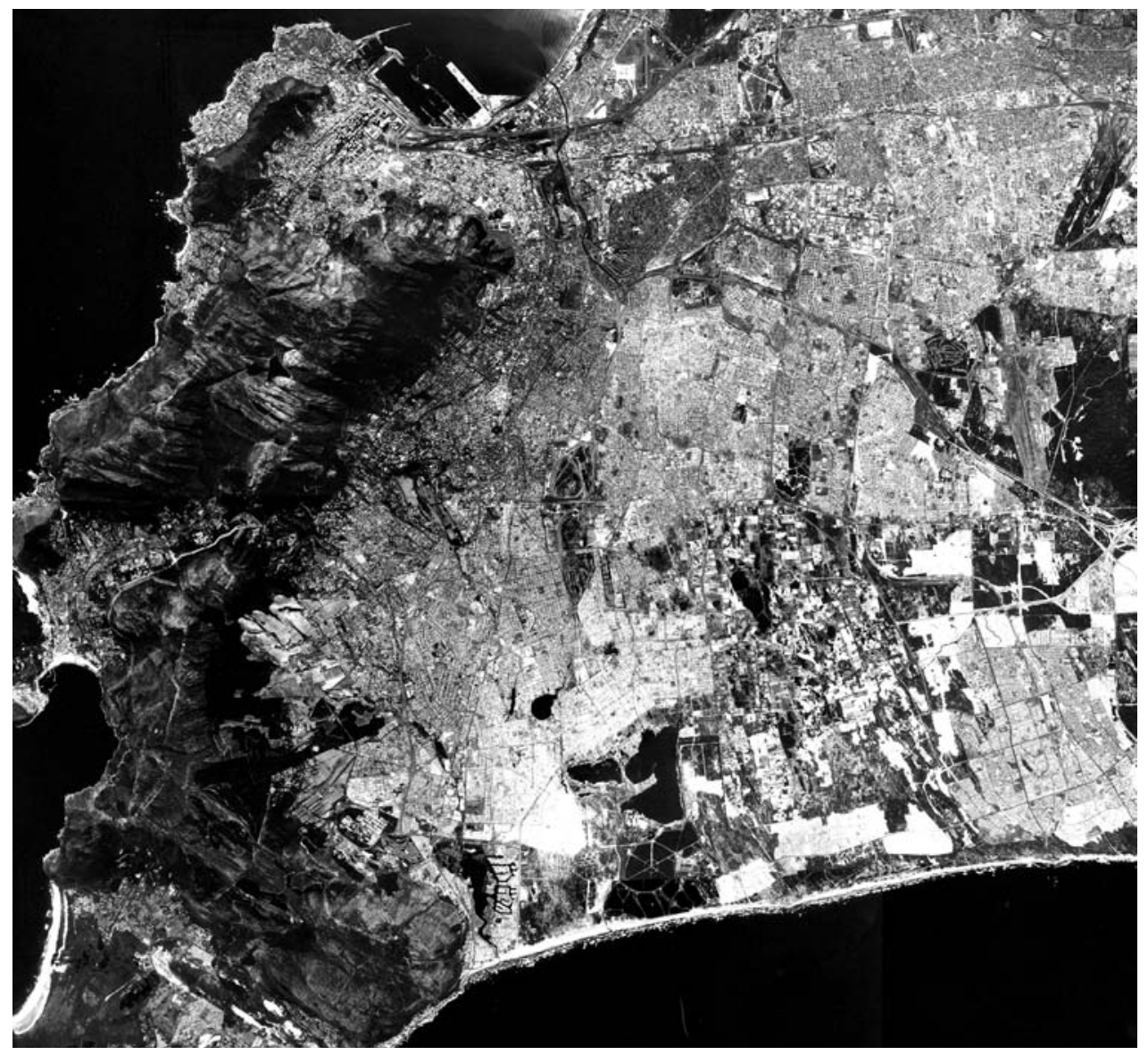

13.7

Aerial photograph of Cape Town (1989). Reproduced under South Africa Government Printer's Copyright Authority no. 11296, 1 November 2005.
The geography of Cape Town is clear in the 1989 photograph, as is the physical bulk of the mountain and the constriction of the routes into and out of the city. In a map the geography of the city is clearly visible, as is the dislocation of the removals from District Six to the Cape Flats (Plate 13.2). Following the previous convention the area of the removal is shown in pale orange, while the areas to which the resident were removed are shown in dark orange. The areas are separated not only by the physical distance between them, but also by the change in the qualities of the environment and their relationship to the landscapes of the mountain and the sea.

It is evident that the demolition of the area would have been visible to the population of the city in a way in which that of Sophiatown was not. The compression of the routes into the central area and the topography of the land meant that knowledge of the removals was almost unavoidable. 


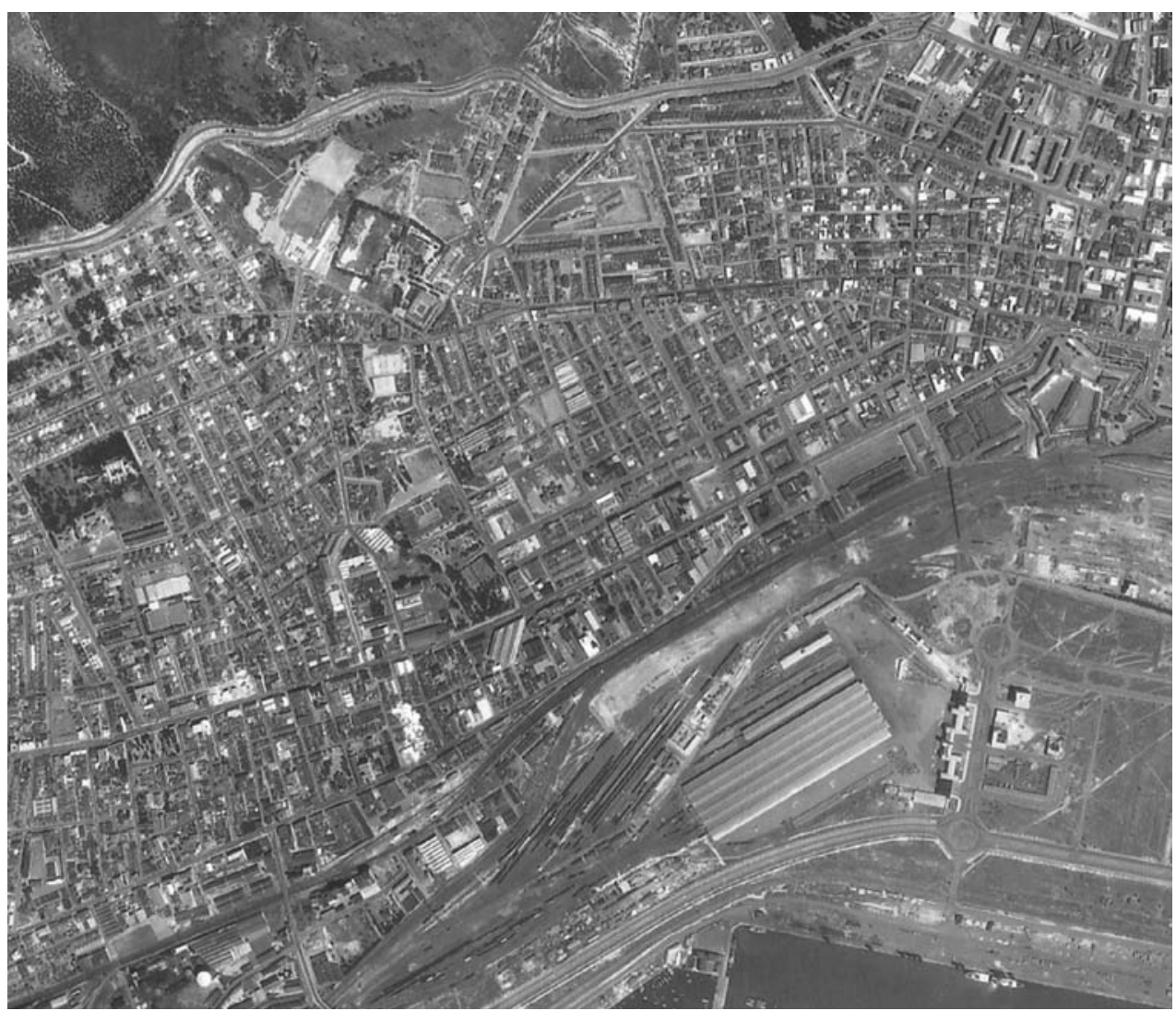

\section{Proposals for rebuilding}

Both District Six and Sophiatown, in common with the majority of other sites of urban forced removals, were not intended to remain vacant after their residents had been removed. The different proposals for the two sites reflect not only their perceived economic value, but also their value as land and landscape.

Sophiatown is topographically largely undifferentiated. Its location in close proximity to the mining land and its associated roads, rail lines and services made it less attractive to a higher income group, who tended to live to the north (and not the west) of the CBD. In addition, low-income Afrikaners, the very people that the National Party had pledged to uplift, were still moving into the city and were gaining protected jobs in public services, such as the railways. The demographic variation of race, skills and buildings in Sophiatown were to be replaced by the homogeneity not only of the circumscribed suburban houses that were constructed in the early 1960s but also of its new occupants.
13.8

Aerial photograph of Cape Town,

before the

demolition of

District Six (1958).

Reproduced under

South Africa

Government

Printer's Copyright

Authority

no. 11296,

1 November 2005. 


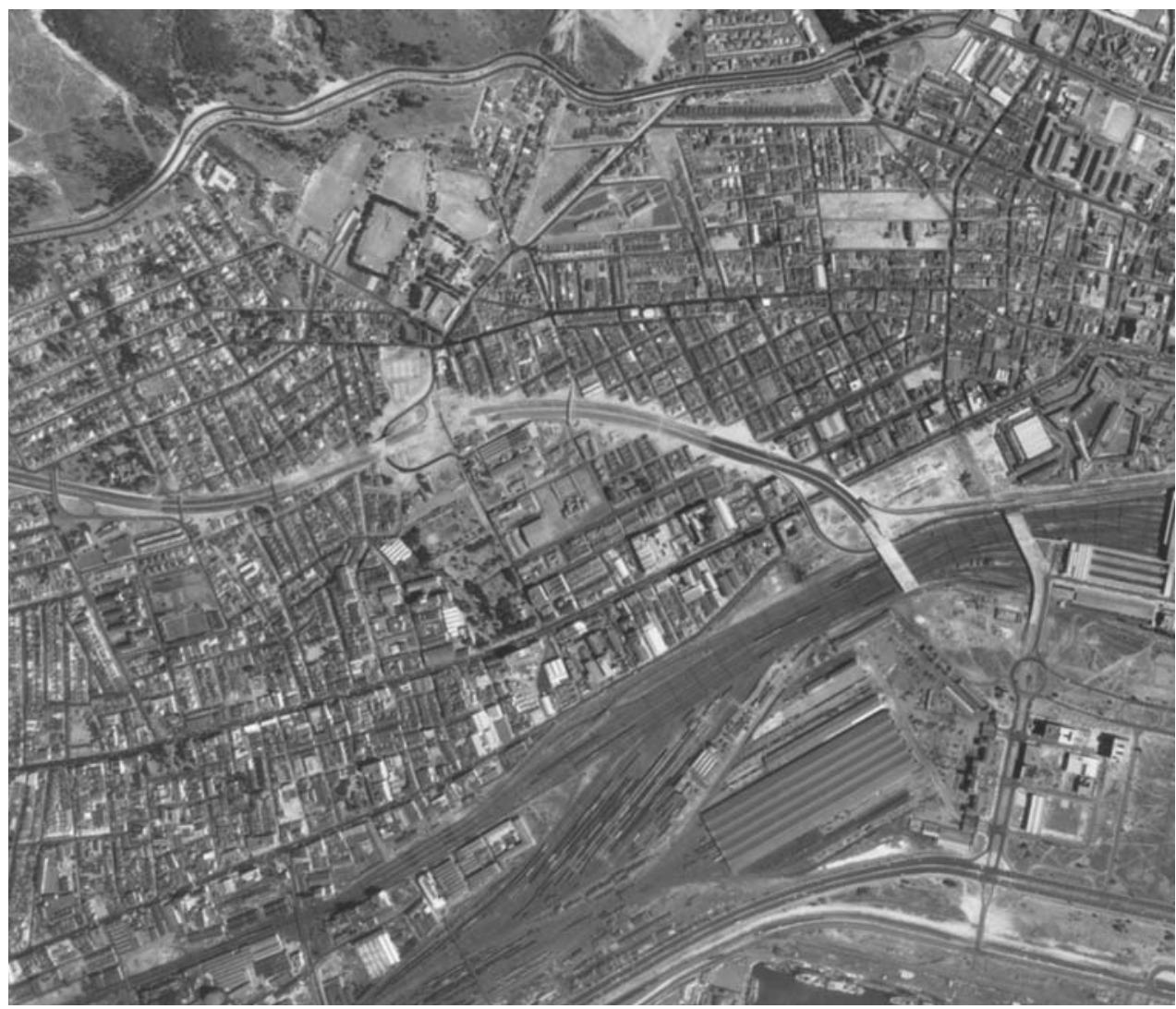

13.9

Aerial photograph of Cape Town,

showing the

insertion of the

highway through

District Six (1968).

Reproduced under

South Africa

Government

Printer's Copyright

Authority no. 11296,

1 November 2005.
The houses reflect not only the economic restrictions of these low-income workers, but also their aspirations to have their own piece of land in the city. Designed by the Department of Housing, the new houses in Triomf were made of plastered brickwork walls, face-brick plinths and pitched corrugated iron roofs. They have standard steel windows, asphalt tiles and curtain rails in every room apart from the bathroom (Figure 13.11). The single-storey buildings are pulled apart on their sites: in a dream of post-war suburbia, open ground separates each family home and gives a front and a back garden (Figure 13.12). The working drawings include a fencing plan - wire and not walls surrounded each small territory. The four different house types were designed around the family unit, with bedrooms, living room, kitchen and bathroom. The different units were repeated around the regular street pattern, the majority of which was retained from the days of Sophiatown. After the long verandas and densities of Sophiatown, the buildings and the spaces in which they are sited seem naked and exposed. The abundance of internal space in the plots and the decrease in the density of the population changed both the use and meaning of the 


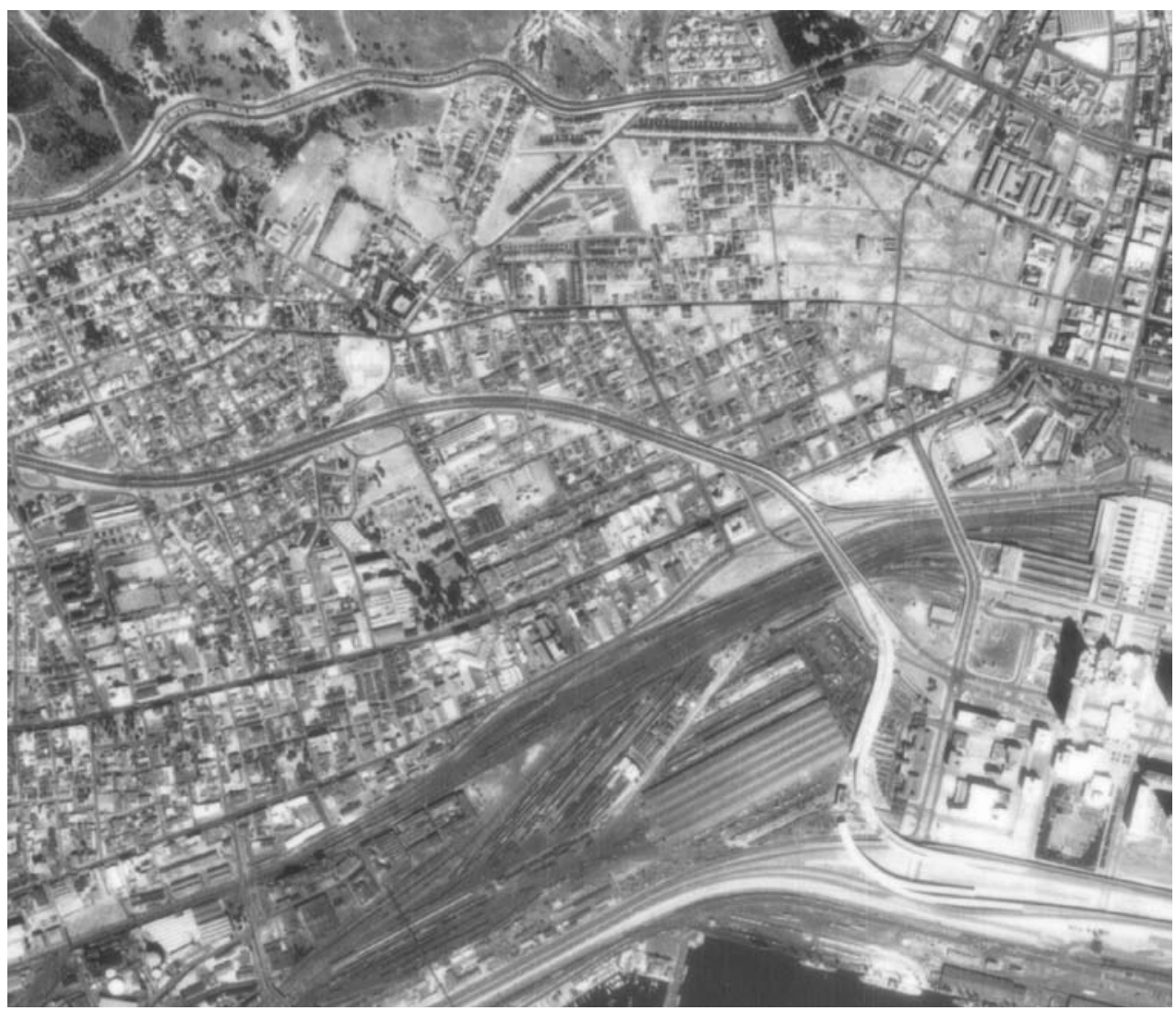

streets. The infertility of the debris of the removals has ensured that little vegetation has softened Triomf, even decades after its construction. The poverty of the materials, the monotony of the architecture and the socio-economic profile of the inhabitants create a sense of quiet but watchful desperation.

It was believed that the beauty and scale of the landscape surrounding District Six could lend credibility to design proposals that embraced modern planning principles. Unlike the more modest houses in Triomf, they were never constructed. The belief in the 'tabula rasa' of urban land that underpinned the architectural and planning proposals of the early 1970s has been replaced by a contemporary image of the ground as pregnant with meaning and memories. It has become a place in which the certainties of modernity have been eroded by protest, contradiction and internal failures. The modern fantasy of clean air, fast transportation and housing slabs floating in an open park-like landscape, below the slopes of Table Mountain, has in turn been superseded by an uncultivated and empty area of ground which has both physical presence and representational content and remains contested and ambiguous.
13.10

Aerial photograph of Cape Town,

showing the partial demolition of

District Six (1977).

Reproduced under

South Africa

Government

Printer's Copyright

Authority

no. 11296,

1 November 2005. 
13.11

House plan for proposed new suburb of Triomf (1963-1969)
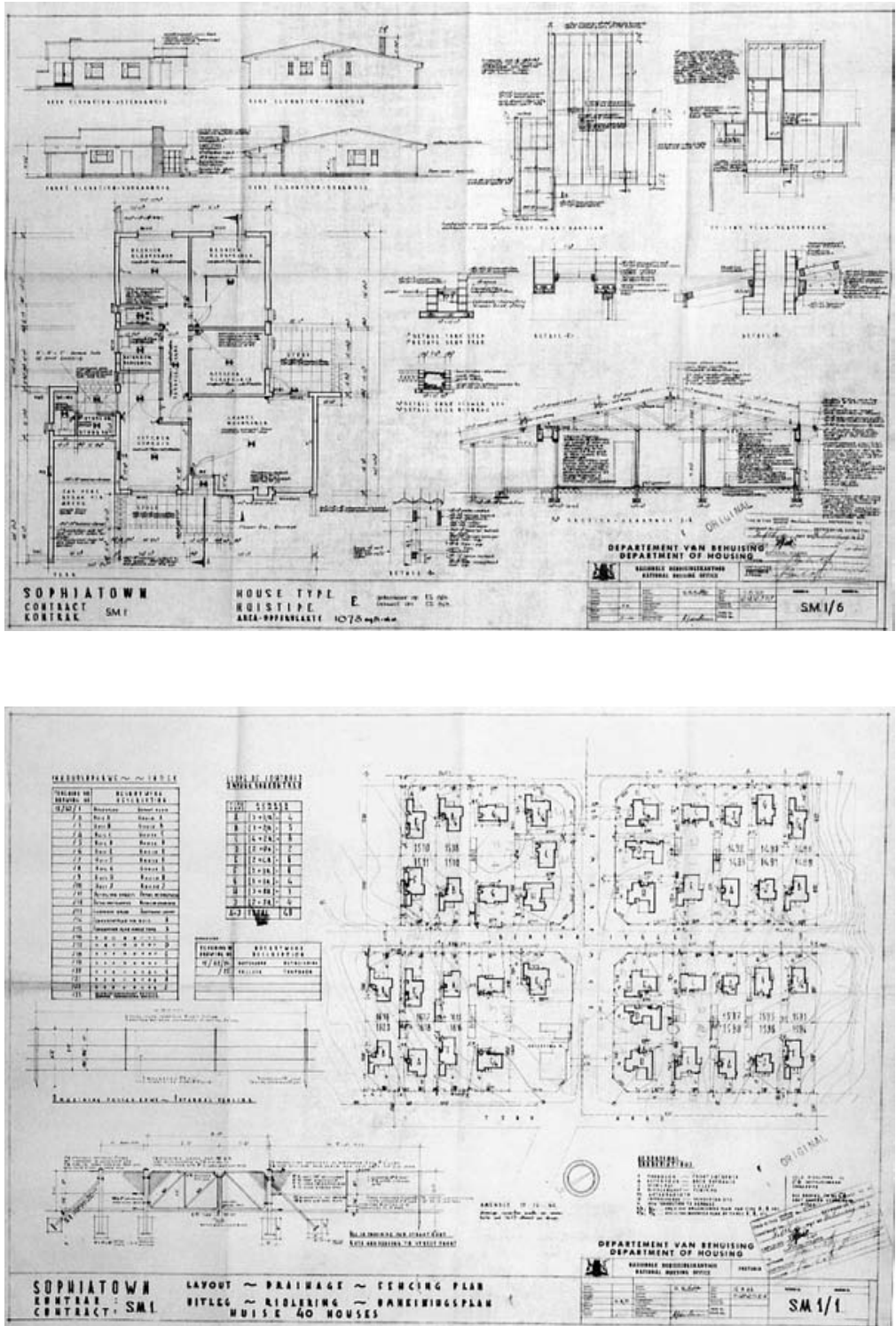

13.12

Site plan for proposed new suburb of Triomf (1963-1969)
Unlike the primarily black residents of Sophiatown, many of the inhabitants of District Six could not be connected to the narrative of tribalism and 'homeland' that was used to justify black removals. The length of their inhabitation of the city also forestalled the familiar arguments against the rapidity of black urbanisation and the consequent threat to white security. In 1966, as District Six was declared a 'white' 


\section{Erasures}

area under the Group Areas Act, the President's Council met and reported on the application of the Act with specific reference to District Six and Pageview in Johannesburg. ${ }^{16}$ In the report, its members referred to the history of land occupation at the Cape in order to place some historical weight behind a contemporary political decision. The reference to the permanence of segregation also sought to preclude the suggestion of miscegenation of the population in South Africa's history.

The principle of separate residential areas for different population groups in South Africa with its diversity of people originated, so far as the whites and coloureds are concerned, with Jan van Riebeeck's directive in 1660 that a bitter almond hedge be planted to mark the dividing line between the Hottentots and the Free Burghers. ${ }^{17}$

The conclusions reached in the report were consistent with the National Party's arguments that segregation should better be termed 'separate development' and that the policy was intended to provide suitable environments for all 'population groups' to develop independent social and cultural identity. In terms of this policy, segregated environments within the townships of the Cape Flats meant that people of the multiracial area were separated still further into smaller racial and ethnic groups, which were then relocated to particular areas in the Flats.

This decision (to declare District Six a white area) was in the opinion of the Council, based on the consideration that it was in the interests of the Coloureds and other groups that they should be concentrated elsewhere in new townships. That would lead to the development of group identification, the mobilisation of economic forces to their own advantage and to the evolution of strong social structures. ${ }^{18}$

The report of the President's Council supported the political belief that the separation of people into their own ethnic grouping was healthy both for the development of the city, 'group identity' and society as a whole. This belief was sustained despite the ambiguities of race and identity, particularly in the historically multiracial community of District Six. One note of slight unease penetrates into the report, giving a flicker of the uncertainty that resurfaces in the political debates around the forced removals:

Over the years the Coloured group has developed a strong emotional attachment to the area. Much can be said and argued about this but it is sufficient to state the fact and take note of it. ${ }^{19}$

The doubt that lingers, even in official documents, was largely put aside in the architectural and planning proposals, produced under the supervision of the Department of Community Development, which were made public in 1970. On 4 June 1965, under the Slum Clearance Act, all building activity in District Six was prohibited. The declaration of the area under the Act had the effect of worsening the deterioration 
of the buildings, which allowed a more forceful argument to be made for their removal. At the same time the Minister of Community Development announced a ten-year plan to be conducted under the Committee for the Rehabilitation of Depressed Areas (CORDA).$^{20}$ The 1969 sketch designs for the site imagine the still-occupied land as a vacant surface. Not only are the buildings removed and replaced by freestanding towers and long curved blocks, but also the dense pattern of the streets has disappeared in the open and even ground that surrounds the buildings. The buildings are separated into types; tower block flats flanking the new road, lower continuous blocks towards the mountain and a central rectangular unit in the middle of the site (Plate 13.3).

The location of the site adjacent to the centre of the city meant that the progress of the demolitions was watched by many of the cities' inhabitants. A photograph taken parallel to the streets of the city in September 1974 towards District Six, documents both the proximity of the area to the city centre and the scale and nature of the demolitions (Figure 13.13). The clearances spread outwards from the city to the mountain: the few religious buildings that managed to escape demolition stand exposed in the vacant ground around them. Two years later, when a photograph was taken looking from Sir Lowry's Road towards Table Mountain, the demolitions had created almost bare land to its lower slopes (Figure 13.14). By 1978, the view from the central area to a bare and devastated land cut into the concentration of surrounding buildings was long confirmed in the consciousness of the city's inhabitants.

13.13

Photograph taken from the central business district in Cape Town, looking towards District Six, as the demolition of the area continued (September 1974).

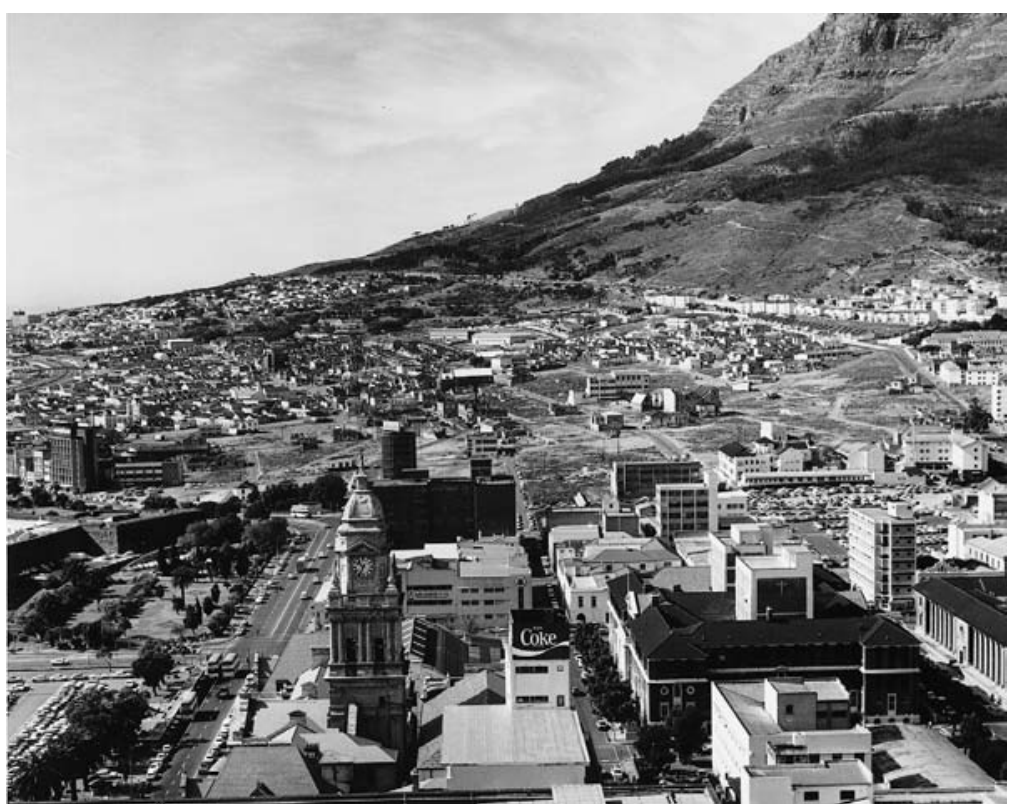




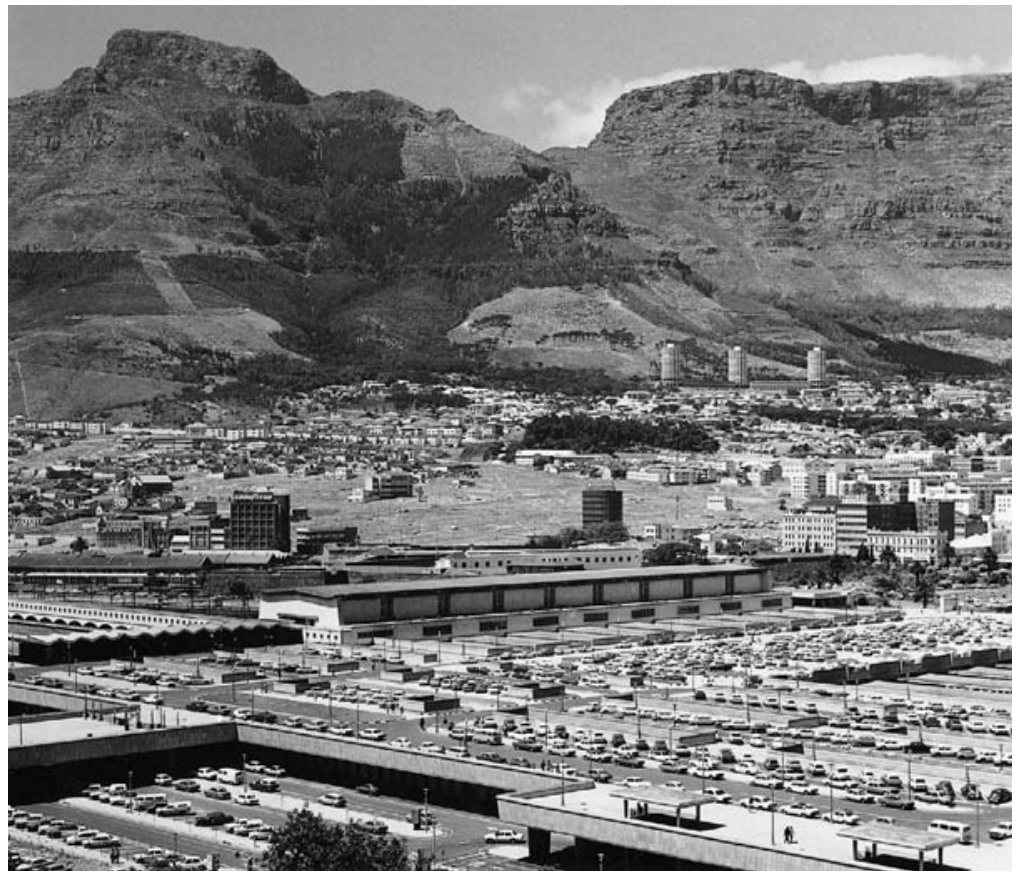

In the midst of the cars and buildings of the city, the forced removals of District Six created an emptied space which has become part of the image of the city and the area. The demolitions formed the subject of intense public debate. The state of the ground, and the growing discomfort and protest against the removals did not, however, penetrate the correspondence conducted between the planning team responsible for the new proposals for the area and the Department of Community Development. In 1969, Mr Fouché instructed the team in a letter that:

(a) District VI should become as far as possible an integral part of the city and its immediate surrounding areas.

(b) District VI should provide a self-contained residential environment for members of the white group, with a unified character of its own despite variation in the socio-economic structure of the population. ${ }^{21}$

Fouché's perception that the area needed to become an integral part of the city confirms the perception that the race of the inhabitants marked the land and served to separate it from the rest of the city. It is also evidence of how the city was perceived. In these terms, a 'complete' city was one in which the race of the inhabitants was identical. In the design report which accompanied the sketch design drawings, the planners described their approach to the still occupied site as though it was already vacant.
13.14

District Six from Cape Town city centre, looking towards the increasingly bare landscape, (1978) 
For purposes of planning and design the whole planning area was regarded as cleared of all structure, with the exception of Buildings of Historic Interest as described under 6 and the better quality buildings to be retained as suggested under $7 \ldots$

In our design we consider Vernon Terrace to be the most important of the historically important buildings and suggest it to be restored or even better, demolished and rebuilt as a particularly good habitat for old age people. ${ }^{22}$

The ambivalence with which the historical fabric of the site was viewed by those planning the 'urban renewal' allies the agenda of the planners to that of the politicians. If the best approach to 'the most important of the historically important buildings' was demolition and rebuilding, it is evident that the planners could raise little sympathy for the demise of a neighbourhood that had been condemned as a slum. For the architects and planners involved in the design, the demolition of the area provided an opportunity to exercise some of the more radical moves of modernism on a dense, centrally located, urban area.

Circumstances prevailing in the District Six project, however, obviate most of [the] obstacles to radical planning. The brief, in fact, made it quite clear that a 'clean sheet' approach was possible. ${ }^{23}$

The certainties of the planners are visible in the 1969 proposal. The areas are zoned into commercial districts, schools and residential areas, with a sinuous green space in the centre. The individual houses and residential and shopping streets of District Six were to be replaced with high-rise flat buildings and consolidated commercial zones. The design proposals were consistent with the tenets of international modernism, which advocated the separation of the activities of life into zones and buildings that were designed in order to respond to the specific functions that they supported. The detachment of the buildings from the ground plane would have separated the residents from the horizontal surface of the site, and created a different kind of spatiality, which promoted a vertical experience of the city. Because the modern roads would not encourage pausing, the chance interactions of urbanity would be less frequent. The proposal therefore sought to replace a multiuse and multiracial area, which prized a strong sense of community, with one in which a community would be difficult to cultivate; uses were separated and the race of the inhabitants was to be uniformly white.

The vision that was intended to replace District Six, therefore, was not only a racial one, but also one which imagined a different kind of city. While this vision had much in common with other projects being drawn and built at the time in Europe and in the United States, here the architecture of modernity was presented as being cohesive with the racial policies of the South African government. The clean air, open ground and vertical buildings exposed the ground and the residents to a much greater level of surveillance than was possible in the complexity of the older district. The 


\section{Erasures}

conviction of the planners and politicians, however, was confronted by the political unrest and economic failures of their own vision. The politicians had forced over 50,000 people to leave District Six and the planners allowed for 15,000 to replace them. While the design proposal was immediately rejected as economically unfeasible because of the large-scale building and demolition involved, the politicians also had to overcome the meaning that the shorn land had acquired by the implementation of the forced removals. The 'innocence' of the land and the beauty of the site positioned between the mountain and the sea was overlaid with doubt and violence, so that it could be stated in 1980 that, 'Private enterprise, with one exception, has declined to purchase land and be associated with what has become "tainted land"'. ${ }^{24}$ The planned commercial area was never built and by 1985 the white population was only $3,000-4,000$, lower-middle-class whites, mainly government employees. ${ }^{25}$ Even the attempt by the government to auction off sites at very low prices could not entice many people to buy the land.

When the construction of the Cape Technikon was first mooted at the beginning of the 1980s, it was seen as a deliberate attempt to complete the transformation of the site that had been planned more than a decade earlier. The building of the Technikon on the site of District Six was seen as an act which would prevent the reconstruction of the community life that had been so valued, through the disruption of the open space that had been retained after the demolitions. ${ }^{26}$

\section{Moving from 'slum' to township}

In a 1955 internal memorandum held in the Group Areas file in the government archive, the 'progress' from the 'primitive bush' to 'nice houses' was used to calm any unease which officials might have felt at the ends employed to move people from Sophiatown to Meadowlands. The name of the new suburb calls up images of abundant nature and picturesque landscapes, serving to confirm the political belief that the inhabitation of the city by black people was itself 'unnatural' and that they would be more at home in remote, rural landscapes. Meadowlands therefore offers a means to return to the land, but the land that it offers is one mediated by European imagery and political fantasy. The memorandum, entitled 'Slum dwellers happy in their new homes', emphasises the separate dwellings, the decency of brick, and the 'wide, open spaces' of Meadowlands. The memorandum was issued at the beginning of the removals process, five years before the last homes of Sophiatown were demolished, in an optimistic and triumphant note at the success of the removals.

The native families who have been moved from the slums of Sophiatown, Johannesburg, are happy in their new separate brick houses and have no intention of ever going back to Sophiatown.

They never had such decent housing in their lives. Many of them have moved from mud shelters in the primitive bush, to slums in Sophiatown, to nice houses in Meadowlands. 
Strangers in the slums have made friends since settling down as respectable neighbours at Meadowlands.

The families were not forcibly removed from the slums. The police were there to protect the Natives from outside agitators but there were no incidents...

The density of the slum dwellers is more than 300 per morgen . . . while the greatest density at Meadowlands, where provision is made for wide, open spaces, will be 50 per morgen, at least six times less. ${ }^{27}$

Contemporary photographs of Meadowlands reveal a strange and contradictory environment. Detached, indistinguishable face-brick houses with two steel windows mirrored around a central doorway line a dusty, hastily constructed street (Figure 13.15). On the other side of the houses, which are identical to the side facing the road, a field of grasses stretches up and over a low hill, scattered with trees. There are no signs of any other buildings, no differentiation in the hierarchy of the structures. It becomes difficult to imagine how these houses could become places of inhabitation and identification. Their roofs were pitched so that extensions were difficult, while the duplication of the units hindered attempts to locate or differentiate a particular house from any other.

The variation in the material environment is limited to the sharp delineation between the buildings and the surface (either dirt or grasses) that they sit on. The accommodations that were made in Sophiatown to the nuances of public and street life - the raised cool verandas, the colonnades - are absent. There is nothing other than the stark reality of building and ground. The Meadowlands houses were published in Drum in December 1957, in an article which reported the ongoing fight to stay in Sophiatown. ${ }^{28}$ The bleak environment of Meadowlands was used to

13.15

Photograph of Meadowlands houses from plots, from 'Sophiatown big shots fight for their homes' (December 1957), Drum, p. 81.

(C) Bailey's African History Archive.

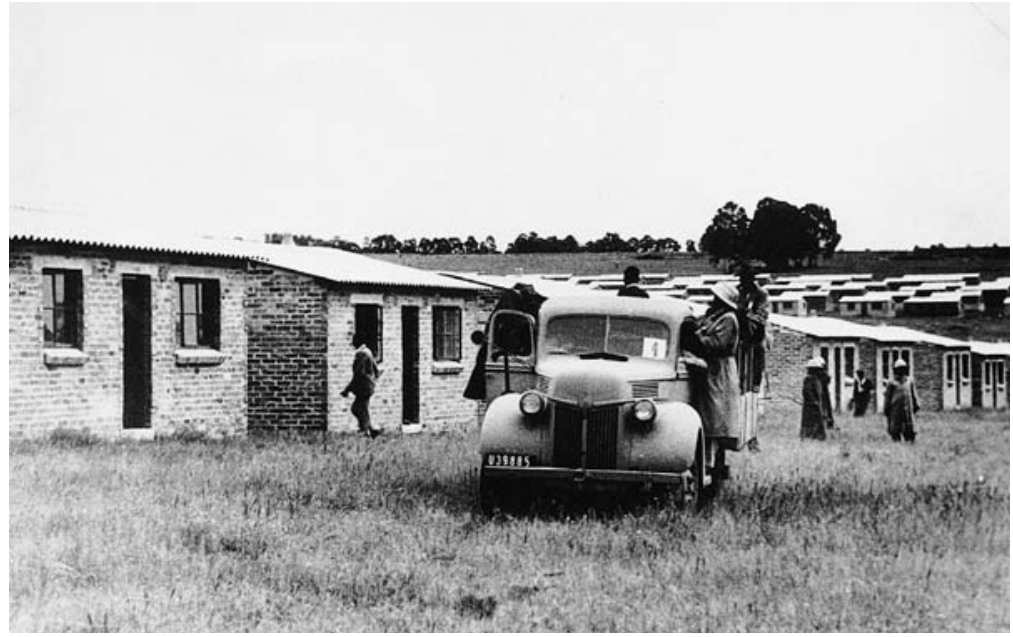




\section{Erasures}

demonstrate the loss of urbanity, and even of social and economic diversity, that occurred in the proximity of the wealth and poverty of Sophiatown.

The monotony of the duplicated houses is also unbroken by the appearance of any other type of building. The shops, churches and schools of Sophiatown have not survived the transfer across the mining land and the buildings still linger in the city. While, in the photographs, the low density of the new area supports the perception that the buildings are empty, abandoned, the watchful eyes of the black police officers scan the open spaces between the houses. Their inclusion into the photographer's frame deliberately recorded the latent threat of violence in the township and confirms, for the readers of the magazine, that the process of the removals was being observed and monitored by government employees.

Police cars also appear in photographs taken in Sophiatown during the forced removals (Figure 13.16). The streets are silent and empty while the police keep close to their vans. The Sophiatown vehicle houses bodies, while the police scan the ruins around them. The ambiguity of these photographs, the speculation that they invite, is akin to the disquiet with which residents regarded the police. They were under threat that the shadowy body almost visible in the back of the van could be that of a relative, friend or potentially their own. The force of the removals, even when not physical, was linked to an accumulation of threat that grew out of the patrol of the streets and the police presence. Even before the buildings were demolished, therefore, the areas were altered by the vans that observed them. This partnership of violence and apparent modernity tore into the representation of cleanliness and rationality of the National Party removals.

Sophiatown and District Six were imagined and built as two very different sites: partly as a consequence of the fifteen-year gap between the removals, their location and their adjacent landscapes. The suburbs of Triomf and Meadowlands, split by the barrier of the mining land, point to the way in which race was seen to

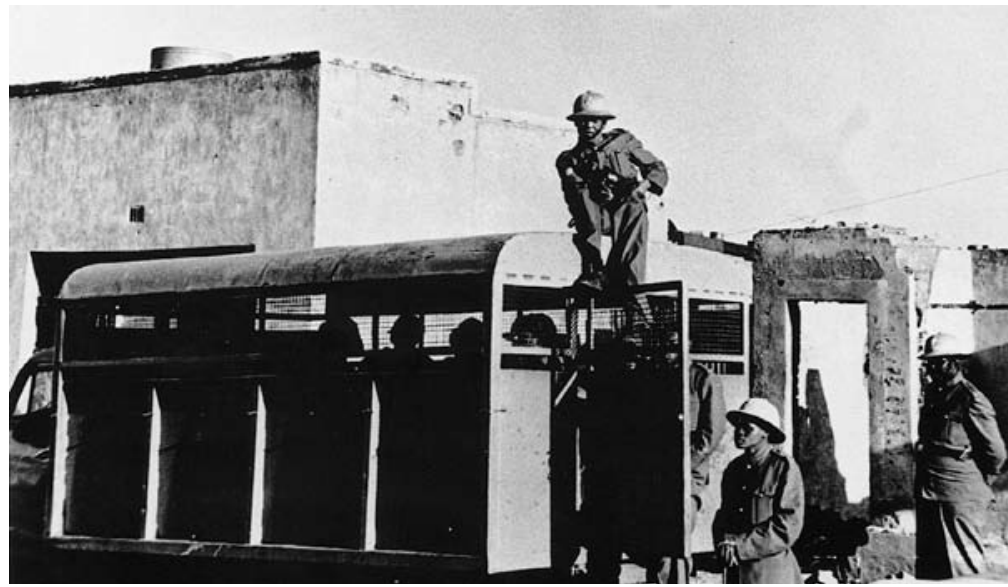

13.16

Photograph of armed police overseeing the forced removals in Sophiatown. (c) Bailey's African History Archive. 
differentiate people, but they remain variations of one another and evidence of a blinkered lack of imagination for the development of the city, and of the absence of any value placed on time, memory and community. District Six was intended to become a radical transformation of urban space - framed by the mountain and the sea; it was to be built as evidence of modern progress and transformation. Both proposals saw physical bodies to be the carrier of contamination and social disorder, and it therefore seems appropriate that it is the bodies and minds of the former residents that created an alternative vision of the city to oppose the one that displaced them, that is discussed in the following chapter. 


\section{Chapter 14}

\section{Landscapes of}

\section{the imagination}

The loss was serious. It was a loss of home, a loss of friendship that one took for granted, a loss of a neighbourhood. The loss was total. For others, moving to places in the Cape Flats was entering a hostile environment away from the safety of their homes...

Dispossessed, the loss of place, of neighbours, of Table Mountain. We must recover our memory. This is the only way to healing and justice. ${ }^{1}$

The recovery and restoration of areas and communities lost through the forced removals was possible during the apartheid years only through remembering and constructing an image in the mind. Unable to access and reinhabit physical places, reinhabitation and reclaiming of the sites of forced removals was reliant on the creation of an apparently complete and whole world through the preservation of memories and artefacts. These images of cohesive communities were inseparable from a remembering of places and landscapes connected to or surrounding the areas that had been destroyed. In addition, the proximity to the city, which was a characteristic of many of the areas that were removed under the Group Areas Act, meant that an image of urbanity and urban density was associated with the memories fostered. The reimaginings of the sites, therefore, also conceived of a different kind of city.

Along with other sites of urban forced removals - for example, South End in Port Elizabeth, Cato Manor in Durban and Simonstown in Cape Town - the removals of Sophiatown and District Six are evidence of the complexity of the meaning of the land, and the way in which this meaning has been altered through politics. The landscape that South Africans have inherited because of the actions of their forefathers is one quite different from that which the National Party government imagined they would secure when the Group Areas Act was passed. Those who gained the sites of 
once multiracial communities inherited transformed places into which the evidence of violence and destruction was embedded, while those who were severed from the area of the city in which they grew up experienced a loss of the familiar landscapes of the city which were bound up with the identity of the community, along with businesses, access to schools and other amenities that closer proximity to the cities offered.

This chapter examines representations which contested the dominant representations of the city and fostered the imagination of places destroyed under the Group Areas Act - mainly of District Six and Sophiatown, but also of other sites of removal. Also discussed are fragments which discuss the consequences of the removals for the image of the city. Through these alternative images, independent as they were of physical constraints and contemporary realities, another form of landscape was created, one which enabled the sites to be reconstructed and reclaimed through the imagination, but which also sought to maintain the presence of the areas in the minds not only of their former residents, but also of South Africans of all races. Through these landscapes of the imagination, the communities subject to the removals remained part of the memory of cities and towns, even though this presence was radically different from before the removals. Simultaneously, the physical places and proposals for their transformation (discussed in Chapter 14) offered other, increasingly destabilised, sites in which land and landscape remained contested territory. It is not a concern here to demonstrate the romanticism and nostalgia which inevitably coloured the representations of lost homes, but rather to set often contradictory representations side by side in order to examine how landscape appears and mutates within different visions of the city.

\section{'Sophiatown is a state of mind'}

Sophiatown is a state of mind, Themba said. There is no way of summing it up better. No longer just a town within a town, a segregated ghetto of South African society, the Sophiatown I know has become an important attitude. An attitude of resilience, stubbornness and unpredictability. It is an attitude of the urban African, who is pressed hard to the wall, toward a white world.

This quote from Can Themba is from an article that Lewis Nkosi wrote in $1958 .{ }^{2}$ Even as the demolitions continued, therefore, the location of Sophiatown was shifting - from a physical place to a way of being, of thinking, which could not be touched by bulldozers and dust. This apparent disassociation from the physical world allowed two things to happen: first, a place in the city became dispersed into many sites - that existed in the minds and memories of its citizens - fragile, ephemeral and intensely personal; second, the representations of this 'state of mind' - writing, music, photographs etc. - concealed their fragility behind an image created out of an accumulation of evidence. 
The density of representations during and after the apartheid years has had the affect of turning Triomf (the constructed suburb) into an unreal usurper, a mirage or a ghost, while Sophiatown (the demolished suburb) still lives and breathes. It has a rich texture and density that the physical place cannot match, and which remains detached both from the past and a physical location. In this sense the naming of Triomf as Sophiatown once more asserts the dominance of a represented world, which has continued to exist (and transform) after its removal, despite the presence of the apartheid buildings and the resident working-class Afrikaners who often still occupy the houses built for them. Sophiatown has been transferred into and cultivated by bodies and minds: it is, however, infinitely more fragile as a dispersed site. Not only is it dependent on memory, and therefore the continuing lives of those who sustain it, but also it has been subject to mutations and alterations, as memories fade and representations add to, alter and stretch its image.

Nkosi's explanation of what constitutes Sophiatown as a state of mind is different from other representations of lost homes, which often focus on loss of community, of place and amenity (as well as familiar landscapes). He defines Sophiatown as 'an attitude of resilience, of stubbornness' - back against the wall, facing the world, but still fighting. It is in a sense a collective state of mind but also one dependent on individuality and self-awareness. For Nkosi, Sophiatown was not a place or a landscape preserved by memory and artefact, but a defiant way of being. Here, bodies and minds had been transformed by the experience of Sophiatown, so that even though the place was ceasing to exist, the spirit of it remained. In the decades since the removal, however, this image of Sophiatown as a 'state of mind' has been supplemented by representations that emphasise physical objects, people and spaces - mainly through photographs of events, buildings, clothing - and music, which seek to preserve an image of a 'complete' world, despite the lack of a supportive physical counterpart to sustain it.

\section{Hygiene and modernity}

This tension and discord within representations of places targeted under the Group Areas Act began as the future of the areas was debated. At stake in representations of threatened areas was their continued survival and a fundamentally different conception of what it meant to inhabit the city. While the modernising agenda of the National Party sought a racially homogenous, hygienic city, the urbanites of Sophiatown defended their territory against simplification and uniformity.

The intense-looking young journalist raised puzzled eyebrows at a group of Sophiatown's articulate young men. 'But I don't understand this,' he pleaded. 'Why don't the people of Sophiatown want to move out to Meadowlands. Houses there are much cleaner and there is no overcrowding. On the other hand, Sophiatown is just a slum.' Bloke Modisane was sitting on the rug. He shifted easily from one side to the other. His grin 
was enticing, ambiguous. 'That's just the trouble,' he smiled, 'Meadowlands is much too clean for us. It's been cleaned up of all colour and spiritual values that one still recognises in the life of Sophiatown.'

The hygiene of the city, so important to the Nationalists, was rejected by Modisane as symptomatic of another kind of absence, of colour and life, recalling the dismissal of 'white' Johannesburg that was described by Themba in earlier discussions of Johannesburg. This 'dirtiness' of Sophiatown was also part of the way in which a modern city was understood by its inhabitants - not as a place of clarity and openness, but a modern world which incorporated pain, hardship and celebration. It is an alternative vision of modernity, one more responsive to (and aware of) the consequences of urbanisation and industrialisation. The typical Drum language, politicised but populist and with a light-hearted, often cynical edge, was also present in an article published in 1959. Benson Dyanti in an article entitled 'Last days of Sophiatown' describes the lost part of the city known as 'Sof'town', and the complexity of 'her' history.

I was robbed on her streets, beaten up in her dark corners ... There is pathos, mirth, murder and sweet abandon in her past history. Way back in the early thirties, where the Odin cinema now stands abandoned, was the Undermoon Hall where African Jazz was born . . .

This was the territory of the Berlin Gang. People were murdered here. But people also laughed, and kids played. .

Sophiatown, the city that was within a city, the Gay Paris of Johannesburg, the notorious Casbah gang den, the shebeenist of them all; ${ }^{3}$ Sophiatown is now breathing for the last time... Her people do not like the fact that she is being murdered and I sympathise with them because she was a free city. ${ }^{4}$

In Dyanti's article Sophiatown is represented as a female body, one which, in turn, owns the bodies of 'her' people. The gendering of the area as female associated Sophiatown with the body of Mother Africa, in contrast to the recurring representation (during National Party rule) of South Africa as a fatherland. Dyanti invokes a picture of Sophiatown as a woman, slightly bruised and battered by life, who looks at the world with knowing eyes, but remains nurturing and resilient; a product of her experiences, violent as well as pleasurable. The body of Sophiatown is therefore one into which people and events are etched, creating a complex form which reflects the ambiguities of the city. The modernity that Sophiatown offered contests the modernist-inspired government representation of the city as a diseased (sexually neutral) body, upon which urgent surgery is to be performed for the sake of its health. This is a body that was to be reconstructed so perfectly as to erase all scars and histories. It is therefore evident that at stake are two very different images of the city and how that city is taken up into the bodies of its citizens.

The vision of the modern city as a place of unexpected complexities was fostered by the presence of modern music, particularly of jazz, which has remained a 


\section{Erasures}

medium in which the identity of Sophiatown is still seen to live. Musicians such as the Manhattan Brothers, Kippie Moeketsi, Hugh Masekela and Miriam Makeba (the Voice of Mother Africa) interpreted North American jazz within a modern African context. Jazz music, and its interpretation in 1950s Johannesburg, connected to international culture and represented the irregular and improvisational aspects of modern life, its discord and freedom. It is outside the scope of this research, but it has been argued that Sophiatown, and the music in particular, was the launching pad for an image of African modernity into the rest of Africa. Music, and therefore an aural representation of place, was critical both to the identity of Sophiatown and the strength of this image both within South Africa and internationally.

The transfer of music into the bodies of its listeners and performers displaced a sense of the area outside its physical limits and destruction. This sense of Sophiatown as a place of modernity and sound was supplemented through Todd Matshikiza's 1959 musical King Kong, while the necessity of building physical stage sets for the performances altered and reimagined a Sophiatown which had ceased to exist. In King Kong, and the 1986 musical Sophiatown (by Malcolm Purkey and the Junction Avenue Theatre Company), colourful sets signified the 'colourful' life of the inhabitants, the mingling of different races and the informality of existence.

In a discussion of 1950s township jazz Michael Titlestad has argued that '[s]ound is a means of . . . identifying space, in the sense that 'sounding out' is a projection into the world of a mode of being, an ideology or a version of history (in short an identity)'. ${ }^{5}$ In this sense sound not only calls to mind (for ex-residents, for example) jazz at the Odin Cinema and a young Makeba in a 1950s dress, but also represents the existence and identity of Sophiatown to outsiders. The recordings that were made at the time, in particular, remain as representations of spaces that no longer exist but that can still invoke a sense of place and time. This ability of representation to elude the control of the National Party government through the exploration of alternative forms, has also forced our understanding of space and landscape to stretch to include less conventional representations. Rather than remaining tied to the physical world, sound and memories reconstruct an image in the mind which includes space, land, history and identity. The image of the urban landscape that results is therefore a hybrid one which is composed of a continually shifting set of representations - including oral, cinematic, aural, visual, literary and physical.

\section{Hybrid bodies}

The stability of racially homogenous cities and landscapes was challenged by people for whom living with others of different races, when they were even recognised as being different, was part of everyday life. In many representations of societies before the removals, therefore, stability was associated with hybridity, while uniformity of place, buildings and people was a source of great unease and discomfort. A recurring theme of the representation of the removal of areas under the Group Areas 
Act is the destruction not only of physical fabric, but also of communities. One description of a forced removal in Mayville in Durban, and the destruction of that community, remembers how a hybrid culture was normative in urban areas.

I have lived all over Durban - Musgrave, Overport, Silverton, Mayville and Cato Manor. There, all races lived together with no problems. We used to make 'isiqatha' to sell like we do here in the townships and there was never any violence ...6

In this area there was no distinction between races. I can't even mention things about the 'coloured' people as we were just one. There were a lot of intermarriages between African and Coloured people and those marriages are still solid, some of them moved here into Clermont and even now it is only because you have asked me that I think of them being Coloured.

We stayed closely and freely with all our Indian neighbours. We all had big families and used to sleep together with them on the floor like one family. We shared what food we had in times of trouble. We were a close community sharing our times of happiness and our sorrows together.

As children, we all engaged in the same games and also mischief. We mixed English and Zulu and some Indian language - our mixed language. A cousin of mine spoke one Indian language fluently. She was dressed by our Indian friends on her wedding day.

Though we attended different schools, they were directly opposite one another and we'd play together during break times and were taking the same bus to and from school. We were not aware that we looked different from one another until we were told to move out of Mayville. It was so painful when we were forcefully separated from one another by the Group Areas Act. ${ }^{7}$

This description of urban life before the removals suggests that multiracial areas enabled the creation of hybrid cultures and languages, which intertwined aspects of seemingly diverse societies. While memories tend to emphasise cohesion, rather than conflict, this sharing of language, clothing, food and play has supported a perception of place in which race was not remembered as being particularly significant. Furthermore, racial classification was itself undermined by the ambiguity of histories, marriages and children born into multiracial societies. Frequently in descriptions of the removals there are references made to families being split up on the basis of the colour of their skins, those with paler complexions able to remain in their childhood homes, while darker-skinned siblings were sent out to the newly created townships. These ruptures in society, culture and families belied the argument for a 'natural' separation of people of different races. It also supports an idea of urbanity in which a sense of belonging and home was dependent on the support of a hybrid society in which stability was associated with relationships and experiences, rather than racial segregation. 
The image of the streets as places of interaction and performance, where the complexities of urban culture were tested and explored, has been stressed in residents' descriptions, photographs, and in the first exhibition staged by the District Six Museum (Streets - Retracing District Six). The museum was launched in 1994 by the District Six Museum Foundation (which was established in 1989) in order 'to keep alive the memories of District Six and displaced people everywhere', ${ }^{8}$ and is located in the Buitenkant Methodist Church Hall, adjacent to the area of the removals. The streets in these descriptions and representations are constructed as complex spaces, that become tied up with the identity of the community and exist as places of the everyday between private and public life. The streets are places of intimacies, secret knowledge and childhood games where the community both watches and interacts with others. One of the former residents, Achmat Davids, described the connection between the streets and the community.

These people stick together. When they came into contact on the streets look District Six life was on the streets. People lived in the streets. There were always children running around as busy as it was with cars, trams going up there, they dodged between them and hardly had any accidents but it was definitely a feeling of community. ${ }^{9}$

Again, therefore, the pressures of dense urban living, the proximity of people of different origins and the consequent adaptation of people to their homes in the city altered the way in which the city was used and inhabited. This porosity of boundaries has been represented as being an intrinsic part of the way in which people belonged in places. Feeling 'at home' in the city was dependent on insider knowledge, comfort with the contradictions of urban life, and feeling able to negotiate the complexities of living in spaces which were simultaneously the home to others of different backgrounds.

\section{The struggle for representation}

From the time that the removals were first suggested, representations, particularly writings, contested the image of the area fostered by National Party officials. Sophiatown was argued for as a complex and differentiated area, which could be improved by targeting individual stands, rather than the entire suburb.

The Regional Committee does not take up the attitude that present conditions in the Western Areas are satisfactory. Far from it. But it is firmly convinced that slums can be cleared and congestion reduced without uprooting a whole population, without breaking those deep emotional ties which bind a people to a familiar environment, without depriving Africans of homes acquired by a lifetime of saving, without compelling the removal and presumable destruction of large schools, missions and churches, without robbing Africans of their only freehold rights in Johannesburg ... 
The spokesmen of the City Council have created the impression that the Western Areas are one undifferentiated slum. This is, the Committee submits, not so. There is grave overcrowding, one of the chief contributory causes of which is the lack of alternative accommodation, and there are many stands which are slums and should be condemned ... [T] he point the Committee stresses is that there are many houses owned by Africans in Sophiatown and Martindale which would do credit to any suburb in Johannesburg. To remove these is needlessly to increase the staggering Native housing problem which seems to already have overwhelmed the Council. ${ }^{10}$

Trevor Huddlestone, the British-born Anglican minister of Sophiatown, countered the description of Sophiatown as a slum by portraying it as a place which had a distinct identity that was visible from lower areas of the largely level city. He connected it to a romantic vision of European urban landscapes. Although Sophiatown lacked the proximity to the central city of District Six to Cape Town, Huddlestone's account confirms the visibility of the area on its slightly raised topography and carefully describes the buildings, people and light which constitute his personal image of Sophiatown.

Sophiatown is not, and has never been, a slum. There are no tenements; there is nothing really old. There are no dark cellars. Sometimes looking up at Sophiatown from Western Native Township, across the main road, I have felt I was looking at an Italian village somewhere in Umbria. For you do 'look up' at Sophiatown, and in the evening light, across the blue haze of smoke from braziers and chimneys against a saffron sky, you see close packed, red roofed little houses. You see, on the farthest skyline, the tall and shapely blue gum trees... You see, moving up and down the hilly streets, people in groups; people with colourful clothes who, when you come up to them, are children playing, dancing and standing around the braziers. In the evening, towards the early South African sunset, there is very little of the slum about Sophiatown. ${ }^{11}$

The cumulative detail of the urban landscape that Huddlestone describes is also repeated in written and photographic descriptions. The social and material complexity reflected in representations of Sophiatown was tied both to the complexity of urban experience that it offered and the lack of spatial clarity that was a frustration to government officials. The demolition and reconstruction of Sophiatown was fraught with contradiction and conflict, which has become part both of the representation of the Sophiatown reconstructed in writings, songs and photographs and of Triomf. The removal of Sophiatown has therefore penetrated into the image of the city held by citizens of all races: its meaning is constituted not only by that which was removed, but increasingly by that which is constructed as an alternative image of the site. The emphasis of the representations continually shifts, as time passes and as priorities change. 


\section{Erasures}

The violence done to cities under the Group Areas Act has been documented in intimate, personal and detailed ways through photographs taken at ground level, oral histories, poems and testimonies. In these representations of the land and of the forced removals the focus is on the everyday, on textures, and on views made possible by the proximity of the creator to the subject. These are narrations of individuals, breathing the air and walking on the soil. Their stories are challenges to overarching political policies in which the experiences and even the humanity of an individual were believed to be limited by the boundaries of race. The poet Mongane Wally Serote's vision of a forced removal forces an intimacy on the reader. The bulldozer becomes anthropomorphic - its teeth '[drip] blood'.

\section{Death Survey}

[Extract]

cruel

even screams don't come in a dream like this

why

this bloody bulldozer had done a good job and its teeth

dripped blood;

bricks-pillars-hunks-of-concrete-zincs-broken-steps-doors-

broken-glasses-crooked window-panes-broken-flower-

pots-planks-twisted-shoes

lay all over the show

like a complete story,

i ran

my toes bleeding

and i held my heart in my right hand

like a jacket. ${ }^{12}$

The violence done to the buildings by the bulldozer is again seen as an act of murder on the physical body of the city, which responds with its own blood. In the debris of the removals, the bricks and concrete fragments are intertwined with the more fragile elements of human inhabitation - flowerpots and shoes. In the death of the city, therefore, its body and that of its citizens mingle. The rawness of 'Death Survey' is in stark contrast to the dispassionate narrations of the Group Areas declarations. The one below, from 1960, declares the Western Areas 'white' - after the majority of the residents had been removed to Meadowlands.

Under the powers vested in me by section twenty of the Group Areas Act, 1957 (Act No. 77 of 1957), I do hereby declare-

(i) that the area defined in the Schedule hereto shall, as from the date of publication hereof, be an area for occupation and ownership by members of the white group; ... . 


\section{SCHEDULE}

Beginning at the point where the prolongation of the western boundary of Best Street in the township of Sophiatown (General Plan S. G. No. A5005/03) intersects boundary LM on the said General Plan; thence southeastwards along the boundaries of the said General Plan to where it is intersected by the western boundary of Gibson Street to where it intersects boundary $C D$ on the said General Plan; thence north-westward along the boundaries of the said General Plan to where it is intersected by the prolongation of the western boundary of the said Best Street; thence north-eastwards along the said prolongation and boundary and the prolongation thereof to the point first named..$^{13}$

These two surveys, which were produced in response to the removals, provide two extreme visions of the land. In Serote's poem the land acquires an intensely personal layer of wreckage. It is the site of a disaster zone, a 'complete story' of debris, which later becomes a layer of the ground. The poem focuses on the materiality of the ruins, on the composition of the rubble. The written survey of the boundaries of Sophiatown in the Group Areas declaration floats, not above the land, but above a map. It is a spare written statement of the tracing of a line. These two representations, produced almost simultaneously, demonstrate how representation became part of the struggle for and meaning of the landscape.

Sophiatown and District Six were also represented as autonomous cities in and of themselves, not primarily as fragments of the larger metropolitan areas of Johannesburg and Cape Town. The physical, functional and emotional intensity of both places advanced not only a sense of self-sufficiency, but also one of autonomy - bounded environments which were set apart from their surroundings, even before the declarations of the Group Areas Act. While this sense of identity and cohesion was present in descriptions of both areas before the removals, it has also been strengthened by representations produced after the demolitions. The separation from the physical space of the city, and the focus on retaining an image of the areas, has served to intensify the emotional boundaries of the places, even as their physical boundaries became less distinct. For Dangor, therefore, the expression of District Six as a city (paradise, even) communicates both the strong physical identity of the area, and the way that the stones and physical constructions of the place themselves carry history and memories.

\section{Paradise \\ Here, around me they destroy my city. District Six, they dismantle you - stone by stone - rock of my history ${ }^{14}$}




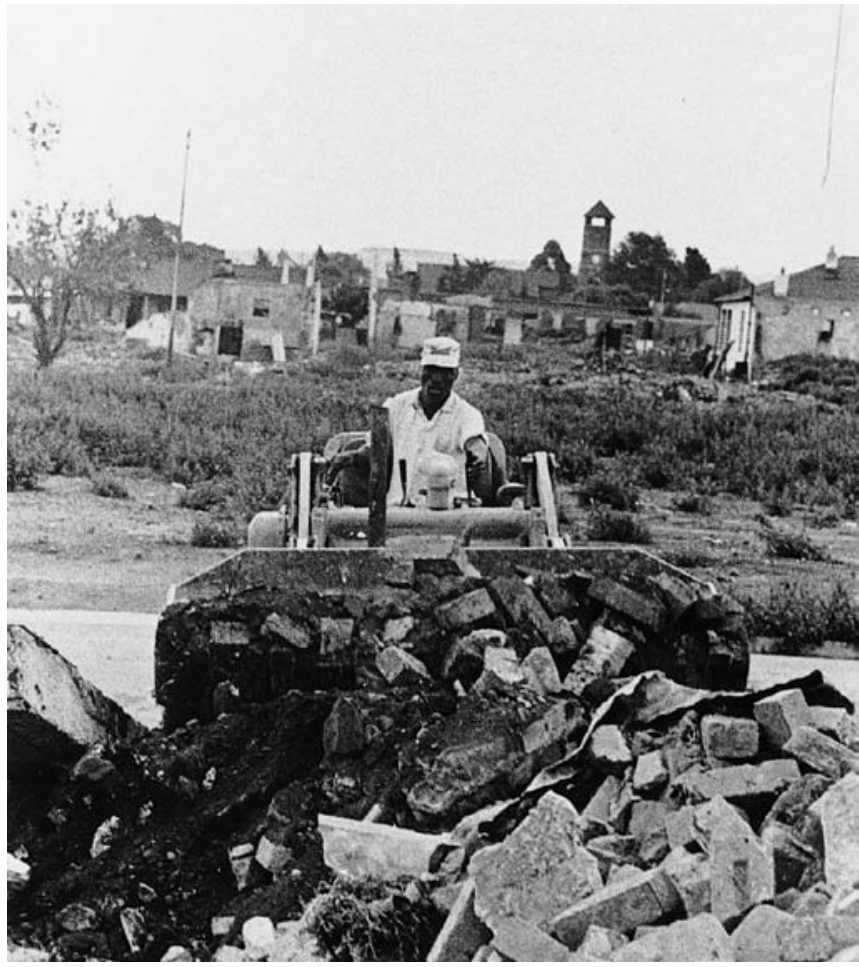

14.1

Photograph of a bulldozer clearing rubble during the demolition of Sophiatown (late 1950s). () Bailey's African History Archive.

A photograph from the Drum archive shows a bulldozer pushing a pile of rubble towards the camera while, in the background, fragments of partially demolished buildings, unroofed gable-end walls and abandoned doorways wait their turn (Figure 14.1). In the distance the outline of a mine dump is visible. Among the debris of the demolitions, grasses slowly take over the ground.

While, in the years immediately after the removals, representations focused on the violence of the bulldozers and the decay of the urban environments, these images of brutality and hardship have been overlaid with more alluring representations of intense lives, and (in the case of District Six) the relationship to a powerful landscape. Jürgen Schadeberg, a Drum photographer still active in South Africa, has noted:

Certain things become glamorised and the tragic things are suppressed. People look into the past and see the best of what happened . . . I've got many pictures of the removals and of when it was demolished and the arrival of the bulldozers, but most of the calls I get are for the glamorous photographs of Sophiatown. ${ }^{15}$ 


\section{Mountain and sea}

Landscape was not only conceived of as being a barrier between people of different races but also seen as a resource which was too valuable for South Africans who were not classified as 'white'. Under the Group Areas Act, views from particular areas of land to mountains or seas were increasingly reserved for white South Africans, while, simultaneously, the Act was used to target black areas which were overlooked by and were built in close proximity to those occupied by whites. In Mossel Bay, on the south coast of South Africa, a journalist remarked that, 'In the suburb adjoining Sunnyside, Tarka, uncertainty reigns. This established non-white area is coveted by many of the town's white residents, merely because of the beautiful view that it commands'. ${ }^{16}$ In District Six, the motivating factors of view and position were explicitly stated. In a quotation published in the Cape Times, in January 1969, a representative of the Department appealed to the (mostly white) readers' appreciation of the immediate landscape.

With a view to its special situation on the slopes of Table Mountain, the beautiful view and the attractive scenery ... [t]he best contribution which can be demanded from the area in the interests of community development is the establishment of economic housing of a relatively high standard therein. ${ }^{17}$

The removal of the citizens of District Six was therefore represented not only as a clearance, but also as the reinstatement to the city of an amenity that was strongly associated with its symbolic landscapes. It was a landscape that had both visual and economic value. ${ }^{18}$ This economic motivation linked a traditional conception of landscape as a picturesque view into the heart of the legislation and the removals. For District Six residents too, the surrounding landscape of Table Mountain and the harbour of Table Bay was a significant part of the meaning of the area and the connection to the land. The presence of the mountain and sea has therefore been maintained as a constant landscape, which frames the site. It has become not only a signifier of that which was lost, but also a means to re-identify with the bare land. As one former resident stated:

I was very passionate about District Six because you looked one way and you saw Table Mountain and you looked the other way and you saw the sea, and then I was forced to go to a place where I couldn't see anything. ${ }^{19}$

The lack of the familiar views is here associated with sightlessness, the resident 'cannot see anything', not even the level ground of the Flats. This perception of the significance of the landscape was shared by others who have given accounts of their lives to the Oral History Project conducted by the University of Cape Town. Mrs Adams related how she associated the proximity of the significant features of the landscape with a pleasurable life. 


\section{Erasures}

Now where we lived the house was one of those that just went down, those steps and then beneath was also another little house. [There] [w]as also a stair. And we lived just the other side of the school. And if we stood on our front porch we could see the whole of Table Mountain. And if we stood in the backyard we could see the whole docks. We lived so well. ${ }^{20}$

Part of the significance of District Six was therefore shifted to the external landscape - the proximity to the central city area and the location between mountain and sea. The emphasis on the views of Cape Town, which remain indivisible from the identity of the city, has allowed residents to retain the dream of returning, even as the residential fabric was destroyed. These views have remained critical to the imagination of home and a fundamental part of the identification with the site. While oral histories collected in the 1980s and 1990s testify to the value that the external landscape had to the residents, some earlier representations of District Six concentrated on the decay of the internal environment.

\section{Mode of Broken Pieces}

[Extract]

a scenery ceases to be anything

if corpses lie like that cold on its surface [. . .]

District Six with hordes of rats

and

damp wooden floors

rising up-

stairs

into some deep stinking arse hole

with toilets wetting the feet with urine

and dagga flames the aura

dazed to forget hunger

why?

did white people have blue eyes

because now District Six dapples them

pitched in a black heart red with blood like leaping flames

glowing in song and warmth

as afro-american horns crack in the air

saying the hour

is disastrous because everyone is fighting on the dump heap

where white people throw refuse thought about us

why look at those people's heads smashing like that into

each other

so

unborn children don't forgive them, they know what they did big people playing with sperms like that 


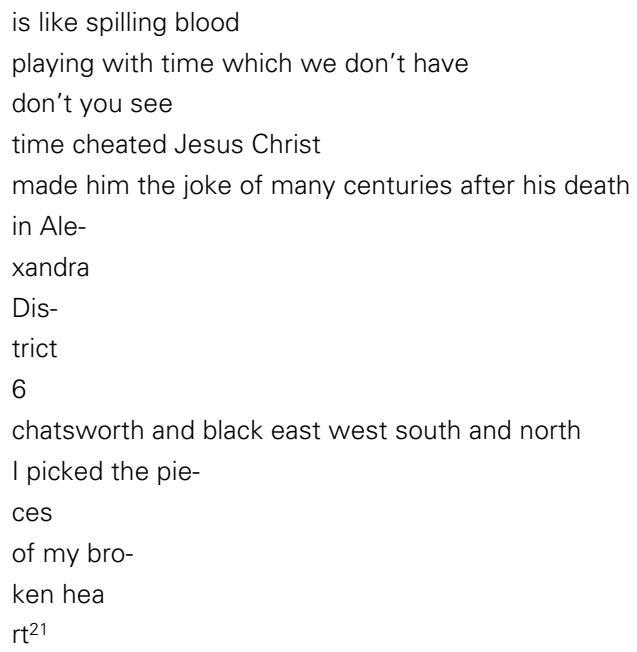

Mongane Wally Serote's vision allies social disorder to the inadequacy of the structures that people inhabited and 'scenery' is represented as meaningless in the face of the debris that lies within the land. Serote portrays the bitterness and anger that were directed at the National Party government at this time. He links the poverty and crime of District Six, in a time before its demolition, to that of the densely populated Johannesburg township of Alexandra and to Chatsworth in Durban. The 'east west south and north' of black South Africa is connected through the physical and social consequences of National Party rule. Here, the visual landscape is rejected as irrelevant, in favour of a conception of the land that is inseparable from violence, desperation and decay.

\section{Lacking landscape - the move to 'nowhere'}

The claiming of areas, partly because of their physical beauty, was countered by those who laid prior claim to the land and landscape. To these residents, the lack of familiar views was a means to express both the loss of home and the lack of identification with the sites on which they were resettled. In an article published in Drum, in 1962, Nat Nakasa documented the response of people to be moved under the Group Areas Act. ${ }^{22}$ Their dislocation from their lands and homes was called a move to 'nowhere'. Nkosi described Meadowlands as 'the ultimate negation' of Sophiatown.

Contrasted to Sophiatown's compactness, Meadowlands is a sprawling army camp that would make organising it for any political action in one night almost impossible. Ethnic grouping will dissipate the cogent atmosphere of multi-tribal Sophiatownism to nothing. Moreover, Meadowlands is the ultimate negation of the multi-racial spirit of Sophiatown's Coloured, African and Indian Community life. ${ }^{23}$ 


\section{Erasures}

There were a number of forced removals in the Cape and coastal area, from District Six to Simonstown, Claremont and Windermere. While in District Six and Sophiatown, entire communities were moved and areas demolished, in some cases, and particularly in the Cape, people of different races had historically been intertwined and the removals maintained the built fabric of the areas, while targeting particular families within the multiracial communities. Some of those affected were moved to places which were given names which related to the sites from which the residents had been moved. Ocean View, in Cape Town, housed residents from Simonstown, Glencairn and Noordhoek, all areas close to, and overlooking the sea, while their new area was displaced inland.

Representations of the settlement areas and their buildings were often depicted as being the inverse, or negative, of the previous communities. Hierarchy was replaced with monotony, properly constructed buildings with poorly made shells, and views of spectacular places with undifferentiated horizons. ${ }^{24} \mathrm{~A}$ description of Newlands and Bonteheuwel in the Cape opposes the two places with language and images that were repeated during many other removals.

There was anger among people who will have to pull up their roots and move from an area where they have lived all their lives. They will have to leave the community in which they feel they belong and start all over again somewhere else... They say there can be no comparison in terms of comfort and pleasant surroundings between the well-established little Newlands community, green in the shadow of the mountains, and the brash, new, expanding Bonteheuwel where the houses are all alike and the roads are narrow strips of concrete bordered by the fine Flats sand. ${ }^{25}$

In other descriptions, 'rootedness' and 'roots' were similarly repeated, countering the representation of black inhabitation of the city as being 'unnatural' with language of innate belonging and growth over time into the depths of the soil. A description of the forced removal planned for Simonstown links this removal of the land's inhabitants to the creation of a town filled with ghosts. In this description the removal alters the sense of home, both for those removed under the Act and the people who remain.

Now they are to have their very roots torn out of their native soil. Nothing can ever replace a lost home with all its memories and associations. When the dread time comes for them all to go, it will be a town of unhappy ghosts, haunted by those who have been so callously ejected from the homes and land of their forefathers. ${ }^{26}$

Here, as in other descriptions, there is a sense that a green, cultivated landscape allowed residents to make a place in the world, while the barrenness and infertility of the new areas connects to a feeling of homelessness. Removals in the urban environment therefore had similar consequences for the representation of vegetation and landscape to those in rural locations. Removed from recognisable places, those 
subject to the removals mourned both community and place. Cultivation and familiar landscapes were associated with the presence on the site over a long period of time and therefore with a sense of home and belonging.

The Group Areas Act and the forced removals contributed to the meaning of urban landscapes in two primary ways. First, the displacement of large numbers of people from central areas in cities and towns transformed physical spaces, multiracial occupations of space and the meaning of the urban landscapes for former residents and remaining residents alike. Second, the reconstruction and reclaiming of the land through the imagination confirmed the presence of landscape in diverse forms of representation, which contributed to a transformation of the way in which landscape can be understood. Landscape is both a battleground for ownership and identification with the land, and a constantly transforming image which incorporates different representations and conflicting meanings. While representations of District Six and Sophiatown have tended to stabilise the images of the sites in order to reclaim them, many representations invert our expectations - associating change, negotiations and the unexpected with a consistency of meaning. In this sense, feeling at home in the city is about reclaiming ambiguity, hybridity and flux. 


\section{Chapter 15}

\section{Transforming landscape}

Mol stares at all the stuff Lambert has dug out of the earth. It's a helluva heap. Pieces of red brick, bits of smooth drainpipe, thick chunks of old cement, and that blue gravel you see on graves. Small bits of glass and other stuff shine in the muck...

She picks Gerty up and looks across the length of the bare yard. The yellow lawn stretches all the way up to the wire fence in front. Lambert says it's just rubble wherever you dig, here where they live. Under the streets too. From Toby right through to Annandale on the other side. Rubble, just rubble...

A lot of their stuff got left behind. Whole dressers full of crockery. You could hear things breaking to pieces when the bulldozers moved in. Beds and enamel basins and sink baths and all kinds of stuff. All of it just smashed. ${ }^{1}$

This extract comes from Marlene van Niekerk's novel, Triomf, which was published in Afrikaans in 1994, the year of the first democratic elections in South Africa. The novel centres on the Benades, a family of Afrikaans 'poor whites' living in Johannesburg in Triomf - that was once Sophiatown. In the extract Mol, the mother figure, muses over the materials that form the ground beneath her feet, and recalls the bulldozers that smashed the paraphernalia of life in Sophiatown.

In the novel, Lambertus - the inbred, and sometimes violent, only son of Mol and one of her resident brothers - continually digs into the layers of infertile rubble beneath their house, excavating the fragmentary evidence of life in Sophiatown that remains. Their home and their lives are built on the debris of another city, one that periodically surfaces in the flashes of humanity that occur in the family's encounters with Johannesburg's black inhabitants - the memory and prior presence of whom 
unsettles the fragile family enough that they constantly fret about leaving their home and heading 'north'.

The book acknowledges both the destruction of lives under the forced removals and the powerlessness and frustration of the less than triumphant lives that the Benades, and others like them, live on land that was once occupied by others. Van Niekerk uses the archaeology of the ground and its layers of debris to maintain the presence of the site's previous inhabitants and to overlay two different political and social landscapes, which are constantly being revised and negotiated. In Triomf, the contemporary state of the area and the memory and physical evidence of its life as Sophiatown intersect, creating a place of not only unease and discomfort, but also reconciliation. Here landscape functions not as a stable 'way of seeing' but rather as unstable ground which is dug deep into the earth, full of memories and debris - the ownership and meaning of which remains uncertain and ambiguous for both black and white South Africans. Triomf contributes to the representation of an unsettled landscape, in which ideas of belonging and being 'at home' are always complicated by the presence of other claimants and other histories.

Landscape therefore emerges at the end of the apartheid period as a mutating representation, or series of representations, which conflict, challenge and contradict one another. The representations which sought to remember and reconstruct the demolished area - through texts, photographs, music and performance - confront and overlay the altered physical places of the cities and rural areas. The meaning and form of the land therefore continues to be complicated both by different claims on its ownership and by its simultaneous, and conflicting, presence in both the physical world (which had political and cultural meaning tied to the memory of the removals) and in the imagination (which sought to preserve and record the sites before the removals). There is a tension between these two locations and types of landscape - places created by violence and political will that could be touched, walked across and seen, and the sites of the mind - personal memories of place and community - that were more fleeting, elusive and intangible. Landscape can be understood as a hybrid representation, the meaning of which is inseparable from ambiguity and uncertainty, but which also draws its power from these struggles, and its presence in varied forms of representation. In post-apartheid South Africa, the intersection of different representations and claims on the land allows the struggle over history and identity to be both written and read.

The alterations to land and to representations that have occurred over the twentieth century have therefore had consequences not only for the physical ground, but also for the way in which the term 'landscape' is used. The shift in emphasis from visual representations of the land to written descriptions and poems to a contemporary interest in oral histories traces an alteration in the way in which the land is understood as meaningful through representation. 'Landscape' is, however, not a term which has a consistent meaning or usage within historical or contemporary texts. It is still uncertain, yielding and is being tested and moulded by the new situations that it is used to describe. After the end of apartheid a new kind of landscape is emerging 


\section{Erasures}

- one which seeks a reconciliation between the physical reality of ownership and structures and the landscape of the imagination, while simultaneously tracing and recording personal histories and memories. This chapter therefore focuses on how landscape is being used and transformed through texts and practices which overlay different occupations and imaginations of the land. It raises a series of questions. Is landscape a valid means to conceptualise the cultural and social meanings of the land and its representation in South Africa? What are the characteristics and mediums of this 'landscape' that has reappeared as part of the language of reimagination and reappropriation? Can a transformed understanding of landscape contribute not only to the reimagination, but also to the remaking of places?

\section{Beyond the visual landscape}

Many writers, poets and artists who have been concerned with describing landscape in South Africa, particularly in the twentieth century, have struggled to represent what is perceived as being the 'deep' meaning of the land, which persists beyond individual lives and experiences. In these encounters the landscape that is represented does not supplant the land which is its source, but always attempts to draw closer to it. This is particularly the case with pictorial representations which, with their emphasis on the visual attributes of the land, were believed to be less able to penetrate below the surface of the ground. There is a sense that the meaning of a place is more intimate and elusive than a representation of it and that its meaning is ploughed into the soil. In this sense the land itself remains the primary source of the representation and the focus of desire. The importance of post-apartheid land claims (details of which lie outside the scope of this book) is evidence of the presence of both rural and urban land for culture, identity and the restitution of political rights. While the landscape is inseparable from society, politics and culture, it remains a representation that is 'hinged' to the land. Landscapes are constituted not only as cultural sites but also as physical places - material presences which are interacted with, driven past, walked upon, rebuilt over and dug into.

While the land bears the evidence of buildings and cultivation (for a time), it is resistant to the recording of events. ${ }^{2}$ The inability of the land to hold the impressions of the lives of its occupants has meant that representation becomes a means through which the details of lives and the, often violent, processes of political change are remembered. Because a distance exists between the land and the representation, narratives which seek to hold and remember the events that occurred on the land are fragile and subject to uncertainty, but are simultaneously one of the only means available to counter the loss of memory and the erasures of the past. This connection between history and meaning has been articulated by those involved in the process of reclaiming urban land.

The historical record shows that District Six has always been a place in which struggles have occurred and over which fierce battles have been 
fought. Those fights have, however, been generative ones which have ploughed deep furrows into the South African landscape and from which have grown authentic cultural and social practices and formations. A surprising diversity of South African experiences take their roots or have been fertilized in one form or another by these struggles. ${ }^{3}$

This extract, from the introduction to a 1990 collection of academic papers on the politics and memory of District Six, identifies the struggle for the land as an intrinsic part of the meaning of the landscape. Conflicts over the ownership and imagination of the land, in this text, have been 'generative' of meaning, while the landscape has both metaphorically and physically been scarred over time. The editors, Jeppie and Soudien, assert that the terms on which the landscape is understood in the collection are not limited to visual or written traditions - more precisely it is the personal memories of individuals which are seen to take priority over other, more established, means of representing the land and its meaning. In contemporary usage 'landscape' has become integrated into the language of reappropriation of the land, a 'way of seeing' the land that is both social and cultural has been supplemented by imagination and reconstruction. The 'landscape' that the editors refer to is also an explicitly political construction. It is both physical ground and theoretical territory that is connected to the history of violence and conflict of the country. Rather than providing an image of order and harmony in a 'natural' world, landscape has been expanded - both into urban territory, and as a term used to describe damage and debris.

The text suggests that the present image of the land, with its cuts and scars, has become part of its meaning. While some texts, along with the imagination of past environments through photographs, music and writing, seek (at least in part) the restoration of destroyed places, others suggest a view of a layered history, in which the meaning of places is cumulative and delicate. A newspaper article on Sophiatown/Triomf acknowledges this density by stating:

Unlike District Six, and nearby Pageview, there are no empty plots of land to mark the scars of forced removal. However, this absence forces us to focus on the intangible, to make the most of the physical remains and include Triomf as part of a historical continuum. ${ }^{4}$

\section{Land restitution}

This layering of different claims over time is acknowledged in the way in which land restitution has been approached in South Africa. The Restitution of Land Rights Act 22 of 1994 allows for claims based on dispossession after the passing of the Land Act in 1913. The goals of the Act include:

To promote justice in respect of all victims of dispossession of land rights as the result of racially discriminatory laws or practices.

To facilitate negotiated settlements, bringing together all stakeholders in matters related to land claims. 


\section{Erasures}

To foster and nurture a spirit of reconciliation through the restitution process among those who use land and within the nation at large. ${ }^{5}$

The Act allows for different kinds of compensation of the loss of land, although the preference is still for the restoration of the land. The options are:

restoration of the land from which claimants were dispossessed; provision of alternative land; payment of compensation;

alternative relief including a combination of the above-mentioned, sharing of the land, or budgetary assistance such as services and infrastructure development; or priority access to state resources with regard to housing and land development programmes. ${ }^{6}$

It is therefore evident that the process of Land Restitution emphasises both a preference for negotiation and compromises which try to determine a settlement appropriate to the present form and ownership of the land. The process is fraught with difficulty, and is time-consuming. As it is still underway, and its full implications are yet to be understood, it is impossible at this stage to assess the long-term impact on the meaning of the land. However, in contrast to a simplified meaning, tied to apparently stable, racially segregated landscapes that were the goal during National Party rule, these political processes acknowledge and confront ambiguity, complexity and conflict in the land.

The process of claiming the land through political processes is also allied to the collection of evidence of sites of removal, and to the presentation of these artefacts in a public area or museum. In one land claim on behalf of the approximately 1000 families moved from the East Bank, in East London, in the 1950s, the research required to document occupations and submit to the Land Claims Court has been linked to an exhibition project, 'based on photographs and stories collected from former East London residents'. ${ }^{7}$ The researchers also suggest that 'it is possible that this project might mature into a permanent facility, such as a museum, commemorating the forgotten histories of this and similar communities in the city'. ${ }^{8}$ Even as the process of claiming the land is underway, therefore, the desire to document and memorialise continues. In imagining and reconstructing places through exhibitions and museums, the former residents are also constructing a future landscape, which aspires both towards restoration of a community and acknowledges its loss.

\section{'Intangible heritage'}

Capturing the fragile and ephemeral through remembering has also been referred to by Phakamani Buthelezi, of the SA Heritage Resources Agency. ${ }^{9}$ He has used the phrase 'intangible heritage' to describe those aspects of inhabitation which do not have a physical presence. Similarly, Bill Nassen distinguishes between the physical 
landscape and one constructed of ephemera - street signs, photographs - and memories, which are recorded in oral histories.

History has left next to nothing by way of physical landscape. What we have of District Six are photographs, providing some transference of remembered social images to the present, and a scattering of streets and place names - urban archaeological material from the 1950s. ${ }^{10}$

Nassen later continues that the substance of District Six resides in the memories that are retained of life in the area, before the demolitions occurred. The intangible and (mostly) unrepresented experiences of the site are argued for as those which are central to its meaning. In these terms the state of the contemporary physical landscape is not only a temporary one, an interruption of the meaning of the land, but is also insignificant. The meaning of the land is complete only in personal histories, and as those personal histories cannot be read in the surface of the ground, 'landscape' itself is not present. This stance has been echoed by others and is a critical inversion of the necessity for physical presence and material qualities, which had been so important to the early settlers. In other texts the remaining land is written about as being a landscape, although it is one that has been stripped of meaning, which again has been displaced into the bodies and minds of its past inhabitants.

So what needs to be stressed is that the crucial material for the history of District Six is the perceptions and experiences of those who once lived there, not its past architecture, nor its present bare and bony landscape. ${ }^{11}$

The stressing of memory and experience over the material world, either past or present, introduces a separation between encounters and the environment in which they occur and both emphasises and creates representations of a time before the removals. Physical place, architecture and pictorial representation, in this account, are (at best) secondary aspects of the meaning of District Six. Oral history is offered as a way to overcome the distance that comes with representation. This emphasis on representations of the land that are not visual is consistent with the way in which the landscape has been perceived and represented in South Africa's past, although it shifts the focus from the land to the details of its inhabitation. In arguing for an oral history, Nassen seeks to insert the everyday life of the public into the narration of the forced removal and the claim made on the land. In his emphasis of experience over materiality the erasure of the buildings is not seen to erase District Six, precisely because it exists, not in the land, but in memory and imagination.

Landscape, therefore, is gradually emerging as a broad term to describe cultural fields of memorialisation, as well as physical spaces. A conference held in May 2005 in Cape Town was entitled 'Hands on District Six: Landscapes of Postcolonial Memorialisation' (attended by, among others, panellists from the Sophiatown Living Landscapes Project) while in a 2001 District Six Museum publication - Recalling Community in Cape Town - landscape appears in the title of two essays: Peggy 


\section{Erasures}

Delport's 'Digging deeper in District Six: features and interfaces in a curatorial landscape' and Anwah Nagia (interviewed by Colin Miller), 'Land restitution in District Six: settling a traumatic landscape'. ${ }^{12}$ In Delport's article, which describes the installation of the core exhibition of the museum, she likens the physical space of District Six (pre-removals) to the complexity of the spatial geography created in the building's interior.

District Six was simultaneously a landscape and an urban entity, a site with a distinct topographic identity: connected to mountain and sea, to slopes, to levels, to inner city, docks and harbour. So, too, the District Six Museum space has a geography. It is comprised of both the openness and totality of its interior: immediately high and low, both exposed and hidden. It has a distinctly spatial experience, within which material traces and features are signposts of the social and physical existence of District Six. Flights of steps, passageways, landings, floors, walls, interiors, echo the steep, simultaneously private and public, city and mountain-bound nature of the place.

The space and complexity of District Six is therefore described as being transferred to and recreated within the museum - which incorporates both fragments from the site (street signs and debris) and memory rooms (constructed spaces which narrate personal histories) (Plates 15.1 and 15.2). Landscape is also used to describe the physical ground in another article, from the Mail and Guardian, which states, 'The landscape is a national symbol of compulsion, dispossession and plunder - scar tissue which still hurts even to look at'. ${ }^{13}$ As with Delport's description of the relationship between place and museum, the journalist suggests a surrogate, an 'archaeology of memory', in which the symbolic spaces of the streets have been reformed within the interior of the District Six Museum.

The central 'exhibit' in the museum is an enormous map of the old neighbourhood, which occupies the double height hall space of the old church. Visiting ex-residents are encouraged to walk over the map, to retrace their steps through the area on a scaled two-dimensional representation, and to record the position of their homes on the map, by writing their family name directly onto its horizontal surface. Through these acts the map becomes a public means of recovery and reinscription; it works against the loss of memory over time by providing a surface which retains the markings of lives. The map in the museum, therefore, is a representation which can (temporarily and within the spatial confines of the museum) freeze time, and erase its consequences. It becomes a means to 'see' District Six again, and for individuals to contribute to a document which becomes a collective representation of that which the community possessed and then lost. There are a number of other maps in the display, which are used to document the process of the land claims and physical evidence of the site (Figure 15.1). The bulk of the Technikon that now dominates the site, as well as other changes to the physical place, do not appear on the surface of the maps. It acts to reinstate those elements of human inhabitation that political action and natural 


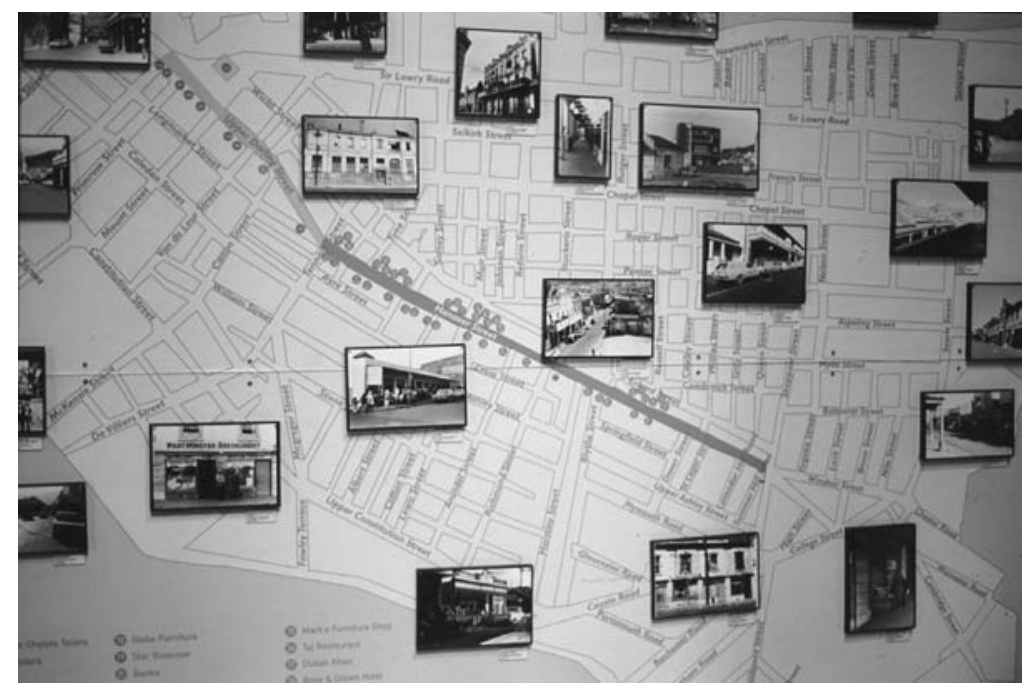

15.1

A map in the
District Six
Museum, which
overlays
photographs of
demolished
buildings onto their
previous locations
on a map of the
district as it was
before the
removals.

\section{A map in the} District Six Museum, which demolished before the removals growth has overcome and allows District Six to be accessed through the imagination. The maps also provide familiar ground to those who don't recognise the characteristics of their old neighbourhood in the contemporary landscape. On visiting the land where the buildings of District Six once stood, Mrs Fortune, a former resident, finds it unfamiliar: 'I tried to pinpoint where the house was but we couldn't make out the street because it was overgrown. ${ }^{14}$

The map therefore becomes not only a document of colonial dispossession and control but also a means to repossess lost land and reconstruct erased structures and inhabitations. The change in the meaning of the land is therefore intimately connected to the change in the use and meaning of those documents used to represent it. The complexity of the use and meaning of these representations, in ways largely unanticipated by their authors, confirms that a simple reading of maps of documents of power and possession does not adequately explain how they function over time and how they are employed as a means to reclaim the land. ${ }^{15}$

While the representations, physical spaces and exhibits of the museum (as well as the political activity of the community) have been directed against the losses of the removals and towards reclamation of the land, the process of rebuilding, and reinhabitation of the site (after the granting of the communal land claim) has also to confront the physical reality of the land, and its additions and alterations, which make close physical reconstruction impossible. Comments made about the return to the site acknowledge this complexity: Mr Schaffers, who works in the museum, observed, 'They'll have the view of the mountain and the sea, OK, but it'll take 40 or 50 years to build a new community. ${ }^{16}$ While at the May 2005 conference, Valmont Layne, District Six Museum co-ordinator asked, 'How can we be true to the memory of District Six so that its former residents can return to it as it once was?'17 
The success of the museum in creating a surrogate landscape, inhabited by spatial configurations which record and foster memory and community, has encouraged, in turn, the imagination of a 'heritage site' on the remaining land - a site of 'memorialisation'. If the physical landscape is seen, as it has often been represented, as a negative condition, an interruption in the 'true nature' of the site, which can be restored, then the idea of returning to a place 'as it once was' raises questions about what the expectations are of what is to be returned and whether it is possible to be 'true' to memory on an altered site, and also, what forms of representation and activity this might involve. The forms of new buildings and streets will have to negotiate a complex set of issues, including not only the reimagination of the land, but also the physical changes to the site, including the highway and the Cape Technikon. Given the exploration and importance of different forms of remembrance and landscapes created through oral history projects, performance, poetry, writing and art projects, from the time of the removals until the present, the challenge is not only the creation of a physical place which can foster community, but also how other means of exploring memory and landscape can become an intrinsic part of a place that is newly built, even as its freshly poured foundations bear into a site loaded with meaning.

\section{Walking the land}

The reconciliation between landscapes of removal, reconstruction and reclamation is being explored in Sophiatown through walking tours which focus both on physical remains of Sophiatown and the changes that have occurred over the years. Unlike District Six, where ownership of at least part of the site is still possible, the construction and inhabitation of Triomf has meant that most Sophiatown land claims have been paid out as financial compensation. Documenting physical remains, the construction of memorial gardens and the uncovering of fragments, as well as organising walking tours, are therefore being investigated as ways to assert a layered history and an understanding of landscape which is incohesive and fragmentary. Like Van Niekerk's novel, Triomf, with which this chapter began, the additions and the walking tours offer the potential to understand the area as a composite site, created over time, which is still in the process of becoming.

The process began by identifying any physical remains of Sophiatown in the 1950s, including buildings, open spaces, kerbstones, remnants of rubble hidden under grass mounds, telephone poles and an oak tree at 8 Bertha Street, under which political meetings were held. It was suggested as part of the 2004 proposals that a 'heritage walking trail' would weave through the fragments and the suburb, creating a narration of the past. The tours have been guided by members of the youth group of the Anglican Church of Christ the King, while 'witnesses' (original residents) accompany the groups. ${ }^{18}$ The tours themselves therefore represent a means for younger members of a new community to learn about the past, and speak a history of the site as they walk the streets of the area. Other plans for Sophiatown include 
the creation of a memorial garden, the uncovering of an area of foundations of the original buildings and an archaeological dig. ${ }^{19}$

The landscape that emerges in these proposals is therefore one which has the potential to incorporate ambiguity, uncertainty and incompleteness. Far from offering a single interpretation and vision for the site the narration of place is negotiated and flexible. It becomes both part of the way in which younger residents can access and engage with the past, as well as offering the potential for further transformations over time.

\section{Landscape and land after the end of National Party rule}

How do we both imagine the landscape and remember it? If the land itself is unable to hold the impressions of the events that play out upon its surface, then it is the landscape, with its precondition of representation, that is called upon to remember, and to remake, the land in the image of the memories held by its inhabitants.

Landscape representations were employed to naturalise political change and to mutate the meaning of the land so that it could be claimed by those of European descent. Alongside this dominant narrative of the land exists a less stable history of landscape, one which developed alongside (and intruded into) the image of the landscape fostered by the government. The presence of landscape in poems, writings, magazines and speeches produced in opposition to National Party rule demonstrates its inseparability from political change and the reclamation of physical and cultural ownership of the land. Landscape is also a presence in the desire to reimagine the land both during and after the apartheid years. The recent political and cultural past of South Africa has altered the inhabitation and experience of the land to such an extent that landscape, revised, unstable and contested, has become inseparable from this history and the means to reclaim it. As is evident from the representations used to stake a claim to the land, those government representations which were an integral part of the control of the surface of the land - the mappings, photographs, legislation and lists of inhabitants and their location - have also become vital evidence for an imperfectly erased past. These emerging processes provide confirmation that the certainty of modernity and its processes of control and scrutiny can also be doubled back, and used to argue for a different kind of history, one in which the documents, representations and landscapes acquire a different, layered meaning.

At the end of National Party rule, Nelson Mandela represented the land as a place both of renewal and conflict, of personal meaning and political violence. $\mathrm{He}$ also identified the land as the 'base' for the practice of 'racial oppression'. ${ }^{20}$ I have argued in this book for an understanding of landscape as both a sensory medium, of earth, sky, stone and mountain and as a represented and experienced world which is altered through the act of inhabitation. The political policy to pursue the segregation of the land in South Africa resulted not only in the separation of people, but also in the 


\section{Erasures}

development of the uncertainty and violence which has become part of the meaning of the land. The landscape has been politicised through representation and through the pursuit of physical changes which sought to enforce a political vision. These alterations have contributed to the complex meaning of landscapes which are both symbolic and strategic, which were used to represent the beauty of nature and to enforce the policies of racial segregation.

In the representation of the communities and forced removals of Sophiatown and District Six, and in the poems and writings of the land that resisted the dominant political vision in the twentieth century, it is possible to trace both an alteration in the way in which 'landscape' is understood and in the meaning of forms of representation of the land. The landscape of South Africa has been altered not only through changes made to its surface, but also through the way in which it is seen, experienced and represented.

The 'landscape' that emerged in the last decades of National Party rule is therefore one which is inseparable from political struggle and memory. The expansion of landscape in South Africa challenged the apparently stable image of the land during the twentieth century and has fostered the development of forms of representation that acknowledge the presence and voice of the individual, by avoiding pictorial representation and seeking rather a focus on oral histories. Alongside claims to dismiss the physical appearance of the land as superfluous to its meaning, the physical presence of landscape and the cultural identification with it remain woven into the narratives used to reimagine the occupation of the sites of removal. The use of oral history, artefacts, maps and photographs to mark retroactively the land and reclaim a cultural identification with the landscape both alludes to the desire to reimagine the landscape in terms of a revised history and to the complexity of this claim.

It is an implicit part of this book to argue for a reimagining of the land which occurs with an awareness of the ambiguity of the political history of landscape representation; its ability to multiply and spawn contradiction and uncertainty and the failure of the myth of an innocent 'natural' landscape. In the alteration of the meaning of landscape through explorations of revised means of representation - together with the accommodation of failure and doubt - the possibility exists that 'landscape' as a cultural, political and social construct can also stretch and deform. The mutation of landscape and its integration into the language of reclamation of the image of the land is born out of the contamination and interweaving of cultural practices and histories. As memory becomes part of the meaning of the land so it remains important to recall and document how landscapes were formed and represented and what their antecedents were. This fosters an awareness of ambiguity, so that the processes that are now underway to reimagine the land do so with a consciousness of contradiction and of the instability of apparently innocent images of the landscape.

In the exploration of different ways of living in cities, recognising the past, and travelling between urban and rural lands, an altered landscape has emerged, one in which the complexity of identities, different forms of representation, and the constant negotiation between change, conflict, violence, damage and reconciliation has 
become part of the way in which the landscape is understood. The image of the land and the physical world that this developing understanding of landscape has to challenge and appropriate remains one in which meanings are multiplied and contaminated. The history of landscape representation and political change in South Africa has created an unpredictable ground, in which the stability of the image of the land has been eroded by uncertainty and ambiguity. It is the complexity of this history that will both have to be confronted in the process of reimagining the land and which offers a means to reinhabit it. 


\section{Notes}

\section{Introduction}

1 Mandela, Inauguration Address, Union Buildings, Pretoria, 10 May 1994.

2 Barton, Frank (1963) 'Transkei: The frightened land', Drum, June: 21-25.

3 See, for example, Coombes, Annie E. (2003) History after Apartheid: Visual Culture and Public Memory in a Democratic South Africa, Durham, NC and London: Duke University Press; and Nuttall, Sarah and Michael, Cheryl-Anne (eds) (2001) Senses of Culture, Cape Town and London: Oxford University Press.

4 Denis Cosgrove has argued in an influential reading of landscape that:

[T]he landscape idea represents a way of seeing - a way in which some Europeans have represented to themselves and to others the world around them and their relationship with it, and through which they have commented on social relations. Landscape is a way of seeing that has its own history, but a history that can be understood only as part of a wider history of economy and society; that has its own assumptions and consequences, but assumptions and consequences whose origins and implications extend well beyond the use and perception of land; that has its own techniques of expression, but techniques which it shares with other areas of cultural practice.

(Cosgrove, Denis (1998) Social Formation and Symbolic Landscape, Madison, WI: University of Wisconsin Press, p. xiv)

5 Interview conducted with Nhlanhla Thwala in London, (School of Oriental and African Studies (SOAS), May 2005.

6 HIV/Aids in South Africa is, however, gradually eroding this practice, as the authorities are becoming increasingly concerned about the sheer numbers of bodies interred in this way.

7 Statement of Deputy President Thabo Mbeki on the occasion of the adoption by the Constitutional Assembly of the 'Republic of South Africa Constitution Bill 1996', Cape Town, 8 May 1996.

8 Kentridge, William, 'Landscape in a state of siege' (1988), reprinted in Cameron, Dan, Christov-Bakargiev, Carolyn, and Coetzee, J.M. (1999) William Kentridge, London: Phaidon Press, p. 110.

9 Cited in Moodie, T. Dunbar (1975) The Rise of Afrikanerdom: Power, Apartheid and the Afrikaner Civil Religion, Berkeley, CA: University of California Press, p. 276.

10 'Coloured' was a term used under National Party rule to describe people of mixed race, often Afrikaans speakers, many of whom live in the Cape. It has remained a term in use in postapartheid South Africa, both by members of the new government and the people themselves. It is for this reason that it is used in this book.

11 See O'Meara, Dan (1996) Forty Lost Years: The Apartheid State and the Politics of the National Party, 1948-1994, Randburg, SA: Ravan Press, pp. 100-104 for a brief description of these events and an idea of the political consequences in the 1960s.

12 Harris, Verne, "'They should have destroyed more": The destruction of public records by the South African State in the final years of Apartheid 1990-1994', unpublished paper presented at the History Workshop, University of the Witwatersrand, 1994. 
13 Coetzee, J.M. (1988) White Writing: On the Culture of Letters in South Africa, New Haven, CT: Yale University Press.

14 Mitchell, W.J.T. (ed.) (1994) Landscape and Power, Chicago, IL: University of Chicago Press, p. 4.

\section{Wilderness and veld}

1 Jonker, Ingrid (1968) Selected Poems, London: Jonathan Cape.

2 In Mandela's speech the poem is quoted as follows:

The child is not dead

the child lifts his fists against his mother

who shouts Africa [!]

The child is not dead

Not at Langa nor at Nyanga

nor at Orlando nor at Sharpeville

nor at the police post at Philippi

where he lies with a bullet through his brain

the child is present at all assemblies and law-giving

the child peers through the windows of houses

and into the hearts of mothers

this child who only wanted to play in the sun at Nyanga

is everywhere

the child grown to a man treks on through all Africa

the child grown to a giant journeys

over the whole world

without a pass!

3 Olwig, K.R. (1993) 'Sexual cosmology: nation and landscape at the conceptual interstices of nature and culture; or "What does landscape Really Mean?"', in Bender, Barbara (ed.) Landscape: Politics and Perspectives, New York: Berg, pp. 310-311.

4 Ibid., p. 312.

5 Ibid., p. 318.

6 Rehan, Ernest, 'What is a nation?', translation by Thom, Martin, in Bhabha, H. (ed.) (2000) Nation and Narration, London: Routledge, p. 11.

7 Brink, André, 'Stories of history: re-imagining the past in post apartheid narrative', in Nuttall, Sarah and Coetzee, Carli (eds) (1998) Negotiating the Past: The Making of Memory in South Africa, Cape Town: Oxford University Press, p. 36.

8 This restriction of the meaning of veld to grassland is perpetuated in the Oxford English Dictionary, where 'veld' is defined as open country, grassland.

9 Coetzee, J.M. (1988) White Writing: On the Culture of Letters in South Africa, New Haven, CT: Yale University Press, p. 167.

10 Ibid., p. 7.

11 David Attwell argues (in Attwell, David (1993) J.M. Coetzee: South Africa and the Politics of Writing, Cape Town and Johannesburg, David Philip; London and Berkeley, CA: University of California Press), that Coetzee's 'dream topographies' are inextricably linked to the landscape of the Cape and Karoo desert. The Transvaal and the interior which was emphasised in political narrations of the landscape that are discussed in this text are 'practically a foreign country' to Coetzee, p. 25.

12 Schreiner, Olive (1999) The Story of an African Farm, Johannesburg: Ad. Donker. First published 1883, London: Chapman and Hall, p. 29.

13 Ibid., pp. 42-43. 
14 Ibid., p. 128.

15 Bosman was also convicted of shooting his stepbrother, and spent a number of years in jail as a result, being released in 1930. He was plagued by darkness and despair, and his writings have an eloquent roughness which is regarded as an closely observed articulation of South African life.

16 Bosman, Herman Charles (1977) Willemsdorp, Cape Town: Human and Rousseau, p. 104.

17 Bosman uses an archaic word 'whilom' meaning former, erstwhile, having been at an earlier time.

18 Bosman (1977) Willemsdorp, pp. 88-89.

19 Plaatje, Sol (1996) Mhudi, Cape Town: Francolin, pp. 29-32.

20 Ibid., p. 128.

21 Ibid., p. 53.

22 Pringle refers to the journey of the prophet Elijah into the wilderness, fleeing from the queen Jezebel. Mount Horeb was another name for Mount Sinai, the sacred mount of God, where Moses had received the Ten Commandments from God. In the desert, away from civilisation, the depressed and desperate Elijah gains strength from his conversation with God.

23 Pringle, Thomas, 'Afar in the Desert', pp. 8-10, from Pereira, Ernest and Chapman, Mark (eds) (1989) African Poems of Thomas Pringle, Durban: Killie Campbell Africana Library and Pietermaritzburg: University of Natal Press.

24 Schreiner, Story of an African Farm, p. 129.

25 Akzin, Benjamin (1964) State and Nation, London: Hutchinson University Library, p. 23.

26 Ibid., p. 61.

27 Celliers, Jan, 'Dis Al', in Grove, A.P. and Harvey, C.J.D. (eds) (1963) Afrikaans Poems with English Translations, Cape Town and London: Oxford University Press, pp. 12-13. Translation by Guy Butler.

28 The reasons given for leaving the colony were documented by Anna Steencamp, niece of Piet Retief, one of the Trekker leaders, as follows:

The continual depredations and robberies of the Kafirs, and their arrogance and overbearing conduct; and the fact that, in spite of the fine promises made to us by our government, we nevertheless received no compensation for the property of which we were despoiled.

1. The shameful and unjust proceedings with reference to the freedom of our slaves; and yet, it is not so much their freedom that drove us to such lengths, as their being placed on an equal footing with Christians, contrary to the laws of God, and the natural distinction of race and religion, so that it was intolerable for any decent Christian to bow down beneath such a yoke; wherefore we rather withdrew in order thus to preserve our doctrines in purity.

Quoted by unknown author in 'Some Consequences of the Great Trek: reflections on Dingaan's Day', typed draft of an article for publication by the Argus Group, 12 December 1936, in the University of the Witwatersrand historical collection, p. 1.

29 While the trade in slaves had been prohibited by Britain in 1807 , slave owners could continue to own their slaves for decades after this date. The formal cessation of slavery in the British Empire occurred on 1 December 1834, and slaves could thereafter be apprenticed to their former owners for a period of up to six years.

30 Songs sung at the inauguration of the Voortrekker Monument given in unknown author (1949) The Voortrekker Inauguration Programme, (no publisher given), p. 30. Author's translation.

31 An appeal for aid was made in the wake of the South African War, and was published in newspapers in South Africa and abroad. The focus of the appeal is on help to rebuild the land, which is now 'a desert' ('The Boer Manifesto', The Star, 17 October 1902).

The people of the two Republics have sacrificed everything for their independence, and now the struggle is over they stand wholly ruined. Although we had no opportunity of 
compiling an exact statement of the devastation wrought in the two Republics, we are convinced from personal knowledge that during the war at least thirty thousand homes on the farms besides a number of villages have been burnt or destroyed by the British.

Our dwellings with the furniture have been burnt or demolished, our orchards cut down, all agricultural implements broken, mills destroyed, every living animal taken away or killed-nothing alas! remains. The land is a desert. Besides, the war has claimed many a victim, and the land resounds with the weeping of helpless widows and children.

Signed

Botha

De Wet

De La Rey

32 Nienaber, P.J., 'Ons Letterkunde en die Trek', article in Die Voortrek (13 December 1949), special supplement to Die Transvaler, p. 20.

33 Van Wyk Louw, N.P. (1947) Die Dieper Reg: 'n Spel van die Oordeel van 'n Volk, Cape Town, Bloemfontein and Port Elizabeth: Nasionale Pers, pp. 15 and 20.

34 Celliers, Jan, 'Die Brand', in Opperman, D.J. (1980) Groot Verseboek, Cape Town: Tafelberg. First published 1952.

35 The Truth and Reconciliation Commission was instituted in 1996 as a means to deal with the secret activities of individual members of the National Party State and other political parties, including the ANC, during the years of National Party rule. It was chaired by Archbishop Desmond Tutu and offered political amnesty to those who fully disclosed their crimes committed as political acts. The commission heard testimony from victims and the relatives of victims, as well as from those who committed acts of violence.

36 Krog, Antjie (1998) Country of my Skull, London: Jonathan Cape.

37 Ibid., p. 204.

38 Mbella Sonne Dipoko was a poet and prose writer from Cameroon, who resisted French colonial rule with his writings. In the poem of which this is an extract, other authors appear. The writer suggests that he is part of a wider African community of writers that have in common a will to document, and oppose colonial rule though their work.

39 'Mielies' is the Afrikaans word for 'corn', which has been adopted into common English usage.

40 Phalanndwa, Nthambeleni, 'In this World, my Sister', in Chapman, Michael and Dangor, Achmat (eds) (1982) Voices from Within: Black Poetry from Southern Africa, Johannesburg: Ad. Donker, p. 182.

41 Somhlahlo, Basil, 'Who Wants to be Mothered?', in Chapman and Dangor, Voices from Within, p. 70.

42 Conversation with Justice Sachs at the April 2005 Architecture Students Congress at the University of the Witwatersrand.

\section{Memory and inscription}

1 Bond, J.J. (1949) The Saga of the Great Trek and Pictorial Record of the Inaugural Celebrations at the Voortrekker Monument, Johannesburg: Rostra Printers (reprinted from The Star), p. 5.

2 Unknown author, 'Some Consequences of the Great Trek: reflections on Dingaan's Day', typed draft of an article for publication by the Argus Group, 12 December 1936, in the University of the Witwatersrand historical collection, p. 9.

3 Comaroff, Jean, and Comaroff, John L. (1988) 'Through the looking glass: colonial encounters of the first kind', Journal of Historical Sociology 1, p. 12.

4 See Bermingham, Ann, 'System, order and abstraction: the politics of English landscape drawing around 1795', in Mitchell, W.J.T. (ed.) (1994) Landscape and Power, Chicago, IL: University of Chicago Press, pp. 77-101, and Barrell, John, 'The public prospect and the private view: the politics of taste in eighteenth-century Britain', in Pugh, Simon (ed.) (1990) Reading Landscape: Country City Capital, Manchester: Manchester University Press, pp. 19-40. 
5 Said, Edward (1994) Culture and Imperialism, London: Vintage, p. 5.

6 Barthes, Roland (1995) Mythologies, New York: Hill and Wang. Translation by Lavers, Annette, p. 143.

7 Barthes, Mythologies, p. 118.

8 Hachten, William A. (1971) Muffled Drums: The News Media in Africa, Ames, IA: lowa State University Press, p. 241.

9 Gustav Preller was also responsible for the production of De Voortrekkers (1916), an early fulllength feature film which contributed to the growing mythology about the Great Trek through an emphasis on authenticity of detail and the personal histories of those involved.

10 Drawings which appeared in Picturesque America, the nineteenth-century document of landscape views of the United States, have in common the elevated viewpoint and a conquering eye. See Rainey, Sue (1994) Creating Picturesque America: Monument to the Natural and Cultural Landscape, Nashville, TN and London: Vanderbilt University Press, for a discussion of the document edited by Bryant, William Cullen and Bunce, Oliver Bell (c.1872) Picturesque America.

11 Barrell, John (1990) 'Eighteenth century Britain', in Pugh, Reading Landscape, argues that the ability to have a far view over the landscape implies not only ownership but also intellectual and political control, and an awareness of the meaning of that control within a wider context.

12 The same artist was responsible for the base paintings over which the women of the AKTV's Women and Mother movement stitched in order to create the 15 scenes which form the 'Historical Tapestry', as well as for the sketch design of the narrative marble panels, both in the Voortrekker Monument.

13 See Vaughan, William (1980) German Romantic Painting, London and New Haven, CT: Yale University Press, for a discussion of the German Romantic movement.

14 Van der Westhuysen, H.M. (1929) 'Pierneef, Die Afrikaanse Landskapskilder', in Van den Heever, C.M. (ed.) Tydskrif vir Letterkunde, including 'Die Nuwe Brandwag', p. 91, in the Pretoria State Archives.

15 The Broederbond was founded in 1918 with religious connotations and no directed purpose. During the 1920s and 1930s it developed into a cultural organisation which became hugely influential in Afrikaner politics from that moment onwards, establishing the FAK in 1929 as its cultural wing.

16 Coetzee, N.J. (1992) Pierneef: Land and Landscape - The Johannesburg Station Panels in Context, Johannesburg: CBM, p. 24.

17 Ibid., p. 4

18 Ibid., p. 10.

19 Van der Westhuysen, 'Pierneef, Die Afrikaanse Landskapskilder', p. 92.

20 Afrikaner labourers were incorporated into the civil service in roles which were reserved for them. After 1907, a policy was adopted which replaced the majority of black labour with Afrikaner labour in the SAR \& H. See South African Railways and Harbours, Special Bulletin 135 (1929) in the Pretoria State Archives, Vol: P203, Ref: 6640.

21 Van der Westhuysen, 'Pierneef, Die Afrikaanse Landskapskilder', p. 93.

22 Bunn, David, 'Comparative barbarism', in Darian Smith, Kate, Gunner, Liz, and Nuttall, Sarah (eds) (1996) Text, Theory, Space: Land, Literature and History in South Africa and Australia, London: Routledge, p. 39.

23 A Pierneef linocut was reproduced on the cover of the quarterly literature magazine of the Afrikaans Writers Circle, whose members included many of the prominent Afrikaans writers of the day. A copy of this journal, dedicated to Pierneef and signed by a number of writers, is held in the collection of the Pretoria State Archives. See Van den Heever (ed.) (1929) Tydskrif vir Letterkunde.

24 'Brandwag', meaning 'guard', 'sentry' or 'outpost', has overtones of past wars, conflicts and the journeys of the Voortrekkers, where sentries were posted each night to sound the alarm if necessary.

25 Van Wyk Louw, N.P. (1947) Die Dieper Reg: 'n Spel van die Oordeel van 'n Volk, Cape Town, Bloemfontein and Port Elizabeth: Nasionale Pers, p. 25. 
26 Moodie, T. Dunbar (1975) The Rise of Afrikanerdom: Power, Apartheid and the Afrikaner Civil Religion, Berkeley, CA: University of California Press, p. 180.

27 Coetzee, N.A. (1958) 'Jacobus Coetzee: Die Boerepioneer van Groot Namakwaland', Historia magazine, quoted by Attwell, David (1993) J.M. Coetzee: South Africa and the Politics of Writing, Cape Town and Johannesburg, David Philip; London and Berkeley, CA: University of California Press, p. 45.

28 The foundation stone of the first Blood River monument was laid on 16 December 1938, in the same year as the Voortrekker re-enactment. The single grey granite ox wagon, completed in 1947 , was replaced in 1971 by a ring of bronzed iron ox wagons that reproduce the defensive formation, or laager, that ensured victory for the Voortrekkers. See Afrikanerbakens (1989) Johannesburg: Federasie van Afrikaanse Kultuurvereniginge (FAK).

29 In 1938 when the re-enactment was underway, Malan (the then leader of the National Party) attempted to gain political ground by renewing the vow as a contemporary commitment to his party by loyal Afrikaners.

30 This extension of the Voortrekker narrative occurred not only on the surface of the ground but also in a film Bou van 'n Nasie (Building a Nation, 1938), which depicted reconstructions of significant events of white history back to the planting of Bartholomew Diaz's stone cross in the fifteenth century. The film culminated in the events of the Great Trek, retrospectively presenting white history as the supporting narrative to the triumph of the Voortrekkers, film held in the National Archive for Film, Video and Sound in Pretoria.

31 The ox wagons were made according to the same specifications as those used a century before, according to Jansen, E.G., 'The Centenary and Laying of the Foundation Stone', in The Voortrekker Monument Inauguration Programme, p. 63.

32 Giliomee, Hermann, 'The rise and fall of Afrikaner women'. Talk given at lunch hosted by editor of Cape Times Literary Lunch and by Fine Music Radio, at Spier Estate, Stellenbosch, on 2 August 2003.

33 Bunn, David (1995) 'Whited sepulchres: on the reluctance of Monuments', in Judin, Hilton and Vladislavic, Ivan (eds) Blank: Architecture, Apartheid and After, Rotterdam: NAi, argues that monuments in colonial territories are always in danger of invisibility and neglect, as they rely on the tending by a small (white) minority.

34 See Steyler, F.A., unpublished report on 'The Routes of the Great Trek in the Cape Province', lodged in the Cape Archives, where he acknowledges the support of the government for the research beginning in January 1950.

35 Ibid., p. 1.

36 Coetzee, J.M. (1988) White Writing: On the Culture of Letters in South Africa, New Haven, CT: Yale University Press, p. 7.

37 Edney, Matthew H. (1997) Mapping an Empire: The Geological construction of British India 1765-1843, Chicago, IL and London: University of Chicago Press. Edney makes an argument for mapping as, at least to some extent, compilations of other maps. He argues that maps never exhaustively represent topographical reality, because of their reliance on locals and guides to flesh out the maps, but rather a conflicted, contested and negotiated process.

38 Hofmeyr, Isabel, 'Building a nation from words: Afrikaans language, literature and ethnic identity', an unpublished paper presented at the University of the Witwatersrand History Workshop, 1984, argues that in the early twentieth century English dominated social relationships and that there was a conscious attempt to repackage everyday life in popular magazines as part of an Afrikaner identity. These maps, produced by commercial firms as well as popular magazines, can be seen as part of this history of representation.

39 Personality magazine is a middle-of-the-road, popular magazine, published in Bloemfontein. The map shown was produced as a supplement to the magazine, entitled 'New Atlas for Southern Africa', in 1968. 


\section{Map and monument}

1 Moerdijk, Gerard (1949) 'The Voortrekker Monument: meaning and symbolism', in The Voortrekker Inauguration Programme, p. 48.

2 Unknown author, 'Some consequences of the Great Trek', pp. 9-10.

3 Boshoff, B.D.T. (c.1970s) 'To the Visitor', in The Voortrekker Monument, pamphlet, p. 18.

4 This extract is part of a litany of assertions as to the validity of the Afrikaner claim to the land:

The whites and the Bantu appeared at approximately the same time in the south of Africa. The right of the whites to claim that they were first in the land, is not less than that of the Bantu... This is a historical fact that is not always known outside of South Africa.

(City Reporter (not identified), 'Van Riebeeck's arrival is impressively commemorated', newspaper article in Die Burgher, Monday 8 April 1951)

5 Coetzee, J.M. (1988) White Writing: On the Culture of Letters in South Africa, New Haven, CT: Yale University Press, p. 3. Coetzee quotes the 'double right' of Governor Winthrop of Massachusetts, who asserted the rights of cultivators over those of nomads and therefore the rights of the settlers over those of the Native Americans.

6 Mostert, Noël (1993) Frontiers: The Epic of South Africa's Creation and the Tragedy of the Xhosa People, London: Pimlico, p. 807.

7 Van den Heever, C.M. (1949) 'Die Monument', in The Voortrekker Monument, souvenir pamphlet in the Cape State Archives.

8 Delmont, Elizabeth (1993) 'The Voortrekker Monument: monolith to myth', South African Historical Journal 29 (November), p. 89.

9 MacDonald, J.R. (1902) What I Saw in South Africa, London: The Echo, p. 24, quoted by Giliomee, Hermann, 'The rise and fall of Afrikaner women'. Talk given at lunch hosted by editor of Cape Times Literary Lunch and by Fine Music Radio, at Spier Estate, Stellenbosch, 2 August 2003.

10 Grundlingh, Albert, 'The National Women's Monument: The Making and Mutation of Meaning In Afrikaner Memory of the South African War' from http://www.fl.ulaval.ca/celat/histoire.memoire/ histoire/cape1/grundlingh.htm accessed 23 February 2005.

11 http://www.voortrekkermon.org.za, accessed 3 March 2005.

12 Malan, F.S. (1949) life chair of the Historical Monuments Commission, 'Nationale Monumente', in The Voortrekker Monument souvenir pamphlet.

13 Caption from an aerial photograph in Die Voortrek (1949), p. 9. Author's translation.

14 Delmont, 'The Voortrekker Monument', p. 100.

15 Quoted by Watkin, David and Mellinghof, Tilman (1987) German Architecture and the Classical Ideal, Cambridge, MA: MIT Press, p. 160.

16 Chipkin, Clive (1993) Johannesburg Style: Architecture and Society 1880's - 1960's, Cape Town: David Philip, p. 280

17 Moerdijk (1949) 'The Voortrekker Monument', p. 47.

18 Ibid., p. 47.

19 Despite the fact that Gertrude Caton-Thompson had verified the date and African origin of Great Zimbabwe in 1932, the origin of the structures was still a political issue during the years of white rule in what was then Rhodesia. The scale and sophistication of the fortress and enclosure was used to argue that the structures could not be the work of black tribes people, while for black 'Rhodesians' Great Zimbabwe was a symbol of what their people had achieved in the past. It eventually gave its name to the country in 1980 at independence.

20 Moerdijk, 'The Voortrekker Monument', p. 47.

21 And to build a monument that would 'last for a thousand years, and more', ibid., p. 43. This desire echoes the sentiments of the 'Thousand Year Reich' of Nazi Germany, and of their architectural aspirations to create buildings that would endure for centuries.

22 Ibid., p. 45. 


\section{A failed Eden}

1 The 'Rand' refers to the Witwatersrand, as it is still named today (White waters' ridge in translation). The Witwatersrand is the region of the highveld on which the gold mines and the city of Johannesburg are located, so the naming of the landscape as the 'Rand' is probably a reference to the wealth of the region, and of the right that Afrikaners had to lay claim to that wealth.

2 Totius (J.D. du Toit), 'Trekkerswee', in Opperman, D.J. (1980) Groot Verseboek, Cape Town: Tafelberg, p. 49.

3 Marx, Leo (1967) The Machine in the Garden: Technology and the Pastoral Ideal in America, New York: Oxford University Press, p. 9.

4 lbid., p. 9.

5 See Marx, The Machine in the Garden, p. 10 and O'Meara, Dan (1983) Volkskapitalisme: Class, Capital and Ideology in the Development of Afrikaner Nationalism, 1943-48, Cambridge: Cambridge University Press.

6 MacDonald, Ramsay (1902) What I Saw in South Africa, London: The Echoes, quoted by Griesel, Christina Johanna (1939) 'Die Invloed van die Lansaard in die Afrikaanse Roman na 1920' (unpublished thesis submitted to the University of the Witwatersrand).

7 See Cumming, William P. (1974) British Maps of Colonial America, Chicago and London: University of Chicago Press.

8 See Coetzee, J.M. (1988) White Writing: On the Culture of Letters in South Africa, New Haven, CT: Yale University Press, pp. 2-6, for an elaboration of this idea.

9 This conception of a stratified society has links to the evolutionary theories proposed earlier in the nineteenth century by Charles Darwin, which were then applied by him and others to racial development, and the idea that those people of darker skins were lower on the evolutionary ladder than those of European descent.

10 Van den Heever, C.M., 'Afrika', in Opperman, Groot Verseboek, p. 122.

11 For a discussion of the colony at this time see Elphick, Richard and Giliomee, Hermann (eds) (1979) The Shaping of South African Society: 1652-1840, Cape Town and London: Maskew Miller Longman.

12 Rousseau, Ina (1952-1960) 'Die Verlate Tuin', in Opperman, Groot Verseboek, p. 356.

13 Coetzee, White Writing, pp. 45-50.

14 Blum, Peter, 'Nuus uit die Binneland', from Opperman, Groot Verseboek, p. 367.

15 Griesel, Die Invloed van die Lansaard, p. 22.

16 Langenhoven, C.J., 'My share in the language struggle', quoted by Nienaber, P.J. (1959) 'The evolution of Afrikaans as a literary language', Lantern (Die Tydskrif vir Kuns en Kultuur), 8 (4).

17 Bermingham, Ann (1986) Landscape and Ideology: The English Rustic Tradition, 1740-1860, London: Thames and Hudson, p. 177.

18 Ibid., p. 13.

19 Marx, The Machine in the Garden, p. 104.

20 Henry Smith in Virgin Land, quoted by Marx, ibid., p. 142.

21 Marx, The Machine in the Garden, p. 112.

22 Louw, W.E.G., (b. 1913), 'Om Boer te Wees', in Opperman, Groot Verseboek, p. 197.

23 Eybers, Elisabeth, 'Wes-Transvaal', in Opperman, Groot Verseboek, p. 222.

24 See Citino, Robert (1991) Germany and the Union of South Africa during the Nazi Period, New York and London: Greenwood Press, for a detailed discussion of the associations and individuals that travelled between South Africa and Germany during this period.

25 Psychiatry and South Africa, http://www.cchr.org/racism/pasa1.htm. Copyright 1996-2002 Citizens Commission on Human Rights, accessed 11 September 2005.

26 A Supreme Court judgment against Verwoerd held that the extremist views of The Transvaler under the editorship of Verwoerd made it a voice piece for the Nazis in South Africa, and that he was aware of the impact of its content. 
27 Strydom, Hans (1982) For Volk and Führer, Johannesburg: Jonathan Ball, has documented political correspondence between the German National Socialist government and the Ossewa Brandwag in a plot to assassinate Jan Smuts, the leader of the United Party, while Norval, Aletta J. (1996) Deconstructing Apartheid Discourse, London and New York: Verso, has argued that National Socialist ideas were grafted onto the culture of Christian Nationalism so that they became part of the history of the Afrikaner people.

28 Kauffmann, F.A., Die Neue Deutsche Malerei, in series Schriftenreihe der Deutschen Informationsstelle, Das Deutschland der Gegenwart no. 11 (Berlin 1941), 26, quoted by Becker, Lutz (1994) 'Aspects of Art in the Third Reich', in Hartley, Keith et al. (eds) The Romantic Spirit in German Art 1790-1990, exhibition catalogue, p. 392.

29 David Bunn has argued that 'The ruts the wagon wheels score in rock both mark a claim and anticipate that future moment when the plough will break the first furrow in the fertile earth' (Bunn, 'Whited sepulchres: on the reluctance of monuments', in Hilton and Vladislavic (eds), Blank, p. 103).

30 Advertisement for Volkskas in Die Voortrek (1949).

\section{5 'Natural' identity}

1 See Giliomee, Hermann, 'The beginnings of Afrikaner ethnic consciousness', in Vail, Leroy (ed.) (1989) The Creation of Tribalism in South Africa, London: James Curry; Berkeley, CA: University of California Press.

2 See Vail, The Creation of Tribalism, for a more detailed discussion of the implications for black South Africans of the displacement from the land.

3 G.G. Munnik giving evidence at the Beaumont Commission, 1916.

4 O'Meara, Dan (1983) Volkskapitalisme: Class, Capital and Ideology in the Development of Afrikaner Nationalism, 1943-48, Cambridge: Cambridge University Press, has argued that the schism between a liberal English controlled economy and a Nationalist Afrikaans government has been overestimated. He argues that the relationship was much more complex and intertwined, with capitalist farmers serving mining interests, and the government legislation providing a steady supply of labour to both large scale industries. See particularly the Introduction.

5 Or a combination of tribalism and mining exemplified in the popular gum boot dances, often performed for visitors to the mines. The miners used traditional rhythms and group dances reinterpreted wearing miners' clothing and footwear.

6 It also refers to the fact highlighted by O'Meara in Volkskapitalisme, pp. 230-231, that the low wages paid to mine workers were at least partly justified by the assertion that the Reserve lands provided migrant labour with a stable subsistence income from agriculture. Moodie has argued that:

Whole areas of the southern African countryside have been able to survive only because they are reservoirs of potential labour for the mines.' His position is that the low wages and migrant labour system was dependent on the continuation of a rural economy (albeit an increasingly impoverished one) and that mine workers were encouraged to see themselves as primarily tied to the land as cultivators.

(Moodie, T. Dunbar with Ndatshe, V. (1994) Going for Gold: Men, Mines and Migration, London and Berkeley, CA: University of California Press, p. 11).

7 In reality mines and farms competed for the labour of the black South African, and farmers often opposed the sapping of their traditional sources of labour through the better paid and more attractive offers that the mining houses were able to make. In the mid 1940s this was an issue of fundamental importance to the political debate about industrialisation, and the map can therefore be read as part of a political campaign, by the Chamber of Mines, to promote their industry along with the system of migrant labour that sustained it. 
8 Also, as O'Meara has argued, the Land Act served the interests of large scale producers by removing tenants and replacing them with wage labour. See Volkskapitalisme, pp. 26-27.

9 After the South African War many Afrikaans farmers took on large numbers of black labour tenants in order to survive. These white farmers did not undertake farming activity themselves and were reliant on the rent that they received from the farming activities of the black farmers, who paid them a share of the revenue from produce. See O'Meara, Volkskapitalisme, pp. 22-25.

10 See Vail, The Creation of Tribalism in South Africa, Introduction. He has argued that, in later years, tribal identity became a means through which the migrant workers could assume some control over their lives, and it was to these men, without urban residential rights, that the tribal land had the most appeal. It was their only way of supporting themselves in retirement, and so had significance as a form of wealth.

11 William, Brian, 'Introduction', p. 3, in Plaatje, Sol (1996) Native Life in South Africa, Randburg, SA: Ravan Press. First published 1916, P.S. King and Son.

12 Plaatje, Native Life in South Africa, p. 434.

13 Unknown author, Some consequences of the Great Trek: reflections on Dingaan's Day, typed draft of an article published by the Argus Group, 12 December 1936, pp. 11-12.

14 Plaatje, Native Life in South Africa, p. 19.

15 P. Duncan, MP for Fordsburg, from the Debates on the Land Bill, quoted by Plaatje, Native Life in South Africa, p. 48.

16 Plaatje, Native Life in South Africa, pp. 17-18.

17 Exchange between Sir George Farrar, Labour Commission, and General Botha, quoted by Plaatje, Native Life in South Africa, pp. 242-243.

18 Bessie Head from the Introduction to the reprinting of Plaatje, Native Life in South Africa, pp. x-xi. 19 Ibid., p. 420.

20 Comments of General Botha in Parliament, quoted by Plaatje, Native Life in South Africa, p. 240.

21 The Natives Land Act, Act No. 27 of 1913, p. 2. First published in the Gazette Extraordinary No. 380 of 13 June 1913.

22 South African Tourist Corporation (1940-1950s) South Africa's Eastern Cape: Land of the Red Blanket People. Archive: National Archive, Cape Town, Source: Library, Type: Pamphlet, Vol: b, p. 88, Ref: 8.

23 Interview with Hosea Bowale by Peter Lekgoathi, Tamaties, Zebediela district, 5 May 1989, quoted by Isabel Hofmeyr, 'Nterata'/'The Wire': Fences, Boundaries and Cultural Resistance in the Potgietersrust District, unpublished paper given at the History Workshop, University of the Witwatersrand, 1990, p. 10.

24 See the Blockhouse Map: p. 412, Vol. V. The Times History of the War in South Africa 1900-1902. General Editor L.S. Amery. Editor Vol. V. Erskine Childers. London: Sampson, Law Marston, 1909.

25 Britain had begun a geodetic survey of the Cape and Natal colonies under Sir David Gill in 1880, which was extended to the Transvaal and Free State after the end of the war. These geodetic chains were used to carry out more dense and detailed trigonomentrical surveys which were able to locate farm beacons in relationship to the larger surveys.

26 Cape of Good Hope. Topographic Survey of South Africa. Proceedings of Congress held at Cape Town, March 1904. Cape Town: 'Cape Times' Ltd, Government Printers 1904. (G.77.—-1904.)

27 Ibid. Opening remarks by Sir David Gill, Chairman.

28 Ibid. Annexure 'B'. Reasons for the formation of a single department to carry out the topographical survey of South Africa, p. 27. Because of lack of funding, the desired comprehensive topographic survey got properly underway only in 1920, although between 1904 and 1920 the Orange River Colony $(1: 125,000)$ and the northwest Cape $(1: 250,000)$ were mapped. The 1:50, 000 map series of the entire country was completed in 1973 .

29 As Hofmeyr documents, fencing came to the Potgietersrust district, in the Transvaal, after the South African War, and was instrumental in fuelling the dispute about land ownership and rights in that area. Hofmeyr, Isabel (1993) 'We Spend our Years as a Tale that is Told': Oral Historical Narrative in a South African Chiefdom, Johannesburg: Wits University Press, p. 69. 
30 Opperman, D.J., 'Edms. Bpk.', from Opperman, D.J. (1980) Groot Verseboek, Cape Town: Tafelberg. First published 1952, p. 284.

31 Hofmeyr, Isabel, 'Nterata'/'The Wire', p. 11.

\section{The fertile desert}

1 Xhosa original from Yako, St. J. Page (1958?) Umtha Welanga, Johannesburg: APB, p. 13.

2 Yako, St. J. Page, 'The Contraction and Enclosure of the Land', translated from the Xhosa, in Chapman, Michael and Dangor, Achmat (eds) (1982) Voices from Within: Black Poetry from Southern Africa, Johannesburg: Ad. Donker, p. 64.

3 See Schapera, I. and Comaroff, J.L. (1991) The Tswana, revised edition, London and New York: Kegan Paul International, for an anthropological picture of the Tswana tribe in which tradition and changes to tradition are documented. For the significance of the ancestors see pp. 53-55.

4 Letter from the Magistrate, Cofimbaba, to the Secretary of Native Affairs, 18 September 1953, from the Cape Archives CMT files, 106/10/1, Vol: 3/1634. Original in Afrikaans, author's translation.

5 Letter from S.J. Potgieter, Natal Provincial Secretary of the National Party to Dr Verwoerd, Minister of Bantu Affairs, 27 November 1951, Pretoria Archives, BAO, Vol: 1423/307, Ref: 2607. Original in Afrikaans, author's translation.

6 Bond, J.J. (1949) 'Cradleland of the Voortrekkers', in Bond, J.J. (1949) The Saga of the Great Trek and Pictorial Record of the Inaugural Celebrations at the Voortrekker Monument, Johannesburg: Rostra Printers (reprinted from The Star), p. 6.

$7 \mathrm{Mr}$ van Straten of Ongeluksnek Farmers' Association, from notes of a meeting held between the Native Affairs Commission and the European Farmers of Matatiele, 4 November 1947, p. 1. Cape Archives CMT, Vol: 3/1642, Ref: C7/5.

8 'Betterment' was introduced in the 1930s, but implemented only in the 1950s under the National Party government, in order to combat soil erosion in the bantustans.

9 Memorandum on the Agricultural Activities of the Department of Bantu Administration and Development in the Transkei Territories, 9 May 1963, p. 1. Pretoria State Archives, BAO, Vol: 1423/307, Ref: 2607.

10 Memorandum on the Agricultural Activities of the Department of Bantu Administration and Development in the Transkei Territories, 9 May 1963, p. 2. From Pretoria State Archives, BAO, Vol: 1423/307, Ref: 2607.

11 Dikobe, Modikwe (1983) Dispossessed, Johannesburg: Ravan Press.

12 W. Morphet from Dairy Farmers' Association, from notes of discussion held between the Native Affairs Commission and the East Griqualand Farmers Congress, p. 4. Cape Archives CMT, Vol: 3/1642, Ref: C7/5.

13 Chief Pupsey Sebogodi quoted by Murray, Christina and O'Regan, Catherine (eds) (1990) No Place to Rest: Forced Removals and the Law in South Africa, Cape Town: Oxford University Press, p. 42.

14 Mamdani, Mahmood (1996) Citizen and Subject: Contemporary Africa and the Legacy of Late Colonialism, Kampala: Fountain; Cape Town: David Philip; London: James Curry. Copyright: Princeton University Press.

15 The erosion of the land was continually referred to in the land debates: 'They [the farms] are slightly eroded and will get worse under the Natives.' Mr Herring, from the Demobilisation Committee, from notes of a meeting held between the Native Affairs Commission and the European Farmers of Matatiele, 4 November 1947, p. 4. Cape Archives CMT, Vol: 3/1642, Ref: C7/5.

16 Makoba's location was a black spot in a white area, which was removed by the government, and given to white owners.

17 Chief Jeremiah Moshesh from notes of a meeting between the Native Affairs Commission and Chief Moshesh and followers, 4 November 1947, p. 2. Cape Archives CMT, Vol: 3/1642, Ref: C7/5. 
18 Daniel Moshesh, ibid., p. 1.

19 Chief Jeremiah Moshesh, ibid p. 3.

20 Dr Smit, deputy chairman, ibid., p. 2

21 M. Mokoatle, the United Transkei Territories Council, Minutes of the Session, 1949. Cape Archives CMT, Vol: 3/1642, Ref: C7/5.

22 'The farms Simpson and Polygon were originally registered in the name of seven Natives; today there are 2000 Natives on these two farms.' Mr van Straten, farmer, from notes of discussion held between the Native Affairs Commission and the East Griqualand Farmers' Congress, p. 2. Cape Archives CMT, Vol: 3/1642, Ref: C7/5.

23 Mr van Straten of Ongeluksnek Farmers' Association, from notes of a meeting held between the Native Affairs Commission and the European Farmers of Matatiele, 4 November 1947, p. 2. Cape Archives CMT, Vol: 3/1642, Ref: C7/5.

$24 \mathrm{Mr}$ Gilson, MP, from notes of discussion held between the Native Affairs Commission and the East Griqualand Farmers' Congress, p. 1. Cape Archives CMT, Vol: 3/1642, Ref: C7/5.

25 Mr van Straten, farmer, ibid., p. 2.

\section{7 'Native' lands}

1 Mphahlele, Es'kia, 'Death', in Chapman, Michael and Dangor, Achmat (eds) (1982) Voices from Within: Black Poetry from Southern Africa, Johannesburg: Ad. Donker, p. 170.

2 Williams, Raymond (1988) Keywords: A Vocabulary of Culture and Society, London: Fontana. First published 1976, pp. 215-216.

3

In the 1950s and early 1960s prose writing by black South Africans was some of the best on the continent. Nearly all these seminal black writers went into exile in the sixties and the books are banned. . . No fiction of any real quality has been written by a black writer still living in South Africa ... Aspirant writers are intimidated not only by censorship as such, but also by the fear that anything at all controversial, set out by a black in the generally explicit medium of prose, makes the writer suspect, since the correlation of articulacy and political insurrection, so far as blacks are concerned, is firmly lodged in the minds of the Ministers of the Interior, Justice and Police.

(Gordimer, Nadine (1973) The Black Interpreters: Notes on African Writing, Johannesburg: Ravan Press, p. 51)

4 Plaatje, Sol (1996) Native Life in South Africa, Randburg, SA: Ravan Press. First published 1916, P.S. King and Son, p. 428.

5 Ogun is a Yoruba god of metal and war. He is one of the most important deities of the Yoruba tradition, and the 'father' and 'protector' figure in the belief system. The Yoruba people live primarily in Nigeria and Benin and their tradition dates back to at least AD 900.

6 The Transkei was the first bantustan, the system of 'independent' tribal lands implemented under National Party rule, to be declared in 1963.

7 Ingoapele Madingoane, extract from 'black trial' (1979), in Chapman and Dangor, Voices from Within, p. 154.

8 Ibid., p. 251.

9 Estimates vary from 192 dead, and 1439 injured from 16, 000 rounds fired with an additional 122 dead and 1006 injuries from 'other causes' (from SAIRR, A Survey, 1976) to between 700 and 800 dead (estimated by journalists who were in Soweto during the uprising). See O'Meara, Dan (1996) Forty Lost Years: The Apartheid State and the Politics of the National Party, 1948-1994, Randburg, SA: Ravan Press, p. 180 footnote.

10 O'Meara, Forty Lost Years, p. 180.

11 Cronin, Jeremy (1989) “"Even under the rine of terror . . .": insurgent South African poetry', Staffrider, 8 (2) 
12 Connie Mulder, Minister of Bantu Affairs and Development, cited in Platzky, Laurine and Walker, Sheryl (1985) The Surplus People Project, Johannesburg: Ravan Press, p. 17. In terms of the National States Citizenship Act 1970 all black South Africans became citizens of one of the bantustans.

13 Mamdani, Mahmood (1996) Citizen and Subject: Contemporary Africa and the Legacy of Late Colonialism, Kampala: Fountain; Cape Town: David Philip; London: James Curry. Copyright: Princeton University Press, p. 39.

14 Ibid., p. 79.

15 See Posel, Deborah (1990) 'The State and policy making in Apartheid's second phase', unpublished paper given at the History Workshop, Johannesburg: University of the Witwatersrand.

16 Vail, Leroy (ed.) (1989) The Creation of Tribalism in South Africa, London: James Curry; Berkeley, CA: University of California Press, p. 7.

17 Dr Eiselen, quoted in 'Whites to stay supreme over Bantustans', (21 March 1959), no author given, newspaper article published in the Rand Daily Mail.

18 Van Onselen, I.P. (1972) Opening address at the congress of Sabra on 'Bantu outside their homelands', published in the Yearbook of the South African Bureau of Racial Affairs 1972, p. 28.

19 Neame, J.R. (1959) 'Verwoerd's "divide and rule" scheme will destroy itself', Rand Daily Mail, 4 September.

20 'Sib' is a group of people who trace their descent lineally from a single real or presumed ancestor.

21 Van Onselen, opening address at the congress of Sabra on 'Bantu outside their homelands', p. 28.

22 Drum was a popular weekly periodical begun by Jim Bailey and ran from March 1951 to April 1965, after which it appeared as a supplement to the Golden City Post. It is now published as a weekly magazine, with a primarily black circulation of about 120, 000 and was bought by Nasionale Pers (Naspers), as part of Drum publications in 1984. Naspers was also the owner of Beeld, Die Burger, and Volksblad, which are Afrikaans newspapers cited in this text with links to the Nationalist government.

23 Nathaniel Nakasa was active in South Africa in the 1950s and 1960s, particularly at Drum with others such as Henry Nxumalo, Es'kia Mphahlele and Can Themba. In 1965 he won a fellowship to study at Harvard University in the United States, but was refused a passport by the South African government. Provided only with an exit visa he was unable to return to his country. He committed suicide in the United States in 1967.

24 Nakasa, Nathaniel (1975) The World of Nat Nakasa, Patel, Esop (ed.), Johannesburg: Ravan Press, p. 160.

25 According to the chairman's opening address ('Bantu outside their homelands', Congress proceedings, Durban, September 1972, Yearbook of the South African Bureau of Racial Affairs, Pretoria: Sabra) the population figures of South Africa in 1970 were as follows:

$\begin{array}{lr}\text { Whites: } & 3,751,328 \\ \text { Coloureds: } & 2,018,453 \\ \text { Indians: } & 620,436 \\ \text { Bantu: } & 15,057,952\end{array}$

26 Boshoff, C.W.H., chairman (1972) 'Bantu outside their homelands', p. 8.

27 From Sampson, Anthony (1983) 'The early Drum', in Caccia, A., The BEAT of Drum: The Story of a Magazine that Documented the Rise of Africa, as told by Drum's publisher, editors, contributors and photographers, Braamfontein: Ravan Press.

28 Drum: advertisement for Vicks Vapour rub: 'In New York bad weather often brings cold miseries. Guard your family against cold and flu the way smart New Yorkers do!' (June 1958, p. 29). Advertisement for Vaseline Petroleum Jelly: 'This American housewife knows it pays to get the best. You see Mrs. Brown outside the New York house where her family live. The Brown family is successful, both in business and socially' (December 1957, p. 76). 
29 Dyanti, Benson (November 1959) 'Last days of Sophiatown', p. 45, in Drum.

30 Nakasa, Nat (1975) 'It is difficult to decide my identity', in The World of Nat Nakasa, p. 159.

31 The Description of Racial Groups: Memorandum by the Department of Coloured Affairs, 12 October 1951. Transvaal Archives, Source: GBR, Vol: 100, Ref: SCB555.

32 Modisane, William 'Bloke' (1956) 'A “Native” boy by mistake', Drum, July, p. 55.

33 Ibid.

34 Neame, J.R. (1959) 'Verwoerd's "divide and rule" scheme will destroy itself', Rand Daily Mail, 4 September.

35 Ibid.

36 The Tomlinson Report was a report commissioned by the National Party government shortly after coming to power in order to investigate the feasibility of stemming the tide of black urbanisation. It concluded that segregation was both desirable and feasible.

37 Matthews, Z.K. and Tomlinson, F.R. (1956) 'Back to the Desert', Drum, September p. 33.

38 South African Press Association (1959) 'Nel refuses to define borders', Rand Daily Mail, 28 May.

39 Field, Arthur (1960) 'Ciskei Bantustan being established without the "impediment" of a map', letter to the editor of The Star newspaper, 5 December.

40 No author given, 'The unreal debate', Rand Daily Mail, 21 April 1972.

41 This was the status of the land in 1972, according to Laurence, P. (1972) 'A cardinal issue: land', The Star, 24 April.

42 The status of these territories, the Transkei, Ciskei and Bophuthatswana, was unstable politically, financially, domestically and internationally. Despite the political assurances of independence the bantustans remained under the political and financial control of the South African government. Their existence and the definition of their borders was not accepted internationally.

43 Biko, Steve (1988) 'Let's talk about Bantustans', in / Write What / Like, London: Penguin Books, pp. 97-98. The desire to retain and extract mineral wealth from black areas was also reflected in the policy to clear the black spots first that had mineral deposits. See Platzky and Walker, The Surplus People Project, p. 115

44 Riekert, P.J. (1972) 'Bantu outside their homelands: policy and administration', in Yearbook of the South African Bureau of Racial Affairs, Pretoria: Sabra, p. 33

45 Biko, 'Fear - an important determinant', in / Write What / Like, p. 89.

46 Dr Mangosuthu Gatsha Buthelezi was (and is at the time of writing) the political leader of the Zulu people.

47 Kaiser Mantanzima was leader of the Transkei.

48 Biko, 'Fragmentation of the Black resistance', in / Write What I Like, p. 50.

49 Dikobe, Modikwe (1983) 'Demarcation Line', in Dispossessed, Johannesburg: Ravan Press, p. 65.

50 Banoobhai, Shabbir, 'the border', in Chapman and Dangor, Voices from Within, p. 144.

51 Biko, 'Fragmentation of the Black resistance', in / Write What / Like, p. 51.

52 'Luthuli hits out', The Star 9 May 1959. He was banned shortly after his comments on the creation of the bantustans were recorded towards the end of May. The terms of the banning order meant that he was sent back to Zululand for five years and removed from political activity in the cities. See 'Comment', Sunday Express newspaper, 31 May 1959

53 The Transkei is sited on the east coast of South Africa, south of KwaZulu-Natal, and borders Lesotho.

54 Barton, Frank (1963) 'Transkei - the frightened land', Drum, June, p. 21

55 Coetzee, J.M. (1992) 'Into the dark chamber: the writer and the South African State', in Doubling the Point: Essays and Interviews, Attwell, David (ed.) Cambridge, MA and London: Harvard University Press, p. 97.

56 Bosman, Herman Charles (1977) Willemsdorp, Cape Town: Human and Rousseau, p. 91.

57 Joseph Conrad has Marlowe (his narrator in The Heart of Darkness) say:

Now when I was a little chap I had a passion for maps. I would look for hours at South America, or Africa, or Australia and lose myself in all the glories of exploration. At that 
time there were many blank spaces on the earth, and when I saw one that looked particularly inviting in a map (but they all look that) I would put my finger on it and say, When I grow up I will go there. The North Pole was one of those places, I remember Well, I haven't been there yet, and shall not try now. The glamour's off. Other places were scattered about the equator, and in every sort of latitude all over the two hemispheres. I have been in some of them, and . . . well, we won't talk about that. But there was one yet - the biggest, the most blank, so to speak - that I had a hankering after.

(Conrad, Joseph (1995) The Heart of Darkness, Hampson, Robert (ed.), London: Penguin Books, pp. 21-22)

\section{Language, nation and landscape}

1 N.P. van Wyk Louw (1959), quoted in the tourist brochure (1999) for the Taal Monument. Note that all quotations from this brochure were originally in Afrikaans and that they have been translated by the author into English.

2 Regis Debray, cited by Brennan, Timothy (2000) 'The national longing for form', in Bhabha, Homi (ed.) Nation and Narration, London: Routledge, p. 51.

3 Die Huisgenoot (a popular South African Afrikaans language women's magazine) reissued the first issue of Die Afrikaanse Patriot to coincide with the inauguration of the Taal Monument in 1975.

4 Marks, Shula and Trapido, Stanley (eds) (1999) The Politics of Race, Class and Nationalism in Twentieth Century South Africa, London and New York: Longman. First published 1987.

5 Mamdani, Mahmood (1996) Citizen and Subject: Contemporary Africa and the Legacy of Late Colonialism, Kampala: Fountain; Cape Town: David Philip; London: James Curry. Copyright: Princeton University Press.

6 Anon. (1999) Afrikaanse Taal Monument, brochure.

7 According to Anon. (1975) Die Afrikaanse Taalmonument, the Volkskomitee was composed of

The Minister of Education as Chairman, the Administrators of the four provinces and South West Africa, representatives from the Afrikaans churches, the rectors from Afrikaans Universities, Representatives of the F.A.K., the South African Academy for Science and Art, ATKB, ATKV, AKPOL, AKVV, ASB, Afrikaans newspapers, the Historical Monuments Commission, Teachers Associations, the Voortrekkers, the Rapportryers, the SABC, the Afrikaans Trade Organisation and other organisations.

8 Anon. (1975) Die Afrikaanse Taalmonument.

9 Ibid.

10 A newspaper article in 1975 documents the participation of the 'coloured' group in the festival: 'Kleurlinge en Taalfees' (Coloureds and Language Festival), no author, no publication recorded, newspaper cutting in the archives of the Taal Museum, Paarl.

11 The film was made by the Afrikaanse Rolprentproduksie, Limited, together with the Department of Information. 'Die Pêrel van Paarl', brochure from the première, held at the Protea Theatre, Paarl, 20 May 1954, Bloemfontein State Archives, Ref: Pam 839 AFR.

12 Bunn, David (1995) 'Whited sepulchres: on the reluctance of monuments', in Judin, Hilton and Vladislavic, Ivan (eds) Blank: Architecture, Apartheid and After, Rotterdam: NAi.

13 Anon. (1999) Afrikaanse Taal Monument, brochure.

14 Anon. (1975) 'Dié Monument Enig in Sy Soort!', from Tegniek (1975). Source: Paarl Archive, uncatalogued.

15 Anon. (1999) Afrikaanse Taal Monument, brochure.

16 Anon. 'Dié Monument Enig in Sy Soort!', p. 8-9.

17 Anon. (1999) Afrikaanse Taal Monument, brochure. 
18 Anon. (1975) Die Afrikaanse Taalmonument, p. 4

19 Ibid., p. 9

20 Anon. (1999) Afrikaanse Taal Monument, brochure, p. 20.

21 Unpublished, uncatalogued memorandum in the collection of the Taal Museum, Paarl.

22 Taal Museum: collection of correspondence between Jan van Wijk (architect), the Taal Committee and P.J. Loots with regard to the construction and meaning of the Taal Monument. Not catalogued.

Taal Museum: collection of minutes and memoranda of the Taal Committee for the design and construction of the Taal Monument.

23 Both, Susan (1987) 'Hoort Taalmonument in die Paarl?', photocopied newspaper article in the collection of the Paarl Archive, uncatalogued and undated.

24 O'Meara, Dan (1983) Volkskapitalisme: Class, Capital and Ideology in the Development of Afrikaner Nationalism, 1943-48, Cambridge: Cambridge University Press, pp. 180-181.

\section{Tribal landscapes}

1 Coetzee, J.M. (1988) White Writing: On the Culture of Letters in South Africa, New Haven, CT: Yale University Press, pp. 12-35.

2 For a discussion of the importance of photography and the English landscape see Taylor, John (1990) 'The alphabetic universe: photography and the picturesque landscape', in Pugh, Simon (ed.) Reading Landscape: Country City Capital, Manchester: Manchester University Press.

3 Meiring, A.L. (1949) 'Die Kultuur van die Bantoe: Blanke Suid-Afrika moet die Kuns van die Tradisievaste Mapoggas hulp bewaar', in Monument Uitgawe: Die Huisgenoot, 25 November.

4 lbid., p. 48.

5 Franco Frescura has argued that the rise of wall painting in southern Africa was a result of disputes over land, mainly between black and white societies, since the 1920s. The wall paintings were a stamp of identity and were themselves a barometer of political tension, tending to reduce when the situation stabilised. See Frescura, F. (1990) 'Accommodation or protest? The rise of a wall decorating tradition in southern Africa', unpublished paper given at the History Workshop, University of the Witwatersrand.

6 The hut that recurred in representations was that of the Zulu people, who held a particular place in the Afrikaner narrative as the murderers of the Voortrekker leader Piet Retief. As Elizabeth Delmont (1993) 'The Voortrekker Monument: monolith to myth', South African Historical Journal 29 (November), pp. 76-101, has noted, their culture was emphasised above others during National Party rule.

7 Die Burger newspaper, 8 July 1959.

8 'Weenen' is an Afrikaans word meaning 'The place of weeping'.

9 Naidoo, G.R. (1958) 'Weenen again!', Drum, June, pp. 24-29.

10 Matthews, Z.K. and Tomlinson, F.R. (1956) 'Back to the desert', Drum, September, pp. 31-33.

11 See Themba, Can (1956) 'Banned to the bush', Drum, August, pp. 22-25.

12 Dyanti, Benson and photographer Magubane, Peter (1960) 'Trouble in the Bantustans', Drum, September, p. 21.

13 Ibid., p. 21.

14 Unknown author (1962) 'Black spots', Drum, November, pp. 63-65.

15 For a detailed discussion of the forced removals of apartheid see Murray, Christina and O'Regan, Catherine (eds) (1990) No Place to Rest: Forced Removals and the Law in South Africa, Cape Town: Oxford University Press.

16 See Murray and O'Regan, No Place to Rest.

17 According to Murray and O'Regan, No Place to Rest, between 1960 and 1983 more than half the removals occurred in rural areas, with the greatest percentage being removals from white-owned farms.

18 Stanley Frielik similarly argued that: 


\section{Notes to Chapter 10}

Most African oral texts represent the inseparability of the human body from the earthly worlds with which we co-exist - the worlds of water, plants, animals and inanimate objects and this notion continues in many ways in African literature.

(Frielik, S. (1992) 'Deep ecology: the environment and African literature', in Bell, Nigel and Carper-Lewis, Meg (eds) Literature, Nature and the Land: Ethics and Aesthetics of the Environment, Durban: University of Natal, Multicopy, p. 60)

Breyten Breytenbach also described this interconnectedness of all aspects of the natural world, of which man was a part. See Breytenbach, Breyten (1996) The Memory of Birds in Times of Revolution, Cape Town: Human and Rousseau, p. 89.

19 Mphahlele, Es'kia, 'We've always known God', The Voice (Johannesburg), 3(38) September.

20 Classens, Aninka, 'Rural land struggles in the Transvaal in the 1980s', citing Petros Nkosi at residents' meeting, July 1989, in Murray and O'Regan, No Place to Rest, p. 51.

21 Marcus, Gilbert, 'Section 5 of the Black Administration Act: the case of Bakwena ba Mogopa', in ibid, p. 23.

22 Oral poem, cited by Harries, Patrick (1984), 'A forgotten corner of the Transvaal: reconstructing the history of a relocated community through oral history and song', unpublished paper presented at the History Workshop, University of the Witwatersrand, Johannesburg.

23 Cited in Platzky, Laurine and Walker, Sheryl (1985) The Surplus People Project, Johannesburg: Ravan Press, p. 51.

24 Ibid., p. 192.

25 I am grateful to Lindsay Bremner for this observation and our discussions.

26 Being a 'banned' person meant that your writings could not be published, your freedom of movement was restricted and you could not meet with more than one other person at a time.

27 Dangor, Achmat (1983) Extract from 'Journey through a Naked Land', in Bulldozer, Johannesburg: Ravan Press.

28 Matthews, James, 'Valley of Plenty', quoted by Gordimer, Nadine (1973) The Black Interpreters: Notes on African Writing, Johannesburg: Ravan Press.

29 Letter from the Chief Commissioner of Bantu Affairs, Western Area (10 July 1964), from government papers held in the Cape Archives, Source: 4/CAL, Ref: 4/1/44, Vol: G/3.

30 Author given as 'The Man on the Reef', 'View that Few are Ever Able to See: Attraction of a Bantustan', The Star, 20 July 1962.

\section{Desire and distance}

1 Serote, Mongane Wally (1982) 'City Johannesburg', in Chapman, Michael and Dangor, Achmat (eds) Voices from Within: Black Poetry from Southern Africa, Johannesburg: Ad. Donker, p. 104.

2 'Donga' is an Afrikaans word which has come to have the same meaning in South African English, i.e. a ravine or gully.

3 Zuma, Dr A.B. 1952 “"Black spots or white spots?” Johannesburg City Council plans to move African Areas out of town', Drum, March, p. 25.

4 Themba, Can (1972) 'Requiem for Sophiatown', in Themba, The Will to Die, Cape Town: David Philip, p. 104

5 Lewis Nkosi, obituary published in Themba (1972) The Will to Die, p. vii.

6 Ibid., p. vii.

7 'Swart' is an Afrikaans word meaning 'black'.

8 Westdene is a suburb which was located adjacent to Sophiatown, and which remains primarily occupied by white Afrikaans-speaking people.

9 Themba, 'Requiem for Sophiatown', p. 107

10 'Baby Come Duze', story by Can Themba, pictures by Gopal S. Naransamy, Drum, April 1956, p. 61 .

11 Ibid., p. 64. 
12 O'Meara, Dan (1983) Volkskapitalisme: Class, Capital and Ideology in the Development of Afrikaner Nationalism, 1943-48, Cambridge: Cambridge University Press, pp. 165-166.

13 O'Meara has argued in Volkskapitalisme that Afrikaner Nationalism was at its core a movement about gaining economic power, and gaining that power from the English speakers, who were represented both as the perpetrators of violence against Boer families in the South African War and the usurpers of the country's mineral wealth (personified in the English Jewish symbol of 'Hoggenheimer'). This name itself was a corruption of 'Oppenheimer', which is the name of the family that controls Anglo American Corporation - a huge mining conglomerate.

14 D.J. Opperman (poem), E. Toussaint van Hove (drawing), Die Huisgenoot (1949).

15 This anti-English sentiment was still present in films such as Jamie Uys' film Doodkry is min (To Kill is Minimal, 1961), filmed partly at the Voortrekker Monument, where the English are blamed for the nation's ills. This film is still restricted by the FAK (Federasie vir Afrikaanse Kuns) and may not be screened without the FAK's permission. Source: National Film, Video and Sound Archives.

16 Unknown author (1949) 'Goud het onder hulle wawiele gelê: Voortrekkers het weg gebaan vir S.A se grootste bedryf', newspaper article published in Die Voortrek, 13 December, p. 80.

17 Ibid., p. 80.

18 Pauw, S. (1949) 'Die Tweede Trek', Die Voortrek, 13 December, p. 11

19 Ibid., p. 11.

\section{Veld and city}

1 Bosman, Herman Charles (1977) Willemsdorp, Cape Town: Human and Rousseau, pp. 162-163.

2 Gordimer, Nadine (1984) Burger's Daughter, London: Penguin Books, p. 207. (First published 1979, Jonathan Cape.)

3 See Davie, Lucille (2004) 'Jo'burg's mine dumps bite the dust', from Gauteng Economic Development Agency http://www.geda.co.za/, accessed 16 March 2005.

4 Rosner, T., Boer, R., Reyneke R., Aucamp, P. and Vermaak, J. (2001) WRC Report Number: $797 / 1 / 01$ (no page numbers). A preliminary assessment of pollution contained in the unsaturated zone beneath reclaimed gold-mine residue deposits.

5 Ibid.

6 Ibid.

7 Ibid., p. 184.

8 Davie, 'Jo'burg's mine dumps bite the dust'.

9 From Johannesburg City website, www.goafrica.co.za/joburg/tourists/index.stm, accessed February 2001

10 Bremner, Lindsay (1995) 'Crime and the emerging landscape of post-apartheid Johannesburg', in Judin, Hilton and Vladislavic, Ivan (eds) Blank: Architecture, Apartheid and After, Rotterdam: NAi, p. 55.

11 Nuttall, Sarah and Coetzee, Carli (eds) (1998) Negotiating the Past: The Making of Memory in South Africa, Cape Town: Oxford University Press, p. 14.

12 Benedict Vilakazi was the first African in the Union of South Africa to receive the degree of doctor of literature. He was a prizewinner of the International Institute of African Languages and Cultures, a distinguished Zulu poet, joint compiler of the standard English-Zulu dictionary and also wrote the first book of Zulu poems to be published. Some of the poems were traditional 'praisesongs'.

13 Vilakazi, Benedict (1945) Amal'ezulu, Johannesburg: University of the Witwatersrand Press, pp. 60-66.

14 Vilakazi, Benedict, 'The Gold Mines', in Chapman, Michael and Dangor, Achmat (eds) (1982) Voices from Within: Black Poetry from Southern Africa, Johannesburg: Ad. Donker, pp. 44-48.

15 Sepamla, Sipho, 'Double-Talk', in ibid., p. 124.

16 See Moodie, T. Dunbar with Ndatshe, V. (1994) Going for Gold: Men, Mines and Migration, 


\section{Notes to Chapter 12}

London and Berkeley, CA: University of California Press, for a detailed discussion about the meaning of mining to migrant workers, and the impact that it has had on cultural and social systems over time.

17 Mbuli, Mafika, 'The Miners', in Chapman and Dangor, Voices from Within, p. 83.

18 Crown Mines Property (CMP) Development Project Report, completed in April 1969 by Roeloef Uitenbogaardt, Anthony Barac, Adele de Souza Santos, Antonio de Souza Santos and John Mayle, p. 35.

19 Japha, Derek (1995) 'The social programme of the South African modern movement', in Judin and Vladislavic, Blank, p. 435.

20 Uitenboogaardt (1969) CMP Development Project Report, p. 51.

21 Ibid., p. 55.

22 Ibid., p. 5.

23 Ibid., p. 37.

24 Ibid., p. 10

25 Ibid., unnumbered page.

26 Moodie, D.W.M. (1969) 'Outline plan for the redevelopment of the mining land', unpublished Town Planning PhD thesis submitted to the University of the Witwatersrand, October 1969, p. 10.

27 Ibid., p. 13

28 Ibid., p. 54

29 GAPPS (June 1993) Interim Strategic Framework for the Central Witwatersrand, pp. 16 and 26.

\section{Invisibility and silence}

1 A 'location' is another word for a township.

2 Langa and Nyanga are black townships on the Cape Flats.

3 Davids, Jennifer, 'Location Fires', in Chapman, Michael and Dangor, Achmat (eds) (1982) Voices from Within: Black Poetry from Southern Africa, Johannesburg: Ad. Donker, p. 97.

4 Later, people could claim residency under so-called 'Section 10' rights, which were available under the Native (Black) Urban Areas Act only if they had been permanently resident and employed in an urban area for more than ten years.

5 The National Party government tried to keep women in particular away from the urban areas and placed restrictive rules on them dwelling and working there. Domestic workers were not entitled to have their husbands to stay in their rooms, even with the owner's permission, enforcing their uncertain status even as they lived in white homes.

6 Dikobe, Modikwe (1983) Dispossessed, Johannesburg: Ravan Press, p. 44

7 See Mabin, Alan (1990) 'Doom at the stroke of a pen: planning and Group areas c1935-1958', unpublished paper presented at the History Workshop, University of the Witwatersrand, for a detailed discussion of planning policy of this period.

8 F.W.C. Aveling (Stadsgebiedekommissaris), 24 January 1956, Letter to the Control Official (City Areas) labelled K. 105(A) Source: NTS, Vol: 4610, Ref: 934/313(3), Pretoria State Archives.

9 Posel, Deborah 'Does size matter? The apartheid state's power of penetration', in Judin, Hilton and Vladislavic, Ivan (eds) Blank: Architecture, Apartheid and After, Rotterdam: NAi, p. 237.

10 Ibid., p. 238.

11 Ibid., pp. 237-247 for a discussion of the changes in the civil service under National Party rule.

12 Letter from the Administrative Section, Land Tenure Advisory Board to Shenker, Shenker and Solomon, lawyers, undated (1953) from the Transvaal archives, NTS, Vol: 4615, Ref: 934/313(1).

13 Letter from M.D. Coovadia to the Minister of the Interior, Dr T.E. Donges, 23 April 1952. Source: NTS, Vol:4565, Ref: 1076/313, Pretoria State Archives.

14 Secretary for the Department of Bantu Administration and Development, 10 January 1962, General Circular 1 of 1962 (file No. A.16/3), from the Pretoria State Archives. Source: NTS, Vol: 4565, Ref: 1076/313.

15 Application for a determination under the provisions of Section 16 of the Group Areas Act of 
1957 (Act No. 77), Form D, from the Pretoria State Archives, Source: NTS, Vol:4565, Ref: $1076 / 313$

16 Ibid.

17 From Johannesburg City website http://www.goafrica.co.za/joburg/tourists/index.stm, accessed 16 January 2002.

18 Crankshaw, Owen, and Parnell, Susan (1995) 'Interpreting the 1994 African township landscape', in Judin and Vladislavic, Blank, p. 440.

19 Biko, Steve (1988) 'What is Black consciousness?' in Biko, I Write What I Like, London: Penguin Books, p. 117.

20 No author given (accessed 12 June 2005). Jurgen Schadeberg quoted in 'Sophiatown recreated' from: http://www.filmmaker.co.za/edition/news_page.php? subaction=showfull\&id $=1107323528$ \&archive $=\&$ start_from $=\&$ ucat $=5 \&$

21 Nakasa, Nathaniel (1975) 'Snatching at the good life', in Nakasa, The World of Nat Nakasa, Patel, Esop (ed.), Johannesburg: Ravan Press, p. 25.

22 Unknown author (1951) 'Growing scepticism over "Black Spots" plan for city', Rand Daily Mail, 10 April.

23 'Klip' is an Afrikaans word meaning 'stone'.

24 Dikobe, Modikwe (1983) 'Klip River', in Dispossessed, p. 31.

25 Serote, Mongane Wally (1974) 'A Poem on Black and White', in Serote, Tsetlo, Johannesburg: Ad. Donker, p. 11.

26 The BPC was co-founded by Biko in 1972. The trial occurred in 1975 and 1976 after the banning of a rally to celebrate Frelimo (the new Mozambiquan government). After the banning BPC leaders were arrested and held in detention without charge, until this trial.

27 Steve Biko, (1988) 'The righteousness of our strength', in I Write What I Like, p. 153.

28 Nakasa, The World of Nat Nakasa, back cover.

29 Dangor, Achmat 'The Voices that are Dead', in Chapman and Dangor (1982) Voices from Within, p. 146.

30 Interview conducted with Mr Mould, reporter for The Star newspaper during the 'black space' period, February 2001

31 Allen, David (1986) 'Black Eye', Sunday Star, 22 June, p. 13.

\section{Landscapes and erasures}

1 Said, Edward (1994) Culture and Imperialism, London: Vintage, p. 271.

2 According to Murray, Christina and O'Regan, Catherine (eds) (1990) No Place to Rest: Forced Removals and the Law in South Africa, Cape Town: Oxford University Press, the numbers of people and the reason for their removals were:

$\begin{array}{lr}\text { Farm evictions } & 1,129,000 \\ \text { Black spots and consolidation } & 614,000 \\ \text { Urban } & 730,000 \\ \text { Informal settlements } & 112,000 \\ \text { Group Areas } & 860,400 \\ \text { Infrastructural } & 103,500 \\ \text { Total } & 3,548,900\end{array}$

3 Higgs, Barry (1971) 'Castles in the air - the tragedy of residential apartheid', Sechaba, 9 September.

4 Archives of the SAIRR, Wits University (195?) Letter to the Town Clerk, Johannesburg City Council, from the Honourable Secretary of the Southern Transvaal Regional Committee of the SAIRR.

5 Quotation from Xuma, A.B. (1952) 'Black spots or white spots?', Drum, March, p. 25.

6 Sophiatown, by Malcolm Purkey and the Junction Avenue Theatre Company premièred at The 


\section{Notes to Chapter 13}

Market Theatre in 1986 with a revival in 1994. District Six, by David Kramer and Taliep Peterson, premièred in 1985 .

7 A 'stoep' (Afrikaans) is a word which describes a usually slightly raised space in front of the house, which can be either roofed (like a veranda) or unroofed. It is commonly used to describe social spaces in domestic buildings which overlook streets and are used as a place of social interaction.

8 Report of the Commission of Inquiry into Matters relating to the Coloured Population, 19 April 1976, quoted on the museum panels at the District Six Museum, Cape Town.

9 See Robins, Steve 'Bodies out of place: Crossroads and the landscapes of exclusion', in Judin, Hilton and Vladislavic, Ivan (eds) Blank: Architecture, Apartheid and After, Rotterdam: NAi, pp. 458-469.

10 In her novel Triomf (1994, Cape Town and Johannesburg: Queillerie and Jonathan Ball) Marlene van Niekerk transposes her own experience of digging in the garden of her Triomf house and finding the debris from the removals.

11 In Triomf the street names were retained from Sophiatown, which many former residents felt to be even more of a violation than if the names had been changed.

12 National Archives, Pretoria, Source: NTS, Vol: 4610, Ref: 934/313(3), Group Areas Act, Reference and Planning, 1952-1961. Racial Zoning Witwatersrand.

13 The restrictions on the race of people who could own land and buildings also enabled mainly white business people to speculate about property values and to make often significant sums of money. See Higgs, 'Castles in the air', for a more detailed discussion of the financial and economic implications of the Group Areas Act.

14 Department of Land Affairs, 12 April 2005, fax from Anna Marie Koster of the Department of Land Affairs to Debbie Sutherland of the Department of Land Surveys and Mapping.

15 Interview with lan Black, curator of the Map Collection, Cape Town City Council, April 2001.

16 Pageview (also known as Fietas) was a primarily Indian business and residential area to the west of the Johannesburg CBD. Like that of District Six, its declaration under the GAA as 'white' unleashed a storm of political protest.

17 Report of the President's Council on the Group Areas Act 1966 (Act 36 of 1966) with special reference to Zonnebloem (District Six) and Pageview. Cape Town: Government Printer, 2.5, p. 2.

18 Ibid., 8.1.7, p.5.

19 Ibid., 8.1.8, p. 5.

20 See Hart, Deborah (1990) 'Political manipulation of urban space', in Jeppie, S. and Soudien, C. (eds) The Struggle for District Six: Past and Present, Cape Town: Buchu Books.

21 L. Fouché (5 June 1969) to Professor Page of the Department of Town and Regional Planning at the University of Stellenbosch on the principles on which to base the town planning. From a letter contained in the Cape Archives, Source: CDC, Vol: 649.

22 De Beer, Daniel S. (April 1969) Report on the planning for the redevelopment of District Six. Cape Archives, Source: CDC, Vol: 649.

23 D. Page, Stellenbosch planner and the Director of Planning team for District Six, letter to the Secretary. Department of Community Development, Pretoria, 16 May 1969. Cape Archives, CDC, Vol 647.

24 District Six (1980), Occasional Paper No. 2, compiled and published by the Centre for Intergroup Studies, p. 8.

25 Hart, 'Political manipulation of urban space', p. 133

26 District Six (1980) Occasional Paper No. 2, compiled and published by the Centre for Intergroup Studies.

27 'Slum dwellers happy in their new homes', 21 March 1955 memorandum. Source: GEM, Vol: 195, Ref: G14/3/139/1, Sophiatown - Development Proposals. Group Areas, Ontwikkelingsgrond, Hervesting, Pretoria State Archives.

28 Anonymous (1957) 'Sophiatown big shots fight for their homes', Drum, December, pp. 76-81. 


\section{Landscapes of the imagination}

1 Stan Abrahams, interview at the District Six Museum, 2000.

2 Nkosi, Lewis (1958) 'Sophiatown is a state of mind', Contact, 1(23), 13 December, p. 5.

3 'Shebeens' were illegal drinking dens, usually run by a female proprietor, who brewed local beer.

4 Dyanti, Benson (1959) 'Last days of Sophiatown', Drum, November, p. 43.

5 Titlestad, Michael (UNISA) 'The acoustics of memory: historiography and alterity in representations of 1950s township jazz', unpublished paper presented to Wiser, University of the Witwatersrand, 27 May 2002.

6 'Isiqatha' is a home-brewed beer.

7 No author given, Speak, 8 August 1985.

8 District Six Museum website, http://www.districtsix.co.za/frames.htm, accessed 14 July 2005.

9 Davids, Achmat (1988?), Cape Town University Oral History Project, p. 18.

10 National Archives, Pretoria, Source: NTS, Vol: 4610, Ref: 934/313(3), Group Areas Act, Reference and Planning, 1952-1961. Racial Zoning Witwatersrand.

11 Trevor Huddlestone, cited by Lodge, Tom (1981) 'The destruction of Sophiatown', unpublished paper presented at the History Workshop, University of the Witwatersrand, Johannesburg.

12 Serote, Mongane Wally (1974) 'Death Survey', in Tset/o, Johannesburg: Ad. Donker, p. 48.

13 Government Gazette, Pretoria, 2 September 1960, Proclamation No. 304 of 1960.

14 Dangor, Achmat (1983) 'Paradise', in Bulldozer, Johannesburg: Ravan Press, p. 3.

15 Jürgen Schadeberg, quoted by Farber, Tanya (2005) 'Sophiatown reincarnated', The Star, 2 February.

16 Contact correspondent (1959) 'Uncertainty at Mossel Bay', Contact, 17th October.

17 Statement by J. Niemand, Secretary of Community Development in the Cape Times, 10 January 1969, cited in Hart, Deborah (1990) 'Political manipulation of urban space', in Jeppie, S. and Soudien, C. (eds) The Struggle for District Six: Past and Present, Cape Town: Buchu Books, p. 124.

18 As it has been shown by researchers at the University of Cape Town, the economic rationale behind the removal of District Six was severely flawed. They conservatively estimate the total cost of the removals at about R45 million, which does not include lost income from the site. See District Six (1980), Occasional Paper No. 2, compiled and published by the Centre for Intergroup Studies, c/o University of Cape Town, p. 4. In the District Six Community Papers, University of Cape Town.

19 Mrs Fortune, former resident of District Six, quoted by Chris McGreal, 'Time to go home for Cape Town's refugees', Guardian newspaper, 17 May 2001, p. 21.

20 Mrs Adams, 1 March 1990, University of Cape Town Oral History Project, p. 25.

21 Serote, Mongane Wally (1974) 'Mode of Broken Pieces', in Tsetlo, pp. 29-31.

22 Nakasa, Nat (writer) and Magubane, Peter (photographer) (1962) 'The move out to nowhere', Drum, May, pp. 61-7.

23 Nkosi, Lewis (1958) 'Sophiatown is a state of mind'.

24 This is despite the fact that model townships were initially based on the model of the garden city, with vegetation and gardens an intrinsic part of their conception. See Japha, Derek (1995) 'The social programme of the modern movement', in Judin, Hilton and Vladislavic, Ivan (eds) Blank: Architecture, Apartheid and After, Rotterdam: NAi, pp. 423-437.

25 Unknown author (1964) 'Let the immigrants go to Bonteheuwel', Contact, 7(2), 24 January.

26 Willis, Barbara (1967) 'The death knell of Old Simon's Town', The Black Sash, November, pp. $25-28$.

\section{Transforming landscape}

1 Van Niekerk, Marlene (1994) Triomf (translated from Afrikaans to English by Leon de Kock 1999), Cape Town and Johannesburg: Queillerie and Jonathan Ball, p. 1. 


\section{Notes to Chapter 15}

2 The South African artist William Kentridge has referred to this in discussions of the landscapes that appear in his work. See Kentridge (1994) Felix in exile: geography of memory', extract reprinted in Cameron, Dan, Christov-Bakargiev, Carolyn, and Coetzee, J.M. (1999) William Kentridge, London: Phaidon Press, pp. 126-127.

3 Jeppie, S. and Soudien, C. (eds) (1990) The Struggle for District Six: Past and Present, Cape Town: Buchu Books, p. 13.

4 Krige, Sue (2004) 'Capturing the spirit of Kofifi', Weekly Mail and Guardian, 22 November, from http://www.mg.co.za/articlePage.aspx?articleid=142513\&area=/insight/insight_escape/

5 From the Department of Land Affairs, http://land.pwv.gov.za/restitution/BACKGROU.RES.htm, accessed 14 July 2005.

6 Ibid.

7 Researchers: Leslie Bank and Landiswa Maqasho http://www.ru.ac.za/institutes/iser/research/ 19.html, accessed 14 July 2005.

8 Ibid.

9 Tse, Joyce (2005) 'Rebuilding District 6 as heritage site a top priority', Cape Times, 27 May.

10 Nassen, Bill (1990) 'Oral history and the reconstruction of District Six', in Jeppie and Soudien, The Struggle for District Six, p. 45.

11 Ibid., p. 46.

12 Rassool, Ciraj and Prosalendis, Sandra (eds) (2001) Recalling Community in Cape Town: Creating and Curating the District Six Museum, Cape Town: District Six Museum Foundation.

13 Morphet, Tony (1995) 'An archaeology of memory', Mail and Guardian, 3 February.

14 Mrs Fortune interviewed by Chris McGreal, Guardian (UK), November 2001.

15 See Harley, J.B. (1988) 'Maps, knowledge and power', in Cosgrove, D. and Daniels, S. (eds) (1997) The Iconography of Landscape: Essays on the Symbolic Representation, Design and Use of Past Environments, Cambridge: Cambridge University Press. First published 1988, p. 278, for a discussion of the political and social content of maps.

16 Carroll, Rory (2003) 'Evicted return home as District Six rises again', Guardian, 29 October.

17 Tse, Joyce (2005) 'Rebuilding District 6 as heritage site a top priority', Cape Times, 27 May.

18 Krige, 'Capturing the spirit of Kofifi'.

19 Davie, Lucille (2004) 'Plan aims to excavate Sophiatown memories', Johannesburg News Agency, 17 September.

20 Nelson Mandela, Inauguration Address, Union Buildings, Pretoria, 10 May 1994. 


\section{Appendix A: South African timeline}

Pre-1652 Khoikhoi in Cape area for thousands of years. No crops except dagga, needed to move to find new pastures constantly.

1590s Ships of Dutch East India Company stopping in Table Bay on way to Indies.

$1652 \quad$ Dutch East India Company settlement founded.

1657 First farms settled behind Table Mountain.

1658 Significant numbers of slaves imported, at first from West Africa, then Madagascar, East Indies, Ceylon, Mozambique and Zanzibar.

1700 Frontier extended into South Western Cape, rapid expansion of trekboer economy. Most settlers were pastoralists and lived on land.

1720 Society settled down. Basis of economy agricultural. 'Free' land in interior, but had to be conquered by removing the tribes that lived there.

$1750 \quad$ Half the male population had at least one slave. Demonstrated that manual labour should not be performed by whites, slaves as status symbols. Most freed slaves urban. Freed slaves had similar rights to burghers.

1770s Rapid expansion of the settlement forced Khoikhoi into employment and also to move almost daily. Pre-1770s Khoikhoi had same rights as white men, were able to own property and were equal in the eyes of the law, although this did not mean that they were not subject to abuse and murder at the slightest provocation.

1795 Slaves largest population at Cape.

$1796 \quad$ End of slave voyages.

1790s Blacks to carry passes to leave town, increasing discrimination towards end of eighteenth century.

1795-1803 British force took control at Cape.

1803-1806 Batavian Republic ruled the Cape.

1806-1814 Permanent British rule, treaty with Dutch.

$1808 \quad$ Abolition of slavery in British Empire.

1811-1812 British drove Xhosa over Fish River.

1812 Black Circuit court used to protect the rights of Khoikhoi.

1813 Proposed name change for 'Bastaards' to Griqua (children of white/ Khoi or slave/Khoi who had special status).

1815 Slagtersnek rebellion of Boer colonists against British powers, British seen as favouring rights of Khoikhoi over those of the Boer farmers.

$1827 \quad$ Free blacks 25 per cent of population of Cape Town.

1828-1830 Legal ties on slaves and Khoi, despite the end of the slave trade.

$1834 \quad$ Emancipation of all slaves.

1834-1838 Great Trek.

1830s 'Afrikaner' loose term, fractured identity. Afrikaans not defined as a language fit for urban social interaction.

1865 Afrikaans replaced by English as medium of instruction in schools.

1870 Subsistence farming no longer sustainable as way of life. 

Paarl in the Cape. Promotion of the use of Afrikaans in publications. Language associated with the identity of the nation.

1881 Institutionalised racism, separate churches for 'non-whites'.

1890s At the end of nineteenth century Afrikaner identity not fixed, subject to conflict.

1899 Abraham Kuyper, Dutch Calvinist, argued for a differentiated society in order to create ideal social order.

1902 Native Reserve Location Act uses tribal argument to provide control over labour for a modern state.

1903 First townships founded - Ndabeni (Cape Town), New Brighton (Port Elizabeth) - for the housing of black South Africans.

1903 Laws of Lerotholi, prohibits allocation of tribal land to non-Basotho.

1905 Sophiatown established near sewage farm to west of city of Johannesburg.

1910 Union of South Africa created out of the Cape Colony, Natal (British- controlled) and the Boer Republics of the Transvaal and Free State.

$1912 \quad$ Fencing Act.

1912 Founding of the African National Congress (ANC).

$1913 \quad$ Native Land Act confined peasants to 13 per cent of the land.

1916 Sol Plaatje publishes Native Life in South Africa, a document which sought help in combating the Land Act from the British government.

1918 Formation of Broederbond - an Afrikaner political organisation which was to become enormously powerful during the apartheid years (its members were white, Afrikaans and regarded South Africa as their only fatherland).

1923 Urban (Bantu) Areas Act. Section 10 defined very few blacks with legal permission to live in cities to be exempt from Act. Required municipalities to accommodate workers in towns.

1926-1929 Countryside site of intense struggle by Industrial and Commercial Workers' Union (ICU).

1931 Urban Areas Act amended to allow removals even when housing was not provided to accommodate those removed. Plans for Orlando (which became part of Soweto - south western townships) drawn up.

1933 Whole of Johannesburg claimed under segregation laws of Urban Areas Act.

1934 Slums Act introduced, so that Council could clear entire areas instead of individual sites.

1930s Poverty entrenched in reserves and therefore an influx of people continued into the urban areas.

1936 Abolition of common voters' roll, franchise removed in Cape and Natal by Hertzog.

1938 The re-enactment of the 'Great Trek' occurred, culminating at the foundation stone of the Voortrekker Monument site outside Pretoria.

1939-1945 Second World War in which South Africa fought on the side of the British.

1938-1952 Enormous industrial expansion because of the war. Urban black population doubled.

1939 Betterment Act hoped to increase carrying capacity of the Reserves.

1940-1965 Political resistance occurred in reserves, initiated by migrant labour.

pre-1948 Despite laws, labour market structured more by economics than government segregation.

pre-1948 Fagan report: no alternative to black urbanisation.

pre-1948 Sauer report: can stem the tide of black urbanisation.

pre-1948 Native Affairs Department (NAD), control over the reserves and lives of people there, not really power in urban areas. 
1948 National Party comes to power with Daniel Malan winning out over the United Party led by Jan Smuts.

post-1948 NAD removed and replaced with Native Authority Administration in rural areas. Urban areas NAD controlled people centrally.

$1949 \quad$ ANC plan of action in the cities.

1949 Interracial sex banned.

1949 Inauguration of Voortrekker Monument (Gerard Moerdijk was Architect)

1950 Suppression of Communism Act and banning of the South African Communist Party.

$1950 \quad$ Group Areas Act passed.

1951 Bantu Authorities Act, served to give greater power to Reserve rulers, helped rich and harmed rural poor, removed all black representation in Parliament.

1952 Pass Laws enacted. Blacks could not enter urban areas without special permits stamped into passbooks.

1955 Tomlinson Commission recommends freehold land to be granted in homelands for development, proposal vetoed by Verwoerd.

1955-1960 Demolition of Sophiatown in Johannesburg.

$1958 \quad$ Verwoerd becomes Prime Minister of South Africa.

1958 Verwoerd created bantustans in response to growing moral dilemma about apartheid among Afrikaners.

1959 Proclamation of Bantu Self Government Act.

1960 Sharpeville massacre in Vereeniging outside Johannesburg by police turning fire on a crowd of people protesting against the Pass Laws.

1960 African National Congress and Pan Africanist Congress (PAC) banned.

$1960 \quad$ South Africa becomes a Republic.

1963-1964 Rivonia Trials in which ANC leaders are tried for treason and Nelson Mandela is sentenced to life in prison.

1966 Prime Minister Verwoerd assassinated.

1968 Political parties forbidden to admit members of more than one racial group.

$1970 \quad$ National States Citizenship Act. All blacks became citizens of one of the bantustans.

1972-1974 Miners' strikes in Durban, Reef and Cape.

1976 Soweto riots over the introduction of Afrikaans as medium of instruction for Bantu education. Undetermined number of black students killed by police, intensifying political will to change the government.

$1977 \quad$ Eighteen Black Consciousness groups banned.

$1983 \quad$ Government introduced measures to control taxis and minibuses. Ten year anniversary of Soweto - newspapers demonstrate their censored texts. Removal of Influx Control and Pass Laws.

1986 White Paper on Urbanisation, shift from rural policy to understanding that urbanisation was desirable and inevitable.

1989 F.W. de Klerk becomes President of South Africa.

1990 ANC unbanned, Nelson Mandela released from prison.

1991 Government of National Unity.

1994 African National Congress wins democratic elections. 


\title{
Appendix B: Main apartheid legislation in South Africa
}

\author{
Prohibition of Mixed Marriages Act, Act No. 55 of 1949
}

Prohibited marriages between white people and people of other races. Between 1946 and the enactment of this law, only 75 mixed marriages had been recorded, compared with some 28,000 white marriages.

\section{Immorality Amendment Act, Act No. 21 of 1950; amended in 1957 (Act 23)}

Prohibited adultery, attempted adultery or related immoral acts (extramarital sex) between white and black people.

\section{Population Registration Act, Act No. 30 of 1950}

Led to the creation of a national register in which every person's race was recorded. A Race Classification Board took the final decision on what a person's race was in disputed cases.

\section{Group Areas Act, Act No. 41 of 1950}

Forced physical separation between races by creating different residential areas for different races. Led to forced removals of people living in 'wrong' areas, for example 'Coloureds' living in District Six in Cape Town.

\section{Suppression of Communism Act, Act No. 44 of 1950}

Outlawed communism and the Communist Party in South Africa. Communism was defined so broadly that it covered any call for radical change. Communists could be banned from participating in a political organisation and restricted to a particular area.

\section{Bantu Building Workers Act, Act No. 27 of 1951}

Allowed black people to be trained as artisans in the building trade, something previously reserved for whites only, but they had to work within an area designated for blacks. Made it a criminal offence for a black person to perform any skilled work in urban areas except in those sections designated for black occupation.

\section{Separate Representation of Voters Act, Act No. 46 of 1951}

Together with the 1956 amendment, this Act led to the removal of 'Coloureds' from the common voters' roll.

\section{Prevention of Illegal Squatting Act, Act No. 52 of 1951}

Gave the Minister of Native Affairs the power to remove blacks from public or privately owned land and to establish resettlement camps to house these displaced people. 


\section{Bantu Authorities Act, Act No. 68 of 1951}

Provided for the establishment of black homelands and regional authorities and, with the aim of creating greater self-government in the homelands, abolished the Native Representative Council.

\section{Natives Laws Amendment Act of 1952}

Narrowed the definition of the category of blacks who had the right of permanent residence in towns. Section 10 limited this to those who had been born in a town and had lived there continuously for not less than 15 years, or who had been employed there continuously for at least 15 years, or who had worked continuously for the same employer for at least 10 years.

\section{Natives (Abolition of Passes and Co-ordination of Documents) Act, Act No. 67 of 1952}

Commonly known as the Pass Laws, this ironically named Act forced black people to carry identification with them at all times. A pass included a photograph, details of place of origin, employment record, tax payments, and encounters with the police. It was a criminal offence to be unable to produce a pass when required to do so by the police. No black person could leave a rural area for an urban one without a permit from the local authorities. On arrival in an urban area a permit to seek work had to be obtained within 72 hours.

\section{Native Labour (Settlement of Disputes) Act of 1953}

Prohibited strike action by blacks.

\section{Bantu Education Act, Act No. 47 of 1953}

Established a Black Education Department in the Department of Native Affairs which would compile a curriculum that suited the 'nature and requirements of the black people'. The author of the legislation, Dr Hendrik Verwoerd (then Minister of Native Affairs, later Prime Minister), stated that its aim was to prevent Africans receiving an education that would lead them to aspire to positions they would not be allowed to hold in society. Instead Africans were to receive an education designed to provide them with skills to serve their own people in the homelands or to work in labouring jobs under whites.

\section{Reservation of Separate Amenities Act, Act No. 49 of 1953}

Forced segregation in all public amenities, public buildings and public transport with the aim of eliminating contact between whites and other races. 'Europeans Only' and 'Non-Europeans Only' signs were put up. The Act stated that facilities provided for different races need not be equal.

\section{Natives Resettlement Act, Act No. 19 of 1954}

Provided for the removal of Africans from any area in the Magisterial District of Johannesburg or adjacent lands. It was enacted primarily to allow for the removal of Sophiatown. 


\section{Natives (Prohibition of Interdicts) Act, Act No. 64 of 1956}

Denied black people the option of appealing to the courts against forced removals.

\section{Bantu Investment Corporation Act, Act No. 34 of 1959}

Provided for the creation of financial, commercial and industrial schemes in areas designated for black people.

\section{Extension of University Education Act, Act 45 of 1959}

Put an end to black students attending white universities (mainly the universities of Cape Town and Witwatersrand). Created separate tertiary institutions for whites, 'Coloureds', blacks and Asians.

\section{Promotion of Bantu Self-Government Act, Act No. 46 of 1959}

Classified black people into eight ethnic groups. Each group had a commissioner-general who was tasked to develop a homeland for each, which would be allowed to govern itself independently without white intervention.

\section{Coloured Persons Communal Reserves Act, Act No. 3 of 1961}

This Act made provision for the reservation by proclamation of land for occupation and ownership by 'Coloured' persons and for land in an area so reserved to vest in the minister in trust for the registered 'Coloured' occupiers.

\section{Preservation of Coloured Areas Act, Act No. 31 of 1961}

This Act made it possible for other groups to be removed from areas declared to be for the occupation of 'Coloureds'.

\section{Urban Bantu Councils Act, Act No. 79 of 1961}

Created black councils in urban areas that were supposed to be tied to the authorities running the related ethnic homeland.

\section{Terrorism Act of 1967}

Allowed for indefinite detention without trial and established BOSS, the Bureau of State Security, which was responsible for the internal security of South Africa.

\section{Bantu Homelands Citizens Act of 1970}

Compelled all black people to become a citizen of the homeland that corresponded to their ethnic group, regardless of whether they had ever lived there or not, and removed their South African citizenship.

Source: http://africanhistory.about.com/library/bl/blsalaws.htm 


\section{Bibliography}

Akzin, Benjamin (1964) State and Nation, London: Hutchinson University Library.

Amery, L.S. (general editor) (1909) The Times History of the War in South Africa 1900-1902, London:

Sampson, Law, Marston.

Anonymous (1902) Picturesque South Africa: An Album of Two Hundred Choice Photographic Engravings

Consisting of Views of Colonial Scenery, Cape Town: Dennis Edwards.

Anonymous (1989) Photographs by Oosthuysen, Hendrik, Afrikanerbakens, Johannesburg: Federasie van

Afrikaanse Kultuurvereniginge (FAK).

Anonymous (1997) William Kentridge, CD-Rom, Johannesburg: David Krut.

Anonymous (1999) Cartographica Magallanica 1523-1945, Ediciones de la Universidad de Magallanes.

Asvat, Farouk (1987) A Celebration of Flames, Johannesburg: Ad. Donker.

Attwell, David (1993) J.M. Coetzee: South Africa and the Politics of Writing, Cape Town and Johannesburg:

David Philip; London and Berkeley, CA: University of California Press.

Barnes, T.J. and Duncan, J.S. (eds) (1992) Writing Worlds: Discourse, Text and Metaphor in the

Representation of Landscape, New York: Routledge.

Barrell, John (1990) 'Eighteenth century Britain', in Pugh, Simon (ed.) Reading Landscape: Country City

Capital, Manchester: Manchester University Press.

Barthes, Roland (1995) Mythologies, New York: Hill and Wang. Translation by Annette Lavers.

Becker, Lutz (1994) 'Aspects of art in the Third Reich', in Hartley, Keith et al. (eds) The Romantic Spirit in

German Art 1790-1990, exhibition catalogue, published by the South Bank Centre, National Galleries

of Scotland and Oktagen Verlag.

Bell, Nigel and Carper-Lewis, Meg (eds) (1992) Literature, Nature and the Land: Ethics and Aesthetics of the Environment, Durban: University of Natal, Multicopy.

Bender, Barbara (ed.) (1993) Landscape: Politics and Perspectives, New York: Berg.

Benjamin, Walter (1999) Charles Baudelaire: A Lyric Poet in the Era of High Capitalism, London and New

York: Verso. First published 1973, New Left Books.

Bermingham, Ann (1986) Landscape and Ideology: The English Rustic Tradition, 1740-1860, London:

Thames and Hudson.

Bermingham, A. and Brewer, J. (eds) (1997) The Consumption of Culture 1600-1800: Image, Object, Text, London: Routledge.

Bethell, E.H. (1904) 'The blockhouse system in the South African War', RE Professional Papers XXX,

pp. 277-294.

Bhabha, H. (1993) The Location of Culture, London: Routledge.

Bhabha, H. (ed.) (2000) Nation and Narration, London: Routledge. First published 1990.

Biko, Steve (1988) I Write What I Like, London: Penguin Books.

Bond, J.J. (1949) The Saga of the Great Trek and Pictorial Record of the Inaugural Celebrations at the

Voortrekker Monument, Johannesburg: Rostra Printers (reprinted from The Star).

Bosman, Herman Charles (1977) Willemsdorp, Cape Town: Human and Rousseau.

Bozzoli, Belinda (ed.) (1979) Labour, Townships and Protest: Studies in the Social History of the

Witwatersrand, Johannesburg: Ravan Press. 
Brattinger, P. (1985) 'Victorians and Africans: the geneology of the myth of the Dark Continent', Critical Inquiry, 12, pp. 166-203.

Bremner, Lindsay (1995) 'Crime and the emerging landscape of post-apartheid Johannesburg', in Judin, Hilton and Vladislavic, Ivan (eds) Blank: Architecture, Apartheid and After, Rotterdam: NAi.

Bremner, Lindsay (2004) Johannesburg: One City Colliding Worlds, Johannesburg: STE.

Brennan, Timothy (2000) 'The national longing for form', in Bhabha, Homi (ed.) Nation and Narration, London: Routledge. First published 1990.

Breytenbach, Breyten (1984) True Confessions of an Albino Terrorist, London: Faber.

Breytenbach, Breyten (1996) The Memory of Birds in Times of Revolution, Cape Town: Human and Rousseau.

British Parliamentary Papers (1884-1885) Vol: LVII pp. 582-671.

British Parliamentary Papers (1901) Report of the Land Settlement Commission Vol. XXIV. 23

Brown, Duncan (1998) Voicing the Text: South African Oral Poetry and Performance, Oxford and Cape Town: Oxford University Press.

Bryant, William Cullen and Bunce, Oliver Bell (eds) (c.1872) Picturesque America, or, The Land We Live in a delineation by pen and pencil of the mountains, rivers, lakes, forests, water-falls, shores, cañons, valleys, cities and other picturesque features of our country, with illustrations on steel and wood by eminent American artists, New York: D. Appleton.

Bunn, David (1994) "“Our wattled cot": mercantile and domestic space in Thomas Pringle's African landscapes', in Mitchell, W.J.T. (ed.) Landscape and Power, Chicago, IL: University of Chicago Press.

Bunn, David (1995) 'Whited sepulchres: on the reluctance of monuments', in Judin, Hilton and Vladislavic, Ivan (eds) Blank: Architecture, Apartheid and After, Rotterdam: NAi.

Bunn, David and Taylor, Jane (eds) (1988) From South Africa: New Writing, Photographs and Art, Chicago, IL: University of Chicago Press.

Burden, Philip D. (1996) The Mapping of North America 1511-1670, Rickmansworth: Raleigh Publications.

Burnett, D. Graham (2000) Masters of All They Surveyed: Exploration, Geography and a British Eldorado, Chicago and London: University of Chicago Press.

Cameron, Dan, Christov-Bakargiev, Carolyn, and Coetzee, J.M. (1999) William Kentridge, London: Phaidon Press.

Cape of Good Hope: Topographic Survey of South Africa (1904) Proceedings of Congress held at Cape Town, Cape Town: 'Cape Times' Ltd, Government Printers. (G.77._-1904.)

Chapman, Michael and Dangor, Achmat (eds) (1982) Voices from Within: Black Poetry from Southern Africa, Johannesburg: Ad. Donker.

Chipkin, Clive (1993) Johannesburg Style: Architecture and Society 1880's-1960's, Cape Town: David Philip.

Citino, Robert (1991) Germany and the Union of South Africa during the Nazi Period, New York and London: Greenwood Press.

Clarke, Kenneth (1963) Landscape into Art, London: J. Murray. First published1949.

Coetzee, A.J. (1976) Poësie en politiek: 'n voorlopige verkenning van betrokkenheid in die Afrikaanse poësie, Johannesburg: Ravan Press.

Coetzee, Ampie and Willemse, Hein (1989) lquabane labantu: Poësie in die noodtoestand: Poetry in the Emergency, Johannesburg and Bramley: Taurus.

Coetzee, J.M. (1988) White Writing: On the Culture of Letters in South Africa, New Haven, CT: Yale University Press.

Coetzee, J.M. (1992) Doubling the Point: Essays and Interviews, Attwell, David (ed.) Cambridge, MA and London: Harvard University Press.

Coetzee, J.M. (1992) 'Into the dark chamber: the writer and the South African State', in Doubling the Point: Essays and Interviews, Attwell, David (ed.) Cambridge, MA and London: Harvard University Press.

Coetzee, J.M. and Brink, André (1986) A Land Apart: A South African Reader, London: Faber and Faber.

Coetzee, N.J. (1992) Pierneef: Land and Landscape - The Johannesburg Station Panels in Context, Johannesburg: CBM.

Cohen, Paul, T. and Augustyn, Robert T. (1997) Manhattan in Maps, New York: Rizzoli.

Comaroff, Jean, and Comaroff, John L. (1988) 'Through the looking glass: colonial encounters of the first kind', Journal of Historical Sociology, 1, pp. 6-32. 
Conrad, Joseph (1995) The Heart of Darkness, Hampson, Robert (ed.) London: Penguin Books.

Coombes, A. (1985) 'For God and England: contributions to the image of Africa in the first decade of the twentieth century', Art History, 8, pp. 453-66.

Coombes, Annie E. (2003) History after Apartheid: Visual Culture and Public Memory in a Democratic South Africa, Durham, NC and London: Duke University Press.

Cosgrove, Denis (1998) Social Formation and Symbolic Landscape, Madison, WI: University of Wisconsin Press.

Cosgrove, Denis (ed.) (1999) Mappings, London: Reaktion.

Cosgrove, Denis, and Daniels, Stephen (eds) (1997) The Iconography of Landscape: Essays on the Symbolic Representation, Design and Use of Past Environments, Cambridge: Cambridge University Press. First published 1988.

Crais, Clifton C. (1991) 'The vacant land: the mythology of British expansion in the Eastern Cape', Journal of Social History, 25(2), pp. 255-275.

Cronin, Jeremy (1989) '“Even under the rine of terror . . .": insurgent South African poetry', Staffrider, 8(2), Johannesburg: Ravan Press.

Crosby, Alfred W. (1986) Ecological Imperialism: The Biological Expansion of Europe 900-1900, Cambridge: Cambridge University Press.

Crown Mines Property Development Project, completed in April 1969 by Roeloef Uitenbogaardt, Anthony Barac, Adele de Souza Santos, Antonio de Souza Santos and John Mayle.

Cubitt, Gerald (1980) The Wild Realms, Cape Town: Don Nelson.

Cumming, William P. (1974) British Maps of Colonial America, Chicago, IL and London: University of Chicago Press.

Curtain, Philip (1964) Image of Africa: British Ideas and Action, Madison, WI: University of Wisconsin Press.

Dangor, Achmat (1983) Bulldozer, Johannesburg: Ravan Press.

Darian-Smith, Kate, Gunner, Liz and Nuttall, Sarah (eds) (1996) Text, Theory, Space: Land, Literature and History in South Africa and Australia, London: Routledge.

Davenport, T.R.H. and Hunt, K.S. (1974) The Right to the Land, Cape Town: David Philip.

Davidson, Basil (1964) The African Past: Chronicles from Antiquity to Modern Times, London: Longman.

De Kok, Ingrid (1988) Familiar Ground, Johannesburg: Ravan Press.

Delmont, Elizabeth (1993) 'The Voortrekker Monument: monolith to myth', South African Historical Journal, 29 (November), pp. 76-101.

Derrida, J. (1982) 'Sending: “On Representation"', Social Research, 49(2).

Dikobe, Modikwe (1983) Dispossessed, Johannesburg: Ravan Press.

du Toit, Andre and Giliomee, Hermann (1983) Afrikaner Political Thought: Analysis and Documents, Cape Town: David Philip.

Edney, Matthew H. (1997) Mapping an Empire: The Geological Construction of British India 1765-1843, Chicago, IL and London: University of Chicago Press.

Elphick, Richard and Giliomee, Hermann (eds) (1979) The Shaping of South African Society: 1652-1840, Cape Town and London: Maskew Miller Longman.

Festenstein, M. and Pickard-Cambridge, C. (1987) Land and Race: South Africa's Group Areas and Land Acts, South African Institute of Race Relations: Johannesburg.

Fletcher, Banister (revised by Cordingley, R.A.) (1963) A History of Architecture on the Comparative Method, London: Athlone Press, University of London.

Gelder, Ken and Jacobs, Jane M. (1998) Uncanny Australia: Sacredness and Identity in a Postcolonial Nation, Carlton, Vic: Melbourne University Press.

Goldblatt, David (1998) The Structure of Things Then, Cape Town: Oxford University Press.

Gombrich, E.H. (1978) Meditations on a Hobby Horse and Other Essays on the Theory of Art, London: Phaidon.

Gordimer, Nadine (1973) The Black Interpreters: Notes on African Writing, Johannesburg: Ravan Press.

Gordimer, Nadine (1974) The Conservationist, London: Jonathan Cape.

Gordimer, Nadine (1984) Burger's Daughter, Penguin Books. First published 1979, Jonathan Cape.

Gott, Richard (1993) Land Without Evil: Utopian Journeys across the South American Watershed, New York and London: Verso. 
Grove, A.P. and Harvey, C.J.D. (eds) (1963) Afrikaans Poems with English Translations, Cape Town and London: Oxford University Press.

Hachten, William A. (1971) Muffled Drums: The News Media in Africa, Ames, IA: lowa State University Press.

Harley, J.B. (1997) 'Maps, knowledge and power', in Cosgrove, D. and Daniels, S. (eds) The Iconography of Landscape: Essays on the Symbolic Representation, Design and Use of Past Environments, Cambridge: Cambridge University Press. First published 1988.

Harmsen, Frieda (1985) Looking at South African Art: A Guide to the Study and Appreciation of Art, Pretoria: Van Schaik.

Harrison, P., Huchsermeyer, M. and Mayekiso, M. (eds) (2003) Confronting Fragmentation: Housing and Urban Development in a Democratising Society, Cape Town: University of Cape Town Press.

Hart, D.M. and Pirie, G.H. (1984) 'The sight and soul of Sophiatown', Geographical Review, 74, pp. 38-47.

Hertzog, J.B.M. (1977) 'n Volk praat met sy leier (A Nation Speaks with its Leader), Hugo, Maria (ed.) Pretoria:

Die Nationale Kultuurhistoriese and Opelug Museum.

Higgs, Barry (1971) 'Castles in the air - the tragedy of residential apartheid', Sechaba, 9 September.

Hobsbawm, E. and Ranger, T. (eds) (1983) The Invention of Tradition, Cambridge: Cambridge University Press.

Hocking, Anthony (1975) South African Farming, Cape Town: Macdonald.

Hofmeyr, Isabel (1993) 'We Spend our Years as a Tale that is Told': Oral Historical Narrative in a South African Chiefdom, Johannesburg: Wits University Press.

Horrell, Muriel (1973) The African Homelands of South Africa, Johannesburg: South African Institute of Race Relations.

Jackson, John Brinckerhoff (Lefkowitz Horowitz ed.) (1997) Landscape in Sight: Looking at America, New Haven, CT and London: Yale University Press.

Jansen, Chris and Small, Adam (1973) Oos Wes Tuis Bes, Cape Town: Human and Rousseau.

Japha, Derek (1995) 'The social programme of the modern movement', in Judin, Hilton and Vladislavic, Ivan (eds) Blank: Architecture, Apartheid and After, Rotterdam: NAi Publishers, pp. 423-437.

Jeppie, S. and Soudien, C. (eds) (1990) The Struggle for District Six: Past and Present, Cape Town: Buchu Books.

Jonker, Ingrid (1968) Selected Poems, London: Jonathan Cape.

Judin, Hilton and Vladislavic, Ivan (eds) (1995) Blank: Architecture, Apartheid and After, Rotterdam: NAi.

Krog, Antjie (1998) Country of my Skull, London: Jonathan Cape.

Kunene, Masizi (1970) Zulu Poems, New York: Africana Publishing Corporation.

Kuper, Leo, Watts, Hilston, and Davies, Ronald (1958) Durban: A Study in Racial Ecology, London: Jonathan Cape.

La Guma, Alex (1986) A Walk in the Night and Other Stories, London: Heinemann Educational Press. First published 1967.

Lodge, Tom (1983) Black Politics in South Africa since 1945, London: Longman.

McClintock, Anne (1995) Imperial Leather, London: Routledge.

Madingoane, Ingoapele (1980) Africa my Beginning, London: Rex Collins.

Malherbe, D.F. (1981) Ongepubliseerde gedigte, Roodepoort, SA: LUM Boeke.

Mamdani, Mahmood (1996) Citizen and Subject: Contemporary Africa and the Legacy of Late Colonialism, Kampala: Fountain; Cape Town: David Philip; London: James Curry. Copyright: Princeton University Press.

Mandela, Nelson (1994) Long Walk to Freedom: The Autobiography of Nelson Mandela, Randburg, SA: Macdonald Purnell.

Marks, Shula and Trapido, Stanley (eds) (1999) The Politics of Race, Class and Nationalism in Twentieth Century South Africa, London and New York: Longman. First published 1987.

Marquand, Jean (1979) 'The farm: a conception in the writings of Olive Schreiner, Pauline Smith, Doris Lessing, Nadine Gordimer and Bessie Head', Dalhousie Review, 59(2).

Marx, Leo (1967) The Machine in the Garden: Technology and the Pastoral Ideal in America, New York: Oxford University Press.

Mattera, Don (1987) Gone with the Twilight: A Story of Sophiatown, London: Zed. 
Mbembe, A. and Nuttall, S. (eds) (2004) 'Johannesburg - the elusive metropolis', Public Culture, 16(3), special issue.

Mda, Zakes (1995) Ways of Dying, Cape Town and London: Oxford University Press.

Miller, A. (1991) 'Transformation of time and space, Oxaca, Mexico 1500-1700', in Kucher, S. and Mehan, W. (eds) Images of Memory, Washington, DC: Smithsonian Institution Press.

Mitchell, W.J.T. (ed.) (1981) On Narrative, Chicago, IL: University of Chicago Press.

Mitchell, W.J.T. (1990) 'Representation', in Lentricchia, F. and McLaughlin, T. (eds) Critical Terms for Literary Study, Chicago, IL: University of Chicago Press.

Mitchell, W.J.T. (ed.) (1994) Landscape and Power, Chicago, IL: University of Chicago Press.

Moodie, T. Dunbar (1975) The Rise of Afrikanerdom: Power, Apartheid and the Afrikaner Civil Religion, Berkeley, CA: University of California Press.

Moodie, T. Dunbar with Ndatshe, V. (1994) Going for Gold: Men, Mines and Migration, London and Berkeley, CA: University of California Press.

Mostert, Noël (1993) Frontiers: The Epic of South Africa's Creation and the Tradgedy of the Xhosa People, London: Pimlico.

Mphahlele, Es'kia (1962) The African Image, London: Faber and Faber.

Mphahlele, Ezekiel and Moffett, Helen (eds) (2002) Seasons Come to Pass: A Poetry Anthology for Southern African Students, Oxford: Oxford University Press.

Mphahlele, Ezekiel, Gardner, Colin, and Chapman, Michael (eds) (1992) Perspectives on South African English Literature, Parklands, SA: Ad Donker.

Mudimbe, V.Y. (1988) The Invention of Africa: Gnosis, Philosophy and the Order of Knowledge, Bloomington, IN: University of Indiana Press.

Murray, Christina and O'Regan, Catherine (eds) (1990) No Place to Rest: Forced Removals and the Law in South Africa, CapeTown: Oxford University Press.

Mzamane, M. (1978) 'Literature and politics among blacks', New Classic, 5, pp. 42-58.

Nakasa, Nathaniel (1975) The World of Nat Nakasa, Patel, Esop (ed.), Johannesburg: Ravan Press.

Nienaber, P.J. (1959) 'The evolution of Afrikaans as a literary language', Lantern (Die Tydskrif vir Kuns en Kultuur), 8(4).

Nienaber, P.J. and Le Roux, C.J.P. (1983) Monumente en Gedenktekens van die Oranje-Vrystaat, Roodepoort, SA: Cum Boeke.

Nkosi, Lewis (1958) 'Sophiatown is a state of mind', Contact, 1(23).

Norval, Aletta J. (1996) Deconstructing Apartheid Discourse, London and New York: Verso.

Norwich, Oscar I. (1983) Maps of Africa: An Illustrated and Annotated Carto-bibliography, Cape Town and Johannesburg: AD Donker.

Nuttall, Sarah and Coetzee, Carli (eds) (1998) Negotiating the Past: The Making of Memory in South Africa, Cape Town: Oxford University Press.

Nuttall, Sarah and Michael, Cheryl-Anne (eds) (2001) Senses of Culture, Cape Town and London: Oxford University Press.

Oberholster, J.J. (1972) The Historical Monuments of South Africa, Cape Town: Rembrandt van Rijn Foundation for Culture.

Olwig, K.R. (1993) 'Sexual cosmology: nation and landscape at the conceptual interstices of nature and culture; or "What does landscape really mean?"', in Bender, Barbara (ed.) Landscape: Politics and Perspectives, New York: Berg.

O'Meara, Dan (1983) Volkskapitalisme: Class, Capital and Ideology in the Development of Afrikaner Nationalism, 1943-48, Cambridge: Cambridge University Press.

O'Meara, Dan (1996) Forty Lost Years: The Apartheid State and the Politics of the National Party, 1948-1994, Randburg, SA: Ravan Press.

Opland, Jeff (ed.) (1992) Words that Circle Words: A Choice of South African Oral Poetry, Parklands, SA: Ad Donker.

Opperman, D.J. (1980) Groot Verseboek, Cape Town: Tafelberg. First published 1952.

Paret, Peter (1988) Art as History: Episodes in the Cultural Politics of Nineteenth Century Germany, Princeton, NJ: Princeton University Press.

Pereira, Ernest and Chapman, Mark (eds) (1989) African Poems of Thomas Pringle, Durban: Killie Campbell Africana Library and Pietermaritzburg: University of Natal Press. 
Petropoulos, Jonathan (2000) The Faustian Bargain: The Art World in Nazi Germany, London: Allen Lane.

Pitkin, H.F. (1967) The Concept of Representation, Berkeley, CA: University of California Press.

Plaatje, Sol (1996) Mhudi, Cape Town: Francolin.

Plaatje, Sol (1996) Native Life in South Africa, Randburg, SA: Ravan Press. First published 1916, P.S. King and Son.

Platzky, Laurine and Walker, Sheryl (1985) The Surplus People Project, Johannesburg: Ravan Press.

Pratt, M.L. (1985) 'Scratches on the face of the country: or what Mr. Barrow saw in the land of the bushmen', Critical Inquiry 12(1), pp. 119-43.

Prendergast, Christopher (2000) The Triangle of Representation, New York: Columbia University Press.

Pretorius, J.C. (ed.) (1988) Op Trek: Die Daaglikse lewe tydens die Groot Trek, Johannesburg: Scripta Afrikana.

Pugh, Simon (1988) Garden, Nature, Language, Manchester: Manchester University Press.

Pugh, Simon, (ed.) (1990) Reading Landscape: Country City Capital, Manchester: Manchester University Press.

Rainey, Sue (1994) Creating Picturesque America: Monument to the Natural and Cultural Landscape, Nashville, TN and London: Vanderbilt University Press.

Randles, W.G.L. (1958) South East Africa and the Empire of Monomatapa as Shown on Selected Printed Maps of the Sixteenth Century, Lisbon: Centro de Estudos Historicos Ultramarinos.

Rassool, Ciraj and Prosalendis, Sandra (eds) (2001) Recalling Community in Cape Town: Creating and Curating the District Six Museum, Cape Town: District Six Museum Foundation.

Rassool, Yousof S. (c.2000) District Six: Lest We Forget, recapturing subjugated histories of Cape Town (1897-1956), Bellville, SA: Harold Herman, Faculty of Education, University of the Western Cape.

Rayston, Robert (ed.) (1974) Black Poets in South Africa, London: Heinemann Educational Publishers.

Rive, Richard (1987) Buckingham Palace District Six, London: Heinemann. First published 1987, Cape Town: David Philip.

Ross, Robert (1993) Beyond the Pale: Essays on the History of Colonial South Africa, Hanover, NH and London: Wesleyan University Press.

Said, Edward (1994) Culture and Imperialism, London: Vintage.

Said, Edward (1995) Orientalism, London: Penguin Books. First published 1978, Routledge and Kegan Paul.

Sampson, Anthony (1956) Drum: A Venture into the New Africa, London: Collins.

Sampson, Anthony (1983) 'The early drum', in Caccia, A., The BEAT of Drum: The Story of a Magazine that Documented the Rise of Africa, as told by Drum's publisher, editors, contributors and photographers, Braamfontein: Ravan Press.

Scafi, Alessandro (1999) 'Mapping Eden: cartographies of the earthly paradise', in Cosgrove, Denis (ed.) Mappings, London: Reaktion.

Schadeberg, Jürgen (ed.) (1987) The Fifties People of South Africa, Johannesburg: Bailey's African Photo Archives Production.

Schama, Simon (1995) Landscape and Memory, New York: Vintage.

Schapera, I. and Comaroff, J.L. (1991) The Tswana, revised edition, London and New York: Kegan Paul International.

Schmidt, Bettina (1996) 'Creating order: culture as politics in nineteenth and twentieth century South Africa', thesis submitted to Catholic University Nijmegen.

Schreiner, Olive (1999) The Story of an African Farm, Johannesburg: Ad. Donker. First published 1883, London: Chapman and Hall.

Serote, Mongane Wally (1974) Tsetlo, Johannesburg: Ad Donker.

Serote, Mongane Wally (2002) Scatter the Ashes and Go, Johannesburg: Ravan Press.

Short, John R. (1991) Imagined Country: Society, Culture and Environment, London: Routledge.

Simone, AbdouMaliq (2004) For the City Yet to Come: Changing African Life in Four Cities, Durham, NC and London: Duke University Press.

Smith, H.N. (1970) Virgin Land: The American West as Symbol and Myth, Cambridge, MA: Harvard University Press.

Soja, Edward (1989) Postmodern Geographies: The Reassertion of Space in Critical Social Theory, London: Verso. 
Strydom, Hans (1982) For Volk and Führer, Johannesburg: Jonathan Ball.

Themba, Can (1972) The Will to Die, Cape Town: David Philip; London: Heinemann.

Thompson, Leonard (1985) The Political Mythology of Apartheid, London and New Haven, CT: Yale University Press.

Titlestad, Michael (UNISA) (2002) 'The acoustics of memory: historiography and alterity in representations of 1950s township jazz', unpublished paper presented to Wiser, University of the Witwatersrand, 27 May.

Tomlinson, Richard (1997) 'Britain's last castles: Masonry blockhouses of the South African War, 1899-1902', Military History Journal, 10(6).

Tooley, R.V. (1963) Essays on Africa: Early Maps and Views of the Cape of Good Hope, London: The Map Collectors Circle, Durrant House.

Tooley, R.V. (1969) Collector's Guide to Maps of the African Continent and South Africa, London: Carta Press.

Vail, Leroy (ed.) (1989) The Creation of Tribalism in South Africa, London: James Curry; Berkeley, CA: University of California Press.

van der Merwe, Werner (1988) 'Herrenvolk-bloed vir die Afrikaner: Veertig Jaar Duitse weeskinders 1948-1988' (Aryan blood for the Afrikaner: forty years of German orphans), Historia, 33(2).

van der Westhuysen, H.M. (1929) 'Pierneef, Die Afrikaanse Landskapskilder', in van Den Heever, C.M. (ed.) Tydskrif vir Letterkunde, including 'Die Nuwe Brandwag', Johannesburg: Die Afrikaanse Skrywerskring.

van Jaarsveld, Floris Albertus (1963) Die Beeld van die Groot Trek in die Suid-Afrikaanse geskiedskrywing (The Image of the Great Trek in South Africa's Historiography), Pretoria: University of South Africa.

van Niekerk, Marlene (1994) Triomf (translated from Afrikaans to English by Leon de Kock 1999), Cape Town and Johannesburg: Queillerie and Jonathan Ball.

van Wyk Louw, N.P. (1947) Die Dieper Reg: 'n Spel van die Oordeel van 'n Volk, Cape Town, Bloemfontein and Port Elizabeth: Nasionale Pers.

van Wyk Louw, N.P. (1981) Vesamelde gedigte (1906-1970), Cape Town: Human and Rousseau.

Vaughan, William (1980) German Romantic Painting, London and New Haven, CT: Yale University Press.

Vilakazi, Benedict (1935) Inkondlo Kazulu (Zulu Poems), Johannesburg: University of Witwatersrand Press.

Vilakazi, Benedict (1945) Amal'ezulu, Johannesburg: University of the Witwatersrand Press.

Watkin, David and Mellinghof, Tilman (1987) German Architecture and the Classical Ideal, Cambridge, MA: MIT Press.

Wesseling, H.L. (1996) Divide and Rule: The Partition of Africa 1880-1914, London: Praeger.

Williams, George H. (1962) Wilderness and Paradise in Christian Thought, New York: Harper and Row.

Williams, Raymond (1972) 'Ideas of nature', in Bentall, J. (ed.) Ecology: The Shaping Enquiry, London: Longman.

Williams, Raymond (1988) Keywords: A Vocabulary of Culture and Society, London: Fontana. First published 1976.

Yako, St. J. Page (1958?) Umtha Welanga, Johannesburg: APB.

Yako, St. J. Page (1959) Ikhwezi, Lovedale, SA: Lovedale Press.

Young, R. (1990) White Mythologies: Writing History and the West, New York and London: Routledge. 


\section{Archives and other}

\section{sources}

\section{Bailey's African History Archive}

Anonymous (1953) 'Snatch! The workings of the (Group Areas) Act', Drum, October, pp. 43-45.

Anonymous (1954) 'Crisis over western areas', Drum, August, pp. 11-13.

Anonymous (1957) 'The writing on the wall', Drum, June, p. 44.

Anonymous (1957) 'Big shots fight for their home', Drum, December, pp. 76-81 (Figure 13.15).

Anonymous (1958) 'Weenen: the place of weeping', Drum, March, pp. 63-67.

Anonymous (1962) 'Black spots', Drum, November, pp. 63-65 (Figure 9.5).

Barton, Frank (1963) 'Transkei - the frightened land', Drum, June, pp. 21-25.

Breytenbach, Cloete (1963) 'District Six - the razzle-dazzle, good-bad land', Drum, June, pp. 15-19 (Figure

13.3).

Collection of unnumbered and undated photographs, uncatalogued (Figures 7.1, 7.2, 13.1, 14.1).

Dyanti, Benson (1959) 'Last days of Sophiatown', Drum, November, pp. 43-45.

Dyanti, Benson and photographer Magubane, Peter (1960) 'Trouble in the Bantustans', Drum, September,

pp. 21-27.

Jeffreys, M.K. (1961) 'Who got here first? Black man or white?', Drum, June, pp. 61-65.

Matthews, Z.K. and Tomlinson, F.R. (1956) 'Back to the desert', Drum, September, pp. 31-33 (Figure

Modisane, William 'Bloke' (1956) 'A "native" boy by mistake', Drum, July, pp. 51-55.

Musi, Obed (1964) 'Will we forever "Hamba"?', Drum, September, pp. 45-49.

Naidoo, G.R. (1958) 'Weenen again', Drum, June, pp. 24-29 (Figure 9.3).

Nakasa, Nathaniel (1962) 'The move out to nowhere', Drum, May, pp. 61-67.

Themba, Can (story) and Naransamy, Gopal S. (photographs) (1956) 'Baby Come Duze', Drum, April, pp. 61-64 (Figures 10.2, 10.3, 10.4).

Themba, Can (1956) 'Banned to the Bush', Drum, August, pp. 22-25.

Xuma, A.B. (1952) 'Black spots or white spots?', Drum, March, pp. 25-28 (Figure 10.1).

\section{Bloemfontein State Archive}

\section{Pamphlets}

Die Afrikaanse Taalmonument, Johannesburg: Printed by T.W. Hayne, Bpk, Johannesburg. Ref: 761.76 AFR, Type: Pamphlet.

Die Afrikaanse Taalmonument. Premiere van: Die Pêrel van Paarl. Film: 20 May 1954. Gedenk en geskenk deur die Paarlse Drukpers Maatskappy. Ref: 839 AFR, Type: Pamphlet.

New Perspectives on the Great Trek, 'Afrikaner perspective: Simbool en Ritueel' and 'English alliance with the Voortrekkers'. Ref: Jaargang 33, November 1988 No. 2, Type: Magazine Historia. 


\section{Cape State Archives}

\section{Accession papers}

Naude, H. (donor) (1938-1940), Publications re Voortrekker Centenary and Monuments. Map of monument site. Commemorative issue of the Volksblad. 1 vol. Donated 1968. Ref: A1640, Type: Accession. Including:

Die Voortrek (13 December 1949) Special supplement to Die Transvaler (Figures 2.2, 2.8, 4.2).

Pauw, S. (13 December 1949) 'Die Tweede Trek', newspaper article published in Die Voortrek.

The Voortrekker Monument, Pretoria: Official Guide (seventh edition, no date) Pretoria: Compiled and published by the Board of Control of the Voortrekker Monument.

Boshoff, B.D.T. (seventh edition, no date) 'To the visitor', in The Voortrekker Monument, Pretoria: Official Guide.

Pictorial Record of the Inaugural celebrations at the Voortrekker Monument (December 1949) Reprinted from The Star newspaper, Johannesburg: Rostra Printers.

Preller, Gustav (30 November 1938) 'Die Boer as Krygsman', article in a supplement to the newspaper Volksblad (Figure 2.1).

'Monument Uitgawe', Die Huisgenoot (25 November 1949) Cape Town: Nasionale Pers, Bpk (Figures $2.3,3.11,10.5)$.

Uniewinkels, Voortrekkereeufees Aandenkings, Pretoria (Advertisement for Voortrekker Centenary Memorabilia) (Figure 2.12).

Steyler, F.A. and Meintjies, J. (January 1950 and January 1951) Research Done into the Routes of the Great Trek $24 \mathrm{f} 1 \mathrm{vol}$. Routes of the Great Trek in the Cape Province. Map and report. Ref: A658, Type: Accession (Plate 2.3).

Voortrekker Monument Inauguration Programmes (1949) $75 f 1$ vol. Ref: A1235, Type: Accession. Including:

Moerdyk, Gerard (1949) 'The Voortrekker Monument: meaning and symbolism', in The Voortrekker Monument Inauguration Programme, Souvenir pamphlet, Pretoria: Voortrekker Board of Control (Figure 3.12).

Jansen, Dr E.G. (1949) 'The centenary and laying of the foundation stone', in The Voortrekker Monument Inauguration Programme.

\section{Government papers}

Group Areas (1974-1978) includes plan proposals for District Six. Department of Community Development. Source: CDC, Vol: 529, Ref: 3.

Group Areas. Matatiele (1953-1958) Department of Native Affairs. Source: CMT, Vol: 3/1563, Ref: Plan and General Information to Public.

Group Areas. Matatiele (1962-1964) Department of Native Affairs. Source: CMT, Vol: 3/1563, Ref: 67.

Land Matters. White Spots. Matatiele (1956). Black Islands (1953-1956). Department of Native Affairs.

Source: CMT, Vol: 3/1634, Ref: 106/10/4.

Native politics and unrest, removals in the Transkei, Confidential files. Source: 1/FSF, Vol: 6/97, Ref: C3/4.

Native unrest and removals, Confidential files (1932-1963) Removals from the Transkei on chief's request.

Source: 1/EDL, Vol: 6/1/35, Ref: C4.

Plans for District Six (1965-1974) Source: CDC, Vol: 647, Ref: 4/10/2/1 (Plate 13.3).

Removal of natives from European Areas: Black Spots in the Matatiele District (1944-1953) Source: CMT, Vol: 3/1642, Ref: C7/5.

South African Native Trust. Removal of black spots in the Matatiele Land District (1948) Source: 1/UKL, Vol: 21, Ref: 2/32/3/3.

Urban and Peri Urban removals (1963-1969) Source: 2/KMN, Vol: 55, Ref: N9/1/3. 


\section{Archives and other sources}

Maps

A draught of Cape Bonne Esperance (c. 1700) by Sam Thorton at the Sign of England, Scotland and Ireland in the Minories, London. Ref: M1/3216.

Bloedrivier Kaart van roetes van die Boerekommando's (1838-1840) (1957) Bloemfontein: Opgestel en uitgemeet deur Prof. C.J. Uys, drawn by P.J. Swanepoel. Ref: M2/2212.

Cape Town showing Woodstock, Constantia and a description of the main buildings (1899, revised by Colonel Morris, 10 February 1900), marked: War Department purposes only. Heliozincographed. Ref: $\mathrm{M} 1 / 2117$ and $\mathrm{M} 1 / 2118$.

Cape Town, Table Bay, Table Mountain and environs (1653-1655). Ref: M1/1235.

Company's Garden. Plan showing fort and house of Gardner Hendrik Boom (1654). Ref: MI 2/150 (Figure 4.1).

District of Matatiele (1892) Surveyor General. Ref: M2/194-9.

Drawing of Cape Town: To General Sir Arthur Clark, Commander in charge of the landforces, with description of land features (1795, published September 1801), London: Rich Reeve, Bond Street. Drawn by Capt. Dillon. Ref: M1/3278.

Geological Survey of Matatiele area showing horizontal section of landscape (surveyed 1911-1914) Department of Mines and Industries. Drawn in Geological Survey Office. Eric H. Banks Cartographer. Ref: M2/308.

Grond Tekening van die vestig en stadt der Kaap de Goede Hoop (1749). Ref: M1/336.

Map of Bechuanaland Protectorate showing boundaries of Native reserves of Chiefs Khama, Sekgome, Sebele, Bathoen and Linghwe (1899) Cape Town: W.A. Richards and Sons. Government Printers. Ref: M3/457.

Map of District of Matatiele showing farms with grant numbers etc. on which are indicated 1904 claims particulars (1902) C. Neumann Thomas. Ref: M3/2139, Type: Map.

Map of the central part of Cape Town showing the Company's Gardens, New Hospital, new barracks and land granted with the names of owners given (1795). Ref: MI 1/29.

Map of the route of the Great Trek from Thaba ' Nchu to the Drakensberg: April to October 1837 (c.1950) Ref: M2/2208.

Map of the settlement at the Cape (1656). Ref: M1/26.

Map of the settlement at the Cape (1656). Ref: M2/17.

Map of the Transkei showing Districts of Matatiele and Mount Frere (1902). Ref: M4/1330.

Map showing crown land reserved or otherwise set apart for native occupation, native reserves or Mission Stations held under title, and mentioned in the scheduled Native Areas Act as per Act 27 of 1913, situated in the fiscal divisions of Griqualand West and Bechuanaland, Surveyor Generals Office. Ref: $\mathrm{M} 4 / 330$

Map showing territories claimed by Khama, Sechele and Gastitsiwe (1885) Charles Warren, Print 12/6/85 Covent Garden Printers. Ref: M1/3349.

Plan of Company's Gardens showing ground plan of company house and location of buildings and canals (1777). Ref: MI 1/21 and 2/145.

Plan of Government Garden (1844). Ref: M1/3569.

Plan of territory over which Khama, Chief of the Bamangwato claims jurisdiction (1878) Public Record Office, signed: Patterson. Ref: M1/2543

Plan of the Kitchens and quarters for servants and slaves of the Government in the Company's Gardens (1790) L.M. Thibault. Ref: M1/990

Sketch map showing where The Vow was taken, Blood River (c.1950). Ref: M2/2211.

Sketch plan of Government Gardens in two parts (1856) Public Record Office. Ref: M1/2594 and M1/2595 Street plan of Cape Town showing Company's Gardens, parade, squares, etc. (1790-1791). Ref: MI 1/5. Table Bay, fort and settlement. Mountains and rivers and False Bay shown (1656). Ref: M1/15.

Table Bay, settlement, Table Mountain, False Bay (1656). Ref: M1/14

Table Bay, mountains, roads, rivers and settlement shown, land grants to freeburghers and names of owners shown (1660). Ref: M1/16, 808. 


\section{Pamphlets}

Cape Countryside: South Africa (no date c. 1950) South African Tourist Corporation, printed by order of the Government of the Union of South Africa. Designed and published by the South African Tourist Corporation, Pretoria. Source: Library, Vol: BP88, Ref: 8, Type: Pamphlet.

Johannesburg: A Sunshine City Built on Gold (1931) Johannesburg Publicity Association and the South African Railways and Harbours Administration. Source: Library, Ref: 968.2 JOH/P, Type: Pamphlet.

South Africa's Eastern Cape: Land of the Red Blanket People (no date c. 1950) South African Tourist Corporation, printed by order of the Government of the Union of South Africa. Designed and published by the South African Tourist Corporation, Pretoria. Source: Library, Vol: BP89, Ref: 1, Type: Pamphlet (Figures 5.6, 5.7).

South African Tourist Corporation: Guardians of South Africa's Cultural Heritage (c. 1950) printed by order of the Government of the Union of South Africa. Designed and published by the South African Tourist Corporation, Pretoria. Source: Library, Vol: BP90, Ref: 11, Type: Pamphlet.

The Truth about the Bechuanas. Ref: JP173, Vol: 5, Type: Pamphlet.

\section{Photographs}

Anton van Wouw bronze sculpture at the Voortrekker Monument, 1949(?), J1840 (Figure 3.3).

Bloodriver Monument. Voortrekker Wagon with Cape Dutch farmstead. Utrecht district, Natal. Ref: AG9155. Boy on a donkey in Matatiele District. Ref: AG 6214.

Castle Bridge and District Six, Cape Town (1974). Ref: CA 1151 (Figure 13.13).

District Six from the City (1978). Ref: CA 3030 (Figure 13.14).

Governor's House, now Tuinhuis, Public Gardens, Cape Town. Ref: 16076.

Governor's House, now Tuinhuis, Public Gardens, Cape Town. Ref: 8150.

Kraals of Tribal Chiefs. Ref: AG 662 and 663 (Figure 9.1).

Ox wagons in convoy. Christmas card (1938). Ref: J6532.

Picture from a South African Christmas card: ox wagon crossing a stream. South African Railways and Harbours. Ref: J6490.

Picture from a South African Christmas card: view of Camps Bay. South African Railways and Harbours. Ref: J6499.

View from gallery seeing rays of setting sun hitting sarcophagus, 12 o'clock, 16 December 1949, Voortrekker Monument, Pretoria. Ref: J1848.

View of District Six and Devil's Peak from Sir Lowry Road, Cape Town (1976). Ref: CA 2657.

Voortrekker Monument, Montagu (1977). Ref: CA2956-8.

Voortrekker Monument, Pretoria. Photo album of inauguration from Die Transvaler, 16 December 1949. Ref: J1823 (Figure 3.1).

Voortrekker Monument, Pretoria. Ref: AG7796.

Christmas cards. Ref: J6457-6488 (Figures 5.3, 5.4, 5.5).

\section{Heemkring/Paarl Archives}

Collection of unumbered and undated photographs of the architectural model of the Taal Monument. Uncatalogued (Figure 8.3).

Collection of unumbered and undated photographs of the construction and completion of the Taal Monument. Uncatalogued (Figure 8.1)

Photocopied article of 'Dié Monument Enig in Sy Soort!', from Tegniek, (1975). Uncatalogued.

Taal Monument: Souvenir Brochure (1975). Uncatalogued. 


\section{Johannesburg Public Library}

\section{Legislation}

Group Areas Act, Act No. 41 of 1950.

Native Trust and Land, Act No. 18 of 1936.

Natives Land, Act No. 27 of 1913.

\section{Maps}

Bartholomew's Tourist Map of South Africa Bartholomew (1900) Edinburgh: John \& Co., Edinburgh Geographical Institute, 1:250,000. Ref: Pam 912.68 BAR, Type: Pamphlet.

Black Homelands Consolidation Proposals (1975) Africa Institute of South Africa. Source: Department of Bantu Administration and Development, Pretoria. Ref: Stack Maps 87 (Plate 7.2).

Briton or Boer: Special Map of the South West Cape Colony, fourth edition (March 1900), Johannesburg: Wood and Ortlepp. Ref: Pam 912.68 WOO.

City of Cape Town and Environs, two sheets of four (1930) Cape Town: Drawn in Office of Surveyor General, Cape Times Ltd. Ref: Stack Maps 193.

General Information Map: South Africa and the Developing States (1987) Johannesburg and Cape Town: Map Studio, 1:1,750,000. Ref: Maps 60 (Plate 7.4).

Geological Map of the Republics of South Africa, Transkei, Bophuthatswana, Venda and Ciskei (1984) Pretoria: Government Printer, 1:1,000,000. Ref: Stack Maps 311556.8 SOU (Plate 10.1).

Geological Survey - Sheet 52 Johannesburg (no date, early twentieth century) Union of South Africa: Department of Mines and Industries. Ref: Stack Maps 482 (Plate 10.2).

Map of the Union of South Africa (1944) Cape Town: Surveyor General. Ref: RM 65.

Map of the Witwatersrand Goldfields (1927?) Johannesburg: Holmen Brothers, Rand Litho. Published by the SA Mining Journal Syndicate for the South African Mining and Engineering Yearbook. Ref: Stack Maps 34 (Figure 10.7).

Map Your Holiday in South Africa (c.1950) South African Tourist Corporation. Designed and published by the South African Tourist Corporation by order of the Government of the Union of South Africa, 50 miles to half an inch. Ref: Pam 912.68.SOU, Type: Pamphlet (Plate 5.3).

Military maps of the Transvaal and Orange Free State (1899) South Hampton Ordnance Survey Office: Lichtenburg Military Map. Great Britain War Office. Intelligence Division, 1367. Ref: Stack Maps 223.

Our Heritage: South Africa (1967) Knorr Soups, no scale. 'Knorr Soups have produced this pictorial map to show some of the highlights of early South Africa'. Brown, Davis and Platt. Ref: Stack Maps 87 (Plate 2.5).

Philips Pictorial Maps: Union of South Africa (1958) London: George Philip and Son. Based on original drawings by Macdonald Gill. Ref: Stack Maps 88.

Pictorial Map of the Transvaal (c.1950s) Johannesburg: Art Maps Pty Ltd. Ref: Pam 912.682 ART, Type: Pamphlet.

Population Distribution Map of the Union of South Africa (1951, Printed 1954) from 1946 census data, revised to contain data from the 1951 census. Research by Government Department and Universities, two sheets. Pretoria: Compiled and drawn in the Office of the Director of Irrigation. Pretoria: Government Printer, 1:1,500,000. Ref: Stack Maps 87 (Plate 5.2).

Population Map (1946, published 1950) Union of South Africa, Pretoria: Government Printer. Ref: Stack Maps 220 (Plate 5.1).

Public Transport Services: Map of Routes (no date, pre-1940) City of Johannesburg. Ref: PAM 912.6822 Joh. School Map series. Republic of South Africa: Political and Communications (1976) Johannesburg: Map Centre, 1:2,500,000. Government Printers Copyright Authority. Ref: Stack Maps 220 (Plate 7.1).

Sources of Native Mine Labour: Map of Southern Africa showing the recruiting systems of the Native Recruiting Corporation and the Witwatersrand Native Labour Association (1946) Johannesburg: Transvaal and Orange Free State Chamber of Mines, drawn A.D. Stead. Ref: Stack Maps 87 (Figures $5.1,5.2)$. 
South Africa: Map of our World in One Country (late 1980s) South African Tourism Board, 1:250,000. Johannesburg: compiled and produced by Map Studio. Ref: Maps 60 (Plate 7.3).

The Homelands of the Republic of South Africa (1976) no place, no publisher, $15 \mathrm{~cm}=150 \mathrm{~km}$. Benbo. Ref: Stack Maps 88.

The Story of South Africa (1968) map produced as a supplement to Personality magazine as 'New Atlas for Southern Africa', Bloemfontein: Nationale Pers Bpk, from Johannesburg Public Library, Ref: Stack Maps 26 (Plate 2.4).

Tourist Map of South Africa (c.1960s) printed in the Netherlands: South African Tourist Corporation. Designed and drawn in SA by Bernard Sargent. Pretoria: Department of Tourism. Ref: Pam 912.68.SOU, Type: Pamphlet

Veld types of South Africa (1951-1953) Botanical Survey Memoir no. 28, Union of South Africa, Pretoria: Government Printer, from the Johannesburg Public Library, Stack Maps 88 (Plate 1.1).

Witwatersrand and Balfour Basins - showing the relative positions of the Main reef series, the Van Ryn reef series, the Nigel reef, the Tatham reef and the Government or Molyneux reef (1921) Author: W.E. Bleloch. Transvaal Bank Building Fox Street, Johannesburg and London Waal Building, London. Ref: Stack Maps 174 (Figure 10.6).

\section{Newspapers}

Die Transvaler, 8 May 1959, Map of industrial areas related to the Bantustans (Figure 7.4).

Rand Daily Mail, 13 March 1959, Map of Bantustan policy (Figure 7.3).

The Sowetan, 17,18 and 19 June 1986, including cartoon Thursday 19 June p. 6 (Figure 12.2).

The Star, 20 July 1962, 'View that Few are Ever Able to See: Attraction of a Bantustan' (Figure 9.6).

The Star, 18 June 1986, front page (Figure 12.3).

Sunday Star, 22 June 1986, p. 13.

Weekly Mail, 20-26 June 1986 (Figures 12.4, 12.5).

\section{Land Survey and Mapping Office}

Aerial photograph of Cape Town (1958), Job no. 424, Flight path 5: photo 7060 (Figure 13.8).

Aerial photograph of Cape Town (1968), Job no. 258, Flight path 8: photo 620 (Figure 13.9).

Aerial photograph of Cape Town (1977), Job no. 786, Flight path 19: photo 1438 (Figure 13.10).

Aerial photograph of Cape Town (1989), Job no. 929, Flight path 5: photo 1640 (Figure 13.7).

Aerial photograph of Johannesburg, contact sheets from original negatives (1984 and 1985) original at 1:150,000, Job no. 881, Flight path 4: photos 366 and 372, Flight path 5: photos 3055 and 3064 (Figure 12.1).

Aerial photograph of Johannesburg, contact sheets from original negatives (1969), Job no. 273, Flight path

2: photos 7484 and 7486, Flight path 3: photos 7508 and 7510 (Figure 13.6).

Aerial photograph of Johannesburg, contact sheets from original negatives (1961), Job no. 438, Flight path

13: photo 2793, Flight path 14: photos 4437 and 4435 (Figure 13.5).

Aerial photograph of Johannesburg, contact sheets from original negatives (1937), Job no. 123 37, photos 02372 and 02375 (Figure 13.4).

Aerial photograph of Matatiele (1952-1953), Job no, 220, Strip 15/40839 (Figure 6.1).

Aerial photograph of Meadowlands in Soweto (1984), Job no. 881, Strip no. 4, photo 372 (Figure 12.1).

Cape Town 1:50,000 Map Series (sixth edition 1995) assembled sheets: 3318 CD, 3318 DC and 3418 BA (Figure 13.2).

Cape Town City Centre (third edition 1992), Orthophoto Map Series 1:10,000, detail of Sheet 3318 Cd 14 and 19.

Detail of Matatiele region from the 1:50,000 Map Series. Sheet 3028 BD Matatiele (Plate 6.4).

Johannesburg/Soweto, 1:50,000 Map Series (fifth edition 1995), Sheet 2627 BB Roodepoort (Plate 13.1).

Matatiele and the Scheduled and Released Areas under the Land Acts, Topocadastral series, Sheet 35 ,

Matatiele, 1:250,000. (Plates 6.2, 6.3). 


\section{National Film, Video and Sound Archive}

'n Nasie Hou Koers, 16 reels. Ref: FA 1728.

African Mirror (1938) (reference to the marriage of 37 young couples during the Voortrekker celebrations). Ref: 1337.

Bou van 'n Nasie (1938) Joseph Albrecht (director) feature length film. Ref: FA 1800.

Centenary of the Great Trek (1937) South African Broadcasting Corporation. Ref: FA 1887.

De Voortrekkers of De Winde van 'n nuwe Wêreld (1916) Gustav Preller directed by Harold Shaw, African Film Productions. Ref: FA73/FA74.

Doodkry is Min (1961) Jamie Uys (director). No ref.

Op die pad van Suid Afrika (1968) Ons nuus no. 900. Killarney: SAUK Production. Ref: FA 1727.

The Colour Line (1970) BBC. Ref: FA 1813.

\section{National Library of South Africa}

\section{Albums}

Imperial Yeomanry Hospital Album. Blockhouses, Anglo-Boer War. Blockhouses for guarding railway line, Cape Town: G. Struik. T (1901?). Ref: Album 42 (2900).

Army Services Corp Album (1899-1902) South African War: Blockhouse - corrugated iron blockhouse sited on bare plain surrounded by earth mound and several wire fences, apparently garrisoned by kilted soldiers, black youth on donkey in foreground. Army. Ref: Album 138 (13987), Type: Photo 14071 and 2. Including: Anonymous (1902) '“The Future" as viewed by "Land and Volk"', Cape Times, 3 October. Wallis, A.E. (1927) Southern African Tour Album: Reef looking west, Johannesburg. Panoramic view with mine dumps, England. Ref: Album 39 (2319) (Figure 11.3).

\section{Manuscript}

Voortrekkers: Album with felt flags etc. (1938-1949) Ref: MSB 752, Type: Manuscript (Figures 3.4, 3.5, 3.6).

\section{Maps}

Platte Grondt van die vermaarde tuyn van die Ed. Oostiind. Comp. Aan kaap de Goede Hoop. Peter Kolb (1675-1726). Ref: KCA CT 1727.

Map of the Fort of Good Hope and Company Garden and any Public and Particular Buildings around it (1693), author (probably) Dane Hendrik Oldenland who served as Company Surveyor between 1691 and 1696 (Plate 4.1).

Sketch plan of the territory over which Khama, Chief of the Bamangwato claims jurisdiction, Bamangwato territory (1878). Despatch no. 23 of 14.9. C.O. 48/486 5/P86. Ref: 3/2704.

\section{Photograph}

Johannesburg, from south with Wemmer's Mine work in foreground (1890?) Ref: PHX (6893). (Fig 11.1).

\section{Pretoria State Archives}

\section{Government papers}

Bantu Administration and Development. Native Affairs, Removals under Admin. Order (1953-1970). Source: KHK, Vol: 2/2/84, Ref: N1/16/5.

Black Spots in Ladysmith and Dundee. Source: BAO, Vol: 1423/307, Ref: 2607 (Plate 6.1).

Definition of Group in Terms of Section 2 of the Group Areas Act, 1950. Source: URU, Vol: 2848, Ref: 681. 
Expropriation of Farms, Natal (1938-1960). Bergville: Black Spots in White Areas (1955-1961). Source:

NTS, Vol: 3286, Ref: 1423/307 and 1423/307 (2).

Group Areas Act of 1950. Definitions and Interpretations (1950-1957). Source: ARG, Vol: 14, Ref: Act 1/1/6/5.

Group Areas Act, 1950. Urban Areas: Policy Matters etc. (1954-1960). Source: NTS, Vol: 4565, Ref: 1076/313.

Group Areas Act, General (1950-1952). Source: GBR, Vol: 100, Ref: SCB555.

Group Areas Act, Reference and Planning. Racial Zoning Witwatersrand. (1952-1961). Source: NTS, Vol: 4610, Ref: 934/313(3).

Group Areas Act, Reference and Planning. Racial Zoning Witwatersrand (1952-1961). Source: NTS, Vol: 4615, Ref: 934/313(1).

Native Affairs, Native Land Act (1913). Source: NA, Vol: 313, Ref: 826/1913/F814.

Oprigting van 40 wonings te Sophiatown, Martindale (1963-1969). Source: GEM, Vol: 1232, Ref: SM1 (Figures 13.13, 13.14).

Photographs for the new publication, 'The African Drum' (1951). Source: NTS, Vol: 9706, Ref: 758/400(1).

Sophiatown - Development Proposals. Group Areas, Ontwikkelingsgrond, Hervesting (1960-1963). Source: GEM, Vol: 195, Ref: G14/3/139/1.

\section{Pamphlets}

Bantu Outside their Homelands (1972) Yearbook of the South African Bureau of Racial Affairs, Vol: P699, Ref: 17, Type: Pamphlet.

'Changing Black perspectives in the Great Trek' (21-22 January 1988) Paper given at the South African Historical Association, University of Pretoria. Vol: P744, Ref: Part 16, Type: Pamphlet.

Johannesburg Station Panels by Pierneef, Johannesburg Art Gallery Publication. Source: Library, Vol: P717, Part: 8 (Plate 2.1, Figure 2.5).

Official IInauguration Programme of the Voortrekker Monument, Pretoria (13-16 December 1949). Vol: P41, Ref: 7305, Type: Pamphlet.

Page, D. (1966) The Urbanisation of the Bantu Homelands of the Transvaal. Vol: P621, Ref: 0, Type: Pamphlet.

South African Railways and Harbours - special bulletin no. 135, 1929. Source: Library, Vol: P203, Ref: 6640.

van Den Heever, C.M. (ed.) Aan ons vriend bevattende die Nuwe Brandwag. Source: Library, Vol: P383.

van Den Heever, C.M. (ed.) (1929) Die Nuwe Brandwag, Johannesburg: Die Afrikaanse Skrywerskring, Source: Library, Vol: P383 (Figure 2.6).

Van Onselen, I.P. (1972) 'Bantu outside their Homelands', opening address at the Sabra conference, published in Bantu Outside their Homelands, Yearbook of the South African Bureau of Racial Affairs, Pretoria: Sabra.

\section{Photographs}

Die Afrikaanse Taal Monument (1975). Ref: 16250.

Die Taalmonument met die Paarlvallei op die agtergrond (1980). Donor: Bureau for Information. Ref: 15894 (Figure 8.2).

District Six (late 1950s). Donor: Cape Archives. Ref: 19732.

Entrance to the Taal Monument (1975). Donor: Department of Information. Ref: 18688.

Photograph of early Johannesburg from Doornfontein Hill (c.1900). Ref: 16248 (Figure 11.2).

Postage Stamp by Pierneef. Loaned by G. Preller. Ref: 30183.

Roger Street, District Six (late 1950s). Donor: Bureau for Information. Ref: 19731 (Figure 13.2).

Scenes from the film of the Great Trek. Ref: 19321-5. 


\section{Taal Museum Archives}

'Taalfeesalbum', Die Huisgenoot (August 1975), Die Geskiedenis van ons land in die Taal van ons volk, Reprinting of the GRA, Cape Town: Nationale Pers. Not catalogued.

Collection of correspondence between Jan van Wijk (architect) and Taal Committee with regard to the construction and meaning of the Taal Monument. Not catalogued.

Laminated prints of the drawings for the Taal Monument - donated by Jan van Wijk. Not catalogued.

\section{University of Cape Town}

\section{Historical Documents Archive}

District Six Community Papers, 1978-85 (donated January 1986). Includes maps, photographs, pamphlets and press cuttings. Donated by Father Basil van Rensburg, Holy Cross Church, Woodstock. Ref: BC847, Type: Manuscript.

Western Cape Oral History Project. Interviews with elderly members of District Six, 1980s and 1990s. Ref: BC1004, Type: Manuscript.

\section{University of South Africa}

\section{Accession}

Department of Information pamphlet on the Transkei: The Indian Question, 1947-1967. SABC pamphlets on Bantu Homelands and Urban Bantu. Ref: AAS29.

Map of SA: A Land Divided Against Itself. Black Sash. Ref: AAS155.

United Party Archives on Apartheid (1951-1975), Newspaper clippings: ANC, Homelands, Defiance etc. Ref: AAS77. Including: City Reporter (not identified), 'Van Riebeeck's arrival is impressively commemorated', newspaper article in Die Burger, 8 April 1951.

\section{University of the Witwatersrand}

\section{Accession}

Unknown author (12 December 1936) 'Some consequences of the Great Trek', Argus Group. Ref: A998f, Type: Manuscript.

Church of the Province of South Africa. District Six. Re Zoning of District Six, four boxes. Ref: AB 1809, Type: Manuscript.

South African Institute of Race Relations. One box. Press clippings and correspondence on unrest, banishment and removals. Correspondence with Department of Justice and Native Affairs. Ref: AD1646, Type: Manuscript.

Voortrekker Centenary 1939. Photograph album commemorating the Great Trek. Ref: A1307, Type: Manuscript (Figures 2.10, 2.11, 9.2).

\section{Maps}

Die Pad van Suid-Afrika (The road of South Africa) (16 December 1938) No place: Vacuum Oliemaatskappy van Suid Africa Bpk and Nasionale Pers Bpk. Ref: Map 236/67 (Plate 2.2).

Possible consolidation of the Bantu Areas. Map of South Africa based on Map 63 of the Tomlinson Report. Map 1 (c.1955) Johannesburg: Issued by the United Party Division of Information and Research, printed by Natal Press. Ref: Map 277/67.

Possible consolidation of the Bantu Areas. Map of South Africa based on Map 63 of the Tomlinson Report. Map 2. Map showing protectorates (c.1955) Johannesburg: Issued by the United Party Division of Information and Research, printed by Natal Press. Ref: Map 277/67. 
South Africa and the Great Trek (1652-1854) (c.1938) Shell Maatskappy van Suid Afrika Bpk. Ref: Map 409/67.

\section{Theses}

Griesel, Christina Johanna (1939) 'Die Invloed van die Lansaard in die Afrikaanse Roman na 1920', unpublished MA thesis, Johannesburg: University of the Witwatersrand. Ref: PT 6570 GRI.

Harmsen, Frieda (1958) 'The South African landscape in painting and literature', unpublished MA thesis, Johannesburg: University of the Witwatersrand. Ref: ND 1367.S7 HAR.

Lammas, Rebecca Caroline (1993) 'Portraits of place: images of southern Africa in landscape painting', unpublished MA thesis, Johannesburg: University of the Witwatersrand. Ref: ND 1367.S7 LAM.

Malesela, Lebelo S. (1988) 'Sophiatown, removals, relocation and political quiescence in the Rand Townships: 1950-1965', honours thesis. Ref: DT 764.B2 Leb.

\section{Unpublished papers submitted to the History Workshop}

Delius, P. (1987) 'The Ndundza Ndebele: The experience of indenture and the making of ethnicity'.

Frescura, Franco (1990) 'Accommodation or protest? The rise of a wall decorating tradition in rural southern Africa'.

Harries, Patrick (1984) 'A forgotten corner of the Transvaal: reconstructing the history of a relocated community through oral history and song'.

Harries, Patrick (1984) 'Songs, stories, rhymes and riddles: African folklore and people's history'.

Harris, Verne (1994) "“They should have destroyed more": the destruction of public records by the South African state in the final years of apartheid'.

Hofmeyr, Isabel (1978) 'The mad poets: an analysis of an early and sub-tradition of Johannesburg literature and its subsequent developments'.

Hofmeyr, Isabel (1981) 'The political dimension of South African literature: an analysis of images of town and country in turn of the century writing'.

Hofmeyr, Isabel (1984) 'Building a nation from words: Afrikaans language, literature and "ethnic identity", $1902-4^{\prime}$.

Hofmeyr, Isabel (1987) 'Turning region into narrative: English storytelling in the Waterberg'.

Hofmeyr, Isabel (1991) 'Nterata/the wire: fences, boundaries and cultural resistence in the Potgietersrust district'.

Lodge, Tom (1981) 'The destruction of Sophiatown'.

Mabin, Alan (1990) 'Doom at one stroke of the pen: planning and Group Areas c.1935-1958'.

Posel, Deborah (1990) 'The state and policy making in apartheid's second phase'.

Rice, Michael (1981) 'Fictional strategies and the Transvaal landscape'.

Rich, Paul (1978) 'Minstering to the white man's needs: the development of urban segregation in South Africa'.

Robins, Steven (1994) 'Fenced in by ideas of modernity: land struggles, "coloured" identity and civic activism in Namaqaland: 1980-83'.

Thabane, M. (1987) 'Africanist historiography, personal reminiscences and romanticisation of the past'. 


\section{Index}

Note: page numbers in bold denote reference to figures and illustrations.

aerial photographs: Cape Town 237-8, 242-4, 243

244, 245, 246; huts 162; Johannesburg 237, 238-42, 239, 241; Matatiele 114, 115;

Meadowlands 217

Africa 68, 79-80, 82, 125; as dystopia 81; 'Magical' $144,145-6,154,155-6,158$; veld 16

African National Congress (ANC) 8, 308, 309, 310

Afrikaans language 37, 142, 308; African landscape

83; national consciousness 28; Taal

Monument 143-6, 149, 150, 151, 152-3,

154-5

Afrikaans poetry $37,75-6,82$; Africa 79-80;

farming $75-6,81,82,85,86,105$;

Johannesburg 184; veld 15, 18, 26-30;

Voortrekker Monument 58-9; Voortrekkers

46-7; see also poetry

Afrikaner Nationalism 41, 42, 159, 292n4;

appropriation of language 123; Christian 21,

41, 82, 85, 180; dominant narrative 57;

economic goals 180, 181, 301n13; farmers 85;

First Freedom War 28; Moerdijk 67; Pierneef

42-3; Taal Monument 142, 155; veld 16, 18,

19; Verwoerd influence on 86

Afrikaners: African continent 80; city life 185-6;

farmers 76, 85, 87, 88, 89, 92; Great Trek 35;

Johannesburg 175, 176, 180-1, 184; literature 28; mythologies 37; Natives Land Act 94;

Pierneef 42-3; Sophiatown 244-5, 258; veld

9, 16, 18, 19, 21, 27-31, 33; Voortrekker

Monument 55, 56, 61-2, 70; see also Boers;

volk; Voortrekkers; white South Africans

Akzin, Benjamin 26

Alexandra 197, 199, 219, 269

ambiguity 16, 77, 273, 281, 283; bantustans 135 ,

164; German Romantic art 42; Johannesburg

192, 193; landscape representations 2, 3, 282;

mining land 199, 200; naked landscapes 166;

political processes 276 ; racial classification

$131,138,261$; reclaiming 271; suppression of

83; Taal Monument 154, 156; Voortrekker

Monument 65

ANC see African National Congress

ancestors 108, 201, 202 apartheid: contradictions of 95, 181; elusive nature 133; legislation 311-14; myths 169; outsider view of 7; urban environments 210; see also racial segregation

archaeology 273

art: Coetzer 39, 39, 40; Dutch 'landskip' painting

16; German Romanticism 40, 42; Pierneef

42-5, 77

Asians 99, 131

Association for Afrikaans Culture (FAK) 47, 301n15

Attwell, David 285n11

'Baby Come Duze' (Themba) 177-9, 178, 179

Bailey, Jim 296n22

Balfour Basin 187, 188

banning of poets 166,220

Banoobhai, Shabbir 140

Bantu Authorities Act (1951) 111, 113, 126-7, 310, 312

Bantu Building Workers Act (1951) 312

Bantu Homelands Citizenship Act (National States

Citizenship Act) (1970) 127, 296n12, 310, 314

Bantu Investment Corporation Act (1959) 313

bantustans 2, 10, 54, 126-7, 167-8, 310; Biko on

137; conflicted meaning of 162 ; cultivation

patterns 111; forced removals $164-5$; maps

133-8, 135; 'natural' basis of 133; nature 169;

placelessness 164; poetic writing about 166;

spatial confinement 140; timelessness 144;

Tribal Authorities 113-14; tribal landscapes

$162,163,230$

barbed-wire fencing 103-5

Barrell, John 36, 288n11

Barthes, Roland 36-7

Barton, Frank 140

Bermingham, Ann 36, 84

betrayal $48,49,65,157,160$

Betterment policy 110-11, 294n8

biblical landscapes 24-6

Biko, Steve 8, 137, 138, 140, 215, 219-20

birthright 123, 181

Black Consciousness Movement 8, 137, 219-20,

310 
Black People's Convention (BPC) 137, 219 $303 n 26$

black poetry 24, 121, 122-3, 209; boundaries 139-40; forced removals 264, 265, 268-9; Johannesburg 173-4, 218-19; land struggles 107-8, 111; mining land 199-202; protest 124-6; Soweto 210; see also poetry black South Africans: bantustans 10, 126-7, $167-8$; claiming of the land by 26,169 ; colonial beliefs about 30 ; cyclical time 144 education system 153; ethnic identity 162 farms and farming 9-10, 89, 90, 109, 110, 293n9; fear of 121 ; forced removals 232,248 ; Group Areas Act 209, 213; identity 90-2, 127 , 128-32; Johannesburg 175; lack of representational information 106; Land Acts 89-90, 94-9, 108; land ownership 108, 109 , 113-18; 'native' land 122; picturesque images 99-102; population distribution maps 99; population figures $296 \mathrm{n} 25$; prose writing 295n3; representations of the land 7; Soweto riots 125; territorial boundaries 133-41; tribal landscapes 158; tribal violence 58; urban rights 126, 175, 209, 230, 262; vacant landscape image 58, 69; Willemsdorp 21; see also race

black spots 108-9, 112, 116, 133, 134, 135, 140

blankness 221

blockhouses 104, 104

Blood River, Battle of 48, 56, 65, 69

'Blood and Soil' 30, 40, 86

Blum, Peter 82

bodies 4, 5, 31, 139; African women 140, 141; city life 216-18; mining 201, 203; Voortrekker Monument 60-

'Boer Manifesto' 286n31

Boer (South African) War (1899-1901) 8, 28, 30, $35,104-5$

Boers xii, 20, 21, 28, 30, 308; farms 9, 76, 187; fences 104; Great Trek 27, 57; Mhudi 23; 'rootedness' 78; women 60, 61; see also Afrikaners; Voortrekkers; white South Africans

Bond, J.J. 34-5, 109-10

Boom, Hendrik 78

Boshoff, C.W.H. 128

Bosman, Herman Charles 21-2, 140, 141, 191-2, $286 n 15$

botanical naming 17-18

Botha, Louis 96, 97-8

Bou van 'n Nasie (film) 289n30

boundaries 98, 103-6, 108-11, 114; cities 209; emotional 265; Johannesburg 176; uncertainty of 132-41

BPC see Black People's Convention

Bremner, Lindsay 199

Breytenbach, Breyten 300n18

Brink, André 17
Broederbond 42, 88, 288n15, 308-9 buffer 192, 194, 203, 204, 205, 206

Bunn, David 289n33, 292n29

Burger's Daughter (Gordimer) 193-4 Bushmen 20

Buthelezi, Phakamani 276

Cape 37, 78, 81

Cape Dutch farmhouse 77, 159-60

Cape Flats 208, 242, 243-4, 248, 256

Cape Technikon 232, 252, 278

Cape Town 49, 97; aerial photographs 237-8, 242-4, 243, 244, 245, 246; forced removals 230-1, 232-5, 236, 237-8, 242-52, 256, 270; views 268; see also District Six

cartouches 54, 92, 93

Caton-Thompson, Gertrude 290n19

Celliers, Jan 26-7, 30

censorship 8, 220-5

Christian Nationalism 21, 41, 82, 85, 180

Christmas cards 63, 64, 99-100, 100, 101

Ciskei 109, 135, 297n42

Coetzee, Carli 200

Coetzee, J.M. 9, 18-19, 53, 78, 82, 140, 157, $285 n 11$

Coetzee, N.J. 43

Coetzer, W.H. 39, 39, 40

colonialism 11, 53

Coloured Persons Communal Reserves Act (1961) 314

Coloured South Africans 7, 99, 138, 147; definition of $132,284 n 10$; forced removals 248,261 ; Group Areas Act 212, 214, 230; population figures $296 \mathrm{n} 25$

Comaroff, Jean and John 36

community $125,255,257,258,273,280$; District Six 251, 262; multiracial 231, 232, 248, 251, 256-7, 261, 269-70

Company Garden 78, 79, 81

compensation 115, 232, 276, 280

completeness 157, 161, 167, 199, 208-9, 211, 215,226

Conrad, Joseph 140, 297n57

contamination 192, 197-8

Cosgrove, Denis 284n4

Country of My Skull (Krog) 31-2

Crankshaw, Owen 215

crime 199

Cronin, Jeremy 125

Crown Mines Property Development Project 198, 203-4, 205

cyclical time 144, 156

Dangor, Achmat 166, 220, 265

Darwin, Charles 291n9

Davids, Achmat 262

Davids, Jennifer 208 
De Klerk, F.W. 310

De Klerk, J. 151

De Klerk, W.A. 147

Debray, Regis 142-3

debris 180, 196, 236, 238, 246, 264-6, 273, 278

decay 82, 177, 192, 206, 236, 266, 268, 269

Delmont, Elizabeth 60, 64

Delport, Peggy 277-8

demolitions 180, 232, 238-44, 249-50, 257,

\section{4-6, 266}

Department of Community Development 248-9, 250

desert veld 20, 25

desire and the city 174

destiny of the volk 28, 67, 69, 71, 152, 156, 159

detention 166, 223-4, 224

Die Burger 37

Die Huisgenoot 39, 159, 181, 298n3

Die Transvaler 37, 39, 86, 134, 291n26

Die Voortrek 39, 185

Dikobe, Modikwe 111-12, 114, 139, 210, 218

Dingaan 48, 65

Dipoko, Mbella Sonne 287n38

dispossession xii, 6, 94, 108, 116, 218, 279; see also forced removals

District Six 208, 230-1, 232, 238, 255, 270; alternative representations $177,265,268-9$, 271; cost of removals $305 n 18$; debris from 236; density and visibility 233-5; hybrid life 175; 'intangible heritage' 277; Museum of 232, 262, 278-80; photographs 234, 242-4,

244, 245, 246, 249, 250; rebuilding proposals 247-52; struggles 274-5; views 267-8

domestic workers 209

Donkin Memorial 103

Doodkry is min (film) 301n15

'dream topographies' 9, 18-19

Drum 2, 128-9, 132, 133, 296n22; bantustans 162, 163; burning huts photograph 161, 161;

Johannesburg 175, 176, 177, 179-80;

Meadowlands 254; Sophiatown 259, 265-6

Du Plessis, W.C. 146, 147

Du Toit, J.D. 75-6

Durban 97, 256, 261, 269

Dutch colonisers 78, 81, 89, 157

Dutch East India Company 78, 79, 81, 307

Dyanti, Benson 163, 259

Eden 79, 82

Edney, Matthew H. 289n37

Eiselen, Dr 126-7

empty spaces 220-5

English-speaking South Africans 21, 28, 85, 94 , $301 \mathrm{n} 13$

equality $57,180,206$

erasure $112,206,238$

ethnicity $126,133,138,139,164,166$ eugenics 86

European imagery 42, 66-7, 70-1, 208

Extension of University Education Act (1959) 314

Eybers, Elisabeth 86

FAK see Association for Afrikaans Culture farms and farming 9-10, 75-8, 81, 83, 86; Afrikaner farmers 76, 85, 87, 88, 92; Betterment policy 110-11; black ignorance myth 109, 110, 112; boundaries 103-6; God 85; Land Acts 95, 96, 97-8; land ownership $113,115,117$; mining land 187; 'natural' identity 89, 90-2; suppression of black farmers 98; western agricultural organisation 111; wilderness relationship 77, 84

fatherland 16, 26-31, 60, 66, 143, 155

fear 117, 121, 140, 142; censorship 225; silence of writers 220; veld 31-3

fertility 4, 69, 76; black 90; claims for fertile land $88,109,115$; female images 87; myths of $108,115,116,167$

forced removals 10, 180, 208, 229-55, 273; bantustans 163, 164-5; black poets and writers 175; exhibitions 276; " intangible heritage' 277; landscapes of the imagination 256-71; number of 303n2; rural areas 108; Soweto 197, 198; see also dispossession; District Six; Sophiatown

forgetting 7, 17

Fouché, L. 250

Free State 19, 37, 53

Frescura, Franco 299n5

Friedrich, Caspar David 40, 41-2, 41

Frielik, Stanley 299n18

gardens $78,81,82,84,114$

Gerdener, T.J.A. 151

German National Socialism 35, 86-7, 292n27

German Romanticism 39-42, 66

Giliomee, Hermann 60

God 29, 30, 85-6; veld 25, 26; Voortrekker Monument 69, 70

gold mining see mining

Golden City 181, 192

Gordimer, Nadine 122, 137, 193-4, 295n3

GRA (Genootschap van de Regte Afrikaners/ Society of True Afrikaners) 28, 143, 308 grass huts see huts

grassland 4, 18, 19, 27, 33, 42; Afrikaans novels 82; Johannesburg 174, 199

Great Britain 155, 308; Plaatje appeals to 95, 123; South African War 8, 28, 30, 35, 104-5; Topographic Survey 105

Great Trek 27, 28, 33, 34-5, 42; economic ambitions 180; Eeufees (Centenary) 27, 35, 49-52, 55, 62, 95, 180; Land Act amendment 94; maps 47-8, 49, 51-4, 64; re-enactments 
29, 35, 37, 47, 49-51, 55, 62, 159; Voortrekker Monument 65, 68; wagon wheels 46, 46: women 60; see also Voortrekkers

Great Zimbabwe 68, 69, 290n19

green belt areas 211

Greyling, G.A. 151

Griesel, Christina Johanna 82

Group Areas Act (1951) 208, 209-14, 215, 217

311; District Six 248; forced removals 163 ,

175, 230-2, 237-8, 256, 260-1, 264-5, 269;

Johannesburg 174 ; meaning of urban

landscapes 271; modernity 235; racial

boundaries 176; 'Section 10' rights 302n4;

views 267

Grundlingh, Albert 60

Harley, J.B. 64

Harries, Patrick 164, 165

Head, Bessie 97

Historical Monuments Commission 61

Hofmeyr, Isabel 104, 106, 289n38

home 4-5, 123

homelessness 270

housing 203-4, 205, 206, 209, 245-6, 252-4

Huddlestone, Trevor 263

huts $157, \mathbf{1 5 8}, 162,163, \mathbf{1 6 4}$; aerial photograph

162; architectural symbols of segregation

159-60, 160; burning of 161, 161; Christmas

card images 100, 101; Taal Monument 154,

159; Voortrekker Monument 65

hybridity $260-2,271$

hygienic city $258-9$

identity 1, 2, 5, 128-32; Afrikaner 37, 43, 77, 153,

155, 186; dual black identity 95, 118; ethnic

$131,138,162,210$; fragmentation of black

139; geographic 229; 'native' 159; 'natural' 88 ,

89, 90-2, 98, 180; racial segregation policy

248; tribal 90, 92, 95, 126-7, 158-60, 293n10;

see also national identity

image 8

imagination 229, 273, 274

Immorality Amendment Act (1950) 311

imperialism 11, 36, 41, 229

impermanence 187, 195, 196, 209

incompleteness 58, 175, 195, 208-9, 225-6, 281

Indian South Africans 7, 138; forced removals 261;

Group Areas Act 212-13, 214, 230; population figures $296 \mathrm{n} 25$

inscription of the land $37,42,54,108,125,169$;

re-enactment 35 , 48, 49; wagon wheels $45-6$

'intangible heritage' 276-7

invisible landscapes 82, 207, 208

Israel 86

jazz music 259-60

Jeppie, S. 275
Johannesburg 97, 128, 173-4, 191-2, 216-17: aerial photographs $237,238-42, \mathbf{2 3 9}, \mathbf{2 4 1}$; economic and cultural goals 180-6; forced removals 230, 231-42; gangsters 129; jazz music 260; mining land 181, 186-90, 192-206, 231, 241-2; Plan of Municipal Area 190; proximity 175-6; representations of 176-80; Serote's poetry 219; tourist information 214-15; 'white' 259; see also Sophiatown; Soweto Johannesburg Station 43-4 Jonker, Ingrid 15-16, 33

Karel Landman Monument 64, 64

Karoo 19, 20, 30, 82, 112

Kentridge, William 6-7, 306n2

Khoikhoi 81, 89, 157, 307, 308

King Kong (musical) 260

Knorr Soups company 54

'koninkrykie' 76

kraals 48, 65, 111

Krog, Antjie 31-2

Kunene, Masizi 125

Kuyper, Abraham 308

laagers 48-9, 50, 56, 65, 69, 71, 103

labour 92, 95, 96-7, 117; Group Areas Act 209; Land Acts 89-90; migrant 201, 202, 292n7; urban areas 229-30

Ladysmith 108, 113

land xii, 3-4, 8, 9, 282-3; Afrikaner legitimisation of ownership 36, 37; ancestors 201, 202; black poetry 125-6; conflicting forms and images 6 , 53; 'deep' meaning 274; 'dream topographies' 18-19; home concept 4-5; intimacy with the 83-4; Johannesburg 174-5; Land Acts 89-90, 94-9; landscape distinction 3; Mandela 1-2, 5 , 281; Mhudi 23-4; 'native' 122, 168-9; as political resource 6 ; racial division of 106 108-9, 112, 113-18, 132-41, 200; reclaiming $126,271,279,281$; restitution 275-6; 'rootedness' 78; South African literature 200; 'tribal lands' 163-4; veld concept 16; Voortrekkers 29, 30, 54; western agricultural organisation 111

landscape xii, 2-3, 5, 273-4, 275, 282-3; Afrikaans novels 82-3; agricultural 77; 'as amenity' 204; 'authentic' 42-5; biblical 24-6; black pastoral 99-100; as buffer zone 206; city 179, 191-2; colonial 38, 39; conflicting forms 6; Cosgrove on 284n4; 'dream topographies' 9, 18, 19; European pictorial conventions 42 ; failed garden metaphor 82; farm concept 9-10; forced removals 10, 230, 231, 237-8, 246-7, 267-9, 271; German National Socialism 86-7; of the imagination 229, 256-71, 274; imperialism 11; 'intangible heritage' 277; 
invisibility 82, 207, 208; land distinction 3; language 144-6, 150, 155; maps 46, 53; mining land 192, 194-6, 199, 200, 205, 206 nakedness 166; nation relationship 16, 143; Natives Land Act 94, 98; newspaper and magazine representations 38-42; political change 36; politics of division 190; post-apartheid 273, 276, 277, 281-2; 'progressive' nature of 214-15; racial segregation 118; representation of 6-7, 10-11; residential developments 203-4; Taal Monument 145-6, 148-9, 152-3, 155, 156; tribal 157-69; veld 9, 18, 31; Voortrekker Monument 55, 65, 69; Voortrekkers 30, 34-5 Langenhoven, C.J. 83, 144, 156

language: Afrikaans poetry 27; English writing 18; Taal Monument 143-6, 147-9, 150, 151, 152-3, 154-5; Zulu 4; see also Afrikaans language

Le Corbusier 235, 236

legislation 106, 118, 220, 311-14; Bantu Authorities Act (1951) 111, 113, 126-7, 310, 312; Bantu Homelands Citizenship Act (National States Citizenship Act) (1970) 127, 296n12, 310, 314; Native Trust and Land Act (1936) 89-90, 94-5, 108, 111, 115, 118; Natives Land Act (1913) 89-90, 94-9, 108, 111, 118, 123; Natives Resettlement Act (1954) 232, 313; Pass Laws 310, 312-13; Population Registration Act (1950) 131, 311; Promotion of Bantu Self Government Act (1959) 111-12, 310, 314; Restitution of Land Rights Act (1994) 275-6; Urban (Bantu) Areas Act (1923) 230, 309; see also Group Areas Act Leith, Gordon 43

light from above ('lig van bo') 69-70, 147, 151 linear historical time 144

the Lo-Six 129, 130

Loots, P.J. 152, 154

Louw, W.E.G. 85

Luthuli, Albert 140

Madingoane, Ingoapele 125

Malan, D.F. 37, 99, 289n29, 309

Malays 132, 213, 214

Mamdani, Mahmood 113, 126

Mandela, Nelson 1-2, 5, 15, 281, 310

Mapogga 159

maps 46-8, 49, 51-4, 98, 132, 133; bantustans

133-8, 135; Cape 78, 79, 81; disempowering nature of 112; District Six Museum 278-9,

279; Dutch East India Company Garden 78,

79, 81; Group Areas Act 210, 213;

Johannesburg mining land 187-90, 188, 189,

190, 204-5; land ownership disputes 108;

Matatieleland 113, Plates 6.2-6.4; population distribution 98-9; reserve lands 113, 114;
'Sources of Native Mine Labour' 90-2, 91, 93 . Topographic Survey 105; urban planning 238; Voortrekker Monument 64-6, 138

Martindale 175, 231, 232, 238

Marx, Leo 77, 84

Matatiele 108, 113-17, 115

Matthews, James 166, 167

Mausoleum of Halicarnassus 68-9

Mayville 261

Mbeki, Govan 5

Mbeki, Thabo 5, 6

Mbuli, Mafika 202

Meadowlands 198, 216, 231-2, 242, 253, 255; aerial photograph 216-7; bleak environment 253-4; government memorandum 252-3; hygiene and modernity 258-9; Nkosi on 269

Meiring, A.L. 159

memorialisation $276,277,280$

memory 17,282 ; forced removals $6,258,277$, 278, 280; of re-enactment 47

Mhudi (Plaatje) 23-4

migrant labour 201, 202, 292n7

mining: aerial photographs 237-8; development proposals 203-6; Johannesburg mining land 181, 185, 186-90, 192-206, 231, 241-2; migrant labour 292n7; mine workers 90-2, 97; poetry 199-202

miscegenation 153, 181, 186, 248

missionaries 36

Mitchell, W.J.T. 11

modernist urban planning 235-6, 242, 251-2

modernity 10, 99, 127, 144, 254; aerial photographs 238; African 260; bantustan policy 126; certainty of 281; economic growth 235; Johannesburg 181, 184, 192; mining land 206; Sophiatown 259, 260; state relationship 211; Taal Monument 149; urban areas 214-16, 229, 231, 251-2

Modisane, William 'Bloke' 132, 258-9

Moerdijk, Gerard 43, 55, 56, 64, 66-70, 88, 159

Moodie, D.W.M. 204-5

Moodie, T. Dunbar 292n6

Moshesh, Daniel 116

Mother Africa 31, 259, 260

Mphahlele, Es'kia 121, 164, 175

multiracial community $231,232,248,251,256-7$, 261, 269-70

Murray, Christina 299n17, 303n2

music 259-60

mysticism 40, 41, 42

myth 36-7, 71, 90, 110, 169; 'Black Danger' 102; dual black identity 95, 118; Edenic 78; emptiness of the land $49,58,181$; farms 77 , 187; fertility $108,115,116,167$; pastoral 97 ; stable past 133; Taal Monument 154-5; tribal landscape 157 
Nagia, Anwah 278

Nakasa, Nat 128, 131, 175, 216, 220, 269, 296n23

naked land 166

narratives $9,36,57,82$

Nassen, Bill 276-7

Natal 37

Natalia Republic 41

nation $16,19,142-3,153$

national consciousness $26,27,28,66$

national identity 1, 2, 28, 127; German Romantics 40, 41; land relationship 16-17, 66; language 144; tribal lands 133; see also identity

National Party 3, 5, 8, 142, 237; banning of poets 166; ethnic identity 131; farming 77; forced removals 236; Group Areas Act 256; ignorant black nation myth 110; industrial economy 47 ; maps 52; modernity 10, 185, 211, 214, 235 , 258; newspapers aligned to 37; parliamentary victory 35, 99, 309; public buildings 50; racial segregation 118, 248; resistance to rule 217 219, 281; Taal Monument 147; violence sanctioned by 31,32

National Socialism 35, 86-7, 292n27

National States Citizenship Act (Bantu Homelands Citizenship Act) (1970) 127, 296n12, 310, 314 nationalism: Christian 21, 41, 82, 85, 180; male 60; perception of difference 26; see also Afrikaner Nationalism

Native Affairs Commission 112

'native communities' 58

'native' concept 10, 121-2, 123-8, 169; bodies/land association 157; racial classification 131; Taal Monument 143; tribal identity 92

Native Labour (Settlement of Disputes) Act (1953) 313

Native Land Commission 116

Native Laws Amendment Act (1952) 312

native soil 47, 88, 151, 270

Native Trust and Land Act (1936) 89-90, 94-5, $108,111,115,118$

Natives (Abolition of Passes and Co-ordination of Documents) Act (1952) (Pass Laws) 310, 312-13

Natives Land Act (1913) 89-90, 94-9, 108, 111, 118,123

Natives (Prohibition of Interdicts) Act (1956) 313

Natives Resettlement Act (1954) 232, 313

'natural' identities 88, 89, 90-2, 98, 180

nature 10, 16, 83-4, 89, 122; bantustans 169 farms 81; German Romantic art 40; God in 85 Taal Monument 149

'natuurmens' 9, 42, 85

Ndebele 159

Newclare 175, 231, 232, 238

newspapers $37,39,135,220-5$

Nienaber, P.J. 28-9
Nkosi, Lewis 177, 257, 258, 269

Nkosi, Petros 165

'noble savages' 157

North America 78-9, 84

Norval, Aletta J. 292n27

Nuttall, Sarah 200

Olwig, K.R. 16

O'Meara, Dan 125, 153, 180, 292n4, 301n13

Ongeluksnek 115, 116

Opperman, D.J. 183, 184-5

oral history 122, 273, 277, 282

Orange Free State 19, 37, 53

O'Regan, Catherine 299n17, 303n2

organic unity 147, 155, 159

Ossewabrandwag 35, 86, 292n27

Paarl Mountain 149, 151

Parnell, Susan 215

Pass Laws 310, 312-13

pastoralism 77, 85, 89, 108, 109, 110

paths 45-7, 65

Personality (magazine) 53, 289n39

Phalanndwa, Nthambeleni 32-3

photographs 7-8, 37-9, 114; 'Baby Come Duze'

177-9, 178, 179; Cape Town 237-8, 242-4,

243, 244, 245, 246; censorship 225; District Six 234, 242-4, 244, 245, 246, 249, 250; Johannesburg 237, 238-42, 239, 241; mining land 194-7, 194-5, 196, 197; Sophiatown 233 , 238-42, 239, 240, 254, 265-6, 266

Pierneef, Jacob Hendrik 42-5, 44, 45, 77, 86, $288 n 23$

Plaatje, Sol 23-4, 94, 95, 97, 123, 308

poetry 24, 121, 122-3, 165, 273; Africa 79-80; bantustans 166, 167; boundaries 139-40; farming $75-6,81,82,85,86,105$; forced removals 264, 265, 268-9; Johannesburg 173-4, 184, 218-19; land struggles 107-8, 111; mining land 199-202; pastoralism 77; protest 124-6; silences 207-8, 220; Soweto 210; veld 15, 18, 24, 25, 26-30, 32-3; Voortrekker Monument 58-9; Voortrekkers 46-7

police 32, 138, 254, 254

political detention 166, 223-4, 224

politics 2, 3, 5; Biko 140; Johannesburg 192; land restitution 276; landscapes 36 , 83; language 147-9; mythologies 37; nature 83-4; political change 8-9; politically sanctioned violence 31 ; protest poetry 125; of racial division 1,118 190; repression 8, 33

pollution 192, 197, 198

population density 97,99

Population Registration Act (1950) 131, 311

Port Elizabeth 256

Posel, Deborah 126, 211, 212 
Postma, Laurike 60

Potgieter, S.J. 35, 109

Preller, Gustav 37-8, 288n9

Preservation of Coloured Areas Act (1961) 314

Pretorius, Andries 41

Prevention of Illegal Squatting Act (1951) 312

primitivism $65,77,89,144$; civilisation dualism

101-2, 156, 185; huts 157, 160; 'Magical'

Africa 155, 158

Pringle, Thomas 24-6

Prohibition of Mixed Marriages Act (1949) 311

Promotion of Bantu Self Government Act (1959)

$111-12,310,314$

proximity 175-6, 209, 235

race $77,126,131-2,211$; evolutionary theories

291n9; forced removals 260-1, 269, 270;

Group Areas Act 210, 212-14, 230; land

ownership 108-9, 112, 113-18; modernist

urban planning 236, 251-2; population

distribution maps 98-9; territorial boundaries

98, 132-41; see also apartheid; black South

Africans; white South Africans

racial classification $131-2$

racial segregation 57, 106, 116, 261, 281-2;

architectural symbols of 159-60, 160; Group

Areas Act 175, 176, 209-14, 230, 231, 248;

Johannesburg 174, 175, 180; Land Acts

108-9; maps 98, 99; mining land 197;

modernising agenda 242; National Party rule

118; as policy of fear 140; residential

developments 203; see also apartheid; forced removals

Rand Daily Mail 37, 126-7, 133, 134, 135, 217

Rehan, Ernest 16-17

Released Areas 94, 99, 109, 113, 116, 134, 230

representation 5, 10, 273-4, 281, 282; alternative

urban 257, 258, 260, 262-6, 270, 271; black 8;

failure of 5, 97; forgetting 7; image distinction

8; landscape definition 3; politics of 122 ;

rational forms of 211 ; reclaiming the land 126 ; white 8, 208

Reservation of Separate Amenities Act (1953) 313 reserve territories 89, 90, 99, 113-14, 117, 118

Restitution of Land Rights Act (1994) 275-6

Retief, Piet 48, 60, 69, 160, 299n6

Riekert, P.J. 137

Romanticism 39-42, 66

'rootedness' 78, 270

rounded huts see huts

Rousseau, Ina 81-2

Runge, Philipp Otto 40, 41

rural areas 3, 4, 5, 100, 209; forced removals 108,

164; pastoralism 77; racial separation 98, 99;

tribal landscape 162; see also bantustans;

farms and farming; veld; wilderness

rural camps 162
Sachs, Albie xi-xiii, 33

Said, Edward 36, 229

Sampson, Anthony 128

SAR \& H see South African Railways and Harbours

SASO see South African Student's Organisation

savagery 157, 180

Schadeberg, Jürgen 215, 266

Scheduled Areas 94, 99, 109, 113, 116, 134, 230

Schmidt, Bruno 66

Schreiner, Olive 19-21, 26, 82, 166

scientific modernity 17,149 ; see also modernity

segregation see racial segregation

self-knowledge 20, 21, 24

Sepamla, Sipho 201

Separate Representation of Workers Act (1951) 312

SEPC see Social and Economic Planning Council

Serote, Mongane Wally 173-4, 219, 264, 265, 268-9

Sharpeville massacre (1960) 8, 16, 220, 310

silences 220-1

Simonstown 256, 270

slavery 286n29, 307, 308

slum clearances 181, 242, 249-50, 262; see also forced removals

Smuts, Jan 211, 292n27, 309

Social and Economic Planning Council (SEPC) 211

Society of True Afrikaners (GRA) 28, 143, 308

Soggot, David 219

Somhlahlo, Basil 33

Sophiatown 180, 215-16, 230-3, 252-5, 270,

272-3; alternative representations and imaginings 177, 257-60, 262-6, 271; debris from 236; density and visibility 233, 235; establishment of 308; gangsters 129; hybrid life 175, 179; legal procedures 236-7;

photographs 233, 238-42, 239, 240, 254,

265-6, 266; rebuilding proposals 244-6;

walking tours 280-1

Sophiatown (musical) 260

Soudien, C. 275

South African Railways and Harbours (SAR \& H) 43-4, 47-8, 60, 100

South African Student's Organisation (SASO) 219

South African Tourist Board 102, 136

South African War (1899-1901) 8, 28, 30, 35, 104-5

The Sowetan 221, 222

Soweto 175-6, 190, 197-8, 238; aerial photographs 239, 240-1, 242; crime 199; dystopia 219; forced removals to 216,231 , 232; GAPPS development proposal 206; peripheral status 189; residential developments 203, 204; riots (1976) 8, 125 , $153,166,193,295 n 9,310$

speech, struggle for 208

stable tribal history $126,127-8$ 
The Star 34, 37, 95, 140, 168, 221-2, 222

State of Emergency 222, 225

Steencamp, Anna 286n28

Steyler, F.A. 52

The Story of an African Farm (Schreiner) 19-21

streets 215, 216, 233, 235, 242, 246; demolitions

239; District Six Museum 262, 278, 280;

Sophiatown walking tours 280

Strydom, Hans 292n27

Suppression of Communism Act (1950) 312

surrogate landscapes 56, 278, 280

surveillance 212, 216, 252

Taal 142, 143, 145-6, 153, 154-5, 156; see also Afrikaans language

Taal Monument 142-56, 145, 148, 150, 152 , 158-9

Table Mountain 81, 231, 235, 242, 248, 267-8

Terrorism Act (1967) 314

Themba, Can 175, 177-9, 180, 215, 216, 257, 259

Thomo, Thoko 129, 130

Thwala, Nhlanhla 4, 5

time 144, 156

timelessness 31, 44, 159, 191; mining land 194; Taal Monument 143, 144, 154, 156

Titlestad, Michael 260

Tomlinson Report 134, 297n36

Topographic Survey 105

torture 32

tourist material 101-2, 198-9, 214-15

Toussaint van Hove, E. 182

townships 174, 209, 210, 215-16, 225; earliest

308 ; political and economic goals 230;

Sophiatown 231

Transkei 2, 111, 114, 138, 295n6; Dyanti 163; fear 140 ; instability $297 n 42$; location 297 n53

Transvaal 19, 37, 53, 86; Group Areas Act 230

Pierneef's paintings 43,44

trees 1, 17, 24, 45, 203, 215

tribal identity 90, 92, 95, 126-7, 158-60, 293n10

tribal landscapes 157-69

tribal rule 113-14

Trichardt, Louis 49

Triomf 240, 242, 255, 258, 275; aerial photographs

241; house and site plans 247; housing 245-6; renaming 232; rubble from Sophiatown 236; street names $304 n 11$

Triomf (Van Niekerk) 272-3, 280, 304n10

Truth and Reconciliation Commission 31, 32, $287 n 35$

Tutu, Desmond 287n35

Tweede Trek (Second Trek) 184

'umhlaba' 4

uncertainty $2,208-9,267,273,281-2,283$ boundaries 132-41; forced removals 248; mining land 195, 199; Taal Monument 154; veld 21, 192

Union of South Africa 8, 37, 94, 95, 96, 123

urban areas 3, 4, 10, 208-25; Group Areas Act 209-14; modernist planning 235-6, 242, 251-2; personal identity 5; see also Cape Town; forced removals; Johannesburg: urbanisation

Urban (Bantu) Areas Act (1923) 230, 309

Urban Bantu Councils Act (1961) 314

urbanisation 4, 21, 118, 248; alternative vision of modernity 259; Johannesburg 176; poetry of 200

Uys, Jamie $301 \mathrm{n} 15$

vacant land 57-8, 69, 106, 184, 192, 195, 206

Vail, Leroy $126,293 n 10$

Valhalla 66

Van Den Heever, C.M. 58-9, 80

Van Niekerk, Marlene 272-3, 280, 304n10

Van Onselen, I.P. 127

Van Riebeeck, Jan 248

Van Wijk, Jan 144, 152, 153, 154, 155-6

Van Wouw, Anton 60-1

Van Wyk Louw, N.P. 29, 144-5, 146, 156 vegetation 17-18, 56, 112, 198, 205, 246, 270 veld 9, 15-33, 77-8; biblical landscapes 24-6; city relationship 186, 191-2; as fatherland 16 , 26-31, 66; maps 47; mining land 194; myth of emptiness 181; Pierneef 44; violence and fear 31-3; Voortrekker Monument 55, 58-60, 66, 70,71

Verwoerd, H.F. 37, 39, 54, 86, 134, 291n26, 310

views 267-8

Vilakazi, Benedict 122, 200-1, 301n12

violence 2, 5, 219, 269, 282; forced removals 254-5; 'heritage' maps 54; mining land 199; 'native communities' 58; townships 217; veld 21, 22, 31-3; Voortrekker Monument 57 virgin land 29, 31, 34, 58, 84, 204 volk 9, 27-9, 80, 102; Afrikaner Nationalism 67, 82; Christian mythology 155; economic ambitions 180; farmers 76, 87, 88; German National Socialism 86; language relationship 146; Taal Monument 147, 152, 153; Voortrekker Monument 60, 62, 149; see also Afrikaners Volkerschlacht Memorial 66-7, 67, 68 Von Klenze, Leo 66

Voortrekker Eeufees (Centenary) 27, 35, 49-52, $55,62,95,180$

Voortrekker Monument xiii, 34, 55-72, 56, 70 African references 159; bank building comparison 88; commemorative material 62 63, 64, 109; cross-section 71; European precedents $66-9,70-1$; foundation stone ceremony $35, \mathbf{5 1}, 55,62$; inauguration 27,35 , 55-6, 62, 138, 159, 180, 309; indigenous 
garden 57; myth of separation 149; newspaper supplements 39; Taal Monument comparison 147, 148; 'Trekker Routes' 65; women 60-1, 61

Voortrekkers 29-30, 33, 34-5, 57-8, 69; Centenary memorabilia 52, 52; farmers 76, 87; gold mining 185; Johannesburg 181, 184, 186; laagers 48-9; maps 47-8, 49, 51-4; Moerdijk on 68; Natives Land Act 94, 95; racial subjugation 57 ; re-enactment $35,37,47$, 49-51, 55, 62; South African Railways map 47-8; visual representations 39; wagon wheels 46, 46; women 50, 97; see also Great Trek

Vorster, B.J. 135, 146

wagon wheels 45-7, 46, 49-50, 54 Walhalla 66

The Weekly Mail 221-3, 223, 224

white South Africans 7, 8, 77, 208; bantustans 167, 168; definition of 131; District Six 250, 252; English-speaking 21, 28, 85, 94, 301n13; farms and farming 9-10, 76, 88, 89, 293n9; Group Areas Act 213, 214, 264, 267; history rewritten by 36 ; Land Acts 96,108 ; land ownership 108, 109, 113-18; 'native' land concept 168-9; population distribution maps 99; population figures 296n25; property speculation $304 n 13$; township violence 217; veld concept 16, 26; Voortrekker Monument
57; Willemsdorp 21; see also Afrikaners; Boers; volk

white spots 108-9, 116, 117, 133

wilderness 9, 16, 30, 31, 47, 90; Afrikaner

Christian Nationalist narratives 82; black identity associated with 109, 110, 112,

117; farm relationship 77, 84, 88; Mhudi

23, 24; Natives Land Act 95; North America

84; paths 45; threats from within 71; see also

veld

Willemsdorp (Bosman) 21-2, 31, 140, 191, 193,

194

Williams, Raymond 121-2

Witwatersrand 185, 187, 188, 189, 205, 291n1

women: absence of voices xiii; black 97, 100;

bodies of 31, 140, 141; urban restrictions

302n5; Voortrekker Monument 60-1, 61;

Voortrekkers 50, 97

Women's Monument, Bloemfontein 60

Xhosa 89, 102, 107, 138, 140, 308

Yako, St. J. Page 107-8, 122

Zimbabwe 68, 69, 220

Zonk 128

Zulu language 4

Zulus 48, 49, 299n6; maps and boundaries 136, 138; tribal violence 58; Voortrekker Monument 56, 57 

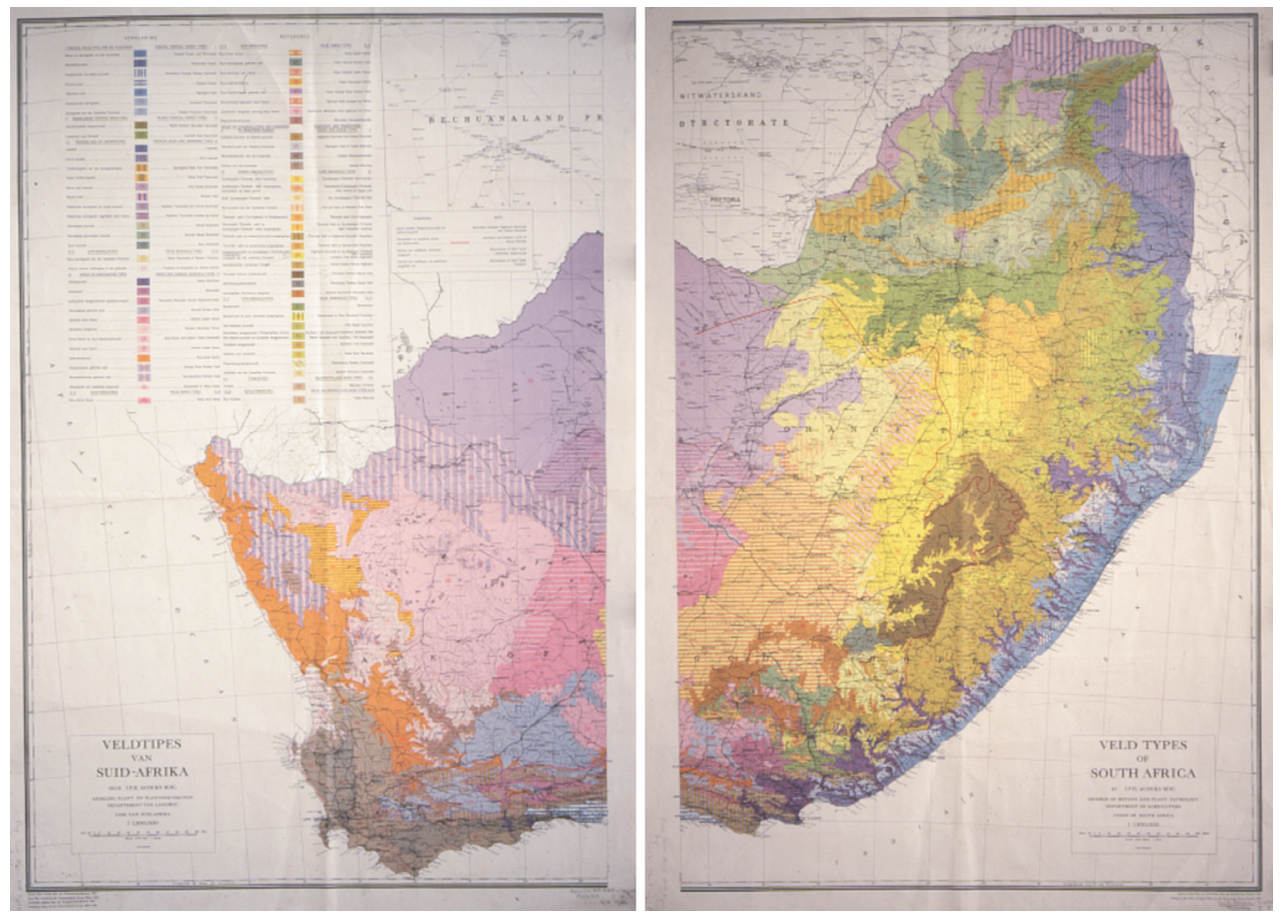

Plate 1.1

Veld types of South Africa (1951-1953)

Botanical Survey

Memoir no. 28

Plate 2.1

Hendrik Pierneef -

Paintings for the Johannesburg

Railway Station

(1929), from The Johannesburg

Station Panels by J.H. Pierneef.

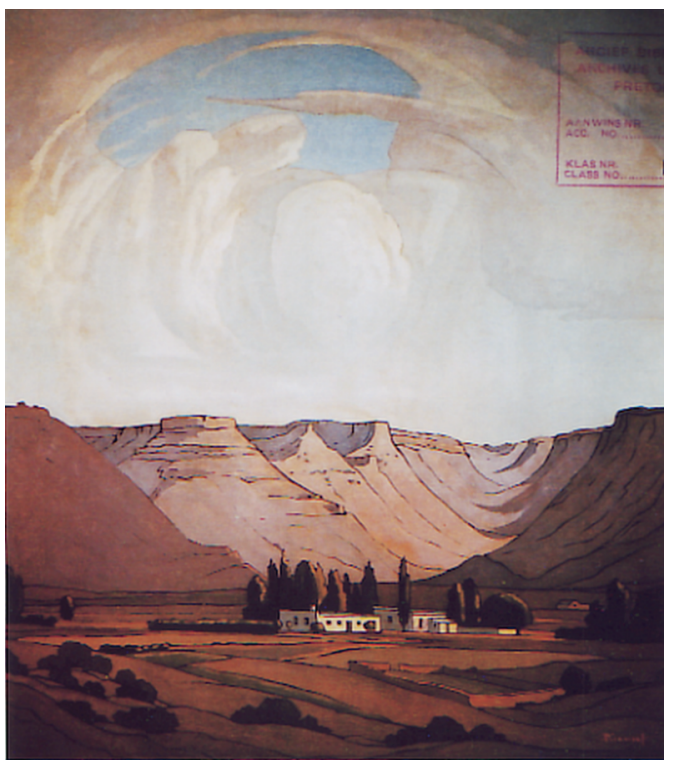




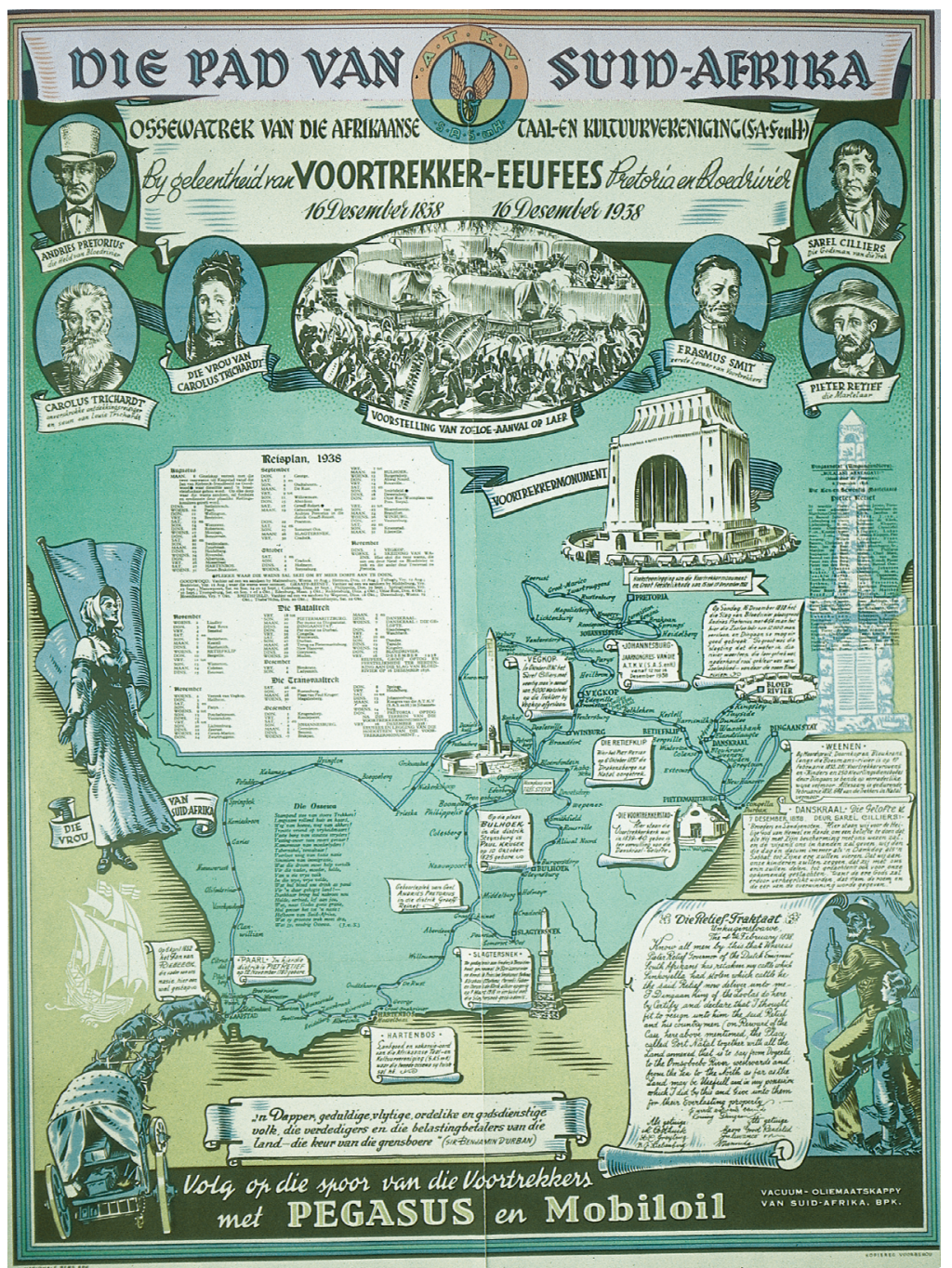

Plate 2.2

Map of the Great

Trek - Vacuum

Oiliemaatskappy

van Suid Africa Bpk,

'Die Pad van Suid

Afrika' (The Path

of South Africa)

(16 December 1938),

Voortrekker

Eeufees. 
Plate 2.3

F.A. Steyler (1951)

Routes of the Great

Trek in the Cape

Province.

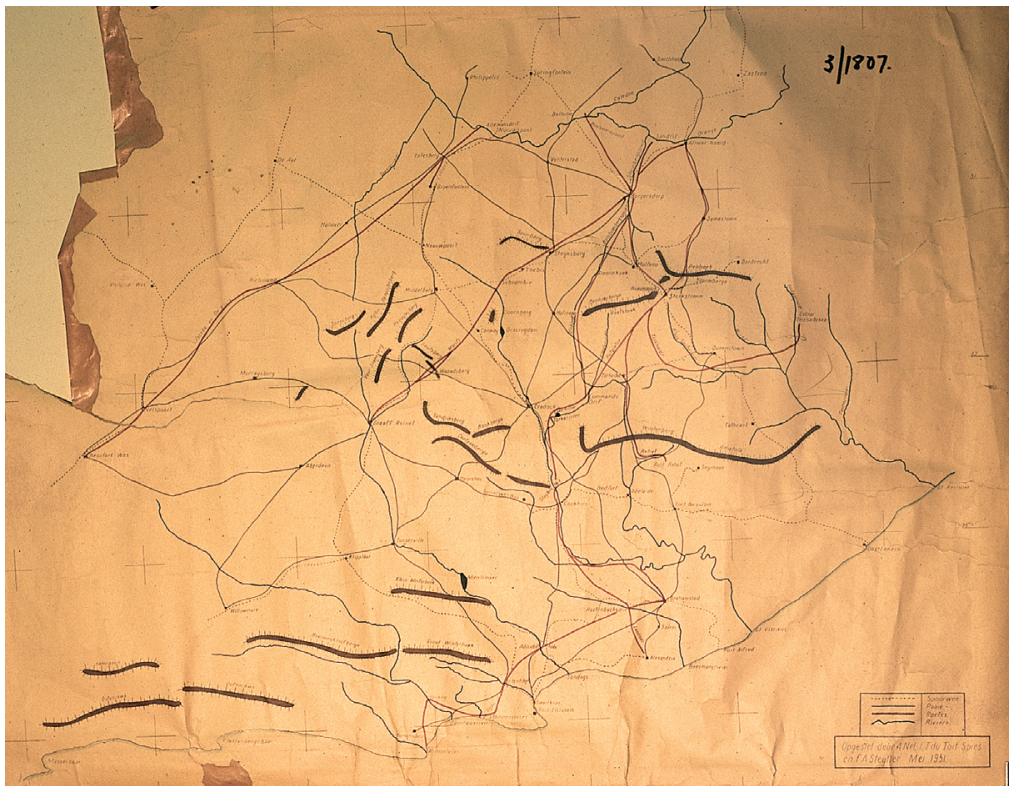

Plate 2.4

The Story of South Africa (1968) Map produced as a

supplement to

Personality magazine as 'New Atlas for Southern Africa'.

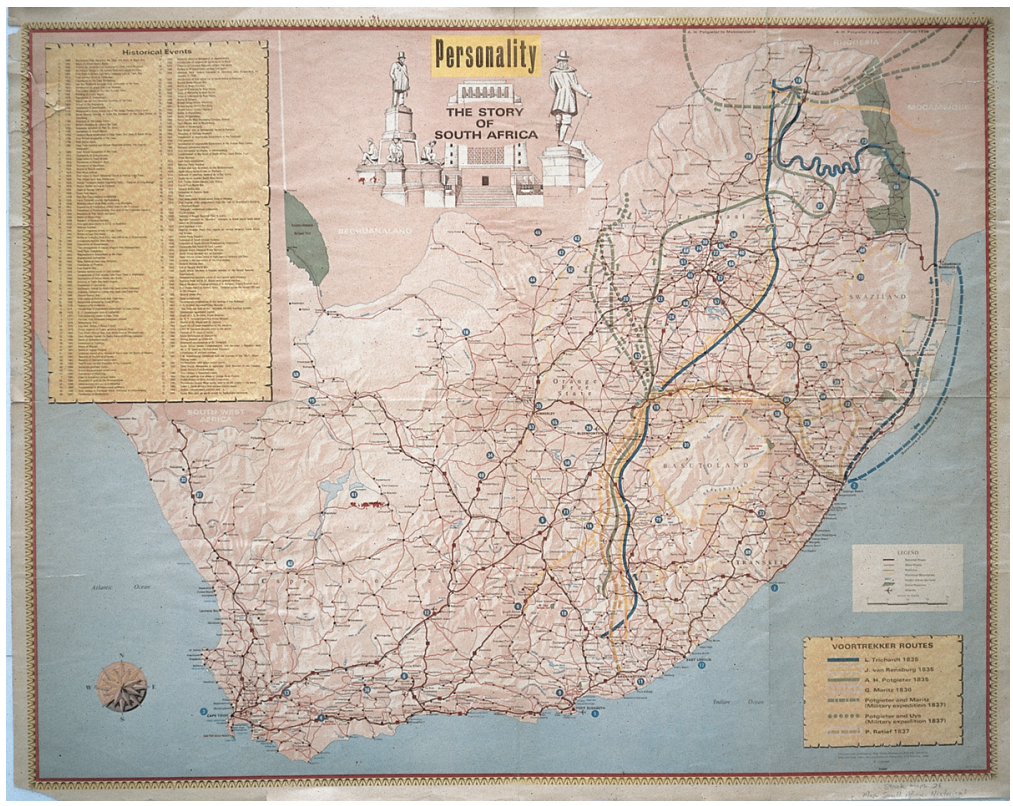



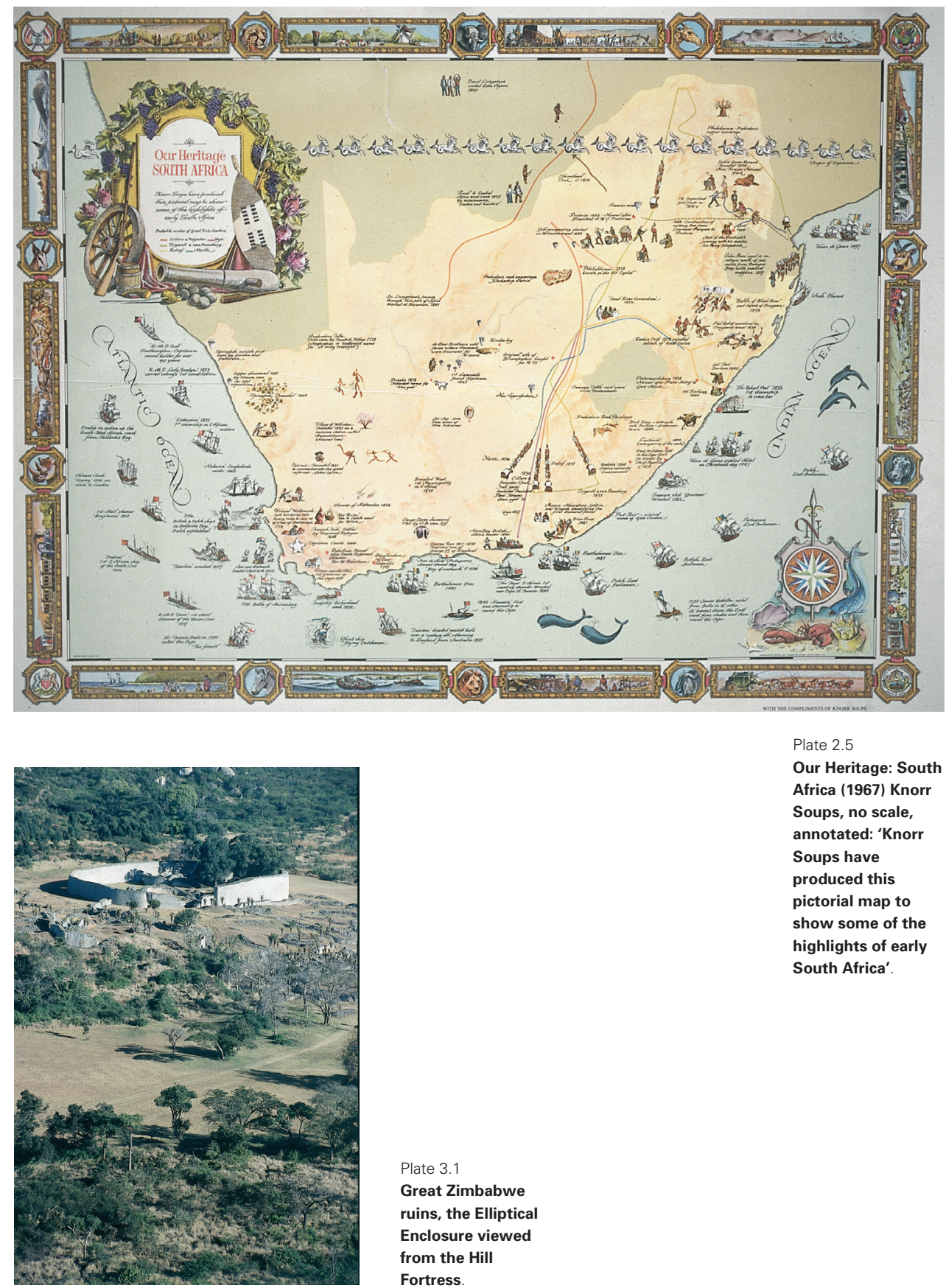

Plate 2.5

Our Heritage: South Africa (1967) Knorr

Soups, no scale, annotated: 'Knorr

Soups have produced this pictorial map to show some of the highlights of early South Africa'.

Plate 3.1

Great Zimbabwe

ruins, the Elliptical

Enclosure viewed

from the Hill

Fortress. 
Plate 3.2

Great Zimbabwe ruins, the double layer of triangular stone patterning at the top of the walls,

replicated by Moerdijk in the stonework above the large arches of the Voortrekker

Monument.

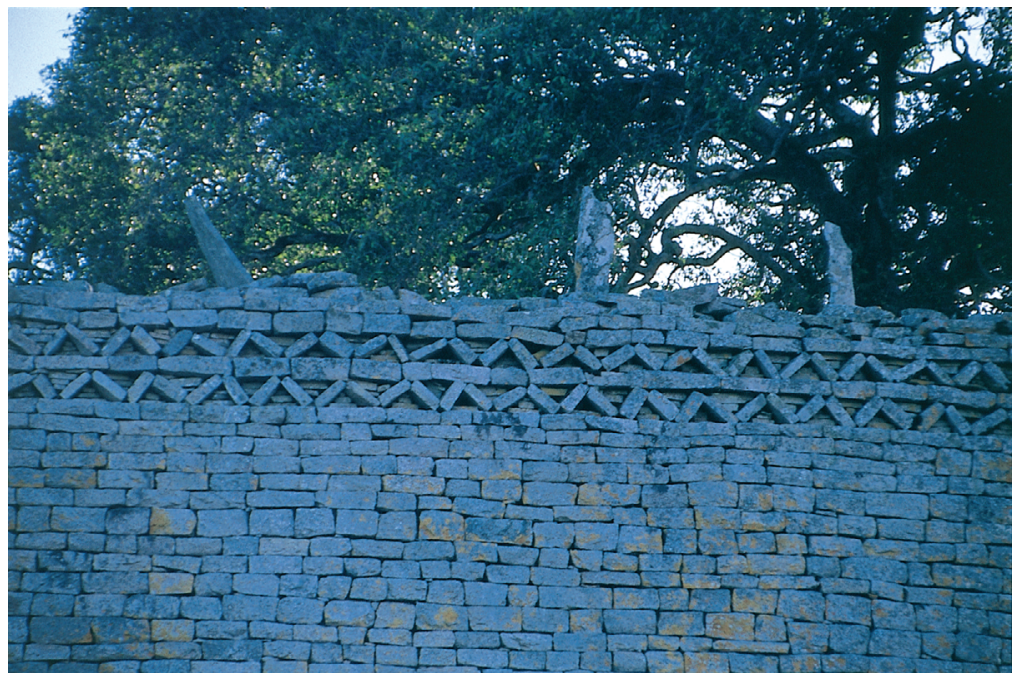

Plate 4.1

Map of the Fort of Good Hope and Company Garden and any Public and Particular Buildings around it (1693), author (probably)

Dane Hendrik Oldenland, who served as Company Surveyor between 1691 and 1696.

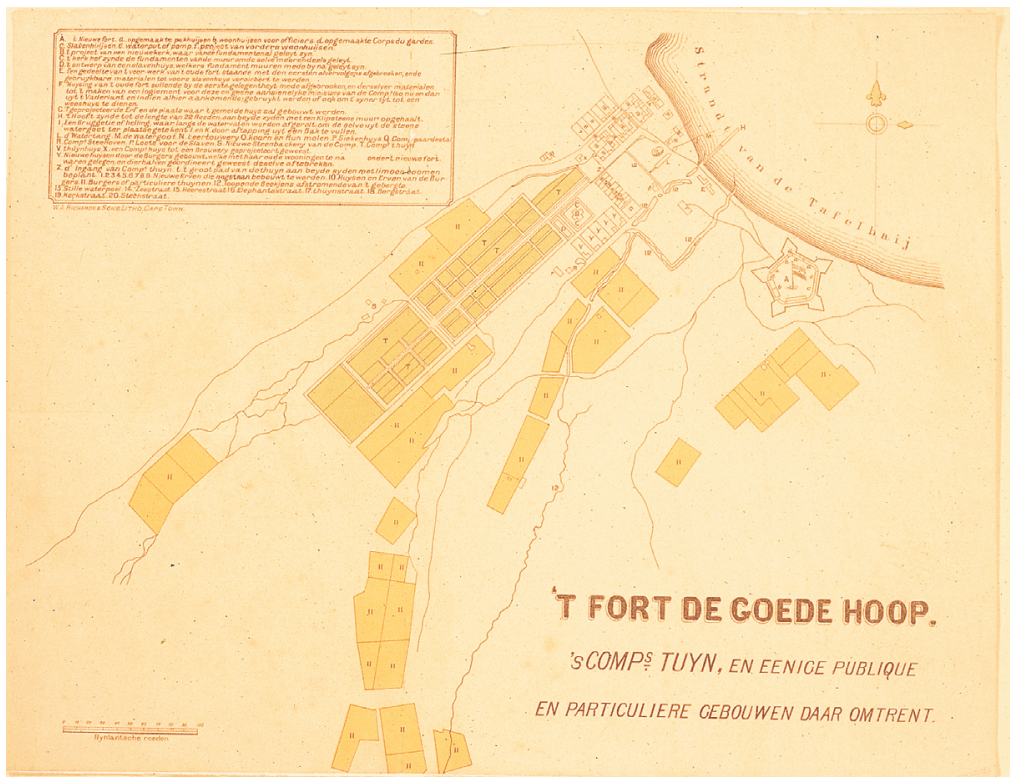




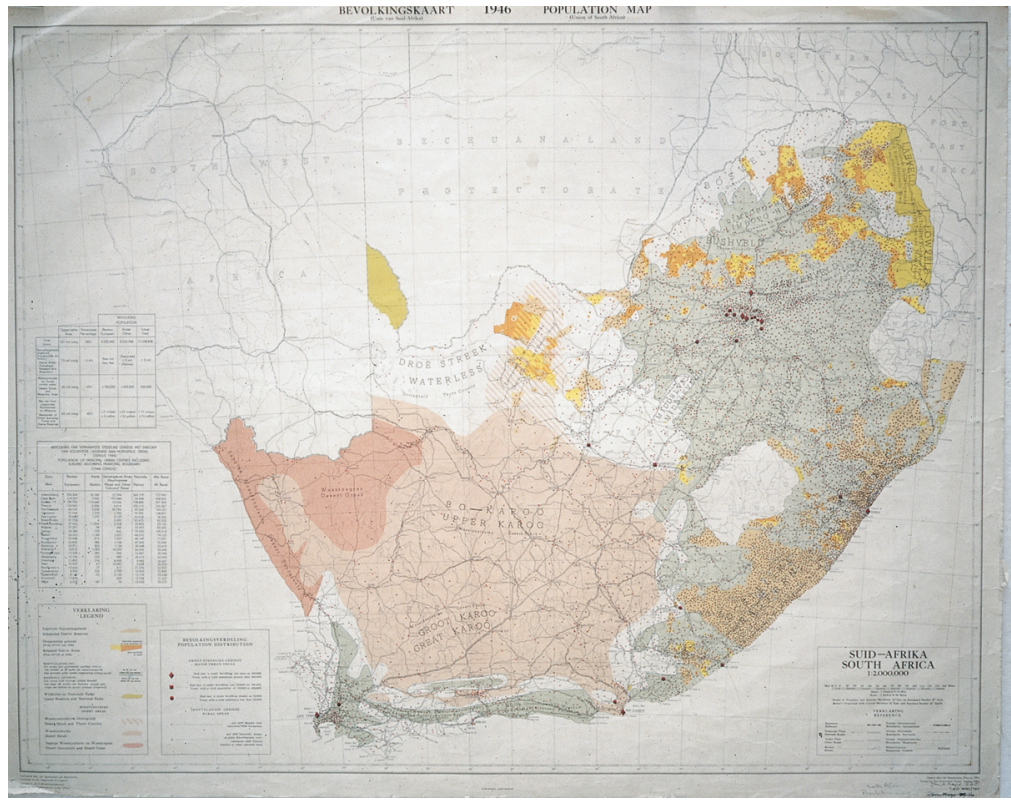

Plate 5.1

Population Map of South Africa (1946) Reproduced under South Africa

Government

Printer's Copyright

Authority no. 11296,

1 November 2005.
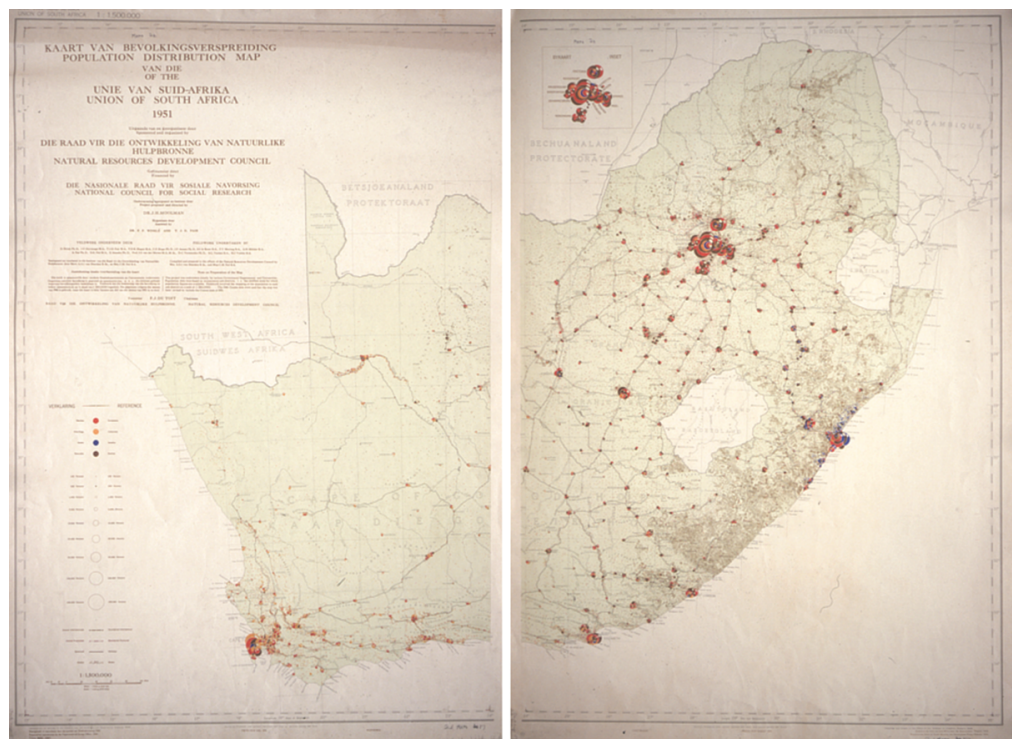

Plate 5.2

Population

Distribution Map of the Union of South Africa (1951) (from 1946 census data, revised to contain data from the 1951 census).

Reproduced under South Africa

Government

Printer's Copyright Authority no. 11296, 1 November 2005. 
Plate 5.3

Map your Holiday in South Africa (1950?). Back cover of a map showing tourist locations in South Africa.

Designed and published by the

South African

Tourist Corporation

by order of the

Government of the

Union of South

Africa. Reproduced under South Africa

Government

Printer's Copyright

Authority no.

11296, 1 November

2005.

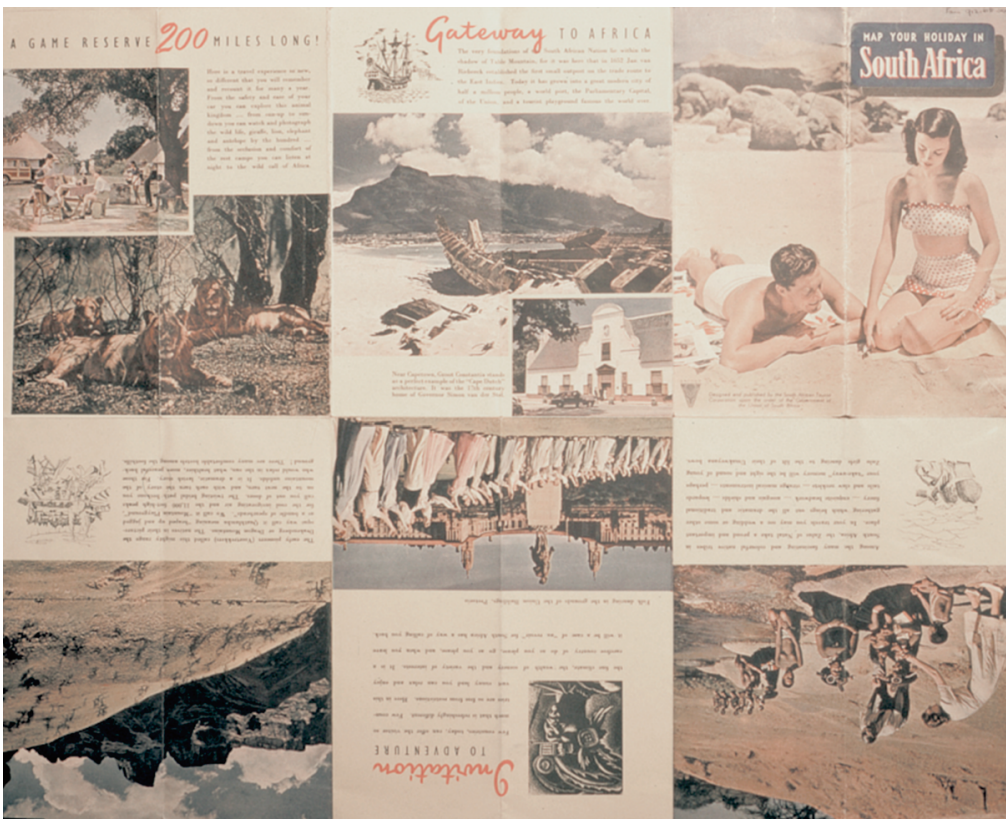

Plate 6.1

Ladysmith Native

Areas, hand-drawn and coloured map

from a report about

the black spots in

the area. The black

lines are the district

boundaries, the

orange boundaries

are the Released

Areas, the blue area are those in reserve areas owned by the South African

Native Trust, and

the yellow areas are the land parcels owned by 'natives'.

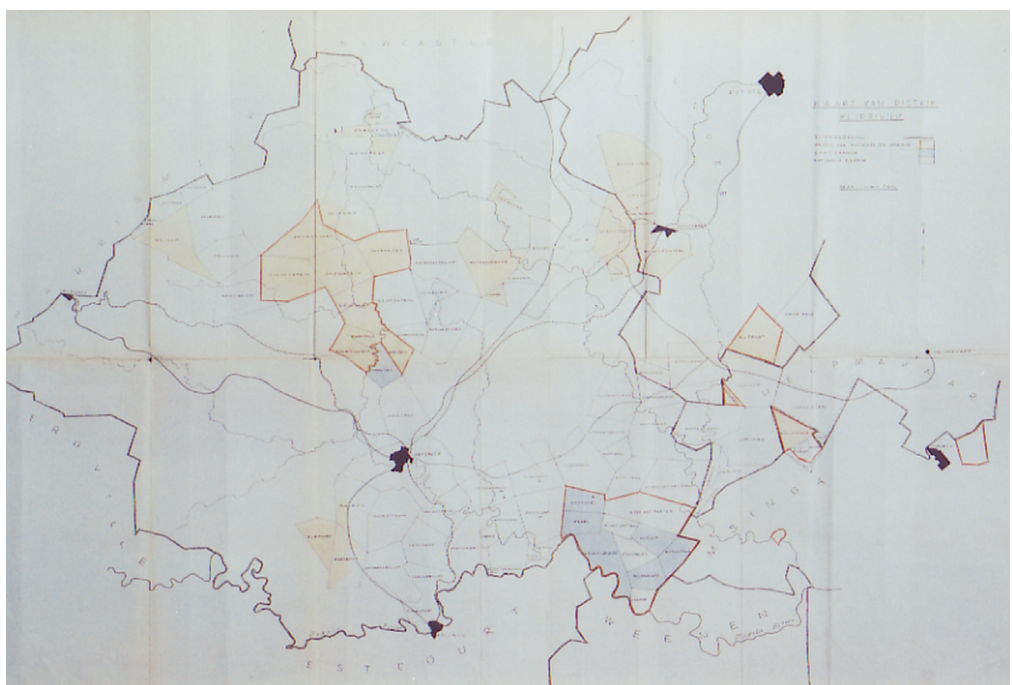




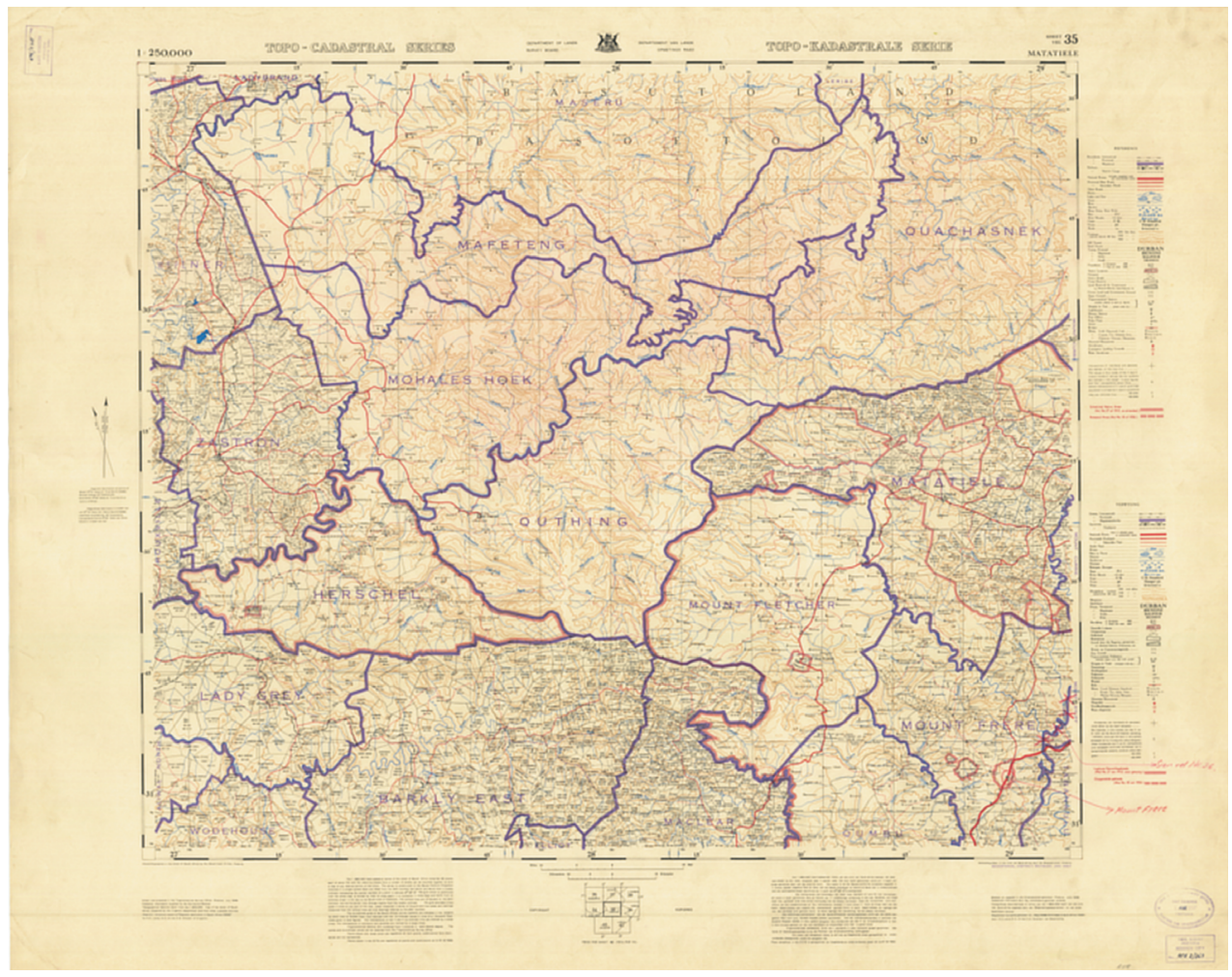

Plate 6.2

Matatiele and the

Scheduled and

Released Areas

under the Land

Acts. Reproduced

under South Africa

Government

Printer's Copyright

Authority no. 11296,

1 November 2005. 
Plate 6.3

Map - Matatiele and the Scheduled and Released Areas under the Land Acts, detail showing the division of whiteowned land into farms, while blackowned land

becomes absorbed into common ownership.

Reproduced under South Africa Government

Printer's Copyright Authority no. 11296, 1 November 2005.

Plate 6.4

Detail of Matatiele region from the 1:50,000 Map

Series, Sheet 3028 BD Matatiele.

Compare this with

Figure 6.1, which illustrates the erosion of the soil in the bantustan to the left of the boundary.

Reproduced under South Africa

Government

Printer's Copyright Authority no.

11296, 1 November 2005.
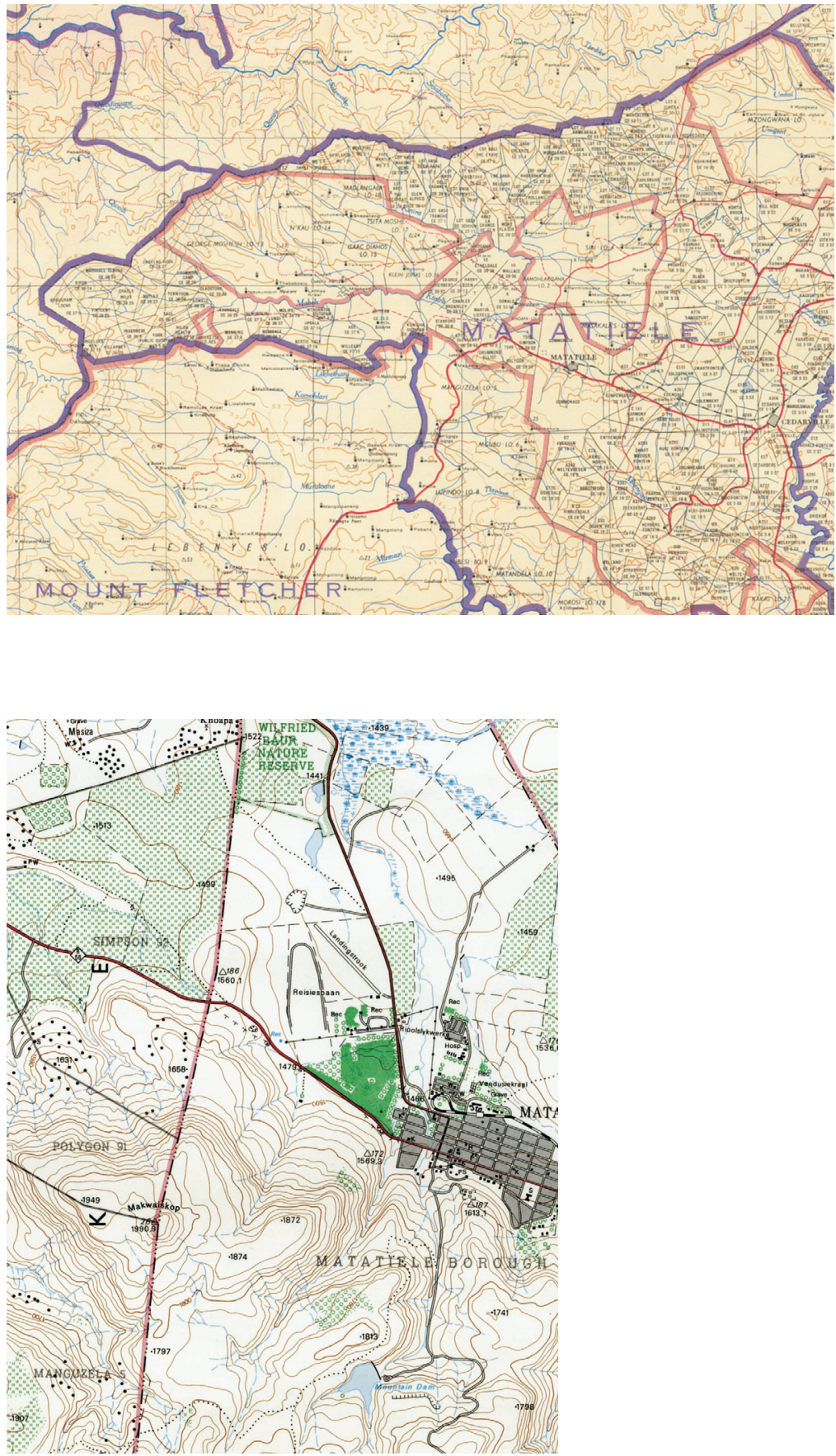


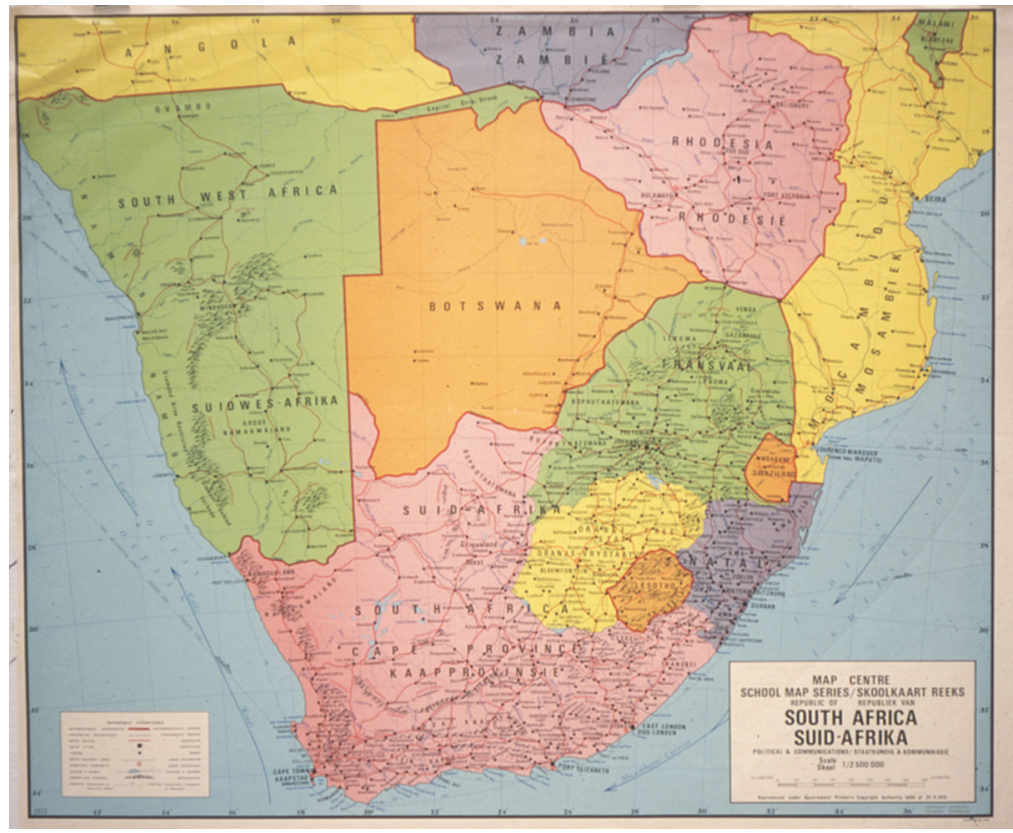

Plate 7.1

School Map series, Republic of South

Africa: Political and

Communications,

Johannesburg,

Map Centre, 1976.

Reproduced under

South Africa

Government

Printer's Copyright

Authority no.

11296, 1 November 2005

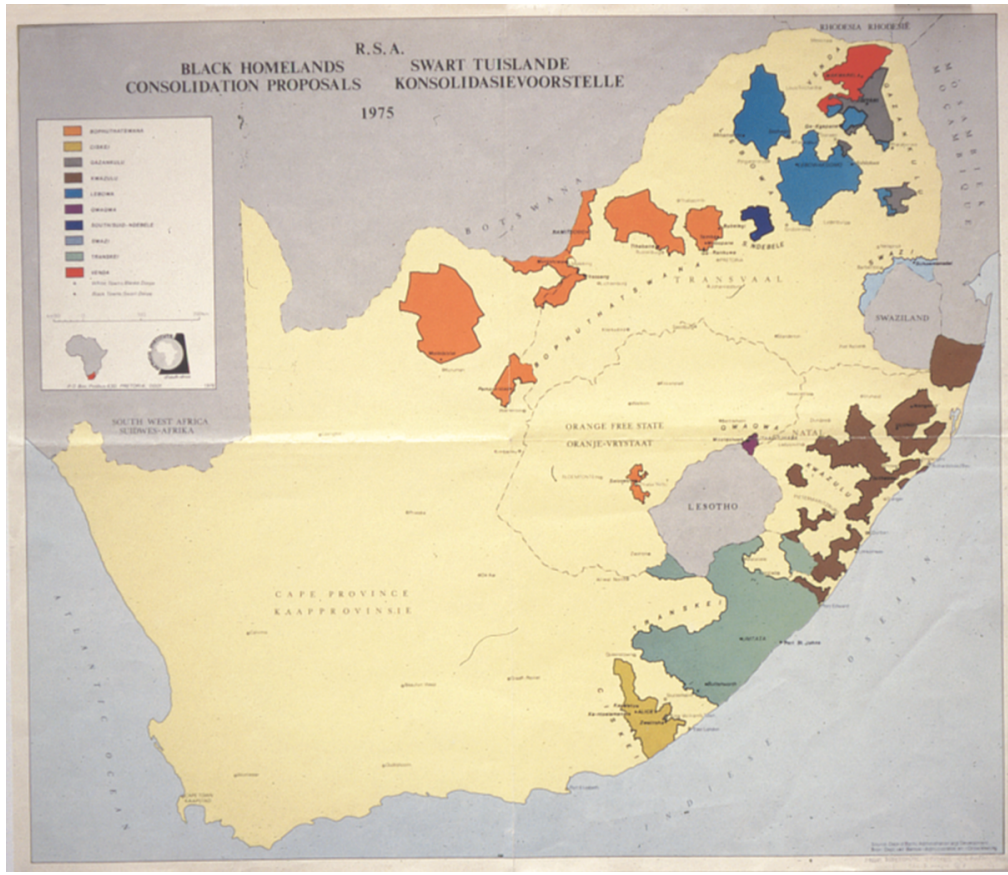

Plate 7.2

Black Homelands

Consolidation

Proposals, 1975.

Department

of Bantu

Administration and

Development 


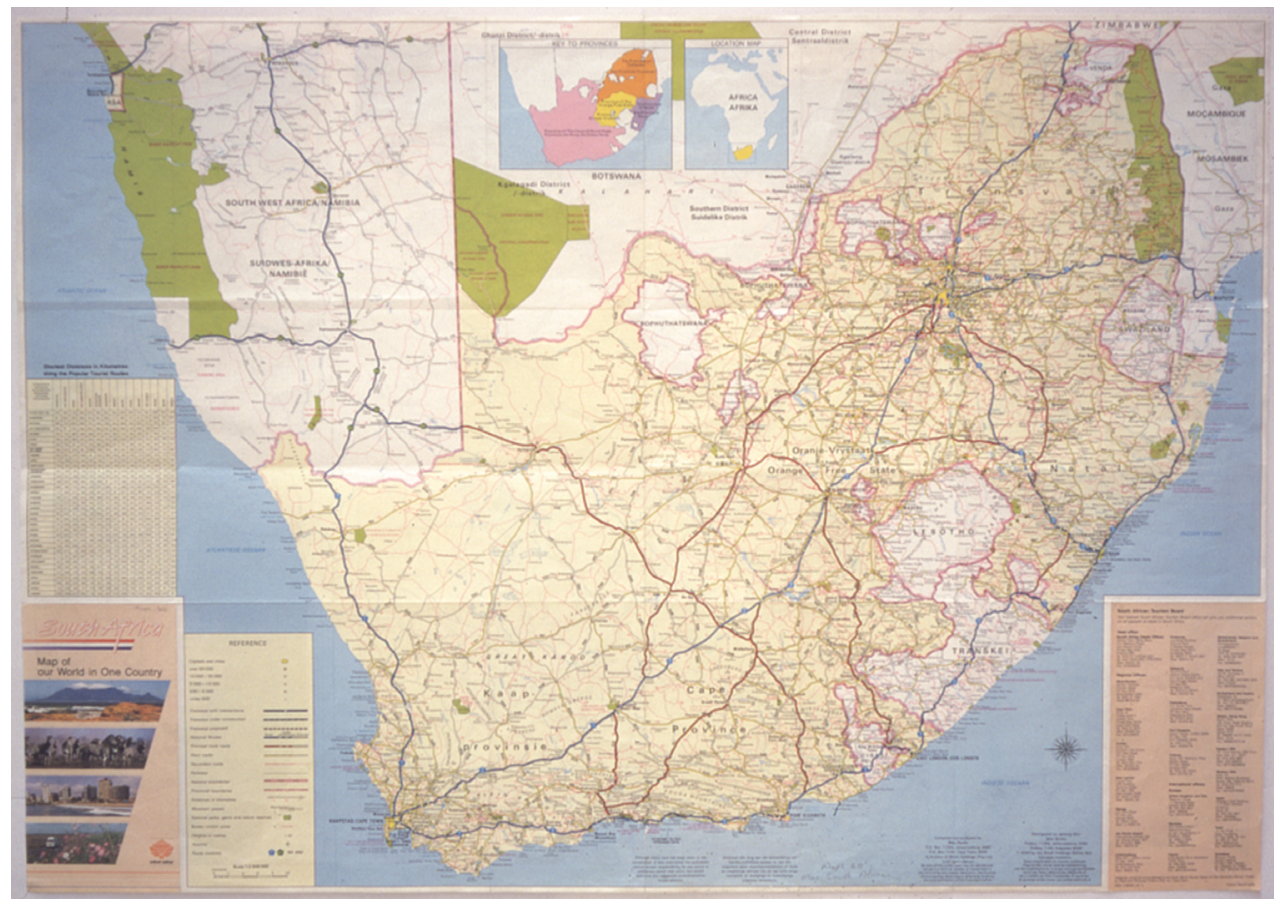

Plate 7.3

South Africa: Map

of our World in One

Country (no date,

late 1980s).

(c) Map Studio.

Plate 7.4

General Information

Map: South Africa

and the Developing

States (1987)

(c) Map Studio.

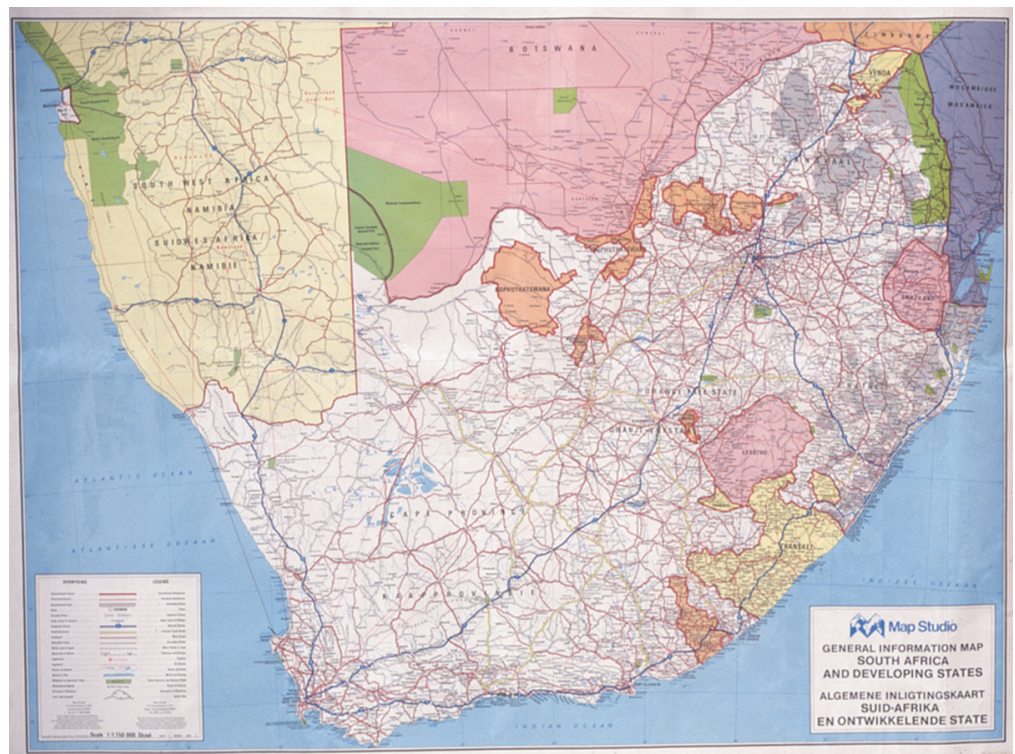




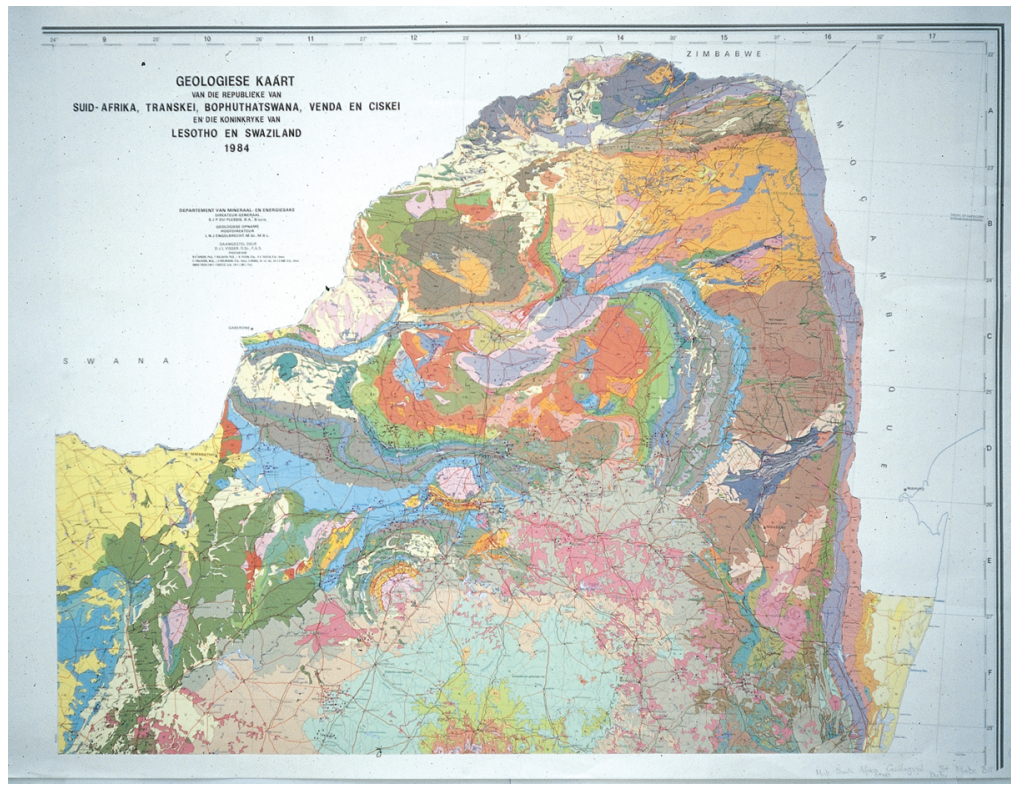

Plate 10.1

Geological Map of the Republic of

South Africa,

Transkei,

Bophuthatswana,

Venda and Ciskei

and the kingdoms

of Lesotho and

Swaziland (1984).

Reproduced under

South Africa

Government

Printer's Copyright

Authority

no. 11296,

1 November 2005.

Plate 10.2

Geological Survey of Johannesburg

(undated - early

twentieth century).

Reproduced under

South Africa

Government

Printer's Copyright

Authority no.

11296, 1 November 2005

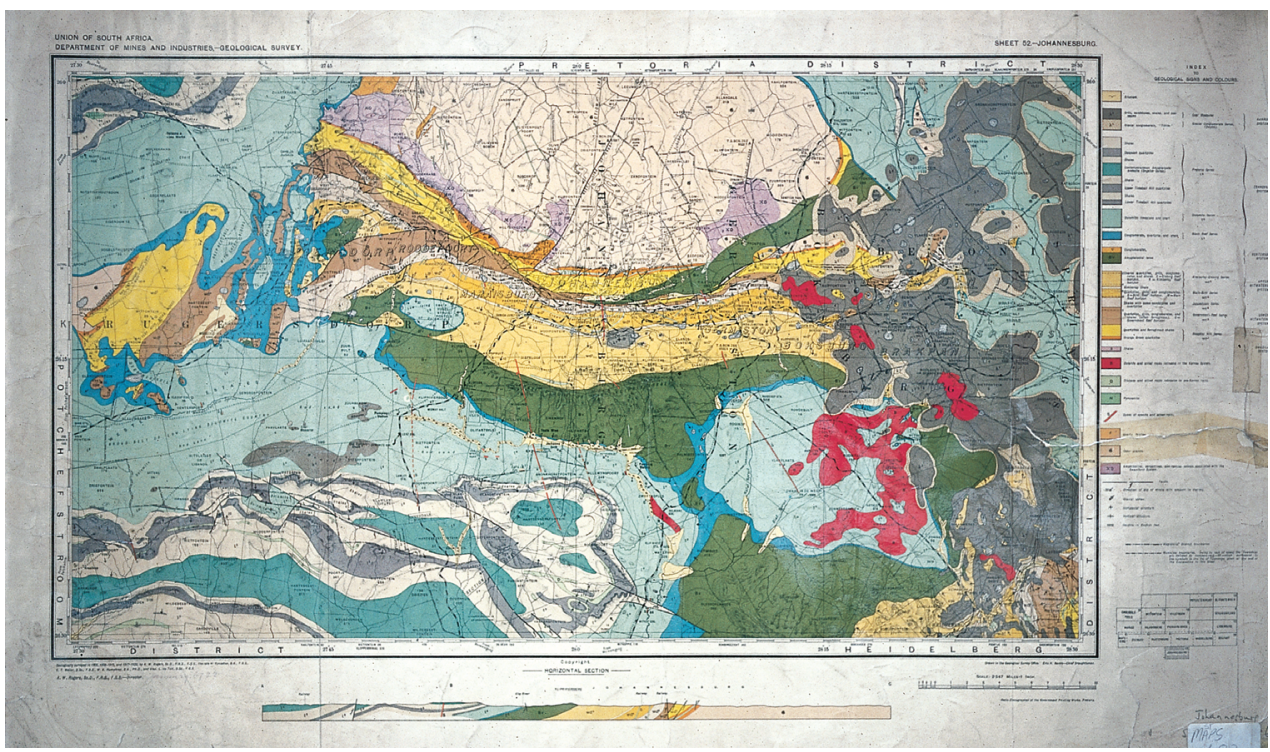


Plate 11.1

Crown Mines

Property

Development

Project, completed

in April 1969

by Roeloef

Uitenbogaardt,

Anthony Barac,

Adele de Souza

Santos, Antonio de

Souza Santos and

John Mayle.

Drawing showing

the mining land

'activated' for

inhabitation by the

overlaying of a

green landscape.
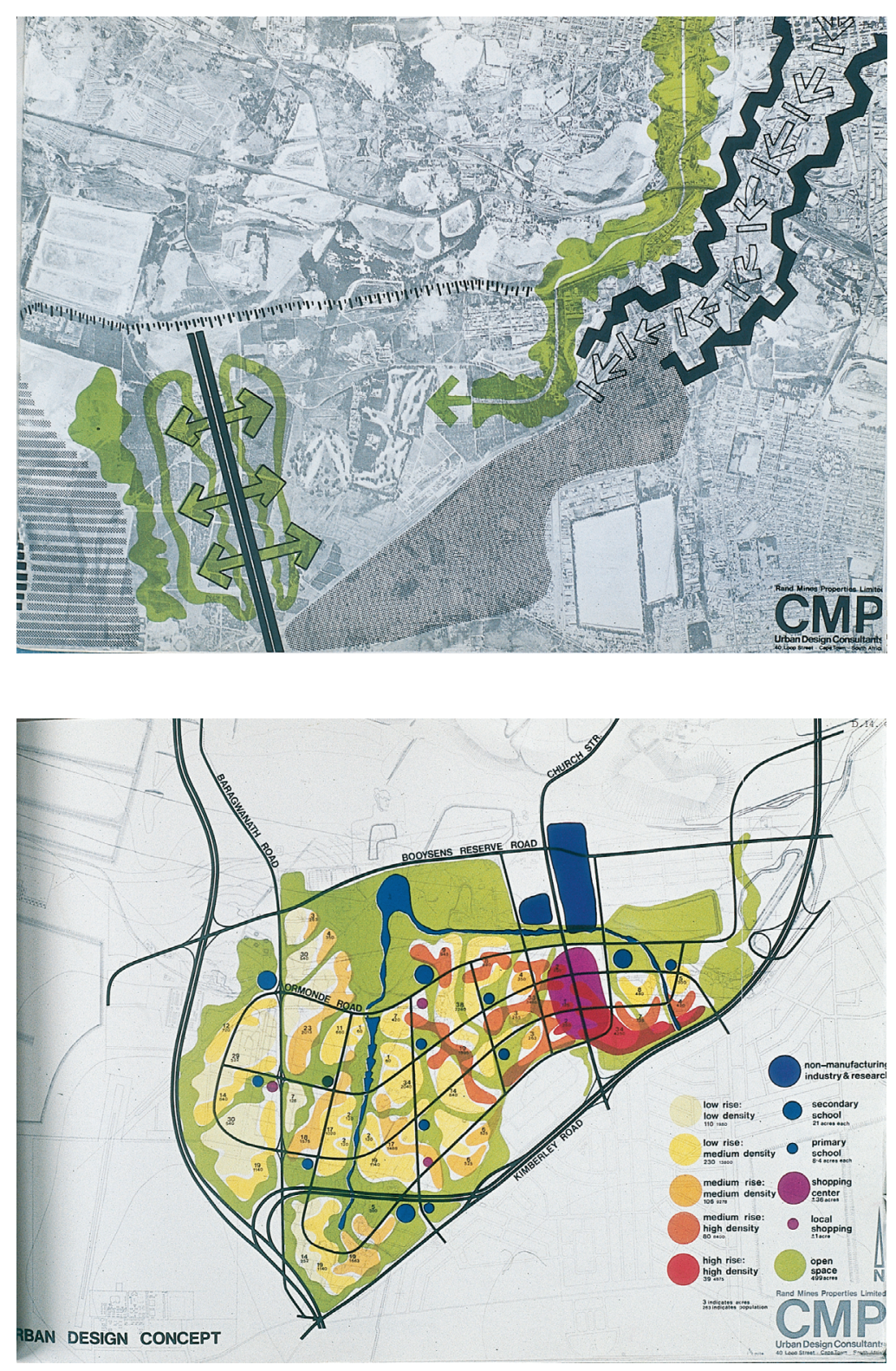

Plate 11.2

Crown Mines

Property

Development

Project, completed

in April 1969

by Roeloef

Uitenbogaardt,

Anthony Barac,

Adele de Souza

Santos, Antonio de

Souza Santos and John Mayle.

Drawing showing

the network of greenery, water and community areas in the proposed development. 


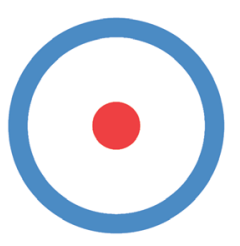

Plate 12.1

Group Areas Act, representational system for (top down) 'Owned by whites and residentially occupied by Indians', 'Whiteowned and

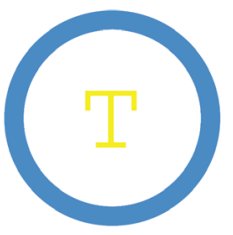
occupied by Chinese for trading purposes' and 'Indian-owned and Indian occupied for residential and trading purposes'. Diagrams by the author after descriptions in

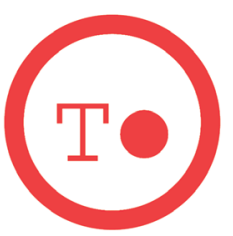
'Application for a determination under the provisions of Section 16 of the Group Areas Act 1957 (Act no. 77), Form D'.

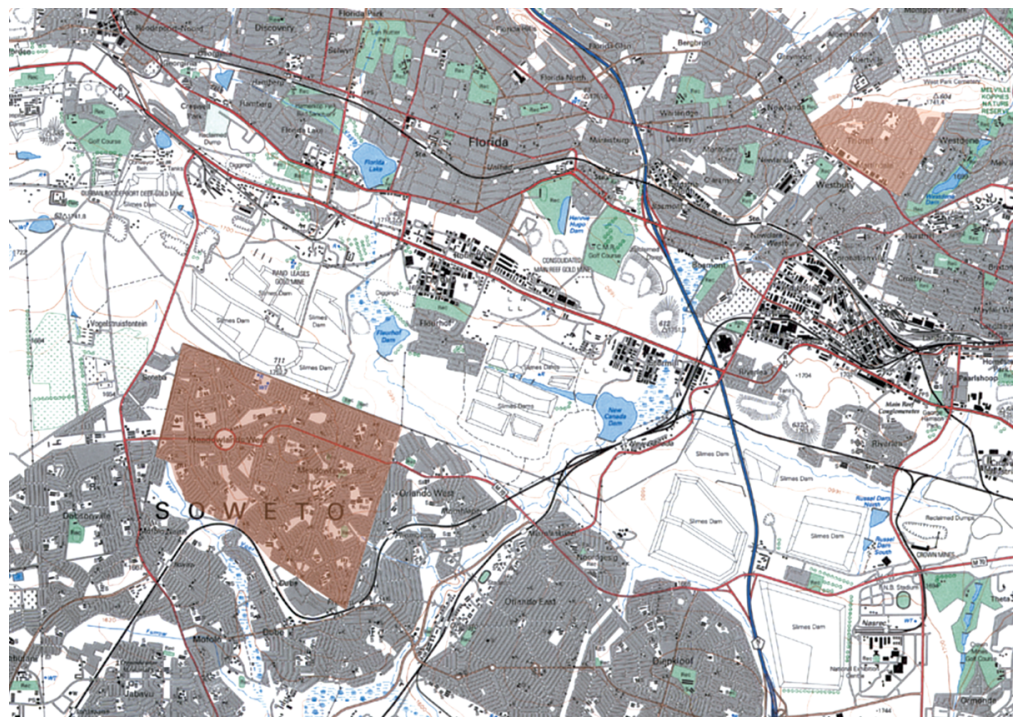

Plate 13.1

Detail of 1:50,000

map series of Johannesburg/Sow eto. Reproduced under South Africa Government Printer's Copyright Authority no. 11296, 1 November 2005. Sophiatown is shown in pale orange, while the areas to which the residents were moved are shown in dark orange. The mining land lies between them. 
Plate 13.2

Cape Town 1:50,000

Map Series (sixth

edition 1995).

Reproduced under

South Africa

Government

Printer's Copyright

Authority no. 11296,

1 November 2005.

District Six is

shown in pale

orange, while the

main areas to which

the residents were

moved are shown

in dark orange.

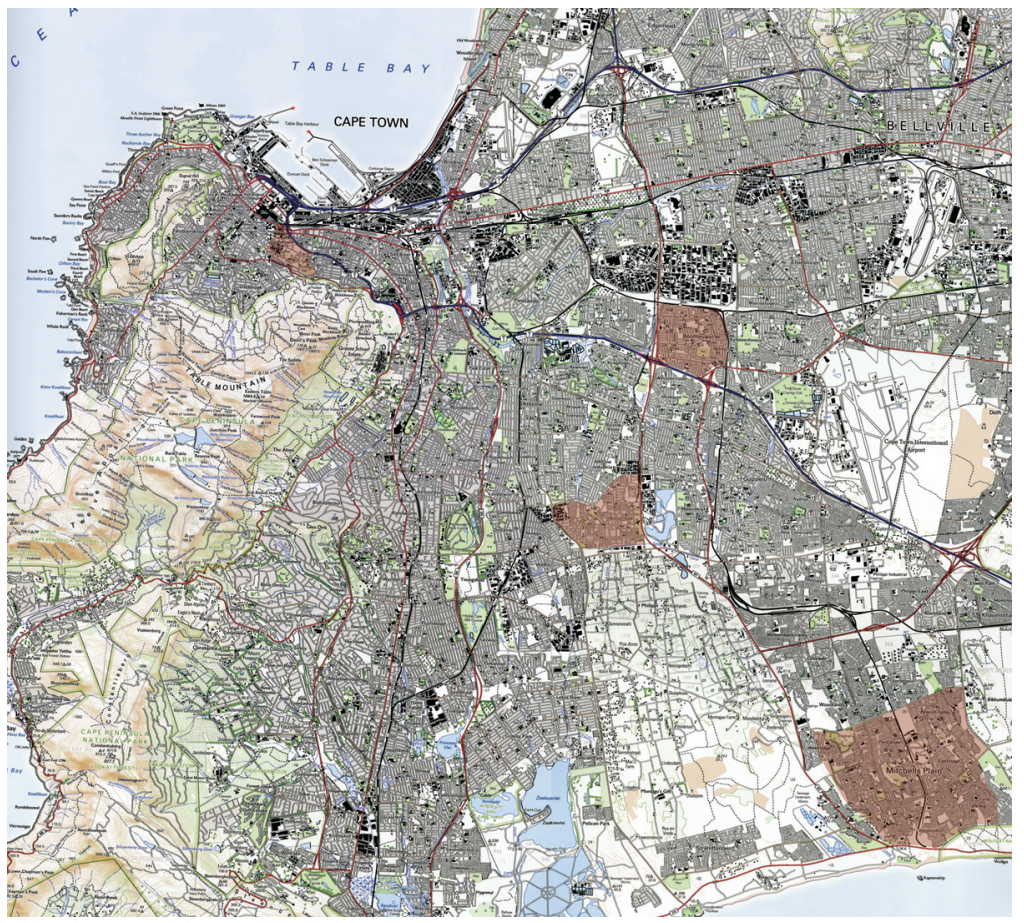

Plate 13.3

Three-dimensional

plan - District Six,

Proposals

(1965-1974)

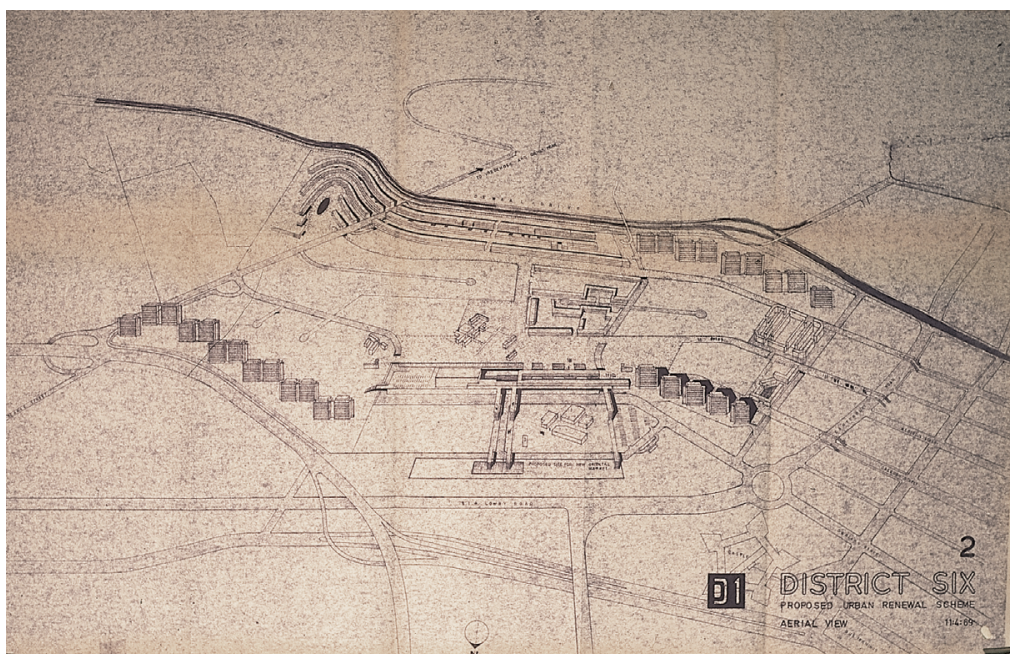




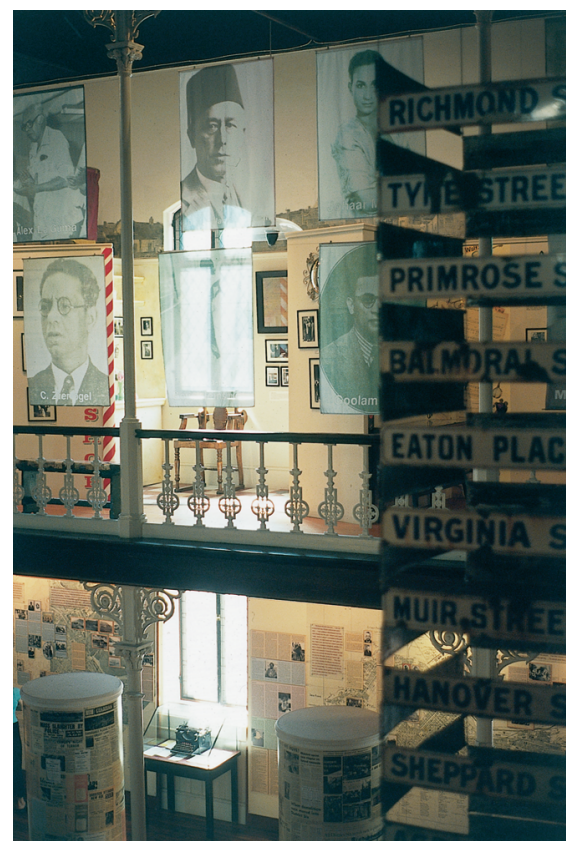

Plate 15.1

Interior of the

District Six

Museum, showing

the vertical

arrangement of

the retrieved street

signs and the hung

photographs of

prominent District

Six citizens.

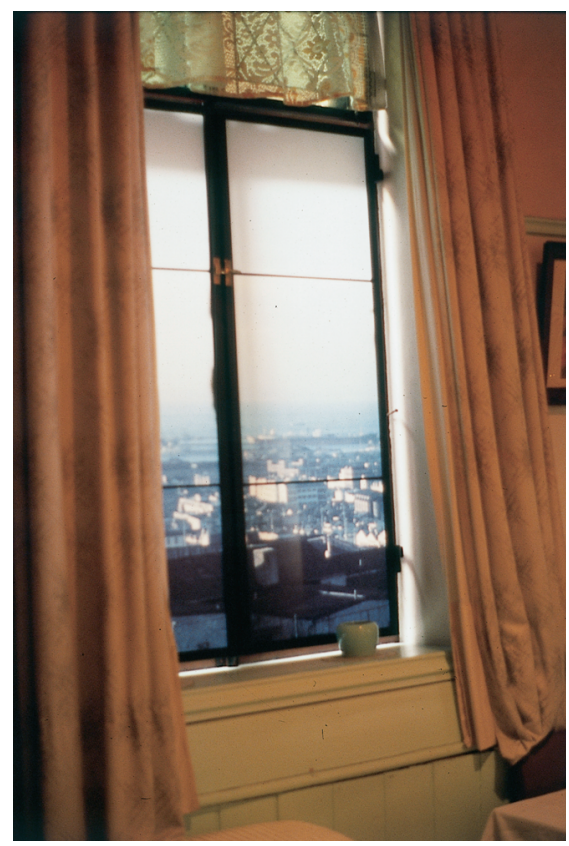

Plate 15.2

The interior of one of the 'memory rooms' in the District Six

Museum -

Nomvuyo's

Room, in which an illuminated photograph of the view from her window is hung in the false window of the museum. 